\title{
Toplum Bilimleri
}

Altı Aylık Hakemli Bilimsel Dergi

Cilt: 1-3 Sayı: 1-6

Ocak-Haziran 2006-2009

ISSN 1306-7877 



\section{Journal of Social Sciences \\ Semi-Annual Academic Journal}

Vol: 1-3 Num: 1-6

January-June 2006-2009

ISSN 1306-7877 


\title{
\% Toplum \\ B) Bilimleri \\ Dergisi \\ Journal of Social Sciences
}

Hakemli Bilimsel Dergi/Semi-Annual Academic Journal

Cilt: 1-3 Sayı: 1-6/Volume: 1-3 Number: 1-6

Ocak-Haziran 2006-2009/January-June 2006-2009

\section{Sahibi/Owner}

Motif Yayıncııık Rek. Paz. ve Tic. Ltd. Şti. adına Mehmet Orhan Özcan

\section{Editörler Kurulu/Editorial Board}

Niyazi Akyüz, Fazlı Arabacı, Şahin Gürsoy, ìnsan Çapcıoğlu

Yayın Kurulu/Managing Committee

Fazlı Arabacı, Niyazi Akyüz, Adil Çiftci, Şahin Gürsoy, Celalettin Çelik, Mehmet Akgül, Ahmet Onay, Fatma Odabaşı, İhsan Çapcıoğlu,

Muhammet Çakmak, Mehmet Cem Şahin

\section{Danışma Kurulu/Advisory Board}

Aytül Kasapoğlu (Ankara Ü.), Ünver Günay (Erciyes Ü.),

Nilüfer Narlı (Bahçeşehir Ü.), Hüsnü Ezber Bodur (Sütçü İmam Ü.),

Korkut Tuna (i̇stanbul Ü.), Zeki Arslantürk (Marmara Ü.),

Niyazi Usta (Atatürk Ü.), Recep Kilıç (Ankara Ü.),

Bayram Kaçmazoğlu (Cumhuriyet Ü.), Cemal Tosun (Ankara Ü.),

Hasan Onat (Ankara Ü.), Mehmet Bayyiğit (Selçuk Ü.),

A. Vahap Taştan (Erciyes Ü.), İzzet Er (Uludağ Ü.), Baki Adam (Ankara Ü.), Beylü Dikeçligil (Erciyes Ü.), Ahmet Hikmet Eroğlu (Ankara Ü.),

Sönmez Kutlu (Ankara Ü.), Ayşe Kadıoğlu (Sabancı Ü.),

Hüseyin Akyüz (Atatürk Ü.), Nevin Güngör (Hacettepe Ü.), Ejder Okumuş (Osmangazi Ü.)

\section{Sorumlu Yazı İşleri Müdürü/Managing Editor}

Kaya Kuzucu

\section{Sekreterya ve Redaksiyon/Secretariat \& Proof Reading \\ insan Çapcıoğlu}

\author{
Toplum Bilimleri Dergisi/Journal of Social Sciences \\ ISSN 1306-7877 \\ Cihan Sokak No: 37/1 Sihhiye / ANKARA \\ e-posta: toplumbilimleridergisi@gmail.com
}


İÇINDEKILER

Makaleler

Ünver GÜNAY

Türkiye'de Din Sosyolojisi: Teorik ve Metodolojik Meseleler

Beylü DİKEÇLİGil

Sosyal Bilimler Epistemolojisinde Sorunların Kaynağı:

Ontolojiyi Unutmak

Hüsnü Ezber BODUR

Dini Organizasyon Tipleri ve Yeni Dini Hareketler

Niyazi AKYÜZ - Şahin GÜRSOY - İhsan ÇAPCIOĞLU Sosyolojide Yönteme Giden Yollar Üzerine

Fazlı ARABACI

Türk Toplumbiliminde Kuram Sorunu: Toplumsal Eylemin Arkaplanı

Şahin GÜRSOY - İhsan ÇAPCIOĞLU Din-Kimlik İlişkisi Üzerine

115

Adil ÇífTÇi

Bilgi Sosyolojisi ve/ile Kelâm'ı Yeniden Kurmak

- 121

Celaleddin ÇELIK - İlkay ŞAHIN Kadın Dindarlığı: Bir Paradoksun Söyledikleri

- 141

M. Cem ŞAHIN Popüler Kültürün İlahiyat Fakültesi Öğrencilerinin Yaşam Stilleri Üzerindeki Etkisi

Halil AYDINALP Intihar Eylemcisinin Sosyal Kimliği:

- 201 Filistinli İlk Kadın Eylemci Vefa İdris

Sefer YAVUZ Dini Yönelim Ölçeği ve Güvenirlik Çalışması: - 221 Sanayi İşçileri Üzerine Bir Araştırma 


\section{Çeviriler}

\section{Robert WUTHNOW • 229}

Sosyoloji ve Din

Tanıtım ve Değerlendirmeler

Hakkı KARAŞAHIN • 249

Ana Başlıklarıyla Din Sosyolojisi

İsmail GÜLLÜ 252

İsim Kültürü ve Din 


\title{
TÜRKIYE'DE DİN SOSYOLOJISİ: TEORİK VE METODOLOJIKK MESELELER
}

\begin{abstract}
Sociology of religion in Turkey: Theoretical and methodological issues. Sociology of religion as a discipline appeared in the modern period and under its conditions in the western world to analyse and investigate the religion as a social event and institution, the relationship and interaction between religion and society and the related facts. The appearence of this discipline in nonwestern world such as Islamic world and Turkey occurred after its full development. This study attempts to deal with developments in Turkey following a historical perspective in the framework of theoretical and methodological problems.
\end{abstract}

key words

Sociology, sociology of religion, theoretical, and methodological problems, Turkey. 


\section{Giriş̧}

Hangi ölçüde modern dönemin şartlarına bağlı bulunursa bulunsun, kendine has araştırma alanı, konuları ve bunları bilimsel perspektifte incelemede izleyeceği yöntem ve teknikleri ile birlikte din sosyolojisinin bağımsız ve sistematik bir bilimsel disiplin şeklinde ortaya çıkması uzun bir tarihsel hazırlık dönemine dayanmaktadır. İlk planda felsefe, sonra sosyal bilimler, insan bilimleri, din bilimleri ve özellikle de sosyolojinin içerisinde bir varlık alanı elde ederek gelişme gösteren din sosyolojisi, özellikle XIX. yüzyılın ikinci yarısında bağımsız bir disipline ve daha doğrusu alt-disipline dönüşmüştür. Öyle ki, din sosyolojisini bazıları sosyolojinin, ötekiler din bilimlerinin bir alt-dalı sayıyor. Her halükârda, Batı'da din sosyolojisinin gelişmesinde çeşitli fikir akımlarının etkileri mevcuttur. Nitekim Kant, Hegel, Comte, Marks, Freud, Malinowski gibi modern Batı düşüncesinin önde gelen düşünürlerinin Batı'da gelişen din sosyolojisi üzerinde derin etkileri bulunmaktadır. İlk olarak "Din Sosyolojisi" (Sociologie de la Religion) terimine, Fransız Sosyoloji Ekolü’nün kurucusu E. Durkheim'ın Sosyoloji Yıllığı dergisinde din olayının tanımına dair yayınladığı bir yazısında rastlanmaktadır (Durkheim, 1899). Ancak, Pozitivist çizgideki Fransız Sosyoloji Ekolünün "sosyolojizm"inin dine yaklaşımı bir tür "ircacılık"la (reductionisme) karakterize olmaktadır. Bunun tipik bir benzeri, XIX. yüzyılın ortalarından başlayarak Marksist çevrelerde önemli temsilciler bulan "materyalist din sosyolojisi" eğiliminde gözlenmektedir. Her halükârda, Batı'da XIX. yüzyılın özellikle ikinci yarısında önemli gelişmelere sahne olan din sosyolojisine, pozitivist ve evrimci felsefe ve düşünceler bir biçimde damgasını vurmuştur. Buna karşılık, XX. yüzyılın başlangıcından itibaren, din sosyolojisi araştırmalarında, XIX. yüzyılda görülen bu pozitivist ve tekâmülcü dalga büyük bir gerilemeye sahne oldu. Öte yandan, din sosyolojisi, uzun süre dinî duygunun menşei ve tabiatını açıklama teşebbüsleriyle vakit geçirmiş ve incelemeleri için ana malzemeyi tercihen etnoloji, etnografya ve folklor gibi dalların verilerinden almış olması sebebiyle imtiyazlı araştırma alanı "ilkel dinlerin etnolojik sosyolojisi" olarak kalmıştır. Buna karşılık, yeni gelişmelerin ortaya çıkardığı süreçte din sosyolojisi, bir taraftan normatiflik ve spekülâsyondan sıyrılarak "objektif” bir karakter kazanmaya yönelmiş, diğer taraftan da etnolojinin yanı sıra tarih, ekonomi, psikoloji, fenomenoloji ve istatistik gibi sosyal bilimlerin yöntem ve verilerini esas almak suretiyle metodolojisini "deneysel" bir temele oturtmuştur. Bu gelişmeler, din sosyolojisinin bağımsız ve sistematik bir bilimsel disiplin olarak kuruluşunu tamamlamasına imkân vermiştir. Din olaylarının sosyolojik yaklaşımda incelenmesinin özel bir araştırma alanını teşkil etmesi şeklinde ortaya çıkan bu olayda en büyük pay Alman sosyologu Max Weber'e aittir. Birçok eleştirilere de konu olan Weber'in açmış olduğu yoldan hareketle din sosyoloji süratle gelişmiş, verimli çalışmalar ortaya konmaya başlanmıştır. Bu çerçevede, E. Troeltsch, J. Wach ve G. Menschig gibi Batılı din sosyologlarının XX. yüzyılın ilk yarısında gerçekleştirmeyi başardıkları çalışmaların önemine işaret etmelidir. Öte yandan, "etnolojik ve tarihî yönelimli 
bir din sosyolojisi eğilimi"ni geniş ölçüde aşarak, günümüz toplumlarında din konusunu sosyolojik yaklaşımda ele almaya başlamanın tipik bir temsilcisi olarak karşımıza Fransız din sosyologu G. Le Bras çıkmaktadır. Nitekim onu takiben, toplumların dinî-sosyal hayatları üzerine tecrübî din sosyolojisinin yaklaşım yollarından hareketle pek çok araştırmaların gerçekleştirildiğine tanık olunmaktadır. Meselâ S. S. Acquaviva, B. R. Wilson, D. Martin, P. Berger, T. Luckmann, D. Bell gibi din sosyologları sekülarizasyon konusunda uzmanlaştılar. Öte yandan, özellikle XX. yüzyılın son çeyreğinde, "yapı", "kültür", "sembol", "işaret", "anlam", "yorum", "sistem" kavramları, yeni tanımları bağlamında, din konusuna yeni yaklaşım modellerinin anahtar terimlerini oluşturdu. Böylece meselâ C. Levi-Strauss din konusuna "yapısalcılık" ve R. Bastide "sürekli değişen kültürel yapı" perspektifinde yaklaşıma yöneldi. Konuyu, J. Berque "derinlik sosyolojisi", E. Gellner "sarkaç teorisi", C. Geertz "kültür sistemi, semboller, işaretler, anlam ve yorum" perspektifinde ele aldı. Buna karşılık, Mary Douglas sembollerde şifrelenmiş anlamların çözümlenmesi", R. Wuthnow "kültürel yapısalcılık", D. Bell "farklılaşmış toplumda din ve kutsalın dönüşü", P. Berger ve T. Luckmann "fenomenoloji ve kognitif işlevselcilik" ve J. M. Yinger de "işlevselcilik" perspektifinde yaklaşmaya yöneldi. Yapısal-fonksiyonalist R. N. Bellah, modern toplumda din konusunun sosyolojik analizi bağlamında "sivil din" kavramını operasyonel biçimde devreye soktu. Bunlara çatışma kuramı, simgesel etkileşimcilik, akılsal seçim, gerçekliğin toplumsal inşası, fenomenoloji, etnometodoloji, sistem teorisi gibi çağdaş sosyoloji kuramları eklendi.

Daha sistematik bir yaklaşımla, Batı'da çağdaş dönemde din sosyolojisi araştırmalarında ortaya çıkan başlıca eğilimlerin, biri dinin değişmez kabul edilen özü ve muhtevasını anlayıp açıklamaya ve ötekisi de dinî olayın değişik tarihsel formları ile spesifik toplumsal kontekstleri arasındaki enteraksiyonu ortaya koymaya yönelen iki ana kategoride toplandığı ifade edilebilir. Ancak, yönelimlerin çeşitliliğinin, bu tür dikotomik bir kategorizasyonu ziyadesiyle aştığı da bilinmektedir. Nitekim bu alanda kayda değer bir yönelimi deskriptif bir "sosyografya" kategorisinde değerlendirmek uygun düşmektedir. Ancak orada "coğrafi”, "tarihî", "etnografik", "demografik", ya da "istatistik" tasvir eğilimlerinin alt kategoriler olarak kendini göstermekte oluşu kayda değerdir. Bununla birlikte, Batı'da özellikle son dönemde deskriptif sosyografya düzeyinin büyük ölçüde aşılmış olduğunu önemle belirtmelidir. Karşıllaştırmalı, formel ve tipolojik eğilim ile fenomenolojik yönelim "anlayıc sosyoloji" kategorisinde değerlendirilmekte, buna, "dinî morfoloji araştırmaları" eğilimi eklenmektedir. "Dinî sosyoloji" şeklinde adlandıran bu sonuncu eğilime yapılan en büyük tenkitlerden biri, teolojik mülâhazaların sosyolojik problemlerin önüne geçirilmesi noktasında toplanıyor. Bu tenkitler "fenomenolojik din sosyolojisi" eğiliminin modern dönemde yeniden güçlü bir biçimde doğuşuna temel teşkil etmiş bulunuyor. Ayrıca, genetik din sosyolojisi, fonksiyonel din sosyolojisi, strüktürofonksiyonel din sosyolojisi, sosyo-praksiler, diyalektik din sosyolojisi ve nihayet 
konfesyonel din sosyolojileri eğilimlerine işaret etmek gerekiyor. Özellikle Marksist eğilimli din sosyologlarında ideolojik ve indirgemeci eğilim öne çıkıyor. Kilise çevrelerinin din sosyolojisi araştırmalarının da genelde değer yüklü ve pratiğe yönelmiş olmaları dikkate değerdir. Esasen bu çevrelerde din sosyolojisinin pratiğe ve eyleme dökülmesinde üç ana eğilim ayırt ediliyor: Empirizm, Konfesyonalizm ve Entervansiyonizm. Öte yandan, Batı'da Müslüman araştırıcılar arasında "bilimin islâmileştirilmesi" hareketine paralel olarak bu tür bir din sosyolojisi eğilimi kendini göstermiş olup, onlar çalışmalarının bir bölümünü "The American Journal of Islamic Social Sciences" adlı dergide yayınlamaktadırlar. Her halükârda, "objektif din sosyolojisi", böylesine ideoloji ve değer yüklü ve aksiyoner eğilimli sosyolojileri normatif buluyor. Din sosyolojisinin normatif toplum felsefeleri ile karıştırılmaması gerekiyor. Özellikle Wach, din sosyolojisini, belli bir toplumsal reform programının bir aleti konumuna indirgemeye kalkışmanın, onun gerçek amacı ve hüviyetine ihanet olacağını belirtiyor (Wach, 1995: 30). Her halükârda, görüldüğü gibi, Batı'da din sosyolojisi tek bir çizgide gelişmek yerine farklı anlayış ve yönelimlere sahip olmuş, bu bakımdan da orada bir "din sosyolojisi" nin değil, fakat "din sosyolojileri"nin varlığından söz edilmiştir (Bkz. Desroche, 1968). Günümüzde din sosyolojisi alanında Avrupa'da önemli çalışmalar yapılmakta; ABD ise önemli bir merkez halini almış bulunmaktadır (1). Öte yandan, modern dönemde din sosyolojisinin, Batı dünyasının dışında önemli bir ilgi ve yaygınlık kazanmış olması da kayda değerdir (2). Zira modern sanayi sonrası "post-modern" veya "ultra-modern" bir dönemde "küreselleşme" ile birlikte geleneksel toplumlar dünya ölçüsünde hızla değişmeye yönelmiş, bunun ekonomik ve kültürel sonuçlarının yanı sıra din alanında önemli yankıları görülmüştür. Bütün bunlar anlaşılan tüm toplumlarda, modern sosyal bilimlere, sosyolojiye, din sosyolojisine ve öteki modern din bilimlerine duyulan ihtiyacı artırmıştır. Nitekim bu durum, din sosyologlarını, ulusal ve uluslar arası teşkilatlar aracılığı ile kurumlaşmaya ve etkinliklere yöneltmiş bulunuyor (3).

Kısacası, bir toplum olayı ve kurumu olarak dini ele almak, din ve toplum ilişkileri ve etkileşimini ve bu çerçevede ortaya çıkan olguları bilimsel olarak araştırıp incelemek üzere din sosyolojisi bilimi ancak modern dönemde ve onun şartlarında Batı'da ortaya çıkmış ve giderek gelişme göstermiş bir disiplindir. Nitekim bu bilim dalının Batı dışında dünyanın öteki ülkelerine ve meselâ İslam dünyası ve Türkiye'ye gelişi de Batıdaki gelişmeleri müteakip olmuştur ve işte bu çalışma Türkiye'deki gelişmeleri tarihsel bir yaklaşım perspektifinde teorik ve metodolojik sorunları bağlamında ele almayı denemektedir.

\section{Türkiye'de Din Sosyolojisi}

Her halükârda din sosyolojisinin ortaya çıktığı ve geliştiği Batı ülkelerinde, daha sonra yayıldığı dünyanın öteki ülkelerine göre çok daha fazla kurumlaştığı ve sistemleştiği önemle belirtilmelidir. Nitekim din sosyolojisi ile ilgili olarak 
ortaya atılan başıca teoriler ve geliştirilen araştırma yöntem ve teknikleri de Batı'da ve hatta Batı toplumlarının sorunlarına göre oluşturulmuşlardır. Bu bakımdan, Batı dışı toplumlarda din sosyologlarının karşı karşıya kaldığı en önemli meselelerden biri, Batılı toplumlarının sosyo-ekonomik, kültürel ve dinî ortamı ve şartlarında üretilmiş olup, onların kültürleri, dinleri, değerleri ve sorunlarına sıkı sıkıya bağıı olan teoriler, yöntemler ve tekniklerin Batı dışı toplumlarda ne şekilde uygulanacağı hususu etrafında toplanmaktadır. Esasen bu mesele gerek İslam ülkeleri ve gerekse de Türkiye'de din sosyolojisi araştırmaları için de önemli bir husus olarak kendini göstermektedir. Aslında i̇slâm dünyası, din, dinî kültür ve din bilimlerinin gelişimi bakımından ilk birkaç yüzyılda oldukça dinamik bir biçimde oluşan ve gelişen bir canlılıkla karakterize olmaktadır. Nitekim bu dönemde ortaya çıkan bilimler hızla gelişen Müslüman toplumda karşılaşılan sorunlara dinamik bir biçimde çözüm üretmeyi başarmışlardır. Bu bakımdan bilgi ve hatta bilim sosyolojisi bakımından onları zımnî birer din sosyolojisi şeklinde değerlendirmek gerekir. Ancak onların meselâ fıkıh biliminin örneğinde tipik bir biçimde gözlendiği üzere, bir tür "sosyal teoloji"ye dönüşmüş olmaları da kayda değerdir. Esasen anlaşılan bu sosyal teoloji, daha sonra bu konuda her şeyi yaptığını ve artık bundan böyle yapılacak pek bir şeyin kalmadığını sanarak "içtihat kapısı"nı kapayan ve kendi içine kapanıp taklitçiliğe ve sonuçta gelenekselleşmeye, durağanlığa ve hatta çöküntüye yönelen statik bir zihniyetin İslam dünyasına egemen olmasına da zemin hazırlamıştır. Yine de, başlangıçta dinamik bir atılım gösteren bilim hareketinin neden bir dönem sonra statikliğe yöneldiği ve bu zihniyetin niçin İslam dünyasına egemen olduğu sorusu sıklıkla sorulmakta ve aslında mesele tam bir çözüme kavuşmuş da görünmemektedir. Her halükârda İslam dünyası, statik tavrın açmazlarının sıkıntılarını, modern dönemin hızlı değişim olgu ve mecburiyetleri çerçevesinde günümüzde çekmeye devam etmektedir. Bu bakımdan İslâmiyet konusunu "yeni yapısalcı" (neo-structuraliste) bir yaklaşımla ele almaya yönelmiş modern bir Müslüman düşünür ve bilim adamı olan M. Arkoun, "düşünülebilir" (pensable), "düşünülemez" (impensable), "düşünülen" (pensé) ve "düşünülmeyen"i (impensé) birbirinden analitik olarak ayırarak (Arkoun, 1984: 9), tahlillere ve yorumlara gitmeye çalışmaktadır. Anlaşılan bu yolla Arkoun, İslâm düşüncesine yeni bir canlılık kazandırmayı amaçlamış görünüyor. Ancak, İslâm dünyasının çok köklü sorunları bu konuda çok yönlü ve sistemli çabalara ve özellikle de modern bilimsel çözümlemelere intiyaç duyuyor. Bu çerçevede din sosyolojisi araştırmalarının önemine işaret etmek gerekiyor. Bununla birlikte, genelde i̇slâm dünyası din konusunda ilk dönemlerin geleneksel "is/âm ilmi"ne ziyadesiyle takılmış görünüyor. Gerçi orada, meselâ Antik Yunun felsefesinden yapılan çevirilerle başlayan ve sonra Farabî ve İbn Sina gibi Meşşaî ekolünün önde gelen isimleri ile hız kazanan felsefe hareketi bir Relionswissensaft'ın öncülüğünü yapmayı da başarmıştır. Öyle ki meselâ özellikle Farabî, ibn Sina, Birûnî ve İbn Tufeyl'in eserlerinde içerisinde din sosyolojisinin de yer aldığı modern dönemin din bilimlerinin en azından bir ön taslağının temellerinin atıldığı, 
ancak takipçi bulamadığı anlaşılmaktadır (Walker, 2006: 85- 101). Esasen anlaşılan böylesine bir Relionswissensaft taslağını meselâ Gazali'de de bulma imkânı olmaktadır (Landolt, 1991: 1-72). Üstelik XIV. yüzyılda İbn Haldun, meşhur Mukaddime'sinde "IIm'ül-Ümran" adını verdiği yeni bir bilimin temellerini atmaya çalışırken, sosyolojinin ve hatta din sosyolojisinin bir öncüsü imiş gibi görünmektedir (Bkz. Günay, 1986: 63-104). Bununla birlikte, dönemin karanlık ortamında onun bu çabası da pek bir yankı uyandırmamışır. Anlaşılan modern dönemin hızlı değişme şartlarının bir ürünü olan modernist akım da durağanlığı aşmada oldukça zorlanmış ve esasen o belli bir entelektüel düzeyi pek aşamamıştır. Nitekim onun etkileri oldukça sınırlı kalmış bulunuyor. XX. yüzyılda ve özellikle onun ikinci yarısından sonra sahnede daha çok görülmeye başlayan siyasal ve radikal İslamcı akımların militan ideolojik vurguları ve sloganlarının İslam dünyasının karşı karşıya bulunduğu ikilemler ve açmazları daha da artırmaktan başka pek bir işe yaramadığı gözlenmektedir. Modern din bilimlerini ve özellikle de din sosyolojisini özgün ve düzeyli metodolojik yaklaşım çerçevelerinde sorunların bilimsel analizi ve bu yolla çözümler üretmek üzere devreye sokma konusunda ise o öyle pek ciddî bir niyet ve kararlılık içerisinde görünmüyor (4). Esasen, Türkiye'nin de olayı gelenek ve değişimin çok yönlü karmaşık etkileşimi bağlamında ancak kendi iç ve dış dinamikleri çerçevesinde sancılı bir biçimde yaşamakta olduğu gözlenmektedir. Gerçi, Türk toplumu özellikle Tanzimat'tan itibaren çok önemli değişimlere sahne olmaya başlamıştır. Cumhuriyetle birlikte büyük bir azim ve kararlılıkla çağdaşlaşmayı ve onun vazgeçilmez ön şartı olan lâikliği seçmiş bulunan Türkiye'de değişim köklü bir karaktere bürünmüştür. 1950'li yıllardan itibaren Türkiye'deki değişim olgusunda kayda değer bir hızlanma gözlenmiş, 1970'li yıllardan itibaren de o yeni bir ivme kazanmış olup, o tarihten bu yana süreç tüm hızıyla devam etmektedir. Ancak, değişime uyumsuzluğun tepkisel anomi ortamı sosyo-kültürel hayatın birçok alanında "eski" ile "yeni" nin yahut "geleneksel" olanla "modern"in dikotomik bir çatışma anlayışı çerçevesinde sancılı bir biçimde karşı karşıya gelmesine yol açmıştır. Bu çerçevede, "eski"nin yahut "geleneksel" olanın "kutsal" ve dolayısı ile "dini" bir anlama bürünmekte oluşu kayda değerdir. Böyle olunca, değişime uyumsuzluğun tepkileri en çok dinî yaşayış ve kültür alanında ve çoğu zaman oldukça "çarpık" bir biçimde ortaya çıkmaktadır. Bu bakımdan, çağdaş Türk toplumunda modernleşme, süreklilik ve değişimin din, dinî yaşayış ve kültür alanlarındaki etkilerinin din sosyolojisinin yaklaşım yollarından hareketle bilimsel analizi, karşı kaşıya kalınan sorunların anlaşılması ve bunlara bilimsel çözümler üretilmesi bakımından hayatî bir önem taşımaktadır. Bu anlamda denebilir ki Türkiye ve Türk toplumu, gerek tarihsel bağlamda ve gerekse de hali hazır yaşantısı itibariyle din sosyologlarının araştırmaları için eşsiz bir laboratuardır. Nitekim Türkiye'de din sosyolojisine, üniversitelerin başta ilahiyat ve sosyoloji bölümleri olmak üzere iktisat, siyasal bilimler gibi sosyal bilimlere ilişkin çeşitli birimlerinde belli bir akademik ilgi duyulmuş ve duyulmaya devam edilmektedir. Bu ilginin ortaya çıkışı ve gelişimini başlıca safhaları, belli başı temsilcileri, ele alınan temel so- 
runlar ve bunlara yaklaşım modelleri ve bu çerçevede kendini gösteren teorik ve metodolojik meseleler bağlamında ele almak oldukça aydınlatıcı olacaktır.

\section{1. Öncüler}

Türkiye'de din sosyolojisine duyulan ilgi ve yapılan çalışmalar hakkında önemli ilk değerlendirme çalışmalarından birini gerçekleştiren $M$. Taplamacıoğlu, gerçekte Türkiye'de sistematik ve tarihî anlamda bir din sosyolojisinin varlı̆̆ından söz etmenin bilimsel gerçeklere pey uymadığı, ancak gelecekte verimli çalışmaların yapılacağının umulacağına önemle işaret emektedir. Taplamacıoğluna göre, Z. Gökalp, i. H. Baltacıoğlu, H. Z. Ülken, Hüseyin Cahit Yalçın ve M. Karasan'ın çalışmaları Türkiye'de bu alanda öncü niteliğindedir. Bunlara dinler tarihi, İslam tarihi, ilahiyat, hukuk ve din psikolojisi gibi alanlarda yapılan çalışmaların katkıları eklenmiştir. Zira Türkiye'de, öteden beri belli bir gelişme kaydetmiş bulunan felsefe, dinler tarihi, edebiyat, tarih ve din psikolojisi gibi komşu disiplinler konu ile ilgili malzemeyi bir biçimde sunmuşlardır. Nitekim meselâ dinler tarihi alanında Ahmet Mithat Efendinin 1329 tarihinde yayınlanan Tarih-i Edyan, M. Şemsedddin Günaltay'ın 1331 tarihinde yayınlanan Tarih-i Edyan, Ömer Hilmi Buda'nın Dinler Tarihi (İstanbul, 1935), Ömer Rıza Doğrul'un Dinler Tarihi (İstanbul, 1947), Annemarie Schimmel'in Dinler Tarihine Giriş (İstanbul, 1955) adlı eserleri buna örnektir. M. Fuad Köprülü'nün Mekteb-i Mülkiye'de verdiği derslerin taş basması notlarını ihtiva eden Türk Tarih-i Dinîsi (Istanbul, 1936) ile Edebiyat Fakültesi Mecmuasında çıkan "Anadolu'da İslamiyet" ve H. Ziya imzasıyla Dergâh mecmuasında 1922'de yayınlanan "Türkmenlerin Dini" adlı çalışma ve yayınları Türkiye'de din sosyolojisi çalışmalarına önemli yardım ve katkıları içermektedir. Bunlara Ahmet Cevdet Paşa, Hüseyin Cahit Yalçın, M. Şekip Tunç, Hilmi Ziya Ülken, Bedii Ziya Egemen ve Nurettin Topçu'nun çalışmaları eklenmektedir (Taplamacıoğlu, 1960: 55-61; 1961, 1968: 106-111). Meselâ Hüseyin Cahit Yalçın E. Durkheim'ın “Les Formes Elémentaires de la Vie Religieuse" adlı eserini "Dinî Hayatın ibtidâ̂ Şekilleri" adı altında Türkçeye çevirmiştir.

Esasen, Türkiye'de modern din sosyolojisinin gelişmesine hazırlık anlamında, yukarıda zikredilen öncü mahiyetindeki çalışmalara, XVII. yüzyıldan itibaren kendini gösteren İbn Halduncu etkileri de eklemek gerekir. Zira bu dönemde giderek önce duraklama sonra da çökmeye yön tutan Osmanlı İmparatorluğunun sorunlarına eğilen Türk mütefekkirleri ibn Haldun'un Mukaddime'sine belli bir ilgi duymuşlardır. Bu anlamda Kâtip Çelebi (1609-1657), Naima (Ölm. 1716), Müneccimbaşı (ölm. 1703), Pirîzâde (1674-1749), Hayrullah Efendi (1817-1866), Abdüllatif Subhî (1818-1886) ve Ahmed Cevcet Paşa (1822-1895) Türk ibn Halduncuları olarak dikkati çekmektedir. Özellikle Pirîzâde'nin başlattığı Mukaddime'nin Türkçeye çevirisini Ahmed Cevdet paşa tamamlamış ve hatta ona birçok notlar eklemiştir. Öte yandan, Türkiye'de ỉbn Haldun ve Mukaddime'ye duyulan ilgi XX. yüzyılın başlarından günümüze bir biçimde devam etmektedir. 
Öyle ki, bu konuda Türkiye'de sadece yeni Mukaddime çevirileri yapılmamış, aynı zamanda oradaki fikirler Türk düşünür ve sosyologlarınca birçok bakımdan analiz ve yorumlara tabi tutulmuştur (Fındıkoğlu, 1961: 116-131). Bununla birlikte, Türk İbn Haldunculuğu bilimsel ve akademik bir geleneğe dönüşmüş de değildir.

XIX. yüzyılın sonları ve özellikle de XX. yüzyılın başlarından itibaren Batı sosyolojisi Türkiye'ye girmeye başladı. Illk planda, Comte, Le Play ve Durkheim gibi Fransız düşünür ve sosyologların yanı sıra Ingiliz Neo-pozitivist $H$. Spencer'in "Organist Sosyoloji" sinin oldukça etkili oldukları anlaşılıyor. Bununla birlikte, toplumu canlı bir organizmaya benzeten sonuncu sosyoloji akımının Türkiye'deki etkileri o kadar kalııı olmuş ve meselâ sosyolojik din araştırmalarında ciddi bir yankı bulmuş görünmüyor (Krş. Sezen, 1989/1: 31, 42). Başlangıçta, Batıdan gelen bu yeni bilime "hikmet-i ictimaiyye" yahut "ilm-i hikmet-i içtimaiye", "ilm-i ictimaî", "ictimaiyyat" gibi adlar verilmiş, sosyoloji terimi de giderek yerini almıştır. Özellikle II. Meşrutiyet döneminde Türk düşünürlerinin sosyolojiye olan ilgilerinde kayda değer bir artış gözlenmiş (Kongar, 1988: 15); nitekim bu dönemde üzerinde durulan çeşitli toplum sorunları arasında din meselesi de belli bir yer tutmuştur. Öyle ki, Batılı etkiler altında kalan ilk Türk sosyologları olarak pozitivist eğilimli Ahmet Rıza, Ahmet Şuayp, Bediî Nuri, M. Satı Bey, Celal Nuri, Prens Sabahattin, Ziya Gökalp ve Mehmet İzzet'in çalışmalarında, çeşitli sosyal meseleler arasında dine ilişkin sorunlara da önemli bir yer verilmekte oluşu kayda değerdir. Meselâ Bedi Nuri (1875-1915) özel sosyolojinin bir bölümü olarak, birer toplum olayı olmak itibariyle din olaylarını sosyolojik bir yaklaşım perspektifinde ele alıp inceleyen bir din sosyolojisi disiplininin varlığından söz etmiştir.

\subsection{Kuruluş}

Türkiye'de sosyolojinin ve onun bir alt dalı sayılan din sosyolojinin yer tutmasında Durkheim sosyolojisi önemli bir rol oynamıştır. Zira Türkiye'de din sosyolojisi biliminin gerçek bir öncüsü ve hatta kurucusu sayılabilecek olan Ziya Gökalp (1875-1924) büyük ölçüde Durkheim'ın izinden gitmiş, bu da onun Türk sosyolojisi ve özellikle de Türk din sosyolojisi üzerinde derin iz bırakmasına yol açmıştır (Ülken, 1969: 349).

\subsubsection{Gökalp ve İlm-i İctimaî Dinî}

Türkiye'de sosyoloji öğretimi 1914'te başlamış, İstanbul Darülfünun'unun Edebiyat şubesinde ilerlemiş öğrencilere 1916-1917 yıllarında "Dinî içctimaiyat" adı altında ilk din sosyolojisi derslerini Z. Gökalp vermiştir. Bu derslerin notları "ilm-i içctimaî Dinî" adı altında taş basması olarak basılmış, böylece Türkiye'de din sosyolojisi konusunda ilk olarak doğrudan telif eser yayınlayan düşünür ve sosyolog Z. Gökalp olmuştur. Esasen Gökalp, dünya ölçüsündeki büyük değişim ve dönüşümlere hantal yapısı nedeniyle ayak uydurmakta zorlanan Osmanlı İmparatorluğunun tarihinin duraklamadan çöküşe sürüklendiği ve bu bağlamda 
"toplumsal kimlik" arayışlarının ön plana geçtiği sancılı bir "toplumsal bunalım" ortamından çağdaş Türkiye Cumhuriyetine geçiş döneminin en etkili düşünürleri ve ideologlarından biridir. Nitekim bunalıma çözüm üretmeye çalışır ve bunun yolunun sosyal bir reformdan geçtiğini düşünürken Gökalp, aynı zamanda bir ulusal kimlik kuramcısı olarak da karşımıza çıkmaktadır. O, doğacak yeni toplumun kimliğini sosyolojinin kılavuzluğunda aramıştır. Anlaşılan Gökalp, Durkheim'ın dışında A. Fouillée (1838- 1912), M. Mauss (1872- 1950) ve G. Tarde (1843-1904) gibi Fransız düşünür ve sosyologlardan da etkilenmiştir. Özellikle Fouillée'nin "kuvvet-fikir" (idée-force) teorisinin Gökalp'in düşünceleri üzerinde derin etkileri bulunmaktadır. Buna, dolaylı yoldan da olsa Alman düşünürü Herder, Max Weber (krş. Kongar, 1996: 64). ve hatta İslam Tasavvufu ve özellikle de Muhiddin Arabî’den eklendiği anlaşılmaktadır (Günay, 1989/3: 223236). Her halükârda, devletçilik, milliyetçilik, korporatizm ve dayanışmacılık Gökalp sosyolojisinin temel dayanaklarını oluşturmakta; son tahlilde bu sosyolojisi natüralist ve pozitivist bir karakter arz etmekte; nihayet din sorunu orada üzerinde önemle durulan bir mesele olarak karşımıza çıkmaktadır. Bunalım dönemi düşünür, ideolog ve sosyologu Gökalp, Durkheim sosyolojisinin metodolojik esaslarını Türklerin tarihî ve toplumsal gelişimine uygulamayı denemekte; bunu yaparken de, kendi deyişiyle, "ümmet" yapısından "millet" yapısına geçiş döneminde "millî tip"in esaslarını belirlemeye çalışmaktadır. Durkheim'ın "kolektif tasavvurlar" kavramı ve sosyal olgulara sosyo-psikolojik yaklaşımından esinlenen Gökalp, ekonomi, san'at, eğitim, ahlâk, hukuk, siyaset gibi toplum olaylarının yanı sıra dini de "maşerî vicdan"dan doğan şuurlu idrakler kategorisine yerleştiriyor. Ulusal kimlik kuramcısı olarak "millî vicdan" telakkisinde kolektif şuur kavramına özel bir değer yüklüyor. Böylece Türklerin, din, soy, dil ve ülkü birliği etrafında bir millet oluşturabileceğini düşünüyor. Milleti, lisanı müşterek ve aynı terbiyeyi almış fertlerden oluşan harsî bir zümre şeklinde tanımlıyor. Bir milletin hayatında, biri "hars"a diğeri de "medeniyet"e ait olmak üzere iki ana unsur görüyor. Bunların belli bir ilişkide birleşmesinin toplum hayatının gelişmesini sağlayacağını düşünüyor. Gökalp'in temel problematiği, Türk millî kimliğinin İslamî ve modern bilimsel-rasyonel kimliklerle bağdaştırıması meselesidir. Dönemin düşünce akımlarını dinamik bir millî kimlik sentezinde uzlaştırmak ve hatta onları millî vicdanın motor gücü olan mefkûrelere dönüştürmek emelindedir. Daha doğrusu Gökalp, kültürde Türkleşmek ve isslamlaşmayı, medeniyette ise çağdaşlaşmayı amaçlıyor. Dini, millî kimliğin temel bir bileşeni olarak görüyor. Ancak, "gelenekçi İslam" anlayışını eleştiriyor. Devletin hukukî temelini dinî esaslardan temizlemeyi düşünmekte, böylece dindevlet ayırımını esas alan bir laikliğe yönelmiş görünmektedir. İslam dinini şeriatın katı kurallarından arındırmayı, sosyolojinin zenginleştirdiği içtenleştirilmiş bir inanç haline getirmeyi ve millî ihtiyaçların hizmetine vermeyi amaçlamakta; son tahlilde fikirleri arasında tam bir birlik kurabilmiş görünmemekle birlikte, dinin millî bir biçimde canlandırılarak yaşanması Gökalp'in din konusundaki esas çizgisini oluşturmaktadır. Her halükârda Gökalp'in, özellikle Durkheim'ın toplum 
ve din analizlerine ilişkin kategorilerini, Türk tarihi, toplumu, kültürü, dini ve hatta İslamiyet'e bir biçimde uygulamaya çalışmış olması Türkiye'de din sosyolojisinin kuruluşu ve yerleşmesi bakımından önemli ilk çabadır. Ancak anlaşılan o bunu yaparken, kategorilerin uygunluluk ve tutarlığının yanı sıra özellikle eski Türk tarihi, kültürü ve dini konusunda malzeme güçlüğü çekmekte, bu da onu yer yer acele çıkarım ve genellemelere götürmektedir. Bu bakımdan da meselâ H. Z. Ülken Gökalp'i eleştiriyor (Ülken, 1939: 37). Buna rağmen, İnalcık'a göre, Gökalp'in Türk toplumu ve kültürüne dinamik yaklaşımı özellikle değişim perspektifinde teorik ve metodolojik önemini sürdürüyor (İnalcık, 1965: 31). Buna onun din konusundaki analizlerinin önemini eklemek gerekiyor.

\subsection{Gökalpçi Etkiler}

Gökalp Malta'ya sürgüne gönderilince, üniversitede onun yerini Necmeddin Sadak alıyor. Anlaşılan Sadak'ın din sosyolojisine olan ilgisi onun "Dini İçtimâiyat Notları" adını taşıyan bir kitap yayınlamasına imkân veriyor (Ayas, 1976: 285-301). Öte yandan, Gökalp'in din konusuna sosyolojik yaklaşımı öğrencileri ve yakın arkadaşları tarafından az çok sürdürülüyor. Ancak tepkiler de eksik olmuyor. Meselâ Halim Sabit, Gökalp'in "ictimaî usulü fıkıh" anlayışını destekleyip geliştirmeye çalışmış; buna karşılık, modenist İslamcı İzmirli İsmail Hakkı ona şiddetle karşı çıkmıştır (Bkz. Efe, 2005: 25-40). Nitekim Gibb de, Gökalp'in bu görüşünü "sübjektif” bularak eleştirmiştir (Gibb, 1949: 125). Her halükârda Gökalp'in, Itttihat ve Terakki Fırkası üyesi Baha Said'i Anadolu'da içtimaiyat tetkikleri yapmak üzere görevlendirmesi, Türk toplumu üzerine alan araştırmalarına dayalı din sosyolojisi çalışma ve yayınlarını da başlatmıştır. Gökalp'in etkisi altında F. Köprülü bu çalışmaları din, tarih ve edebiyat alanlarında sürdürmüş, kelamcı i. H. İzmirli "islam içtimaiyatı"na yönelmiştir. M. Şerafettin (Yaltkaya) İslam Mecmuasında yayınlanan makalelerinde (S. 15, 19) "içtimaî ilm-i kelam"dan söz etmiştir. Öte yandan, Gökalp'in etkilerini meselâ Mehmet İzzet ve Z. F. Fındıkoğlu'nda bir şekilde görme imkânı olmaktadır. Ancak bunların her ikisinin de tam bir Gökalpçi çizgide kalmadıkları anlaşılıyor. Gökalp'in fikirlerinden yola çıkan Mehmet İzzet (1891-1930) felsefî idealizme yöneliyor (Ülken, 1979: 426-432). Fındıkoğlu ise, Fransa'da Strasbourg'da yaptığı doktora tezinde Gökalp'in sosyolojisi ve fikirlerini konu alıyor (Fındıkoğlu, 1935). Ancak, Fransa'da doktora öğrenimi esnasında fikirlerini geliştirme imkânı elde ediyor ve sırf Durheimcı ve Gökalpçi kalmayarak, Fransız sosyolojisini Kantçı bir yorumla bir iş ve "eylem" (aksiyon) felsefesine dönüştürüyor (Ülken, 1975: 475). Her halükârda, onun çalışmaları münhasıren din sosyolojisi alanında gerçekleşmiyor. Din konusuna o, yeri geldikçe temas ediyor. Yine de anlaşılan Fındıkoğlu, meselâ dinin toplumsal etkileri üzerinde önemle durmuş (Fındıkoğlu, 1959/1960: 174-175), hatta Türkiye'de din sosyolojini konu alan bir çalışma da yapmıştır (Fındıkoğlu, 1966: 223, 224). 
Anlaşılan 1920'li yılların sonları ve özellikle de 1930 'lardan başlayarak din konusu Türkiye'de sosyoloji incelemelerinde belli bir yer tutmaya başlamış; bu çerçevede, Fındıkoğlu'nun çalışmalarına H. Z. Ülken, S. Şakir Ülgener, M. Turhan, N. Ş. Kösemihal, C. Tanyol, N. Berkes, i. Yasa ve diğerlerinin çalışmaları eklenmiştir. Bunlardan meselâ N. Şazi Kösemihal (1909-1972), Türkiye'de Durkheim sosyolojisine eleştirel yaklaşımın tipik bir örneğini sunmakta olup; bu çerçevede onun Türk din sosyolojisine katkıları dikkate değer görünmektedir. Nitekim onun "Durkheim Sosyolojisi" başlıklı eserinin bütün bir bölümünde Durkheim'ın "Din Hayatının Iilkel Biçimleri" adlı eserinin eleştirel bir değerlendirmesi sunulmakta (Kösemihal, 1971: 98-172); buna onun din ve büyü ilişkilerini konu alan çalışması (Kösemihal, 1952, 1953) eklenmektedir.

\section{4. Ülken ve Dinî Sosyoloji}

Bununla birlikte, Türkiye'de din sosyoloji çalışmaları bakımından özellikle H. Z. Ülken'in (1901-1974) katkıları oldukça önemlidir. Nitekim onun Felsefe ve içtimaiyât mecmuasında "Dini Içtimaiyat" başlığı altında, 1927 ve 1928 yıllarında yayınlanmış bulunan üç makalesi oldukça dikkate değerdir (Ülken, 1927: 264-271; 319-333; 1928: 28-41). Keza onun, Totemizm tartışmalarını konu alan çalışması (Ülken, 1939) da Türkiye'de din sosyolojisi literatürüne önemli katkıları içermektedir. Bunlara Ülken'in öteki çalışma ve katkılarını eklemek gerekir (Ülken, 1946; 1959: 35-57). Esasen Ülken, Türkiye'de, Cumhuriyet döneminde din sosyolojisi alanında ilk olarak başlı başına eser ortaya koymayı da başarmıştır. Nitekim onun "Dinî Sosyoloji" adlı eseri (Ülken, 1943), dinlerin başlangıçları ve tarihsel evrimi üzerine Totemizm, Animizm, Natürizm, Fetşizm gibi kuramların yanı sıra, ölülere tapınma, kurban, giriş ayinleri, bayramlar, tabular, üstûreler, Tanrı, kozmogoniler, din ve içtimaî morfoloji, sihirbaz, Hıristiyanlık ve İslamiyet çeşitli tarihsel, toplumsal ve dinsel olgu ve kurumu konu almış bulunmaktadır. Bu şekli altında eser, Türkiye'de, din olgusunu sosyolojik bir yaklaşım perspektifinde sistematik bir biçimde ele alarak analiz ve açıklamaya çalışan bir din sosyolojisi anlayış ve yaklaşımı ortaya koyması bakımından dikkate değerdir. Esasen Ülken, İstanbul Üniversitesi Edebiyat Fakültesi’nde, 1950'li yıllarda verdiği sosyoloji dersi bağlamında din sosyolojisi de okutmuştur. Anlaşlan Ülken'in bu derslerinde konuya yaklaşımı Dinî Sosyoloji adlı eserindekinden ayrılmaktadır (Ayas, 2007).

Öte yandan, Türkiye'de din sosyolojisi XX. yüzyılın başlarından itibaren Batılı etkiler altında, ancak muhtelif arayışlar biçiminde bir gelişme göstermiş, bu durum bu bilim dalına verilecek isim arayışlarına da bir şekilde yansımıştır. Nitekim bu bakımdan meselâ Ülken'in 1943'te kaleme aldığı eserinde din sosyolojisi için "dinî sosyoloji" terimini seçmiş olması dikkate değerdir. Fransız din sosyologu G. Le Bras ile Alman din sosyologu G. Menschig de din sosyolojisi için bu terimini kullandılar. Ancak onların din sosyolojisi anlayışları birbirinden oldukça farklıdır. Öte yandan, XX. yüzyılın başlarında din sosyolojisi Türkiye'de üniversiter düzeyde yerini alırken Gökalp'în adlandırması ile ona "ilm-i içtimaî 
dinî" denmiş, ancak anlaşılan bizzat Gökalp "dinî içtimaiyat" terimini de kullanmıştır. Öte yandan, Gökalp'in bazı çalışmalarında "Islam içtimaiyatı" terimine yer vermiş olması da dikkate değerdir (Gökalp, 1331/1915a; 1331/1915b; 1331/1915c). Esasen İzmirli İsmail Hakkı'nın da "islam içtimaiyatı" terimini kullandığı anlaşılıyor (Efe, 2003: 325-333, 328). Ülken ise, gerek "dinî sosyoloji" terimini kullandığı bu eserinden önce ve gerekse de sonra genellikle "din sosyolojisi" terimini tercih etmiştir. Öte yandan, Türkiye'de din sosyolojisi için, "din toplumbilimi" gibi adlandırmalar da kendini göstermiştir. Ancak anlaşılan "din sosyolojisi" terimi Türkiye'de bu bilim dalı için genel bir kabul görmüştür. Yine de, doçentlik bilim dalları arasında onun önceleri "din sosyolojisi" şeklinde yer alırken daha sonra "din, bilgi ve kültür sosyolojisi" halini almış olması kayda değerdir.

\subsection{Le Play Sosyolojisi, Prens Sabahattin ve Monografi Yöntemi}

Türkiye'de Gökalp'le başlayan, sonra Ülken ve Kösemihal gibi sosyologlarca sürdürülen sosyoloji geleneği felsefî, hümanist ve spekülatif bir çizgide seyretmesi ve orada olgusal toplumsal gerçekliğin yeterince dikkate alınması yönünden eleştirilere maruz kalmış; öte yandan, XIX yüzyılda Fransa'da ortaya çıkıp gelişen Le Play sosyolojisinin Ed. Demolins'ci (1852-1907) yorumu Prens Sabahattin'in (1877-1952) öncülügünnde ve "Meslek-i İctimaî" adı altında Türkiye'ye uzanmıştır. Bu sosyoloji anlayışının monografi yöntemi, alan araştırmaları aracığı ile Türkiye'de toplumsal gerçeklikle doğrudan temas imkânı sağlamış; böylece Türkiye'de, "yaşanan din"in sosyolojik araştırmalara konu teşkil etmesine de zemin hazırlanmıştır. Nitekim U. Turhan ve M. Ali Şevki ile başladığı anlaşılan alan araştırmaları özellikle i. Yasanın monografi çalışmaları ile sürmüştür (Kongar, 1996: 210-211). Öyle ki, bu yol ve yöntem aracılığıyla, özellikle 1940 'lı yıllardan itibaren gerçekleştirilen alan çalışmaları köy, kasaba, şehir, bölge monografilerinde dine ve dinî yaşayışa bir ölçüde temas edilmesine imkân vermiştir. Nitekim meselâ ỉbrahim Yasa'nın, köyde dinî yaşayış konusunun başlı başına birer bölümde ele alındığı Hasanoğlan Köyü üzerine monografi çalışmaları, orada köyün dinî yaşayışı, din ve sihirle ilgili inanışlar ve adetlerin yanı sıra bu alanda meyanda gelen değişmeler ve buna yol açan etkenler üzerinde durmuş olması bakımından dikkate değerdir (Yasa, 1955; 1969). Kayda değer bir başka husus da, bu çalışmalarda sosyografik tespitlerin ötesinde faktör analizlerine yer verilmekte oluşudur. Ülken ve Tanyeli'nin "Gönen Bölge Monografisi" buna tipik bir örnektir. Esasen bu araştırma, Ülken'in sosyoloji ve hatta din sosyoloji çalışmalarında sırf felsefî ve spekülatif düzeyde kalmadığını da göstermektedir. Öte yandan, çalışmada, mevsimsel değişim, yerlilik/göçmenlik, cinsiyet ve yaş faktörlerinin dinî ilgiye olan etkilerine işaret edilmekte oluşu dikkate değerdir. Anlaşılan, köy hayatının yaz ve kış şeklindeki mevsimsel değişimi özellikle kırsal hayatta dinî pratiklere olan ilgiyi etkilemektedir. Keza göçmenlerde dine olan ilgi, yerlilerden daha fazladır. Cinsiyet ve yaş faktörleri de dine olan ilgiyi bir biçimde etkiliyor (Ülken ve Tanyeli, 1955-1956: 
114-154). Nitekim hemen bütün toplumlarda genelde kadınlar dine erkeklerden daha çok ilgi ve eğilim gösteriyor. Yaşın ilerlemesi genellikle dine olan ilgide bir artışla karakterize oluyor. Türkiye'de, köylerde dinî yaşayış ve kültürün kısmî monografik çalışmalar aracılığı ile sosyolojik tetkiki bakımından C. Tanyol'un Elifoğlu Köyü araştırmasının (Tanyol, 1962-63: 203-204, 215-222) yanı sıra, Mümtaz Turhan'ın "Kültür Değişmeleri” adlı eserinde yer alan monografi çalışmasının (Turhan, 1972: 112-115) önemine de işaret etmek gerekiyor.

\subsection{Weberci Etkiler}

Gökalp'in din sosyolojisinde Weberci etkilerin bulanık izlerine işaret edilmişti. Weber ve Sombart'ın din ve ekonomi ilişkileri ve özellikle de Weber'in, Batıda kapitalizmin ruhunun şekillenmesinde Protestan ahlakının oynadığı role dair görüşü, 1930'lu yılların ortalarından itibaren bu yaklaşımın Osmanlı-Türk toplumuna uyarlaması çabalarını beraberinde getirmiştir. Nitekim özellikle S. F. Ülgener'in (1911-1983) Osmanlı-Türk toplumunun sosyo-ekonomik hayatı ve tarihinde zihniyet ve din ilişkilerine dair çalışma ve yayınları dikkate değerdir (Ülgener, 1941, 1951a, 1951b, 1981a, 1981b, 1983). Anlaşılan Ülgener, Türkİslam iktisat ahlâkına dinî etkinin tasavvuf kanalı ile işlediğini ve Türkiye'nin ekonomik geriliğinde, Orta Çağdan aktarılan düşünce geriliğinin önemli rolünün bulunduğunu düşünmektedir. Türkiye'de Weberci etkileri meselâ Ş. Mardin, N. Vergin ve O. Türkdoğan'ın çalışmalarında da görme imkânı olmakta (Türkdoğan, 1985); konu son dönemde Türkiye'de din ve modernleşme ilişkileri, Kalvinist ahlâk ve Anadolu Kaplanları bağlamında "European Stability Initiative" (ESI) in "Kayseri Raporu" ile yeniden gündeme gelmiş bulunmaktadır (5).

\section{7. Çağdaș Türkiye'de Din, Modernleșme ve Sekülerleșme}

Türkiye'de Tanzimat'la başlayan, özellikle Cumhuriyet'in kuruluşu ile hızlanan değişim ve dönüşümler 1950 'ler ve 1960 'larda, çeşitli iç ve dış dinamikler bağlamında yeni bir ivme kazanmış, bu gelişmeler özellikle 1970'lerden itibaren ülkede İslamî bir yeniden canlanmadan söz edilmesine kapı açmıştır. Türk toplumunun karşı karşıya kaldığı bu yapısal değişimleri incelemek üzere gerçekleştirilen sosyolojik araştırmalarda din konusuna olan ilginin de bu çerçevede giderek bir artış kaydetmiş olması dikkate değerdir. Esasen, 1945'ten sonra başta Avrupa olmak üzere tüm dünyaya yayılan analitik ve empirik karakterli Amerikan sosyolojisi Türkiye'ye de uzanmış, bu çerçevede Türk sosyolojisinde yapısalişlevselcilik yaklaşımına dayalı modernleşme analizleri kendini göstermiş, buna diğerleri ve meselâ Marksist yaklaşımlar bağlamındaki modernleşme teorileri eklenmiştir. Her halükârda, din konusu bu tür teorik yaklaşımlara dayalı sosyolojik incelemelerde bir ölçüde yerini almıştır. Nitekim Türkiye'de, modernleşme teorilerine dayalı din incelemelerinin örneklerini meselâ M. B. Kıray, N. Berkes, i. Yasa, E. Güngör, Ş. Mardin, B. Akşit, O. Türkdoğan, N. Göle, vd.nin çaıışmalarında görmek mümkündür. Aslında, Batı'daki gibi, Türkiye'de de, din sosyolojisinin gelişmesi, Türk toplumunun modernleşmesi ve bu çerçevede 
dinle ilişkiler bağlamında kendini gösteren değişim ve dönüşüm sorunları ile yakından ilişkili olmuştur. Öyle ki köklü değişim ve dönüşüm sorunlarına çözüm arayan Türk din sosyologları modernleşme, çağdaşlaşma, sekülarizasyon, laiklik, değişme, post-modernizm ve küreselleşme konuları üzerinde önemle durmuşlardır. Hakikaten meselâ modernleşme ve laiklik konusu, Gökalp'in üzerinde önemle durduğu bir meseledir. Öyle ki o bunu üçlü sentezinde "muasırlaşma" terimi ile ifade etmektedir (Gökalp, 2008). Çalışmalarına 1930'lu ve 1940 'ı yıllarda Türkiye'de başlayan ve 1950 'li yıllardan itibaren Kanada'da McGill Üniversitesi'nde sürdüren sosyolog N. Berkes'in Türkiye'de Çağdaşlaşma (Berkes, 1973) ile Teokrasi ve laiklik (Berkes, 1997) adlı eserleri, Osmanlıdan itibaren Türk toplumunun dinle ilişkiler bağlamında geçirdiği değişimleri ve bu bağlamda ortaya çıkan modernleşme ve sekülarizasyon meselelerini konu almaktadır. Laiklik ile sekülarizmi birbirinden ayıran Berkes'in "çağdaşlaşma" terimine "sekülarizasyon" anlamını yükleyerek, Osmanlıdan günümüze Türk toplumunun uğradığı değişime din-devlet ayırımının ötesinde geleneksellikten modernliğe uzanan bir değişme perspektifinde yaklaşımı ve bu bağlamda kendini gösteren dinî oluşumların aslında çağdaşlaşmaya tepkisel oluşumlar olduğu şeklindeki diyalektik yorumu dikkate değerdir (Kongar, 2008). Ancak böylesine bir yorumun dinî olguları öteki toplumsal olgulara indirgeme tehlikesine işaret etmelidir. Nitekim meselâ geleneksel tarım toplumundan modern sanayi toplumuna geçiş sürecindeki Türk toplumunun sosyolojisine iliş̧in analizlerinde "fonksiyonalist" yaklaşımı esas alan ve "tampon kurumlar" terimi Türkiye'de din araştırmalarında sıklıkla kullanılan M. B. Kıray'ın dine yaklaşımı da anlaşılan son tahlilde bu tür bir indirgemeciliğin tipik bir örneği olarak karşımıza çıkmaktadır. Öyle ki, Kıray'ın din ile ilgili açıklamaları temelde, dinin aşama aşama kaybolacağı şeklindeki, XIX yüzyıldan kalma evrimci pozitivist düşünceye dayanmaktadır. Kıray sekülarizmi, dinselliğin alanının daralması ve sonra da kaybolması şeklinde değerlendirmektedir (Kıray, 1982; Başak, 2005: 44). Din konusuna böylesine bir pozitivist yaklaşım çerçevesi anlaşılan meselâ i. Yasa'nın Türkiye'de toplumsal yapı analizleri ve bu bağlamda ortaya koyduğu yorumlara da temel teşkil etmiş görünmektedir (Yasa, 2005: 47). Bunun gibi, Türkiye'de kadının sosyal konumunun belirlenmesinde dini tek başına bir etken olarak değerlendiren B. Gökçe'nin din tanımına da anlaşılan pozitivist yaklaşım çerçevesi egemendir (Gökçe, 2005: 53).

Öte yandan, Türkiye'de laiklik ve hatta daha geniş perspektifte sekülarizm konusu sosyologların üzerinde önemle durdukları bir mesele olmuş ve olmaya devam etmektedir. Nitekim meselâ A. Kurtkan'ın bir çalışması Sosyolojik Açıdan Tasavvuf ve Laiklik meselesini ele almış (Kurtkan, 1977), buna onun din sosyolojisine ilişkin öteki çalışmaları eklenmiştir (Kurktan Bilgiseven, 1985, 1989, 1992). "Din ve Laiklik Sosyolojisi", ODTÜ'den sosyolog B. Akşit'in önemli bir ilgi alanını oluşturmakta, nitekim meselâ onun bir makalesi konuya tipolojik perspektifte yaklaşmayı denemektedir (Akşit, 2005: 65-103). F. Atacan'ın bir çalışması İslam 
ve sekülarizm ilişkilerini analiz etmekte (Atacan, 2002), onun bir başka çalışması Türkiye ve Arap dünyasında sekülarizmin karşılaştırılmasına yönelmektedir (Atacan, 2000). Modernleşme-lâikleşme-sekülerleşme teorisi perspektifinde çağdaş Türkiye'de İslâm, dinî hareketler ve tarikatlar konusunda sekiz ayrı çaıışmanın sonuçlarını sunan ve değerlendiren $R$. Tapper'in analizleri de dikkate değerdir. Tapper, Türkiye'deki İslâmî canlanışın köklü biçimde yeni ekonomik koşullara, 1980 sonrası gençliğin ana babalarının laik çizgisini izlemek istememelerine, dış kökenli isslâmî para kaynaklarına ve modern iletişim araçlarına bağlandığııı; ancak orada temel unsurlardan birinin, değişen ve bu çerçevede yabancı değerlerin baskısı altında bunalan bir toplumun kimlik arayışı olduğuna işaret etmektedir. Tapper'a göre, daha genel bir çerçevede bu hareketler, Üçüncü Dünya'nın, Batı ve Sovyet uygarlıkları ile ilişkilendirilen materyalizm ve lâikliğe tepkisinin ifadeleri addedilmelidir. Nitekim, nasıl ki, 1908-23 Türk devrimi XIX. yüzyılın sonuna damgasını vuran dünya çapındaki büyük çalkantıya Türklerin bir cevabı olmuşsa, 1970'ler ve 1980'lerin Türkiye'sinde i̇slâm'ın canlanışı da, antimateryalizm ve belki de postmodernizm gibi daha geniş XX. yüzyıl sonu hareketlerinin bir parçası olmuştur. Tapper, olayın yine de Türkiye'ye özgü bulunduğunu ve farklı evreleri ile dışa vurumların daha özgül etkenlere dayandırılabileceğini önemle belirtiyor (Tapper, 1993: 30-31).

Modernleşme-lâikleşme teorisi ile ilişkili olmakla birlikte, Türkiye'de dinî hareketler, cemaatler ve tarikatlar konusuna değişik bir yaklaşımı temsil etmesi sebebiyle "Merkez/Çevre Modeli" yahut E. Gellner'in deyişi ile "Sarkaç Teorisi"ne işaret etmelidir. Zira anlaşılan Gellner'in salınma nazariyesi, çok sistemli olmasa da, Türkiye'de 1970 ve 1980'lerden itibaren kendini gösteren dinî oluşumların çözümlenmesine bir referans oluşturabilmiştir. Davide Hume'un, Dinin Tabiî Tarihi (The Natural History of Religion) adlı eserindeki, dinî tarihin "politeizm ile monoteizm arasındaki bir salınma" şeklinde açıklanabileceği şeklindeki teorisi ile ibn Haldun'un, siyasal sistemin dinamiklerini "elitlerin kabilevî sirkülasyonu" ile açıklayan nazariyesini birleştirerek Müslüman dinî-sosyal ve siyasal hayata uygulayan Gellner, İslâm tarihi içerisinde Müslüman dinî hayatın kitabî İslâm'ın şehir medeniyetine dayalı sıkı monoteizmi ile kabilelerin mistik eğilimli sûfi ìsâm'ı arasında ve Orta Çağ boyunca Müslüman toplumsal ve siyasal hayatın da merkezî iktidar ve onun şehir medeniyeti ile kırsal bölgelerin kabile asabiyeti arasında gelgitlerle karakterize olan bir döngüsellikte cereyan ettiğini öne sürmüştür (Gellner, 1968: 5-14). Nazariye modern dönemin Müslüman toplumlarının dinî-toplumsal oluşumları ve dönüşümlerine uygulanmaya başlayınca, bu çift kutuplu salınma, Gemeinschaf'ı yani "gelenekli toplum yapısı"nı temsil eden taşra kültürü veya kırsal kültür yapısı ile temelinde modern Batı kaynaklı "Gesellschaft" (cemiyet) tipi şehir kültürü arasındaki bir döngüye dönüşmektedir. Yeni şekil altında bu paradigmayı modern dönemin Müslüman topluluklarına uygulayanlardan Kupferschmiat, Mısır'da "Müslüman Kardeşler" (ihvan-ı Müslimin)in militan İslâmcı hareketini, onun tabanının çevresel kasa- 
balarda gelişmiş olması sebebiyle, Mısır'daki köy/şehir ikilemi çerçevesinde algılıyor (Kupfershmiat, 1987: 403-419). Bu çerçeveden yaklaşıldığında, meselâ Ş. Mardin'in, Türkiye'deki İslâmî canlanmayı çevreye ve özellikle de taşra kasabalarına odaklayarak, süreci "çevrenin merkezi fetih hareketi" biçiminde değerlendirmekte oluşu kayda değerdir (Mardin, 1989: 163-186). Teoriyi, Türkiye'deki çevresel nitelikli tarikatlara uygulayan S. Ayata, taşra kasabasının geleneksel din görüşlerinin radikal inançlara dönüşmesi için son derecede elverişli bir ortam oluşturduğunu belirtmektedir (Ayata, 1993: 134). Öte yandan, 0 . Türkdoğan da, Gellner'in iki kutuplu salınma nazariyesine, Türk toplumunda çevrenin gelenekli yapıdaki kırsal kültüründen modern toplumun cemiyet tipi anonim kültürüne geçişin sancıları ve uyumsuzlukları ve bu çerçevede oluşan kaos ortamında dinin odak noktasına dönüşmesi ve buna bağlı olarak toplumda sûfi İslâm'ın yükselişini değerlendirirken atıfta bulunmaktadır. Türkdoğan, insan aklını yücelten, deney ve gerçeklik dışında hiçbir varlık alanı kabul etmeyen Mantıkçı Pozitivist düşünce ve Sekülarizm, Batıda dini sosyal hayattan söküp atarak özelleştirdiği gibi, lâikliğin de Türkiye'de dine bu niteliği kazandırdığını düşünüyor. Türkdoğan'a göre, Türkiye'de özellikle 1940'lardan itibaren dozu gittikçe artan dinî değerlerin bizzat dinden soyutlanması anlamındaki bir sekülarizm gündeme gelmiştir. Böylece, millî ve tarihî köklerden uzaklaşma hatta Greko-Latin kültüre yönelik tutum ve zihniyetlerin belirmesi, Bennigsen'in Sovyetler Birliğindeki Müslüman topluluklarda gözlediği biçimde (bkz. Bennigsen, 1988), halk katlarında veya "Volk is/âmı"nda yasal olmayan çizgide "sûfi" gelişmeleri yasal çizgide ise "komiser" imajını oluşturmuş, bu şekilde kültürel yaşantımıza "paralel islâm" sokulmuştur. Öyle ki, Mardin'e göre, toplum yaşantımızda seküler girişimler ne kadar hızlanmışsa, sûfi tepki de o nispette toplum katlarında yayılma olanağına erişmiştir. R. Bellah'ın deyişi ile, Türk toplumunda, "kök paradigma" şeklinde ifade edilebilecek olan çelişkili sosyal oluşum ortaya çıkmıştır. Nitekim Türkdoğan'a göre, Türkiye'de özellikle son dönemin Aczimendi ve tarikatlaşma olgusu, artan Sünnî-Alevî, laik-Müslüman, İslâmcı-devrimci türünden derin sosyal yarılma ve zıtlaşmalar, Volk i̇slâm'ın kendine daha güvenilir yerler aramak için sûfi geleneğe sarılmasını gündeme getirmiştir. Türkdoğan, Türkiye'de, bu aşırı sekülârizm veya dünyevileşmenin yanında, 1950'lerden sonra kapitalistleşme sürecinin gündeme getirilmiş olması ve "cemaatçi" yapıdan "cemiyetçi" yapıya yahut "gelenekli" yapıdan "modern toplum" ve "kültür"e geçişin de önemli ve köklü bir dönüşüme yol açtığını belirtiyor. Dayanışma ve birliktelik gibi eski yapısal unsurlar çözülmeye başlamış, bunun yerine kültürel bağlara dayalı ilişkiler sistemi geçirilmek istenmiştir. Batı'nın iki yüzyılda tamamladığı teknolojik ilerleme ve sanayileşme sürecinin Türkiye'de çok kısa bir zamanda kat edilmeye çalışılmış olması, Türk toplumunun geleneksel yapısal değerlerini derinden etkilemiş; böylece aile, akrabalık ve yöresel bağların çözülmeye başlaması yapısal bir kimlik zemininin de kaybolmaya yüz tutmasını beraberinde sürüklemiştir. Nitekim bu durumda kalabalıklar içerisinde yalnız kalan insanları toplamak için din, milliyetçilikle de birleşmek suretiyle, 
toplayıcı, birleştirici ve çekici bir unsur olarak ön plana çıkmıştır. Geleneksel toplumdan modernleşmeye geçiş düz bir çizgide gitmemekte, önemli toplumsal bunalımlara ve gerginliklere yol açmakta, değerler sistemini alt-üst etmekte, bu durumda "standart Kültür" veya "büyük Toplum" diye belirlenen çoğunluk kültüründe "karşıt-kültür" ve "alt-kültür"lerin tepkileri belirmekte, gecekondu ve varoş çizgisinde gelişen marjinal gruplaşmalar bu karşıt-kültür alanını teşkil etmektedir. Böylesine bir toplumsal kaos ortamında din ve milliyetçilik, "kalabalık içindeki yalnız insan"a bir dayanışma çerçevesi oluşturabilecektir. İşte, Türkdoğan'a göre, II. Dünya savaşından sonra ve özellikle de 1970'li ve 1980'li yıllardan itibaren Türkiye'de geleneksel İslâm'ın yükselişinde bu ortamın payı bulunmaktadır. Zira, yeni yapısal paradigma, tüm gelenekli dokuyu bozmuş, kişiyi bir belirsizlik içine itmiştir. Bu, bir anlamda kimlik arayışıdır. Türkiye'de son yıllarda giderek İslâmî okullaşmanın yoğunluk kazanması, yerli ve yabancı İslâmî kültürün yayın hayatına sokulması, İslâmî eğilimli siyasî partiler, sendika ve medya kuruluşlarının gündeme gelmiş olması, yurt içi ve yurt dışı sınaî kuruluşların büyük çapta örgütlenmesi, "sûfi" hareketin İslamcı üst tabakaya yansımasıdır. "Cemaatleşme", hem "Aydıncı İsâm" hem de "Volk islâm"ın mobilizasyonudur. Toplum dinamiğinin alt ve üst katlarında yeni i̇slâmcı oluşumlar böylece ortaya çıkıyor. Gerçekte ise, daha geniş bir perspektiften bakıldığında, tüm İslâm ülkelerinde, Batının sömürgeci ve oryantalist eğilimli politikalarına karşı bu bir diriliş, bir çeşit "katarsisa" (ruhu yıkama) eylemi biçimidir. 1980'lerden sonra Aydıncı İslâm, güçlü cemaat liderleri öncülüğünde, yeraltı döneminde kazandığı meslek grupları ve okumuş-eğitilmiş kadroları ile iktisadî alana yönelmek suretiyle holdingleşme sürecine girdi. İslâmî bir burjuva sınıfı belirmeye başladı. Birbirine kapalı bu cemaaatleşme modeli, kısa sürede finans kuruluşları, medya ve basın alanındaki örgütleşmeleri, ithalat ve ihracata dönük eylem biçimleri yanında, inşaat sektörü, tıbbî örgütlenme ve yüksek düzeyde eğitim sektöründeki girişimleriyle adeta "devlet içinde devletçik" durumuna geldi. Türkdoğan'a göre, bu, bir tür "islâmî anlayışın iktisadîleşmesi" olgusudur. Halk katlarına yönelik "irşad" görevini dinlenmeye alan sûfi hareket, böylece üst tabakaya yönelik tutum ve davranış biçimlerini karşılayan bir iktisadîleşme ve aydınlanma sürecine girmiş; halk i̇slâm'ı ise adetâ dışlanmıştır. Bu bakımdan, Türkdoğan, Türkiye'de son dönemde gelişen tarikatlaşma ve Aczimendi karşıtkültür oluşumlarının, aslında 1923'ler Türkiye'sinde rafine edilmeyen ve illegal alana itilen din gerçeğinin adeta yeni biçim ve kalıplarla tarih sahnesine çıkması olgusu şeklinde değerlendirmektedir (Türkdoğan, 1997: 35-38). Türkdoğan'ın çağdaş Türkiye'de din, modernleşme, sekülerleşme ve dinî cemaatler konularına öteki birçok çalışmasında az çok yer ayırmaktadır. Nitekim meselâ onun Türkiye'de millî kültür, modernleşme ve İslam konusuna dair eseri (Türkdoğan, 1983) bu çerçevede kayda değer analiz ve yorumları içeriyor. Esasen Türkdoğan'ın analizleri, Türkiye'de din sosyoloji konusunda en dikkate değer isimlerden biri olan Ş. Mardin'inkilerle büyük ölçüde paralellik arz etmektedir. 
Gerçekte, Türkiye'de din konusunda sosyolojik analizlere gerek "merkez/çevre" ve gerekse de "Kitabî İslam/Volk İslam'ı" kategorilerini akademik bir bağlamda devreye sokan Ş. Mardin olmuştur. Öte yandan, Mardin'in, Türkiye'de halk katlarında "yaşanan islam"ın en azından Osmanlıdan Türkiye Cumhuriyetine ve hatta oradan günümüze uzanan süreçte, tarihsel, toplumsal, kültürel ve işlevsel boyutları altında ve din sosyolojisinin yaklaşım perspektifinde bilimsel araştırma ve incelemelere konu olmaya başlamasında oldukça önemli bir rol oynadığı ısrarla vurgulanmalıdır. Bu çerçevede, onun özellikle din ve ideoloji ilişkilerini konu alan çalışmasının önemine işaret etmelidir. Çalışmanın daha başında "Metodolojik Bir Not" başlı̆ı̆ altında yönteme ilişkin sorunlara işaret edilmiş olması, Mardin'in Türkiye'de din konusuna sosyolojik yaklaşımda yöntem arayışının önemini göstermek bakımından dikkate değerdir. Modern tarih bilimleri ile sosyoloji, psikoloji ve sosyal antropoloji gibi modern davranış bilimlerinin metotları bu çalışmada kombine edilmeye çalışılmak suretiyle bir analiz şeması oluşturulmaya çalışılmaktadır. Ancak Mardin, eserinin ikinci baskınsa Önsöz' ünde "davranışsal" sözcüğünden vazgeçtiğini, zira davranışsalcılığın sosyal bilimlerde basitleştirici bir analiz şeması sunmaktan öteye gidemediğini, dolayısıyla da davranışsalcı yaklaşımın sosyal aksiyonu esas alan ve "ideal tip" yaklaşımına yönelen Max Weber sosyolojisi ile birlikte kullanılmak istenmesinin uygun olmadığına işaret ediyor. Öte yandan, anlaşılan Mardin, Levi-Strauss'ın yapısalcığını Geertz' in "sembolik süreç" tarzındaki din tanımı ile kombine etmek suretiyle, Türk toplumunda "yumuşak" bir ideoloji olarak din olgusunu incelemeye yönelmiş bulunmaktadır. Yine de Mardin, aslında M. Arkoun'un "neostrüktüralist" yaklaşımının çok daha anlamlı olacağını düşünmektedir. Her halükârda, anlaşılan Mardin, çağdaş Türk toplumunda sosyolojik yaklaşım perspektifinde din analizi konusunda dinamik bir metodolojik tutum ve hatta arayış içerisindedir. Öte taraftan, Mardin'in analizleri, Türkiye'deki dinî yaşayış ve oluşumlar konusunda, Türk toplumunun kendi iç ve dış şartları ve dinamiklerini belli bir ölçüde gözetmeyi inmal etmemeye özen göstermektedir. Mardin'e göre, Tönnies'in deyişiyle, "Gemeinschaft" (Cemaat) ilişkilerden "Gesellschaft" (Cemiyet) ilişkilere geçiş, modern dünyanın başka yerleri gibi Türkiye için de en önemli uyum problemini oluşturmaktadır. Geleneksel Osmanlı sosyo-kültürel yapısı, "padişah-kul", "baba-evlât", "hoca-talebe" ve "pîr-mürid" gibi kişiye bağlılık ve patrimoniyal ve karizmatik ilişkiler üzerine temellenmiş bulunmaktaydı. Buna karşılık, ümmet yapısından yeni çıkmış olan Türk toplumunda, Cumhuriyet'in "sembolizm"i fazla "kök salamayacak" kadar yüzeysel bir biçimde ortaya çıkınca, kimlik sağlama ve hayatın ilkelerini düzenleme konusunda İslâm'a alternatif olamadığını göstermiş ve sonuçta özellikle kırsal nüfusu kendine çekmede oldukça başarısız kalmıştır. Böyle olunca boşluk, halk katlarında, topluma bir dünya görüşü ve kişisel denge sağlayan "halk dini" (Volk islâmı) tarafından sağlanmıştır. Mardin'e göre, İslâm dünyasının başka yerlerinde olduğu gibi, Türkiye'de de değişime karşı İslâmcı tepki ve İslâmî yeniden canlanış, merkeze karşı "çevre"den oluşmaya başlamak suretiyle gelişmiştir. Mardin'in tahlilleri, mo- 
dernleştirici görüşün, toplum sorunlarını sırf ekonomik problemler biçiminde ele alıp, kişisel denge unsurlarını sağlama yoluna gitmediği sürece bize yalnızca "güdük, eksik ve kendini beğenmiş bir toplum modeli vermekten başka bir şey yapmış olmayacă̆ı" sonucuna erişiyor (Bkz. Mardin, 1983). Öte yandan, Mardin'in Türk toplumunun dinî yaşayışının sosyolojisi konusundaki bu eserine, öteki çalışma ve yayınları eklenmektedir (Bkz. Mardin, 1991, 1992a, 1992, 2006).

Modern Türkiye'de din, dinî yaşayış ve özelikle de sûfi İslâm'ın canlanışını ve hatta dinî ve mistik hayatı ve dolayısıyla da bundan kaynaklanan toplumsal oluşumları, toplumsal kadrosu bağlamında ele almak ve analiz etmek ve meselâ toplumsal değişim perspektifinde açıklamak yerine, son tahlilde, tarihî, toplumsal, sosyo-ekonomik ve kültürel kadrosundan büyük ölçüde bağımsız bir iç dinamik perspektifinde ele alan bilimsel paradigmanın tipik bir örneğini belki de E. Güngör'ün, misitisizmi, İslâm tasavvufunun meselelerini ve tasavvufun halk katlarında teşkilatlanmış şekilleri olan tarikatları ve nihayet günümüzde ve özelikle de Türkiye'de tasavvuf ve tarikatlar konusunu ele alıp tartıştığı çalışmasında görme imkânı olmaktadır. Gerçi Güngör, tasavvuf ve tarikatları, bir ölçüde toplumsal çerçevesi ile ilişkilendiriyor görünmekle birlikte, son tahlilde onun bunu aşan bir gerçeklik olduğunu önemle belirtiyor (Bkz. Güngör, 1982). Güngör'ün konuya böylesine spiritüalist bir perspektiften yaklaşımı, konuya meselâ Eliade örneğindeki fenomenolojik yaklaşımı eğilimi ile kayda değer bir paralellik arz ediyor. Bununla birlikte olayı iç dinamiklerinin yanı sıra dış dinamikleri çerçevesinde incelemek de oldukça önemli ve aydınlatıcı görünmekte, ancak bunu yaparken, bu defa da sosyolojistler, psikolojistler, tarihî maddeciler yahut historisistler gibi ircacıların aşırı eğilimlerine sürüklenmemeye dikkat etmek de gerekecektir. Nitekim ülkemizde konu ile ilgili olarak bu güne kadar gerçekleştirilmiş bulunan çalışmalarda anlaşılan bu son durumun yankıları da eksik değildir.

Türkiye'de örgütlenmiş dinin sosyo-ekonomik tabanını sosyolojik bir perspektifte ele alan A. N. Yücekök'ün temel analiz çerçevesini Marksist diyalektik yaklaşım modeli oluşturmaktadır. Gerçi Yücekök'e göre din konusuna sosyolojik yaklaşım için fonksiyonalist kuram da mevcuttur. Ancak o bu kuramın yapıyı ve özellikle de değişmeyi yeterince açıklayamadığını düşünmektedir. Konuya böylesine diyalektik yaklaşım ve analizler ise onu, Türk toplumunda dinin sadece, ya az gelişmiş bölgelerde hâkim toplumsal ve ekonomik grupların çıkarlarını korumaya yaradığı veya hızı gelişmeden olumsuz biçimde etkilenmiş bireyler yahut gruplar için bir protesto işlevini üstlendiği çıkarımına götürmektedir. Anlaşılan böylesine bir diyalektik yaklaşım, dini toplumdaki sosyal fonksiyonlarından birine ve genellikle de sosyo-ekonomik işlevine indirgemek suretiyle anlamak şeklindeki bir tek yanlılığa kapı açmakta; mamafih Yücekök'ün çalışmasında fonksiyonalist yaklaşımı bir şekilde devreye sokmaktan da geri kalmadığı görülmektedir (Bkz. Yücekök, 1968). 
Bununla birlikte, modern Türkiye'de din konusuna fonksiyonalist yaklaşımın oldukça tipik örneklerini özellikle F. Atacan ve N. Vergin'in çalışmalarında bulmak mümkün olmaktadır. Atacan, M. Kıray'ın fonksiyonalist modelinden hareketle, genel toplumsal değişme perspektifinde, Türkiye'de dinin tarikat düzeyinde geçirdiği değişimi Cerrahiler örneğinden hareketle inceleme konusu yapmaktadır. Türkiye'de özellikle II. Dünya savaşını takip eden dönemden itibaren gerçekleşen yapısal değişime paralel olarak dinin de hem örgütlenme hem de değerler, davranış biçimleri ve dünya görüşü bakımından önemli değişmelere sahne olduğu belirtiyor. Sonra da, Türkiye'de İslâmî yeniden canlanış denilen olgunun, gerçekte değişen toplum yapısında dinin yeni bir tarzda kendine yeni bir konum aramasından ibaret bulunduğu sonucuna varıyor. Atacan'a göre, hızla değişen Türkiye'de, Nakşibendî oluşumların alt gelir gruplarını harekete geçirici yeni etkin örgütlenme modelleri geliştirmek suretiyle yaygınlık ve önem kazanmalarına karşılık, Cerrahîler gibi alt-orta ve üst-orta tabakalara dayanan tarikatlar birer ara form olarak uyum mekanizması işlevi görmek suretiyle önemlerini artırmışlardır. Klâsik tarikat yapısını koruyan Mevlevîler, Rıfaîler ve Kadirîler toplumsal yapı ile bütünleştiklerinden nispeten zayıf kalmakta; her halükârda, hızlı sosyo-ekonomik değişimin güvensizlik ortamında, İstanbul'da Cerrahi tarikatı, önemli bir sosyal güvenlik mekanizması olarak çalışmakta ve bu mekanizma sayesinde hem grubun kendi içinde bütünleşmesi hem de dış sosyal yapıya entegrasyon sağlanmaktadır (Atacan, 1990: 18- 19). Sanayileşme ve bunun beraberinde getirdiği toplumsal değişmenin fonksiyonel olarak din alanındaki yankılarını başıca Ereğli çevresindeki gözlemlerinden hareketle ele alan Vergin'e göre ise, Türkiye'de özellikle son dönemde gözlenen "dinsellikteki artış", aslında ekonomik gelişmeye paralel olarak toplumu istilâ eden yabancı kültür değerlerinin yarattığı bir bunalımın tepkisel anlatımından ibarettir (Vergin, 1985: 9-28).

Her halükârda, dindarlık ve muhafazakârlık Türk toplumunun önemli özellikleri arasında kalmaya devam etmektedir. Bununla birlikte, sanayileşme, teknolojik gelişmeler, kentleşme, eğitim öğretim ve iletişimin yaygınlaşması, iç ve dış göçler, küreselleşme vb. etken, olgu ve süreçler bağlamında kendini gösteren değişim ve dönüşümler Türk toplumunun geleneksel yapısı, yaşantısı, kültürü ve değerlerini oldukça olumsuz biçimde etkilemekte, büyük çalkantı ve bunaIımlara kapı açmaktadır. Öyle ki, toplumun geleneksel dinî yaşantısı ve kültürü yoğun farklılaşma ve hareketliliğe sahne olmakta; bu da, Türk toplumunu din sosyolojisi incelemeleri için eşsiz bir laboratuar kılmaktadır. Nitekim 1970'li ve özellikle de 1980'li yıllardan bu yana Türkiye'de gözlenen değişimler, başta sosyologlar olmak üzere din konusuna olan sosyolojik ilgiyi giderek artırmıştır. Din ve siyaset ilişkileri, radikal dinci hareketler, şiddet, tarikatlar, Diyanet, Alevilik, kimlik, sivil toplum, demokrasi, insan hakları, özellikle de kadın sorunu ve hatta göç ve Batı toplumlarında Müslüman kadın ve örtünme yahut radikal İslamcı oluşumlar üzerinde önemle durulan konular arasında yer almaktadır. 
Öyle ki, Batılı bir kısım araştırmacıların bile Türkiye'de din sorununa sosyal bilimsel ve sosyolojik yaklaşım bağlamında çözümlemelere yöneldikleri dikkati çekiyor (6). Öte yandan, Türkiye'den meselâ D. Kandiyoti (1997), Y. Arat (2001: 31-46; 2007), B. Toprak (1979: 381-391; 1990: 39-49; 1994: 293-306), N. Narlı (2002: 91-96), A. Saktamber, C. Aktaş (2004: 826-36), R. Çakır (2007) vd. din ile ilişkileri bağlamında Türk kadınının toplumsal konumu ve sorunlarını sosyolojik yaklaşım perspektifinde araştırmalarına konu edinmiş bulunuyorlar. Nitekim meselâ dinî hareketlerde kadın konusu anlaşılan özellikle ODTÜ'de A. Saktamber'in temel ilgi alanını oluşturmaktadır (Bkz. Saktanber, 1994: 99-134; 2004: 813-7). Aynı şekilde, meselâ N. Göle'nin “melez" modernleşme süreç ve oluşumları bağlamında kamusal alan, kadın ve örtünme konuları üzerine sosyolojik analizleri de oldukça dikkate değerdir (Göle, 1991, 2000a, 2000b). E. Özdalga'nın örtünme, laiklik, popüler İslam ve cemaatler konu ve sorunlarına dair çalışmalarına da işaret etmelidir (Özdalga, 1998). A. Çarkoğlu, B. Toprak ve i. Sunar'ın çalışmaları din ve siyaset ilişkileri üzerine odaklanmış bulunuyor (Çarkoğlu ve Toprak, 2000, 2006; Sunar ve Toprak, 1983: 421-441; Toprak, 1984: 119-133). B. Toprak'ın ayrıca Türkiye'de dinin denetim işlevi (Toprak, 1978: 173-185) ve Müslüman aydınlar (Toprak, 1987) konuları üzerine dikkate değer çalışmalar ortaya koyduğu gözleniyor. TESEV araştırmaları bağlamında, Y. Arat'ın siyasal İslam ve kadın organizasyonları (Arat, 1999) ve A. Buğra'nın da siyasal İslam ve ekonomi (Buğra, 1999) ilişkileri üzerine projeler gerçekleştirdikleri anlaşılıyor. T. Atay'ın Batı'da bir Nakşi cemaati üzerine olan çalışması oldukça dikkate değerdir (Atay, 1996). Keza A. Yükleyen ve A. T. Kuru'nun Avrupa'da İslam, laiklik ve demokrasi konusundaki çalışması da kayda değerdir (Yükleyen ve Kuru, 2006). Aynı şekilde, F. Atacan'ın Batı'ya göçün beraberinde getirdiği radikal İslamcı bir oluşum üzerine sosyolojik analizleri de oldukça dikkate değerdir (Atacan, 1993). Öte yandan, R. Çakır'ın, Türkiye'de İslamcı hareket içerisindeki ideolojik, politik ve örgütsel sorunları konu alan çalışması da kayda değerdir (Çakır, 1990). Onun ayrıca İ. Bozan ve B. Talu ile birlikte İmam Hatipler meselesi üzerine çalışma ve yayınları da bulunuyor (Çakır, Bozan ve Talu, 2004). A. Y. Sarıbay'ın çalışmaları postmodernite, sivil toplum ve İslam konusuna yönelmiş görünüyor (Sarıbay, 1994). Öte yandan, Diyanet (Gözaydın, 2006; Çakır ve Bozan, 2005; Bozan, 2007) ve Alevilik konularının da Türk sosyologları için giderek sosyolojik bir ilgi alanı oluşturmaya başladığı anlaşılıyor. Aslında, Türk heterodoksisinin sosyolojisine, XIX. yüzyılın sonları ve XX. yüzyılın başlarından itibaren Batılı araştırmacıların belli bir ilgi duydukları, buna Türk araştırmacıların eklendiği bilinmektedir. Bu çerçevede, özellikle Baha Said'in 1910'larda başlayan Alevilik ve Bektaşilik incelemeleri dikkate değerdir. Anlaşılan onun Alevi inançlarının kökeninde Türklerin Şamanlık dönemine ait inanışlarının yer altığı şeklindeki tezlerini (Said, 1994; Görkem, 1998: 117-125), F. Köprülü’nün Türk din tarihi üzerine çalışmaları (Köprülü, 1972: 141-152) ile özellikle Y. Z. Yörükhan'ın Tahtacılar üzerine alan araştırmalarına dayalı çalışmaları (Yörükhan, 1998) izlemiş, buna zamanla A. Gölpınarlı (1979), M. Eröz (1990), R. 
Fığlalı (1990), O. Türkdoğan (1995), A.Yaşar Ocak (1996, 2000) vd.'nin konu ile ilgili çalışma ve yayınları eklenmiştir. Esasen, Türkiye'de heterodoks oluşumların sosyolojisine olan ilgide giderek bir artı̧̧ gözlenmektedir.

Öte yandan, günümüzde Türkiye'de, başta üniversiteler olmak üzere bilim çevrelerinde din sosyolojisine duyulan ilgide giderek bir artışın gözlenmekte oluşu kayda değerdir. Nitekim meselâ sosyolog Y. Aktay din sosyolojisine ilişkin dikkate değer çalışma ve yayınlar ortaya koymaktadır (Turner, 1997; Aktay ve Köktaş (der.); 1998, 1999). Ege Üniversitesinden H. Okçay'ın din sosyolojisinin yanı sıra dinî azınlıklar sosyolojisi ile de ilgilendiği ve din sosyolojisi, din ve toplum konularında lisans ve lisansüstü düzeylerde dersler verdiği anlaşılıyor. Keza Anadolu Üniversitesinden F. Sündal'ın din sosyolojisi konularında çalışmalar gerçekleştirdiği ve dersler verdiği de anlaşılmaktadır (Sündal, 1993, 2002, 2005: 109-130; 1996: 211-218). İnönü Üniversitesinden sosyolog H. C. Tatar'ın doktora tezi şehirleşme ve dinî cemaatleşme meselesini konu almıştır (Tatar, 1999). Bu tür örnekler artırılabilir. Ancak, bu sınırlı çalışmada, Türkiye'de din sorununa sosyolojik bir perspektifte yaklaşan tüm Türk sosyologlarını sayma imkânı bulunmuyor. Her halükârda, 1985 yılından bu yana Türkiye'nin 7 gelişmiş üniversitesinde gerçekleştirilen 989 sosyoloji araştırmasının 51'inin yani \% 5.2'sinin din sosyolojisine ilişkin konularda gerçekleştirildiğini önemle belirtmek gerekir. Bu 51 din sosyolojisi araştırmasının en büyük bölümünün yani \% 58.8'inin, Türkiye'de en gelişmiş Sosyoloji bölümünün yer aldığı ODTÜ'de gerçekleştirilmiş olması kayda değerdir. Geri kalanların üniversitelere dağılımı ise şöyledir: Boğaziçi \% 19.6; Ege \% 7.8; Ankara \% 5.9; Istanbul \% 3.9; Mimar Sinan \% 2.0; Hacettepe \% 2.0 (Kasapoğlu, 2005: 543- 544).

\section{8. İlahiyat Fakültelerinde Din Sosyolojisi}

Osmanlı medreselerinde din sosyoloji hiçbir zaman bir varlık alanı etmedi. Gökalp'in 1916-17'de Darülfünun'un Edebiyat şubesinde ilerlemiş öğrencilerine din sosyolojisi dersleri verdiğine işaret edilmişti. Cumhuriyet'in kuruluşu, Türkiye'de din sosyolojisi bakımından önemli bir gelişmeyi beraberinde getirdi. Zira bu dönemden başlayarak din sosyolojisi ilahiyat fakültelerinde köklü bir yer edinmeye başlamış, üstelik giderek kurumlaşmış, böylece Türkiye'de ilahiyat fakülteleri, din sosyolojisi çalışmaları için önemli bir merkez oluşturmuş ve oluşturmaya devam etmektedir. Hakikaten, 1924 yilında istanbul'da Darülfünun'a bağlı olarak kurulan Illahiyat Fakültesinin programında haftada 2 saatlik bir "dinî ictimaiyat" dersi yer almış, nitekim orada i. Hakkı Baltacıoğlu "dinî ictimaiyat" müderrisi olarak görevlendirilmiştir (Koştaş, 1989: 7). Bununla birlikte, Darülfünun Illahiyat Fakültesinde din sosyolojisinin yerini almış olması birtakım yadırgama ve hatta tartışmalara da neden olmuş; hatta anlaşılan bu tartışmalar sonraki dönemde de sürmüş, nitekim 1949 yılında Ankara Üniversitesine bağlı olarak illahiyat Fakültesi açılırken, Baltacıoğlu'nun Darülfünun illahiyat Fakültesini "bir nevi sosyoloji fakültesi" yaptıklarından yakındığı görülmüştür. Baltacıoğlu, 
Ankara'da açılacak illahiyat Fakültesinde "Islamî bilgilerin esas, sosyolojik bilgilerin yardımcı olacağını" belirtiyor (Bkz. Aynî, 2005: 26-30; krş. Aydın, 2003: 106123). Her halükârda, Ankara'da, 1949 yılında ilâhhiyat Fakültesi açıldığında din sosyolojisi programdaki yerini alıyor ve bu dersi felsefeci Mehmet Karasan okutuyor (7). Öte yandan, Karasan'ın din sosyolojisinin tarihsel gelişimine dair iki makalesi Türkiye'de din sosyolojisi çalışmalarına önemli katkılar olarak dikkati çekiyor (Karasan, 1953a: 21-27; 1953b: 61-69). 1959-60 öğretim yılında Alman sosyolog Hans Freyer, Ankara Illahiyat'ta misafir profesör olarak din sosyolojisi dersleri veriyor. Freyer'in ders notları Türkçeye çevrilerek "Din Sosyolojisi" adı altında yayınlanıyor (Freyer, 1964). Her halükârda, Ankara illahiyat'ta ve hatta bir bakıma tüm Türkiye'deki ilahiyat fakültelerinde din sosyolojisi biliminin kurumlaşması bakımından M. Taplamacıoğlu'nun katkılarını önemle belirtmek gerekiyor.

\subsubsection{Mehmet Taplamacıoğlu ve Anlayıcı Din Sosyolojisi}

Hakikaten, M. Taplamacıoğlu (1910-1995), Türkiye'de özellikle ilahiyat fakültelerinde din sosyolojisi bakımından üzerinde önemle durulması gereken bir isimdir. Lisans düzeyinde siyasal bilgiler öğrenimi görmüştür. Bilimsel ve akademik ilgisi itibariyle önce hukuka, sonra sosyolojiye yönelmiş ve din sosyolojisi alanında uzmanlaşmıştır. 1951 yılında Ankara Üniversitesi İlahiyat Fakültesinde din sosyolojisi kürsüsünde asistan olarak göreve başladığı tarihten emekli olarak ayrıldığı 1982 yılına kadar Taplamacıoğlu, din sosyolojisine dair çeşitli çalışma ve yayınlar ortaya koymuştur. Onun bu çalışmaları, başta Ankara Üniversitesi illâhiyat Fakültesi olmak üzere, Türkiye'de, XX. yüzyılın ortalarından itibaren açılmaya başlayan ilahiyat fakültelerinin programları ve akademik bünyelerinde bu bilim dalının yer tutup kökleşmesinin yanı sıra, bilim çevrelerinde din sosyolojisinin tanınması ve gelişmesine de önemli katkı sağlamıştır.

Taplamacıoğlu'nun, sosyoloji çalışmalarında, Fransız sosyologlar E. Durkheim, R. Maunier (1887-1946), A. Cuiller (1887- 1973) ve Alman sosyologlar J. Wach, Hans Freyer (1887-1969), G. Mensching ile hocası H. Z. Ülken'in eserlerinden faydalandığı anlaşılıyor. Esasen bu durum, onun sosyoloji ve özellikle de din sosyolojisi anlayışında yankısını bulmuş görünüyor. Zira Taplamacıoğlu'nun sosyoloji anlayışı, büyük ölçüde Durkheim'ın başını çektiği, pozitivist çizgileri ağır basan ve tabiat bilimci yahut natürist sosyoloji olarak nitelenen Fransız Sosyoloji Ekolü ile Almanya'da gelişen ve manevî ilimler akımına bağlı bulunan anlayıcı ve formel sosyolojilerden derinden etkilenmiş bulunuyor. Esasen bu etkilerin özellikle G. Tarde (1843-1904) ve Durkheim'ın görüşlerinin etkisi altında kaldığı anlaşılan Fransız sosyologu Maunier ile Freyer'in sosyolojileri bağlamında kendini göstermekte oluşu dikkate değerdir. Öte yandan, bu durum, onun din sosyoloji anlayışında da kendini göstermiş bulunmaktadır. Mamafih, onun din sosyolojisi çalışmalarında, Almanya'da gelişen formel ve anlayıcı din sosyolojisi akımından daha büyük ölçüde etkilendiği anla- 
şılmaktadır. Bu etkilerin, G. Simmel ve Leopold von Wiese'ın başlıca temsilcileri oldukları formel sosyoloji yönelimi ile en önemli temsilcilerini G. van der Leeuw ve R. Otto'da bulan din fenomenolojisi eğilimini formel ve anlayıcı ve din sosyolojisi anlayışı bağlamında birleştiren ve aynı zamanda Max Weber ile E. Troetsch'ün din sosyolojisi anlayışlarından da oldukça etkilenen Wach ve Mensching'in çalışmaları ve yönelimleri bağlamında şekillendiği önemle belirtilmelidir. Öyle ki o, din sosyolojisi çalışmalarında anlayıcı yaklaşıma yönelmekte, tipolojik analiz yönteminden yararlanmaya çalışmaktadır. Taplamacıoğlu, din ve toplum ilişkileri ve dinî gruplar (Taplamacıoğlu, 1965: 13- 20; 1975: 210-239) konusunun yanı sıra din devlet ilişkileri ve özellikle laiklik (Taplamacıoğlu, 1963: 35-53; 1975: 240-294) meselesi üzerinde önemle durmakta; bunlara yaşlara göre dinî yaşayışın şiddet ve kesafetine dair anket denemesi (Taplamacıoğlu, 1962: 141-151) ile din sosyolojisine dair sözlük çalışması eklenmektedir (Taplamacıoğlu, 1975: 295-420).

Hocası Ülken'e göre Taplamacıoğlu, kısa sürede din sosyolojisi konusunda ilim çevresine makaleler ve eserler vermeyi başarmış olup, onun çalışkanlığı ve verimliliği takdire şayandır. Öyle ki o, "konusuyla uzaktan yakından ilgili malzemeyi toplama bakımından arı gibi"dir. Nitekim Ülken, Taplamacıoğlu'nun özellikle Din Sosyolojisi adlı eserinin zengin ve ayrıntılı bilgilerle donatılmış bulunduğuna önemle işaret etmekte ve onların, din sosyolojisi gibi Türkiye'de az işlenmiş bir alanda, bu ilimle uğraşanlar için oldukça faydalı olacağını düşünmektedir. Aynı şekilde o, Taplamacıoğlu'nun Türkçe bakımından gösterdiği titizliğe de katılmaktadır. Bununla birlikte, Ülken, Taplamacıoğlu'nun sosyolojinin başlıca konusu olarak gördüğü toplumsal yapı hususunda F. Tönnies'in cemaat ve cemiyet sınıflamasına egemenlik, sınıf ve zümre cemiyetleri gibi yeni tipleri eklemiş olmasını, kendisinin oldukça yararlandığı H. Freyer gibi "eklektik" kalmayı tercih etmiş bulunmasına bağlıyor. Esasen, Ülken'in gayet yerinde olarak işaret ettiği üzere, Taplamacıoğlu'nun din sosyolojisi, gözlem, tecrübe, monografi, istatistik ve tarihi vesika usullerini kullanmak suretiyle, bir tabiat bilimci gibi, olayların sui generis mahiyetini incelemeye pek yönelmemektedir. Bunun yerine o, eski içe bakış metodunun yeni bir şekli olan ve toplum olgularına birer ideal tip gözüyle bakmak suretiyle onları kavramlar halinde tanımlamayı ve sonra da ince sınıflamasını yapmayı esas alan, Alman din sosyologlarının "anlayış metodu" ya da "ideal tipler" yöntemine yönelmektedir. Ancak bunu yaparken onun, meselâ Marx, Comte ve Freud'ün adlarını zikretmekle birlikte, onların doktrin ve görüşlerine ilişkin sistemli tartışma ve tenkitlerden kaçınmış olmasını Ülken önemle belirtiyor. Aynı şekilde o, bir monografi denemesi ile Taplamacıoğlu'nun, kökü Kant'a uzanan ve Dilthey'da olgunlaşan ve esasında felsefî, kavramcı, soyut, sınıflayıcı ve anlayıcı Alman sosyolojisi geleneğinden ayrılmış olmasına da işaret ediyor. Böylece Taplamacıoğlu, geçen yüzyılın bütün toplumsal problemleri bir hamlede çözmek isteyen geniş sistemci sosyolojilerine karşı, problemleri ayrı ayrı ele alan ve her birinde ona elverişli yöntemi 
kullanarak acele senteze ulaşma sabırsızığını göstermeyen, tahlilci araştırma ve çalışmaya yöneldiğini göstermiş oluyor. Esasen Ülken'e göre, Türkiye'nin ihtiya$\mathrm{cl}$ olan da budur. Nitekim olayların karakteristik tetkikine girmek için bu yolda ilerlemek gerekmektedir(Ülken, 1975). Bununla birlikte, Taplamacıoğlu, müteakip çalışmalarında hocasının bu temennisini sürdürmüş görünmüyor. Öte yandan, kendisinin bağlandığı, etkileri günümüzde din sosyoloji çevrelerinde az çok süren ve temel malzemesini dinler tarihi, din etnolojisi ve din arkeolojisi gibi bilimlerden sağlayarak, tipolojik bir yaklaşımla dinlerin en genel ve sistematik sosyolojisini ortaya koymayı amaçlayan formel ve anlayıcı din sosyolojisi eğilimi de Batı'da olduğu gibi Türkiye'de de yeni ciddi takipçiler bulmuş görünmüyor.

\subsubsection{Yeni gelișmeler}

Bununla birlikte, başta Ankara Üniversitesi Illahiyat Fakültesi olmak üzere, Türkiye'de 1970 ve özellikle de 1980 'li yıllardan itibaren sayıları giderek artan ilahiyat fakültelerinin akademik bünyelerinde din sosyolojisi önce kürsü, sonra bilim dalı ve daha sonra da anabilim dalı olarak yerini almış almak suretiyle kurumlaşıyor. Bu gelişme çerçevesinde, çoğu ilahiyat kökenli oldukça genç ve dinamik bir kadronun giderek din sosyolojisine kendini adamakta oluşu kayda değerdir. Bu genç ve dinamik akademik kadrodan beklenen, Türkiye'nin din konusunda çok ihtiyacı olan, problemlere ele atarak her birinde ona elverişli yöntemi kullanmak suretiyle acele senteze ulaşma sabırsızlığını göstermeyen, fikrî, teorik ve metodolojik bakımlardan iyi temellendirilmiş, tahlilci ve sentezci bilimsel araştırma ve çalışmalar ortaya koymaktır. Zira bu, din konusunda Türk toplumunun çarpık gelişmelere ve ikilemlere düşmemesi bakımından hayatî bir önem taşımakta, anlaşılan bu yönde çalışmalar hızla devam etmektedir. Öyle ki, bu gün artık ilahiyat fakültelerde din sosyolojisi üzerine hem lisans ve lisansüstü düzeylerde dersler verilmekte, seminerler, sempozyumlar düzenlenmekte, hem de bilimsel araştırma ve yayınlar yapılmaktadır. Nitekim, Türkiye'deki ilahiyat fakültelerinin din sosyolojisi anabilim dallarında görev alan din sosyologları 2004 yılından bu yana her yıl bir "Anabilim Dalı Koordinasyon Toplantısı" ve bunun yanı sıra özellikle Türkiye'de din sosyolojisinin sorunlarına ilişkin bir sempozyum düzenlemektedirler. 11-13 Haziran 2004 tarihinde Gazi Üniversitesi Çorum Illahiyat Fakültesi'nde düzenlenen ilk sempozyum "Türk Din Sosyolojisinin Temel Sorunları"nı konu almış ve 23 bildiri aracılığı ile tartışmışır. 23-24 Haziran 2005 tarihinde Konya'da Selçuk Üniversitesi Illahiyat Fakültesi'nde düzenlenen ikinci sempozyumun konusu ise "Türk Din Sosyolojisinin Teorik ve Metodolojik Sorunları" olmuştur. 06-07 Temmuz 2006'da Elazığ'da, Fırat Üniversitesi illahiyat Fakültesi'nde düzenlenen üçüncü sempozyum ise "Türk Din Sosyolojisinde Sosyolojik Din Teorileri Tartışmaları"nı konu almış, beş bildiri aracılığı ile, "Peter Berger'in fenomenolojik din anlayışı", R. N. Bellah'ın 'Sivil Din' teorisi, "Niklas Luhmann'ın din teorisi" ve "Rasyonel Seçim Teorisi" üzerine tartışma ve değerlendirmeler yapılmıştır. 06-07 Temmuz 2007'de İstanbul'da Marmara Üniversitesi Illahiyat Fakültesi'nde düzenlenen dördüncü Sempozyum, 
"Batılı" din sosyologlarının ürettikleri sosyolojik din teorilerinin Türk Din Sosyolojisinin sorunlarına uygulama imkânını tartışma konusu yapmakla, bir anlamda bir önceki yılın sempozyumunda ele alınan meselenin daha geniş bir perspektifte tartışılıp değerlendirilmesine imkân sağlamıştır. Nihayet 04-05 Temmuz 2008'de Uludağ Üniversitesi Illahiyat Fakültesinde düzenlenen beşinci Sempozyum “Günümüz Türkiye'sinde Din-Toplum ilişkileri”ni konu edinmiş; bildirilerde "Diyanet", "Popüler Din", "Alevilik", "Şehirleşme" ve "Toplumsal Değişme" konuları üzerinde durulmuştur. Anlaşılan bu tür bilimsel etkinlikler karalılıkla sürdürülecektir.

Öte taraftan, bir tespit çalışmasının verilerine göre, Türkiye'deki ilahiyat fakültelerinde din sosyolojisi alanında, 183'ü (\% 76.2) yüksek lisans ve 57'si (\% 23.8) de doktora tezi çalışması olmak üzere toplam 240 lisansüstü tez çalışması gerçekleştirilmiş olup, yüksek lisans tezlerinin \% 60'ı, doktora tezlerinin ise \% 47'si "teorik" çalışmalar olarak değerlendirilmekte, geri kalanların ise "empirik" metodolojiden yararlanmak suretiyle gerçekleştirildiği ifade edilmektedir (Çapcıoğlu, 2004: 203-224). Mamafih burada "teorik" kategorisinde değerlendirilenlerin aslında genelde literatürden derleme ve aktarma çalışmaları oldukları anlaşılıyor. "Empirik" kategorisinde yer alanlar ise temelde alan araştırmasından sağlanan verilere dayalı sosyografik tespit çalışmalarıdır. Şu halde, ilahiyat fakültelerinde gerçekleştirilen lisansüstü çalışmalar Türkiye'de yaşanan dini gerek literatür taraması gerekse de alan araştırması suretiyle incelemeye yönelmiş bulunmaktadır. Bununla birlikte, anlaşılan Türk din sosyolojisinin, literatür derlemesi yahut alanda gözlem ve tespit çalışmalarına dayalı sosyografyadan belli bir problem çözümüne dayalı ve kuramsal alt yapısı güçlü, daha geniş kapsamlı karşılaştırmalı ve sistematik analizlere yönelmesi gerekmektedir.

Teorik ve metodolojik yetersizlikleri yahut literatürden derleme ve aktarma eğilimini genelde ilahiyatlarda gerçekleştirilen öteki din sosyolojisi çalışma ve yayınlarda da görme imkânı olmaktadır. Nitekim meselâ 21 ilahiyat fakültelerinde görev almış ve esasen çok büyük bölümü ilahiyat kökenli 70 dolaylarında din sosyologunun 1036 çalışma ve yayınını üzerine gerçekleştirilen bibliyografik tespitler, bu çalışma ve yayınların "makale", "bildiri", "kitap", "tez", "çeviri", "ansiklopedi maddesi", "kitap içinde bölüm" ve "proje" kategorilerinde aşağıdaki Tablo: 1'deki şekilde yelpazelendiğini göstermektedir (Bayyiğit, 1986: 403445; Çapcıoğlu, 2003: 207-255; Efe, 2007; krş. Günay, 2000: 203-208): 
Tablo 1:

\begin{tabular}{llcr}
\hline Sıra No. & Tür & Toplam sayı & $\%$ \\
1. & Makale & 488 & 47.1 \\
2. & Bildiri & 173 & 16.7 \\
3. & Kitap & 148 & 14.1 \\
4. & Tez & 105 & 10.5 \\
5. & Çeviri & 104 & 10.1 \\
6. & Ansiklopedi maddesi & 13 & 1.3 \\
7. & Kitap içinde bölüm & 3 & 0.3 \\
8. & Proje & 2 & 0.2 \\
& --------------------------- \\
Toplam: & & -1036 & -100 \\
\hline
\end{tabular}

Tablo 1'deki tespitlerden anlaşıldığına göre, Türkiye'de ilahiyat fakültelerinde görev yapan din sosyologları en çok makale türü bilimsel çalışma ve yayın yapmakta, onu sırasıyla bildiriler ve diğer kategorilerde yer alan çalışmalar izlemektedir. Makaleler genelde yurt içi hakemli yahut hakemsiz dergilerde yayınlanmış olup, yurt dışı hakemli dergi yayını yok denecek kadar azdır. Tez türüne birkaç lisans tezi de dâhil edilmişse de genellikle orada yüksek lisans ve doktora tezi yer çalışmaları yer almakta, buna az sayıda doçentlik tezi çalışması eklenmiş bulunmaktadır. Çevirilerin önemli bir bölümü makaledir, ancak kitap türü çeviriler de mevcuttur. Mamafih anlaşılan özellikle kitap çalışmalarında yerli ve özellikle de yabancı literatürden derleme ve aktarma eğilimi oldukça güçlü biçimde kendini göstermektedir.

Ele alınan konular itibariyle çalışmalar, din, dinî yaşayış, sosyo-kültürel yapı ve değişme (34), küreselleşme (24), Diyanet (20), kadın (18), gençlik (17), Alevilik- Bektaşilik (15) gibi heterodoks gruplar, yöntem (14), laiklik (13), demokrasi (6), Yezidilik (4), Süryaniler (2), güncel ve tarihsel boyutları altında dinî ve sosyo-kültürel yaşantı, çok kültürlülük, hoşgörü, adak ve ziyaret dindarlığı, popüler din ve dindarlıklar, din sosyolojisinin tarihsel gelişimi ve fikrî ve felsefî arka planı, Farabi, Gazali gibi Türk ve İslam bilginlerinin toplum görüşleri, Comte, Le Bras, Wach, Weber, Gökalp'in din sosyolojisine ilişkin çalışmaları üzerine sosyolojik değerlendirmeler, çeşitli toplum kesimlerinin dinî tutum ve davranışları, sosyalleşme, eğitim, yaş, şiddet, modernleşme, post-modernizm, kimlik, cemaat ve tarikatlar, radikal dinci hareketler, poligami, dinî ve kültürel hayat, göç, şehirleşme, gecekondulaşma, sosyal çözülme/bütünleşme, terör ve şiddet, yeni dini hareketler, Mevlevilik, Kadirilik, Rufailik, Nakşilik gibi dinî ve tasavvufi gruplar, cemaatler, tarikatlar, monografiler, din-devlet ilişkileri, din ve siyaset, Avrupa Birliği, Tanzimat, Meşrutiyet ve Cumhuriyet dönemlerinin tarihî ve sosyo-kültürel bakımdan değerlendirilmesi gibi çok çeşitli meseleleri sosyolojik bir yaklaşım perspektifinde incelemeye yönelmiş bulunuyorlar. 
Çalışmalarda nicel ve nitel araştırma yöntem ve tekniklerine başvurulduğunun örneklerini görmek kayda değerdir. Bununla birlikte, başvurulan yöntem ve tekniklerin daha etkin ve başarılı kullanımı yönünde gayretlere ihtiyaç duyulduğu da açıktır. Öte yandan, derlemeci, aktarmacı yahut en çok durum tespitine yönelik deskriptif sosyografya çalışmalarının teorik ve metodolojik bakımlardan daha özgün bir düzeye erişmesi de önemlidir. Türkiye'de özellikle ilahiyatlarda gerçekleştirilen din sosyolojisi çalışmalarının teorik ve metodolojik alt yapısı çoğu zaman oldukça yüzeysel kalmakta, buna terminoloji yetersizlikleri eklenmektedir. Acele genellemelere ve masa başı üretimlere eğilim oldukça fazladır. Teorik düzeyde genelde Batılı sosyologlar yahut sosyal bilimcilerin ortaya koydukları kuramlara dayanılmaya çalışılıyor. Ancak çalışmaların kuramsal düzeyi derinleştirilmeye, sistemleştirilmeye ve olgunlaştırılmaya intiyaç duyuyor. Bu bakımdan anlaşılan yapılacak çok şey, kat edilmesi gereken uzun bir yol mevcuttur. Her şeyden önce Türkiye, gerek tarihi ve gerekse de günümüzdeki, toplumu, kültürü ve yaşantısıyla din sosyolojisi araştırmaları için eşsiz bir laboratuar sunuyor. Bu bakımdan Türk din sosyologlarının araştırmacı bir zihniyetle Türk toplumunun dinî yaşantısını incelemeye özel bir ilgi ve özen göstermeleri gerekiyor. Bu ilginin teorik alt yapısı güçlü, sistematik, metotlu araştırma ve incelemelere dönüşmesi oldukça önemlidir. Hatta çalışmaların usulüne uygun projeler üzerine bina edilmesi de çok önemlidir. Bilindiği gibi kuram, deneye imkân veren bir alanda araştırmanın düşünsel bir temele oturmasını sağlamakta, ona fikrî bir derinlik, genişlik ve zenginlik kazandırmaktadır. Nitekim dünya ölçüsünde gerçekleştirilen bilimsel ve özellikle de sosyolojik araştırma ve çalışmalarda ve özellikle de din sosyolojisi araştırmalarında kuramsal yaklaşım konuları üzerinde önemle durulmakta (8), hatta son zamanlarda kuramsal sosyoloji çalışma ve yayımlarında bir artı̧̧ gözlendiği gibi, onlar eskiye oranla daha sistematik, analitik ve kritik bir nitelik kazanmış görünmektedirler. Çalışma ve yayımların özellikle son dönemde giderek çağdaş sosyoloji kuramları üzerine odaklanmakta oluşu da kayda değerdir. Buna karşılık, Türkiye'de sosyoloji ve özellikle de din sosyoloji alanındaki bilimsel çalışma ve yayımların aynı ölçüde özgün bir kuramsal ve metodolojik yaklaşım düzeyine erişmediği hususunu ısrarla belirtmek gerekiyor. Esasen Türkiye'de kuramsal sosyolojik yaklaşım konularını ele alan çalışmalar da sınırlı sayıda olup, bunların çoğu çeviri yahut derleme niteliğindedir. Bununla birlikte, son dönemde bu yöndeki çalışma ve gayretlerde bir artış da gözlenmektedir. Bunlar, Türkiye'de sosyoloji ve özellikle de din sosyolojisi araştırma ve çalışmalarının belli bir bilimsel, kuramsal, analitik ve sistematik düzeye erişmesi bakımından önemlidir. Ancak sonuçta bunlar meseleyi belli bir düzeyde ele alan el kitaplarıdır (Bkz. Günay, 2006: 509-542). Bu bakımdan bu tür çalışmalar başlangıç için önemli olmakta, onları bu teori ve yöntemlerin uygulandığı özgün çalışma ve yayınlara ilişkin literatürle beslemek gerekmektedir. Bunlar da genelde yayınlandıkları Batı ülkelerinin dilinde kaleme alınmıştır. Bu durum ilahiyat fakültelerinde din sosyoloji alnında görev ve çalışma yapan genç bilim adamları için yabancı dil bilgisinin önemini ortaya koymak- 
tadır. Öte yandan, her bilimsel çalışma gibi kuramsal sosyolojik yaklaşım çalışmalarının da her şeyden önce ortaya çıktıklara sosyo-kültürel çevre ve toplumla ilişkili oldukları gözden kaçııılmamalıdır. Şu halde Türk düşünür ve sosyologları ve özellikle de Türk din sosyologları için kuramsal sosyolojik yaklaşım bağlamında sorun, Batı toplumlarının sosyo-ekonomik ve kültürel ortamı ve şartlarında üretildiğinden onların kültürleri, değerleri ve sorunlarına sıkı sıkıya bağıı bulunan teorilerin Türk toplumu, kültürü ve sorunlarına özgün bir biçimde nasıl uygulanabileceği meselesidir. Esasen bu mesele Türkiye'de din sosyolojisi araştırmalarında uygulanacak yöntem ve teknikler konusunda da kendini göstermektedir. Böylece meselâ Türkiye'de dindarlık araştırmalarında, Batı toplumlarında dindarlığın boyutlarına ilişkin araştırma modeli ve şemalarının aynen uygulanmaya kalkışımasının önemli sorunlara yol açtığı anlaşılmaktadır (Bkz. Günay ve diğerleri, 2006). Türkiye'deki dinî akım, hareket, grup, cemaatler ve tarikatların din sosyolojisi bakımından incelenmesi konusunda da buna benzer önemli sorunlar mevcuttur. Alevilik-Bektaşilik konusunun yahut geleneksel halk dindarlığının incelenmesi meselesi de benzeri sorunları içermektedir. Kuramsal sorunlara yöntem, terminoloji, vb. meseleler ekleniyor.

Her halükârda, kuramsal, yöntemsel ve hatta terminolojik yetersizliklere, literatür derlemesi, aktarmacılık ve acele çıkarım ve genelleme eğilimine rağmen, özellikle ilahiyat çevrelerindeki Türk din sosyolojisi incelemelerinde giderek bir arayış ve farklı modelleri ve yaklaşım şemalarını deneme çabaları da eksik olmuyor. Türkiye'de din olgusuna, sosyolojik perspektifte bu farklı yaklaşım arayışı, gerçekte Türkiye'de yaşanmakta olan din olgusunu, basit ve indirgemeci modellerden hareketle tek yanlı algılamanın ve acele çıkarım ve genellemelere kalkışmanın noksanlı̆ıını kavramaya izin veriyor. Anlaşılan, Türk toplumunda din konusu, sanıldığından çok daha önemli, köklü, derin ve çok manalı, çok veçheli ve çok işlevli, kendine özgü bir olgudur. Bu bakımdan da onu, tek bir kalıba oturtup, benzerleri ile aralarında hiçbir farklılaşma gözetmeksizin çözümleyivermek yanılıcı olmaktadır. Aynı şekilde, Türkiye'de din incelemelerinde ve özelikle de tasavvuf ve tarikat incelemelerinde çoğu zaman gözlendiği ve konu ile ilgili olarak değerli bir uzmanın işaret ettiği üzere (Lanternari, 129-136), onların inanç sistemlerini, doktrinleri, ritüelleri derleyip, sonra da onları ister teolojik, ister fenomenolojik isterse de psikolojik olsun, basitleştirilmiş üniter bir çerçevede açıklamak ve onları tarihî, toplumsal ve kültürel muhtevalarından soyutlamak da aydınlatıcı olmuyor. Keza, kendi öz varlıkları ve dinamiklerini hesaba katmaksızın onları yalnızca çevresel faktörlerin bir sonucu ve fonksiyonuna indirgemeye kalkışmak ta tek yanlı ve hatalı olmaktadır. Öte yandan, bilimsel objektiflik konusu önemli bir problem olarak karşımıza çıkıyor. Bununla birlikte, zamanla bunun aşılacağı ve bu alanda özgün ve düzeyli bilimsel yaklaşım şemaları, modelleri ve bu çerçevede ortaya konulacak olan bilimsel ve düşünsel ürünler aracılığı ile Türk toplumunun karşı karşıya bulunduğu devasa sorunların çözümüne olumlu katkılar sağlanacağını ümit etmek gerekiyor. 


\section{Değerlendirme ve Sonuç}

Bağımsız bir bilimsel disiplin olarak, uzun bir hazırlık dönemini takiben ancak modern dönemde ve modernitenin bir ürünü olarak Batı'da ortaya çıkan ve bir anlayışa göre sosyolojinin, bir başkasına göre de modern din bilimlerinin bir alt dalı sayılan din sosyolojisi, oradan dünyanın başka ülkelerine, İslam dünyasına ve Türkiye'ye uzanmıştır. Bu bakımdan, din sosyolojisinin modern ve "Batılı" bir bilim olduğu ifade edilebilir. Yine de, daha geniş bir perspektifte, modern dönemde Batı'da ortaya çıkan ve din sosyolojisinin bağımsız bir bilim olması ile sonuçlanan gelişmelerde, Batı dünyasının iç dinamiklerinin yanı sıra dış dinamikler ve bu çerçevede meselâ İslam dünyasından alınan etkilerin önemli payına da işaret etmelidir. Her halükârda, ne kadar modern ve "Batılı" olursa olsun din sosyolojisi dinamik bir bilimdir. Öyle olduğu için din sosyologları onu çabalarıyla sürekli yeniden üretmeye ve daha doğrusu geliştirip olgunlaştırmaya gayret etmektedirler. Esasen Batı'da din sosyolojisi tek bir çizgide gelişmemiş, tersine farklı anlayışlar ve eğilimler ona damgasını vurmuştur ve hatta vurmaya devam etmektedir. Öte yandan, Batılı din sosyologları geliştirdikleri teori, yöntem ve tekniklerin Batı dışı toplumlar, kültürler ve dinler için de, gerekli uyarlamaların yapılması kayıt ve şartıyla, uygulanabilir olduğunu düşünmekte ve hatta bu yönde çaba harcamaktadırlar.

Her halükârda, Batı dışı toplumlar, İslam dünyası ve Türkiye'de din sosyolojisinin varlığı, Batı'ya oranla daha da yenidir. Üstelik o, büyük ölçüde Batı kaynaklıdır. Bununla birlikte, meselâ Türkiye'de din sosyolojinin Türk ve İslam tarihi, toplumu ve kültüründen belli bir ölçüde beslendiği de muhakkaktır. Ancak modern dönemde Türkiye'de bu bilim dalının gelişmesinde, iç dinamiklerin yanı sıra dış dinamikler ve bu çerçevede Türk toplumunun karşı karşıya kaldığı değişim ve modernleşme sorunları ve bu bağlamda kendini gösteren Batılı etkiler oldukça belirleyici olmuştur. Böylece, Türkiye'de din sosyolojisinin, Batıdaki gelişmelere paralel olarak ve hatta önemli ölçüde onların bir uzantısı şeklinde, ancak yine de Türk toplumunun değişim ve modernleşme sorunlarına bağlı olarak ortaya çıkmış bir bilimsel disiplin olduğu önemle belirtilmelidir. Hatta bu anlamda Türkiye'de din sosyolojisinin Türk modernleşmesinin bir ürünü olduğu ve bu süreç bağlamında ilahiyat fakültelerindeki yerini aldığı hususu da önemle ifade edilmelidir. Nitekim anlaşılan Türkiye'de meselâ Darülfünun İlahiyat Fakültesinin açılışı ve orada özellikle din sosyolojinin yerini alışı da öyle olmuştur. Öyle ki, gerek bu Fakültenin, gerekse de 1949'da Ankara Üniversitesi İlahiyat Fakültesinin açılışı dolayısıyla ortaya çıkan tartışma ve eleştiriler aslında, kurumsal değişimin ötesinde bir zihniyet değişimi, geleneksellikten modernliğe bir geçiş ve buna uyum ve uyumsuzluğun sancılarını tipik bir biçimde yansıtmaktadır. Nitekim bu bağlamda tartışmaların önemli ölçüde din sosyolojisinin ilahiyat fakültelerindeki varlığı meselesi üzerine odaklanmış olması dikkate değerdir. Her halükârda, Türkiye'de, üniversiter ve akademik bir düzeyde din sosyolojisi, önce Darülfünun Edebiyat Şubesinde, sonra Darülfünun ilâhiyat 
Fakültesinde ve daha sonra da müteakip dönemlerin ilahiyat fakültelerinde bir yer elde etmiş ve kurumlaşmıştır. Aynı şekilde, Türkiye'de bu bilim dalına, üniversitelerin sosyoloji bölümleri, iktisat ve siyaset bilimleri gibi sosyal bilimler mensuplarının belli bir ilgi duydukları ve eğitim ve öğretim programlarının yanı sıra bilimsel çalışmalarında ona belli bir ölçüde yer ayırdıkları görülmektedir. Buna karşılık, geleneksel medrese uleması ilk planda din sosyolojisine pek bir ilgi duymuş görünmüyor. Hatta medreselerin kapatılmasından sonra da geleneksel zihniyetin mensuplarının bu bilim dalına sıcak bakmadıkları biliniyor. Illahiyatların dışındaki Türk sosyologları yahut öteki sosyal bilim mensupları sosyal konularla ilgili araştırmalarında genellikle din konusuna sosyolojik yaklaşıma ancak yeri geldikçe ve çoğu zaman ikinci dereceden bir yer ayırmış görünüyor. Ancak Türkiye'de özellikle 1970 'ler'den bu yana hızlanan değişim ve dönüşüm sorunlarına bağlı olarak din ile ilgili meselelerin de sıklıkla gündeme gelmiş olması Türk sosyologlarının din sosyolojine olan ilgisini artırıyor. İlahiyat fakültelerinde anabilim dalı düzeyinde akademik kurumlaşma, oralarda görev alan akademisyen din sosyologlarının bilimsel çabalarının hemen tamamını din sosyolojisine ilişkin konulara ayırmalarına ve bu konularda giderek uzmanlaşmalarına imkân sağlıyor. Beş yıldan bu yana gerçekleştirilen Din Sosyolojisi Anabilim dalı koordinasyon toplantıları ve sempozyumlar, karşııklı fikir alış verişine ve gelişmeye kapı açıyor. Ancak Türkiye'de din sosyolojisi eğitimöğretimi ve çalışmalarına ilişkin ciddi güçlükler ve sorunlar da ortada duruyor.

Bir kere, Türkiye'de din sosyolojisinin, modern Batı ülkelerinde gözlenen ölçüde gelişip kurumlaşmadığı önemle belirtilmelidir. Öyle ki, meselâ Türkiye'de henüz bu konuda uzmanlaşmış bir araştırma enstitüsü, merkezi yahut periyodik yoktur. Illahiyatçı din sosyologlarının kendi çabalarıyla düzenledikleri koordinasyon toplantıları ve buna bağlı olarak gerçekleştirilen sempozyumların dışında geniş çaplı bilimsel aktiviteler de Türkiye'de henüz kendini göstermiş değildir. Esasen, Türk din sosyologlarının konu ile ilgili bilimsel araştırma ve yayınları birbirinden kopuk ve dağınık bir biçimde gerçekleşmektedir. Bu durum, Türkiye'de din sosyolojisine ilişkin konularda bir sinerji yaratılmasına imkân vermemekte, bu da bu alandaki gelişmeleri olumsuz etkilemektedir. Hatta denebilir ki, Türkiye'de din sosyolojisi henüz çocukluk çağındadır. Nitekim öyle olduğu için Türkiye'de din sosyolojisi alanındaki çalışmalara Durkheim, Weber, Wach, Berger gibi Batılı büyük din sosyologlarından yapılan çeviriler, derlemecilik, aktarmacllık, yüzeysellik, spekülasyon yahut en çok sosyografya egemendir. Keza Türk din sosyologlarının çalışmalarında Türk toplumunun dinî yaşayış gerçekliklerinden önemli ölçüde kopukluk da dikkati çekici biçimde kendini göstermektedir. Türk din sosyologlarının din sosyolojisi konularına ilişkin çalışma ve etkinlikleri genelde yerel ve en çok ulusal düzeyde kalmakta; evrensel düzey ve geçerlikte bilim üretme ve paylaşma kaygısı oldukça düşük görünmektedir. Kağıtçıbaşı'nın ayırt ettiği (Kağıtçıbaşı, 1986: 7-20) ve Türkiye'de genellikle sosyal bilimler için geçerli olduğu düşünülen (içcli, 2001: 30-32) "taklit sosyal bilim", 
"ülkenin sosyo- kültürel gerçeklerine dönük sosyal bilim" ve "evrensel sosyal bilim" aşamalarının din sosyolojisinin Türkiye'deki gelişimi için de geçerli olduğu ve Türk din sosyologlarının genelde birinci ve kısmen ikinci aşamalarda kümelendikleri önemle belirtilmelidir.

Her halükârda, Türkiye'de din sosyolojisine olan ilgi ve yönelim tek bir kanaldan beslenerek bir gelişme göstermiş değildir. Şüphesiz orada "Batıı" etkiler güçlüdür. Ancak bu çerçevede, Fransız sosyoloji ekolü, Alman, İngiliz ve Amerikan sosyolojileri, sosyal psikolojisi, etnoloji ve antropolojinin önemli etkileri söz konusudur. Buna, din bilimleri alanındaki gelişmelerin, Marksist din sosyolojisi akımının, yapısalcılığın, işlevselciliğin, çatışma teorilerinin ve öteki akımların etkileri ekleniyor. Ancak, din sosyolojinin Batıdan hiçbir eleştiriye tabi tutulmadan ve ülke gerçeklerine uyarlanmadan aktarılmakta oluşu önemli bir olumsuzluktur. Esasen, Batıdan farklı olarak, Türkiye'de genel olarak sosyal bilimlerin ve özel olarak sosyolojinin köklü bir fikrî ve felsefî bir temelden yoksun olduğu hususu Türkiye'de din sosyolojisi için daha da geçerli görünmektedir. Bununla birlikte, Ülken'le birlikte, sosyolojinin ve özellikle de din sosyolojisinin bu fikrî ve felsefi temeli kurması ve güçlendirmesi gerektiğini düşünmekteyiz (Ülken, 1955: 24; Krş. Kongar, 1996: 194-195). Türkiye'nin kendine özgü sorunlarının çözümü Batıdakilerden yararlanarak, ancak yeni ve özel yöntemler ve açıklamaların ortaya konması suretiyle gerçekleştirilebilir. Bu anlamda Türkiye'de din sosyolojinin Batılı din "sosyolojileri"yle ilişkilerinin iyi belirlenmesi ve Türk toplumunun ve gerçeklerinin aydınlanması için yapılması gerekenler saptanmalıdır. Teorik ve metodolojik bakımlardan yapılması gereken çok şey kalmaktadır. Bir kere, Türk din sosyologları için temel bir sorun, Batı toplumlarının sosyo-ekonomik, kültürel ve dinî ortamı, şartları, değerleri ve sorunlarına sıkı sıkıya bağlı bulunan teori, araştırma modeli, yöntem ve tekniklerin Türk toplumu, kültürü, dinî yaşayışı ve sorunlarına özgün bir biçimde nasıl uygulanabileceği meselesidir. Bu soruya doyurucu bir cevap verilemediği sürece Türkiye'de özgün bir "Türk Din Sosyolojisi"nin varlı̆ı̆ıdan söz etmek oldukça iddialı olur. Öte yandan, bir kısım din sosyologları sadece literatür çalışmasına dayalı kuramsal ve hatta spekülatif çalışmalarla yetinmekte, alana hemen hemen hiç inmemektedir. Öteki bir kısım din sosyologlarının ise sadece alan çalışmasında derledikleri yığın bilgilerle oyalandıkları, çalışmalarının fikrî ve teorik boyutunun yok denecek düzeyde ve yüzeysel olduğu görülmektedir. Halbuki, teorik ve ampirik çalışmaların birlikte yürütülmesi gerekir. Zira saha araştırmalarıyla elde edilen bilgiler ancak kuramsal bir çerçeve içinde bir anlam ifade edebilir. Aksi halde belli bir sosyolojik tasvir düzeyi aşılmamış olacaktır. Nitekim Türkiye'de aslında din sosyolojisi alanında gerçekleştirilmiş bulunan çalışmaların önemli bir bölümü belli bir sosyografya düzeyini aşamamaktadır. Tekrarlardan sakınmalı, çok daha çeşitlenmiş ve daha farklılaşmış konuların araştırılmasına yönelmelidir. Bunun, hem Türkiye'de din sosyolojisi araştırma ürünlerinin çoğalmasına, hem de bu bilimsel araştırmalardaki fikrî boyutlar ve ufkun genişlemesine katkıda bulunabileceğine önemle 
işaret etmelidir. Öte yandan, araştırma konularında farklılaşma ve çeşitlenme, Türk Din Sosyolojisinin kapsamı ve içeriğinin zenginleşmesine de imkân sağlayabilecektir. Bu amaçla Din Sosyolojisi koordinasyon toplantıları önemli bir fırsat ve imkân sağlamaktadır. Belli periyotlarda Türk toplumunun dinle ilişkileri bağlamındaki dinamiklerini esas almak suretiyle Türkiye'de din sosyolojisi çaıışmalarının hangi sorunlar etrafında yoğunlaşması gerektiği meselesi bu toplantılarda ele alınarak belli koordinasyon ve yönlendirmelere gidilebilir. Aksi halde tekrarlara yahut tali ya da önemsiz meselelerle yönelme riski mevcuttur. Türk din sosyologları her şeyden önce, Türk din sosyolojisinin temel kavramları ve terminolojisi meselesi üzerinde önemle durmak zorundadır. Zira kavramlar ve terminoloji oturmuş değildir. Kuramlar ve yöntem konusu da oldukça önemlidir. Türk dindarlığı konusu etraflıca işlenmiş değildir. Sekülerleşme konusunda da durum aynıdır. Türk toplumunda Aleviliğin yahut Alevilik-Bektaşiliğin ya da Türk heterodoksisinin sosyoloji sistematik bir biçimde gerçekleştirilemedi. Kadın yahut gençlik konuları yeterince işlenmiş değildir. Dinî cemaatler ve tarikatların yahut dinî grupların sosyoloji konusunda da durum aynıdır. Bu ve benzeri konuların tarihsel perspektifte ele alınması da ayrı bir mesele olarak karşımıza çıkmaktadır. Türk din sosyologlarının dinî tarih, dinler tarihi, sosyal tarih, kültür ve medeniyet tarihi konularında yeterli bilgi sahibi olmaları ve çalışmalarına tarihsel boyuttaki bir yaklaşım perspektifi katmaları oldukça önem arz etmektedir. Esasen, Türk din sosyologlarının sadece Türkiye'yi, Türk toplumunu ve hatta Türk dünyası yahut İslam dünyasını incelemekle yetinmeyip, hızla ülkelerarası ve dinler arası karşılaştırmalara yönelmelerinde de yarar görülmektedir. Zira karşılaştırmalı araştırmalar, bilgi birikiminin artmasına, bilimsel üretim sürecinin gelişmesine katkıda bulunabilecektir. Ayrıca, makro ölçekli çalışmaların gerçekleştirilmesi, geniş çerçeveli kapsamlı genellemelere, kavramlaştırmalara gidilebilmesi, yeni önermelerin geliştirilebilmesi açısından üzerinde durulması gereken bir diğer noktadır. Keza, makro ölçekli çalışmaların yanı sıra, mikro ölçekli çalışmalar da dinî-toplumsal süreçlerin bileşimleri ve dinamiklerinin belirlemesi açısından önemlidir. Nihayet, özellikle Türk din sosyolojisi alanında kavram ve kuram geliştirmeye yönelik ve gözleme ağırlık veren analitik ve sistematik araştırmalara yönelmek ve bu amaçla araştırma projeleri üretmek ve gerçekleştirmek oldukça önemlidir. Bunun için de mali destek gerekmektedir. Din sosyolojisinin çalışmalarını, sosyolojinin yanı sıra diğer sosyal bilimler ve din bilimleri ile işbirliği içerisinde ve disiplinler arası bir açılımda gerçekleştirmesi de oldukça önemlidir. Aksi halde, Türkiye'de din sosyoloji alanındaki bilimsel çaIışmalar başlangıç dönemindeki bir derlemeci, aktarmacı ve taklitçi bir çerçeveye yahut en çok deskriptif bir sosyografyaya tıkanıp kalabilir. Din Sosyolojisi, Türk toplumunun yapısı, kültürü, orada dinin yeri, işlevleri, etkileşimi, değişimi ve sorunlarını, uygun kuram, yöntem ve teknikler çerçevesindeki özgün araştırma ve çözümlemeler aracılığıyla daha derinden ve sistematik biçimde analiz etme imkânı sağlayacak niteliktedir. Böylece, toplumu, insanı ve sorunlarını ve özellikle de onun dinî yaşayış alanındaki güçlüklerini daha iyi anlama ve daha 
sağlıklı çözümler üretme imkânı olacaktır. Tersine durumda ise, Türkiye'de din sosyolojisi spekülâtif ve normatif bir toplum ve din felsefesine yada bir tür sosyal teolojiye dönüşebilir. Esasen Türkiye'de din konusunda mesele oldukça çetrefil bir manzara arz etmektedir. Zira geleneksel ilahiyat, bilimi kendi değerlerinden hareketle üretmeye alışkındır, normatif ve savunmacıdır, bilimsel kritikten pek hoşlanmamaktadır. Modern bilim de, en azından başlangıçta kendi önsel kabulleri yahut varsayımlarına sahipse de, bilimsel kritiğe kapıyı ardına kadar açmıs olup, bu durum sosyoloji ve modern din bilimleri ve özellikle din sosyolojisi için de geçerlidir. Böyle olunca, ilâhiyat alanında bilimsel üretim konusunda sorun ve seçenek, geleneksel algılara sarılarak tekrarcılık ve aktarmacılık ve her halükârda skolâstik spekülâsyonlarla avunma ile din konusuna özgün bir analitik, sistematik ve kritik bir bilimsel yaklaşım arasındadır. Din sosyolojisi, en azından ideal olarak ikincisini amaçlamış bulunmakta, Türk din sosyolojisinin bunu başarıp başaramayacağı, felsefî ya da teolojik spekülasyonlar, normatif çıkarımlar yahut derlemecilik, aktarmacılık ve yüzeyselliğe takılarak orada tıkanıp tıkanmayacağını zaman gösterecektir.

\section{Notlar}

(*) Prof. Dr., Erciyes Üniversitesi İlahiyat Fakültesi, e-posta: ugunay@erciyes.edu.tr

(1) Din sosyolojisinin tarihsel gelişimi ve günümüzdeki durumu konusunda daha geniş açıklamalar için bkz. Günay, 2000: 85-176.

(2) Meselâ Rusya'da din sosyolojisi başlangıçta Çarlık döneminin dinî hareket-lerinin incelenmesine yönelmiş görünüyor. Sovyetler Birliği döneminde Pivovarov ve Alekssev'in çalışmalarında dinî inanışlarla yaş, cinsiyet, eğitim ve meslekî statü arasındaki ilişkilerin araştırılmasına öncelik vermiştir. (Bkz. "Sociologie de la religion en U.R.S.S", Social Compass, C. XXI, 1974/2). Japonya'da din sosyologları Japon toplumunun din sorunlarına sosyolojik bir yaklaşıma yönelmiş görünüyorlar. Anlaşı-lan, Japon toplumunda yaygın dinler olan Şintoizm, Budizm, Protestanlık ve Katolik-liğin incelenmesine özel bir önem atfedilmektedir. Kırsal yörelerin geleneksel din-darlığı ve popüler dinin yanı sıra Soka Gakkai yahut Rişo Köseikai gibi yeni dinî hare-ketler yahut gençliğin dinî tutumlarının incelenmesi gibi konular da önemli ilgi alan-ları oluşturuyor. Japonya'da dindarlık eğilimleri üzerine önemli araştırmaların ya-pılmakta oluşu da kayda değerdir. Weber'in tezlerinden hareketle Japon toplumu üzerine din sosyolojisi araştırmaları da mevcuttur. (Bkz. "Sociologie de la religion au Japon.", Social Compass, C. XVII, 1970/1; Yanagawa Kei'ichi ve Abe Yoshi, "Some Observations on the Sociology of Religion in Japan", Japanese Journal of Religious Studies, 5/1, Mart 1978). İsrail'de, din sosyolojisi, Yahudilik araştırmaları etrafında odaklanmış görünüyor. Ancak, orada din sosyolojisinin Batı'daki ölçüde bir gelişme-sinden söz etmek mümkün olmuyor. Öyle ki, İsrail'de din sosyolojisi araştırmalarında temel teorik çerçeve genelde Batılı sosyal bilimcilerin geliştirdikleri kuramlara dayanıyor. Bu bakımdan da son dönemde yapılan bir çalışma bunun nedenlerini sorguluyor. (Bk.: Ezra Kopelowitz, Yael Israel-Shamsian, "Why has a sociology of religion not developed in Israel? A look at the influence of socio-political environment on the study of religion: a research note", Sociology of Religion, Spring, 2005, C. 66/I: 71-84).

(3) Fransa'da din sosyologları "Centre d'Etudes Interdisciplinaires des Faits Religieux" yahut "Groupe de Sociologie des Religions et de la Laïcité" gibi kuruluş-larda teşkilatlanmış bulunuyor. Buna meselâ ABD'deki "Center for the Study of Religion" yahut 
"Hartford Institute for Religion Research" gibi kuruluşlar ekleniyor. Nihayet din sosyologları dünya ölçüsünde "The International Society for the Sociology of Religion" (ISSR) gibi uluslararası organizasyonlara yönelmiş bulunuyor. Bu teşkilatın 1991'de 47 ülkeden 445 üyesinin bulunduğu anlaşılıyor. (Bkz. J.P. Willaime, Sociologie des Religions, Paris: PUF, 1995, s. 56). Uluslararası din sosyolo-jisi konferanslarının 29.sunun 2007 yılında Almanya'da, Leipzig'de "Sekülerlik ve Dinî Canlılık" (Secularity and Religious Vitality) konusunda gerçekleşmiş olması kayda değerdir. Fransa'da "Archives de Sociologie des Religions" adlı altında 1956'da yayın hayatına başlamış bulunan din sosyolojisi dergisi daha sonra "Archives de Sciences Sociales des Religions" adı altında yayınlanmayı sürdürmektedir. Buna öteki Avrupa ülkeleri, ABD ve hatta Kanada'daki periyodikler eklenmektedir. Hollanda'da 1953'te uluslararası bir din sosyolojisi dergisi olarak kurulan "Social Compass", 1959'dan bu yana Belçika'da Louvain Katolik Üniversitesinin yayını olarak devam ediyor. ABD'de, "Review of Religious Research" 1959'da, "Journal for the Scientific Study of Religion" ise 1961'de yayın hayatına başladı. Bu sonuncu derginin sosyoloji, psikoloji, siyaset bilimi, iktisat, antropoloji, din incelemeleri ve tarihi gibi çok çeşitli disiplinleri kapsayan disiplinlerarası bir hüviyeti bulunmaktadır. 1940'da yayın hayatına başlayan "American Catholic Sociological Review" 1964'ten itibaren "Sociological Analysis" ve 1993'ten bu yana da "Sociology of Religion" adı altında yayınlarını sürdürüyor. Buna "Journal of Contemporary Religion" ekleniyor. Kanada'da "Religiologiques" adlı dergi 1990'dan bu yana yayınlanıyor.

(4) Her halükârda, çağdaş İslam dünyasında sosyologlar ve sosyal bilimcilerin din sosyolojisine akademik dü-zeyde belli bir ilgi duydukları ve dikkate değer çalışmalar ortaya koyduklarını önemle belirtmek gerekir. An־cak bu ilginin bu alanda ileri düzeyde bir gelişme ve kurumlaşmaya imkân vermiş görünmediğine de işaret etmelidir. Din bilimleri ve öğretimi alanında ise bu ilginin çok daha düşük bir dü-zeyde seyrettiği anlaşılmakta-dır. Esasen İslamiyet konusunda araştırmalar yapan Batılı bilim adamları, şarkiyatçılar yahut İslamologların yahut sosyologların buna ilgilerinin de belli bir düzeyin ötesine gitmemiş olması da kayda değerdir. Her ha-lü-kârda bu çerçevede J. Berque, J. P. Charnay, Cf. Geertz, E. Gellner gibi ünlü bilim adamlarının değerli katkıla-rına işaret etmelidir.

(5) “islami Kalvinistler. Orta Anadolu'da Değişim ve Muhafazakârlık”, 19 Eylül 2005, Berlinİstanbul, www.esiweb.org, 20.03.2008.

(6) R. Tapper'in yukarıda zikredilen çalışmasına meselâ E. Olson'un "Muslim Identity and Secularism in Contemporary Turkey: The Headscarf Dispute", Anthropological Quarterly, 1985, 58 (4) adlı çalışması eklenmektedir.

(7) M. Karasan'ın din sosyolojisi ders notları için bkz. "Din Sosyolojisine Giriş" (43 sayfa), Ankara Üniversitesi Illahiyat Fakültesi Kütüphanesi.

(8) Batı'da din sosyolojisi alnında gerçekleştirilen çalışmaların kuramsal boyutu ile ilgili olarak özellikle bkz. Hamilton, 2001.

\section{Kaynaklar}

Akşit, B., "Laikleşme Tipolojisi ve Türkiye'de Laiklik Deneyimi", Şerif Mardin'e Armağan, İstanbul: İletişim Yayınları, 2005.

Aktaş, C., "Cemaatten Kamusal Alana İslamcı Kadınlar", İslamcılık: Modern Türkiye'de Siyasi Düşünce, İstanbul: iletişim, 2004, C. 6: 826-36.

Aktay, Y. (der.), Din Sosyolojisi, (M. Emin Köktaş'la birlikte), Ankara: Vadi Yay., 1998.

Aktay, Y., Türk Dininin Sosyolojik İmkanı, İstanbul: İletişim Yayınları, 1999.

Arat, Y., "Feminism and Islam: Considerations on the Journal Kadm ve Aile" in Şirin Tekeli (ed.), Women in Modem Turkish Society, Londra: Zed Boks. 
Arat, Y., "Group-Differentiated Rights and Liberal Democratic State: Rethinking Headscarf Contraversy in Turkey", in New Perspectives on Turkey, Fall 2001: 31-46.

Arat, Y., Politik İslam ve Kadın Organizasyonları, TESEV, 1999.

Arat, Y., Rethinking Islam and Liberal Democracy: Islamist Women in Turkish Politics, New York, State University of New York Pres, 2007.

Arkoun, M., Pour une Critique de la Raison İlamique, Paris: Maisonneuve-Larose, 1984.

Atacan, F., "Islam and Secularism: The Case of Turkey", Cultural Frontiers in Question: Nation, Religion, Refugees, 10-12 Temmuz 2002, Canberra Üniversitesi, Avusturalya.

Atacan, F., "Secularism in Turkey and the Arab World", lléme congrés du dialogue arabo-turc sur: Modernisation Politique, Economique et Scientifique dans les Pays Arabes et en Turquie (1918-1998), 2-5 Haziran 2000, Zaghouan, Tunus.

Atacan, F., Kutsal Göç: Radikal İslamcı Bir Grubun Anatomisi. Ankara: Bağlam Yay., 1993.

Atacan, F., Sosyal Değişme ve Tarikat: Cerrahiler, İstanbul: Hil Yay., 1990.

Atay, T., Batı'da Bir Nakşi Cemaati: Şeyh Nazım Kıbrısi Örneği. Istanbul: Illetişim, 1996.

Ayas, M. R., "Mehmet İzzet'in Bir Yazısı”, A. Ü. Ilahiyat Fakültesi Dergisi, Ankara, 1976/XXI: 285-301.

Ayata, S. (1993). “Çevresel Nitelikteki Geleneksel Tarikatlar”, R. Tapper (ed.), Çağdaş Türkiye'de İslâm, çev. Ö. Arıkan, İstanbul.

Aydın, M. Ş., "Yüksek Din Öğretimi Kurumları: Gelgitler Alanı", Tezkire, Mart-Haziran 2003/31-32: 106-123.

Aynî, M. A., "Vuzuhsuzluklar", Haz. A. Efe, İslamiyât/Kitabiyât, Bülten 16, Temmuz-Eylül 2005: 26-30.

Başak, S., "Türk Sosyolojisinde Yapı Araştırmaları", Bilig, Kış - 2005 /32.

Bayyiğit, M., "Türkiye'de Genel ve Özel Din Sosyolojisi Ille Illgili Bir Bibliyografya Denemesi", Selçuk Üniversitesi İlahiyat Fakültesi Dergisi, 1986/2: 403-445.

Bennigsen, A., Chantel Lemercier-Quelquejay, Sufi ve Komiser. Rusya'da islâm Tarikatları, çev. O. Türer, Ankara, 1988.

Berkes, N., Teokrasi ve Laiklik, İstanbul: Adam Yay., 1997.

Berkes, N., Türkiye'de Çağdaşlaşma, Ankara: Bilgi Yayınevi, 1973.

Bozan, i., Devlet ve Toplum arasında Bir Okul: Imam Hatip Liseleri, Bir Kurum: Diyanet İşleri Başkanlığı, İstanbul: TESEV, 2007.

Buğra, A., Politik islam and Ekonomi, TESEV, 1999.

Çakır, R. ve İ. Bozan, "Sivil, Şeffaf ve Demokratik Bir Diyanet İşleri Başkanlığı Mümkün mü?”, istanbul: TESEV, 2005.

Çakır, R. ve I. Bozan, B. Talu, Imam Hatip Liseleri: Efsaneler ve Gerçekler, i̇stanbul: TESEV, 2004.

Çakır, R., Ayet ve Slogan. Türkiye'de İslami Oluşumlar, İstanbul: Metis Yay., 1990.

Çakır, R., Direniş ve İtaat: i̇ki İktidar Arasında İslamcı Kadın, İstanbul: Metis yay., 2000.

Çapcıoğlu, İ., "Türkiye'de Akademisyen Din Sosyologları Bibliyografyası. A. Ü. ilahiyat Fakültesi Dergisi, Ankara, 2003/XLIV (2): 207-255.

Çapcıoğlu, ì., "Türkiye'deki İlahiyat Fakültelerinde Din Sosyolojisi Alanında Tamamlanmış Lisansüstü Tezler Üzerine Bir Araştırma", A. Ü. ilahiyat Fakültesi Dergisi, Ankara, 2004/XLV, S. I: 203-224.

Çarkoğlu, A. ve B. Toprak, Değişen Türkiye'de Din, Toplum ve Siyaset, İstanbul: TESEV YayInları, 2006.

Çarkoğlu, A. ve B. Toprak, Türkiye'de Din, Toplum ve Siyaset, İstanbul: TESEV Yay., 2000.

Desroche, H., Sociologies Religieuses, Paris: PUF, 1968.

Durkheim, E., "De La Définition Du Phénomene Religieux", Année Sociologique, 1899.

Efe, A., "II. Meşrutiyetten Cumhuriyete Geçiş Sürecinde İçtimaî Usul-i Fıkıh Tartışmaları", islâmiyât, 2005/8, Sa. I: 25-40. 
Efe, A., "Salahaddin Asım'ın İslam Sosyolojisi ile illgili Bir Yazısı Münasebetiyle", Tabula Rasa, Mayıs-Ağustos 2003/8.

Efe, A., Türkiye'de Akademik Din Sosyolojisi Araştırmaları (illahiyat Fakülteleri Örneği), İstanbul: Ensar Neşriyat, 2007.

Eröz, M., Türkiye'de Alevilik ve Bektaşilik, Ankara: Kültür Bakanlığı Yay. 1990.

Fığlalı, E. R., Türkiye'de Alevilik ve Bektaşilik, Ankara: Selçuk Yay. 1990.

Fındıkoğlu, Z. F., "Bizde Dinî Sosyoloji ve Tarih Çalışmaları", Folklor Postası, Sa.: 7, 8, 9, İstanbul: Aralık 1965-Ocak 1966, Sa. 223, 224.

Fındıkoğlu, Z. F., "Sınaî Sosyoloji ve İnsanlararası Münasebetler Teorisi", i. Ü. İktisat Fakültesi Mecmuası, 1959/1960, C. 21/1-4: 174-175.

Fındıkoğlu, Z. F., İçtimaiyat. Metodoloji Nazariyeleri, C.II, İstanbul: i.ü. İktisat Fakültesi Yay., 1961.

Fındıoğlu, Z. F., Ziya Gökalp, Sa Vie et Sa Sociologie, These Principale Rour Le Doctorat és Lettres, Paris: Imprimerie Berger-Levraut, 1935.

Freyer, H., Din Sosyolojisi, çev. T. Kalpsüz, Ankara: Illahiyat Fakültesi Yay., 1964.

Gellner, E., "A Pendulum Swing Theory of İslam", Annales de Sociologie, 1968: 5-14.

Gibb, H.A.R., Les Tendances Modernes de I'Islam, Paris: Maisonneuve, 1949.

Gökalp, Z., "islam İçtimaiyatı: Dinin İçtimaî Hizmetleri 2", İslam Mecmuası, Yıl: 2, Sayı: 36, 10 Eylül 1331/1915a.

Gökalp, Z., "İslam Içtimaiyatı: Dinin içtimaî Hizmetleri 3, Müspet Ayinler", íslam Mecmuası, Yıl: 2, Sayı: 37, 24 Eylül 1331/1915b.

Gökalp, Z., "İslam İçtimaiyatı: Dinin İçtimaî Hizmetleri", Islam Mecmuası, Yıl: 2, Sayı: 34, 14 Ağustos 1331/1915c.

Gökalp, Z., Türkleşmek, İslamlaşmak, Muasırlaşmak, İstanbul: Eflatun Yayınevi, 2008.

Gökçe, B., Türkiye'nin Toplumsal Yapısı ve Toplumsal Kurumlar, Ankara: Savaş Yayınevi, 1996.

Göle, N., İslam'ın Yeni Kamusal Yüzleri. İslam ve Kamusal Alan Üzerine Bir Atölye Çalışması, İstanbul: Metis Yayınları, 2000a.

Göle, N., Melez Desenler, İslam ve Modernlik Üzerine, İstanbul: Metis Yayınları, 2000b.

Göle, N., Modern Mahrem, Medeniyet ve Örtünme, İstanbul: Metis yay., 1991.

Gölpınarlı, A., Tarih Boyunca İslam Mezhepleri ve Şiilik, İstanbul, 1979.

Görkem, ì., "Baha Said Bey'in Türkiye'deki Alevi-Bektaşi ve Nusayri Zümreleri Hakkındaki Araştırmaları”, Türkiye Günlügü, 1998/51: 117-125.

Gözaydın, İ. B., "A Religious Administration to Secure Secularism: The Presidency of Religious Affairs of the Republic of Turkey", Marburg Journal of Religion, V. 11, No. 1, June 2006.

Gülçiçek Ayas, K., Türk Din Sosyologları, M. Rami Ayas, (Yüksek Lisans Tezi), M. Ü. Sosyal Bilimler Enstitüsü, İstanbul, 2007.

Günay Ü. ve diğerleri, Dindarlı̆̆ın Sosyo-Psikolojisi, Adana: Karahan Kitabevî, 2006.

Günay, Ü., "İslâm Dünyasında Bir Din Sosyolojisi Öncüsü: İbn Haldun (1332-1406)", Atatürk Üniversitesi Ilâhiyat Fakültesi Dergisi, 1986/6: 63-104.

Günay, Ü., "Kuramsal Yaklaşım ve Türk Sosyolojisi”, Erciyes Üniversitesi Sosyal Bilimler Enstitüsü Dergisi, Kayseri, 2006/2: 509-542.

Günay, Ü., "Ziya Gökalp ve Din Sosyolojisi”, Erciyes Üniversitesi Sosyal Bilimler Enstitüsü Dergisi, Kayseri, 1989/3: 223-236.

Günay, Ü., Din Sosyolojisi, İstanbul: İnsan Yay., 2000.

Güngör, E., islâm Tasavvufunun Meseleleri, İstanbul, 1982.

Hamilton, M., The Sociology of Religion : Theoretical and Comparative Perspectives. London, UK: Routledge, 2001.

İçli, G., "Türkiye'de Toplumbilim Araştırmalarının Gelişimi”, Felsefe Dünyası, 2001/1, Sayı 33. 
“islami Kalvinistler. Orta Anadolu'da Değişim ve Muhafazakârlık”, 19 Eylül 2005, Berlinİstanbul, www.esiweb.org, 20.03.2008.

İnalcık, H., "Sosyal Değişme, Gökalp ve Toynbee", Türk Kültürü, 1965, III, S. 31.

Kağıtçıbaşı, Ç., "Sosyal Psikoloji Araştırmaları: Geleceğe Iliş̧in Öneriler", Türkiye'de Sosyal Bilim Araştırmalarının Gelişimi, Der. S. Atauz, Ankara: TSBD Yay., 1986: 7-20.

Kandiyoti, D., Cariyeler, Bacılar, Yurttaşlar: Kimlikler ve Toplumsal Dönüşümler. Istanbul: Metis Yay., 1997.

Karasan, M., “Din Sosyolojisinin Öncüleri ve Kurucuları”, A. Ü. İlahiyat Fakültesi Dergisi, Ankara, 1953a/2 (4): 61-69.

Karasan, M., "ilk Yunan Düşüncesinde Din İlmi Denemeleri", A. Ü. Ilahiyat Fakültesi Dergisi, Ankara, 1953b/2 (1): 21-27.

Kasapoğlu, A., "The Study of Sociology in Turkish Higher Education", International Education Journal, V. 6, N. 4, September- 2005: 543- 544.

Kıray, M. B., "Toplum Yapısı ve Laiklik”. Toplumbilim Yazıları, Ankara: Gazi Üniversitesi i.i.B.F. Yay., 1982.

Kongar, E., “Niyazi Berkes'de Çağdaşlaşma Kavramı”, Niyazi Berkes Sempozyumu, Doğu Akdeniz Üniversitesi, 21-23 Nisan 1999, Gazimağosa, http://www.kongar.org/makaleler/mak_ni.php, 25.03.2008.

Kongar, E., Türk Toplum Bilimcileri I, İstanbul: Remzi Kitabevi, 1996.

Kongar, E., Türk Toplumbilimcileri 2, İstanbul: Remzi Kitabevi, 1988.

Koştaş, M., "Ankara Üniversitesi Illahiyat Fakültesi”, Ilahiyat Fakültesi Dergisi, 1989/XXXI.

Köprülü, F., "İslam Sûfi Tarikatlerine Türk-Moğol Şamanlığının Tesiri”, çev. Y. Altan, A. Ü. ilahiyat Fakültesi Dergisi, Ankara, 1972/XVIII: 141-152.

Kösemihal, N. Ş., "Büyü ve Din Probleminin Bugünkü Durumu”, Sosyoloji Dergisi, 1952.

Kösemihal, N. Ş., "ilim Gözüyle Büyü ve Din”, Sosyoloji Dünyası Dergisi, 1953.

Kösemihal, N. Ş., Durkheim Sosyolojisi, İstanbul: Remzi Kitabevi, 1971.

Kupfershmiat, M., "Reformist and Militant Islam in Urban and Rural Egypt", Middle Eastern Studies, 23(4), 1987: 403-419.

Kurktan Bilgiseven, A., Din Sosyolojisi, İstanbul: Filiz Kitabevi, 1985.

Kurktan Bilgiseven, A., İslamiyet'in Kültürel Özellikleri ve İslami Kavramlar, İstanbul: Filiz Kitabevi, İstanbul, 1989.

Kurktan Bilgiseven, A., Sosyolojik Açıdan İslamiyet ve İslami Kavramlar, İstanbul: Filiz Kitabevi, 1992.

Kurktan, A., Sosyolojik Açıdan Tasavvuf ve Laiklik, İstanbul: Kutsun Yayınevi, 1977.

Landolt, H., "Ghazali and 'Religionswissenschaft': Some Notes on the Mishkat al-Anwar for Professor Charles J. Adams", Asiatische Studien (Etudes asiatiques), 1991/45, no. 1: 1-72.

Lanternari, V., "Sciences Religieuses et Mouvements Religieux Nouveaux Dans l'Occident", Current Progress in the Methodology of the Science of Religions, Varşova.

Mardin, Ş., "Culture and Religion Towards the Year 2000", Turkey in the Year 2000, Ankara: Türk Siyaset Bilimi Derneği, 1989: 163-186.

Mardin, Ş., Din ve İdeoloji, İstanbul: İletişim Yay., 1983.

Mardin, Ş., Religion, Society and Modernity in Turkey, Syracuse University Pres, 2006.

Mardin, Ş., Türkiye'de Din ve Siyaset, Makaleler 3, İstanbul: iletişim Yay., 1991.

Mardin, Ş., Türkiye'de Din ve Toplumsal Değişme: Bediüzzaman Said Nursî Olayı, İstanbul: Iletişim Yay., 1992a.

Mardin, Ş., Türk Modernleşmesi, Makaleler 4, İstanbul: İletişim Yay., 1992b.

Narlı, N., "Modernization, Political Islam and Women", in N. Arat (ed.), Mediteranean Women and Democracy, İstanbul, 2002: 91-96.

Ocak, A. Y., Alevi ve Bektaşi İnançlarının İslam Öncesi Temelleri, İstanbul: İletişim Yay., 2000. 
Ocak, A. Y., Türk Sûfiliğine Bakışlar, İstanbul: İletişim Yay., 1996.

Özdalga, E., Modern Türkiye'de Örtünme Sorunu, Resmi Laiklik ve Popüler İslam, çev. Y. Alogan, İstanbul: Sarmal, 1998.

Said, B., Ittihat Terakki'nin Alevilik Bektaşilik Araştırması, nşr. N. Birdoğan, İstanbul: Berfin Yay., 1994.

Saktanber, A., "Becoming the "other" in a Muslim Turkey. Turkish Women versus Islamist women", in New Perpectives on Turkey, 1994/11: 99-134.

Saktanber, A., "Gündelik Yaşamda Dinin Yeniden Keşfinin Bir 'Aracı' Olarak Kadınlar", is/amcıIık: Modern Türkiye'de Siyasi Düşünce, İstanbul: İletişim, 2004, C. 6: 813-7.

Sarıbay, A. Y., Postmodernite, Sivil Toplum ve Islam, İstanbul: Iletişim Yayınları, 1994.

Sezen, B., "Türk Sosyologları ve Eserleri, I", Sosyoloji Dergisi, İstanbul, 1989/1.

Sunar, i. ve B. Toprak, "Islam in Politics: The Case of Turkey," Government and Opposition, Vol. 18, No. 4, Autumn 1983: 421-441.

Sündal, F., "Din Sosyolojisi, Gündelik Hayat, Etik Kaygılar" insan, Toplum, Bilim (der. Kuvvet Lordoğlu), Istanbul: Kavram Yay., 1996: 211-218.

Sündal, F., "Invisible Women Visible Islam: Engendering Everyday Lives Of Educated Islamist Women In Turkey", Anadolu Üniversitesi Sosyal Bilimler Dergisi, 2005/1: 109-130.

Sündal, F., An Islamic Tarikat and Everyday Life in a Small Turkish Town (Yüksek Lisans Tezi), ODTÜ, 1993.

Sündal, F., The Logic of Veiling: Engendering Everday Lives of Educated Islamist Women in Turkey (Doktora Tezi), ODTÜ, 2002.

Tanyol, C., "Elifoğlu Köyü", Sosyoloji Dergisi, 1962-63/17, 18: 203-204, 215-222.

Taplamacıoğlu, M., "Din Sosyolojisi Çalışmaları (Batıda ve Bizde)", A.Ü. Ilahiyat Fakültesi Dergisi, Ankara, VII, 55-61.

Taplamacıoğlu, M., "Din ve Toplum İlişkileri ve Dini Gruplar", A. Ü. Ilahiyat Fakültesi Dergisi, Ankara, 1965, XIII: 13- 20.

Taplamacıoğlu, M., "Laiklik illkesi ve Türkiye'deki Durum”, A. Ü. Ilahiyat Fakültesi Dergisi, Ankara, 1963, XI: 35-53.

Taplamacıoğlu, M., "Yaşlara Göre Dini Yaşayışın Şiddet ve Kesafeti Üzerinde Bir Anket Denemesi", A.Ü. Ilahiyat Fakültesi Dergisi, Ankara, 1962, X: 141-151.

Taplamacıoğlu, M., Din Sosyolojisi Giriş, Ankara: A. Ü. İ. F. Yay, 1961, 1968.

Taplamacıoğlu, M., Din Sosyolojisi, Ankara: A.Ü.i..F. Yay., 1975.

Tapper, R., Çağdaş Türkiye'de İslâm, çev. Ö. Arıkan, İstanbul 1993.

Tatar, H. Canbay, Nuh'un Gemisindekiler. Şehirleşme ve Dini Cemaatleşme, İstanbul: Turan Yayıncilık, 1999.

Toprak, B., "Emancipated but Unliberated Women in Turkey: The Impact of Islam," Ferhunde Özbay (ed.), Women, Family and Social Change in Turkey, Bangkok: UNESCO, 1990.

Toprak, B., "Islamic Intellectuals of the 1980's in Turkey," Current Turkish Thought, "Perspectives on Islam" Series, Spring 1987, No. 62.

Toprak, B., "Politicization of Islam in a Secular State: The National Salvation Party in Turkey," Said Amir Arjomand (ed.), From Nationalism to Revolutionary Islam, Oxford: Macmillan, 1984: 119-133.

Toprak, B., "Türk Kadını ve Din," in Nermin Abadan-Unat (ed.), Türk Toplumunda Kadın, Ankara: Türk Sosyal Bilimler Derneği Yay., 1979: 381-391.

Toprak, B., "Türkiye'de Dinin Denetim İşlevi," Ankara Üniversitesi Siyasal Bilgiler Fakültesi Dergisi, C. XXXIII, No. 1-2, Mart-Haziran 1978: 173-185.

Toprak, B., "Women and Fundamentalism: The Case of Turkey," Valentine M. Moghadam (ed.), Identity Politics and Women: Cultural Reassertions and Feminisms in International Perspective, Boulder, Colorado: Westview Press, 1994.

Turhan, M., Kültür Değişmeleri, İstanbul, 1972. 
Turner, B. S., Max Weber ve İlam: Eleştirel Bir Yaklaşım, çev. Yasin Aktay, Ankara: Vadi Yay., 1997.

Türkdoğan, O., “Batı ve Türk Toplumunda Yeni Dinî Hareketler”, Türk Yurdu, 1997, 17/116117.

Türkdoğan, O., Alevi-Bektaşi Kimliği, ìstanbul: Timaş Yay., 1995.

Türkdoğan, O., Max Weber, Günümüzde ve Türkiye'de Weberci Görüşler, İstanbul: Türk Dünyası Araştırmaları Vakfı, 1985.

Türkdoğan, O., Millî Kültür, Modernleşme ve İslam, İstanbul: Üçdal Neşriyat, 1983.

Ülgener, S. F., "Iktisadî Hayatta Zihniyetin Rolü ve Tezahürleri”, i. Ü. iktisat Fakültesi Mecmuası, İstanbul, 1941, II/3-4.

Ülgener, S. F., Iktisadi Inhitat Tarihimizin Ahlak ve Zihniyet Meseleleri, İstanbul: i. Ü. İktisat Fakültesi Yayınları, 1951a.

Ülgener, S. F., Tarihte Darlık Buhranları ve Iktisadi Muvazenesizlik Meselesi, İstanbul: i. Ü. iktisat Fakültesi Yayınları, 1951b.

Ülgener, S. F., iktisadî Çözülmenin Ahlâk ve Zihniyet Dünyası, İstanbul: Der Yayınları, 1981a.

Ülgener, S. F., Zihniyet ve Din: İslam, Tasavvuf ve Çözülme Devri İktisat Ahlakı, İstanbul: Der Yayınları, 1981b.

Ülgener, S. F., Zihniyet, Aydınlar ve Izmler, Ankara: Mayaş Yay., 1983.

Ülken, H. Z. ve A. Tanyeli, “Gönen Bölge Monografisi”, Sosyoloji Dergisi, 1955-1956/10-11: 114-154.

Ülken, H. Z., "Dinî İçtimâiyât", Felsefe ve içtimâiyât Mecmuası, İstanbul 1927/4: 264-271.

Ülken, H. Z., "İptidailerde İçtimâi Bünye Ve Din”, Sosyoloji Dergisi, S. 13-14, İstanbul: i. Ü. Edebiyat Fakültesi Yay., 1959: 35-57.

Ülken, H. Z., "İslamiyet'te Eski Dinlerin İzleri”, İstanbul Mecmuası, C. 6, S. 63, İstanbul, 1946.

Ülken, H. Z., "Totemizm Etrafında Münakaşalar", insan, C. II, S. 11, İstanbul, 1939.

Ülken, H. Z., Dinî Sosyoloji, İstanbul: i. Ü. Edebiyat Fak. Yay., 1943.

Ülken, H. Z., Sosyoloji Sözlüğü, İstanbul: Milli Eğitim Basımevi, 1969.

Ülken, H. Z., Sosyolojinin Problemleri, İstanbul: İ. Ü. Edebiyet Fakültesi Yay., 1955.

Ülken, H. Z., Türkiye'de Çağdaş Düşünce Tarihi, İstanbul: Ülken Yay., 1979.

Ülken, H. Z., Ziya Gökalp, İstanbul: Kanaat Kitabevi, 1939.

Vergin, N., "Toplumsal Değişme ve Dinsellikte Artış", Tarih ve Toplum, Bahar-Yaz 1985, 2930: 9-28.

Wach, J., Din Sosyolojisi, çev. Ü. Günay, İstanbul: Marmara Üniversitesi İlahiyat Vakfı Yay., 1995.

Walker, P. E., "Philosophy of Religion in al-Farabi, Ibn Sina and Ibn Tufayl”, in Lawson, Todd (Editor), Reason and Inspiration in Islam : Theology, Philosophy and Mysticism in Muslim Thought, Londra, , GBR: I. B. Tauris and Company, Limited in association with the Institute of Ismaili Studies, 2006.

Willaime, J. P., Sociologie des Religions, Paris: PUF, 1995.

Yasa, i., Hasanoğlan Köyününü Iktisadî ve Içtimaî Yapısı, Ankara, 1955.

Yasa, I.., Türkiye'nin Toplumsal Yapısı ve Temel Sorunları, Ankara: TODAiE Yay., 1970.

Yasa, I., Yirmibeş Yıl Sonra Hasanoğlan Köyü-Karşılaştırmalı Bir Toplumbilimsel Araştırma, Ankara: SBF. Yay., 1969.

Yörükhan, Y. Z., Anadolu'da Aleviler ve Tahtacılar, (Haz. T. Yörükhan), Ankara: Kültür Bakanlığı Yay., 1998.

Yücekök, A. N., Türkiye'de Örgütlenmiş Dinin Sosyo-Ekonomik Tabanı, Ankara, 1968.

Yükleyen, A. ve A. T. Kuru, Avrupa'da İslam, Laiklik ve Demokrasi. Fransa, Almanya, Hollanda, İstanbul: TESEV, 2006. 


\title{
SOSYAL BİLİMLER EPISTEMOLOJİSINNDE SORUNLARIN KAYNAĞI: ONTOLOJIYYI UNUTMAK $^{(* *)}$
}

\begin{abstract}
The source of problems in epistemology of social sciences: Forgetting about ontology. This study deals with problems in social sciences in general and in sociology in particular resulting from forgetting about ontology in the discussions concerning the philosophy of social sciences. The study focusses on the concept of paradigm in order to show how ontological, epistemological and methodological conventional rules establish the understanding of science. In the study, the significance of ontolological assumptions that are the basis of other assumptions of the paradigm is emphasized. Then, problems that occur due to isolated epistemology are taken into consideration. Finally, the cognitive and sociological reasons for epistemolgy without ontology are analysed. The ultimate aim of the study is to focus on the significance of the concept of scientific paradigm and to indicate that despite all sociological dynamics, ontology as a scientific requirement can not be ignored.
\end{abstract}

\section{key words}

Ontology, epistemology, sociology, paradigm, methodology. 


\section{Sosyal Bilimler Epistemolojisinde Sorunların Kaynağı: Ontolojiyi Unutmak}

Post-modernist söylem ile birlikte, sosyal bilimler ile felsefenin buluştuğu alanlarda epistemoloji, sanki sosyal bilimlerin tüm dertlerine deva sihirli bir kavram oluverdi. Epistemolojinin ontoloji ile bağı adeta kesildi ve kavram çoğunlukla metodoloji anlamında da kullanılır oldu. Oysa en yalın anlamıyla bilim anlayışı diye adlandırabileceğimiz bilimsel paradigma; iç içe geçmiş ontolojik, epistemolojik ve metodolojik sayıltılardan/temel kabullerden oluşmuştur ve bilim insanına bilimsel faaliyetlerini başlatabileceği, anlamlandırabileceği ve sınayabileceği bir referans çerçevesi sunar.

$\mathrm{Bu}$ temel kabullerden biri eksik olduğunda, bilim anlayışı biçimlenemez; paradigma diye bir kavramdan da söz edemeyiz. Zira bilgisini edinmek istediğimiz gerçekliğin nasıl bir şey olduğunu (ontoloji) bilmeliyiz ki, bu gerçekliğin bilgisine hangi tür bilgi (epistemoloji) ile nasıl ulaşabileceğimizi (metodoloji) bilebilelim.

Paradigmayı biçimlendiren ve onu diğerlerinden ayıran şey, en derinde yer alan varlığın mahiyetine ilişkin ontolojik sayıltıdır. Ontolojik, epistemolojik ve metodolojik sayıltılar arasındaki bağıntılara baktığımızda paradigmayı, güneş sistemine benzetebiliriz (Dikeçligil 2005:42). Burada sistemin güneşi, "Gerçeklik nedir?/Gerçekliğin yapı taşı nedir?" gibi sorulara cevap veren ontolojik sayıltıdır. Epistemolojik ve metodolojik sayıltılar ise, güneşe bağlı olarak belirli yörüngeleri izleyen gezegenler gibidir. Bu nedenle bir bilim anlayışının/paradigmanın ne olduğunu anlamanın yolu, onun güneşinin ne olduğunu anlamaktan geçer.

Güneşi olmayan bir 'güneş sistemi'nden söz edebilir miyiz? Ontolojiyi yok sayarak, epistemolojik sorunları tartışmak sorunların derinleşmesinden ve çoğalmasından başka bir şeye yaramayacaktır.

Bildirimizin konusu olarak, sosyal bilimler felsefesi ile bağlantılı tartışmalarda ontolojiyi unutmanın, genelde sosyal bilimlerde özelde sosyolojide, yol açtığı sorunları ve bu unutkanlığın nedenlerini ele alacağız.

Konuyu ele alırken önce ontolojik, epistemolojik ve metodolojik temel kabullerin bilim anlayışını nasıl oluşturduğunu gösterebilmek amacıyla paradigma kavramı üzerinde durmak istiyoruz. Bu aynı zamanda ontolojinin neden önemli olduğuna ve bilime dair sorunların neden yalıtılmış bir epistemoloji ile anlaşılamayacağına ve çözülemeyeceğine dair yapacağımız açıklamalar için bir zemin oluşturacak. Paradigmanın diğer sayıltılarının da kaynağı olan ontolojik sayıltıların önemini ve vazgeçilmezliğini vurguladıktan sonra yalıtılmış epistemolojinin yol açtığı sorunlara değineceğiz. Son olarak da bu ontolojisiz epistemolojinin bilişsel ve sosyolojik nedenleri üzerinde duracağız.

Böyle bir konuyu ele almaktaki amacımız, bilimsel paradigma kavramının önemine dikkat çekmek ve bütün sosyolojik dinamiklere rağmen bir bilimsel zorunluluk olarak ontolojinin görmezden gelinemeyeceğini göstermektir. 


\section{Paradigmanın Bileșenleri: Ontolojik, Epistemolojik ve Metodolojik Sayıtlılar}

Sosyolojik dünya ile ilgili bütün önemli kavramların kaderine bilimsel paradigma kavramı da ortak oldu. Kavram zihinlerde yeterince açıkığa kavuşmadığı gibi uluorta kullanılıyor. Zaten içi yeterince dolu değildi, böylece iyice boşaltıldı. Bu olumsuzluklara, herhangi bir açıklama yapmaksızın, kendi ilgi alanının dışında kalan meselelere genellikle, "çok fazla kullanılıyor!" veya "son zamanlarda da moda oldu!" diyen küçümseyici entelektüel (!) tutumları da ekleyebiliriz. Oysa bilimsel paradigma, sadece bilimin nasıl bir faaliyet olduğunun anlaşılmasını sağlayan değil, aynı zamanda gelişmesini de tetikleyecek bir kavramdır. Konumuzun sınırlarını aşmamak için, bilimsel bunalımlar ve devrimlere dair bilgilere değinmeyerek, sadece paradigmanın yapısı üzerinde duracağız ve işlevlerine de "Ontolojisiz Epistemolojinin Yol Açtığı Sorunlar" başlığı altında yer vereceğiz.

Bilim insanları topluluğu tarafından benimsenmiş bilim anlayışı olarak adlandırabileceğimiz bilimsel paradigma, epistemik cemaate bilimin ne olması gerektiği ve bilimsel bilgiye nasıl ulaşılacağını gösteren bir dizi temel kabullerden oluşmuştur. Bu temel kabulleri üç kategoride analiz edebiliriz (Bkz. Dikeçligil 2003).

1) Bilgisini edinmek istediğimiz gerçekliğin doğasına dair ontolojik sayıltılar şu soruları cevaplar: Gerçekliğin kaynağı nedir? Gerçekliğin doğası nedir? Olgular arasında ne tür ilişkiler vardır? Sosyal bilimler söz konusu olduğunda sorular artıyor: Insanın doğası nedir?/Insan nasıl bir varlıktır? Toplumun doğası nedir? Birey-toplum/birey-yapı ilişkilerinin doğası nedir? Bu iki sorunun cevabı sosyolojik yaklaşımı ve yaklaşımın metodolojisini belirlemesi nedeniyle çok önemlidir.

2) İncelemekte olduğumuz gerçekliğe ait bilginin mahiyeti ve imkânlarına dair epistemolojik sayıltılar ise şu soruları cevaplar: Bilginin kaynağı nedir? Ne kadar bilebiliriz? Bilimsel bilgi ne tür bir bilgidir? Bilimsel bilgi ve diğer bilgi bağları arasında nasıl bir ilişki vardır? Bilgi edinmenin, bilimin amacı nedir? Bilen ve bilinen arasında nasıl bir ilişki vardır?

3) Bu gerçekliğin bilimsel bilgisine nasıl ulaşabileceğimize dair metodolojik sorular ise şu soruların cevabını vererek izlenecek yolu gösterir: Araştırmanın amacı nedir? Araştırma yöntemi nasıl olmalıdır? Araştırıcının rolü nedir?/ne olmalıdır? Değerlerin rolü nedir? Araştırma raporunun dili nasıl olmalıdır? (Son iki soruya verilen cevaplardan ilkine aksiyolojik sayıltı, ikincisine ise retoriksel sayıltı da denilmektedir)

Paradigma kavramının çeşitli metaforik anlatımlarla somutlaştırımaya çalışıldığını görüyoruz. Bir referans çerçevesi olması itibariyle paradigma, çoğu zaman bir yapının temeli gibi düşünülmüş ya da bilim anlayışını biçimlendiren ve aynı bilim tasavvurunu paylaşan teorileri kuşatan bir bilim tasarımı olması nedeniyle "çatı" ya benzetilmiştir. Biz burada ontolojik, epistemolojik ve meto- 
dolojik sayıltılar arasındaki ilişkiyi anlatabilmek amacı ile paradigmayı buzdağına benzetiyoruz. Buzdağı benzetmesi ile, ayrıca, bu paradigmatik temel kabullerin teori ve yöntemi de nasıl biçimlendirdiğini görebiliyoruz.

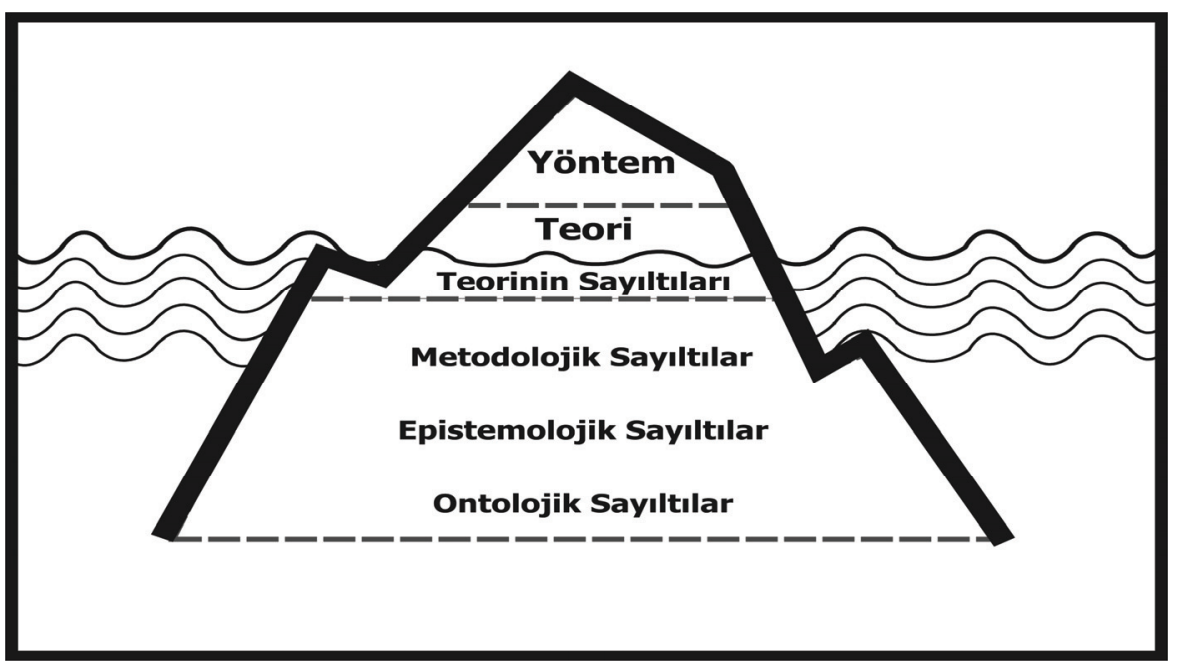

Şekil: Buzdağı Örneğinde Paradigma ve Sayıltıları

Gövdesinin çok az bir kısmı su üstünde kalan buzdağının göremediğimiz büyük kitlesinin üst üste üç kattan oluştuğunu farz edelim: En altta ontolojik, ortada epistemolojik ve en üste metodolojik sayıltılar yer alıyor. Ontolojik sayıltılar tabakasının en altta yer almasının nedeni, bunların epistemolojik ve metodolojik sayıltıların kaynağı olmasıdır. Hatırlayalım: Varlığın doğasına ilişkin temel ontolojik sayıltı bilim faaliyetinde bilim adamına bilgisini edinmek istediği gerçekliğin tasarımını verir. Böyle bir temel kabul olmaksızın bilim yapabilmek imkânsızdır. Tekrarlayalım: Bilgisini edinmek istediğimiz gerçekliğin nasıl bir şey olduğunu (ontoloji) bilmeliyiz ki, bu gerçekliğin bilgisine hangi tür bilgi (epistemoloji) ile nasıl ulaşabileceğimizi (metodoloji) bilebilelim. Görülüyor ki, buzdağı metaforunda hiyerarşik biçimde sıraladığımız bu temel kabuller aslında " birbiri içinde yuvalanmış" (Capra 2002), içiçe geçmiş bir halde paradigma bütününü oluşturur.

Buzdağının su üstünde kalan kısmı ise teorinin olgulara yönelik açıklamalarını ve kullanılan, izlenilen yöntemi simgeliyor. Tabii teoriyi oluşturan bileşenlerden biri olan teorinin sayıltıları su yüzeyinin hemen altında. Paradigmanın sayıltıları ile ilişkilendirilmeden teori ve yöntem çerçevesinde yapılan bilimsel faaliyetlere Kuhn'un normal/olağan bilim adını verdiğini biliyoruz. Konudan sapmamak amacıyla kavrama işaret etmekle yetinelim.

Buzdağı benzetmesinde normal bilim, buzdağının üzerinde görünen kısımdır. Burada bir parantez açalım: Sosyal bilimler felsefesi ile ilgilenmek, buzdağının görünen kısmı ile yetinmemek demektir ve normal bilim sürecinde gerçek- 
leşen her bilimsel faaliyet paradigmanın bütün bileşenleri ile temellendirildikçe anlam kazanmış olur.

Yalıtılmış bir epistemoloji ile bilimin neden anlaşılamayacağı tezini birbirini tamamlayan iki adımda açıklamaya çalışalım. illk basamakta geştaltçı yaklaşımın algılamaya dair temel bilgilerini kullanarak paradigma kavramını nasıl algıladığımızı görelim. İkinci basamakta ise, ayrı bir başlık altında, sosyal bilimlerde var olan üç paradigma üzerinden somut örnekler vermeye çalışalım.

Bilimsel paradigma ontolojik, epistemolojik ve metodolojik sayıltılardan oluşan bir bütün olduğuna göre, onu, bütün ve parçaları arasındaki bağıntıyı ortaya seren geştalt yaklaşımından yararlanarak açıklayabiliriz. Bütün, kendini oluşturan parçaların toplamı değil, parçalar arasındaki anlamlı ve dinamik ilişkilerin bir ürünüdür. Parçalar arasındaki ilişkileri algıladığımızda bütünün bilgisine ulaşabiliriz. Bilimsel faaliyetleri bir farkındalık ortamında gerçekleştirebilmek için, sayıltıları arasındaki anlamlı ve dinamik ilişkilerin bir ürünü olması nedeniyle paradigmayı anlamaya çalışırken sayıltılar arasındaki ilişkiler hareket noktamız olmalıdır. Sosyal bilimlerde birbirleri ile yarışan paradigmaları yerli yerine koyabilmenin ve zihnimizi paradigmalar karmaşasından kurtarabilmenin şifresi burada saklıdır. Paradigmayı analiz ederken, ontolojik, epistemolojik ve metodolojik sayıltıları ayrı hücrelere hapsetmekten kaçınarak bunların aynı pota içinde kaynaştıklarını düşünmek gerekiyor. Ancak anlamlı ve dinamik iliş̧ileri keşfedebilmek için bileşenlerin tümü göz önüne alınmalıdır. Indirgemecilik bileşenler/parçalar arasındaki ilişkilerden çok indirgenen parçayı vurgular, bütün kaybolur. Bu nedenle sadece epistemolojik sayıltılar ile bilimin nasıl bir faaliyet olduğunu gösteren paradigma kavramının anlaşılması mümkün değildir. Bilime dair tartışmalarda paradigma sadece epistemolojik sayıltılardan ibaretmiş gibi davranmak, diğer iki sayıltı kümesini yok saymak, bilimin ne olduğunu bir türlü kavrayamamak gibi bir sonuca yol açar. Bu çıkmaz, paradigma diğer sayıltılara indirgenirse de geçerlidir. Bütünü algılamak, indirgemeden kaçınarak, onu oluşturan parçalar arasındaki bağıntıların kurulması demektir.

Yukarıda geştaltçı yaklaşımın algılamaya dair temel bilgilerini kullanarak, diğer bütün kavramlar gibi paradigma kavramını nasıl algıladığımızı gösterdikten sonra, sosyal bilimlerde birbirleri ile yarışmakta olan üç paradigma üzerinden somut örnekler vermeye çalışalım.

\section{Bilimsel Paradigma Neden Sadece Epistemolojik Kabullerle Anlaşllamaz?}

Sadece epistemolojik açıklamalarla bilimin ne olduğunun anlaşılamayacağına dair görüşümüzü şu şekilde irdelemeye çalışalım: Şimdi paradigmaları sadece epistemolojik sayıltılardan ibaretmiş gibi düşünelim. Ve önce bu temel kabulleri kısaca özetleyelim. Daha sonra ontoloji ve metodolojik sayıltılar yokmuş gibi düşünerek, soracağımız bütün sorulara epistemoloji ile cevap vermeye 
çalışalım. Bakalım mümkün olabilecek mi? "Neden?" ve "Acaba?” ile oluşturulan zincirleme sorulara epistemoloji nereye kadar cevap verebilecek?

Birinci Basamak: Sosyal Bilimlerde Üç Paradigma ve Epistemolojik Temel Kabulleri

Farklı paradigmaların bilgiye ilişkin temel kabullerini görebilmek amacıyla, ilk basamağa doğrudan epistemolojik sorularla başlayalım: "Bilimsel bilgi ne tür bilgidir?". Bu soru farklı bir şekilde de sorulabilir: "Bir bilginin bilimsel bilgi olarak kabul edilebilmesi için ne tür özelliklere sahip olması gerekir?"

Önce, pozivitistik epistemolojinin vermiş olduğu cevaba bakalım: (i) Bilimsel bilgi nicelleştirilebilir bilgidir: Sayılarla ifade edilebilmeli, istatistik analizlere elverişli olmalıdır. Bu yüzden sosyal bilimlerde 'ölçekler' vazgeçilmez veri toplama teknikleridir; (ii) Bilimsel bilgi nesneldir: Araştırmacıya ait öznel bilgi ve yorumlara kapatılmış bir bilgidir. Özne ve nesne arasında kesin bir ayırım vardır; (iii) Bilimsel bilgi kesin bilgidir: bilimsel yöntemlerle teori-hipotez ilişkisi içinde sınandıktan sonra mutlak bilimsel kanunlar olarak ifade edilebilen bilgidir; (iv) Bilimsel bilgi tümelin, evrenselin bilgisidir: Kesin bilgiler bütün zamanlar ve mekânlar için geçerli değişmez bilgilerdir.

Fenomenolojik epistemoloji için ise bilimsel bilgi şu niteliklere haizdir: (i) Bilimsel bilgi nitel bir bilgidir. Sosyal dünyanın bilgisi sayılara indirgenemez, nitel olarak ifade edilir; (ii) Bilimsel bilgi özneldir: Hem araştırmacılar hem de araştırılanlar için öznelerarası (intersubjective) bir bilgi değildir; (iii) Bilimsel bilgi kesin değildir: Zira özneldir; (iv) Bilimsel bilgi tikelin bilgisidir: Tümelin bilgisi diye bir bilginin gerçeklikte karşılığı yoktur.

Son olarak bütüncül yeni sosyal bilim paradigmasının epistemolojik kabullerine göz atalım: (i) Bilimsel bilgiler nicel olabildiği gibi nitel de olabilir: Birinden birini yok saymak mümkün değildir; (ii) Bilimsel bilgi nesnel değildir: Ancak bilim insanının nesnel olmaya gayret etmesi, kendi öznel değerlendirmelerinin ve tutumlarının bilimsel bilgi üretim sürecinde nerede, hangi koşullarda karışabildiğini gözlemleyebilmesi ve denetleyebilmesi gerekir; (iii) Bilimsel bilgi "geçici kesin bilgi" (Dikeçligil 1994)'dir: Bilim insanları topluluğunca, Hüsamettin Arslan'ın kavramlaştırmasıyla "epistemik cemaat" tarafından, bilimsel kabul edilen bilgi, aksi ortaya çıkana kadar kesin olarak kabul edilir. Bilimsel bilgi tabu değildir. Bugün doğruluğu kesin olan bir bilgi zaman içinde yanlışlanabilir. (iv) Bazı bilimsel bilgiler tümele ait iken, bazıları tikel durumların bilgisidir. Bilimsel bilgi hem tümelin hem de tikelin bilgisidir (1).

İkinci Basamak: Epistemolojik Sayıltıları Anlamaya Çalışmak

Her üç epistemolojinin yukarıda belirtilen temel kabullerini daha iyi anlayabilmek için soru sormaya devam edelim: Peki, neden bu böyledir? Bu nasıl gerçekleşir? Neden nicel/nesnel/kesin/tümel bilgi gerekir? Nicel/nesnel/kesin/ 
tümel bilgiye nasıl ulaşılır? Pozitivist epistemoloji için sorduğumuz bu türden soruları diğer epistemolojiler için de sorabiliriz.

Oysa sosyal bilimlerde bu kapsamdaki metinlerine baktığımızda, epistemolojik kabulleri tanımlayan ilk basamak bilgiler ile yetinildiğini ve bu türden sorulara, dolayısıyla bu soruların yol açıı̆ı cevabi açıklamalara çoğu zaman rastlanılmadığını görebiliyoruz. Bir adım ileriye götüren açıklamalar gerektiği zaman epistemolojik sayıltılar, bütün soruların tüketildiği nihai referans çerçevesi olarak düşünülmektedir.

Pozitivist epistemolojinin nicel bilgiye dair sayıltısını daha iyi anlamak için "Neden nicel bilgi gereklidir?/Bilimsel bilgi neden nicel olarak ifade edilebilen bilgidir?" diye soralım. Çoğu zaman cevap şu şekildedir: Sosyal bilimler doğa bilimlerinin yöntemini model olarak almıştır; doğa bilimlerinde bilimsel bilgi sayılarla ifade edilebilir bilgidir (daha doğrusu matematiksel ifadelerdir) de ondan.

"Sosyal bilimlerde nesnel bilgi mümkün müdür? Nesnel bilgiye nasıl ulaşııır?" sorularının irdelenmeden benimsenmiş olan cevabı ise, bize göre aslında pek fazla bilgi vermeyen kapalı bir cevaptır: Evet, sosyal bilimler pozitif bilim olmak istiyorlarsa nesnel bilgi peşinde olmalıdırlar. Nicelleştirilebilir bilgiye ulaşabilmek için sosyal bilimcinin nesnel olması gerekir. Bilim insanı değer hükümlerini bilime katmaz (Katmaz, denilince katmadığı 'bir peşin hüküm olarak' kabul edilmiş, 'Acaba?' diye sorgulanmamıştır). Çünkü Decartes'ın dediği gibi, yöntem kuralları olarak apaçıklık, analiz, sentez ve sayma kurallarının işlemesi için önce zihnin bir elma sepeti gibi boşaltılması gerekir. David Hume da, zihnin boş bir levha gibi olduğunu söylemiştir. Böylece değer yargılarından, ideolojilerden bağımsız bir zihin ile bilimsel araştırma yapılır. Teori ve hipotez ilişkisi çerçevesinde gerçekleşecek olan gözlem, deney, genelleme yöntemini izleyerek sosyal bilimler nesnel bilgiye ulaşır.

"Bilimsel bilgi neden kesin bilgidir? Neden tümelin kesin bilgisini edinmeliyiz?" gibi soruların cevapları da yalıtılmış bir epistemoloji içinden cevaplanır: Sosyal bilimlerde bilimsel bilgi, toplumsal gerçekliğin işleyiş kanunlarını gösteren nesnel bir bilgi olduğu için kesindir. Nasıl ki doğa ve toplumda bütün zamanlar ve mekânlar için geçerli ve değişmeyen kesin işleyiş kanunları vardır, bilim bu kanunlara ulaşmak için tümelin bilgisini edinmek zorundadır. Böylece "tümelin bilgisini veren evrensel yasaların hepsini bilimsel olarak bilebiliriz miyiz?" sorusunun da cevabı 'evet' diyerek verilmiş olur. Pozitivistik sosyal bilimler için doğa bilimlerindeki gelişmeler izlenecek yolu gösteriyordu: Bilimsel teorilerin, özellikle Newton'un (1643-1727) çekim yasasının başarısı, ondokuzuncu yüzyıın başında Fransız matematikçi ve gökbilimcisi Laplace'ı (1749-1827), evrenin tümüyle belirlenir olduğu savına vardırdı. Laplace'a göre, öyle bir bilimsel kanunlar takımı olmalıydı ki, bunların yardımı ile yalnızca belirli bir an için evrenin tümünün durumunu bilirsek evrende olup bitecek her şeyi hesaplayabilmeliydik. Örneğin, güneşin ve gezegenlerin belirli bir andaki hızlarını ve ko- 
numlarını biliyorsak, Güneş Sisteminin başka zamanlardaki durumunu Newton'ın yasalarını kullanarak hesaplayabilirdik. Laplace bununla kalmayıp insan davranışları da içinde olmak üzere her şeye hükmeden benzeri yasaların varolduğunu ileri sürdü. İnsana ait gerçekliğin doğası üzerinde fazla durmayan pozitivist sosyal bilimciler için bu türden açıklamalar her zaman yol gösterici oldu.

Fenomenolojik epistemolojinin, varlığın doğasına ilişkin daha açık bir tutum içinde olduğunu görüyoruz. Bu yüzden cevaplar daha tatmin edicidir, diyebiliriz: Bilimsel bilgi nitel bir bilgidir; çünkü sosyal dünya doğal gerçeklikten farklıdır. Sayılarla ifade edilemez. Anlam atfeden bir varlık olan insan, atfettiği anlamlar ile kendi sosyal dünyasını kendisi kurar. Bilim insanının da kendi anlam dünyası vardır. Bu yüzden de bilimsel bilgi nesnel değil, özneldir. Sosyal dünya doğal gerçeklikten farklı olduğu için doğa bilimlerinin yöntemi model alınamaz. Evrensel kanunların peşinde koşan tümelin bilgisi yerine her bir sosyal dünyayı derinlemesine anlamaya çalışan tikelin bilgisi üzerinde derinleşmek gerekir.

Bu basamakta yeni/ bütüncül bilim anlayışını ele almayacağız. Zira adı üzerinde gerçekliği iç içe geçmiş boyutlar arasındaki bağıntıların dinamik ve ahenkli bir bütün olduğunu kabul eden bu yaklaşım için bu tür sorular ancak epistemolojik, ontolojik ve metodolojik sayıltıların içiçeliği içinde cevaplanabilir. Bu bilim anlayışına üçüncü basamakta ele almak üzere yolumuza devam edelim.

Yukarıdaki açıklamalara baktığımızda, özellikle pozitivist epistemolojik sayıltılar ile ilgili açıklamaların bizi yeni bir yere götürmediğini görüyoruz. Epistemolojik kabullerin nedenlerini yine epistemolojik kabuller ile açıklayamayız. Paradigmayı tam olarak anlayabilmemizi sağlayacak soru dizisine devam etmeliyiz. Epistemoloji ve ontoloji bağıntısını kurarak ve gerektiğinde metodolojik sayıltıları da işin işine katarak cevap vermeye çalışalım. Böylece her bir epistemoloji, ait olduğu paradigma bütünü içinde anlaşılır hale gelecektir.

Üçüncü Basamak: Epistemoloji İçinden Verilen Cevapları Ontolojik Kabullere Dayanarak Açıklamak

İkinci basamakta bilgiye ilişkin sorulara, yine epistemoloji çerçevesinde, verilen cevapları daha anlaşılır kılmaya çalıştığımızda, paradigma mantığının kaynağı olan ontolojik kabullere gelip dayanırız. Temel epistemolojik sorulara tatmin edici cevaplara ancak, gerektiğinde metodolojik sayıltılar ile destekleyerek, ait oldukları paradigmanın ontolojik kabullerine dayanarak ulaşabiliriz. Burada "tatmin edici" ifadesi ile kastedilen, cevapların her bir paradigmanın kendi iç tutarlılı̆ı̆ı yansıtıyor olmasıdır.

Pozitivistik epistemolojide biliyoruz ki, bilimsel bilgi nicel ve nicelleştirilebilir bilgidir. "Neden böyledir?" sorusunun cevabı ancak ontolojiye doğru gidildikçe netleşecektir: "Gerçeklikteki değişim niceliksel ve birikimseldir; bu demektir $\mathrm{ki}$, gerçekliğin makine düzeni evrensel bir dille, matematiğin diliyle ifade edilebilir" (Özlem 2001: 57). 
"Peki, neden gerçeklikteki değişim niceliksel ve birikimseldir?": Gerçeklik tüm heterojen görünümüne rağmen homojendir; o bir kosmos'tur; onun akla uygun bir yapısı vardır; bilimin görevi gerçekliğin bu akılsal yapısını gözlem/deney yoluyla ve evrensel doğa yasalarını bularak ortaya koymaktır" (Özlem 2001: 56).

Bu kosmosun akla uygun yapısı iki parçalı ve mekanistiktir. Bu iki parçalı yapıda maddi olmayanı, beş duyu ile algılayabildiğimiz maddi olana indirgenebilir olduğu için gerçeklikteki değişim nicelikseldir. Bu değişimin birikimsel olmasının nedeni ise, gerçekliğin işleyiş mekanizmasının yani olgular arasındaki ilişkiler düzeninin neden-sonuç zinciri şeklinde deterministik özellik göstermesidir ve bu işleyiş bütün zaman ve mekanlar için geçerlidir, yani tümele aittir, evrenseldir.

"Bilim neden evrensel bilginin peşinde olmalıdır?": Her şeyin bir makine düzeni halindeki işleyişi determinizm ilkesi ile ifade edilir; belirli bir neden belirli sonuca yol açar; eğer bir oluşun nedenini bilirsek, sonucu da önceden kestirebiliriz. Bunu nasıl bilebiliriz? Gözlem ve deney ile bilebiliriz. Çünkü maddi olmayan parçasının maddi olana indirgenebildiği bu gerçeklik, bizim dışımızda varolan, beş duyu ile algılanabilen ve akla uygun bir biçimde evrensel kanunlara göre işleyen bir yapıdadır. Neden-sonuç zinciri dediğimiz bu deterministik işleyişi keşfeden her bilim dalı kendi alanındaki evrensel kanunlara ulaşmış olur. Bu işleyiş, gerçekliğin her bir parçasında varolduğu için bilim evrenselin/tümelin bilgisinin peşindedir

"Bilimsel bilgi neden nesneldir?": Bilim insanı, teori-hipotez ilişkisini kurarak gözlem, deney, ölçme ve genelleme sürecinde tümevarım ile bilimsel bilgiye ulaşırken, değerlerden arınmıştır; zira bilimsel araştırma sürecinin başında "boş bir levha" gibi bir zihin ile yola çıkar. Bizi insanın doğasına ve olgular arası ilişkilere dair ontolojik kabullere götürecek olan pozitivist epistemoloji kapsamındaki açıklamaların hepsine sorular yöneltebiliriz: Toplumsal gerçekliğin nicel, nesnel, kesin ve tümel bilgisini elde etmek mümkün mü? Bu kapsamda; bilim insanının değer yargılarından, ideolojiden, dünya görüşünden, dini inançlarından sıyrılması, zihnini boş bir levha haline getirebilmesi mümkün mü? Bu nasıl gerçekleşebilecek? Toplumsal gerçeklikte her olguyu ve süreci sayılarla ifade etmek mümkün mü? Eğer sayılarla ifade edilemeyen olgular var ise, bu ne anlama gelir? Bu tür olguları görmezden gelerek edinilen bilgiye kesin ve tümel bilgi denebilir mi? Her şey doğa bilimlerindeki gibi ölçülebilir mi?/Doğa bilimlerinde kullanılan ölçeklerin hepsi sosyal bilimlerde kullanılabilir mi? Hepsi kullanılmaz ise neden?

"Bir bilgi nasıl nesnel olabilir?": Gözlem ve deneye tabii tutulabilen ve nicel olarak ifade edilebilinen bilgi nesneldir. Gerçeklik bizim dışımızda ve beş duyu ile algılanabilen ve akla uygun bir yapıya sahip bir gerçekliktir. Evrensel yasaların hepsini bilimsel olarak bilebiliriz. Beş duyu ile algılanamayan bilgiler bilimin dışında tutulmalıdır. Bu nedenle bilim felsefe, din gibi diğer bilgi bağlarından 
farklıdır ve onlar ile herhangi bir ilişkisi kalmamıştır. Bütün bu ontolojik zorunluluklar nedeniyle sosyal bilimler, eğer bilim olmak istiyorlar ise, doğa bilimlerinin yöntemini model olarak almak zorundadır.

Fenomenolojik sosyal bilim anlayışının, varlığın doğasına ilişkin daha açık bir tutum içinde olduğunu söylemiştik. Zaten fenomenolojik sosyoloji, sosyal bilimler kurulurken sosyal bilimlerin yöntemi noktasındaki yol ayırımında kendi yönünü, yöntem ve gerçekliğin doğasına ilişkin temel kabulleri belirlemişti. Insan ile ilgili bu bilimlerin doğa bilimlerinin yöntemini model olarak alabilmesinin imkansızlığı, insan ve toplum ile ilgili olan gerçekliğin doğası ile temellendirilmişti. Pozitivizmin belirli kanunlara göre işleyen evrensel gerçeklik tasarımının aksine bireylerin anlam dünyaları ile yaratılmış çok sayıda öznel gerçeklik dünyası vardır. Bu nedenle bu dünyanın işleyiş kanunlarından, nicel, nesnel ve tümel bilgiden söz edilemez. Her bir sosyal dünyayı kendine özgü özellikleri ile anlamak gerekir. Bu, tikelin derinlemesine nitel ve öznel bilgisini edinmek demektir. Olgular arasındaki ilişkiler determine bir belirleniş, yani neden-sonuç ilişkileri şeklinde değil, kendiliğinden (spontane) oluşan karşılıklı biçimlendirmeler olarak gerçekleşir. Pozitivizmin özne-nesne ayırımı, yani inceleme nesnesinden bağımsız ve yalıtılmış bilim insanı tasavvurunun olgusal bir karşılığı yoktur. Zira hem özne hem de nesne, anlam atfeden insandır. Bu nedenle öznelerarası, yani bilim insanlarının paylaştı̆̆ı, nesnel bir bilgiden söz edilemez.

Bütüncül paradigma ise çok farklı bir gerçeklik tasarımına dayanır. Bu nedenle bilimsel bilgi hem nitel hem de nicel bilgidir ve bilim hem evrenselin/ genelin hem de tikelin bilgisine ulaşmaya çalışır. "Ya - ya da" şeklindeki Aristo mantığına dayalı olan pozitivist ve fenomenolojik paradigma için bu kabuller son derece şaşırtıcıdır. Zira bütüncül paradigma "hem - hem de" şeklinde özetlenen bir mantığa dayanır. Bu mantık farklılığı, farklı evren tasarımları ile örtüşür.

"Bilimsel bilgi, nasıl hem nitel hem de nicel bilgi olabilir?" : Gerçeklik, iki parçalı mekanistik bir tasarımın çok ötesinde dinamik bir örüntüdür. Pozitivist bilim anlayışı için gerçekliğin yapı taşı 'madde' iken fenomenolojik bilim anlayışı için bu 'ide' dir. Oysa bütüncül bilimde gerçeklik, bu iki özelliğin iç içe geçmiş, birbiri içinde yuvalanmış olduğu bir mahiyete sahiptir. Kısacası gerçeklik hem madde hem de madde olmayandır; ancak bunların toplamı değil, bunların içiçe geçmişliği ile oluşan çok katlı ve çok boyutlu dinamik bir örüntüdür. Bu gerçeklik tasarımı pozitivist ontolojinin gerçeklik tasarımı gibi önce felsefede kurgulanıp daha sonra klasik fizik ile doğrulanmadı; aksine pozitivist paradigmanın yaşadığı derin ve sürekli anomalinin, yani bunalımın bilimsel olarak çözümü sürecinde ortaya çıktı (2) ve tasarım için gerekli olan yorumlar Batı felsefesinden değil Uzakdoğu mistik geleneklerinden destek aldı (Bkz. Capra 1997).

Madde ve madde olmayan, gerçekliğin birbirini tamamlayan/ bütünleyen iki farklı görünümüdür. Sosyolojik gerçeklikte hem sayılarla ifade edilebilen hem de edilemeyen özellikler ve süreçler vardır; bunlar biri diğerine indirgenebilecek 
nitelikte de değildir. Bu nedenle sosyal bilimci araştırma amacına ve konusuna göre kullanacağı yönteme karar verir. Gerektiğinde nicel, gerektiğinde nitel yöntem kullanır. Bazen de hem nicel hem nitel yöntemleri bir arada kullanarak inceleme konusunu kendi bütünlüğü içinde sergilemeye çalışır. Gerçekliğin bütüncül tasarımı bize bilimsel bilginin hem evrensel/ genel hem de tikel bilgi olmasının nedenlerini de açıklar.

Bilimsel bilgi hem evrenselin/genelin hem de tikelin bilgisini edinebilir mi? : Bilindiği gibi pozitivist sosyal bilim evrensel bilginin, fenomenolojik sosyal bilim tikelin bilgisinin peşindeydi.

Bütüncül yaklaşım için özünde birbiri içine yuvalanmış madde ve madde olmayandan oluşan gerçeklik, bu içiçeliğin sonsuz sayıdaki farklı görünümlerinin oluşturduğu çok katlı ve çok boyutlu, sürekli değişen ve kendi içinde değişmez unsuru da barındıran dinamik, ahenkli ve organik bir bütündür. Ancak bu çok sayıdaki farkıı görünümlerin temelinde tek ve ortak özellik vardır. Bu durumun en güzel tasvirini Mevlana'nın prizma ve güneş ışını örneğinde bulabiliriz: Prizmadan geçen güneşışını yedi farklı renge ayrılır; her bir farklı görünüm aslında, özünde güneş ışınından başka bir şey değildir. Yedi farklı renk gerçekliğin "çokluk" özelliğini; her bir rengin içinde onları oluşturan güneş ışını ise, "teklik" özeliğini simgeler.

Şu halde gerçeklikte her bir farklı görünümün kendine özgü özellikleri vardır; ama bunların derininde her bir fark için geçerli, bir anlamda bütün farkların/çokluk görünümlerinin ana kaynağı olan ortak bir özellik de vardır. Farkların, yani çokluktaki tekillerin kendine özgü özelliklerinin ve süreçlerinin bilgisi, tekilin bilgisi demektir; bütün farklarda mündemiç olan tekliğin bilgisi ise evrenselin/ genelin bilgisidir. Bilimin tek tür bilgi ile yetinmesi halinde bilgi her zaman eksik kalacaktır; hem tikelin hem de genelin bilgisine ulaşmak gerekir. Böylece "tümel kavramın içlemsel/niteliksel olarak dışarıda bıraktığı tekillerin kendine özgü özellikleri" (Özlem 1998: 8-9) gerçekliğin bütün katları ve boyutları için geçerlidir. Gerçekliğin teklik-çokluk görünümü hayatın bilgisini edinebildiğimiz katmanında ve her boyutunda karşımıza çıkar.

Hücreyi ele alalım. Kas hücresi, sinir hücresi, doku hücresi, beyin hücresi, bitki hücresi gibi çok sayıda farklı hücrenin kendine özgü özellikleri vardır; ama hepsinde hücrenin temel yapısı aynıdır. Aynı durum atom için de geçerlidir. Atom ile ilgili bilgilerimizi hatırlayalım. Temel bir atom modeli, proton ve nötronun oluşturduğu çekirdek ve çekirdeğin etrafında dönen elektron ile tasavvur edilir. Ne var ki, kimyasal yollarla daha basit maddelere ayırmak imkansız olduğu için varolan en basit maddeler olarak kabul edilen elementlere göre bu atom altı parçacıkların sayıları, elektron sayılarına göre de yörünge/kabuk sayısı değişir. Ya da tersinden söyleyecek olursak, farklı sayıdaki atom altı parçacıkların bir araya gelişleri ile farklı elementler ortaya çıkar. 
Bu temel ve yalın bilgiler bile bize, çokluktaki bütün farkların kendine özgü özelliklerinin ortak bir temele dayandığını göstermektedir.

Aynı durum sosyolojik dünya için de geçerlidir. Milattan önce yaşamış Anadolu uygarlıklarından kalan taş tabletlere oyulmuş bir ticari anlaşma veya bir aşk şiiri bugün bizleri hayrette bırakıyorsa, ilk insan topluluklarından beri süregelen değişim sürecinde bir şeylerin de hiç değişmediğini gösterdiği içindir. Cleopatra'nın aşkları ve iktidar tutkusu hala insanların ilgisini çekiyorsa; ilkçağlardan bugüne her alandaki sanat eserleri hala insanları etkiliyorsa, Mevlana, Yunus Emre, Dante, Makyavelli, Shakespeare, Goethe, Tolstoy vd. hala okunuyorsa, insana ait değişmeyen evrensel özellikleri veya oluşları bizlere aktardıkları içindir. Teklik-çokluk ilişkisi burada da canlı bir biçimde kendini gösterir. Bütün bu eserler, evrensel olanı barındırdıkları ve yansıttıkları için zaman ve mekan boyutlarını aşmışlardır; ama aynı zamanda kendine özgü nitelikleri ile çokluk boyutunda ayrı bir yere sahiptirler.

Ancak pozitivist bilim için sadece tikellerin ortak özelliklerine ve süreçlere ait bilgi yani evrenselin/genelin bilgisi önemlidir. Fenomenolojik bilim anlayışı ise, yukarda sözünü ettiğimiz üzere tikelin bilgisini talep eder. Bunun en dipteki nedeninin evren tasarımını biçimlendiren ontolojik sayıltı olduğunu biliyoruz.

Oysa bütüncül bilim anlayışına sahip bir sosyal bilimci, hangi bilim dalında olursa olsun, olgular dünyasında genel geçer özellikleri ve ilişkileri gösteren genelin bilgisi ile her tekilin kendine ait özelliklerinin içiçeliğinin idrakindedir. Dikotomik mantık ile akıl yürütmediği için bu kavrayış kendiliğinden gerçekleşir. Sosyolojiden bir örnek verelim. Toplum nazarında bireylerin itibar derecelerine göre hiyerarşik sıralanması demek olan tabakalaşma, ilk insan topluluklarından beri vardır. Bütün zamanlar ve mekanlar için bu hiyerarşik sıralanma en soyut düzlemde uzun süre birlikte yaşama, doğuştan gelen bireysel farklılıklar ve çevre faktörleri ile oluşur. Bu üç faktör sosyal tabakalaşmanın evrensel dinamikleridir. Ancak bu dinamikler ve zaman içinde toplumdan topluma, yani tekillere göre değişen itibar ölçütleri ile kaynaşır ve farklı tabakalaşma türleri ortaya çıkar. Tabakalaşma hiyerarşisinde iktidar ve ekonomik güç her zaman en önemli belirleyici faktörlerdendir. Ancak bunlara ilave olan belirleyici nitelikteki tabakalaşma ölçütünün/ölçütlerinin zamana ve toplum yapısına göre değişmesiyle farklı tabakalaşma sistemleri oluşmuştur.

Avrupa'da asaletin belirleyici bir itibar ölçüsü olduğu feodal yapıdaki zümre tabakalaşması, sanayi devrimi ile birlikte sermayenin öne çıkmasıyla kapitalist sınıf sistemi olmuş, yirminci yüzyılda eğitim ve meslek faktörünün ağırlık payının artmasıyla açık sınıf sistemine dönüşmüştür. Reenkarnasyon ile desteklenen ve soya dayalı kast sistemi Hindistan'a özgüdür. Osmanlı tabakalaşma sistemi bunlardan tamamiyle farklı kendine özgü tekil bir olgu olarak biçimlenmiştir. Tabii tabakalar/sınıflar arasındaki geçişleri ifade eden sosyal hareketlilik olgusu da tabakalaşma sistemlerine göre farklı özellikler gösterecektir. Zamanlara ve toplumlara göre bu gibi örnekler çoğaltılabilir. Bütüncül sosyoloji, prizma ve 
yedi renk örneğinde olduğu üzere farklı renklerdeki tabakalaşma sistemlerinin kendine özgü nitelikleri kadar onların özündeki ortak nitelikler ile de ilgilenir.

Bilim anlayışlarının evrensel/genel-tekil ilişki konusundaki tutumlarını şöylece özetleyebiliriz: Gerek olguların nitelikleri gerekse olgular arası ilişkiler söz konusu olduğunda pozitivist anlayış için "istisnalar kuralı bozmaz"; fenomenolojik anlayış için zaten "kural yoktur"; bütüncül anlayış için ise "kural, istisnaları ile birlikte vardır."

\section{Ontolojisiz Epistemolojinin Yol Açtığı Sorunlar}

Sorunların bir kısmına, dolaylı da olsa, metin içinde yer yer değinilmişti. Aralarında bir öncelik sırası yerine karşılıklı besleme sürecinin bulunduğu gerçeğini gözden kaçırmayarak bu sorunlara açıklık getirmeye çalışalım. Aşağıda vermeye çalıştığımız açıklamaların bize, sosyal bilimler için neden sosyal bilimler felsefesinin elzem olduğunu da anlatacağını düşünüyoruz.

Ontolojisiz epistemolojinin, bilimin nasıl bir faaliyet olduğnun tam olarak anlaşılmasına engel teşkil etmesi önemli bir sorundur. Diğer bir sorun da ontolojisiz epistemolojinin, bilimde ortaya çıkan bunalımların ve çözümlerin anlaşılması için yetersiz kalmasıdır. Yaptığı faaliyetin ne olduğunu anlamak ve anlamlandırmak isteyen bir bilim insanı, ister doğa bilimci isterse sosyal bilimci olsun, bilimsel paradigma kavramını analitik bir biçimde bilmek durumundadır. Zira paradigma, epistemik cemaatte bir ortak anlayışın/konsensüsün oluşmasını sağlayarak bilim cemaatine, bilimin amacı ve işlevi; izlenecek teorik ve metodolojik kurallar; neyin gözlemleneceği ve irdeleneceği; ne tür soruların sorulması ve araştırılması gerektiği, bu soruların nasıl ifade edileceği; başvurulacak yöntemler, teknikler ve araçlar; bilimsel araştırma sonuçlarının nasıl yorumlanacağı ve araştırmaların bilimselliğini değerlendirecek ölçütler konusunda yol gösteren bazı standartlar sunar. Ontolojiden yalıtılmış bir epistemoloji ile bu işlevlerin anlamlandırılması mümkün olamamaktadır.

Paradigmanın işlevlerini sorgulayarak paradigmanın ne olduğunu kavramaya çalışmayan ve epistemik cemaatte geçerli olan konu ve yöntemler çerçevesinde yapılan bilimsel çalışmalara Kuhn'un normal bilim adını verdiğini biliyoruz. Tek bir egemen paradigmanın biçimlendirdiği araştırma modelinin yol gösterdiği klasik fizik, kimya gibi fen bilimlerinde ve bu bilimlere dayanan çeşitli mühendislik alanlarında normal bilim yapanlar için bilimin epistemolojik kabuller ile sınırlandırılmış olması pek fazla bir şey ifade etmeyebilir. Ancak, ister sadece kişisel ilgi nedeniyle, bilimsel bunalımları anlamak veya çözmek amacıyla çalıştığı alan ile felsefe arasındaki bağıntıyı kurabilen doğa bilimcileri ve sosyal bilim paradigmalarını anlamlandırmak isteyen sosyal bilimciler için bu bağıntılar hayati önem taşır.

Ontolojisiz epistemoloji, paradigma çokluğunun neden kaynaklandığının anlaşılmasını engeller. Egemen teorilere de paradigma denilmesi nedeniyle 
paradigma bolluğundan bunalan sosyal bilimciler için parça-bütün ilişkisi içinde paradigmayı kavramak ve bu yapay paradigma bolluğunu gerçek sayısına indirmek çok önemlidir. Kaldı ki bugün doğa bilimlerinde klasik fiziğe dayanan pozitivist paradigma ile yeni fizik ile başlayan ve diğer bilim dallarınca da beslenen bütüncül yeni paradigma olmak üzere iki farklı paradigmanın varlığı söz konusudur.

Sayıltılar eksik olduğunda paradigmalar arasındaki benzerlikler ve farklılıkların nedenleri irdelenemediği için paradigmaların sistematik mukayesesi de yapılamaz. Bu durumda sadece bilişsel anlamda paradigma kaosu ortaya çıkar $\mathrm{ki}$, bu zihinlere sıkıntı vermekten başka bir işe de yaramaz. Birden fazla paradigmanın yarıştığı sosyal bilimlerde ise, paradigmaların birbirlerine göre konumlarının belirlenmesi çok önemlidir. Zira ne kadar paradigma var ise, o kadar sosyal bilim anlayışı var demektir. Bu nedenle sosyal bilimcilerin bilim denilen olguyu ve bilimsel faaliyet denilen süreci tam olarak anlayabilmeleri, kendi çaıışmalarını anlamdırabilmeleri ve yaklaşımları yerli yerine koyabilmeleri için paradigmaları mukayese etme zorunluluğu ortaya çıkar.

Ontolojisiz epistemolojinin neden olduğu sorunlardan biri de eklektik yöntem anlayışıdır (Dikeçligil 2003). Özellikle pozitivist yaklaşımı benimsemiş sosyal bilimcilerin son zamanlarda nicel ve nitel yöntemleri bir arada kullanmaları, ancak bilim mantığına ters düşen bir moda ile açıklanabilir. Bu modanın yaygınlaşmasında saha araştırmasının sadece survey ile yapılabileceğine iman etmiş sıkı-surveycilerin (Dikeçligil 2003) etkisinin büyük olduğunu söyleyebiliriz. Pozitivist olduğunu ilan ederek nitel yöntemi kullanmanın ve bu arada hermeneutik inceleme denemenin (!) hangi paradigmanın çatısı altında yer bulduğunu bilemiyoruz.

Pozitivist olarak, beş duyu ile algılanabilir bir gerçeklikteki işleyişin genel ve kesin bilgisine ulaşmak zorunluluğunu kabul etmiş iken, tekillerin kendine özgü özelliklerini derinlemesine inceleyen nitel yöntemi bu yaklaşımın neresine yerleştirebilirsiniz? Bu durumda ya bu objektif gerçeklik tasarımından, dolayısıyla pozitif bilim anlayışından vazgeçmek gerekir ya da nitel yöntemden. Ancak metodolojinin mantığı bunu söylerken, moda hükmünü sürmektedir.

Nicel ve nitel yöntemler ancak bütüncül bir bilimsel anlayıştan yola çıkıldığında bir arada kullanılabilir. Çünkü hem nitel hem de nicel yöntemleri gerektiren bir gerçekliğin bilgisini söz konusudur ve hem de bilimsel bilgi birikim sürecinden yararlanmak gerekir. Bir anlamda bütüncül bilim anlayışı, iki karşıt paradigmaya "yiğidi öldür, ama hakkını ver" ilkesine göre davranır. Her bir paradigma gerçekliğin farklı görünümlerini ontolojik kabul olarak seçtiği için, bütünleyici bir anlayış için her ikisi de kendi açısından haklıdır. Bu kullanım modanın getirdiği esintiler değil, paradigmanın getirdiği bir zorunluluktur.

Ontolojisiz epistemoloji, metodolojik bağlamda nitel yöntem ve genellemenin bir arada kullanılması gibi ikinci bir soruna da neden olur. Biliyoruz ki derin- 
lemesine mülakat, hayat hikayesi, katılımlı gözlem gibi yöntemleri kapsayan nitel yöntem betimleyici bir yöntemdir. Genelleme diye bir kavramın bu yöntemin terminolojisinde yeri yoktur.

Tekilin kendine özgü dünyasının derinlemesine tasviri ile tekillerin ortak özelliklerini ve tekiller dünyasındaki ortak işleyişi/determinizmi gösteren genelleme nasıl uzlaşabilir! Evet, insan zihni hem geştaltçı algılamaya hem de indirgeme-genelleme işleyişine, hatta aşırı genellemeye yatkındır. Her ne kadar bütüncül yaklaşım "nitel yöntem, tekilin özelliklerini ve işleyişini verir, genel bir kuralı ifade etmez" dese de, ontolojisiz epistemoloji çerçevesindeki bir zihin alışmış olduğu işleyiş tarzı gereği, tekili genellemeye çalışacaktır. Bu yüzden nitel yöntem kullanan sıkı-surveycilerin, genelleme-açıklama işlevinden dolayı nicel yöntemin vazgeçilmez araçlarından biri olan, hipotezler kurarak veya olasılıklı örneklemler çıkarmaya çalışarak işe başlamaları şaşırtıcı gelmemelidir. Bu durum modanın, bilimde bile nelere kadir olduğunu gösteren örneklerden biri olarak değerlendirilebilir.

Bilimsel paradigma söz konusu olduğunda epistemolojiyi ontolojiden ayırmanın sakıncalarından biri de, bu ayrıştırmanın bilimsel teori kavramının yeterince anlaşılamamasına neden olmasıdır. illgili olduğu olgular dünyasındaki ilişkileri açıklamak üzere inşa edilen teori, sınanmak üzere öne sürülen bir açıklamadır. Bu kadar bilgi ile yetinildiğinde teori, sadece hipotezlerden oluşuyormuş gibi bir anlayış ortaya çıkmaktadır. Oysa hipotezler teoriyi oluşturan bileşenlerden sadece biridir. Teori başta kavramlar olmak üzere, bilimsel olarak doğru kabul edilen bilgilere ( $k i$, bunlar teorisyeni etkileyen diğer teoriler ve/veya bilgi birikimi demektir) ve teorinin ilgili olduğu alana dair sınanması mümkün olmayan önermelere, yani sayıltılara dayanır. Buzdağında teorinin suyun altında kalan kısmını oluşturan bu sayıltılar, şüphesiz paradigmanın sayıltılarına göre biçimlenir; en azından onlarla çelişmez. Bu gerçeğin bilinmemesi, yaygın etkisi olan teorilerin paradigma olarak adlandırılmasına yol açar.

Ontolojisiz epistemoloji, psikoloji ve sosyal psikoloji hariç diğer sosyal bilim teorilerinde insana ilişkin sayıltının ihmal edilmesine neden olur. Epistemolojik düzleme hapsedilmiş tartışmalar, sosyal bilimlerde bütün olguların ana kaynağı olan insanın gözden kaçmasına yol açar. Evrenin en büyük bilinmezi olan insanın nasıl bir varlık olduğu sorusu ancak metafizik zemin üzerine kurulu ontoloji labirentinde dolaşmakla cevaplanabilir. Doğal olarak, tek bir cevap değil farklı cevaplar vardır ve her bir cevap farklı insan tasavvuru demektir. Insana ilişkin sayıltı sosyal bilimlerde teorileri biçimlendiren temel ontolojik sayıltılardan biridir. Hem paradigma hem de teori için önemli olan, benimsenmiş olan sayıltılar arasında bir çelişkinin bulunmamasıdır. Bir teoriyi anlamanın yollarından biri, teorisyenin insanı nasıl gördüğüne, soysal varlı̆̆ını nasıl tasarladığına bakmaktır. Sözgelimi Weber'e göre insan anlam atfeden rasyonel bir aktördür/eyleyendir; Marx'ta ise insan, doğuştan iyi olan ve kötü özellikleri üretim araçlarının mülkiyetinin başlaması ile sonradan kazanmış olan edilgen bir varlık- 
tır. Parsons'ın işlevselci teorisi ise, insan sayıltısını es geçen pozitivistik teorilere bir örnektir. Bu nedenle işlevselci teorinin temel kavramlarından olan sosyal statü ve sosyal rol, toplumun değerlendirmelerine ve beklentilerine göre belirlenmiştir ki, sosyal konumu işgal eden ve rolü ifade eden insanın bireysel yorumu düşünülmemiştir bile. Parsons'ın "aktör"ü, Weber'in aktöründen çok farklı bir insanı ima eder. Aslında bu insan aktörden çok toplumsal yapının kuklası gibidir.

Ontolojisiz epistemolojinin olumsuz sonuçlarından bir diğeri ise, olgular arasındaki ilişkileri gösteren ontolojik sayıltının adeta silinip gitmesidir. Bilim, olgular dünyasındaki işleyişlerin bilgisini edinebilmek için, nasıl bir işleyişin bulunduğuna dair bir hareket noktasından yola çıkmak zorundadır. Ne var ki, bu sayıltı bilim anlayışının her zerresine öylesine nüfuz etmiştir ki, ileri sürülen önermenin bilimsel bir gerçek olduğu sanılır. Neden-sonuç zincirinin bilimsel bir gerçek olmadığı, atomaltı dünyanın keşfi ile birlikte ortaya çıktı. Gerçekliğin doğası, mahiyeti ile gerçekliğin işleyişi, birbirini anlamlı kılan iki ontolojik sayıltıdır. Birini görmezden gelmek, diğerinin açıkıkla anlaşıımasını engeller; ikisini de yok saymak ise paradigma ve paradigma çatısı altındaki teorilerin işlevlerinin anlaşılmamasına yol açar.

\section{Ontolojisiz Epistemolojinin Nedenleri}

Bilime ilişkin meselelerin epistemoloji kafesine hapsedilmesine yol açan bilişsel ve sosyolojik nedenler birbirini besler. Sözgelimi bilgi ve varlık arasındaki bağlantının kopmasının arkasında, ontoloji ve metafiziğin ayrılmazlığında varlığa ilişkin soruları sormanın getirdiği bireysel maliyet ve risk kadar, doğa bilimlerindeki gelişmelerin sıkıntıya soktuğu pozitivizmin, özellikle ülkemizde, siyasallaşmış pozitivizmin baskısı da yatmaktadır. Buna anti-pozitivistlerin konumlarını pozitivizme göre ayarlamaları, epistemolojiye odaklanmış olan post-modernist söylemin etkisi, bilimsel eleştiri ortamının kurulamamış olması gibi diğer etkenleri de kattı̆̆ımızda, etkenler arasında bir öncelik sırasının olmadığını görebiliriz. Şimdi birbirlerini besleyen bu nedenlere bir öncelik sıralaması yapmaksızın göz atalım.

Bilgi ve varlık arasındaki bağlantının kopması ontolojisiz epistemolojinin nedenlerinden biridir. Sayıltı/temel kabul/aksiyom/postula, ne derseniz deyiniz, bilimsel olarak sınanması mümkün olmayan ve doğru olarak kabul edilen önermedir. Bu nedenle ontolojik sayıltıları metafizikten ayırmak mümkün değildir. Bu durumda her paradigma gibi pozitivizmin bilişsel kökleri de en derinde metafizik bir temele dayanır. Gözlem ve deney ile sınanmaya elverişli olmayan bilgileri 'anlamsız' sayan pozitivizmin özellikle ontolojik sayıltıları görmezden gelmesi doğaldır. Bilgi ile varlık arasındaki bağlantı yok sayılmış ve bilim epistemoloji ile anlaşılmaya çalışır olmuştur. Ancak, bütün zihinsel-davranışsal faaliyetlerde olduğu gibi, bilim yapabilmek için de insan referans çerçevesine intiyaç duyar. $\mathrm{Ne}$ var ki, ontolojisiz epistemoloji ile referans çerçevesi değil (güneş sistemi 
metaforunu hatırlayalım), dağınık referans noktaları söz konusudur. Bu dağınıklıkta metodoloji ile ilişkilendirilerek epistemolojik sayıltıların bir nebze somutlaşması, hatta metodolojinin normatif özelliğinden yararlanması sorunun temelden çözümünü sağlayamamaktadır.

Doğa bilimlerindeki gelişmelere gerektiği kadar ilgi gösterilmemesi yalıtılmış epistemolojinin süregelmesinde önemli bir nedendir. Batı'da epistemoloji ile ontoloji arasına giren bu soğukluk, tartışmaların epistemolojik düzlemde kalması kanaatimizce, hem pozitivistlerin hem de post-modernistlerin, her zaman bilinçli olmasa da, kendiliğinden oluşan bir tercihi idi. Bu tercihin kendini koruma içgüdüsünden kaynaklandığını rahatlıkla ileri sürebiliriz. Zira yirminci yüzyıl ile başlayan ve giderek hızlanan doğa bilimlerinde gelişmeler Batı felsefesinin karakteristiği olan idealizm ve materyalizm karşıtlığının ötesine geçmeye zorlayan bilimsel kanıtlar sundu. Bu da, yeni bir ontoloji talebi demekti.

Yirminci yüzyılın ilk çeyreğinde makro boyutta Newton fiziğinin sınırlarını gösteren relativite teorisi ve mikro boyutta atomaltı dünyada gerçekliğin iki parçalı, mekanistik ve deterministik olmadığını gösteren kuantum fiziği ile başlayan bütüncül yeni paradigma yüzyıl boyunca diğer disiplinlerdeki gelişmelerle beslendi ve beslenmeye devam ediyor. Hızla genişleyen ve derinleşen bilimsel bilgi birikimi bugün bize makro ve mikro boyutta yeni bir evren sunmaya devam ediyor. Ondokuzuncu yüzyılın insanları, yıldızlarla dolu bir gökyüzünde Kopernik'in dokuz gezegenli (onuncusu daha bulunmamıştı) güneş sistemi içinde yaşarken; yirminci yüzyıl ile beraber evren içinde kapladığımız yer görece değişti: Ucu bucağı olmayan bir evrende 125 milyar galaksiden biri olan Samanyolu gökadasında, Samanyolunun kucakladığı 300 milyar yıldızdan biri olan küçük bir gezegende yaşıyoruz. Kozmolog Carlos Frank'ın ifadesiyle, "Kopernik'in başlattığı devrime eşdeğer bir değişim döneminden geçiyoruz."

Bu tür bilgilerin insanın algılarını nasıl değiştirdiğini anlamak için, uzun boylu araştırmalar yapmak yerine, bu konuda popüler düzlemde olsa da bilgilenmek ve içgözlem yapmak yetebilir. Aynı şekilde atomaltı dünyanın keşfi de algıladığımız dünyanın değişmesine neden oldu.

Yirminci yüzyılın ilk üç on yılında fizik, paradigma dönüşümünü başlatan disiplin oldu. Ne var ki yeni fizik, modern bilimi biçimlendiren klasik fiziğin temel ilkelerini sarstı (Kocabaş 2005) ve en azından evrensel olmadığını gösterdi. "Fizik, şimdi, bilimsel anlamda gerçekliğin en temel betimlemesini sağlama rolünü kaybetmiştir... Bugün bilimdeki paradigma değişimi, en derin düzeyde, fizikten yaşam bilimine doğru bir dönüşümü içermektedir" (Capra 1996: 13). Yeni fiziğin başlattığı ve temelini attığı paradigma dönüşümünün artık mikrobiyolojinin önderliğinde devam ettiği kabul edilmektedir. Bütüncül yeni bilim anlayışı, klasik fiziğin cansız dünyasındaki ilişkilerin bilgileri ile değil, yaşam sistemlerinin bilimsel bilgileri ile biçimlenmektedir. Bütüncül bilim anlayışına sistem düşüncesi, kompleks sistemlerin bilimi de denilmektedir (3). 1920'lerde çeşitli disiplinlerde ortaya çıkan "sistem düşüncesine, canlı organizmaların birleşik bütünler 
olduğunu vurgulayan biyologlar öncülük etmişlerdir. Daha sonra geştalt psikolojisi ve yeni çevre bilim tarafından zenginleştirilmiştir" (Capra tarihsiz: 17). Batıda çok sayıda bilim insanının çalışmaları, bütüncül yeni bilim paradigmasının gelişmesine yol açmaktadır (Bkz. Capra 1992). Canlı ve cansız varlıkların işleyiş mekanizmasını inceleyen sibernetik de sistem düşüncesine destek vererek paradigma dönüşümünde önemli bir rol oynamış ve bu sürece kaos teorisi ve gaia hipotezinin de derin katkıları olmuştur. Bu yeni disiplinlerin katkılarıyla bugün çok sayıda yeni kavram, bilim dünyasının önemli araçları haline gelmiştir. Görelilik, bağlamsalcılık, eşevrelilik, bütünleyicilik- tamamlayıcılık ilkesi, yeni zihin bilimleri, zihinle ilgili kuantum teoremleri, bilişsel yaklaşım, bilişsel bilim, kendinden farkındalık, bootstrap yaklaşımı, sibernetik, geribildirim, Santiago kuramı, yaşayan sistemler, açık sistemler, dağılmaya yatkın yapılar, kendinden organizasyon, doğrusal olmayan/nonlinear dinamik, network dinamiği, kompleks oluşun bilimi, kaos, türbulans, kaotik çekerler, fraktalar, kelebek etkisi vb. gibi kavramlar düşüncenin ufkunu zorlamaktadır (Marshall ve Zohar 2002; Capra 1996 ve 2002; Gleick 2003).

Sosyal bilimler felsefesinin ve metodolojisinin bu kavramlar yabancı kalmaması, sosyal bilimler için önemlidir. Ancak bilgileri yenilemeden yeni fikirler ileri sürme kolaycılığının doğuracağı bir sakınca da bizi bekliyor. Doğa bilimleri ve sosyal bilimler felsefesi arasındaki ilişkiyi ondokuzuncu yüzyıldaki ilişkiye benzetmekten kaçınmalıyız. Geçmişte hiyerarşik sıralanmada doğa bilimlerinin altında yer alan pozitivistik sosyal bilim, gerçeklik tasarımı ve yöntemi konusunda doğa bilimlerini örnek almıştı, kendi gerçekliği üzerine düşünmesine gerek yoktu. Günümüzde ise fiziki ve sosyal bilimler, doğa bilimlerindeki gelişmelerin sunduğu çok katlı ve çok boyutlu gerçekliğin farklı görünümleridir. Klasik fiziğin dünyası, bu gerçekliğin beş duyu ile algılanabilir dış kabuğu gibidir. Gerçekliğin iç katlarına doğru gidildikçe doğa bilimleri ile sosyal bilimlere ait boyutlar arasındaki soyut benzerliklerin arttığı görülmektedir Bu nedenle her iki boyutun aynı gerçekliğin farklı görünümleri olduğu kabul edilmektedir. Ancak burada önemli bir bilginin altını çizmeliyiz. Bugün sosyolojik gerçekliğin doğası hakkında ulaşacağımı noktayı, sadece doğa bilimlerindeki gelişmelere bağlamak, sosyolojik düşünce tarihine haksızlık etmek olur. Pozitivistik sosyal bilim paradigmasının egemenliğin zirvesinde olduğu yıllarda hakim anlayışın aksine Sorokin, Gurtvich gibi felsefeden korkmayan sosyologlar, daha sonraları ise Mead, Berger gibi sosyolojik gerçekliğin bilişsel boyutuna önem veren sosyologlar yeni gerçeklik tasarımının ana hatlarını çizmişlerdi (4).

Yalıtılmış bir epistemoloji ile yetinmenin ardında varlığa ilişkin meselelerin getirdiği bireysel maliyet ve riskin yatığını da göz ardı edemeyiz. Bu maliyet ve riski, içsel yolculuk ve dışsal etkenler olarak iki bağlamda ele alabiliriz. İçsel yolculuk bağlamında, varlığın mahiyetine dair soyut düzlemdeki genel soruların, bireyin kendi var oluşuna dair özel sorulardan ve sorunlardan ayrılmaz olduğu bilinen bir gerçektir. Sözgelimi, klasik fiziğin resmettiği dünyadan tamamıyla 
farklı bir dünyada yaşadığını keşfeden ve varoluş bunalımı yaşayan kuantum fizikçilerinin bilimsel bilgi ağının boşluklarını yorumlamak için Batı felsefesinden değil, mistik geleneklerden yararlandıkları gerçeği, artık kimse için bir sır değil. Yeni bilim anlayışının kuruluşunda ve gelişiminde bilimsel gelişmeler kadar, kimi bilim adamlarının içsel deneyimlerinin de payı büyüktür.

Her nimet külfete tabidir; ancak her bilim adamının bir bedel ödemesi de gerekmiyor. Bugün yukarıda sözünü ettiğimiz sosyologlar ve doğa bilimlerindeki gelişmeler, paradigmanın yapısını ve işleyişini anlamak için, bizlere bedeli büyük ölçüde ödenmiş bir bilimsel bilgi birikimi sunuyor. Ayrıca kendi disiplini dışındaki gelişmeleri izlemek isteyen bilim insanları için büyük bir titizlikle yazılmış popüler bilim kitapları sosyal bilimcilere bu imkânı veriyor. Bütün bu kolaylıklara rağmen ontolojisiz epistemoloji ile yetinmenin nedenlerini anlayabilmek için dışsal etkenleri de hesaba katmalıyız.

Bu dışsal etkenlerin biri, pozitivizmin siyasallaşmasıdır. Türkiye'ye siyasal bir kimlikle giren pozitivizm, ne yazık ki bu kimliğini akademik dünyada da sürdüregelmiştir. Şüphesiz pozitivist paradigmayı benimsemiş değerli bilim insanları yetişmiştir ve yetişmektedir; ancak kurumsal anlamda pozitivizmin bir bilim anlayışı olarak tesis edilmiş olduğu söylenemez. Ne yazık ki, pozitivizmin bilim anlayışı olmaktan çok siyasal kimlik haline gelmesi, Türkiye'de bilimin gelişmesine sekte vurmuş ve Batı'daki bilim anlayışındaki değişmelerin paradigmatik anlamının kaybedilmesine neden olmuştur. Bugün, katı pozitvizmin ondokuzuncu yüzyıl ilkeleri, birbirleri ile bağıntısız dağınık referans noktaları şeklinde, geçerliliğini sürdürüyor. Bu nedenle, bilim ile diğer bilgi bağları arasındaki ilişkiyi yok sayan ve bilim-karşıtı ile bilim-dışını birbirine karıştıran bir anlayışın, ontoloji üzerindeki tartışmalardan, hatta ontoloji ve metafizik gibi kavramlardan rahatsız olması doğaldır. Ancak bu rahatsızlığın dışavurumu, zaman zaman pasif-agresif tutumlarla ifade edilen baskıcı bir atmosfer haline dönüşebilmektedir. Böyle bir ortamda, ontolojik sayıltılarla ilgilenmenin sosyal maliyeti yüksek olabilmektedir. Hak etmedikleri etiketleri taşımamak için kimi sosyal bilimcilerin, önemini bilmelerine rağmen ontolojiden uzak durmaları son derece doğaldır. Kişiselleştirmeler ve etiketlemelerin yapılması, tartışmaların siyasal veya ideolojik zemine çekilmesi ve örtük sosyal kontrol mekanizmalarının kullanılması bilimsel eleştiri ortamının kurulmasının önündeki en büyük engellerdir. Bilimsel eleştiri ortamının kurumsal olarak tesis edilememiş olmasının yalıtılmış epistemolojinin hüküm sürmesindeki etkenlerden biri olduğu görülmektedir.

Sonuç olarak diyebiliriz ki, bir yandan Batı bilimindeki ve bilim anlayışındaki gelişmeleri yirmi-otuz yıl geriden takip etme geleneğimiz, diğer yandan Türkiye'nin kendine özgü sosyolojik koşulları epistemoloji ve ontoloji arasındaki bağın kurulamamasına neden olmuştur. Oysa bilgi ile varlık arasındaki ilişkiye eğildikçe epistemolojinin işlevi artacaktır. 
Bilim alanında Batıyı izleme geleneğimizde bu süre azalmış olsa da hala aydınlanma çağı keşfedilmeye çalışılmaktadır. Şüphesiz Batı düşüncesinde yeni bir dönemi başlatmış olan bu değerli bilgi birikimi önemlidir; ne var ki artık Batıda, Alev Alatı’ının ifadesi ile, ikinci bir aydınlanma çağı yaşanmaktadır. Etiketlenme riskine rağmen siyasi ve ideolojik bağımlılığı olmayan bilim insanlarının bu kopmayı onarmaya çalışmaları, bilimsel eleştiri ortamının kurumsallaşmasına da katkı sağlayacaktır. İki ayrı felsefe disiplini olarak bu tür bir ayrılma, kopma sayılmayabilir. Ancak konu bilimsel bilgi üretimini besleyen, düzenleyen ve zenginleştiren bilim paradigması olduğunda, bu durumu ciddi sonuçlara yol açan bir kopma olarak nitelendirebiliriz. Bilgi bağları arasındaki ilişkileri dikkate aldığımızda epistemolojik ve ontolojik, metodolojik sayıltılardan oluşan bilişsel haritanın sadece bilimi değil, başta sanat olmak üzere kültürün/sosyal dünyanın diğer bütün bileşenlerini zenginleştireceğini ve bu zenginliğin bir medeniyetin habercisi olacağını söyleyebiliriz.

\section{NOTLAR}

$\left(^{*}\right)$ Prof. Dr., Erciyes Üniversitesi Fen-Edebiyat Fakültesi Sosyoloji Bölümü,

e-posta: bdikecligil@erciyes.edu.tr

(1) Sosyal bilimlerde iki karşıt epistemolojinin dışında kalan, üçüncü paradigma söz konusu olduğunda bizi, bir kavram karışıklığı bekliyor. Zira 'yeni bilim' terimi iki farklı bilim anlayışı için kullanılmaktadır. Kapsamlı bir makale konusu niteliğindeki bu konuya burada kısaca değinmek zorundayız. Zira benimsemiş olduğumuz yeni / bütüncül bilim paradigması ile, post-modernist görüşleri, melez yöntem anlayışını, inşacı yaklaşımı, hatta bazen post-pozitivizmi ima eden "yeni" bilim paradigmasını kesinlikle kastetmiyoruz. Aralarında bazı benzerlikler bulunmasına rağmen yalıtılmış epistemolojiye dayanan farklı yaklaşımları kuşatan "yeni" bilim anlayışı, sosyal bilimlerin geleneksel karşıt iki paradigmasının ontolojilerini yok sayarak sadece epistemolojik sayıltılarını bir araya getiren eklektik bir özelliğe sahiptir. Bu nedenle pragmatik kaygılarla oluşturulmuş, ontolojik temeli olmayan bu melez ya da eklektik yaklaşımları, aslında paradigma olarak adlandırmamak gerekir. Bütüncül yeni bilim anlayışı ise doğa bilimlerindeki gelişmelerin yol göstericiliğinde yeni bir gerçeklik tasarımına dayanır; birbiri içine yuvalanmış ontolojik, epistemolojik ve metodolojik sayıltılardan oluşan bir örüntüdür.

(2) Yirminci yüzyılın başlarında ışı̆̆ın hem dalga hem de tanecik özelliğinin keşfi ile ortaya çıkan bunalım önce her iki özelliğin de geçerli olduğunun kabul edilmesi ile biraz duruldu. Niehl Bohr (1985-1962) tamamlayıcılık/ bütünleyicilik ilkesi ile çözümü formüle etti. Bu ilkeye göre, dalga-tanecik gerçekliğin iki farklı parçası değil, gerçekliğin birbirini bütünleyen/ tamamlayan iki farklı görünümüdür. Erwin Schrödinger (1887-1961) de ışığın hem dalga hem de cisimcik olma özelliğini ve deneyin deneyciden bağımsız olamayacağını gösteren ve "Schrödinger'in Kedisi" diye anılan kuantum deneyini yaptı. Bu birikim, fizikteki madde-enerji karşıtlığına son veren etkenlerden biri oldu: Madde bir tür enerji, enerji de bir maddedir; her ikisi gerçekliğin birbirini bütünleyen iki farklı görünümüdür. Tamamlayıcılık/bütünleyicilik ilkesi fiziğin dışındaki alanlarda da yaygın biçimde kullanılmaktadır. Kuantum fiziğindeki bu tür gelişmeler sosyal bilimlere derin bir nefes aldırmıştır diyebiliriz. Fiziksel gerçekliğin ilk katmanı için karşıtlık mantığı geçerli olsa bile sosyal bilimlere konu olan gerçeklik, tıpkı atomaltı dünya gibi sadece 'hem - hem de' mantığı ile kavranabilir. Sosyolojik gerçeklikteki soyut ve somut bütün karşı olumlar (ni- 
cel-nitel, tümel-tikel, evrensel-yerel, doğru-yanlış, iyi-kötü, güzel-çirkin, faydalı-faydasız, kısa-uzun, geniş-dar, pahalı-ucuz vb.) ve bunlar arasındaki çeşitlenmeler (daha güzel, çok çirkin, kısmen doğru, tamamıyla faydalı, çok geniş, çok ucuz vb.) çok boyutlu bir gerçeklik bütününü oluşturan farklı görünümlerdir ve ancak saçaklı (fuzzy / bulanık) ile kavranabilir.

(3) Yeni kullanılmaya başlayan "karmaşıkığın bilimi" terimindeki "karmaşıklık" kavramı bu organik bütünleri, sistemleri ifade edemiyor. Karmaşıklık, açık veya saklı olsun, içinde herhangi bir düzen barındırmayan bir kavramdır; bu nedenle ne kompleks ne de kaos kavramını karşılayabilir. Sözgelimi "Aliağa kompleksi" derken, karmaşık gibi görünen ancak en ince ayrıntının bile belirli bir sistemin parçası olarak düzenlenmiş olduğu bir bütünü kastediyoruz. Aynı şekilde biliyoruz ki, kaotik oluşumlar görünürdeki düzensizliğin, belirsizliğin ardında bir düzeni barındırır. Türkçenin yapısına uygun düşmediği için "kompleksliliğin bilimi" denilemeyeceğine göre "kompleks sistemlerin bilimi" terimi daha uygun düşmektedir.

(4) Şüphesiz psikoloji, sosyal psikoloji, ekonomi ve siyaset bilimi gibi diğer sosyal bilimlerde de pozitivist paradigmayı eleştiren fikirleri, yaklaşımları ortaya koymuş olan sosyal bilimciler bulunmaktadır; ancak yeterince bir inceleme yapamadığımız için, haddimizi bilerek, örnekleri sosyolojiden seçtik.

\section{Kaynaklar}

Capra, F., The Hidden Connection, Random Hause, New York 2002.

Capra, F., Yaşamın Örgüsü - Zihin ve Maddenin Yeni Bir Sentezi, çev. Beno Kuryel, Yapı Merkezi, İzmir tarihsiz.

Capra, F., The Web of Life - A New Understanding of Living Systems, Anchor Books (A Division of Random House, Inc.), New York 1996.

Capra, F., Yeni Bir Düşünce, çev. Mustafa Armağan, Ağaç Yayıncılık, İstanbul 1992.

Dikeçligil, B., "Eski ve Yeni Sosyolojide Nedenselliğin Anlamı ve Ziya Gökalp’te Büyük Adam Sorununa Yeniden Bakış", Sosyoloji Dergisi, 3. Dizi, 10. Sayı, iÜ Edebiyat Fakültesi, İstanbul 2005, 39-63.

Dikeçligil, B., "Sosyolojide Metodlar Arası Farklılaşma ve Bütünleşme", içinde Sosyolojide Bütünleşme ve Farklılaşma-Üçüncü Ulusal Sosyoloji Kongresi, Sosyoloji Derneği Yayını, Ankara 2003, 97-126.

Dikeçligil, B., "Batı'da Değişen Bilim Anlayışı ve Türkiye'de Sosyal Araştırmalar", içinde Mahmut Tezcan ve Nilgün Çelebi (Haz.), Sosyolojide Son Gelişmeler ve Türkiye'deki Etkileri, Unesco Türkiye Milli Komisyonu, Ankara 1993, 39-58.

Gleick, J., Kaos, çev. Fikret Üçcan, TÜBiTAK yayınları, 11. basım, Ankara 2003.

Kocabaş, Ş., Fizik ve Gerçeklik - Bilim Felsefesine Kavramsal Bir Yaklaşım, Küre Yayınları, 3. baskı, İstanbul 2005.

Marshall, I ve Zohar, D., Kim Korkar Schrödinger'in Kedisinden - A'dan Z'ye Yeni Bilimin Kılavuzu, Gelenek Yayıncılık, İstanbul 2002.

Özlem, D., "Evrenselcilik Mitosu ve Sosyal Bilimler”, Sosyal Bilimleri Yeniden Düşünmek Sempozyum Bildirileri, Metis yayınları, İstanbul 2001, 53-66.

Özlem, D., "Doğa Bilimleri ve Sosyal Bilimler Ayırımının Dünü ve Bugünü Üzerine”, Toplum ve Bilim, Bahar 1998, 56: 7-39. 



\title{
DINII ORGANIZASYON TIPLERİ VE YENI DINI HAREKETLER
}

\begin{abstract}
Types of religious organization and new religious movements. Studies in the field of sociology of religion, sociologists of religion dealing with categories about religious groups searched for various social factors beyond religiousideological factors and they also developed single models in addition to these with multi-factors. Religious ideal types developed by Weber, his pupil Troeltsch and Niebuhr as well as Johnson and Yinger are certainly products of Christian tradition based on sociologists' religious experiences in their own societies. However, it should be noted that Church-Sect typologies forming two poles of the scala are sociological analysis tools. Major criterion in categorization of religious organizations is the tensions and interaction between religious movements with different representations and patterns and their social environment.
\end{abstract}

\section{key words}

Sociology of religion, NRMs, church-sect typology, secularization. 


\section{Dini Organizasyon Tipleri ve Yeni Dini Hareketler}

Birbirleriyle ilişkili olan kültürel kalıp ya da örüntülerin; din, ekonomi, eğitim gibi çeşitli toplumsal kurumları meydana getirdiğini biliyoruz. Bu çerçevede din kurumunun toplumsal bağlamı ve etkileşimi sürecindeki toplumsal görünümleri, din sosyolojisinin araştırma alanına girmektedir. Öte yandan dinin sosyal bir fenomen olması, bireylerin dinsel davranışlarının bir inanç etrafında oluşan sosyal organizasyonlar çerçevesinde kazanılması ve bununla birlikte yeni dinsel formasyonların oluşumu ve içinde doğduğu toplumla ilişkileri, dini kurum ve tiplerin sosyolojik perspektiften de ele alınabileceğini göstermektedir.

Bir dinin, kurucusunun vefatından sonra varlığını sürdürebilmesi için Weber'in "karizmanın rutinleşmesi" dediği kurumsallaşma sürecine girmesi bir ön koşuldur. İslam dini de $\mathrm{Hz}$. Muhammed'in vefatından sonra hızla kurumsallaşmıs, karmaşık rasyonel bir teoloji ve bununla ilişkili olarak ahlak sistemi geliştirmiş, formel inanç esaslarını ve pratiklerini belirlemiştir. Şüphesiz bu gerekli şartların yanı sıra, müteakip gelişmeler bağlamında kurumsallaşan dinin marjinalleşmemesi için, içerisinde yer aldığı toplumla bir uyum sürecine girmesi ya da değişim tecrübesi yaşaması ve inanç sistemini taraftarları ve diğer potansiyel bağlıları için makul ve inandırılabilir hale getirmesi de gerekli görülmüştür (Roberts, 1990: 147-148). Ancak çeşitli dinsel tecrübeler, mitler, ritüeller ve sembol sistemlerinden meydana gelen din kurumunun, bu temel oluşturucuları arasındaki dengenin sürdürülemediği ve bu sebeple de dini gelenek içerisinde zamanla farklılaşmaların ve çeşitlenmelerin doğduğu da bir gerçektir.

Dinin temel sosyolojik karakteristiklerinden birini belli bir toplumda hayatiyet bulması ve toplumun fertleri tarafından paylaşılması olgusu oluşturur. Bu bakımdan dinin toplumsal yönünü anlamak ve açıklamak bakımından sosyal faktörlerin son derece önemli olduğu görülür. Bu çerçevede sosyoloji yazınında bilimsel analitik araçları olarak geliştirilen birçok kavram yoluyla, dini hayatta meydana gelen gelişmeleri ve değişmeleri açıklamak ve analiz etmek mümkün olabilmektedir.

Toplumun birçok üyesinin inançlarını ve pratiklerini dini organizasyonlar yoluyla ifade etmesi ve öte yandan bunların mensuplarının dini tutum ve inançlarını biçimlendirme eğiliminde olması, dini organizasyon tiplerinin sosyolojik bağlamda incelenmesini önemli kılmaktadır. Farklı dini organizasyonlarla ilgili bir tipoloji geliştirme hususunda din sosyolojisinin kurucusu Weber'den, öğrencisi Ernst Troeltsch ve Reinhold Niebuhr'a ve günümüzdeki Rodney Stark, William Bainbridge ve Roy Wallis'e kadar birçok din sosyoloğu yoğun bir çaba içerisine girmiştir. Tüm dünyada dini oluşumların neredeyse sonsuz çeşitlilik arz etmesi, hiçbir inanç sisteminin sosyologlar tarafından geliştirilen grup tipinin tüm özelliklerine uymasının mümkün olamayacağını da göstermektedir. Yine de din sosyologları, tipik karakteristiklerini belirledikleri sekt-kilise tipolojisini geliştirmişler, ayrıca resmi ve resmi olmayan din ayrımından söz etmişler ve bilhassa 
1960 'lı yıllardan sonra yeni dini grup tipolojisi bağlamında yeni dini hareketlerin temel karakteristiklerini tanımlayarak yeni ideal tipler oluşturmuşlardır (1). Elbette bu tipleri belirleyen karakteristiklerin üzerindeki vurgu da dinsel geleneklere göre değişmekte, bir toplumda önemli olan bir karakteristiğin başka toplumda hiçte öne çıkmadığı görülmektedir.

\section{Sekt (Sect)- Kilise (Church) Tipolojisi}

Din sosyolojisi çalışmalarında dini gruplarla ilgili kategorileştirmelerde, din sosyologları, dini-ideolojik faktörlerden ayrı, çeşitli sosyal nedenleri araştırmışlar ve birçok faktörle beraber tekli modeller de geliştirmişlerdir. Weber'den, öğrencisi Troeltsch'a ve Niebuhr'dan Johnson ve Yinger'e kadar birçok sosyoloğun çeşitli girdileri kullanarak oluşturdukları bu dini ideal tipler, şüphesiz Hristiyan geleneğinde gözlenen gelişmeler bağlamında sosyologların kendi toplumlarındaki dini tecrübelerinden din algılarına kadar toplumsal ve tarihsel şartların etkisi altında geliştirilmiştir. Ancak skalanın iki ucunu oluşturan sektkilise tiplendirmelerinin birer sosyolojik analiz araçları olduğunu da belirtmekte yarar vardır.

Her şeyden evvel Hristiyan Batı'nın dini geleneğinde görülen ve kilise-sekt biçimindeki bu tipolojiye yönelik eleştiriler, Weber'in öğrencisi Alman ilahiyatçı ve sosyal filozofu olan Troeltsch'ın bu konudaki çalışmalarıyla artmıştır. Aslında kilise-sekt kavramsallaştırmasına sosyolojinin saç ayağından biri olan Weber'in yazılarında rastlanır. Hatta Weber'in tanımlamaları hem sade, hem de teolojik kriterden uzak oluşu nedeniyle daha sosyolojik temelli ve daha bilimsel olarak değerlendirilmiştir. Oysa Troeltsch'ın genellemeleri Hristiyan Avrupa kültürü ile sınırlı olduğundan, dönemindeki dini oluşumları karakterize eden faktörlerin, mesela aynı dini geleneği tecrübe eden $\mathrm{ABD}^{\prime}$ deki dini grupları tanımlayabilmesinde problemli olacağı belirtilmiştir.

Sekt-kilise tipolojisinin geliştirilmesine yönelik bir diğer çaba da, Amerikan dini geleneği içerisinde yetişmiş Amerikalı teolog Niebuhr'un çalışmalarında görülür. Dini grubun gelişmesindeki safhaları dikkate alan Niebuhr, bu gelişim sürecinde bir ara form olarak mezhep (denomination) tipini de ekleyerek evrimci bir model oluşturmaya çalışmaktadır (Roberts, 1990: 186). Niebuhr her ne kadar dini grup tipolojisinde her bir grubun oluşmasında etkili olan sosyal faktörleri ve şartları dikkate alsa da Hristiyan etiğe dayalı olarak değer yargısı içerisinde olmaktan asla vazgeçmemiştir.

Farklı sosyal sınıflara dayanan grupların, değişik teolojik bakış açıları geliştirme eğiliminde olacağını belirten Niebuhr, ayrılığın ve bölünmenin kaynağının dini-ideolojik farklılıklardan ziyade sosyal temelli olduğunu iddia etmiştir. Toplumun tabakalaşma sisteminin hem Hristiyan sosyal organizasyonları üzerine hem de onun ideolojisine etki edeceğini savunan Niebuhr, sekteriyan yapıdan kiliseye doğru bir harekette, değişime neden olan sosyal güçleri tasvir etmiştir. Niebuhr, sekt tipinden denominasyona doğru gelişmenin temelinde dini eğitim 
programlarının geliştirilmesinin neden olduğunu belirtirken bu süreçte oluşturulan din eğitiminin bu tür yapılandırmada önemli bir karakteristik olduğunun altını çizer (Roberts, 1990: 186). Böylece birçok sekteriyan gruplarda dini eğitim programlarının geliştirilmesi, kurumsallaşmanın ilk safhasını oluşturmaktadır. Sekt tipi gruplarda dini pratiklerde hâkim olan duygusallık yerine daha kitabi, rasyonel ve düzenli ibadet stilinin geçmesi kilise organizasyonuna doğru bir gelişmenin varlığını gösterir.

Birçok din sosyoloğu, sekt ve kilise kavramlarını açıklığa kavuşturma ve her bir grup tipinin formasyonuna katkıda bulunan faktörleri belirlemeye gayret etmiştir. Bazı sosyologlar tek faktörlü model oluşturarak "sekt" $i$ "kilise"den ayıran temel kriterin, içinde yer aldığı geniş toplumla girişilen değer çatışması olduğunu iddia etmişlerdir. Tüm sekt tipi oluşumları karşıt-kültür sayan bu görüşe göre grubun ideolojisi ile ana toplumun değerleri arasındaki çatışma önemli bir kriter olmaktadır. Mesela Benton Johnson (Roberts, 1990: 188), kilisenin sosyal çevreyi kabul eden, sosyal realiteyle daha uyumlu bir ilişkiye giren bir oluşum olduğunu oysa sektin içerisinde yer aldığı sosyal çevreyi reddettiğini ileri sürerek tek değişimli bir model geliştirmiştir.

Yinger sektleri, denominasyonları ve kiliseleri tanımlamada tek faktörlü açıklama yerine birkaç faktörü birden kullanmayı tercih eder. Troeltsch ve Niebuhr gibi sosyologların sekt ve kilise'yi tiplendirmede hem sosyal hem de teolojik birçok faktörü kullanmalarına karşııı Yinger, yalnızca sosyolojik değişkenleri kullanarak üç faktörlü bir model geliştirir. Çeşitli sosyal bilimcinin sekt ve kilise tipolojisi ile ilgili belirledikleri bu iki ideal tipin temel karakteristiklerini aşağıdaki şekilde özetleyebiliriz (Vernon, 2002: 174):

\begin{tabular}{|c|c|}
\hline Sekt & Kilise \\
\hline Ölçek itibariyle küçük dini organizasyon & $\begin{array}{l}\text { Ölçek itibariyle geniş dini organizasyon, } \\
\text { gruba katılım genellikle doğum yoluyla } \\
\text { (çocukların dini eğitimine vurgu) }\end{array}$ \\
\hline $\begin{array}{l}\text { Dışlayııı üyelik politikası, mutlak bağlı̆ı̆ı arttıra- } \\
\text { cak kontrol mekanizmaları, belirlenen kurallara } \\
\text { uymayanların gruptan çıkarılması }\end{array}$ & $\begin{array}{l}\text { Kuşatıcı üyelik, genellikle coğrafi sınırlar } \\
\text { içerisinde vatandaşları kapsama }\end{array}$ \\
\hline $\begin{array}{l}\text { Partikülarizm; yalnızca üyelerinin doğru bilgiye, } \\
\text { hakikate ve iyiliğe sahip olduğuna inanma }\end{array}$ & $\begin{array}{l}\text { Evrensellik; büyük coğrafi sınırlar içerisin- } \\
\text { deki vatandaşların ve tüm insanlığın } \\
\text { kardeşliğine vurgu }\end{array}$ \\
\hline $\begin{array}{l}\text { Grubun inançları doğrultusunda belli bir aktiviz- } \\
\text { min, hatta militanlığın teşvik edilmesi; Karizmatik } \\
\text { veya manevi özelliklere sahip olduğuna inanılan } \\
\text { liderler önderliğinde grup içerisinde üretilen } \\
\text { "dava"lar uğruna üyelerinin mobilize edilmesi }\end{array}$ & $\begin{array}{l}\text { Ulusal davalar uğruna vatandaşların } \\
\text { mobilize edilmesi. }\end{array}$ \\
\hline $\begin{array}{l}\text { Gruba katılım tecrübesinin canlı tutulması için } \\
\text { duygusal yoğunluklu cemaatsel faaliyetlere katı- } \\
\text { lım; informal ve spontane dini pratiklere önem } \\
\text { verme }\end{array}$ & Formal ve düzenli dini pratikler \\
\hline
\end{tabular}




\begin{tabular}{|l|l|}
\hline \multicolumn{1}{|c|}{ Sekt } & \multicolumn{1}{|c|}{ Kilise } \\
\hline $\begin{array}{l}\text { Kötü ve bozulmuş olarak algılanan çevreyle sü- } \\
\text { rekli mücadele halinde olma, kendisinden olma- } \\
\text { yanlara karşı düşmanca bir tutum içerisine girme, } \\
\text { geleneksel dini ve toplumsal değerlere karşı } \\
\text { çıkma }\end{array}$ & $\begin{array}{l}\text { Mevcut sosyal değerleri ve sosyal yapıları } \\
\text { destekleme ve uzlaşma eğilimi içerisinde } \\
\text { olma }\end{array}$ \\
\hline $\begin{array}{l}\text { Kutsal metinlerin literal yorumuna dayalı inanç } \\
\text { esasları geliştirme ve fundamentalistik bir din } \\
\text { anlayışını benimseme }\end{array}$ & $\begin{array}{l}\text { Tutarlı ve sistematik teoloji geliştirme ve } \\
\text { bununla uyumlu din yorumu yapma }\end{array}$ \\
\hline $\begin{array}{l}\text { Grup üyelerinin dini elitler olarak görülüp, din } \\
\text { adamları sınıfının ve profesyonel din eğitiminin } \\
\text { olmayışı }\end{array}$ & $\begin{array}{l}\text { Sofistike, hayli eğitilmiş ve profesyonel } \\
\text { din adamlarının gelişmesi, liderliği ve } \\
\text { kontrolü }\end{array}$ \\
\hline $\begin{array}{l}\text { Gelişmiş bir organizasyon yapısına sahip olma- } \\
\text { ması ve iş bölümünün gelişmemesi }\end{array}$ & $\begin{array}{l}\text { Gelişmiş, geniş bir bürokratik organizas- } \\
\text { yonun olması }\end{array}$ \\
\hline Sosyal adalet ve eşitlik talebi & $\begin{array}{l}\text { Mevcut sosyo-ekonomik ilişkileri meşru- } \\
\text { laştırma yönündeki ahlaki anlayış }\end{array}$ \\
\hline $\begin{array}{l}\text { Çeşitli açılardan hayal kırıklıklarına uğramış daha } \\
\text { çok nasipsizlerden meydana gelme }\end{array}$ & $\begin{array}{l}\text { Tüm liderlik pozisyonlarının profesyonel } \\
\text { din adamları tarafından kontrol edilmesi, } \\
\text { başta orta ve üst tabaka olmak üzere } \\
\text { toplumun her kesiminden insanlardan } \\
\text { meydana gelmesi }\end{array}$ \\
\hline
\end{tabular}

\section{Resmi Din ve İnancın Halk Versiyonu}

Sosyologlar, dini grupların önemli olduğu varsayılan kimi karakteristiklerine dayanarak dörtlü bir tipoloji (kült, sekt (2), denominasyon ve kilise) çerçevesinde sınıflandırılabileceğine dikkat çekmişlerdir. Bazı sosyologlar ve yazarlar, çoğu kere resmi ve resmi olmayan din dikotomisini de kullanmışlardır (3).

Birçok din sosyoloğu, dini sembollerle ilgili çok çeşitli açıklama ve yorumlamaları, kültürel çeşitlilik ile birlikte dinin resmi olan ve olmayan formasyonlarının incelenmesinin gerekliliğini vurgulamışlardır. Bu çerçevede inancın volk versiyonları mahalli kültür ve adetleri muhafaza ederken, evrensel karakterli dünya dinleri karmaşık rasyonel teolojisi, buna dayalı bir ahlak sistemi, formel ibadet usulleri geliştirme eğilimindedir. Ayrıca evrensel dinler teoloji, etik ve pratikleri en ince teferruatına kadar belirleyen, bunları geliştiren, koruyan ve hizmet gören, dini iş bölümüne dayalı bir din adamları grubunu da geliştirir.

Dünya dinleri, inancın halk tipi ya da volk versiyonları da geliştirme eğilimindedir. Kitlelerin karmaşık rasyonelleştirilmiş teolojiler tarafından hareket ettirilmeleri çok zor olduğundan mahalli karakter kazanmış inanç şekillerinin gelişmesi oldukça muhtemeldir. $O$ halde birçok evrensel din, resmi boyutunun yanı sıra mahalli adetler, inançlar ve mitlerle harmanlaşmış bir volk versiyonuna da sahiptir. Bazen evrensel dinlerin farklı kültürlere sahip mensupları, aynı dini geleneği, değişik bir biçimde anlayıp yorumlayabilmektedir. Mesela XVI. yüzyıldaki Hint Müslümanlığı ile aynı dönemdeki Arabistan'ın Hicaz ve Necd Bölgesi'ndeki Müslümanlık arasında farklılıklar vardır. Hindistan'daki Müslümanlık, Hinduizm ve Budizm ile bir arada yaşamış olarak, verimli etkileşim ilişkisi içerisi- 
ne girebilmiştir. Belki de Hint Müslüman mistikleri arasındaki panteistik ağılıklı düşüncelerin varlı̆ı̆ böyle bir etkileşimin somut örneği olarak görülürken bunların, iki toplumu birbirine yakınlaştıran güçler olarak değerlendirmemizi mümkün kılabilir.

Iki kültür arasındaki benzerliklerin ve farklıııkların toleransa ve karşılıklı anlayışa yol açmasına karşılık, bazı şartlar altında hoşgörüsüzlüğü alevlendirecek şiddete dayalı dışlayıcılığa da neden olabilmektedir. Daha sonra Hindistan'ın 1947 'de iki devlet halinde bölünmesi sürecinde farklılıkları vurgulayan ikinci trendin galip gelmesine şahit olunacaktır (Abu Zayd, 2006: 13-14). İslami kültürel dinamizmin Hint örneği ile ilgili söylenenlerin aynısını, İslam'ın varlığını değişmeden sürdürdüğü Arabistan'daki Müslümanlık hakkında söylemek zordur. Görüldüğü gibi çeşitli faktörler ve güçlerin etkisiyle farklı coğrafyalarda aynı dini geleneğin değişik yorumlamaları ile karşı karşıya gelmekteyiz. Bazen aynı coğrafyada farklı grupların inançla ilgili kendi yorumlamaları da aynı inancın resmi formundan ayrı halk dini biçimini oluşturmaktadır.

Resmi dinle volk dini arasındaki çatışmanın, sosyologları ilgilendiren boyutlarından biri resmi dinin sistematik teoloji geliştirme yönündeki rasyonelliğinin nispi önemi ile ilgilidir. Rasyonelleştirilmiş teolojinin ortalama insan için güçlü, şümullü ve kalıcı anlam sistemi sağlayabilme kapasitesi düşüktür. Halk dini ile resmi din arasındaki farklılıktaki ikinci önemli faktör ise, dini elitin inancı tüm kültürler ve insanlar için geçerli kılması yani kültürel bağlamından ayrı evrensel kurallar oluşturma girişimidir. Böylece formel dinsel yapılarda ve geleneklerde belirli bir kültüre özgü olan değerler ve tutumlar önemsiz hale getirilmektedir. Öte yandan halk dindarlığı; lokal adetler, değerler, inançlar ve geleneklerle ana dini inancın bir sentezini oluşturmasının yanı sıra mitsel bilgilerle karışık, senkretist bir karaktere bürünebilmektedir. Aslında volk dini, resmi dinin bir tipini oluştursa da resmin inancın çok çeşitli resmi olmayan versiyonları vardır.

Profesyonellerin ya da teologların ve ahlakçıların herhangi bir inanç sisteminin evrensel unsurlarını ortaya çıkarma girişimleri ve soyut formüllendirmeleri bunların dışındaki diğer insanları çok fazla tatmin etmeyen beyhude çabalar olarak görülebilmektedir. Bu süreçte, toplumun temel moral değerlerini ortaya çıkarma ve birçok geleneksel değerleri destekleme yönünde bazı çabalara girişen dini organizasyonların doğmasına şahit olunur.

ABD'de "Virginia"lı Jerry Falwell tarafından kurulan "Ahlaki Çoğunluk (The Moral Majority)" hareketi Amerikan toplumunun ahlaki değerlerini yeniden tesis etmeyi amaçlayan bir dini organizasyon olarak Amerikanizmi Hristiyanlıkla harmanlayan güçlü bir volk dini olarak görülmüştür (4). Birçok geleneksel Hristiyan değerlerini destekleyen Ahlaki Çoğunluk hareketi, geleneksel Amerikan değerlerinin ve tutumların çoğu temel Hristiyan değerleri olarak takdim etmiştir. Aslında bunların çoğu Hristiyan teolojisi ya da etiğinin hiçbir zaman parçası olmamış, hatta bazısı Hristiyan kiliselerin tarihi pozisyonuna ters bile düştüğü ifade edilmiştir. 
Ülkemizde Fethullah Gülen Cemaati olarak bilinen bir dini hareketin de Amerika'daki Ahlaki Çoğunluk hareketine benzer faaliyetler sergilemesini, siyasi yapıyla etkileşimi bağlamında bu cemaatin resmi din karşııında bir güç elde etme mücadelesi olarak değerlendirebiliriz. Kendine özgü yaşam biçiminin Türk kültürel değerlerinin bir yansıması olduğunu ifade eden cemaat, cemaatin mensupları, taraftar elde etmeyi, ümit ettikleri kültürün değerlerine vurgu yaparak bir genişliğe ve yaygınlığa ulaşmayı hedeflemektedir. İslami değerleri aslında taraftar elde etmeyi ümit ettiği kültürün değerleriyle uyumlu hale getirmeye çalışmaktadır. Böylece serbest piyasa sistemi, orta sınıf değerleri ve benzeri türden değerlere vurgu yaparak geliştirilen yaşama stili; dini referansta bulunularak meşrulaştırılmaya çalışılmaktadır.

\section{Yeni Dini Hareketler}

Yeni dini hareketler (5) konusuna girmeden evvel, kült (Jary ve Jary, 1991: 98) (cult) tipi dini grup oluşumu üzerinde kısaca durmakta yarar vardır. Aslında yeni dini hareketler kavramı sosyologların sekt ve kült etrafındaki tartışmaları bağlamında geliştirilmiştir. Stark ve Bainbridge, Bryn Wilson ve Roy Wallis gibi din sosyologları sekt tipleri, kült ve yeni dini hareketler hakkında yaptıkları sosyolojik araştırma tartışma ve tahliller bağlamında bu kavramları ele alıp sekülerleşme süreci ile ilişkilendirmişlerdir.

Dini alanda kelime olarak daha çok herhangi bir ibadet çeşidi anlamına gelen kült kavramı ile belli bir inanca güçlü bir bağııı̆ı ifade eden ve küçük topluluğu belirtmek üzere kullanılan sekt kelimeleri, yirminci yüzyılda din sosyolojisinde yeni anlamlar kazanarak değişik kullanıma sahip olmuşlardır. Geleneksel din sosyolojisinde sekt ve kültler, toplumun egemen dininden daha doğru, daha saf ve daha iyi olduğuna inandıkları inanç ve pratikleri uygulamak üzere ayrılanların oluşturdukları küçük dini grupları belirtmek üzere kullanılmaktadır (Ellwood ve Alles, 2007: 109).

Sosyologların bir kısmı kültü, büroktarik yapısı olmayan karizmatik liderin önderliğinde bazı ezoterik hatta büyüsel fikirlerden oluşan inanç ve uygulamalara dayalı küçük bir dini grup olarak tanımlamaktadır. íkinci kullanımında kült, Troeltsch'ın mistisizm kategorisinden geliştirilmiş olarak şehirli, bazı ezoterik inançlara sahip insanların oluşturduğu gevşek yapılı bir birlik anlamına gelmektedir (Roberts, 1990: 195-196). Sosyologların büyük bir bölümünün üzerinde ittifak ettiği üçüncü yaklaşımda ise kült, belli toplumlarda en azından yeni olan dinleri belirtmek üzere kullanılan ve daha faydalı bir araç olma ihtimali yüksek bir dini grup tipi olarak tanımlanmaktadır. Buna göre mevcut dini geleneğin içerisinde bir ayrılığın sonucu olarak biçimlenen sekt tipi organizasyonların aksine kültler, diğer toplumlardan ithal yoluyla getirilen tamamen yeni olan dini gruplardır.

Stark ve Bainbridge, $A B D^{\prime}$ de kült formasyonunun 1960 'larda en yüksek seviyede seyrettiğini belirtmiş, Wallis de aynı yıllarda, yeni dini hareketlerin doğ- 
masına neden olduğunu söylediği birçok sosyal değişmeye dikkat çekmiştir. Buna göre, yüksek öğrenim görenlerin sayısının artması ve eğitimde geçen zamanın uzaması gibi eğitim alanındaki gelişmeler, çocukluktan yetişkinliğe geçişin zamanının genişlemesine yol açmıştır. İş ve aile sorumluluğu fazla olmayan ancak özgürlük talebinde olan gençlerin sayılarının artmasından dolayı bir gençlik kültürü gelişmiştir. Aynı zamanda gelişen teknolojinin, fakirliği ve ekonomik kıtlığı sona erdireceği yönünde bir inanç da özellikle gençler arasında belli bir yaygınlık kazanmıştır. Öte yandan 1960 'larda toplumda hâkim sosyal normlar ve değerlere alternatif sağlayan radikal siyasal hareketler de gelişmiştir. Bütün bu gelişmelere dikkat çeken Wallis, yeni dini hareketlerin doğmasında ve gelişmesinde en önemli faktörün hızlı sosyal değişimi sürecinin etkili olduğunu belirtmektedir (Haralambos ve Holborn, 1997: 474).

Kültü, sekt tipi dini organizasyondan ayırma kriteri olarak Stark ve Bainbridge ikincisini toplumda mevcut dini geleneği yenilemek veya saflaştırmak girişimi olarak görürken, birincisini yeni ve farklı bir dini oluşumu belirtmek üzere kullanmaktadır. Ülkemizde "Moonculuk" olarak bilinen "Unification Church"(6) hareketi yeni dini hareketlerle ilgili ilginç bir örnek oluşturmaktadır. Bu grubun mensupları, hareketin kurucusu olan Sun Myung Moon'un, Mesih olduğuna inanırlar. Moon'un öğretisine göre, $\mathrm{Hz}$. İsa misyonunu tamamlamadan öldürülmüş ve kendisine tevdi edilmiş tüm görevler yerine getirilemeyerek yarım kalmıştır. Bu ilahi görevi tamamlama hususunda Tanrı, Moon'u görevlendirmiştir.

Açıkçası Moonculuğun bu doktrini geleneksel Hristiyanlıktan çok ciddi bir ayrııı̧ı ortaya koymaktadır. Organizasyonel yapısı ve egemen toplumsal değerlerle giriştiği çatışmacı ilişkiler, ilkin Mooncuların sekt tipi bir oluşum şeklinde gözükmelerine yol açarken, yeni ve kendilerine özgü bir doktrin geliştirmeleriyle de sekteriyan yapılardan ayrılmıştır. Bir kült hareketi olarak başlayan Moonculuk, yeni dini hareketler dediğimiz bir oluşumun tipik örneğini teşkil etmiştir.

Aslında yeni dini hareketler, kendilerini mesela Hristiyanlık gibi ana dini geleneğin bir kolu olarak görseler de, sahip oldukları ya da geliştirdikleri teolojik yenilikler, diğer Hristiyan gruplar tarafından Hristiyan doktrininin bir parçası olarak kabul edilmezler. Bilhassa ABD üzerinden dünya ölçeğinde bir genişliğe ulaşma isteğindeki yeni dini hareketlerin, olağanüstü güçlere sahip olduğuna inanılan karizmatik liderin merkeziliği etrafında gelişme göstermesi, onların tipik özelliği olmaktadır. Bu çerçevede bazı yeni dini hareketlerin komünizm karşıtı faaliyetleri ve aileye verdikleri önem, neo-liberalist ekonomik modeli benimsemeleri gibi bazı Amerikan değerlerine vurgu yapmaktadırlar. Bu tür faaliyetleri bir yandan meşruluk zemini oluşturma, bir yandan da bazı ailelerin şiddetli tepkilerinden dolayı, takibata uğramaktan kurtulma yolu olarak da görülebilir. Çünkü bu tür gruplar hızlı sosyal değişmelerin bir sonucu olarak marjinallik ve nispi yoksunluk içerisinde olan bilhassa gençlerden meydana gelen bir 
sosyal destek tabanına sahip olduklarından, varlıklarını sürdürebilmeleri için üyelerinin kaynak mobilizasyonu teorisi bağlamında aile bağlarından kopup kendilerini gruba adamaları şeklindeki gelişmeler kapsamında toplumda bazı huzursuzlukların yaşanması da sebebiyet vermektedir. Çünkü bu tür hareketler bütünleşmiş, cemaat yapısıyla kendi kitaplarını okuyan, konferanslarına katılan, zaman zaman da pratiklerini yapan yerleşim alanı olarak oldukça dağınık bir taraftar kitlesine sahiptirler.

Dini organizasyonların kategorize edilmesinde belli başı kriter olarak çeşitli görünüm ve yapıdaki dini hareketlerin sosyal çevreleriyle yaşadıkları gerilim ve etkileşim ilişkisi önemli rol oynamaktadır. Bu çerçevede ortaya çıkan sekt tipleri, kült ve yeni dini hareketler gibi çok çeşitli küçük dini, ruhsal veya mistik grupların sınıflandırılması hususunda çok sayıda girişimin yapıldığını biliyoruz. Eileen Barker (Haralambos ve Holborn, 1997: 468), bunların doğdukları dini geleneğe göre sınıflandırımasının uygun olacağını ifade etmiştir. Yine Barker yeni dini hareketleri sınıflandırmanın diğer bir yolu olarak, mensuplarının bağlılık derecesini göstermektedir. Roy Wallis gibi diğer sosyologlar da daha detaylı sınıflandırma sistemi geliştirmişlerdir. Sosyologlar arasında yeni dini hareketler teriminin popüler hale gelmesi sosyo-kültürel değişmeleri, sekülerleşmeyi ve dini plüralizmi yansıtır (Tınaz, 2005: 97).

Bireylerin bir yandan dini oluşumlarla bağlılık ilişkisi ve etkileşimleri bir yandan da bireysel dindarlıklarında gözlenen değişimleri anlayabilmek bakımından çeşitli sosyolojik modellerin geliştirildiğini ve bunlara başvurulduğunu belirtmiştik. Aslında çeşitli ülkelerin kendine özgü tarihsel, toplumsal tecrübeleriyle ve yaşayışlarıyla ilişkili olarak modellerin geliştirilmesi ve bu yolla dini kurumsal gelişmelerin analiz edilmesi önem arz etmektedir. Öte yandan bu süreci tanımlama ve açıklamada söz gelimi ABD'de ekonomik pazar modelinin geliştirilmesine karşılık çeşitli Avrupa ülkelerinde, dini gelişmeleri sekülerleşme tezine dayanarak açıklama girişimleri ve hem Amerikan hem de Avrupa toplumunda bireyselleşme teorisinin önemli analitik araçlar olduğunu söyleyebiliriz.

Dinin sosyal öneminde gözlenen değişmelere bakarak bu süreci desekülerizasyon, "yeniden kutsallaşma" ya da "dinin geri dönüşü" gibi kavramlarla açıklamak ve bu süreci, dinin bütün boyutlarında zayıflayacağı düşüncesini ileri süren sekülerleşme tezinin yanlışlandığının işareti olarak görmek ihtiyatla karşılanmalıdır. Son onlu yıllarda sosyal ve beşeri bilimlerde şehirleşme, sanayileşme, bireyselleşme, yaşam standartlarında yükselme, dini-kültürel çoğulculaşma gibi modernleşme süreçlerinin dini kurum, inanç sistemi ve pratiklerinin sosyal öneminde bir değişmeye yol açtığı iddia edilmiştir. Bu değişmeleri anlamak için ekonomik pazar modeli; bireyselleşme tezi ve sekülerleşme teorisi gibi farklı yaklaşımlar kullanılmaktadır. Son yıllarda dini canlanış ile ilgili seslerin yükselişine rağmen, uzun vadede Batılı toplumlarda dinlerin ve kiliselerin sosyal önemini kaybedeceğinden söz edilmektedir. Yeni dini hareket veya grupların sayısında gözlenen artışın ve senkretistik dindarlığın bireyselci formlarında be- 
lirgin bir yükselmenin gözlenişi, sekülerleşme süreciyle birlikte kiliselerin ve geleneksel dini formların hem taraftar hem de bağlılık biçiminde gözlenen kayıplarını telafi edebilecek boyutta olmadığı ifade edilmektedir (Pollack, 2008: 168: 186).

Modernleşme süreciyle birlikte sosyal yapının yoğun bir biçimde farklılaşmasına yol açan hızlı sosyal değişimin meydana getirdiği yeni şartlar altında, geleneksel dini kurumların içsel sekülerleşmeyi başaramaması ve toplumsal değerlerle uyum problemi yaşaması; sübjektifliğin, bireyciliğin ve antikurumsalcılığın meydana getirdiği neo-mistik oluşumlardan çeşitli dini hareket formalarına kadar bir dizi dini organizasyonun gelişmesine zemin hazırlamıştır. Bunun yanında bu tür dini oluşumların artması geleneksel kurumsal dinin parçalanması anlamına geleceğinden, dinin toplumsal bütünleşmeyi sağlayıcı etkisinin ve gücünün zayıflaması da bir başka problemli alan olarak dikkati çekmeye devam edecektir.

\section{Notlar}

(*) Prof. Dr., Sütçü İmam Üniversitesi İlahiyat Fakültesi, e-posta: hebodur@ksu.edu.tr

(1) Kilise-sekt tipi organizasyonların genel karakteristikleri için bkz. Vernon, 1962: 162-177; Roberts, 1990: 181-202.

(2) Sekt tipinin Haricilik hareketinin analizinde kullanılması ile ilgili olarak bkz. Bodur, 2007: 25-53.

(3) Geniş bilgi için bkz. Roberts, 1990: 94-98.

(4) Roberts, Religion in Sociological Perspectives, s. 96-97

(5) Yeni dini hareketler ve onların tipolojileriyle ilgili bkz. Tınaz, 2005: 63-108.

(6) Moonculuk hareketi ile ilgili bkz. Bodur, 2003: 13-39.

\section{Kaynaklar}

Roberts, K. A., Religion in Sociological Perspective, Wadsworth Publishing Company, California, 1990.

Vernon, G. M., Sociology of Religion, McGraw-Hill Book Company, New York, 1962.

Bodur, H.E., "Sekt (Fırka) Tipi Dini Organizasyonun Örneği Olarak Haricilik Hareketine Sosyolojik Bir Bakış", KSÜ Ilahiyat Fakültesi Dergisi, 10 (2007): 25-53.

Abu Zayd, N., Reformation of Islamic Thought, Amsterdam University Press, Amsterdam, 2006.

Tınaz, N., "A Social Analysis of Religion Organisations: The Cases of Church, Sect, Denomination, Cult and New Religious Movements (NRMs) and Their Typologies", islami Araştırmalar Dergisi, Sayı: 13, 2005: 63-108.

Jary, D. \& Jary, J., Sociology, HarperPerennial, New York, 1991.

Ellwood, R. S. \& Alles, G. D. , The Encyclopedia of World Religions, DWJ BOOKS LLC., New York, 2007.

Haralambos, M. \& Holborn, M., Sociology Themes and Perspectives, Collins Educational, London, 1997.

Bodur, H. E., “Moonculuk Hareketi ve Türkiye'de Benzer Bir Cemaat Yapılanmasının Sosyolojik Analizi", KSÜ Ilahiyat Fakültesi Dergisi, 1 (2003): 13-39.

Pollack, D., "Religious Change in Europe: Theoretical Considerations and Empirical Findings", Social Compass, 55 (2), 2008: 168-186. 


\title{
SOSYOLOJIDE YÖNTEME GIDEN YOLLAR ÜZERİNE
}

\begin{abstract}
On the ways towards methods in sociology. It has been known that people have developed several ways to analyse their own social and natural environments. Development process of these ways includes some interesting facts. Beginning by renaissance, dominant world-view of the medieval ages in Europa which saw the world through a metaphysical understanding was challenged and a critical and scientific world-view began to be initiated. The ultimate aim of science is to achieve a series of deductions after definitions and explanations. In fact, natural sciences and humanistic sciences do not vary in terms of aims and methods. However, experiments and observations employed in humanistic sciences are limitedly used in natural sciences. Therefore, in humanistic sciences, it is much more difficult to reach generalizations and laws. However, it is also true that humanistic sciences deal with observable and objective facts and is based on systematical knowledge that includes deductions resulting from causal relationships between these observable and objective facts. This article is concerned with methodological preferrences in sociology depending on the similarities and differences between the basic paradigms of natural science and those of humanistic sciences.
\end{abstract}

\section{key words}

Natural sciences, humanistic sciences, methodology, sociology. 


\section{Giriş}

Dünyanın diğer ülkelerinde olduğu gibi, son zamanlarda ülkemizde de sosyologların toplumsal gerçekliği yakalamak için farklı paradigmalara dayanan sembolik etkileşimcilik, etnometodoloji vb. farklı yöntemler kullandıkları görülmektedir. İnsanın kendi doğal ve sosyal çevresini incelemek için çeşitli yöntemler geliştirdiği bilinmektedir. Bu yöntemlerin geliştirilme sürecinin bilim tarihinde izlenmesi ilginç manzaralar ortaya çıkarmaktadır. Bu makalede doğa bilimlerinin ve sosyal bilimlerin bilim ve yöntem anlayışları üzerinde durulacak ve farklı bilim paradigmalarından hareketle nicel ve nitel yaklaşımın temel sayıtlıları karşılaştırmalı olarak incelenecektir.

\section{Doğa Bilimlerinin Bilim Anlayışı}

Rönesansla birlikte Avrupa'da Ortaçağın, dünyayı metafizik bir gözle gören hakim dünya görüşü sarsılmış, eleştirel, bilimsel bir dünya görüşüne giden yol açılmıştır. Bu dönemde Avrupa'da, birçok alanda (felsefe, din, siyaset, sanat, ekonomi vb.) reform yaşanması, bilimde yeni bir bakış açısının ortaya çıkmasıyla yakından ilişkilidir. Daha sonra 17. ve 18. yüzyıllarda yaşanan Aydınlanma Dönemi ile birlikte, 'Akıl Çağı' denilen dönem başlamıştır. Aydınlanma, insan mutluluğunun "doğru aklın", insani, manevi ve doğal düzene uygulanması ile elde edilebileceğini varsayar. Buradan hareketle, insanın, Tanrı'nın ellerinde değil, aklını kullanarak kendisini geliştirebileceğini savunur. Aydınlanma döneminin en önemli temsilcilerinden Luther, Bacon, Descartes, Galileo, Newton, Voltaire, Wesley, Rousseau, Locke, Hume, Kant ve Smith gibi filozof ve bilim adamları, yukarıda bahsettiğimiz temel dönüşümün ayrıntılarını, toplum hayatımızda kabul ettiğimiz uygulamalara dönüştürme konusunda ilk tartışmaları başlatanlardır (Yıldırım ve Şimşek, 1999: 2). Örneğin Martin Luther, Protestan devrimi ile özelde Hıristiyanlı̆ı̆ı, genelde dinlerin yeniden şekillendirilmesi konusunda yeni bir çığır açmış, Bacon, Descartes ve Kant, modern felsefe, matematik ve mantığın yeniden ele alınmasına katkıda bulunmuştur. Voltaire ve Rousseau, devletin rolü ve devlet-birey ilişkisinde, günümüz demokrasisinin temel ilkelerini tespit etmişlerdir. Locke ve Hume, felsefenin temel sorunlarını, bilginin ne olduğu ve nasıl üretildiğine (epistemoloji) doğru yönelterek ampirisizm ve gerçekçiliğin (realism) ilkelerini formüle etmişlerdir. A. Smith, ekonomik faaliyetin, rekabet ve girişimcilik üzerine oturması gerektiğini savunarak, günümüz kapitalizminin ilk ve temel tartışmalarını yapmıştır. Galileo ve Newton ise bugün bile geçerli olan pozitivist paradigmanın temelini oluşturan çağdaş bilimsel düşünceye ilk şeklini vermişlerdir (Yıldırım ve Şimşek, 1999: 2-3; Gökçe, 1992: 7-8).

Baconian-Newtonian bilim anlayışı, 17. yüzyıldan günümüze (her ne kadar 19. yüzyılın sonlarından itibaren eleştiriler giderek artsa da) kadar hakimiyetini sürdürmüştür. Bu anlayışın temel öğelerini gözden geçirdiğimizde insanın dışında duran reel maddi evren görüşü göze çarpar. Bu maddi evrende olup biten her şey, evrensel doğa yasaları tarafından yönetilmektedir. Bilim de esas olarak 
bu yasaları keşfetme faaliyetidir. Evrensel yasaları keşfetmek için geçerli tek yol, empirik soruşturmadır. Empirik soruşturma ölçmeyi gerektirir. Yasalar konusunda doğru bilgi için ölçüm araçları geliştirilmelidir. Ölçüm araçları geliştirildikçe bugün bilinemeyen verileri elde etmek mümkün olacaktır. Görülüyor ki bu anlayışa göre doğal olguların çoğu doğrusaldır, yasaları evrenseldir ve tüm yasalar matematik diline dönüştürülebilir. Böylece olgular zamanı aşmaktadır. Dolayısıyla bir yasaya sahip olup, şartlarını bilmek, ne olacağının kestirilmesi için yeterlidir. Yani, bize başka türlü görünen her süreç, aslında farklıdır. Elbette bu, sadece bugünkü ölçüm araçlarımızın yetersizliğinden kaynaklanmaktadır (Kuş, 2003: 6-7).

Avrupa hermönetik geleneğinden etkilenmiş olan pek çok felsefeci, sosyal alemin, bireylerin rasyonel amaç ve kararları tarafından etkilendiğine işaret eder. Bu anlamda sosyal bilimin işlevi, nedenleri ortaya çıkarmak değil, anlaşılır olanı yorumlamak, tefsir etmektir. Doğal bilimi model olarak alan sosyal bilimcilerin "natüralist" yaklaşımına karşı, bu yaklaşım, "hümanist" olarak nitelendirilmekte ve her iki yaklaşımın da gerçeğin bir başka parçasına odaklandığı iddia edilmektedir:

Bu bilimler sosyaldir, yani inceledikleri fenomenler bilinçli olarak seçilmiş fenomenlerdir ve bu yüzden de kendi amaçları açısından tanımlanmalıdır. İkincisi, bu bilimler, çok farklı türden fenomenlerin altında yatan nedensel etkileşimleri açıklamak üzere sistematik teoriler geliştirmeye çalışmaları bakımından bilimdir. Hümanizm ve natüralizm akımlarının her ikisi de bu özelliklerin sadece bir tanesine takılıp kaldıklarından, sosyal bilimleri gerektiği gibi açıklamakta yetersiz kalırlar (Bay ve Moon, 1977: 227; Trigg, 2001: 11).

\section{Pozitivizm ve Sosyoloji}

Doğa bilimlerinin, sosyal bilimler üzerinde büyük bir ağırlığı olmuştur. Bugün bu yaklaşımın varsayımlarından kuşku duyulsa bile, sosyal bilimler üzerine yapılacak bir inceleme, onunla başlamak durumundadır. Bu yaklaşım, sosyal bilimlerin bilimsel karakterini sık sık vurgulamakta ve bilimsel kanunların çatısı altında incelenemeyen her şeyi dışarıda bırakmaktadır. Ampirist bakış açısına sahip olan ve 1920-1930'larda Viyana'da bir araya gelen felsefeci grubu, dünyanın bilimsel kavranışının, ancak ampirist ve pozitivist yaklaşımla mümkün olacağını savunuyordu (Trigg, 2001: 12). 19. yüzyıl ortalarından itibaren bir taraftan pozitif bilimlerin gelişmesiyle sosyolojinin doğması için gerekli şartlar ortaya çıkmış, diğer taraftan Avrupa'da karşılaşılan sosyal problemler, böyle bir bilime pratik olarak ihtiyaç duyulmasına yol açmıştır. 19. yüzyıl Avrupa'daki Sanayi devrimiyle birlikte gelen yapısal dönüşümlerin ve dolayısıyla toplumsal sorunların açık seçik ortaya çıktığı bir dönemdir. Bu dönemde sosyoloji, "toplumsal olayları bilimsel yöntemle inceleyen, olaylara yön veren yasaları bularak, bu yasalar çerçevesinde toplumu düzenlemek amacıyla bağımsız bir bilim olarak kurulmuş ve bilimler sınıflamasındaki yerini almışıı" (Gökçe, 1992: 8). 
Pozitivizm terimini ilk defa kullanan A. Comte'tur. S. Simon, Comte ve pozitivistler için bilim, kesin bilgi veren bir faaliyettir. $O$ dönemde toplumsal ortamdaki savaş ve anarşi durumu, bilim adamlarının entelektüel, ahlaki ve sosyal hayata yeni bir temel aramasını teşvik etmiştir. Bu temel, bilimin metot ve bulguları ile sağlanacaktır. Sosyoloji ise bu yeni düzen içinde zirvedeki yerini alacaktır. Bu anlayışa göre pozitif toplumdaki problemler, bilimsel hesaplamalarla çözülebilir; inançlar ve politik düşünceler bilimle uyuşabilir ve böylece toplumda bir düzen ve ilerleme sağlanabilirdi (Keat ve Ury, 1994: 85).

Comte'un birinci iddiası, doğa bilimleri gibi sosyolojinin de pozitif olduğudur. Ona göre toplumlar, düşünce tarzları olarak teolojik, metafizik aşamalardan geçer ve pozitivizme ulaşır, sonra sosyal organizasyon tiplerinde de aynı değişimler olur. Bu aşamalardan pozitif aşamada bilim, sadece gözlenebilir olgularla ilgilenir ve bu biriken olgular arasında yasa benzeri ilişkiler kurar. Bu ilişkiler, gözlem ve deneye dayalı, karşılaştırmalar ve kestirimler yoluyla kurulur. İster birlikte, ister ardı ardına gelsin, gözlenebilen olgular arasındaki ilişkiler, değişmez ve evrensel yasalarla düzenli olarak birbirine bağlanır. Comte'un ikinci iddiası, bilimler arasındaki hiyerarşidir. Bu hiyerarşide matematik başta, sosyoloji ise en sonda yer alır (Keat ve Ury, 1994: 85-86).

Comte, bilimsel önermenin bilimsel olmayan önermeden, kesinlik ve hatadan uzaklık sayesinde değil, sınanabilirlik açısından ayrılabileceğini ileri sürer. Görülüyor ki bilimsel önermeler, doğa veya toplum hakkında genel iddialarda bulunan ve empirik kontrole açık olan önermelerdir. Böylece sınanabilir ve kestirilebilir sonuçlara sahip olan önermelerin doğruluğu bilimsel olarak kabul edilir. Üstelik bu kestirimler sadece gelecek hakkında olmaz. Geçmiş ve günümüzdeki olaylar da kestirimleri sınamak için kullanılabilir. Çünkü kestirimler, sadece bilinenden bilinmeyene bir sıçramadır. Sonuçta Comte'a göre anlamlı önermeler, kontrol edilebilen, sınanabilen ve reddedilmesi mümkün olan önermelerdir. Zaten pozitivist yaklaşımı teoloji ve metafizikten ayıran da budur (Keat ve Ury, 1994: 87).

Pozitivist Epistemoloji, öncelikle şu ontolojik sayıltıya dayanır:

"Benim dışımda bir gerçeklik mevcuttur". Bu temel sayıltı üzerine diğer sayıltılar kurgulanır:

(1) Bu dış gerçekliği duyularımla bilebilirim.

(2) Duyularımla elde ettiğim bu bilgi nesneldir.

(3) Sosyal bilimlerin bu nesnel konuları, doğa bilimleri metodolojisi kullanılarak incelenebilir (Kuş, 2003: 5).

Bu sayıltılar, bugünkü modern bilimin ortaya çıktığı sürece büyük katkıları olan doğa bilimcileri ya da felsefeciler tarafından ifade edilen düşüncelerle ilişkilidir. İlkin doğa bilimlerinde, sonra sosyal bilimlerde pozitivist yaklaşımın temel sayıltıları hakim olmuştur. Pozitivizm, bilim ve felsefe içinde uzun bir geçmişe sahiptir. Pozitivizm terimini ilk kullanan Comte olmuşsa da, onun sistemleştirdiği bu yaklaşım, aslında Bacon, Galileo, Newton, Descartes gibi doğa bi- 
limci ve felsefecilerin açıklamalarıyla uygunluk arzetmektedir. Adı geçen düşünürlerin, bilime ve onun yöntemine büyük katkıları olmuştur. Descartes'a göre insan, aklı sayesinde doğayı, onun işleyişinin düzenini ve yasalarını keşfedebilir ve ona hakim olabilir. Bacon'a göre ise "bilmek, hakim olmak içindir" (Kuş, 2003: 5-6).

Sosyal bilimler açısından 'değerlerden arındırılmış' bir bilim fikri çok önemlidir. Sosyal bilimciler, toplum hakkındaki olguları, bir fizikçi ya da kimyagerin, doğal olguları açıklamakta kullandıkları yöntemlerle tespit eder.

\section{Kültür Bilimleri ve Anlayıcı Sosyoloji}

Alman felsefe geleneğinde, Kant'ta ifadesini bulan doğal gerçeklik-manevi gerçeklik ayırımından yola çıkan ve Alman İdealizmi akımına bağı bulunan Hegel'le birlikte bir "kültür felsefesi" gelişmiştir. Bu Kantçı ayırım başka bir koldan, Herder, Alman Tarih Okulu, Dilthey, Yeni Kantçı okullar ve Weber'i de içine alarak gelenekleşmiştir. Örneğin Dilthey, doğal gerçekliği bir algı gerçekliği, kültürel gerçekliği, insan ürünü bir anlam gerçekliği olarak ayırmış, bu iki gerçeklik alanını incelemeye yönelen bilimleri, 'konu' ve 'yöntem' bakımından kesinlikle farklı yerlere koymuştur. Bu anlayışa göre doğa bilimleri, doğayı genel kavramlar ve yasalar dahilinde betimlemek ve açıklamak isterler. Kültürel gerçekliği incelemeye yönelen bilimler (Dilthey bunlara Kültür Bilimleri der) ise konusunun tarihselliği ve bireyselliği dolayısıyla, genelleştirici kavramlarla çalışamazlar, yasa koyucu olamazlar ve toplum ile kültürü bir doğal belirlenimin sonucu olarak göremezler (Özlem, 1990: 13-14).

Dilthey'e göre tarih ve toplum empirik yöntemlerle doğrudan ele alınabilecek alanlar değildir. Çünkü bu alanlar bir algılama nesnesi değil, bir anlama nesnesidir. Doğa bilimleri doğayı, tekrar ve süreklilik gösteren olgular bütünü olarak görür. Bu durum ona evrensel doğa yasalarını ortaya çıkarma imkanı verir. Onun, doğa yasalarına dayanarak tekil olguları açıklayabilmesi de buna bağlıdır. Şu halde doğa bilimleri, empirik ve açıklayıcı bilimlerdir (Özlem, 1990: 29).

Dilthey'e göre kültürel dünya, doğa bilimlerinin nedensellik ilişkileri içinde ele alınamaz. Çünkü kültür alanında insanın, belli değer, ilke, norm ve kurallar altında gerçekleştirdiklerini bilmek ve anlamak gerekir. Bütün bu değer, ilke, norm ve kurallar ise, doğal belirleyiciler değil, insan yapısı, simgeler ve anlamlardır. Ancak insan eylemlerini yönlendiren bu anlamlar, evrensel yasalara bağlı değildir. Çünkü insan eylemlerini sürekli belirleyen hiçbir değer, ilke, norm ve kural yoktur. Bu sebeple kültür alanında sebep-sonuç bağıntısı, ancak bir anlameylem bağıntısı olarak kurulabilir. Sonuç olarak kültür gerçekliği, her toplumda, her zaman diliminde farklı bir görünüm kazanır. Kültür, her toplumun kendine özgü simgeler dünyası içinde varlık kazanır. Dolayısıyla tarihi ve toplumu inceleyen bilimlerde, doğa bilimlerinde olduğu gibi, tümevarım halinde bir genelleş- 
tirme ilkesiyle çalışma imkanı yoktur. Bu bilimler için özel bir yöntem olarak anlamanın ikili işlevi şöyle ortaya çıkar:

(1) Kültürel gerçeklerde sebep-sonuç bağıntısı, anlam-eylem bağıntısı olarak kurulduğuna göre, önce eylemi motive eden anlamı kavramak gerekir. Eylemi motive eden bu anlam, bir değer, bir norm ya da bir kural olabilir. Yani bunlar doğal nedenler değil, yine insandan kaynaklanan motiflerdir. Anlama, insan ve kültürü, yine insandan yola çıkarak kavrama yöntemidir.

(2) Kültür gerçekliği, özü gereği tarihsel olduğundan, anlama yöntemi, tüm zamanlar için geçerli nedensellikler belirlemede kullanılamaz. Tam tersine anlama yönteminin işlevi, her insanı, her toplumu, her ulusu kendi tarihselliği ve bireyselliği içinde kavramamıza yardımcı olmaktır (Özlem, 1990: 29-30).

Comte'un şekillendirdiği 19. yüzyıl pozitivist bilim anlayışında doğal ve kültürel gerçeklik arasında böyle bir ayırım yoktur. Aralarında bazı farklar olduğu kabul edilse bile her iki gerçekliği doğa bilimlerinin yöntemleriyle ele almanın gerekliliği kabul edilir. Bu pozitivist bilim anlayışı en somut örneğini, bizzat Comte'un temellendirdiği şekliyle "sosyoloji"de bulur. Renan, Saint Beuve, Taine gibi kültür eleştiricileri ve tarihçilerden Durkheim'e kadar uzanan bu gelenek içinde pozitivist çıkışı bir "sosyal bilim" anlayışı geliştirilmiştir. Alman Felsefe geleneğinin "kültür bilimi" anlayışıyla, pozitivist "sosyal bilim" anlayışı arasında 19. yüzyılın başından bu tarafa, Alman idealizmi-pozitivizm, tarihselcilik-olguculuk, hermönetik-doğalcılık şeklinde günümüze kadar ulaşan bir geleneksel karşıtlık oluşmuştur ki, bu karşıtlığın vurgulanmasında Weber'in bilim anlayışı ve sosyolojisinin büyük etkisi olmuştur. Çünkü Weber büyük ölçüde Alman sosyoloji geleneğinde ağırlığı olan kültür bilimi anlayışına bağlıysa da bilimin genelleştirici/açıklayıcı bir faaliyet olmasını arzulayan pozitivist bilim anlayışının da etkisindedir (Özlem, 1990: 14-15).

Weber, tüm kültür bilimleri için anlama yönteminin geçerliliği konusunda Dilthey'le aynı görüştedir. Zaten Weber, sosyolojinin yöntemini şöyle isimlendirir: Sosyolojik anlama yöntemi (Özlem, 1990: 82). Weber'e göre sosyoloji, sosyal eylemi yorumlama yoluyla anlamak, böylece onun oluşumunu ve nedenlerini açıklamak isteyen bir bilimdir. Weber burada, eylem ile, bireyin öznel bir anlam yükleyerek yaptığı bütün davranışlarını; sosyal eylem ile ise bireyin ona yüklediği öznel anlam gereğince, başkalarının davranışlarını göz önünde bulundurarak sergilediği bütün davranışlarını kastetmektedir (Weber, 1995: 10-11). Keat ve Urry, bu tanımlamadan yola çıkarak Weber'in, sosyal bilimlerdeki iki rakip yaklaşımı bütünleştirmeye çalıştığını iddia eder. İlk yaklaşım, nedensel açıklama konusundaki "natüralist" yaklaşım, ikincisi ise öznel anlamların yorumlayıcı anlaşılmasına ağırlık veren "anti-natüralist" yaklaşımdır. Weber, yorumlayıcı anlama ile doğrudan veya güdüsel anlama arasında bir ayırıma gitmektedir. Birisi $2 \times 2=4$ önermesini söylediğinde veya yazdığında biz bunun anlamını doğ- 
rudan doğruya anlarız. Aynı şekilde birisinin kızgınlığını da beden hareketlerinden anlarız. Oysa güdüsel anlama, bu doğrudan anlaşılan eylemin arkasındaki 'güdü'lerin bilgisiyle ilgilidir. Weber, güdüyü, aktörün kendine ve aktörü gözlemleyene, yapılan hareket için yeterli bir açıklama sağlayan öznel bir anlam olarak tanımlar. Bu tür güdüsel açıklamalar diğer tüm nedensel hipotezlerle aynı şekilde empirik olarak sınanmalıdır. Weber, başlangıçta oldukça makul görülen pekçok hipotezin, daha sonradan reddedildiğini ileri sürer. Bunun çeşitli sebepleri vardır. Birincisi, eylemin, 'gerçek itici gücünü' gerek aktörden gerek gözlemciden saklayan bilinçli güdüler bulunabilir. İkincisi, aktör, farklı ve çelişen güdülere sahip olabilir. Bu durumda bunların göreli gücünü veya önemini belirlemek zordur. Üçüncüsü, aktör ve gözlemci, aktörün durumunu farklı algılayabilir. Böylece gözlemciye makul güdü olarak görülen ile, aktörün makul güdüsü birbirinden farklı olabilir (Keat ve Ury, 1994: 177). Görülüyor ki kültürel olgular, yoğunluk derecelerine göre, belki de sınırsız sayıda güdülere bağlıdır. Bu motivleri tümüyle bilmek, bilim adamı için imkansızdır. Diğer taraftan kültürel olguların, sürekliliği bir defa ile sınırlı olduğu için, onları motive eden anlamları, öncelikle bireyselleştirici bir tutumla tespit etmek gerekir. Tarih biliminde böyle bir tutum benimsenebilmekle birlikte sosyolojide bu mümkün değildir. $O$ halde kültür bilimlerinde nedensellik iki anlamda kullanılabilir:

(1) Bir defada olup biteni, kendi bireysel bütünlüğü içinde kavramayı gerektiren nedensellik.

(2) Geniş kapsamlı tarihi ve kültürel analizler içinde, tüm insanlık tarihi için yaklaşıklık ve benzerlikten öteye gidemese de, genelleştirmeler yapmak için başvurulan nedensellik (Özlem, 1990: 83).

Bununla birlikte Weber'e göre kültür bilimlerinde nedenselliğin, daima motivleri anlamakla kurulabileceğini belirtmek gerekir. Sonuç olarak Weber'e göre kültür bilimlerinin yöntemi konusunda şu üç husus dikkate alınmalıdır:

(1) İster bireyselleştirici, ister genelleştirici olsun, kültür bilimlerinde motivasyon zincirinin tüm halkalarını belirleyerek tümel nedensel açıklamalar yapma imkanı yoktur.

(2) Kültür bilimlerinde anlama yöntemine başvurmadan belirlenebilecek bir olgu türü yoktur.

(3) Nedensel açıklama, tüm bilimler için, konusu karşısında daima parçalı ve kısmi kalan bir açıklamadır (Özlem, 1990: 84).

\section{Bilim ve Bilimsel Yöntem}

İnsanoğlu, varoluşundan beri ihtiyaçlarını karşılamak, çevresini tanımak, içinde yaşadığı dünyayı anlayabilmek için çeşitli faaliyetler yürütmektedir. Böylece hem etrafı ve kendisi hakkındaki gerçekleri öğrenmeyi, hem de doğal çevresini denetimi altına alabilmeyi hedeflemektedir. Bu çerçevede yapılan her türlü faaliyeti bilim adı altında toplayabiliriz. Bilim hakkında pek çok tanım yapılmış olmasına rağmen, bu tanımların, her bilim adamının kendine özgü pers- 
pektifini yansıttığını söylemek mümkündür. Bilim hakkındaki tanımları topluca gözden geçirdiğimizde, "bilimsel yöntemlerle ve sistematik olarak toplanmış tüm bilgiler"'in, en kısa ve özlü bilim tanımı olduğunu söyleyebiliriz. Bu tanımdan, her bilginin bilim tanımı içine yerleştirilemeyeceği, çünkü her çeşit bilginin bilimsel bilgi olmadığı, bilimsel bilgi toplama konusunda yöntemin ağırlıklı olarak önem kazandığı anlaşılmaktadır. Bilginin sınırları iki kritere göre belirlenir. Birincisi konusu, ikincisi amaçlarıdır. Bilginin bilimsel olabilmesi için, konusunu oluşturan olay ve nesnelerin; gözlenebilirliği, nesnelliği ve tekrar edilebilme özelliğine sahip olması gerekir. Bilimsel bilgi üretmenin amacı ise kuramlara ve yasalara ulaşmaktır. Bu çerçevede bilim, amacına ulaşmada üç aşamalı bir yol izler:

(1) Konusunu oluşturan olguları gözleyerek kavramak ve tanımlamak.

(2) Olgular arasında nedensellik ilişkisi kurmak, gözlem yoluyla bu ilişkileri sınadıktan sonra açıklamak.

(3) Ortaya çıkan çeşitli ilişkileri kuramlar ve yasalar halinde ifade ederek bazı çıkarımlar yapmak.

Görülüyor ki bilimin amacı, tanım ve açıklamalardan sonra belli bir çıkarım dizisine ulaşmaktır. Geleneksel bilimler sınıflamasına göre, bilgi üretmede tümdengelim yöntemini kullanan matematik bilimler ve tümevarım yöntemini kullanan pozitif bilimler birbirinden ayrılır. Pozitif bilimler içerisine Astronomi, Fizik, Kimya gibi bilim dallarını kapsayan Doğa Bilimlerini, Sosyoloji, Antropoloji, Psikoloji gibi bilim dallarını kapsayan İnsan Bilimlerini alabiliriz (Gökçe, 1992: 14). Esasen Doğa Bilimleri ile İnsan Bilimleri arasında amaç ve yöntem bakımından bir fark yoktur. Sadece İnsan Bilimlerinde kullanılan deneyler ve dayanılan gözlemler, Doğa Bilimlerine göre daha sınırlı olmaktadır. Bu sebeple de İnsan Bilimlerinde genellemelere ve yasalara ulaşmak daha zordur. Bununla birlikte Insan Bilimlerinin, pozitif bilim olarak gözlenebilir, nesnel olguları kendisine konu edinen ve o olgular arasında nedensel ilişkiler kurmaya çalışarak çıkarımlarda bulunan sistematik bilgilere dayandığını belirtmek gerekir (Gökçe, 1992: 5-7).

Doğayı, toplumu, bireyi, kültürü ve bunlar arasındaki ilişkileri betimlemek, açıklamak ve yorumlamak çabasında olan insan, sanattan felsefeye, dinden mitolojiye, geleneklerden bilime kadar geniş bir alan üzerinde araştırma yapmaya, farklı konular hakkında tutarlı, geçerli betimlemeler, açıklamalar ve yorumlar geliştirmeye çalışır. Bu bilgi üretme faaliyetlerini birbirinden ayıran, kullandıkları yöntemlerdir (Çelebi, 2004: 140). Buraya kadar yapılan açıklamalardan bilimsel bilgi üretmede seçilen yöntemin önemi ortaya çıkmaktadır. Burada yöntem, belirlenmiş bir hedefe doğru yürüme ya da hedefe doğru uzanan yol anlamında kullanılmaktadır. Yöntembilim ise, zihnin olaylar üzerinde, nesnel doğrulara veya yasalara ulaşmak için harcadığı düşünme faaliyetini ifade eder. Şu halde bilimsel yöntem, doğa, toplum, birey hakkında doğru betimleme ve açıklama yapabilme hedefine ulaşabilmek için bilim adamının yürüdü- 
ğü/yürüyeceği yolda harcadığı/harcayacağı her türlü çabayı belirleyen kurallar topluluğu olarak tanımlanabilir. Bilimsel yöntem, bir yönü ile zihinsel, bir yönü ile eylemsel bir süreçtir. Zihinsel yönü, aklın işleyiş kuralları ve akıl yürütme ile ilgisinden; eylemsel yönü ise bilimsel araştırmaların uyguladığı kurallar topluluğu olmasından kaynaklanır. İki süreç, birbirini tamamlayan ana unsurdur. Yöntem, bilimsel faaliyetin, eksiksiz bir şekilde yerine getirilmesini sağlar. Bilim, gerçeğin bütün açıklığıyla doğru bir biçimde ifade edilmesini gerektirir. Doğruları ifade etmek ise, bilimin, konu edindiği obje (doğa, toplum, birey) üzerine bilim adamı tarafından yapılan betimleme ve açıklamaların örtüşmesi sayesinde gerçekleşir. İşte yöntem, bilim adamının hedefine ulaşabilmesi için objeye nereden ve nasıl bakması gerektiğini, nerede, ne zaman ve ne yaparsa objeyi tam olarak betimleyip açıklayabileceğini, objelerin genel-ortak niteliklerini (nedensellik bağı, olasılık, belirsizlik gibi), objeye yaklaşırken zihinsel tutumun ne olması gerektiğini öğreten, açıklayan kurallar topluluğudur (Çelebi, 2004: 131-132).

Yöntem kavramı, başka anlamlarda da kullanılmaktadır: Aklın işleyiş kuralları, akıl yürütme biçimleri, yaklaşım, kuram, araştırma tekniği... Aklın işleyiş kuralları ile akıl yürütme biçimleri, zihinsel bir tutum olarak yöntem ile sıkı bir bağlantı içerisindedir. Akın işleyiş kurallarını konu edinen bilim dalı mantıktır. Farklı mantıkların aklın işleyiş kuralları üzerine getirdiği betimlemeler, bilim adamının yöneldiği objenin doğasına uygun biçimde düşündüğünü ortaya koyar (Çelebi, 2004: 132-133). Akıl yürütme, bilimsel yöntemin zihinsel yanının temelidir. Bilim adamının, objesini tanımlama ve açıklamada ona nasıl yaklaşabileceği, hangi akıl yürütme biçimini kullandığı ile yakından ilgilidir. Seçilen akıl yürütme biçimi kullanılan yöntemi belirler. Şu halde akıl yürütme biçimleri, bize, objeye ilişkin bilgi üretebilmek için bilim adamının zihninin hangi yol doğrultusunda çalışması gerektiğini öğretir. Bu yolların bazıları tümevarım, tümdengelim, hipotetik-dedüktif vb.dir. Ancak bilinmelidir ki bu yollar, öncelikle akıl yürütme biçimidir, yöntem değildir. Ayrıca bunlar zihinsel süreçlere işaret eder. Zihindeki bu süreçler bilim adamının uyması gereken kurallarla birleşirse ancak o zaman yöntem anlamını ifade edebilir. Çünkü yöntem salt zihinsel değil, aynı zamanda eylemsel bir süreçtir (Çelebi, 2004: 133-134).

\section{Sosyal Bilimlerde Yöntem}

Sosyal bilimlerde dört araştırma yönteminden söz edilebilir: Deneysel psikolojide ve kısmen sosyal psikolojide kullanılan laboratuar deneyi; sosyolojide ve bütün diğer sosyal bilimlerde kullanılan survey (saha taraması); sosyal antropolojide, etnografyada ve özellikle son otuz yıla yakın bir zamandan beri sosyolojide (hatta sözel tarih çalışmalarında, kültür incelemelerinde, tarihte ve siyaset biliminde) kullanılan saha çalışması; tarih araştırmalarında, sosyolojide, siyaset biliminde vb. sosyal bilim dallarında kullanılan tarihsel karşılaştırma yöntemi. Son zamanlarda bu araştırma yöntemlerinin ilk ikisine Nicel Araştırma Yöntemi denirken, son ikisine Nitel Araştırma Yöntemi denilmektedir (Dikeçligil, 2002: 97-126). 
Nicel olarak isimlendirilen araştırma geleneği içinde birçok farklı teknik kullanılmaktadır (deney, gözlem, survey vb.). Ancak sosyal bilimlerde en yaygın kullanılan teknik, surveydir. Survey tekniğinin tarihçesi, 19. yüzyıla kadar geri götürülebilir. Bu teknik, Avrupa'da tasarlanmış ve doğmuş olmasına rağmen, Amerika'da gelişmiş̧ir (Kuş, 2003: 38-39). 20. yüzyılın başlarında Charles Booth'un çok sayıda katılımcı ile gerçekleştirdiği kamuoyu araştırmalarından ( $A$ Survey of London Life and Labour, 1889) etkilenen Jane Adams, Hull House projesini Chicago' da başlatmıştır (Mayring, 2000: 6). Modern survey metotlarının kökleri, surveyin üç temel yönünün geliştirildiği ve rafine edildiği 1930'lara dayanmaktadır: Örnekleme teknikleri, veri toplama teknikleri ve veri analizi için istatistik metotlar. 1930'lardan 1950'lere kadar Amerika'daki üç önemli gelişme, surveyin yerini sağlamlaştırmasını derinden etkilemiştir. ABD Nüfus Sayımı Bürosunda örneklem teknikleri denenmiş, örnekleme şemaları geliştirilmiştir. Gallup ve Roper gibi pazar araştırması şirketleri, veri toplama tekniklerinin gelişiminde ve uygulanmasında aracı olmuştur. Toplum hakkındaki geçerli bilgiler için büyük oranda talep olmuş, bu talepler, tutumları ve fikirleri ölçmek için standart araçlara ihtiyaç duyulmasına yol açmıştır. Thurston, Likert, Guttman, Cantril ve Stevens gibi sosyal psikoloji ve psikometri öncüleri, bu ihtiyaca cevap veren bilimsel ölçüm teknikleri ve ölçekler geliştirmişlerdir (Kuş, 2003: 38-39). Surveyler, İkinci Dünya Savaşı'ndan sonra Avrupa'da yaygınlaşmaya başlamış; birçok ülkede pazar araştırması şirketi kurulmuş ve ilk defa örnekleme dayalı görüşmeler yapılmıştır. Avrupa üniversitelerinde 1960'lı yıllardan itibaren survey görüşmesi ile metodolojik araştırma başlamıs ve 1970'lerin ortalarına kadar bu teknikler hızla geliştirilmiştir.

Sosyal bilimlerde pozitivizmin alternatifi olarak günümüzde rağbet görmeye başlayan anlamacı yaklaşımın kökleri de 19. yüzyıla dayanmaktadır. Weber'in "anlayıı" sosyolojisi, bu tekniğe önemli bir karşı çıkışın ilk adımı olmuştu. Weber'in sosyolojisinin temelini, insanların davranışlarının objektif anlamlarının, kendi davranışına verdiği subjektif anlamdan farklı olabileceği, dolayısıyla bu subjektif anlamın ortaya çıkarılabilmesi için değişik ve derinlemesine analizlere başvurulması oluşturuyordu. Şu halde bireyi anlamak, ilk yöntemsel adım oluyordu. "Anlama", Weber için 'eylem tipleri yani ideal tipin oluşturulması yoluyla inşa edilen sosyolojik bilgi aracı' konumuna yükselmiş oluyordu. Fakat Almanya'da savaş sonrasında sosyoloji alanında metodolojik gerginlikler ortaya çıkınca Köln Sosyal Araştırmalar Enstitüsü, Renè König yönetiminde sosyal araştırmaların nicel temellerini sistemleştirdi ve geliştirdi. Bu araştırmaların temel araçları deney, görüşme, anket ve istatistiksel analiz idi (Kuş, 2003: 40).

Nitel bilgi eğilimi, 20. yüzyılın üçüncü çeyreğinde sosyal bilimlerde çok derin değişiklikler meydana getirdi. Son yıllarda değişik araştırma alanlarında nicel yaklaşımlar tek başına yeterli olmaktan çıkmış gibi görünmektedir. Nitel yaklaşım, 1970'li yıllardan beri Almanya'da bir hayli güçlenmiştir. Bu yaklaşım, önce sosyolojide, daha sonra eğitim bilimlerinde tercih edilmiştir (Mayring, 2000: 2). 
Nitel yaklaşıma yönelmede özellikle şu ortak eleştiri rol oynamıştır: Ölçekler, testler gibi standartlaştırılmış araçlarla yapılan araştırmalar, "kişilere" söz hakkı tanımamaktadır. Araştırma, insana sunulan seçeneklere verilen cevaplara indirgenmektedir. Buna karşılık alan araştırması geleneği, sosyal olay ve olguları, standartlaştırılmamış gözlemlerle ve açık uçlu anketlerle, günlük sosyal yaşamın doğallığı içinde anlamaya çalışmaktadır. Ayrıca nitel sosyal araştırmaların, disiplinler arası yeni girişimlere de (biyografi araştırmaları, yorumsal paradigma, kadın araştırmaları, eleştirel psikoloji vb.) zemin hazırladığı ifade edilmektedir. Özellikle Amerika'da Behaviorizm'in, psikolojinin etkili bir dalı olmasından sonra Avrupa ve Avrupa dışındaki ülkeleri de saran "Amerikanlaşma" dalgası, 1950'li ve 1960 'lı yıllarda Almanca konuşulan ülkelerdeki psikoloji araştırmalarını da etkileyince, nicel yaklaşım ile deneysel-keşifçi-sezgisel-bütünsel yaklaşım arasında şiddetli bir yöntem tartışması ortaya çıktı ve bu tartışma halen hüküm sürmektedir (Mayring, 2000: 7).

\section{Sosyolojik Kuram}

Sosyoloji'de kuramsal bakış açıları dört bakımdan birbirinden ayrılabilir (Wallace ve Wolf, 2002: 21-25):

Ele aldıkları konular itibariyle makro ve mikro sosyolojiye ağılık verenler: Bunlardan birincisi toplumsal yapıya ağılık verenler olup, İşlevselcilik ve Çatışma kuramları bunu benimser. İkincisi bireylerin algılamalarına ve aralarındaki etkileşime ağırlık verenler olup, Sembolik Etkileşimcilik ve Etnometodoloji kuramları bunun örnekleridir.

Kuramlar önceden kabul ettikleri temel önermelere göre birbirinden ayrılabilir. Bu temel kabullerden birincisi, insan davranışının (bazı toplumsal süreçlerden ve yapılardan etkilenmesi dolayısıyla) önceden belirlenebilmesi, dolayısıyla önceden bilinebilmesidir. İkincisi, insanların davranışları üzerinde (her ne kadar toplumsal süreçler ve yapıların etkisi olsa da) insanın yaratıcılı̆ı̆ın daha fazla etkiye sahip olduğunu kabul eder. Burada kuramlar açıkça birbirinden ayrılmaz. Her birinin diğeri üzerinde farklı vurgulara sahip olduğu söylenebilir.

Kuramların birbirinden ayrıldıkları üçüncü nokta araştırma yöntemleridir. Bu konuda iki yaklaşımdan sözedilebilir. Birincisi tümdengelim yaklaşımıdır ki İ̧̧levselcilik, Çatışma (Frankfurt Okulu hariç) ve Alışveriş kuramları bu (nicel) yaklaşımı benimsemektedir. İkincisi tümevarımdır ve Sembolik Etkileşimcilik ve Etnometodoloji bu (nitel) yaklaşımı benimsemektedir.

Sosyolojik kuramları birbirinden ayıran dördüncü nokta amaçlarıdır. Amaçlar ikiye ayrılır. Birinciler eşyayı ve olayları tarif etmeyi amaçlayanlardır. İkinciler eşya ve olayların aralarındaki ilişkileri açıklama, hatta önceden tahmin etmeyi amaçlayanlardır. Esasen toplumsal bilimler, eşya ve olaylara farklı bir perspektiften bakarak, onları çeşitli açılardan tarif ederek, kavramlar oluşturarak, eşya ve olaylar arasında ilişkiler kurarak bu ilişkileri hem açıklamaya hem de anlamaya çalışırlar. Şüphesiz bu araştırmalar, insanın toplum anlayışını önemli ölçüde 
geliştirdiği gibi, önceden tahmin yürütmesini de mümkün hale getirir. Bu anlamda Sembolik Etkileşimcilik ve Etnometodoloji en fazla ağırlığı anlamaya (nitel yaklaşıma) vermiştir. Böylece onlar, genel yasalara itibar etmeyerek bireyi ön plana çıkarmaya çalışmaktadır. İ̧̧levselcilik, Çatışma ve Alışveriş kuramları, olayları daha genel ilkeler bağlamında açıklama (nicel yaklaşım) amacındadır. Bunlardan işlevselcilik, toplumu bir sistem olarak tarif etmeye daha yakındır, fakat genel ilkelerle toplumu açıklamaya da ağılık verir. Çatışmacılar açıklamayla daha fazla ilgilenir, fakat tahminlere de yer verir. Alışveriş kuramı, tarifle en az, açıklama ve tahminle ise en çok ilgilenen bakış açısıdır (Wallace ve Wolf, 2002: 22-23, 65-66; Stinchcombe, 1968: 15vd.).

Görülüyor ki toplumsal kuramların bakış açıları, modeller, yaklaşımlar, yöntemler, teknikler, amaçlar ve öncelikleri açısından birbirinden oldukça farklıdır. Şu halde, bu kadar farklı kuram, yaklaşım, yöntem, teknik ve model arasında yolumuzu nasıl bulabiliriz?

\section{Paradigmaların Farklı Sayıltıları}

Dikeçligil; "bilim, görünürdeki benzerlik ve farklılıklar arasındaki karmaşık etkileşimlerin arkasındaki değişmeyen benzerlikler ve etkileşimlere soyutlama yoluyla ulaşmaya çalışır... Bütün bunlar, sosyal bilimlerde bilim adamları topluluğunca benimsenmiş bir bilim anlayışının (paradigmanın) bilim mantığının (metodolojinin) üzerinde kurulan süreçlerle (yöntemlerle) gerçekleşir. Şu halde sosyal bilimlerde tek bir bilim anlayışı ve metodolojisinden söz etmek mümkün değildir" demektedir (Dikeçligil, 2002: 103). Dikeçligil'e göre her iki yaklaşım farklı paradigmalara dayanmaktadır. Bu sebeple her iki paradigmaya yöneltilen eleştiriler sonucu ortaya çıkan ve metotlar arası işbirliğini savunan, "çok katı yöntemler", "çoklu yöntem araştırması" gibi isimler alan bütüncü bir anlayıştan söz edilebilir (Dikeçligil, 2002: 98-99). Farklı paradigmaların varlığı bir kez kabul edildiğinde, tercihimiz hangisi yönünde olursa olsun, farklı sosyolojilerin ve farklı metodolojilerin varlı̆ı̆ı görmezden gelemeyiz. Her bir paradigmanın ontolojik, epistemolojik sayıltılarıyla içiçe geçmiş olan metodolojik sayıltıları vardır. Bu metodolojik referans noktaları, diğerleri ile olan iç bağıntıları inmal edilmeksizin, o sosyal bilim anlayışının metodolojisini oluşturur. Yöntem, bilimsel bilgi elde etme sürecinde araştırmacının olgu ile doğrudan karşı karşıya geldiği safhada nasıl bir yol izleyeceğinin ifadesidir. Bu konuda çok sayıda teori vardır. Farklı teoriler farklı metodolojik yaklaşımları kapsar. Esasen metodolojik ilkeler, bilim anlayışını ortaya koyan paradigmadan farklı bir safha değil, paradigmanın diğer sayıltıları (ontolojik, epistemolojik) ile sıkı sıkıya ilişki halindeki metodolojik sayıtlılardır (Dikeçligil, 2002: 104-105).

Dikeçligil'in (2002: 110-111), Williams (1990: 31-53), Dikeçligil (1993: 45), Erkilet Başer (1995: 18-20) ve Özlem (1998: 10-14)'den yararlanarak oluşturduğu "iki ana sosyolojik paradigmanın temel sayıltıları" isimli tablodaki bazı bilgileri burada hatırlatmak istiyoruz. 


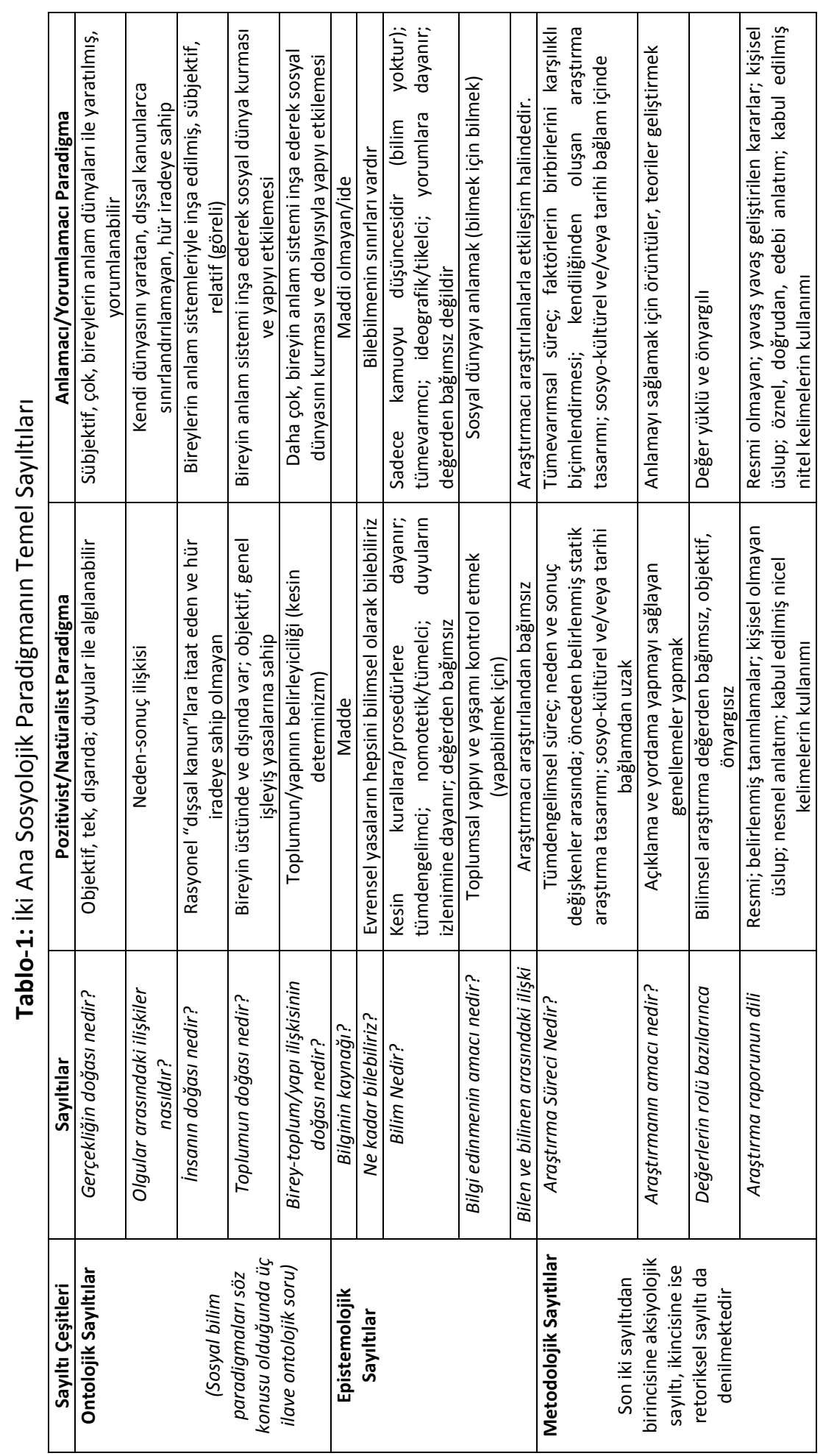


Tabloda görüldüğü gibi potizitivist/natüralist paradigma ile anlama$\mathrm{cı}$ yorumlamacı paradigmanın temel sayıtıları birbirinden farklıdır. Bu iki ana sosyolojik paradigmanın daha iyi anlaşılabilmesi için nicel ve nitel araştırma yaklaşımını çeşitli açılardan karşılaştırmak yararlı olabilir. Bu çerçevede nicel ve nitel araştırma yaklaşımı arasındaki belli başlı farklar şöyle sıralanabilir:

(1) Nicel araştırmalarda gerçek nesneldir. Nitel araştırmalarda ise gerçek oluşturulur.

(2) Nicel araştırmalarda asıl olan yöntemdir. Nitel araştırmalarda ise asıl olan çalışılan durumdur.

(3) Nicel araştırmalarda önceden belirlenmiş hipotezler test edilir. Nitel araştırmalarda ise davranış ve olayların anlamını ortaya çıkarmak için çaba sarf edilir.

(4) Nicel araştırmalarda kavramlar, farklı değişkenler haline getirilir (bağımlı ve bağımsız değişken) ve bunlar arasındaki ilişkiler ölçülebilir. Nitel araştırmalarda ise değişkenler karmaşık ve iç içe geçmiştir ve bunlar arasındaki ilişkileri ölçmek zordur.

(5) Nicel araştırmalarda sonuçlar, kesin ölçümlerden elde edilmiş verilerin (rakamların) yorumlanmasıyla ortaya çıkar. Nitel araştırmalarda ise sonuçlar, gözlem ve belgeler yoluyla elde edilen verilerin anlamlandırılmasından ibarettir.

(6) Nicel araştırmalarda kuram, büyük ölçüde tümdengelim esasına dayanır ve nedensellik ilişkisini açıklamak amaçlanır. Nitel araştırmalarda kuram, tümevarım esasına dayanır ve sosyal aktörlerin perspektiflerini anlamak amaçlanır.

(7) Nicel araştırmalarda standardize edilmiş veri toplama araçları kullanıIır (Nesnellik). Nitel araştırmalarda ise araştırmacının kendisi veri toplama aracıdır (Öznellik).

(8) Nicel araştırmalarda izlenen yollar standarttır ve tekrarlanması mümkündür. Nitel araştırmalarda ise izlenen yollar özgündür, tekrarlanabilme ihtimali çok zayıftır.

(9) Nicel araştırmalarda çözümlemeler, istatistik teknikler, tablolar ve şekiller kullanılarak, hipotezlerle ilgili sonuçların ortaya çıkıp çıkmadığı tartışılarak yapılır. Nitel araştırmalarda ise araştırılan konulardan elde edilen kanıtlar yorumlanır.

(10) Nicel araştırmalarda pozitivist bakış açısı hakimdir. Nitel araştırmalarda ise yorumlayıcı bakış açısı hakimdir (bilginin empirik olmayıp deneyüstü ve aşkın olduğu kabul edilen).

(11) Nicel araştırmalarda sonuçlar genelleştirilebilir ve gerekçesi verilebilir. Nitel araştırmalarda ise sonuçların genelleştirilmesi daha zordur, en azından her bir tekil olay için mümkündür ve gerekçesi verilebilir. 
(12) Nicel araştırmalarda örneklem grubunun evreni hiçbir zaman tam olarak yansıtamayacağı söylenir. Nitel araştırmalarda ise örneklem daha az sayıda olduğu için evreni temsil kabiliyeti daha zayıf olacaktır.

(13) Nicel araştırmalarda konu-büyük grup merkezli yönelim geçerlidir. Nitel araştırmalarda ise sorun-küçük grup ya da sapma-küçük grup merkezli yönelim geçerlidir.

(14) Nicel araştırmalarda yöntem kontrolü (işlemlerin açıkça ortaya konması, yani gidişin açık oluşu, araştırma sürecinin her adımının açıkça tanımlanması, her basamağın izah edilip belgelenmesi; izlenen kuralların gerekçelerinin verilmesi, yöntemsel kontrollü işleyiş kuralarına bağııık, işleyişin garantisi, prosedürün açık kurallara bağlanması ve gerekçelerinin aktarılması) mümkündür ve kolaydır. Nitel araştırmalarda ise yöntem kontrolü pek kolay değildir.

(15) Nicel araştırmalarda bireyin bazı toplumsal süreçlerin ve faktörlerin etkisi altında ve yasalara göre davranışlarını gerçekleştirdiği kabul edilir. Nitel araştırmalarda ise bireylerinin davranışlarının bir düzeni olmakla birlikte, bu düzenin, genel toplumsal süreçlerin değil, günlük hayatın çeşitli yansımalarının etkisi altında kalabileceği, hatta insanın çoğu zaman bu etkilerin bile dışına çıkabileceği kabul edilir.

(16) Nicel araştırmalarda karşılaştırmalar yapmak mümkündür. Nitel araştırmalarda ise karşılaştırmalar yapmak pek kolay değildir.

(17) Nicel araştırmalarda geleceğe yönelik tahminler yapmak mümkündür. Nitel araştırmalarda ise geleceğe yönelik tahminler yapmak mümkün değildir, en azından çok zordur.

(18) Nicel araştırmalarda araştırmacı sosyal olay ve olguların dışında tarafsız ve nesneldir. Nitel araştırmalarda ise araştırmacı sosyal olay ve olguların içindedir, empati kurmaya çalışır ve perspektifi özneldir.

\section{Sonuç}

Sosyolojik araştırmalarda kullanılacak metodoloji ve teknikler araştırmanın desenine göre belirlenir. Araştırma konusunun gerektirdiği şekilde bir metodolojik seçim yapılırken, aynı zamanda birden çok araştırma tekniğinin kullanımı da mümkün olabilir. Toplumbilim araştırmalarında metodolojiler birbirini dışlamaktan çok, birbirini tamamlar niteliktedir. Sosyolojik araştırmalar, çalışmanın amaç ve niteliğine göre açıklayıcı, betimsel veya anlayıcı/keşfedici araştırmalar olarak sınıflandırılabileceği gibi (Özcan ve Özbey, 2002: 71), yaklaşım farklarını dikkate alarak nicel veya nitel metodolojik yaklaşımlar olarak da değerlendirilebilir. Açıklayıcı bir yaklaşım olarak nicel metodolojik yaklaşımda, istatistiksel ölçek, analiz ve açıklama öne çıkmaktadır. Burada, doğa bilimlerinin sebepsonuç ilişkisine dayalı açıklama yaklaşımının da izleri görülmektedir. Nicel yaklaşımda, çalışmanın hipotezi oluşturulur, değişkenler belirlenir ve nedensellik 
içeren tahminlerde bulunulur, genellemelere gidilir. Nitel yaklaşımda ise, nesnel gerçekliğin yerini, oluşturulan nesnellik alır. Nitel çalışmalarda yöntemden çok çalışılan durum öne çıkarken; genellemeler yerine derinlemesine betimlemeler ve araştırılan konunun niteliğine bağı ılarak yorumlar söz konusu olur. Nitel yaklaşımda, empatik nitelik önemli bir yere sahiptir. Buna karşın, nicel yaklaşımda yasalar ve genel-geçerlik daha çok yer almaktadır. Bu nedenle, bir sosyolojik araştırma metodolojisi olarak nicel yaklaşım, nitel yaklaşımla birlikte ortaya çıkan subjektiflik sorununa karşı daha nesnel görünmektedir. Aynı şekilde nicel yaklaşım, sosyolojik olgusalıkları belirlemesi, izlenebilirlik ve ölçülebilirlik gibi yönleriyle nitel yaklaşımdan ayrılmaktadır. Nitel yaklaşımda bir başka sorun da araştırmacının sosyal gerçeklikleri anlayabilme yeteneğinin araştırma üzerinde çok etkili olabilmesidir. Buna karşın nicel yaklaşımda, daha çok izlenebilir ve ölçülebilir bilgiler ve bulgular yer almaktadır. Anlayıcı bir yaklaşım olarak Nitel yaklaşım ise, sosyal olayların ve grupların sosyal ve kültürel örgüt yapılarının anlaşılmasında önemli bir yere sahiptir. Burada, sosyal gerçekliğe görüşme ve gözlem yoluyla bir katılım söz konusudur ve bu yolla sosyal gerçeklik anlaşılmaya çalışılmaktadır. Böylece, nicel yaklaşımın dışarıda bırakan sınırlayıcı tutumundan kaynaklanan sorunlar da aşılabilmektedir. Buradan da anlaşılacağı üzere, sosyolojik çalışmalarda dengeli ve araştırma desenine uygun bir metodolojik kullanım, çalışmanın başarısı açısından önemli bir etkiye sahiptir.

\section{Notlar}

$\left(^{*}\right) \quad$ Prof. Dr., Ankara Üniversitesi İlahiyat Fakültesi, e-posta: nakyuz06@hotmail.com

$\left.{ }^{* *}\right)$ Doç. Dr., Atatürk Üniversitesi Illahiyat Fakültesi, e-posta: sahingursoy@yahoo.com

$(* * *)$ Dr., Ankara Üniversitesi Illahiyat Fakültesi, ihsancapcioglu@yahoo.com

\section{Kaynaklar}

Başer, A. Erkilet, "Bilge Bir Sosyolog: Pitirim A. Sorokin'in Tarih Felsefesi", Tarih Çevresi, S. 18, Eylül-Ekim 1995.

Bay, B. ve J. D. Moon, 'What Would an Adequate Philsophy of Social Science Look Like?', Philosophy of Social Sciences, 7, 1977.

Borg, W. R. ve M. D. Gall, Educational Research, 4th Edition, New York, 1983.

Cole, S., Sociological Method, Rand Mc. Nally College Publishing Company, Chicago, 1972.

Çelebi, N., "Metodolojik Sorunlara Bir Bakış", Sosyoloji ve Metodoloji Yazıları, Anı Yayıncılık, Ankara, 2004.

Dikeçligil, B., "Batı'da Değişen Bilim Anlayışı ve Türkiye'de Sosyal Araştırmalar", Mahmut Tezcan ve Nilgün Çelebi (Hazl.), Sosyolojide Son Gelişmeler ve Türkiye'deki Etkileri, UNESCO Türkiye Milli Komisyonu, Ankara, 1993.

Dikeçligil, B., "Sosyolojide Metodolojik Farklılaşma ve Metotlar Arası İşbirliği", III. Ulusal Sosyoloji Kongresi Dünyada ve Türkiye'de Farklılaşma Çatışma ve Bütünleşme-II, Sosyoloji Derneği Yayınları, Ankara, 2002, 97-127.

Gökçe, B., Toplumsal Bilimlerde Araştırma, Savaş Yayınları, Ankara. 1992.

Keat, R. ve J. Urry, Bilim Olarak Sosyal Teori, çev. N. Çelebi, İmge Kitabevi, Ankara, 1994.

Kuş, E., Nicel-Nitel Araştırma Teknikleri, Anı Yayıncılık, Ankara, 2003. 
Mayring, P., Nitel Sosyal Araştırmaya Giriş, çev. A. Gümüş, M. S. Durgun, Baki Kitapevi, Adana, 2000.

Özcan, Y. Z. ve Ö. Özbey, "Sosyolojide Yöntem”, der. İhsan Sezal, Sosyolojiye Giriş, Ankara, 2002.

Özlem, D., “Doğa Bilimleri ve 'Sosyal Bilimler' Ayırımının Dünü ve Bugünü Üzerine”, Toplum ve Bilim, S. 76, Bahar 1998.

Özlem, D., Max Weber'de Bilim ve Sosyoloji, Ara Yayıncılık, İstanbul, 1990.

Stinchcombe, A. L., Constructing Social Theories, Harcourt, Brace and World, Inc., New York, 1968.

Trigg, R., Sosyal Bilimleri Anlamak, çev. B. Sümer ve F. Ülgüt, Babil Yayınları, Ankara 2001. Wallace, R. A. ve A. Wolf, Çağdaş Sosyoloji Kuramları, çev. L. Elburuz, M. R. Ayas, Punto Yayıncılık, İzmir, 2002.

Weber, M., Toplumsal ve Ekonomik Örgütlenme Kuramı, çev. Ö. Ozankaya, İmge Kitabevi, Ankara, 1995.

Williams, R., "From Cognitive Style to Substantive Content: Programmatics and Pragmatics in the Development of Sociological Knowledge", C. G. A. Bryant ve H. A. Becker (eds.), What Has Sociology Achieved?, St. Martin's Press, New York, 1990.

Yıldırım, A. ve H. Şimşek, Sosyal Bilimlerde Nitel Araştırma Yöntemleri, Seçkin Yayınevi, Ankara, 1999. 



\title{
TÜRK TOPLUMBILLIMINDE KURAM SORUNU: TOPLUMSAL EYLEMIN ARKAPLANI
}

\begin{abstract}
Problems of theory in Turkish sociology: Background of social action. Problems in regard to theory are among the most significant and major issues in social sciences. It seems very difficult to solve these problems due to unique conditions of social sciences. However, there are several suggestions in regard to these problems. Social domain can be regarded as the sea. Those on the shore produce various descriptions about the sea. Such descriptions are combined to other descriptions on the sea produced by those who swim and travel through the sea. Nevertheless, such knowledge are not complete about the current and future state about the sea and those in the sea. Social domain, like the sea, can be analysed and its general framework can be developed depending on our knowledge, experience and understanding. This article deals with the problem of theory in Turkish sociology and understanding of social action.
\end{abstract}

\section{key words}

Turkish sociology, social action, theory, method. 


\section{Türk Toplumbiliminde Kuram Sorunu: Toplumsal Eylemin}

Arkaplanı

Kuram sorunu toplum bilimlerinin en önemli ve önde gelen konulardan biridir. Toplum bilimlerinin kendine özgü şartlarına bağlı olarak bu konuda mutlak çözüme ulaşmak zor görünmektedir. Ancak edinilen bilgi, tecrübe ve kavrayış çerçevesinde görüşler ileri sürülebilmektedir. Toplumsal alan tıpkı bir deniz gibidir. Denizin sahilinde bulunanlar onun dış görüntüsüne bakarak tasvirlerde bulunmaktadırlar. Denize dalarak ve çeşitli araçlarla onun içinde ya da üzerinde seyahat ederek hakkında bilgi edinenler sahilde gördükleriyle bu tecrübelerini birleştirmekte ve deniz hakkında bilgi vermektedirler. Ne var ki bu bilgiler denizin ve içindekilerin mevcut durumda ve gelecekteki hallerine ilişkin tüm bilgiler değildir. Toplumsal alan da tıpkı deniz gibi bilgi ve tecrübelerimiz, kavrayışımız çerçevesinde çözümlenebilmekte, ona ilişkin genel çerçeveler çizilebilmektedir.

Biz bu makalede Türk toplumbiliminde kuram sorununu toplumsal eylemin anlaşılması bağlamında genel çerçeveleriyle ele almaya çalıştık. Konuya girmeden önce Türk toplumbilimi nitelemesi üzerinde açıklamada bulunup, bu açıklamaları temellendirmeye çalıştık. Bu makalede serdedilen görüşlerin mutlak olarak değerlendirilmemesi, ilave ve çıkarmaların da yapılabileceği gerçeğini unutmamak gerekir. Burada ele alınan görüşler toplumsal eylemin arka planını anlama bağlamında genel çerçeveye işaret etmektedir.

\section{“Türk Toplumbilimi” Nitelemesi Üzerine Bazı Gerekli Açıklamalar}

Türk toplumbilimi, genel toplum bilim içinde "özel bir toplum bilime" işaret etmektedir. Burada Türk toplumbilimi(Türk sosyolojisi) ifadesinin kullanımı bir ilk değildir. Ayrıca bu tür bir adlandırma, ne duygusal ve biçimsel bir yaklaşımdan ne de bilimi etnik bir çerçeveye hapsederek örgüleme ya da düzenleme düşüncesinden hareketle polemiklerin yaratacağı kargaşa ortamında ciddi problemlerimizi buharlaştırma girişimidir. Bizatihi batıda olduğu gibi(Fransız, Alman sosyolojisi) adını toplumun kendisinden ve gerçekliklerinden alan bir adlandırmadır. Nitekim Türkiye'de toplumbilimin kurucusu olan Gökalp'in dilinde "milli sosyoloji", sosyolojimizin gelişmesine önemli katkılarda bulunan Fındıkoğlu'nun ifadesiyle taklitten kurtulmuş bir "Türk sosyolojisi" nitelemesiyle toplumumuza ait bir toplumbilim kavramsallaştırılmasına bilim tarihimiz şahitlik etmektedir.

Türk Toplumbilimi üzerinde başlangıçtan itibaren gösterilen bu denli ısrarın nedeni, sosyolojinin ismi gibi cisminin de batı ilmi olması ve mevcut haliyle bizim meselelerimizi çözecek bir bilim olmamasından kaynaklanmaktadır. Çünkü sosyoloji Batının bunalım ve buhran çă̆ında ortaya çıkan sorunlarına çözüm bulmak amacıyla oluşturulmuş ve sistemleştirilmiş bir bilimdir. Hâlbuki tarihte ve günümüzde yaşanan sosyal değişime paralel olarak gelişme gösteren bizim problemlerimiz batının problemlerinden farklıdır. Bu nedenle sosyolojiyi kendi 
toplumsal problemlerimizi çözecek bir bilim haline getirmek ve toplum dinamiklerimiz çerçevesinde yeniden kurmamız gerektiği ısrarla vurgulanmıştır (1).

Tuna, sosyolojinin kendi başına bir bilim olmayıp varlığını ve kimliğini içinde yer aldığı toplumun özelliklerinden ve olaylarından kazandığını belirtirken (Tuna, 2002: 96), Sezer, Türk toplumunun kendi tarihi, siyasi, sosyal, kültürel, ekonomik ve dini özelliklerine göre şekillenen olaylarını inceleme ve açıklamayı kendine konu edinen sosyoloji "Türk sosyolojisi" (Sezer, 1988: 173) olmalıdır der.

Sosyolojinin tarafsı bir bilim dalı olmadığını bilinen üslubuyla dillendiren Meriç'in (Meriç, 1999: 19) uyarısını teyit eden Tuna, etrafımızda olup biten ve bizi etkileyen olayların dünya ilişkileri boyutunda değerlendirilmesini taraf olarak yapma ihtiyacı hâsıl olduğunu, artık olayları bu dünyadaki yerimize, ilişkilerimize ve çıkarlarımıza göre değerlendirmek mecburiyetinde olduğumuzu vurgulamaktadır (Tuna, 2002: 98).

Baykan'ın toplumbilim anlayışını tahlil edip ondan mülhem olduğu anlaşılan ve haliyle aynı paralelde görüş beyan eden Kızılçelik, Türk toplumbiliminin gerekliliğini temel bir iddia olarak şu şekilde ortaya koymaktadır. "Türk toplumunun kendine özgü yapısı ve gerçekleri vardır. Türk toplum gerçeğini salt Batı'lı sosyolojik teorilere dayalı olarak açıklama imkânı yoktur. Aslında en büyük sefaletimiz, Türk toplum gerçeğini açıklayan ve kendimize özgü olan bir sosyoloji geleneği oluşturamamamızdır. Biz ebetteki Batı'lı sosyoloji teorilerinin önemini inkâr etmiyoruz. Batı'lı sosyolojik teorilerin bütün sosyologlar tarafından çok iyi bilinmesi gerekir. Çünkü Türk sosyolojisinde öne sürülmüş çoğu görüşleri anlayabilmek için Türk sosyolojisine de kaynaklık eden batı sosyolojisini bilmek gerekir. Ayrıca Batı sosyolojisi sadece kendi toplumlarının sorunlarının çözümüyle ilgili kalmaz. Batı-dışı toplumlar sözgelimi Türk toplumu için de değer yargıları ve görüşleri geliştirir. Ancak hemen belirtelim ki Batılı sosyolojik teoriler, öncelikle Batı toplum gerçeğinin bir ürünüdürler ve genellikle Batı dünya egemenliğini meşrulaştırırlar. Genel hatlarıyla Batı sosyolojisi Batının çıkarlarını gözeten bir sosyolojidir. Türk sosyologları Batı sosyolojisini bilmenin yanında, öncelikle kendi sosyoloji geleneğini inşa etmelidir. Türk toplumu ve gerçeği Batı'nınkinden farklılıklar sergilediği için, o farklılığı tanıyabilecek, anlayabilecek ve açıklayabilecek bir "Türk sosyolojisi"ne gereksinim vardır" (Kızılçelik, 2002: 299-300).

Anlaşılacağı üzere her toplumun farklı olduğu ve bu farklılıklara dayalı olarak farklı olayların meydana geldiği, dolayısıyla toplumsal çıkarların ve menfaatlerin de farklı olduğu, her toplum için sosyolojinin işlevsel bir yönünün olduğu ve bu nedenlere bağlı olarak toplumların kendilerine özgü bir toplumbilimlerinin olması gerektiği ortaya çıkmaktadır.

Türk toplumuna özgü bir toplumbilimin gerekliliği konusunda bu denli olumlu vurgular yanında, bunun nasıl olacağı konusunun kapalı olduğu ya da 
geçiştirildiği üzerine bazı eleştiriler bulunmaktadır (2). Haklılık payı bulunan bu eleştiriler, zorluklarıyla beraber zaman içersinde telafisi mümkün eksikliklerdir. Umut ediyoruz ki bu alanda gösterilen çabalar, Türk toplumbiliminin inşasında önemli aşamalar kaydettirecektir.

Türk toplumbiliminde bugün aşılması gereken sorunlardan en önemlisi ve temel olanı kuram sorunudur. Biz şimdilik bu sorunun genel çerçevesine ilişkin bazı hususlara değinecek daha sonraki yazılarımızda detaylandırmaya çalışacağız.

\section{Türk Toplumbiliminde Kuram Korunu}

Toplumsal kuram arayışı toplumbilimin ilk oluşum evrelerinden itibaren var olagelen ve hâlâ devam eden bir çabadır. Bu bağlamda tabiat bilimlerine dayanarak pozitivist bir yaklaşım çerçevesinde oluşturulan kuramlar olduğu gibi bu yaklaşıma alternatif olarak üretilen hümanist(anlamacı ya da yorumsamacı) yaklaşım çerçevesinde önerilen kuramlar da olmuştur (3). Ne var ki, bu zamana kadar ne tüm toplumbilimcileri tatmin ve cezbeden ne de toplumbilimin tüm ilgi alanlarında eksiksiz kullanılabilecek bir kuramsal model olmuştur. Bu alanda beliren çeşitlilikler insan ve toplum doğasına ilişkin farklı varsayımlardan kaynaklanmaktadır (Poloma, tarihsiz: 25).

Kuram, her hangi bir topluma ait gerçekliğe ilişkin bilginin elde edilmesinde, elde edilecek bilgiyle kendisi hakkında bilgi edinilen alanın gerçekliğinin örtüşüp örtüşmemesi ya da ne kadarıyla örtüştüğüyle ilgilidir. Kuramların biçimlendirilmesi gözlemlenebilir durumların ilişkilendirilmesiyle olmuştur (Poloma, tarihsiz: 17). Ancak bunlar da Giddens'in ifadesiyle, "dar odaklıdır ve belirli toplumsal koşulları veya oluşum türlerini açıklama girişimleridir. Genellikle araştırma sürecinin bir parçası olarak oluşturulmuş olup, daha çok araştırma yapılması gereken problemleri önerirler." (Giddens, 2000: 607).

Türkiye'de toplumbilim çalışmalarının, gerek bilginin elde edildiği alan, gerek bu alana yaklaşırken zihinde kurgulanan ilkeler, sayıtlılar bütünü olan yaklaşımlar, gerek seçilen konunun içinde kavramsallaştırıldığı kuram, gerekse o kuram ışı̆̆ında gözlemlenen olgunun bilgisini elde etme yöntemleri açısından 'batılı' sosyologların çalışmalarından esinlenerek yürütüldüğü, özgün bir bakış, kuram, yaklaşım ve yöntem anlayışımızın bulunmadığı (Çelebi, 2001: 17) tespiti bugün hâlâ geçerliliğini korumaktadır.

Türk toplumbiliminin dili kargaşa hali arz eden bir duruma getirildiği için batı sosyolojisinin kelime ve kavram hazinesinden yararlanma eğiliminin ortaya çıkması, ister istemez, sosyolojiyi Batı'dan alırken, sosyolojik meseleleri de Batılı bir gözle görme eğilimini beraberinde getirmiştir. Ne var ki bu durumda Toplumbilim, bir bilim olarak toplumların hayatı ile bu toplumları oluşturan grupları yönlendiren genel kuralları elde etme konusunda Batı toplumlarını incelemede kullanılan kuramlarla sınırlanma ve etnosentrik kalma yönünde belli bir risk 
altına girmektedir. Bu risk, özellikle genel kuralların, farklı toplumlarla ilgili ampirik çalışmalardan tümevarımsal olarak elde edilmesi yerine, araştırmacının kendi toplumundaki mevcut olan durumdan ya da araştırmacının toplumun nasıl olması gerektiğini istemesine ilişkin özel görüşlerinden ya da ideolojisinden elde edildiği durumlarda ortaya çıkmaktadır. Özellikle müslüman toplumlara sosyolojik yaklaşım daha belirgin olarak ideolojik bir eğilim göstermektedir ki, bu da araştırmacının siyasal tercihlerin ve ideolojik seçimlerin etkisi altında olmasından kaynaklanmaktadır (Waardenburg, 2002: 265-266).

Bir bilim dalı olarak ortaya çıkan toplumbilimin Türkiye gibi Batı'lı olmayan ülkelerde Batı'da oluşturulan şablonların aktarımıyla gelişmesi, yayıldığı yerlere onun kuram ve kavramlarını, yöntemlerini de beraberinde getirmiştir. Ancak kuram ve yöntemler, incelenen toplumun gerçekliklerinden bağımsız kalamazlar. Çünkü sosyal bilimlerin söz dağarcığı belirli bir sosyal gerçekliğe dayalı tek anlamlı tanımlamaların konusu olmayıp, içeriği her topluma ve bu toplumların tarihî dönemlerine ait sosyal diyalektiğe bağlı olduğundan (Arkoun, 1984: 208), kavramların anlam alanları ve sınırları değişebilmektedir. Öyleyse "bir toplumun medeniyet, kültür ve sisteminin tam olarak anlaşılması, tanımlanması ancak ve ancak o topluma, o toplumun diline özgü semantik çerçevenin, toplumsal oluşumun yakinen bilinmesi ve kavramlara yüklenilen mana ve değerlerin bu çerçeve içinde geliştirilmesi ile mümkün olabilir." (Davudoğlu, 1992: 77). Çünkü Batı'dan aktarılan sözde bilimsel yaklaşımlar öncelikle doğası itibarıyla buyurucu olmuşlardır. Bunlar daima kendi tasniflerini, tanımlarını, ayırımlarını, kavramlarını ve kuramlarını dayatmışlardır (Arkoun, 1984: 229). Oysa "toplumbilim kendi başına her yerde genel geçer bir bilim olmayıp varlığını ve kimliğini içinde yer aldığı toplumun özelliklerinden ve olaylarından almaktadır" (Tuna, 2002: 96) ve her hangi bir toplum için ortaya konulan sosyolojik kuramlarla bütün toplumları açıklamaya girişmek oldukça problemli görünmektedir. Bu nedenle bir toplumun kendine özgü tarihsel durumunu açıklamak için geliştirilmiş bazı kavram ve kuramları, 'şema' ve 'sistem'leri, bir başka toplum için aynen uygulamaya kalkışmak, 'yanlış bir kavram realizmi'ne ve dolayısıyla yanlış bir toplumbilime yol açacaktır (Özlem, 1999: 335).

Türk toplumunun sosyal meseleleri batının meselelerinden farklıdır. Bu nedenle toplumbilimcilerimizin bizim toplumsal meselelerimize, kültürümüzün değerlerini dikkate alarak bakmaları gerekmektedir." (Bilgiseven, 1995: 20-21). Aksi halde bir toplumun toplumbilim açısından incelenmesinde o toplumun gerçekliğini oluşturan bütünlük kavramına ya da kavramlarına doğrudan doğruya bağlanmadan elde edilen somut veriler, koleksiyon yapılmış gibi toplanmış bilgiler olmaktan öte bir anlam taşımayacaklardır (Ergun, 1993: 48). Yamalama türü bir model oluşturmanın olumsuzluklarını gidermede azami gayret gösterilse de ödünç olan hangi kuram, yöntem ve kavram alınırsa alınsın, bir türlü kurtulmak mümkün olmayan belirsiz ve aynı zamanda sosyal bilimlerde tehlikeli olan kavramların özündeki zorluklardan kaçınılamaz (Arkoun, 1984: 206). 
Öyleyse geriye kendi toplumumuzun var oluşsal özelliklerine göre oluşturulacak bir kuram arayışını sürdürmek gerekmektedir. Her topluma uygun genel geçer bir model olmadığına göre, hatta aynı toplumun farklı dönemleri için bile oluşturulan modelin yeterli olamayacağı sözkonusu ise, incelenen toplumsal gerçekliğe uygun ya da o gerçekliği en az eksiklikle anlamayı ve açıklamayı sağlayıcı bir kuramsal çerçevenin oluşturulması önem taşır. Bu duruma bağlı olarak Türk toplumu üzerine yapılan toplum bilim araştırmalarında başka toplumlara ait ya da genel geçer olarak kabullenilen kuramlardan hareketle yaklaşım içersinde bulunmak, toplum gerçekliğine aykırı ya da yanlış çözümlemelere götürecektir.

Sosyolojik araştırmalarda kuram oluşturma ya da mevcut kuramı geliştirme, yapılan araştırmalardan kazanılan bilgilerin ışı̆̆ında olmaktadır. Kuramlar sabit ve donuk ya da genel geçer çerçeveler değildir. Kuramlar "tarihsel ve toplumsal evrimin gerekli sonucu olarak bilimlerdeki evrimlere göre değişiklik arz ederler. Bu değişme durumu onların geçici olduklarını göstermekle birlikte, ilgili sosyal gerçekliği açıklamaya yardımcı olmalarına ve geçici kesinlik taşımalarına engel teşkil etmez (Ergun, 1982: 54). Kuramların toplumsal ve tarihsel gelişme, değişme ve dönüşümlere göre değişmesi, bütün toplumlar için hatta aynı toplumda sürekli olarak genel geçer bir kuramdan söz etmemizin mümkün olamayacağını göstermektedir. Öyleyse hem incelenen toplumun sosyal gerçekliğine uygun bir kuram oluşturmak hem de bu sosyal gerçekliğin farklı dönemlerdeki değişimine göre mevcut olan kuramı geliştirmek zaruri görünmektedir.

Kuramlar boşlukta doğmayıp belirgin ve bilinen bir felsefi geleneğe dayanırlar (Çiftçi, 2003: 8). Kuramların dayanmış olduğu felsefi düşünceler sosyal bilimcinin hem bakış açısını belirlemekte hem de bu bakış açısına göre şekillenen yöntemi, verileri toplama yollarını, tekniklerini ve kuramsal formülasyonları yönlendirmektedir (Bodur, 2005: 76). Trigg'in ifadesiyle "yaptığımız gözlemleri ve onları sınıflandırma yöntemimizi belirleyen şey, kuramın bizzat kendisidir." (Trigg, 2005). Bu duruma bağlı olarak kuram ile yöntem birbirinden kopmayan ve aralarında kopmayacak türden bir ilişki olan, sosyolojik bilginin elde edilmesinde kendilerine dayanılan iki temel olmaktadır. Bu nedenle sosyolojide kuramla araştırma (yöntem) arasındaki ilişkileri düzenlemek bilim adamının ilk çabası olarak görülmektedir (Ergun, 1982: 54). Bunlardan birinde gözlemlenecek zaafiyet ya da eksiklik diğerinin gelişmesine etkili olacağından her birinin diğerini destekleyici mahiyette olması gerekecektir.

Genel toplum bilim içinde Türk toplum biliminde belirli bir kuramın oluşturulamaması yöntemin de yokluğunu getirdiğinden her iki alanda ödünç ve aktarma ya da uyarlama türünden kuram ve yöntemler kullanılmakta, bunlar da araştırma alanı ile uyumsuzluk arz ettiğinden, topluma ait elde edilen bilgiyi problemli kılmaktadır. Bu durum, başlangıçtan günümüze toplum bilim alanında oluşturulan kuramların -kendi toplumumuz açısından- yetersiz olduğunu ortaya koyarken (4) gerekli olan, olması gereken bir kuram intiyacını da ortaya koy- 
maktadır. Ne var ki bu ihtiyacın giderilmesi, gerekli olan kuramın oluşturulması, yazımızın başında da vurguladığımız gibi, bu zamana kadar oluşturulan kuramların inkârını ya da tamamıyla yadsınmasını gerektirmez. Aksine onlardan yararlanmayı gerektirir.

Toplum bilim alanında bu zamana kadar öne çıkan toplum anlayışı (doğal toplum ve sembolik toplum anlayışı) çerçevesinde iki temel ve aynı zamanda birbiriyle çelişen iki uç kuram olmuştur. Birbirine alternatif olarak üretilen bu kuramlardan birinin yerine diğerini tercih etmek, tarihsel eylemi eyleyeni ve eylemin bizzat kendisiyle oluştuğu alanın varoluşsal (ontolojik) ve bilgisel (epistemolojik) şartlarının bir kısmını ihmal etme ya da görmezden gelmeye neden olurken sosyal gerçekliğe ilişkin elde edilmesi istenen bilgide bir yanlışlığa, eksikliğe ve hataya sürükler görünmektedir.

Doğal toplum anlayışında toplumun varsayılan ontolojik yapısı tıpkı doğada bulunan olgu ve olaylar düzeyine indirgenerek "toplumsal eylemi" eyleyene, nedensel ilkelerle işleyen doğanın, canlı ve cansız varlıkları arasında sıradan, bayağı bir varlık, yapı ve statüsü yüklenmektedir. Dayanılan, varsayılan ontolojik yapı böyle olunca izlenen yöntem de eşyalarda olduğu gibi kabul edilmekte ve bu durum irade ve özgürlüğünü elinde bulunduran insanın yapmış olduğu eylemi cansız varlıkların derecesine indirgeme anlamına geleceğinden yapıp eden insan iradesini hiçe sayarak problemli ve eksik görülmektedir.

Doğal toplum anlayışını benimseyenler insan eylemlerini doğal intiyaçların gereği olarak kabul ettiklerinden, eylemin aktörü olan insanı ve onun yapıp etmelerini bizzat kendisinin fizyolojisine indirgeyerek, onun eylemlerine yönelik açıklamaları da fizyolojik hareketlerine denk düşen doğa bilimlerinin nedensel ilkesi çerçevesinde gerçekleştirmişlerdir. Oysa kendini ve dış dünyayı bilen ve dönüştüren insanı, tabiatla ve fiilleri sınırlandırılmış varıklarla aynı görmek sorunlu bir yaklaşımdır.

Felsefe ve bilim tarihinde uzun tartışmalara yol açan bu varsayım ve kabullenme diğer yandan kendisine alternatif olarak bir bakış açısını, ruhçu maneviyatçı akımı doğurmuştur. Bu akım da insan eylemlerini tek yanlı olarak insanın ruhsal yönüne indirgeyerek açıklama girişiminde bulunmuş ve neticede iki zıt indirgemeci toplum anlayışı ortaya çıkmıştır. Oysa insan ne tamamen doğal ihtiyaçların peşinden koşan ve buna bağlı olarak sosyal dünyasını inşa eden ne de doğal intiyaçları terk ederek sadece ruhsal manevi yönüyle insanî, sosyal gerçekliğini inşa eden bir varlıktır. Belki her ikisinin de etkin olduğu ama bazen birinin diğerine baskın geldiği bir etkileşimle sosyal dünyasını oluşturan bir varlıktır. Öyleyse insan eylemlerini daha özel bir anlamda belirtmek gerekirse sosyal eylemi indirgemeci bir yaklaşım çerçevesinde değil de bütüncü bir yaklaşımla ele almak daha mantıklı ve makul görünmektedir.

Bunu yaparken antropolojik olarak insanın her toplumda aynılığını içeren hususlara ilişkin durumları dikkate alan mevcut kuramlardan yararlanmak gere- 
kirken, insanın içinde bulunduğu ferdi-grupsal ve toplumsal gerçeklik, gerekli olan kuramın dayanacağı temel olmalıdır. Başka bir ifadeyle kapsamlarına göre sınıflandırıldığında makro ve mikro olarak isimlendirilen, dayandıkları bilim anlayışlarına göre pozitivist, anlayıcı ya da yorumlayıcı veya realist olarak isimlendirilen kuramlardan yararlanarak, kendi tarihi sosyal gerçekliğimizi ortaya koyacak bir kuramın peşinde olmalıyız.

Kuramın genel bir özelliği ya da genel olanı yansıtan, gösteren bir özelliği vardır ki, bunu bu zamana kadar yapılan gözlemler, düşünceler ve bilimsel bilgiler sağlar. Örneğin insanın doğal, tarihsel ve toplumsal bir varlık olması (Ergun, 1982: 54) insan eylemlerinin, ilişkilerinin tarihsel, sosyal bir alanda gerçekleşmesi, tarihsel eylemin varlığa, bilgiye ve ahlaki bir temele dayanması genellik taşır. Bu temellerin yapısı ve içeriği değişmekle birlikte her toplumsal ilişskiye ve eyleme yön vermesi, toplumsal kuramda dikkate alınan, alınması gereken temel ve genel özelliklerdir. Ne var ki, toplumların tarihsel, toplumsal eylem alanının mekânsal ve toplumsal durumu, yönü, her toplumun ve bireylerinin dayandığı epistemolojik ve ahlaki, normatif değer alanları, ideolojik ve sembolik değerleri, kültürel alt yapısı, daha genel çerçevede bağlı oldukları medeniyet farklı olduguundan, toplumsal kuramın dikkate alması gereken temel ve genel özellikler özelleşebilir. Bu nedenle toplumsal kuramların her toplumda dayandığı genel olan yönleri vardır, ancak genel geçer değildir. Weber bu durumu din özelinde açıkça ortaya koymuştur. Ona göre sosyolojik bağlamda din gibi toplumsal bir olguyu insanlık tarihi için geçerli ortak belirleyicilere göre açıklamak mümkün değildir. Bu nedenle dinlerin tek tek ayrı tarihsel dönemlerdeki değişik konum ve işlevlerine, anlaşılma ve yaşanış biçimlerine bakmak gerekmektedir (Özlem, 1999: 175). Weber'in bu yaklaşımını toplumların eylem biçimlerini şekillendiren, onlara yön veren, normlar, kültürel değerler, ideolojik ve sembolik değerler için de dikkate almak oldukça yerinde görünmektedir.

Bu bağlamda Türk toplumunun toplumsal gerçekliğine ilişkin bir kuram geliştirme girişiminden söz edilecekse, öncelikle tarihi-sosyal eylemin yapısını bu eylemi topluma özgü bir şekilde oluşturan temel unsurları dikkate almak, daha sonra bu temel ve genel özelliklerden farklılaşan özel durumları göz önünde bulundurmak gerekir.

\section{Toplumsal Eylemin Arka Planı}

Belirli bir hedefe ve amaca yönelik olarak gerçekleştirilen insan eylemleri, bir bütün halinde organizeli olarak belirmektedir (Krech ve Crutchfield, 1970: 134-135'den nk. Arslantürk ve Amman, 1999: 149). Türü ne olursa olsun belirli bir amaç taşıyan eylem, Weber'in ifadesiyle "anlamlı eylem"dir.

Eyleme anlam katan diğer bir ifadeyle eylemi belirleyen onu yönlendiren şeyler ise eylemde bulunan kimselerin eylemleri sırasında kendisine bağlanmış oldukları özel ve öznel anlam dünyalarıdır (Özlem, 1999: 138). Burada özel anlam dünyası olarak nitelenen şeyler, eylemin gerçekleşmesi sırasında kendisine 
bağlanılan yönlendirici etkenler başka bir ifadeyle içsel ve dışsal faktörler olmaktadır.

Bu faktörlerden içsel olanlar ve tamamıyla eylemi gerçekleştirenin kendi fizyolojik ve psikolojik yapısından kaynaklanıp, öznel durumunu yansıtan, zihinsel ve duygusal (arzu, istek, tutku, hiddet, korku, heyecan, sevgi, öfke) özelliklerdir. Dışsal faktörler ise, toplumun değer anlayışları (iyilik, güzellik, adalet, eşitlik vs.); kanun ve yasalar, kültürel ve geleneksel örf, adet vs.; dini ve ahlaki normlar; doğal intiyaçlarını karşılama gerekleri; geleceğe yönelik tasarımlar; kurallar ve alışkanlıklar; toplumsal yaptırımlar olarak nitelenebilir ve bu çerçeve daha da genişletilebilir (Özlem, 1999: 141).

Herhangi bir eylemi gerçekleştiren kişi, sıradan bir özne değil, akıl ve irade sahibi, eylem yapabilme gücü olan ve bu gücün sınırları dâhilinde özgün, özgür, aşkın ve üretken yapı özellikleri kültür ve uygarlık ürünlerini ortaya koyan kendisini ve çevresini değiştirip anlamlı kılan, edilgen olmayıp etken olan aktif bir varlıktır (Açıköz, 105).

Etken olan ve karşısındaki hemcinsiyle beşeri ilişkilerde bulunan insanın yapmış olduğu eylemler yukarıda belirtilen iç ve dış faktörlerle ya da bunlardan biri yahut birileriyle belirli bir amaç çerçevesinde başkalarına yönelmiş eylemler olarak ortaya çıkarlar. Eylemlerin bu şekilde belirmesi sosyal eylem olmalarını sağlar. Weber'in ifadesiyle, "eylemde bulunan kişi veya kişilerin, öznel bir anlama göre başkalarının durumu ile bir ilgi içerisine girmeleri ve bu ilgi temelinde öznel anlama göre yönlendirilmiş olması" (Özlem, 1999: 141) eylemi sosyal bir eyleme dönüştürmektedir. Başka bir ifadeyle eylem, bireyin kendisine özel bir anlam yüklediği davranış olup, diğerlerinin davranışlarının birey tarafından dikkate alınması anlamında sosyaldir. Öyleyse toplumsal eylemin temel özelliği onun, başkalarının durumuyla ilişkili olmasıdır. Başkalarına yönelik olarak toplumsal eylemleri anlaşılır kılan şey, eylem ile eylemi yönlendiren anlam arasındaki ilişkidir, anlamın bağlamıdır. Anlamlar ise temel olarak kültürel nitelikler halinde kendilerini gösterirler.

Belirli bir amaca dayalı, anlamlı davranış ya da sosyal eylem, toplumbilimin konusu olmaktadır. Sosyal eylem belirli bir amaca bağlı olarak gerçekleştiğinden farklı eylem ve davranış alternatifleri arasından seçilip alınmasını sağlayan bir iradeyle gerçekleşmekte, bu seçici irade belirli bir duruşu ve kararlılığı sağlayan değerlerden, kurulu ve kabul gören bilgisel ve ahlaki temellerden beslenmektedir. Öyleyse her bir sosyal eylem içerisinde bulunan kişi ya da gruplar yaptıkları şeyin, gösterdikleri davranışın rengini, dozunu, düzeyini bağlı bulundukları değerlerden, diğer bir ifadeyle bilgiye ve ahlaki değerlere dayalı temellerden almaktadırlar. İnsanın zihin ve düşünce dünyasından dışsallaşırken, davranış haline gelirken, anlamlı bir eylem olarak belirirken, farklı nedenlere bağlı olarak bazı kırılmalar olsa da eylemin bağlı olduğu bu değerler alanı gözardı edilemez. Bu değerler sayesinde insan eylemleri yorumlanabilip açıklanabilirler. 
Belirli değerleri benimseyip herhangi bir eylemi gerçekleştiren kişi ya da gruplar farklı alternatifler arasından seçici iradeyi kullanmaları bakımından özgür olsa da, eylemi gerçekleştirme sürecinde ferdi ve toplumsal (içsel ve dışsal) imkân ya da imkânsızlıklarla çevrili olabilir yahut belirli kayıtlarla bağımlı durumuna düşebilir. Sosyal eylemi belirli sınırlarla çevreleyen ya da şekillendiren bu kayıtlar, kalıplar ve bağımlılıklar o eylemi gerçekleştiren(ler)i diğer benzerlerinden ayıran bilgisel, kültürel kodlara dayalı toplumsal farklılıklardır. Toplumsal farklılıkların sınırlarının belirginleştiği alanda gerçekleştirilen anlamlı ve amaçlı sosyal eylem aynı zamanda içselleştirilmiş, zihniyet haline gelmiş bir düşüncenin dışa vurumu, dışsallaşmasıdır. Bu dışsallaşma anlamlı eylemin tarihselliğine işaret etmektedir. Tarihsel eylemin arka planı değerler tarafından belirleniyorsa ve bu değerlerin de dayandığı bir kaynak varsa toplumsal araştırmalarda yüzeysel değerlendirmelerden kurtulmak için, hem değerleri hem de bunların dayandığı kaynağı açıklamakta yarar vardır.

Eylem, dayandığı bilgi ve kültürel değerlerin ışı̆̆ında ilgi, talep ve beklentilere cevap vermek amacıyla belirli bir iradenin ürünü olarak zihni bir kararlılığa göndermede bulunurken, ferdi aşıp dışsallaşarak sosyal alana taşınması, uygulanması ve dalgalar halinde yaygınlaşması, onun tarih içindeki etkinliğini ve tarihe müdahalesini gösterir.

Oldukça farklı ve iç içe geçmiş fenomenlerin birbirini tamamladığı ya da sınırladığı bir ortamda gerçekleşen eylem, düşünüldüğü ve tasarlandığı şeklin dışında çeşitli kırılma ya da engellerle karşılaşabileceği gibi farklı formlara bürünme özelliklerini de barındııı. Bu özelliklerin olabilirliği karşısında eyleyenlerin ferdi entelektüel kapasitesi, aktör ve etkin olabilme becerisi ve kabiliyeti ile amaçlanan hedefe ulaşmada mümkün olan beşeri ve araçsal her türlü imkânın devreye sokulması söz konusudur. Bu çerçevede içinde yer aldığı toplumsal alanda imkânların sağladığı özgürlük ortamı ve imkânsızlıkların kısıtladığı sınırlı bir alanda eylem kendini dışa vurmuş olur.

Her eylem böyle bir tarihi ve sosyal alanda ortaya çıkar. Ancak her eylemin tarihe müdahale etme yeteneği ve gücü olmayabilir. Tarihe ve sosyal alana etki edip, damgasını vuran eylem belirli bir hedef ve amaca kilitlenen anlamlı eylemdir. Anlamlı eylem eyleyenin kendisi dışında başkaları ya da başka şeyler üzerinde etkinliğini, müdahalesini göstermesi, diğer bir ifadeyle tarih yapma yeteneğini gösterme yetkinliğidir.

Eylemin belirli bir amaca yönelik olması ve anlam içermesi onun değer yüklü olduğunu ve kültürel içeriğe sahip olduğunu gösterir. Eylemin diğer varlıkların oluş ve hareketlerinden ayrı olarak akıl ve iradeyle hareket eden insan tabiatına uygun genel bir ifade olması, onun her yerde aynı türden belirdiği anlamına gelmez. Bilakis dayanmış olduğu bilgi yapısından ve kültürel kodların bağlı bulunduğu değerler alanından niteliğini alır. Eylemin değer aldığı ve kültürel içerikle dolduğu alan eyleyenin kendisinden beslendiği, hareket noktasını gösterir. Farklı etki ve etkenlerin devreye girdiği bir süreçte gerçekleştirilen eylem renk 
ve formunu, düzey ve boyutunu bağlı bulunduğu bu merkezi hareket noktasından, başka bir ifadeyle değerler dünyasından alır.

Eylemin gerçekleştirilmesine imkân veren özgürlükler alanı eyleyenin içinde bulunduğu ortamda eylemini perdeleyen engelleri aşabilme kabiliyet ve becerisiyle, kendini çevreleyen zaman, mekân ve toplumun sahip olduğu siyasal, ekonomik, sosyo-kültürel ve dini şartlarının sınırlamaları çerçevesinde oluşur. Bu durum eylemin toplumsal bağlamına işaret ederken aynı zamanda onun gerçekleştiği ontolojik zemini resmeder. Şu halde eylemin ontolojik zemini bir yandan onu gerçekleştirenin varoluşsal şartları tarafından oluşturulurken, diğer yandan eylemin gerçekleştiği fiziki mekân ve toplumsal bağlam tarafından belirlenmektedir.

Toplumsal eylemin bilgi örgüsü belirli bir tarihin içinde yaşayan insanın, içinde yaşadığı tarihi ve sosyal ortamın etkinliğini oluşturan unsurlarla mensup olduğu medeniyetin yazılı metinlerine, sözlü anlatımlarına yönelerek yaptığı yorumlar sonucu elde edilen düşünsel ve bilgisel ürünlerden oluşur. Tarihi, toplumsal, entelektüel, dini, mitik ve mistik ürünler, bir yandan eyleyen bir aktör olarak insanın kendi kimliğini inşa etme eyleminde ve toplumsal anlam evreninin kurulmasında rol oynarken diğer yandan insanlar arası davranış ve eylemlerin kodlarını belirlemekte ve aynı zamanda eylemle değerler arasındaki ilişkinin rengini, düzeyini ve boyutlarını belirleyen bilgisel temele işaret etmektedir.

İnsanlar nasıl davranacaklarına onları çevreleyen dünyanın nasıl olduğuna ilişkin görüşlerine dayanarak karar verirler (Winch, 1994: 27-28). Belirli bir toplum içinde belirli şartlar içerisinde yorumlanan görüşler, davranış kodlarına etki eden değerler ve normlar sosyal ilişkileri belirlerler. Sosyal ilişkiler ise değerler ve normlardan bağımsız kalamayan gerçekliğe ilişkin düşünce ve fikirlerin birer ifadesi olarak belirirler (Winch, 1994: 29).

Eylemde bulunan kişiler ya da gruplar kesin ve netleş(tiril)miş değerler alanından, fikri örgülerden, bilgi ve kültür havuzlarından beslenerek amaçları çerçevesinde, alternatif sonuçları dikkate alarak, verili şartlar eşliğinde, uygun araçları kullanarak ve yönlendirerek eylemde bulunurlar.

Toplumsal eylemi yönlendiren temeller zaman, mekan ve coğrafi zeminde beliren ihtiyaç ve hedeflerin yanında, normatif değerler, ideolojik ve sembolik değerler kültür ve medeniyet (Guy, 1968: 40vd) olarak nitelenebilir.

Insan eylemleri bu temeller üzerine kurulur. Ancak eylemlere temel teşkil eden bu unsurlara bağlı olarak eyleyen aktörlerin var oluşsal durumu, fiziki ortamı ve toplumsal alanı, bilgi durumu, değerleri algılama ve anlama biçimleri, fertten gruba, gruptan topluma uzanan çizgide farklılaşabilmektedir. Bu nedenle özellikle ve özenle tekrar belirtmeliyiz ki, tarihsel-sosyal eylemlerin anlaşılmasında tek bir toplum için ya da bilinen bir toplumun her dönemi için gelişstiri- 
len kuramlar tümüyle geçerli olamazlar. Onları geliştirmek ve yeniden düzenlemek gerekir.

\section{Toplumsal Eylemin İçinde Gerçekleştiği Anlam Ağı}

Insan eylemleri diğer canlıların hareketlerinden farklı olarak belirli bir bilince dayanırlar. Bu bilinci oluşturan anlam ağı insan eylemlerine bir nitelik ve anlam kazandırır. Bu anlamı ve anlamın içeriğini oluşturan dinamikleri bilmeksizin insan eylemlerini anlamaya çalışmak boşuna olmasa da eksiklikle malül olacaktır (Trigg, 2005: 61).

Sosyal varlık alanının temel öğesi olan ve bu alanda aktör konumunda bulunan insan çok klasik ve bilinen bir tanımlamayla bio-psiko-sosyo-ekonomik ve kültürel bir varlıktır. Onun biyolojik ve psikolojik özelliği eylemi gerçekleştirmede varoluşsal bir etken olarak karşımıza çıkmaktadır. Insan, gerçekleştirilen eyleme varoluşsal bir temel teşkil ederken, eylemi gerçekleştirenin yaşadığı fiziki ve sosyal çevre, eyleyene varoluşsal temel olmaktadır.

Eylemin ve eyleyenin dayandığı varoluşsal temellerde eylemin dinamiğini teşkil eden nedir? Acaba fertleri belirli eylem ve davranışlara belirli hedeflere yönelmeye iten kuvvetler her zaman aynı mıdır? Aynı hedef ve amaçlar karşısında itici güçlerin değişmesi mümkün değil midir? Veya aynı itici güçlerin fertlere ve çevreye göre değişen farklı hedeflere yönelmiş etkiler yapması beklenemez mi? Bu soruların cevabı ancak bazı genellemeler çerçevesinde verilebilmektedir. Bu genellemeler çerçevesinde ele alınması gereken eylem (davranış) kavramı fertlerin topyekün davranışı olmaktadır. Bu topyekün davranışın iki ayırt edici özelliği bulunmaktadır.

Bu özelliklerden birincisi eylemi meydana getiren ihtiyaçlar, heyecanlar bu ihtiyaç ve heyecanlarla oluşan düşünceler, düşüncelerin olgunlaşması ile ortaya çıkan idrakler ve hareketler gibi bütün eylem unsurlarını ihtiva etmesidir.

Özelliklerden ikincisi hareketin devamı süresince unsurlardaki kuvvet derecesi farklılıkları halinde ortaya çıkan muhtelif evrelerin hepsinin tek bir istikamete göre şekillenmeleridir. Böylece eylem dinamiğinde evrelerin sonuna yaklaştıkça hedefe de yaklaşılmakta ve hedefe ulaşıldığında mevcut gerginlik ortadan kalkmaktadır. Eylem dinamiğini incelerken dikkate alınması gereken ünite budur. Ve ferdin topyekün davranışını yönlendiren bu ünite, kültür örf, adet, taklit, telkin ve kurumların ancak dolaylı bir şekilde tesiri altında bulunmaktadır (Bilgiseven, 1977: 117-118).

Anlaşılan o ki, ferdin eylemi daima intiyaçlarla ve hedeflerle ilgili bir eylem olmakta ve bu eylem kültür, din vb. değerlerden oluşan etkenlerin etkisi altında bulunmaktadır. İnsanın biyolojik ihtiyaçları ve psikolojik tatmine ulaşma çabaları onu belirli hedef ve amaçlara yönlendirmekte bu amaç ve hedeflere ulaşmak için vereceği kararlarda, amaç ve hedeflere ulaşma esnasında kendinde bulunan bio-psikolojik özelliklerle yine kendini çevreleyen dış faktörler eylem yapma 
iradesini belirlemektedir. Şüphesiz insan iradesinin belirli faktörlerle belirlenmesini söylemek, determinist ve indirgemeci bir yaklaşımla eylemlerin arka planında yer alan ve yapabilme gücünü niteleyen iradeyi salt bir düzeye indirgediğimiz anlamına gelmez. Ancak eyleyen bir aktör olarak insanın gerek zihni düzeyde gerekse sosyal alanda sürekli etkileşim içinde olduğunu ve eylemin bu etkileşimler neticesinde verilen karara bağı olarak beliren irade sonucu gerçekleştiğini görmemiz gerekir.

Bu etkileşime bağlı olarak insanın dünyayı algılama tarzı, her şeyden önce onun içinde bulunduğu fiziki ve sosyal çevrenin özelliğine bağlı kalmakta, aynı fiziki ve sosyal çevrenin içinde yaşayan insanların dünyayı algılama tarzları birbirine benzer olsa da, fertler arasındaki fizyolojik farklılıklar, zekâ dereceleri, kabiliyetleri, öğrenme tecrübeleri, istek, arzu ve ihtiyaçları, geçmişe ait tecrübeleri ve geleceğe ait ülküleri, beklentileri, inanç sistemleri dünyayı farklı algılamalarına neden olurken (Krech ve diğerleri, 1970: 26-27) farklı eylem türleri ortaya koymaktadırlar.

Toplumsal eylemler belirli bir anlam evreni içinde ferdi sübjektif durumların şartları altında gerçekleşirler. Beşeri sosyal eylemlerin anlama bağı olması onları tabiat olaylarından fizik kimya gibi alanlarda belirli kanunlara bağlı olarak gerçekleşen olgulardan ayırır. Tabiat olayları tâbi oldukları kanun içerisinde işlerken beşeri eylemler belirli kurallar çerçevesinde işlese de aralarında benzerliğin kurulması zordur. Çünkü insan eylemleri belirli genel kurallara bağlı olsa da insanın sübjektif durumlarını içeren faktörlerle sınırlanmakta ya da başka bir yöne kayabilmektedir. Kimyasal bir karışımın gerçekleşmesinde her hangi bir sübjektiflik söz konusu değildir. Ama belirli kurallarla çevrili herhangi bir beşeri eylem, sübjektiviteyi içermektedir. Bu durum futbol maçı oynayan futbolcuların kendilerini bağlayıcı maç kurallarına bağı olmakla birlikte kendi özel ve öznel dünyalarının, kabiliyet ve becerilerinin ortaya koyduğu performansla çıkardıkları oyuna benzer. Bir bütün veya bir görüntü olarak futbol maçı, oyuna katılanların anlayıp değerlendirebildiği kural ve talimatlardan oluşan bir anlamın içerisinde gerçekleşmektedir. Bu genel anlamdan habersiz olan seyirci, sadece, herhangi bir mantıktan yoksun eylemlerin karmakarışık bir görüntüsü ile yüz yüze gelecektir. Futbolcuların gerçekleştirdiği ferdi eylem, kendine özgü anlamını genel anlamdan kazanır. Oyunun genel anlamı yalnızca kurallar ve talimatlardan ibaret olmayıp aynı zamanda oyunda yer alan oyuncuların zihinlerinde bulunan amaç tarafından da ifade edilmektedir. Oyuncuların özel niyetleri bu genel amaç tarafından yönlendirilmektedir (Zijderveld, 1985: 72-73).

Futbol maçını belirleyen kurallar bütününden hareketle kişinin bir aktör olarak gerçekleştirdiği eylemlerden olan sosyal eylemi dikkate aldığımızda eylemi gerçekleştirenin davranışlarını genel olarak belirleyen kültür ve medeniyete bağlı olarak şekillenmiş normatif değerler, ideolojik ve sembolik değerler ve dini, mitik ve mistik kurallardır. Eylemi belirleyici etkenlerden dini ele aldığımızda, dini kuralların anlaşılma ve yorumlanma biçimine göre oluşturulan değerler, 
normlar dindar insanın öznel dünyasında algılandığı ve anlaşıldığı biçimde ve kendisinin zihninde beliren ihtiyaç ve hedefler doğrultusunda o dini eylemlerini gerçekleştirir. Ne var ki dindar ferdin eylemlerini yönlendiren sadece dini değerler alanı değildir. $O$ sosyal hayatın içinde eylem yaparken yaptığı eylemi bağlayı$\mathrm{Cl}$, yönlendirici, sosyal, kültürel değerleri, kanuni, bürokratik yaptırımları da dikkate alır. Dini, sosyal, kültürel, kanuni, bürokratik kurallar, normlar sarmalında özel amaç ve niyetleri çerçevesinde davranış gösteren dindar kişi eylemine yüklediği özel anlamı bu sözü edilen kuralların oluşturduğu genel anlam çerçevesine uydurmaya çalışır. Uyulmadığında onun dînî ve kanuni müeyyidelerinin olacağını düşünerek eylemini gerçekleştirir.

Toplum bilimde kuram, "ne" ve "nedir"i arama ve araştırma varsayımlarını kurmaya yarıyorsa (Ergun, 1982: 55), toplumsal eylemin arka planını anlama bağlamında son olarak şunları söyleyebiliriz.

Toplumsal eylem, yukarıda belirttiğimiz genel esaslar çerçevesinde, toplumsal alanda, toplumsal alanı dışarıdan kuşatan uluslararası sistem ya da sistemlerin etkisiyle, ferdin biyolojik, psikolojik ve fizyolojik yapısı içinde, fiziki ve coğrafi bir alanda gerçekleşir.

Toplumsal alan sosyal eylemin gerçekleştiği bir saha olarak son derece karmaşık ve iç içe geçmiş yapılardan oluşur. Eylemi gerçekleştiren kişiyi çevreleyen en dar alandan başlayarak tasvir etmek gerekirse, ferdi çevreleyen ilk grupsal çevre aile çevresidir. Ailenin büyük aile ve çekirdek aile olması ferdin sosyalleşmesi açısından önem arz eder. Aileden sonra kişinin içinde yer aldığı grupsal, cemaatsel, siyasi ve ideolojik çevre söz konusudur. Ferdin grup içinde davranışları grupsal psikolojiyi devreye sokarken grup dışında ferdi davranışlarda grubun etkisinin görülmesi fert üzerinde grubun sosyal (grupsal) tesirini, baskı ve etkisini gösterir. Grubun kendine göre oluşturduğu dil ve anlam evreni grup üyeleri arasında iletişimi sağlar. Burada grup dili ile umumi dilin karşılıklı etkileşimi ve grup dilinin çeşitli yayın araçlarını kullanarak topluma açılması bağlamında etkinliğini artırması toplumun umumi diline gösterdiği etkiyi gösterir. Grubun kendi dili bağlamında oluşturduğu yerel, bölgesel, ulusal ve uluslar arası kültürün etkileşimiyle ya da bunlardan birini yahut birkaçını tercih etmekle oluşturduğu kültürel evren o grubun anlam haritasını oluşturur. Bu harita, belirli bir gruba ait eylemlerin gerçekleştirilmesinde ifade edildiği üzere her ferdi etkileyen ailevi, kırsal, köy, kasaba, şehir ve bölgesel düzeyde olduğu gibi ulusal ve uluslar arası düzeyde etkinliğini gösteren bir faktördür. Varsayımları kurarken bu anlam haritasını dikkate almak gerekir.

Kültürü şekillendiren ve karşııklı olarak kültürün kendisiyle şekillendiği dil, grupsal bağlamda olduğu gibi toplum içinde yaşayan ferdi etkilemekte, ulusal anlamda dilin örgülediği anlam çerçevesinde özelliklerini fert ya da toplumsal düzeyde ortaya koymaktadır. İnsanlar arası etkileşimin ve anlaşmanın vasıtası olan dil, mitik, mistik ve dini kutsal değerlerle anlam evrenini genişleterek, ya da bu kutsal değerler dili kutsal bir anlama büründürerek insanlar arası ilişkilere 
manevi bir haz ve düzey getirirken, insan ilişkilerini sadece dünyevi menfaat ve beklentiler düzeyinden çıkarıp dini bir atmosfere büründürebilmektedir. İnsanlar arası ilişkilere yön veren dildeki bu tür dini, manevi yönleri görmeksizin toplumsal eylemi çözümlemek eksik olacaktır.

Şu halde toplumsal alanda oluşan beşeri ve aşkın, dini değerler de toplumsal eylemi etkileyen bir faktör olarak her zaman devrede olmaktadır. Dini değerlerin tesiri toplumsal bir alanda her zaman belirgin, açık ve seçik olarak belli olmamakta. Manevi değerler etkisini gayet ince bir şekilde icra edip, görülmeden müesseselere, tutum ve davranışlara, hayat tarzına ve ma'şerî şuura nüfuz etmektedirler (Carrier, 1967: 39). Öyleyse, toplumsal alanda gerçekleşen sosyal eylemi anlamaya çalışan araştırmacı yukarıda adı geçen kurum ve kuruluşlara dayalı olarak oluşan müesseselere, bunlardan kaynaklanan tutum ve davranışlara, hayat tarzına ve ma'şerî şuura gayet ince bir şekilde görülmeden tesir eden, etkileyen bu değerleri dikkate alacaktır. Çünkü kişilerin davranışlarını etkileyen ve kişilerin uyum sağlamaya çalıştığı değerler alanı, bu değerlerin oluşturduğu çevre, kişilerin gerçek dünyasını oluşturur. İnsanlar etraflarında olup bitenleri içinde yaşadıkları bu dünyaya göre değerlendirirler. Yapıp etmeleri bu dünyanın içinde gerçekleşir. Bu nedenle sosyal gerçekliğe ilişkin her hangi bir incelemede bu gerçekliğin kurumlarının ve işlevlerinin biçimsel görüntüsüyle yetinmek araştırmayı yüzeysel kılacaktır. Esasen yapılması gereken bireylerin yaşamına etki eden kurumlar tarafından empoze edilen ve algılanan, algılandığı şekliyle içinde bulunulan şartlara göre anlamlandırılıp hayata aktarılanın ne olduğunu, bunun arkasındaki anlamı kavramaktır. Başka bir ifadeyle belirtmek gerekirse, sosyal eylemlerin arka planında yer alan sosyal bir kurumun bütünüyle anlaşııması yalnızca bu kurumun biçimsel organizasyonunun soyut bir incelemesiyle kendimizi sınırlayarak değil, toplumun çeşitli ve farklı kesimlerinde yaşayan fertlerde ortaya çıkış biçiminin ve söz konusu fertlerin yaşamlarındaki etkilerinin incelenmesiyle mümkündür (Zijderveld, 1985: 40).

Toplumsal alanda gerçekleştirilen bir eylemin özgürlük çerçevesi ve bu sInırları belirleyen kanuni ve sosyal yaptırımlar da söz konusudur. Bir eylemin gerçekleşmesi ferdi çevreleyen diğer şartlarla birlikte onun özgürlüğünü belirleyen anayasa, kanun ve yönetmelikler olduğu gibi sosyal çevreden gelen baskı ve etkileşimler de söz konusudur. Bazen kanuni yönden mahzur olmamakla birlikte toplumun değişik sebeplere bağlı olarak oluşan baskılarından kaynaklanan bir sınırlama söz konusu olduğu gibi, bazen de toplum açısından mahzur olmadığı halde kanuni yönden sınırlamalar söz konusu olabilir. Toplumsal eylemin araştırılmasında bu hususların da dikkate alınması gerekecektir.

Toplumsal alan artık önceki çağlarda olduğu gibi sadece içinde bulunulan toplumsal, siyasal, kültürel ortama göre değil uluslar arası siyasal ve kültürel sistemlerin, bu sistemleri yönlendiren aktörlerin etkisi ile de şekillenebilmektedir. Küreselleşme sürecinin felsefi arka planı olarak niteleyebileceğimiz 
postmodern akımlarla şekillenen toplumsal oluşumları bu bağlamda değerlendirmek mümkündür.

Toplumsal eylemlerin gerçekleştirilmesinde ferdi biyolojik, fizyolojik ve psikolojik durumlar toplumsal eylemim dışa vurumu açısından önem arz etmektedir. Araştırmacı eylemin anlaşılmasında eylemi gerçekleştirenin varoluşsal durumlarını görmezden geldiği takdirde yanlış sonuçlara varabilir. Aynı toplumsal bir eylem farklı biyolojik, fizyolojik ve psikolojik özelliklere sahip kişilerde özünde olmasa da dışavurumunda farklı şekillerde tezahür edebilir. Bu tür farklılıkların biyolojik, fizyolojik ve psikolojik kökenlerini ayırt edebilmek çözümlemeyi kolaylaştıracaktır.

Toplumsal eylemler aynı kaynaktan beslenseler de, aynı değerlere bağlı olsalar da fiziki ve coğrafi şatlar bunların farklı şekillerde tezahür etmelerine neden olabilir. Bunun en belirgin örnekleri dini yapılanmalarda görülür. Örneğin fiziki ve coğrafi şartlar bir din ve medeniyet olarak i̇slam'ın tarih boyunca farklı şekillerde tezahür etmesine neden olmuştur. Bu bağlamda mezhepler arasında farklılaşmalar olduğu gibi (Arabacı, 2005: 347-356) İslam'ın mimari sanatına varıncaya kadar değişik alanlarda bu farklılıkları tespit etmek mümkündür.

\section{Sonuç yerine}

Toplumlar birbirleriyle ilişkileri olsa da birbirlerinden farklı gerçeklikler üzerine inşa olmuşlardır. Diğerlerinden farklılaşan Türk toplumunun toplumsal gerçekliğine ilişkin bilim, genel toplumbilim içinde özelleşmekte ve "Türk toplumbilimi" olarak nitelenmektedir.

Toplumların görece gerçekliklerinin olduğu, Türk toplumunun diğer toplumlara göre gerçekliliğin farklı şekillerde tezahür ettiği hatta tarihin dikey boyutlarında bile farklılaştı̆̆ı gerçeğinden hareketle kendine özgü toplumsal bir kuramının olması zorunlu görünmektedir. Ancak tarihsel-sosyal eylemlerin anlaşılmasında tek bir toplum için ya da bilinen bir toplumun her dönemi için geliştirilen kuramlar her zaman tümüyle geçerli olamamaktadır. Onları geliştirmek ve yeniden düzenlemek gerekir. Bunu yaparken, Türk toplumbiliminde kurama ilişkin bu zamana kadar yapılan aktarma ya da inşa anlamında olsun her türlü çabayı eleştirel bir bakışla dikkate almak ve toplumsal eylemin belirleyicileri başta olmak üzere bu belirleyicilerin örgülediği toplum yapısını ve değişim süreçlerini de ihmal etmeksizin yeni bir kuram oluşturmalıyız.

Notlar

(*) Prof. Dr., Hitit Üniversitesi İlahiyat Fakültesi, e-posta: farabaci@yahoo.com

(1) Kendisine yöneltilen bir soruyu cevaben söylenmiş bu ifadeleri Meriç'ten nakleden (Arslantürk, 1995: 84).

(2) Özellikle yöntem önermeme konusunda getirilen eleştiriler için bkz. (Ergun, 1993: 6571).

(3) Her iki kuram içinde oluşturulan farklı yaklaşım biçimleri için bkz. (Poloma, tarihsiz). 
(4) Bu kuramların yetersizlikleri için bkz. (Ergun, 1982: 62vd).

\section{Kaynaklar}

Arabacı, F., "Hanefiliğin Oluşumunda Coğrafi Etkenler (Sosyolojik Açıdan Bir Değerlendirme)", Imam-ı Âzam Ebu Hanife ve Düşünce Sistemi I, Kurav Yay., Bursa, 2005, 347356.

Arkoun, M., "Religion et Société d'Après l'Exemple de I'Islam", Pour Une Critique de la Raison Islamique, éd. Maisonneuve et Larose, Paris, 1984.

Arslantürk, Z. ve T. Amman, Sosyoloji, iFAV Yay., İstanbul, 1999..

Arslantürk, Z., "Nasıl Bir Sosyoloji”, Türk Sosyoloji Dergisi, 1995, C. I, sayı: I.

Bilgiseven, A. K., "Sosyolojinin ve Türk Sosyolojisinin Problemleri", Türk Sosyoloji Dergisi, Yıl: I, Sayı: I, Yaz 1995.

Bilgiseven, A. K., Sosyolojik Açıdan Tasavvuf ve Laiklik, Kutsun Yayınevi, İstanbul, 1977.

Bodur, H. E., "Sosyolojik Din Teorisi ve Türk Din Sosyolojisi", Türk Din Sosyolojisinin Temel Sorunları Sempozyumu, G.Ü Çorum Illahiyat Fakültesi Yay., Çorum, 2005.

Carrier, H., "Comment étudier les valeurs et les Institutions religieuses d'un pays (Bir Ülkenin Kıymet hükümleri ve Dini Müesseseleri Nasıl incelenir?)", Essais de sociologie religieuse, Paris, 1967. Bu makalenin Türkçe çevirisi için bkz. M. Koştaş, AÜiFD, C.XXIX, s. 335-346.

Çelebi, N., Sosyoloji ve Metodoloji Yazıları, Anı Yay., Ankara, 2001.

Çiftçi, A., Nasıl Bir Sosyal Bilim, Kitabiyat, Ankara, 2003.

Davudoğlu, A., Bilgi, Bilim ve İslam, II, i. neş. a.ş. İstanbul, 1992.

Ergun, D., Sosyoloji ve Tarih, Der Yay., 2. basım, İstanbul, 1982.

Ergun, D., Yöntemi Bulmak, Gerçek Yayınevi, İstanbul, 1993.

Giddens, A., Sosyoloji, (Haz. H. Özel, C. Güzel), Ayraç Yayınevi, Ankara, 2000.

Guy, R., Introduction à la sociologie générale, L'action sociale, Ed. HMH, Ltée, 1968.

Krech, D., ve R. S. Crutchfield, Sosyal Psikoloji, (çev. E. Güngör), İstanbul, 1970.

Kızılçelik, S., Sefaletin Sosyolojisi, Anı Yay., Ankara, 2002.

Meriç, C., Sosyoloji Notları, Konferanslar, İletişim Yay., İstanbul, 1999.

Özlem, D., Max Weber'de Bilim ve Sosyoloji, Küyerel Yayınları, İstanbul, 1999.

Poloma, M. M., Çağdaş Sosyoloji Kuramları (çev. H. Erbaş), Gündoğan Yay., 2. Basım, Ankara, tz.

Sezer, B., Türk Sosyolojisinin Ana Sorunları, Sümer Kitapevi Yay., Ankara, 1988.

Trigg, R., Sosyal Bilimleri Anlamak (çev. B. Sümer, F. Ülgüt), Babil Yay., İstanbul, 2005.

Tuna, K., Yeniden Sosyoloji, Karakutu Yay., 2002.

Waardenburg, J., "İnsan Bilimleri, Sosyal Bilimler ve i̇slam Çalışmaları”, (Çev. Ö. M. Alper)”, Batı'da Din Çalışmaları, Metropol Yay., İstanbul, 2002.

Winch, P., Sosyal Bilim Düşüncesi ve Felsefe (çev. Öç Demir),Vadi Yay. Ankara, 1994.

Zijderveld, A. C., Soyut Toplum (çev. C. Cerit), Pınar Yay., İstanbul, 1985. 



\section{DİN-KIMLIKK İLISSTISİ ÜZERİNE}

abstract

On the relationship between religion and identity. Religion interacts with society as well as affects it and it is also affected from society and social facts. Within this interaction, religion affects culture, arts, population, economy, politics, daily life and religious ceremonies and sparetime activities. As a result, religion contributes to shape the social identity. In addition to its influence on the shape of social identity, it has a significant role in protecting the national identity. On the other hand, religion is also affected from social facts and therefore, many religious perceptions are shaped through the interaction with society.

\section{key words}

Social identity, religion, culture, formation and conservation of identity. 


\section{Giriş}

Insanın doğuştan sosyal bir varlık olduğuyla ilgili pek çok teori bulunmaktadır (ibn Haldun, 1990: 100). Birlikte yaşama eğilimi ve belki de zorunluluğu, toplumsal yaşamı destekleyip, insan ilişkilerini şekillendiren birçok kurumun varlığını gerekli kılmaktadır. İşte din de, ilk sosyal yaşamla birlikte toplum hayatında var olmuş ve toplumsal olanla derin etkileşimler gerçekleştirmiş temel sosyal kurumlardan biridir. Toplumsal yaşamı sağlayan ve kolaylaştıran unsurlar arasında kan bağı, dil, kültür, duygu ve yarar birlikteliği gibi unsurlar sayılabilir (Kongar, 1995: 41-43). Bu unsurlar milletin tanımında da hemen farkedileceği üzere milletleşmiş toplumlar için de geçerlidir (Demir ve Acar, 1993; Smith, 1994: 24vd; Krş. Günay, 1986: 162).

Insanlık tarihinin erken dönemlerinde dinin toplum yaşamında derin izleri ve sosyal yaşamı şekillendirici etkileri olmuştur. Sosyal değişimin bütün evrelerinde var olan din; pozitivistik akıl ve seküler algılar etrafında şekillenen modern dönemlerde de, kutsala ilişkin inanç ve bağlılı̆ın yanı sıra, sosyo-kültürel bir motif olarak toplum yaşamında var olmaya devam etmiştir (1).

illk dönemlerden itibaren insanın çeşitli şekillerde ilişki kurduğu kurumlardan biri olan dinin, toplumsal yapının şekillenmesinde de etkin bir tavır takınması kaçınılmazdır (Sezen, 1993: 73). Bu durum, onun, toplumun belki hemen bütün etkinlik ve yaşam alanlarını kuşatarak kültürün şekillenmesinde derin bir tesir gücünün var olduğu gerçeğini de ortaya koyar. O halde din, milli kimliğin oluşumunda ve milli birlikteliğin temininde önemli bir unsur olarak ortaya çıkabilmektedir (Komisyon, 1984: 143).

Bilinen ilk toplum yaşamından itibaren etkinliğini hissettiren din (Eliade, 1990: 120), modern dönem toplumların sosyal, kültürel ve hatta ekonomik hayatında da çok geniş etki sahaları bulmuştur. Bu çerçevede, her toplum din algısını kendi kültür çevresinde şekillendirmiş; onunla algıları ve diğer kazanımları etrafında kendine özgü bir kimlik dünyası inşa etmiştir. Toplumsal kimliği ifade eden sosyo-kültürel ve dini yapıda, hemen bütün sosyal kurumlarla etkileşim yaşayan dinin derin motiflerinin bulunması kaçınılmazdır (Gökalp, 1976: 32). Modern zamanlara kadar kültürün hemen bütün alanlarında görülen dini içerikli motifler, sekülerleşmenin hemen bütün sosyal dokular üzerinde kendisini hissettirdiği modern toplumsal yapılar içerisinde de yine sosyo-kültürel ve ekonomik yapıyla etkileşerek toplumsal benlik içerisinde yerini almış olur (Weber, 1997; Gökalp, 1976: 26). Bir başka ifadeyle; milli ayırımın en belirgin özelliklerinden biri olan kültürün şekillenmesinde dinin de önemli bir yerinin olduğunu belirtmek gerekir. Bu nedenle, bir milletin özgün kimliğinde önemli yer tutan edebiyat, sanat, hukuk, felsefe, ahlak, duyuş ve değer yargıları gibi toplumsal unsurların hemen hepsinde dinin izleri vardır (Begoviç, 1994: 74-75; Güngör, 2007: 81). Birçok büyük edebiyat yapıtı dini içerikli olduğu gibi, dini özellikli birçok mimari sanat şaheserinin de bulunduğunu belirtmek gerekir. Taç Mahal, Ayasofya veya Selimiye Camii hep bu türden eserlerdir. Buradan hare- 
ketle dinin, geçmişten günümüze milletlerin sosyal, kültürel ve ekonomik yaşamlarında etki tonu ve içeriği değişmekle birlikte hemen her dönemde bir etkisinin olduğunu söylemek mümkündür (Komisyon, 1985: 92).

Toplumsal duyuş, düşünüş ve davranışlarla etkileşen din; aynı zamanda, kendisi de toplumsal olandan etkilenerek toplumsal dokuya uygun bir içerik ve form kazanır (Begoviç, 1994: 274-275). Dinin toplumsal olanla etkileşmesi, onun genel inanç dünyası içerisinde birçok toplumsal farklılıklarının ve zenginliklerinin de ortaya çıkmasını sağlar. Bu durum, göçer Türk Müslümanlığı şeklinde oluşan Alevilik örneğinde veya İslam'ın değişen dönem ve topluma göre zenginleşen din bilgisi, dini mekan ve ritüel zenginlikleriyle anlaşılır kılınabilir. Böylece, bir yandan dine ait medeniyet dünyasının oluşumu gerçekleşirken (Turan, 1994: 70); diğer taraftan din ile toplumsal olanın etkileşimiyle ayrı bir toplumsal özgünlük ortaya çıkmaktadır. Bir inanç, duyuş, düşünüş, davranış ve ritüeller dünyası olan din de, bu toplumsal kimliğin özgünleşerek belirmesinde önemli bir yere sahip olmaktadır. Dinle etkileşerek kültürel oluşumlarını gerçekleştiren toplumlar aynı zamanda inançlarına ait bir medeniyet dünyasının kurulmasına da katkıda bulunurlar. Bu duruma Müslüman olan Türklerin hayatındaki değişmeye paralel olarak İslam dünyasında yaşanan değişme ve gelişmeler açık bir örneklik teşkil etmektedir. Türklerin İslam'ın yayılmasına, kurumsallaşarak gelişmesine ve birçok kurumsal ve kültürel içerikle birlikte zenginleşmesine yaptığı büyük katkılar bilinmektedir (Ateş, 1994: 106; Kafesoğlu, 1991: 364; Yazıcı, 2004). Burada, iletişim ve ulaşım ağının hemen bütün küreyi saracak bir şekilde genişleyip zenginleşmesinin toplumsal iletişim ve etkileşimi de önceki dönemlere nazaran son derece artırdığı; fakat bu durumun, toplumsal olanın özgün içerikle zenginleşmeye devam ettiği gerçeğini ortadan kaldırmadığı görülmektedir (Gürsoy, 2007: 89-90).

Toplumsal doku ile yoğun bir etkileşim yaşayan din, toplumun sanat, mimari, siyaset, ekonomi, kültür ve boş zaman değerlendirmesine kadar hemen her alanına etki ederek toplumsal kimliğin oluşumunda ve gelişiminde yer almaya devam eder. Ayrıca birer dini ritüel mekanları olan ibadethaneler inananları bir araya toplamanın yanı sıra bir birliktelik bilinci ve toplumsal yakınlaşma sağlayarak toplumsal kimliğin muhafazasında önemli bir rol üstlenir. Aynı şekilde din görevlileri de; dini öğreti, bilgi ve pratikleri din mensuplarına aktarırken birçok toplumsal duyuş ve değeri bireylere aktararak ulusal kimliğin sürekli kılınmasında önemli fonksiyonlar üstlenmiş olurlar (2).

Din, toplumsal kültür içerisinde yer bulan dini ritüel ve törenlerin etkisiyle de ulusal kimliğin muhafazasında önemli işlevler gerçekleştirir. Sovyet döneminde yoğun olarak uygulanan kimliklerden arındırma ve eritme politikaları karşısında; dini bayramlar, evlilik, doğum veya cenaze merasimleri, kabir ziyaretleri ve birçok vesile ile yapılan dualar gibi daha pek çok kültür içerisine yerleşmiş ve milli-dini toplumsal alışkanlık haline gelmiş dini unsurun Orta Asya 
Türk toplumlarının milli kimliğinin korunmasında yerine getirdiği misyon bilinmektedir (Monteil, 1992: 200; D’encausse, 1992: 76-77).

Milli içerikli bilgilerin dini söyleyiş ve telkinlerde kullanılması yoluyla da toplumsal birikimlerin ve ulusal bilincin kuşaklara aktarılması sağlanır. Bu çerçevede, birçok önemli tarihi olay veya önder şahsiyet dini-milli bir unsur olarak dini anlatımda yerini alır. Tarihi bir diyaloga sahip olan din-millet hayatında dini birçok unsurun milli gelenek ve göreneklere nakşolunmasıyla dini-milli bir özgünlük ortaya çıkar ki, bu durum dini propagandada milli motiflerin kullanılmasına yol açar. Ayrıca, dini inancın baskıya maruz kaldığı dönemlerde birçok dini değerin milli geleneklerde yaşıyor olması dini faaliyetlere tarihsel bir bağımlılık kazandırır. Burada dini olanla toplumsal olan özdeşleştirilerek sunulur. Yine burada da din, ulusal bilinç ve kimliğin canlı tutulmasında önemli bir unsur olarak ortaya çıkmaktadır (Wach, 1995: 208; D’encausse, 1992: 52-53).

Din ile milli oluşumların iç içe geçtiği ve ulusal kimliğin dinin belirleniminde olduğu durumlarda dini ve milli unsurlar aynı şeyi ifade eder (Wach, 1995: 131). Yahudilik ile İsrail oğulları arasında yaşanan dini ve milli kimliğin birlikteliği/iç içeliği bu durumun tipik örneklerinden biridir. Günümüzde milli bir din haline gelmiş olan Yahudilik, İsrail toplumunun hemen bütün duygu, düşünce ve yaşam alanına nüfuz ederek toplumun şekillenmesinde kendisine derin tesir sahaları bulmuştur (Mensching, 1994: 34; Wach, 1995: 32). Böylece din, toplumsal/ulusal kimliğin oluşumunda çok önemli bir yere ve işleve sahip olabilmektedir. Din ile toplum arasında görülen bu güçlü geçişkenlik hali kutsal bir birliktelik karakterine bürünerek (Mensching, 1994: 31), tarihin çeşitli dönemlerinde savaş, sürgün gibi nedenlerle dünyanın dört bir yanına dağılan Yahudilerin asırlar süren fasılalardan sonra "Arz-ı Mev'ud" denilen ve İsrail oğullarına Tanrı tarafından vaad edildiği düşünülen kutsal topraklarda İsrail Devleti çatısı altında toplanmalarında oldukça yapıcı bir rol oynamıştır. Böylece toplumsal kimliği belirleyen milli din; aynı zamanda, dağılma dönemlerinde ulusal benlik ve bilincin canlı kalmasını ve inananların büyük ideal etrafında bütünleşmelerini sağlamıştır.

Dini öğreti ve algılar; toplumların nüfus ve çoğalma algılarına, insan ilişkilerine, eğitim tutumlarından hukuksal yapılarına kadar toplumun daha birçok alanına etki edebilir (Öztürk, 1994: 106). Örneğin; İslam'ın, nüfus artışına karşı görece pozitif bir tutum ortaya koyması ile hemen bütün İslam ülkelerindeki yüksek nüfus artışı arasında bir paralellik görülebilmektedir. Elbette burada, İslam dünyasında gözlemlenen nüfus artış hızında eğitim ve ekonomik faktörler başta olmak üzere daha birçok unsurun etkili olduğunu belirtmek gerekir. Yine, daha seküler bir karaktere sahip olan Protestan bölgelere nazaran Katolik bölgelerde daha yüksek bir nüfus artışının olması (Tümertekin, 1984: 102-105) da dinin toplumsal algılar üzerindeki etkisine bir başka örnek olabilir. Bu ilişki, toplumdan topluma yoğunluk ve içerik farkı gösterse de, din-toplum ilişkisinin daha birçok başka alanlarda da var olması durumunu değiştirmez. Böylece din, bu tür 
ilişki tarzlarıyla da toplumsal yaşamı etkileyerek ulusal kimliğin ve yapının şekillenmesine etki etmiş olur.

Din-toplum ilişkilerinin yoğunluğu ve dinin toplumsal kimliğin oluşumunda ve muhafazasında oynadığı etkin role rağmen, dinin zaman zaman ulusal kimlikte bilinç çözülmelerine de yol açabileceğini belirtmek gerekir. Evrensel dinler, özellikle toplumsal dinamizmin kaybolduğu dönemlerde, kimlik ve bilinci yıkı-

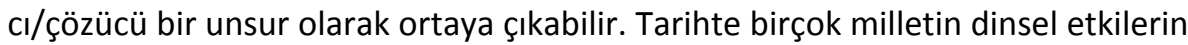
de yardımıyla kimlik kaybına uğrayarak tarih sahnesinden silindiği ya da yapı ve form değiştirerek varlığını sürdürdüğü bilinmektedir ki, Bulgar, Peçenek ve Kuman Türklerinin Hıristiyanlaşarak Slavlaşması bu duruma tipik örneklik oluşturabilecek niteliktedir (Komisyon, 1985: 92-93).

\section{Notlar}

$\left(^{*}\right)$ Doç. Dr., Atatürk Üniversitesi Illahiyat Fakültesi, e-posta: sahingursoy@yahoo.com

${ }^{* *}$ ) Dr., Ankara Üniversitesi Illahiyat Fakültesi, e-posta: ihsancapcioglu@yahoo.com

(1) Modern toplumların seküler dokusu içerisinde din-birey ve toplum ilişkileriyle ilgili açıklayıcı bir çalışma için bkz. Zuckerman, 2005: 223-229.

(2) Din-kimlik ilişkisi ile dini mekan ve din görevlilerinin milli kimliğin korunmasında oynadığı role ilişkin olarak bkz. Tosun, 1993.

\section{Kaynaklar}

Ateş, T., Osmanlı Toplumunun Siyasal Yapısı, Ankara, 1994.

Begoviç, I., Doğu ile Batı Arasında İslam, çev. Salih Şaban, İstanbul, 1994.

D'encausse, H. C., Sovyetlerde Müslümanlar, çev. Adnan Tekşen, İstanbul, 1992.

Demir, Ö. ve M. Acar, 'Millet' maddesi, Sosyal Bilimler Sözlüğü, İstanbul, 1993.

Eliade, M., Dinin Anlamı ve Sosyal Fonksiyonu, çev. Mehmet Aydın, Ankara, 1990.

Gökalp, Z., Türkleşmek islamlaşmak Muassırlaşmak, İstanbul, 1976.

Günay, Ü., Din Sosyolojisi Dersleri, Kayseri, 1986.

Güngör, Ö., Araf'taki Kimlik: Alevilik/Bektaşilik, Ankara, 2007.

Gürsoy, Ş., "Küreselleşme Ulus-Devlet ve Din”, Ş. Gürsoy ve i. Çapcıoğlu (eds.), Küreselleşme, Ulus-Devlet ve Din, Ankara, 2007.

Haldun, i., Mukaddime, çev. Kadiri Ugan, İstanbul, 1990, C. 1.

Kafesoğlu, ì., Türk Milli Kültürü, İstanbul, 1991.

Komisyon, Milli Kültür, Ankara, 1984.

Komisyon, Türk Milli Bütünlüğü Içerisinde Doğu Anadolu, Ankara, 1985.

Kongar, E., Toplumsal Değişme Kuramları, İstanbul, 1995.

Mensching, G., Dini Sosyoloji, çev. Mehmet Aydın, Konya, 1994.

Monteil, V., Sovyet Müslümanları, çev. Mete Çamdereli, İstanbul, 1992.

Öztürk, O., Osmanlı Hukuk Tarihinde Mecelle, İstanbul, 1973.

Sezen, Y., Sosyoloji Açısından Din, İstanbul, 1993.

Smith, A. D., Milli Kimlik, Çev. B. S. Şener, İstanbul, 1994.

Toktamış A., Osmanlı Toplumunun Siyasal Yapısı, Ankara, 1994.

Tosun, C., Din ve Kimlik, Ankara, 1993.

Turan, O., Türk Cihan Hakimiyeti Mefkuresi Tarihi, İstanbul, 1994, C. 1.

Tümertekin, E., Beşeri Coğrafya, İstanbul, 1984.

Wach, J., Din Sosyolojisi, çev. Ünver Günay, İstanbul, 1995. 
Weber, M., Protestan Ahlakı ve Kapitalizmin Ruhu, çev. Zeynep Aruoba, Ankara, 1997. Yazıcı, N., İlk Türk-islâm Devletleri Tarihi, Ankara, 2004.

Zuckerman, P., "Sekülerleşme: Avrupa: Evet, Amerika: Hayır. Sekülerleşme Neden Avrupa'da Ortaya Çıktı da Amerika Birleşik Devletlerinde Ortaya Çıkmadı? Teoriler ve Araştırmalar Üzerine Bir İnceleme", çev. Şahin Gürsoy, AÜiFD, C. 46/1 (2005): 223-229. 


\section{BÍLGi SOSYOLOJISİ VE/İLE KELÂM'I YENIDEN KURMAK}

abstract

Sociology of knowledge and re-construction of theology. Main aim of the essay to establish a close relationship between Social Sciences, particularly Sociology of Knowledge, and Theology (Kalam). In realising the aim the argued connection between Theology and Philosophy of Social Sciences will be discussed too. In the process, re-construction of Kalam is going to be subject of inquiry and ways of doing this shall be examined.

\section{key words}

Theology, sociology of knowledge, philosophy of social sciences, ontology, epistemology, human nature, re-construction. 


\section{Bilgi Sosyolojisi ve/ile Kelâm'ı Yeniden Kurmak}

Bu çalışma; Bilgi Sosyolojisi ve islam Araştırmaları adlı kitabımızın ana tezi olan; 'dînî ilimler'in (1) "bilim felsefesi" ve "sosyal bilimler felsefesi"ndeki "ontoloji", "epistemoloji”, "insan doğası" ve "yöntem" tartışmalarından ve bunlara dâir varsayımlarından uzak kalamayacağı tezine dayanmaktadır. Bunun üzerinden, onların bilimlerin bir taraflarında yer almaları gerektiğini ileri sürmekteyiz.

İlk anda istisna tutulabilir gözüken Kelâm İlmi, tam aksine, bundan hiç uzak duramaz diye düşünüyoruz. Çalışmanın bir maksadı bunun gerekçelerini göstermeye çabalamaktır.

Diğer maksat, "bilgi sosyolojisi"nin esas alacağımız tarifinin ve görevinin Kelâmcılar tarafından da esas alınarak "Kelâm'ı yeniden düşünmelerini" önermek; gerekçesini ve "yeniden kurma"nın yöntemini anlatmaya gayret sarf etmektir.

İlk iki başlık ikinci maksat ile ilgilenecektir. Birinci maksadın açılımı ve gerekçesi diğer üç başlıkta serdedilecektir. Bunlar üzerinden “Kelam’ın yeniden kuruluşu" meselesine yine dönülecek, son iki ta bundan söz edilecektir. Değerlendirme ve Sonuç ilave bazı tahlillere de girmiş olabilecektir.

\section{Kelâm'ı Yeniden Düşünmek: Gerekçe}

"Kelâm'ı yeniden düşünmek" (2) ifadesini birkaç anlamda kullanıyoruz. (।) Eğer Kelâm İlmi “ilâhi Kelâm/Kur'ân" üstüne kelime etmek ise, bu kelime etmenin yöntemini yeniden düşünmelidir. (ı) Kelime etmenin yöntemini yeniden düşünerek sağlam bir usûle varınca, "Kelâm/Kur'ân"ı yeniden düşünmeli. (III) “Kelâm/Kur'ân"ı yeniden düşünerek ve düşününce de Kelâm'ı yeniden düşünüp yeniden kurmalıdır.

Kelâm'ı ve "Kelâm"ı (3) yeniden düşünmenin "bilgi sosyolojik" gerekçesi özetle alttaki paragraflarla sunulabilir.

"Din”in ona dayanarak düşünsel temellerini koyma ve savunma iddiasıyla kurulan Kelâm, "Kelâm" dan kopmuşluk ve insanları koparmışlık manzarası sergilemektedir. Bunun nedeni bugünün dünyasından kopmuşluğudur. Halbuki o, dünya yani zamanında mevcut şartlar, fikirler, inançlar, bilgiler vs ile Kelâm/Kur'ân arasında, onları onaylama, reddetme yahut değiştirerek bünyeye alma bakımından bağlantı tesis etme ve böylece "din"in esaslarını (akaid) inşa ve müdafaa amacıyla kurulmuştu. "Dünün dünyası”nda yaptığı, "dün"e yaptığı bu işi; "bugünün dünyası"nda, "bugüne" de yapmak zorundadır ve yapamadığından dolayı da Kur'an'dan kopuvermiştir.

Kelâm hem bilimsel gelişmelerin, hem toplumsal değişmelerin meydana çıkardığı yeni durumlar ile Kur'ân arasında bağlantı kuramadığı için, "din"den de ayrı düşmüştür. "Bilgi-din sosyolojisi" diliyle söylersek; "din" insanların fiziksel ve toplumsal dünyayı anlama, onlardaki tekil unsurları "aşkın" ile irtibatlandırıp 
yorumlama ve böylece de bireysel ve toplumsal hayatı bir "düşünsel düzen"e sokma işlevi görecekse; geleneksel Kelâm'ın ortaya koyduğu akideler günümüzde bunu yapabilmekten, böylece de "din"den uzak düşmüştür. Halbuki o, geçmişteki zamanların ve mekanların değişmeleri ve fiili durumları ile Tanrı arasındaki irtibat bakımından Kelâm/Kur'ân'ı anlama ve anlamlı bir "din(sel dünya)" kurma gayreti idi. "Kelâm ilmi" tâbirindeki "ilm" sözcüğü tam da bu irtibatlandırma ve anlama etkinliğini ifade etse gerektir.

$\mathrm{O}$, elbette, her yeni bilimsel bilginin veya toplumsal ibdânın peşinden koşuşturamaz. Böyle bir çabaya hem de alelacele girenlerde karşılaştı̆̆ımız, "Bu zaten Kur'ân'da vardı" söyleminin Tanrı'yı teorilerin ve bulguların peşinden koşturmadaki, 'bayalığını' demesek de, naifliğini herkesten çok bir Kelâmcı fark edebilir ve buna karşı çıkar. Mamafih, birtakım gelişme ve değişmelerden tamamen bağımsızca, sırf metin analizine dayanan, üstelik bunu da pek beceremeyebilen bir Kelâm İlmi ne kendi varlığını sürdürebilir; ne de, ana görevi olarak biçilen, dinin varlığını sürdürebilir. "Din" $i$ kendi başına veya kendinde varlık gibi görenler, bazı ayetlere de atıfta bulunarak, bunu kabul etmeyebilirler. Fakat, "din"in varlık gerekçesi olan insanlara bir "din"in artık anlamsız; halihazır hayat ve dünya ile ilgisiz alakasız gelmesi halinde o din'e ne olacağını da düşünmeliler bu kabulü tahkimden evvel.

Kelâm'ı ve "Kelâm"ı yeniden düşünmenin gerekçesini, o sefer "bilim felsefesi" ve "sosyal bilimler felsefesi" üzerinden, göstermeye başka alt başlıkta döneceğiz. Gelen alt başlık, yeniden düşünmenin yönteminin ana hatlarını arza mâtuftur. Kelâm IIImi insan bilimlerinden ve insandan uzak durmayacaksa, Metn'i anlama yöntemi açısından bazı şartları yerine getirmelidir. Fakat buna götüren gerekçeler daha önemlidir ve bu yüzden başa aldık. Çünkü, gerekçe kabul edilmeyecekse, yeni bir yönteme de ihtiyaç hissedilmeyecektir.

\section{Kelâm'ı Yeniden Düşünmek: Yöntem}

Bilgi Sosyolojisi ve islam Araştırmaları isimli araştırmamızın bizde uyandırdığı algılardan biri; Tasavvuf'un metodu ile Hukuk ve Kelâm'ın metodu arasında temel farkın; öncekinin "sözcü", sonrakinin "yazıcı" olduğu idi.

Bunun Hermeneutik'te tartışılan ama burada alabildiğince kısa değineceğimiz bir soru(n) ile yakın bağlantısı olmalı: "Söz" mü, "yazı" mı?

"Yazı"yı esas alanların, bunu, "yazı"nın bağlamsız olarak özerk bir dil, bir özerk söylem kurmuşluğuna veya kurma yeteneğine dayandırdıkları söylenebilir. "Yazılı söylem" yazarından ve yazarın tarihsel koşullardaki niyetinden en azından o anki fizikselliği bakımından ayrı tutulabileceğinden, "konuşma" veya "karşılıklı konuşma" durumunun (ikisine de "söz" dersek, "söz"ün) aksine o, soru sorulamayan, sorgulanamayan bir söylem kabul ediliyor görünmektedir (Hirsch, 1977: 21-23, 26). 
Evet "kitap/yazı" bir kaynağın, kitabı gerçekten ve aslında "söyleyen"in ifadelerini aktarmaktadır. Erişilebilir yani hayatta ise eğer, "söyleyen"e sorular veya sorgulamalar yöneltilebilir ve "niyet"e ulaşılabilir. Fakat bu mümkün değilse, hiçbir kitapta/yazıda yalnızca kitap/yazı aracılığıyla söyleyene, "söyleyenin niyeti"ne erişilemez. Erişilmesi gerekmez de. Bu nedenle, bir metin veya lafız (kısaca, "yazı"); söyleyenin niyetlerine gönderme yapmakla; yazarın maksatlar dünyasına ircâ etmekle çürütülemez. Böyle bir metinci (lafızcı, yazıcı) tutum, geleneksel Hukuk ve Kelâm'dan aşina olduğumuz bir sonuca varmamızı bekler bizden: "Kitapta bu yazılı" demek, "bu gerçektir" demektir. Çünkü "metin (yazı)", doğası gereği, dikkafalı ve inatçıdır (Ong, 1995: 97-98) (4).

Yukarıdaki kısa tartışmayla gelmek istediğimiz; Kelâmcının (mütekellim), "metinci/yazıcı" bir tutumla, varlık ve bilgiyi "Kelâm"da "işte-orada-var" addetmesi, kendisine düşenin sadece onu "tespit/bulma"dan ibaret olduğunu düşünmesidir.

"Düşünmesidir" sözcüğünü gayet bilinçli istihdam ettik. Çünkü, bilgi sosyolojisi gözüyle bakarsak, bunu sırf "düşünmekle" kalmış gözükmektedir çokluk: aslında pek de nesnel "metinsel tespit" peşinde koşmamış, mevcut bazı tarihsel peşin hükümleri "Kur'ân'a/Metn'e tespit ettirme" gayretine girmiş epeyce konuda. Başka söyleyişle; Kur'ân'dan kendisine gelmek yerine, kendisinden Kur'ân'a gitmiştir. Ama geleneksel Kelâmcı böyle bir keyfiyeti itiraf etmez, bilakis tamamen Metn'e dayandığını söyler. Öte yandan; özellikle bazı konularda veya kavramlarda gerçekten "metinsel tespit" yapıldığı ve tam da bu yüzden sıkıntı doğduğu da söylenebilir.

Diğer bir ifade biçimiyle; sırf "metinsel (yazısal) tespit" bile alışıldık sorunlarını Kelâmıının çalışmalarında da göstermektedir. Metin çözümlemelerinde "anlam/bilgi bütüne aittir" ilkesine riayet edilmeyişi büyük sorunlar çıkarmaktadır. Mesela, en basit örnekle, "evrenin yaratıışı" ("kozmogoni”) meselesini izahta apaçık sıkıntılara duçar kalınmıştır. ilgili ayetlerdeki sayısal çelişki, bütünsel anlam ve anlama ilkesi uygulanarak, örneğin "yaratmak Allah'ın vaktini almaz" demekle çözülebilecekken; gün sayısı farklılığına dikkat kesilinmediği gibi, "gün" ile neyin kastedildiğinin kılı kırk yaran tahlilleri yapılmıştır.

Önemli olmakla birlikte pek az kimse Kozmogoni'ye ilgi duyabileceğinden bu bir yana; "nihai mânâ bütüne aittir" ilkesi en fazla kader, kudret, irade, insan hürriyeti, mucize, şefaat ve diğer konularda gözden kaçırılmıştır. Halbuki insanları toplumsal yaşamlarında ve bireysel varoluşlarında hayati ehemmiyeti haiz birer konu niteliğiyle asıl ilgilendiren ve anlamlı bir dünya kurmada veya dünyaya anlam vermede en önemliler de bunlardır. "Bize düşen tek iş Kur'ân'ın kelimelerini çözüp orada zaten mevcut olan bilgiyi çıkarmaktır" denmesine rağmen; "kelime çözümlemesi"nin ifadeleri parça parça almayıp anlamsal tutarlılık içerisinde çözümleme olduğu gözden ırak tutulduğundan; bunların en muhtemel mânâları tespit ve teşhis edilememiştir. 
Böylece, "nesnel bilgi"nin yani bizim öznel zihinlerimize bağlı olmayıp Allah'a ait bilginin "nesneci, orada-varcı tutum"la bulunabileceği düşünülürken ve bu düşünce iyi uygulanırsa pek de sakıncası yokken; kötü uygulanmış, "varlık" tekil ayetlere bağlanmıştır: "sayılar-orada-var", "determinizm-orada-var" ve diğerleri "orada-var."

Halbuki, şeksiz şüphesiz gördüğümüzü kabul ettiğimiz, yani 'olgusal' görünen 'şeyler' as/ında "işte-orada-değildirler" belki de. Bu, onların Metin'de veya metinlerde kelimeler/çizgiler (yazı) olarak mevcutluğunu inkar değildir. Ama bütünsel anlamdan hareketle ve bütünün anlamına varmak için yaklaşılırsa, onların bir kısmı yöntemsel maksatla susturulabilir, ayraç içerisine alınabilir.

Kozmogoni örneğini buraya taşırsak şunu söylemek olanaklı. Bir ayette yaratış süresinin "altı gün", diğerinde, dikkatli toplandığında "sekiz gün" olmaklığı yazılı gerçektir. Fakat gün sayısı gösteren lafızlar fenomenolojik askıya alınıp "nihai anlam" aranır ve "anlam bütüne aittir" ilkesi kullanılırsa, konu ile ilgili diğer ayetler hesaba katılmakla kalınmaz, ilk anda ilgisiz görünen ayetler ile de bağlantı kurulup bir "genel/asıl anlam (maksat vs)" çıkarıı.ı. Bu genel anlamı bazen tek ayet verebilir. Şimdiki konuda, mesela "Ol der, olur" ayeti bu niteliktedir. Böylece, "yaratmanın Allah'ın vaktini alamayacağı" anlamına varılabilir ve sayılar belki tamamen "anlamsal askıya" alınır, lafzen (kelime, yazı olarak) orada duruverseler de.

Diyelim insan davranışlarının önceden belirlendiği ("kader") fikri Metin'de -Kur'ân ve Hadis'te- "kelime-olarak-var" gözükebilir. Ancak, metnin tümünün lafızları ve nihayet "zihni" çözülüp "insanın Allah tarafından hür yaratıldığı" da çıkarılırsa, o "kelimeler" ile bu "kelimeler"i uzlaştırmak gerekecektir. Bütün çabalara rağmen uzlaşma meydana getirilemiyorsa bir tür "ağırlıklı tercih" yapılabilir Kur'an'ın umumi dünya görüşüne göre. Bunda sakınca bulunmadığı gibi, Metn'e peşin hüküm taşımak da sayılmaz. Şahsımızın dahil olduğu bilgi sosyolojik yaklaşımın çıkarsadığı "Kur'an'ın umumi dünya görüşü" dayanaklı tercihi, başat varsayımları gereği, "insanın özgür olduğu" tarafındadır (5).

Şimdiye kadarki iki başlığın Kelâm'ı ve "Kelâm"ı yeniden düşünmenin "bilgi sosyolojik" gerekçesinin ve yönteminin ana hatlarını arza mâtuf olduğunu, gerekçeye başka başııta yine döneceğimizi söylemiştik. Bahsettiğimiz başık aşağıdadır ve Giriş başındaki şu ifadelere yaslanarak dönüşü yapacaktır: Bu çalışma; 'dînî ilimler'in "bilim felsefesi" ve "sosyal bilimler felsefesi"ndeki "ontoloji", "epistemoloji", "insan doğası" ve "yöntem" tartışmalarından ve bunlara dâir varsayımlarından uzak kalamayacağı tezine dayanmaktadır. Bunun üzerinden, onların sosyal bilimlerin bir taraflarında yer almaları gerektiğini ileri sürmekteyiz. İlk anda istisna tutulabilir gözüken Kelâm İlmi, tam aksine, bundan hiç uzak duramaz diye düşünüyoruz. Çalışmanın bir maksadı bunun gerekçelerini göstermeye çabalamaktır. 
Başka türlü dersek; şimdiki gerekçe öncelikle bu "uzak duramazlık" üzerinden anlatılan bir "yeniden kurma" gerekçesi olacaktır.

\section{Kelâm'ın İşlevi ve Yeniden Kuruluşu}

Kelâm IImi'nin metodolojik tartışmalardan ve sosyal bilimlerden uzak tutulmaması ve yakın tutulmakla yeniden kurulması en az iki gerekçeyledir.

Birinci gerekçe onun işlevi ile alakalıyken; ikincisi yeniden kuruluşunda sosyal bilimlerden faydalanması ile alâkalıdır. Başka söyleyişle; birincisi sosyal bilimler felsefesindeki temel tartışmalarla, ikincisi sosyal bilimlerin kendiyle ilgilidir.

SBF eserlerinde tartışılan, karşılaştırmaları yapılan bazı paradigmaların zemininde yatan ontolojik, epistemolojik ve insan doğasına dâir bütün temel varsayımlar belki asla tamamıyla kanıtlanamayıp (6) sırf "teorik kabul" kalabileceklerinden fakat inceleme ve araştırmalarda kullanılan yöntemler açısından zarûrî olduklarından; varsayımları felsefî tartışmalar yerine doğrudan dinsel metinlere dayandırmada sakınca görmeyecek bir sosyal bilimciye bile Teoloji/Kelâm verebilir onları. Diğer söyleyişle; sosyal bilimler felsefesinin insan bilimlerinde yerine getirdiği işlevin bir kısmını hem sosyal bilimler, hem dînî ilimlerde Kelâm yüklenebilir isteyenler için. (Bunun suistimallere açık olduğunun farkındayız, ama üstünde durmayacağız).

Zaten, Kelâm eserlerine şöyle göz ucuyla bakıp ilgilendiği meseleler ile bi$\lim$ felsefesi ve sosyal bilimler felsefesi bağlamında ilgilenilenler karşılaştırıldığında aralarında epeyce örtüşme görülecektir (7).

Bundan ötürü; toplumsal bilimlerin ana kabullerini Felsefe verirken, 'dînî ilimler'in kabullerini Kelâm veriyordu denilebilir. Bu işlevi zamanla unutulmuş ise de, Gelenek'te ona 'ilimler kraliçesi' gözüyle bakılması bundan olsa gerektir. "FIkh" terimini burada "ilim" anlarsak; Kelâm Fıkhu'I-Ekber'di (8); yani "ilimler Başı, Baş ilim" idi (9).

Ne var ki, 'dînî ilimler' ile değil de sosyal bilimsel yaklaşımlara kuramsal temel sağlama ilişkisinden bahsedeceksek birden fazla Kelâm'dan söz etmek durumundayız ki; onu yeniden kurmanın ilave gerekçesi de böyle açığa çıkar. Mesela, "Geleneksel Kelâm Öğretisi" benimseniyorsa, ontolojik, insan doğası, epistemolojik ve yöntemsel tüm ana varsayımlarıyla "pozitivist (açıklamacı) yaklaşım" daha uygundur. Ama eğer bir nevi "Modern Kelâmî Öğreti”ye yaslanılıyorsa (10), yukarıdakilere ilişkin ana varsayımlarıyla "idealist (anlamacı) yaklaşım" (11) daha uygun (12). Kısacası, isteniyorsa, her iki halde de Kelâm illmi olabilir temel kabulleri verecek saha. Bununla birlikte, "temel varsayımlar" köklü biçimde ayrışacaktır son sayfalarda görüleceği üzre.

Kelâm IIImi'nin sosyal bilimler felsefesindeki tartışmalardan ve sosyal bilimlerden uzak duramayacağına dair birinci gerekçe, üstte anlattığımız gibi, onun "işlevi" ile alakalı iken; ikinci gerekçe onun "doğa bilimleri" ve "insan bilimleri" 
ile irtibatının kopartılamayacağı ile alakalıdır. Ve bu da bizi yine, onun "yeniden kuruluş" gerekçesine götürür. Gelecek iki başlık bunları işleyecektir. Bu arada:

"Sosyal bilimler neyse de, doğa bilimleri nereden çıktı şimdi, denilebilir. Bunun cevabının bir kısmı SBF'nin kapsamı ile, diğer kısmı Kelâm'ın kapsamı ile ilgilidir. Herhangi bir SBF eserine baktığımızda mutlaka "doğa" ve "doğa bilimleri" odaklı yığınla çözümlemeyle karşılaşırız. Herhangi bir Kelâm kuramına baktığımızda da "doğa"nın ve onun hakkında "bilgimiz"in en önemli konulardan olduğu görülür (13). Bu nedenle, doğa bilimlerindeki gelişmelerden ve değişmelerden habersiz bir Kelâm olası ve yeniden kurulması olanaklı değildir.

Doğa bilimleri ile Kelâm arasında bağlantının zorunluluğunu sıradaki başlıkta anlatmaya çalışacağız. Buna Nasıl Bir Sosyal Bilim, ve Anlayıcı Yaklaşım adlı eserlerimizde uzunca üstünde durduğumuz "doğa bilimleri ile sosyal bilimler" ilişkisinin ve zorunluluğunun gerekçesini kısaca hatırlatarak başlamak uygun düşecektir.

Illk gerekçesi; sosyal bilimlerdeki "pozitivist yaklaşım"ın "klasik fizik"e dayanmasıdır. Onun ontolojisine, epistemolojisine ve insan doğası anlayışına oturmakta ve bunlara göre metodoloji oluşturmaktadır. Kısacası; "pozitivist yaklaşım"dan bahsetmek, "klasik fizik"e gönderimle bahsetmektir. İkincisi; "yeni fizik"ten bahsedip onun varlık, bilgi ve insan kuramını ve bunlara dayanabilecek metodolojisini zemine yerleştirdiğimizde, "pozitivist sosyal bilim"den söz etmek neredeyse olanaksız hale gelir. Bilhassa Kaos Fiziği'ne dayanan bir sosyal bilim kesinlikle pozitivist olamaz. Üçüncüsü; bu fizik ile ilgili eserlerin giriş kısmına baktığımızda bile şu tür ifadelere rastlayabiliriz: Bu fizik her ne kadar klasik fiziğe (Galileo-Newton fiziğine) muhalifse de, bilimsel keşiflerin büyük bölümü hala onun temel varsayımlarından hareketle yapılmaktadır. Bu, klasik fiziğin bir yana ve tamamen atılamaması demektir. "Anlamacı/anti-pozitivist" da olsa, sosyal bilimsel yaklaşımların bir tür 'genel'den ve yine bir tür 'nedensellik'ten vazgeçememesi bundan da olsa gerektir.

Şimdi bunları "Kelâm ve doğa bilimleri ilişkisi" içerisinde fakat biraz farklı bir çerçevede ele alırsak aşağıdakiler söylenebilir.

\section{Doğa Bilimleri ve Kelâm}

Günümüzde Evren hakkındaki, en umumi mânâlarıyla, "ontoloji" ve "kozmoloji" büyük ölçüde "klasik fizik" çıkışlıdır. Teoloji/Kelâm bunu yok sayamaz. Kelâm'ın ontolojisi ve kozmolojisi onunla çok fazla çelişemez. Aksi taktirde günümüzün egemen Evren telakkisi ile ilişkisini yitirir. Kelâm'ın ana vazifelerinden biri Tanrı ile bağlantı açısından varlıklar dünyası üstüne kelam etmek ise, Evren'e dair egemen paradigmayı göz önünde tutmamak Tanrı'yı yitirmek ve yitirtmek sonucunu getirebilir.

Ama şunu da bilmek gerekir. Bu klasik fizik, doğuş ortamı itibariyle öncelikle Hıristiyanlığın klasik kozmolojisine bir meydan okuyuşlukla ortaya çıkmışsa 
da, "varlığın varoluşunu, idaresini ve idamesini Tanrıya atfeden" bütün teolojik kozmolojilere meydan okumaktadır.

Ona göre, Evren'in kendi içkin düzeni vardır ve, bundan dolayı, kendi kendini açıklayabilmektedir. Sadece kendi iç düzenindeki yasaları yeniden keşfetmek ve her tikel olguyu o yasaların altına yerleştirerek determinist nedensellik biçiminde açıklamak gerekmektedir. Bu açıklamada "Tanrı"ya yer yoktur. Laplace'a -ki katıksız bir pozitivist/deterministtir- atıfla bunu ortaya koyabiliriz sanıyoruz. Napolyon ona, "Senin uzay mekaniğinde Tanrı nerede?" diye sorduğunda, verdiği cevap şöyledir: "Efendim, böyle bir hipoteze hiç ihtiyaç duymadım ve duymamaktayım. (14)" İtalikle vurgu yapıp dikkat çektiğimiz gibi, Evren'i açıklamada değil Tanrı'ya, "varsayımına" bile ihtiyaç hissetmediğini söylüyor (15). Öte yandan:

Kelâm, Kuantum ve Kaos fiziğindeki, ikisinin ortak adıyla "yeni fizik"teki ve ondan kaynaklanan gelişmeleri de hesaba katmak zorundadır. Çünkü, Evren'de sanıldığı kadar yasal/kesin-nedensellikli düzenlilikler (determinizm) bulunmadığının işaretlerini vermektedir bu fizik. Bundan ötürü, örneğin, Kelâm'ın, "hayır ve şer Allah'tandır"ın ötesine geçip, "her şeyin ne zaman, nerede, nasıl ve ne şekilde olacağının önceden Allah tarafından belirlendiği" gibi en temel "kader akidesi", dolayısıyla da ontolojisi ve kozmolojisi yıkılabilir bu fizik ile. Zira o, anladığımız kadarıyla, "hiçbir olayın ne Tanrı ne doğa tarafından önceden belirlendiğini" ileri sürmektedir. Fakat, Evren'de, en azından "Tanrı hipotezine" bari yer bulma imkanı da verebilir. Pozitivist determinizm (klasik fizik) bunu "hipotez" olarak bile kabul etmemektedir. Bir hipotezin Kelâmcıya yetmeyeceğini düşündüğümüzden, bunda acele edilmeyeceğini ve bu yeni fiziğe 'kurtarıcı' gözüyle bakılmayacağını umuyoruz (17). Kaldı ki:

Kelâm, her durumda, yukarıdaki önemli hususu; günümüzde de bilimsel keşiflerin büyük bölümünün klasik fiziğin temel varsayımlarından hareketle yapıldığını da bilmeli ve göz önünde tutmalıdır. Dahası; büyük bilimsel gelişmeler hala klasik fiziğe dayanarak gerçekleştirildiği gibi, onun kozmolojisine veya evren telakkisine "güven" ile, en basitinden, "evimize her gün aynı yoldan gidebileceğimize" inandığımız da unutulmamalı. Ama, Klasik Fiziğin nedensel ve düzenli (determinist) evrenini kabul etmek, geleneksel Kelâm'ın "kader ve kaza" akidesini benimsemek ile aynı değildir.

Bunu başka cümle yapılarıyla söylersek; geleneksel Kelâm'ın yaygın ve hakim paradigması Eş'arilikte her tekil olaya Allah'ın doğrudan karışarak gerçekleşmesini belirlediği ve böylece de fiziksel düzenin ve düzen mantığının sürekli Tanrı tarafından işletildiğini söylerken verir gibi gözüktüğü 'nedensellik' fikri ile, bahsettiğimiz "nedensellik" ve "düzenlilik" bir tutulamaz. Günümüz Kelâmcısının, "klasik fiziğin evreni" ile "Tanrı"yı nasıl uzlaştıracağı kuşkusuz büyük bir sorundur ve ne bizden hemen çözümlenmesi, ne de Kelâmcıdan hemen çözülmesi beklenebilir. 
Fakat, İdealist Paradigmanın "açıklama" ve "anlama" arasında koyduğu ayırım yardımıyla ifade edeceğimiz aşağıdaki husus, tabiri caizse, hem klasik fiziğe hem Tanrı'ya hakkını verebilir. Bu diğer alt başlığa da iyi bir geçiş olabilecektir.

Evren'in açıklanmasında, aynen klasik fiziğin yaptığı gibi, nesnelerin hareketlerinde Tanrı devreye sokulmayabilir. Zaten Eş'arî Kelâm, devreye sokayım derken nesnelerden bir nesne haline getirivermiş̧ir O'nu. Bu yüzdendir belki, Mutezile bu Kelâm ile resmen dalga geçebilmiştir. Günümüz Kelâmcısının da "Tanrı'yı devreye sokma" işini eline yüzüne bulaştırma ihtimali epeyce büyüktür. Devreye sokmadığımızda, Evren'i "açıklama açısından" hiçbir şey kaybetmiş de olmayabiliriz. Ama Evren'in "anlamını" araştırıyor veya bulmaya çalışıyorsak; dahası onu insanlar için "anlamlı" kılmak istiyorsak; Tanrı hesaba katılmadığında Evren'in "anlamı" kaybolur. Anlamlı hale de getirilemez. Günümüzdeki bazı yeni-teoloji hareketlerinin varlık nedeni de budur. Ona anlam vermek, en azından "Evren ve insan niçin vardır" temel sorusunun cevabını sunarak dünyayı anlamlı kılmaktır. Çünkü Klasik Fizik, insanı, Whitehead'in dediğince, maddenin anlamsızca dolaşıp durduğu buz gibi bir Evren'de yapayalnız bırakıverdiği için (17), insanda Evren'e karşı "sorumluluk" duygusunu da kökünden yıkmıştır. Ama tekrarlayalım, bu anlam, anlamlandırma ve sorumlulukk yükleme işi bizdeki mevcut Kelâm ile başarılabilir görünmüyor. Zira Eş'arilik her şeyi doğrudan doğruya Tanrı'ya bağladığında aslında aynısını yapmış, insanın sorumluluğunu veya insânî sorumluluğu yok etmiştir.

Peki "yeni Kelâm" en azından "anlam verme" işini nasıl deruhte edebilecektir öyleyse?

Gelen alt başlık, onun sosyal bilimlerden faydalanmasıyla veya, en iyisi, onların arasında yer almakla bunu yapabileceğini ve yapabilirliğini söyleyecektir. Çünkü, insanların modern zamanlarda "anlamsız bir evrende sorumsuzca yaşamak zorunda bırakıldıkları" tezinin bizde de gerçekliği varsa ya da yoksa (18), bu ancak sosyal bilimsel araştırmalarla bulunabilir, Kelâmcının zihinsel kurgusuyla kararına varılamaz. Gerçekliği sosyal bilimsel araştırmayla tespit edilen bir sorunun çözümlenmesi ve çözülmesi de onlar yardımıyla olabilir ancak (19). Sosyal bilimler, "çözümlemeye" evet ama, bizatihi "çözme" ile uğraşmayabilirler. Kelâm'ın ise asıl vazifesidir bu, ve sosyal bilimlerden katkı alabilir.

\section{Sosyal Bilimler ve Kelâm}

Yukarıdaki nedenlerle; doğa bilimleri ile irtibatı koparılamayacak olan Kelâm ilmi'nin, sosyal bilimler ile hiç kopartılamaz.

Çünkü; hem inançların, hem bunlardan kaynaklanabileceği düşünülen davranışların veya uygulamaların toplumsal bağlamlarında empirik olarak incelenmesi Kelam alanına katkıda bulunabilir. Nasıl ki özellikle din sosyologları Weber'den beri hep böyle yapılır- bir toplumsal eylemi anlayabilmek için toplumun dinsel deneyimlerini yani dinî dünya görüşünü ve içeriğini soruşturmak 
zorundadır; Kelâmcı da Tanrı ve O'nun toplumsal evrendeki 'rolü'nü anlamak için insanı ve insanın yaşamsal-toplumsal deneyimlerini araştırma konusu yapmak mecburiyetindedir.

Nasıl ki doğa bilimleri ile bağlantısını kopardığında "maddesel evren" ile ilgisiz alakası duruma düşerse; toplum ile ilintisini kaybettiğinde "toplumsal evren" ile kopuk inançlar sunma durumuna düşer Kelâm.

Elbette, sosyolojinin ilgilendiği, inançların nereden kaynaklanıp nasıl kuruldukları konusu, onların doğruluk veya tutarlıı̆ından ya da tersinden ayrı meseledir ve sosyologun sessiz kaldığı bu sorun Kelâm'ın vazgeçilmez unsurudur (Scharf, 1970: 12). Yani, geçici de olsa doğru inançları, yine geçici de olsa tutarlı bir kozmoloji haline getirecek alandır o. Toplum ile ilintisini kaybetmemesi, "toplumsal evren"den kopuk inançlar sunma durumuna düşmemesi böyle mümkündür. Bunu başarabilmek için de, insan deneyimini veya hayatını şekillendirebilen hatta kurabilen dünya görüşünün veya kozmolojilerin anlamını, gerçekliğini/hakikatini ve kudretini toplumsal ve bireysel hayatın bizzat kendi gerçekliklerinde incelemekle meşgul olabilmelidir. Bu, sosyal bilimlerin yardımı ve desteğiyle başarılabilir işte.

Sosyoloji, burada özelleştirirsek "bilgi sosyolojisi", Kelâm'a dinsel ya da diğer deneyimlerin ve yaşamların her zaman belli bir kültürün sembolik (anlam/sal) yapısınca biçim kazandırılan yorumsal deneyimler ve yaşamlar olduğunu hatırlatmakla bir başlangıç desteği sağlayabilir mesela (29). Böylece Teoloji/Kelâm, bu sembolik evrenlerin yani anlam dünyalarının genişlemesine ve biçim kazanmasına katkıda bulunan disiplin haline de gelebilir.

Bu katkısal etkinlik, elbette, dışarıdan, kopuk ve nötr bir perspektiften yürütülmeyip; daha doğru, anlamlı ve güçlü bir "vizyon", bir "evren görüşü" yaratmaya yönelik bir ilgi ile yürür. Bundan dolayı Kelâm, tüm katkı almalara rağmen, din hakkındaki fenomenolojik ve tarihsel araştırmalardan; kısacası sosyal bilimlerden bu "inşacı hedefi"; yani daha yetkin, tutarlı ve doğru dinsel görüşler geliştirme ülküsü ile ayrııır da. Teologun aynı zamanda belli bir dinin mümini ve teologu olmaklığından ötürü değildir ayrılma. Az önce dediğimiz gibi, İslam geleneğinde, hem doğuşunda hem sonrasında, ona yüklenilegelen görev de, pek başaramasa bile, budur gibi.

Kelâm İlmi'nin daha güçlü ve sağlam sembolik (anlamlı) fikirler üretilmesine veya bunlardan oluşan bir dünya inşasına katkıya yönelen amelî ilgisi, metodolojisini de şekillendirecektir. Bu, anlamlı ve güçlü kavramsal çerçeveler yaratmaya ve onları sürdürmeye elverecek bir metodoloji olacaktır. Bu kavramsal çerçevelerin insanlarca kabul edilebilmesi ve sürdürülmesi zihinlerde mesken edinebilmesine bağımlı olduğu için; Kelâmcı, sadece, mantıksal olarak tutarı (21), estetik olarak çekici ve ahlaki olarak büyüleyici "hayalî dünyalar" kurmamalı, bilhassa bilgi sosyolojisinin yöntem ve tekniklerinden istifade ederek anladığı gerçek dünyaya yönelik anlamlı yeni dünyalar kurmalıdır. 
Teoloji daha etkili yeni sembolik dünyalar kurmaya daima sıfır noktasından başlamaz kuşkusuz. Uzun nesiller boyunca oluşmuş bir kültürde ortaya çıkmış hatta kurumsallaşmış muayyen bir dünya görüşünden de hareket alabilir. Tabiri caizse, bir ayağını gelenekli evren görüşünde sabit tutarak, onu en uygun biçimde anlamsal genişliğe kavuşturmaya, günümüze uyarlamaya çalışabilir. Eğer böyle istiyorsa, bu gelenekli dünya görüşünü ana çizgileriyle başarılı tarzda devam ettirebilmesi için, daha önce yazılanları ve söylenenleri bilmesi, hesaba katması ve yeni sembolik dünyayı, yani yeni anlamlı fikirler ve inançlar dünyasını oluşturmada ana senaryoya sadık kalması gerekir. Bu ana senaryonun temel niteliklerini gelenek zaten sunar: İnsanı ve eşyayı Tanrı yaratmıştır; varlık O’ndandır ve O'na döner... Kimse tanrılık iddiasında bulunamaz...

Bu, yeni Kelamcı hiçbir yaratıcı rol oynamaz demek de değildir. Fakat, bazılarında, yerleşik ama işlevsiz kalan dünya görüşünü değiştirmek hedefiyle sıfırdan başlamak yerine daha evvel geçenlerle devamlılıkta yürüme talebi tarafından sınırlanabilir bu yaratıcılık. Bundan dolayı, yerleşik sembolik evreni sürdürmek, Kelâm çevresi içerisindeki muhafazakar eğilimlerin hedefidir çoğunlukla.

Berger ve Geertz'in dediği gibi, sembolik dünyalar uygun şekilde işlevlerini yerine getirebileceklerse bir "olgusallık havasına" veya "kozmik meşrûiyete" muhtaç olduklarından (Geertz, 1973: 109-112; Berger, 2000: 29-39) (22), eldeki veya muayyen bir "verili" sembolik dünya ile asgari irtibatı bile bulunmayan yeni "gerçeklik/dünya görüşleri" teolojik olarak daha az etki icra ederler. "Muhafazakarlar" bir yana konulsa bile, her yeni teolojik çaba bunun için de en azından ana senaryoya sadık kalmak zorundadır.

$\mathrm{O}$ halde, bir yeni teoloji, tercihen bilgi sosyolojisi yardımıyla, bir yandan geçmişin eleştirel yorumunu yapmalı, diğer yandan günümüze veya halihazıra yönelik olarak onu yeniden inşa ile ilgilenmeli. Bilhassa fenomenolojiye dayanan bilgi sosyologları bilir ki, sembolik düzenler büyük ölçüde ortak hafızalarla sürdürülür. Teologun geçmişi yorumlaması böyle sembolik evrenlerin devamında ve değiştirilmesinde aslî unsurdur. Yani geçmiş, mevcut sembolik düzeni hem öz (senaryo) itibariyle sürdürmek, hem de değiştirmek için dikkate ve hesaba alınır. Bu hazır sembolik sistem, hafızalarda yer etmiş diye, yeni Kelâmcı sanki eleştirel düşünme yeteneğini kaybetmişcesine, "otorite olarak" yüceltilemez elbette. Tam aksine; mevcut sembolik sistem hayatı hala anlamlı, doğru ve kuvvetli tarzda yönlendirme kudretine biraz olsun sahipse ancak göz önünde bulundurulur.

Ahlakî ve siyasi olarak çökmüş görünüyorsa (23), mevcut teolojik anlam (sembol) sistemi tadilatla bile devam ettirilemez ve dikkate alınması bile gerekmeyebilir. Ama eğer toplumsal hayatı yönlendirme kaynaklarına veya etkilerine bir şekilde sahipse, sürdürülebilir. Bu ziyadesiyle önemlidir. Zira, Aydınlanma ile birlikte, "aklı bütün diğer otoritelerden özgürleştirme çabasında" tüm gelenekler "köleleştirici" görülerek, kayıtsız şartsız reddedilmiştirler. Bir geçmiş otoritenin veya geleneğin gerçekten bir hakikat açıklayıcısı veya ifadesi olabile- 
ceği duygusu kaybolmaya yüz tutmuştur. Geçmişin otoritesinin reddi, hakiki ve doğru fikirlerin ve görüşlerin mümkün kaynağı olarak geçmişin de reddedilmesi ile elele gitmiştir. Halbuki, geçmişe yeniden yönelmek, eleştirel aklımızı ona teslim etmek ya da eleştirel akıldan vazgeçmek değildir. Geçmişe yöneliş, onun, kendi önyargılarımızın maskesini düşürme ve yeni hakikatler açığa çıkarma gücüne sahip olabileceğini, en azıyla, varsaymaktır (24).

Kısacası, sosyal bilimlerden, özellikle de bilgi sosyolojisinden alabildiğince faydalanan bu teolojik hermeneutik, geçmişe bir hakikat habercisi, ifşa edicisi veya göstericisi olarak bakmakla birlikte; ona teslim olmayacaktır. Bu yenilikçi teolojik hermeneutik, "eleştirel bakış"ı, tarihsel olarak ve yaygınlıkla bazı kurumsal tezahürlere bağlanmış "geleneksel akide" ile değil de, "Sonsuz Zihn'in Kelâm'ı" ile uzlaştırma çabasına girişecektir.

Biz bu "eleştirel bakış ile Sonsuz Zihn'i uzlaştırma çabası"nın, şimdiki çalışmada esas aldığımız anlamı ve yöntemi kullanılarak bilgi sosyolojisi yardımıyla başarılabileceğini ileri sürüyoruz.

\section{VI. Üç Kelâm Tarzı}

"Tanrı ve sıfatları üstüne konuşma" anlamına gelen Teoloji/Kelâm; aynı zamanda, "insan dahil diğer varlıklar ile ilişkisi içerisinde Tanrı hakkında konuşma ve yazma"dır (Ryba, 1991: 15) (25). Bunu, değişmeye ve gelişmeye açıklık kaydıyla, "doğru" bir ontolojik, epistemolojik ve insan doğasına dair varsayımlar sistemi kurarak tutarlı bir "dünya görüşü" oluşturmakla ve diğer sahalara felsefi-teolojik zemin sağlamakla başarabilir.

Bunun yapılabilmesinde üç yoldan veya tarzdan bahsedilebilir kanaatindeyiz. Birincisi "Islahat" veya "reformizm"dir: Günümüz için daha uygun ve sağlam akideler geliştirmek maksadıyla, sonuçları açısından günümüzde muğlak veya anlamsız görülebilecek bazı gelenekli akidelerin devamlı tefsiri veya yorumu gerçekleştirilir. Yani "Islah" edilirler.

ikinci yol "modernizm"dir. Birtakım geleneksel akideler tesirleri ve neticeleri bakımından zamanımızda son derece anlamsız ve işlevsiz görülüyorsalar; "ıslah" yerine, onlardan açık bir kopuştur bu. Hele bir Kelâmî gelenek "asıl Metn'in/Kur'ân'ın" tahrifi gibi algılanıyorsa bu haydi haydi meydana gelir.

"Reformizm" mi yoksa "modernizm" mi kararına varmadan evvelki süreç şöyle betimlenebilir: Örneğin "Eş’arî Kelâm geleneği" söz konusu ise, "gerçekten ne demişti" diye sorarak bizzat Eş'ari'nin kendisi üzerinde; "acaba ilk Müslümanların dünyaya bakışları böyle miydi?" diyerek Metn'in ilk muhatapları üzerinde; ve, hepsini karşılaştırmak için, "Bizzat ne demektedir?" sorusuylayla da Kur'ân'ın/Metn'in kendi üzerinde yoğunlaşııır.

Misali devam ettirirerek şunu diyebiliriz. Yanlış anlaşıldığını düşündüğünden Eş'arî̀nin Kelâm sistemini "ıslah"ı Muhammed ikbal'in gerçekleştirmeye teşebbüs ettiği söylenebilir. Eş’arî geleneğini hem Kur'ân'ın ilk muhatapları, 
hem Kur'ân ile karşılaştırması açısından Fazlur Rahman birincisine de (ıslahat) dahil edilebilir gözüküyorsa da; onu neredeyse "Metn'in tahrifi" gördüğünden ondan kopuşu, yani, hala ve her halükarda bağlayıcı addedilen "Vahiy illkeleri"ne geri gitmeyi (modernizm) daha açık temsil eder.

Üçüncü yol ise en köklü "anlam krizine" işarettir. Geleneğin her boyutu "geri dönülemez" hatta "düzeltilemez" görülüp, tamamen değiştirilmeye veya silbaştan "yeni"nin yaratılmasına gidilir. Bilgi sosyolojisi bakımından önemine binaen bunu diğerlerine nazaran uzun ele alacaksak da, yine aynı bakımdan böyle görülmesi gerekmediğini de söyleyeceğiz.

Bu tarz, şöyle bir sosyolojik analize dayandırılabilir ve yeni İslam Kelamcıları tarafından gayet ciddiye alınmalıdır. Modern dünyanın doğuşu, gelişatı ve gidişatı, teolojik (Tanrı merkezli) yorumların fiziksel ve toplumsal dünyaya yönelik sonuçlarını çok önemli oranda başkalaştırdığı için, devamlılıkları engellemektedir. Çünkü, "gelenek" ile "bugün" arasındaki teologun meşgul olması gerekecek metodolojik "boşluk" alabildiğince genişlemiştir. "Modern dünya"nın doğuşu ve mevcudiyeti böyle metodolojik çabaları boşa çıkarır. Örneğin modern bilimlerdeki gelişmeler geleneğin kozmolojisini (evren görüşünü) ve antropolojisini (insan doğası görüşünü) olanaksız kılar (26). Bu da, bizzat bazı teologlara bile, teolojik akideleri yeniden ifade çabalarını beyhude gördürür (27).

Ancak, bize göre, bilgi sosyolojisi açısından bakılırsa, geçmişi ve geçmiş bilgileri şimdiki egemen fikirlerden ve bilgilerden ayıran "büyük boşluk" geçilemez ve aşılamaz addedilemez. Yine aynı açıdan bakılınca, "boşluk"un gerçekliği gerçektir kuşkusuz; ne var ki, bu gerçeklik, miras alınan sembolik dünyaları sürekli yeniden donatmak için yaratıcı itki gibi de düşünülebilir.

Başka söyleyişle; modernitenin (modern dünyanın) adeta yapısal nitelikleri yeni teolojik hermeneutiğin kendini "gereklilik şüphesine" düşürmüşse de, dünyayı dinsel açıdan anlamlı kılmak isteyenler mevcut oldukça, "dinsel sembol sistemleri" ile diğer ve yeni varlık ve bilgi alanları arasında irtibatlar kurulmaya devam edilecektir gibi görünüyor bilgi sosyolojisiyle bakınca (28). Ne ki; "modernlik fenomeni"nin doğası veya özü yani "anlam krizi", yöntemsel tutumlardaki tutarlılığı ve gelenek ile devamlılığı dumura uğratabilmektedir yine de.

Mamafih, bilgi sosyolojisinin temel önermeleri zaviyesinden bakınca; mesele gelenekten ya da günümüzden yeni olgular toplamak da değildir zaten. Onların bütünlüğüne ve tutarlılığına yeni teolojik yorum getirmek ve yeni bir terkibî sunuşta bulunmaktır. Başka ifadeyle; "din”in gücünü zamanımıza iletmek, mekânımıza taşımaktır. Yani mesele, Tarih ilımi'nin yaptığı gibi "olgular toplamak" değil, "hermeneutiksel"dir: Metni veya metinleri günümüzdeki okuyucunun veya muhatabın fiziksel ve toplumsal evren'e dair anlam ve anlama krizi ile irtibatlı hale getirecek yorumlar yapmaktır. Daha başka türlü dersek; yapılacak iş, Metnin ve metinlerin şu anki bireyler tarafından ilgisel algılanması ve kendi hayat durumlarına ve durum tanımlarına aktarılabilmesidir. İi de bir 
hatırlatmak ve tahkim etmek istemiyoruz ama, bu görev bilgi sosyolojisinin anlama usullerini kullanan bir "Yeni Kelâm" ile yerine getirilebilir ancak.

\section{Yeni Kelâm}

Geleneksel Kelâmî Öğreti "gerçeklik/varlık/hakikat" bizim tamamen dışımızda ve "işte-orada-var" diyen bir realist ontoloji; "bilgi" dışarıda "verili" ve kesin olup yalnızca yeniden keşfedilmeyi bekler diyen bir dışarıdancı epistemoloji; insanın tüm davranışlarının ta önceden belirlenmiş ve insanın "etkisiz" bulunduğunu temele alan bir determinist insan doğası/fıtratı görüşü; ve, sırf fiziksel evrenin değil insansal evrenin de, yalnızca, verili olanları yeniden "genel ve tanrısal insanlık yasaları uyarınca" toplamak ile bilinebileceğini ileri süren nomotetik metodoloji çerçevesinde, yani neredeyse tam bir "pozitivist yaklaşım”la hareket ediyor gözükmektedir.

Şöyle de denebilir: o, "tarih-dışıı"bir manzara sergilemekte yukarıdaki temel varsayımları açısından:

Sadece fiziksel gerçeklik değil, toplumsal gerçeklik de "işte-oradaezelde(n)-vardı". "Eğer yok gibi idiyse"; yalnızca ezelde belirlenen, determine edilen vaktin gelmesi, getirilmesi gerekiyordu olgusal varlık alanına çıkması, çıkarılabilmesi için. Kur'ân'ın vahyedilmeye; böyle telakki edildiğinden, "akıtılmaya" başlanmasında bizzat Peygamber'in tarihsel koşulları ve zihni, vahyin sonraki devamında o dönem insanlarının zihni; ve başka zaman ve mekanlardaki tüm insanların da vahyi anlama bakımından zihinleri edilgendi. Kur'ân önceden "yazılmış" olduğundan; tarih de, toplum da önceden kurulmuştu. Toplumda geçen olaylar ve durumlar ezelde zaten yazılı olanların tekrarı, temsilî yeniden-üretimleriydi. İnsanların tarih içerisindeki gerçek üretimleri değil, ezelde Tanrı yaratısı idi onlar. Ebu Leheb şu yılda, şu günde, şu saatlerde değil de, "ezelde" Peygamber'e zulmetmiş ve Peygamber'e ezelde "Ebu Leheb'in eli kurusun" detirtilmişti. Peygamber'i yalnızca umumi toplumla değil, en yakını kimselerle az kalsın ciddi ihtilafa düşüren ve Aişe'ye büyük ıstıraplar çektiren "ifk Olayı" ezelde olup bitmişti aslında, ama yeniden-üretilmişti. Peygamber'in "Taif elemleri" ezelde belirlenmiş; çocukların arkasından "deli deli küpeli..." diye koşuşturup yırtık pırtık elbisesine çalı çırpı takıştırmaları "temsilî olarak" yeniden-yaşatılmıştı. Kız bebecikler, aslında, ezelde diri diri toprağa gömülmüşlerdi de, tekrar, ezeliyi temsilen gömülmeleri gerekiyordu... (29)

Yani, kısacası, her türden toplumsal ve bireysel 'olgu' ve onlara dair 'bilgi' ezelde 'hazır' idi; sadece açığa çıkması, çıkarılması gerekiyordu "genel ve tanrısal doğa yasaları" nın zorunlu ve kaçınılamaz uzanımları gibi. İnsanlar, "doğaları gereği", hem geniş manada "toplumsal davranışları" açısından, hem diğer insanlara ve dünyaya mukabeleleri açısından "önceden-belirlenmiş" biçimde hareket etmekteydiler. Bu nedenle, toplumsal dünyaya ve tarihsel sürece "insanın dışında bir dünya ve süreç" olarak bakmak gerekiyordu epistemoloji ve yöntem yönünden. 
Yeni Kelâm bunların hepsinin tersini savunacaktır. Kur'ân elbette Peygamber tarafından yazılmamış ise de, Fazlur Rahman'ın dediği gibi, "onun Allah'ın vahyi olduğuna inanmayan bir kimse ismen bile Müslüman olamasa" da; ezelde de yazılmış değildir. Bu yüzden, yedinci asırdaki toplumsal gerçeklik/dünya ezelde "işte-orada-yok"tur. Toplumsal dünyayı kurumlarıyla, kurallarıyla, ıstıraplarıyla yönelimsel insan bilinçleri kurmuşlardır. Peygamber'in zihni kuşkusuz dahil, insan zihni etkindir; pasif alıcı değildir. Öyleyse, insan ve davranışları önceden belirlenmiş (takdir) hatta aynen kurulmuş (kader) olamaz. Yalnızca tarihsel ve toplumsal dünyayı değil, Kur'ân'ı da böyle bir epistemoloji ve buna dayalı bir yöntem ile inceleyecektir Yeni Kelam.

\section{Değerlendirme ve Sonuç}

Bu çalışma, Kelâm İlmi'ni bilgi sosyolojisine davet ve bunun uzanımlarını göstermek maksadıyla kaleme alınmıştır. "Giriş" olarak kararlaştırıldığından sınırlı tutulmuştur. Uzanımları birkaç misalle olsun sunmaya çabaladığımız için, sonraki çalışmalarda ne yapacağımız belli de olabilmiştir. Dolayısıyla, "giriş" hedefi şimdilik yeterince gerçekleştirmiş̧ir denilebilir.

Demek istediğimiz şudur. Kelâmi akideler, din sosyolojisine dönüştürülen bir bilgi sosyolojik bakış açısıyla; yani, "her türden dinsel bilginin (burada akidenin) ancak ortaya çıktığı veya çıkarıldığı bağlamlarda anlaşılabileceği ve anlamlandırılabileceği" görüşüyle yeniden ve tekraren incelenmelidir.

Tamamlayıcılık bakımından, aynı görüşle günümüz halleriyle de incelenmeliler hepsi. Aksi takdirde, zaten, bilgi sosyolojisi bir "tarihsel çaba" niteliğinden çıkıp "tarih çabası"na dönüşüverir. Halbuki, varsa, anlam ve anlamlandırma ve böylece "dinsel dünya kurma" ayrılıkları ve yenilerini kurma ihtiyacı, yalnızca, geçmiş ve bugünü karşılaştırmalı bir "tarihsel çaba" ile anlaşılabilir.

Yukarıdakileri, Berger-Luckmann'ın özgün bilgi sosyolojisine borçlu olduğumuz muayyen bir ontolojik varsayım ve gerektirdiği yöntemsel bir tutumla söylüyoruz.

Anti-realist olan bu ontolojik varsayımı fenomenolojik dile dökersek şudur: Toplumsal/dinsel dünya (dinsel kurumlar, kurallar, davranışlar; ve de akideler...), zamansal ve mekansal açıdan belli bir yerde duran ve oradan hayata bakan yönelimsel zihin edimlerinin dışa vurumu olan insan eylemlerinin ürünüdür. "işte-orada-var-olan" hazır bir toplumsal/dinsel dünya yoktur. Aşkın'a atıfla da olsa, insan hayatını açıklama, insani ve fiziki hadisatı tanımlama ve tüm bunları anlayıp bir düzene sokma faaliyetinde bulunan insanların zihinlerindekini "dışşallaştırmaları", "nesnelleştirmeleri" ve böylece "dinsel dünya kurmaları" vardır. Bu kuruluş böyle sürer gider ve yöntemsel olarak da bu gidişin izlerini sürer yöntemimiz.

Bu türden bir bilgi-sosyolojik "tarihsel çaba" ile ortaya konulan hatta ortalığa serilen tüm "dinsel dünya değişimi" verilerine rağmen; gelenekten devralı- 
nan bilgileri/akideleri (Geleneksel Kelam'ı) iman meselesi addedenlerin onlarla kurdukları dünyalarını sürdürme hakları bulunabilir. Gelenekli bilgiler ile bugünkü bilgileri; ikisi ile de kurucu Metinleri karşılaştırarak yeni bir dinsel dünya kurmanın imkanını veya imkansızlığını bizzat görmek isteyenler de daha aşağı hakka sahip değildirler ama. Çünkü; eğer ki mukayeseli incelemeler ve araştırmalar sonucunda veriler değişirse, insanların hayatı anlamlandırma çerçevesi değişebilir. Bu değişirse, toplumsal-dinsel dünya(lar) değişebilir.

Kelâm'ı bilgi sosyolojisine çağııı̧ımızın ilk ve son anlamı en azından bu ihtimalin farkına varma ve vardırmadır. Böyle bir Kelâm, 'dini ilimler'e, hatta isteniyorsa sosyal bilimlere temel varsayımları sunan ana bilgi dalı olma işlevini de deruhte edebilecektir.

Yaptığımız, bir "ihtimal muhasebesi"ne çağrı; bir "olasılıklara açıklık" çağrısıdır. Yoksa, Kelâm'a ne "eşyanı topla bizim eve yerleş" seslenişidir; ne "geçmişi lanetleyip bugünü kutsayan" bir tutuma davettir. Bilgi sosyolojisi "gel ve hep bizde kal" diyecek denli tekelci olamaz. "Zamanı ile evlenen, çok vakit geçmeden boşanmış bulur kendisini" dediğinden, "bugünü kutsayıcı" da olamaz.

Velhasıl, öyle görünüyor, "kader akidesi" bilhassa tâbi tutulmalı bilgi sosyolojik analizlere. Münhasıran ve mütemadiyen çağrılmalıdır ona. Kelâm’ı sosyolojiye davette en iddialı olunabilecek konu da budur muhtemelen.

Dolayısıyla; Kelâm'ı bu konuda bari mutlaka ve uzunca misafir etmeliyiz diye düşünüyoruz (30).

\section{Notlar}

$\left(^{*}\right)$ Doç. Dr., Dokuz Eylül Üniversitesi İlahiyat Fakültesi, e-posta: adil.ciftci@deu.edu.tr

(1) 'Dînî ilimler' tabirini tek tırnak içerisinde kullanmak çekince ifade etmektedir.

(2) Kelâm IIlmi'nde "yenilik" çabalarının kısa tarihi için bkz. Harputî, 2005 içinde Muammer Esen'ce yazılan Giriş. Aynı konuda tartışma ve teklifler için; Baloğlu-Ünal, 2000.

(3) Tek başına ve çift tırnak içinde "Kelâm" ile hep Kur'an kastedilecektir.

(4) Kitapların bazen yakılma nedeni de budur. Herkesin yanlış dediğine doğru diyen bir metin, varolmaya devam ettiği sürece, sonsuza dek "yanlışıyla yaşar" (Ong, 1995: 98).

(5) "Kader" konusuna farklı maksatlarla geri dönebileceğiz.

(6) Orhan Türkdoğan, bilimin "kesinlik kazanmayan temellerini” sıralayıp "ka-nıtlanmaları mümkün değildir" der (Türkdoğan, 2000: 212-213). Buraya "kanıtlan-maları" olarak aldığımız kelime, "kanıtlanmamaları" yazılmış. Öncesine sonrasına baktığımızda yanlış yazıldığı anlaşılmaktadır. S. 213, sondan 4. satır başı. Böylece, bir kelime "lafzen" mevcut ise de "anlam olarak" mevcut olmayabilir şeklindeki hermeneutiksel ilkemizin çok açık uygulanışını da sergilemişizdir. Okuyucu bunun başka örneklerini diğer telif ve tercümelerimizde de bulabilir.

(7) Kelâm'ın temel konularından Tanrı ve sıfatları gibi meselelerin BF ve SBF eserlerinde asla yer alamayacağı söylenerek itiraz edilebilir. Ama bu eserlerde, hele mesela Locke ve Berkeley söz konusu ise, bir şekilde işlendikleri de iddia edilebilir. İddiamızı destekler mi emin değilsek de bkz. (Açıköz, 2003). 
(8) Ebû Hanife'nin Çantay tarafından terceme edilen Fıkh-ı Ekber adlı risaleyi ve içeriğinin çok büyük oranda Kelâmî olduğunu hatırlatmaya gerek var mı bilmiyoruz. En azından, Çantay'ın takdim yazısında, "Ehl-i Sünnet itikadının ilk temel bilgilerini kucaklayan ve Fıkh-ı Ekber adı verilen bu risâle..." ifadesinin şimdiki paragrafın içeriği olan belirlemelerimizle örtüştüğüne dikkat çekmek isterdik.

(9) Fazlur Rahman el-fıkh el-ekber yazarak benzer analizler yapar, fakat Ke-lâm'ın Baş ilimliğini pek de bizim gibi anlamıyor görünmektedir. Ne var ki dînî ilimler hiyerarşisinde yeri açısından Gazali'ye atıfla söylediklerine bakılınca birleşme müm-kündür (Rahman, 2000: 80-81).

(10) Mesela, Adil Çiftçi, Fazlur Rahman ile İslâmı Yeniden Düşünmek, "Kelâm” Bölümü.

(11) íki tutumun ontolojik, insan doğası, epistemolojik ve yöntemsel ana varsa-yımları ve alabildiğince ayrıntıları için bkz. (Çiftçi, 2003).

(12) Biz bu ikincisini savunuyor, burrdaki yeniden kuruluş gerekçesini de buna dayandırıyoruz.

(13) Bu ve diğer konular açısından hemen hemen tüm Kelam kuramlarını kısa kısa ele alan bir çalışma için bkz. (Tritton, 1978).

(14) "Sir, I have no need of such an hypothesis." (Hobsbawn, 1985: 267). Bura-daki ve çevirideki vurgu bize ait.

(15) En somut örnek olarak Laplace"a atfedilen bu düşünce, klasik fiziğin tam zemininde vardır desek pek hatalı olmayız.

(16) En azından "Tanrı fikri”ne yer açtığına imâda bulunulduğu izlenimi veren analizler için bkz. (Güngör, 1993: 61-78). Muhammed ikbâl imâ etmenin ötesine geçmekteydi görünüyor. Bir çevirimiz vesilesiyle İkbal'e yönelttiğimiz eleştiriler için bkz. (Rahman, 2000: 88, 18. dipnot -çevirenin notu). Acaba Türkdoğan'dan da böyle bir imâ çıkarsanabilir mi? Bilimsel Araştırma Metodolojisi, "Modern Fizik ve Evren Teorisi” başlı̆̆ı.

(17) Bu mesele için bkz. (Çiftçi, 2002).

(18) "Bizde de gerçekliği varsa" sözcüklerini bilinçlice, temkin ve tedbir için kul-lanıyoruz. Zira, biz "varlığını" biliyorsak da, başka konularda olduğu gibi bu konuda da bazılarının "Batı'da ortaya çıkan sorunları bize yansıtıyor, bizde de varmış gibi konuşuyorsun" deme ihtimali epeyce büyük.

(19) Wiles bu anlamda sosyolojiye çağırıyor teolojiyi (Wiles, 1976: 6).

(20) Nelson Goodman Ways of Worldmaking, Peter L. Berger The Sacred Canopy, Clifford Geertz The İnterpretation of Cultures çalışmaları, Berger hariç, münhasıran "bilgi sosyoloji"si merkezli konuşmasalar da bu hususu işlerler. Onun mahsusen "dinsel deneyim" ile ilişkisi bakımından incelenişi için bkz. (Proudfoot, 1985).

(21) Fazlur Rahman, Eş’ari sistemini kastederek, mantıksal tutarlılı̆ı̆ dinin ha-kikatlerini yansıtmada yeterli olamayacağını söylüyordu.

(22) Berger ve Luckmann'ın Social Construction of Reality adlı eserine müraca-atla "sembolik evren" tabirinin güzel bir sunuluşu için bkz. (Brent, 1975: 212-213).

(23) İlhamî Güler'in Allah'ın Ahlâkîliği Sorunu isimli eserinin ana teması budur desek yazar itiraz etmezdi sanırız. Fakat bununla vardığı mantıksal sonuç şu anki ile aynı gözükmüyor.

(24) "Aydınlanma" sözcüğü ile başlayan cümleler, fişe bakılırsa, pek muhtemelen Gadamer'den mülhem. Fakat test edemedik. 
(25) İslam geleneğinde buna "Kelâm" denilmesi bu yüzden de boşuna değildir: O, varlıklar ile ilişkisi içerisinde Allah ve sıfatları üzerine "kelam etme"dir. Bilindiği gibi "kelâm" sözle de yazı ile de edilir.

(26) Bunun biraz olsun ayrıntıları için bizim "Toplumbilim, Teoloji ve Bilgi Sosyo-lojisi” adlı yazımıza bakılabilir.

(27) Diğer yandan; başka kültürler ve dinler ile her zamankinden daha açık ve yoğun ilişkiler, teologu seçeneksel dünya görüşlerinin farkına ve bilincine de vardı-rır. Bu da, onun "neyin doğru ve ahlakî olduğu" hususundaki kabullerini kaçınılmaz biçimde dönüştürebilir. Şimdilik bunun üzerinde durmayacağız.

(28) Berger'in “"'Dinî ve Toplumsal Kurumların Değişimi” başlığıyla çevirdiğimiz bir makalesi tam da böyle biter; s. 173-174. Şimdi ilgilendiğimiz konudaki birkaç analizimiz için de ona bakılabilir.

(29) Farklı bağlamda girdiğimiz Bilgi Sosyolojisi ve İslam Araştırmaları adlı kita-bımızda vurgulayıp biraz açtığımız gibi; bunlar Allah'ın ahlakiliği ile ilgili ciddi sorunlar çıkarmakta.

(30) Kelam ile ilgili bilgi sosyolojik çalışmalarımızı sürdürdüğümüz gibi, üzerinden diğer alanlara dair de kitap hacminde çalışmaktayız. Buna, Bilgi Sosyolojisi ve İslam Araştırmaları kitabında Bölüm ayırdığımız Tasavvuf dahil. Tamamlanmış sayılabilecek o kitap şu teze dayanmaktadır: "Gerçeklik/varlık/hakikat" bizim tamamen dışımızda ve "işteorada-var" diyen bir realist ontoloji; "bilgi" dışarıda "verili" ve kesin olup yalnızca yeniden keşfedilmeyi bekler diyen bir dışarıdancı epistemoloji; insanın tüm davranışlarının salt şimdiki koşullarca değil ta önceden belirlenmiş ve insanın "etkisiz" bulunduğunu temele alan bir determinist insan doğası/fıtratı görüşü; ve sırf fiziksel evrenin değil insansal evrenin de, yalnızca, verili olanları yeniden "genel ve tanrısal insanlık yasaları uyarınca" toplamak ile bilinebileceğini ileri süren nomotetik metodoloji çerçevesinde; yani neredeyse tam bir "pozitivist yaklaşım" ile hareket eden "Geleneksel Kelâmî Öğreti"; köklü değişimi onaylamayan bir Hukuk’a ve bir "tarih-dışı Peygamber anlayışı"na (Hadis Usulü) varabilirdi ancak.

\section{Kaynaklar}

Açıköz, H. M., Berkeley ve İmmateryalist Metafiziği, Elis, Ankara 2003.

Baloğlu, B. ve B. Ünal (ed), Kelâmın İşlevselliği ve Günümüz Kelâm Problemleri, İzmir 2000.

Berger, P. L. \& T. Luckmann, "Sociology of Religion and Sociology of Knowledge", Sociology of Religion, ed. Roland Robertson, Penguin Books, Middlesex 1969.

Berger, P. L., Kutsal Şemsiye, çev. Ali Coşkun, Rağbet Yayınları, İstanbul 2000 (2. baskı).

Berger, P. L., The Social Reality of Religion, Penguin Books, Middlesex 1973.

Berger, P. L. ve T. Luckmann, "The Social Construction of Reality", Modern Sociology, ed. P. Worsley, The Open University, New York 1966 (2. baskı).

Berger, P. L, "Dinî ve Toplumsal Kurumların Değişimi", çev. Adil Çiftçi, Din ve Modernlik: Toplumbilim Yazıları I, Ankara Okulu, Ankara 2002 içinde.

Brent, A., "The Sociology of Knowledge and Epistemology", British Journal of Educational Studies, Vol XXIII No 2 June 1975.

Cobb, J. B., Process Theology as Political Theology, Manchester University Press, Manchester 1982.

Çiftçi, A., "Toplumbilimi, Teoloji ve Bilgi Sosyolojisi", Din ve Modernlik: Toplumbilim Yazıları I, Ankara Okulu, Ankara 2002.

Çiftçi, A., Fazlur Rahman ile İslam'ı Yeniden Düşünmek, Kitabiyat Yayınları, Ankara 2001 (2. baskı).

Çiftçi, A., Nasıl Bir Sosyal Bilim, Kitabiyat, Ankara 2003. 
Çiftçi, A., Anlayıcı Yaklaşım ve Din Sosyolojisi için Uzanımları, Kitabiyat, Ankara 2004.

Ebû Hanife, İmâm-ı A'zam, Fıkh-ı Ekber, çev. Hasan Basri Çantay, Olgaç, Ankara 1982.

Green, R. M., Religion and Moral Reason: A New Method for Comparative Study, Oxford University Press, Oxford 1988.

Geertz, C., "Religion as a Cultural System", ed. M. Banton, Anthropological Approaches to the Study of Religion, London 1966.

Geertz, C., The Interpretation of Cultures, Basic Books, New York 1973.

Goodman, N., Ways of Worldmaking, Hackett, Indianapolis 1978.

Gustafson, J. M., Theology and Ethics, Basic Blacwell Publisher, Oxford 1981.

Güler, ì., Allah'ın Ahlâkîliği Sorunu, Ankara Okulu, Ankara 1998.

Güngör, E., i̇slâmın Bugünkü Meseleleri, Ötüken, İstanbul 1993

Harputî, A., Kelâm Tarihi, sadeleştiren ve notlandıran Muammer Esen, Ankara Okulu, Ankara 2005, Giriş.

Hirsch, E. D., The Philosophy of Composition, UC.Press, Chicago 1977.

Hobsbawn, E. J., The Age of Revolution: 1789-1848, Abacus, London 1985.

Ong, W. J., Sözlü ve Yazılı Kültür, Metis, İstanbul 1995.

Martin, D. ve diğerleri, Sociology and Theology: Alliance and Conflict, St. Martin's Press, New York 1980.

McGuire, M. B., Religion: The Social Context, Wadsworth Publishing Company, BelmontCalifornia 1992 (3. baskı).

Proudfoot, W., Religious Experience, UC.Press, Los Angeles, 1985.

Rahman, F., "Hukuk ve Teolojinin Karşılıklı Bağımlılı̆ı", İslamî Yenilenme: Makaleler II, (çev. Adil Çiftçi), Ankara Okulu, Ankara 2000 (2. baskı).

Remmling, G. W., The Sociology of Karl Mannheim, Routledge \& Kegan Paul, London 1975.

Ryba, T., The Essence of Phenomenolog and Its Meaning for the Scientific Study of Religion, Peter Lang, New York 1991.

Scharf, B. R., The Sociological Study of Religion, Hutchinson \& Co, London 1970.

Tritton, A. S., İslâm Kelâmı, çev. Mehmet Dağ, Aüif Yayınları, Ankara 1978.

Türkdoğan, O., Bilimsel Araştırma Metodolojisi, Timaş, İstanbul 2000.

Wiles, M., What is Theology, Oxford University Press, Oxford 1976. 



\title{
KADIN DINDARLIĞI: BİR PARADOKSUN SÖYLEDÍKLERİ
}

\begin{abstract}
Religiosity of women: What a paradox says. Women and men have different types of religiosity as a result of their roles and status in the context of sociocultural life. Research indicates that women with their inborn biological characteristics and their position in social life seem to be much more religious both qualitatively and quantatively. The fact that women are much more religious is a paradox given their position in social life. This study deals with an analysis of religiosity of women that is regarded as a paradox. In order to carry out such an analysis, both gender and sociocultural role and status of women are used to investigate the factors shaping the religiosity of women. Thus, the assumption that women are much more religious is shown and analysed using factual samples from several cultures and theoretical information on the religiosity of women is provided as an outcome of the paradox.
\end{abstract}

\section{key words}

Religiosity of genders, religiosity of women, gender, social gender. 


\section{Giriș}

Sosyokültürel yaşamın iki ayrılmaz yaratıcı bileşeni olarak kadın ve erkek, sosyal gerçekliğin bağlamı ve kendi varoluşsal karakterleri ile birbirlerinden farklı değer, dünya görüşü, tutum ve davranış biçimlerine sahip olagelmişlerdir. Kadın ve erkeğin bu çerçevede şekillenen değer, tutum ve davranışlarının temel özellikleri sosyokültürel yaşam ile biyolojik varoluş zemininde inşa ettikleri kendi öznelliklerine dayanmaktadır. Başka bir ifadeyle kadın ve erkeğin düşünsel ve eylemsel yönelimleri toplumsal cinsiyet ile biyolojik cinsiyet özelliklerinden çeşitli biçimlerde etkilenmektedir. Bununla birlikte toplumsal ve biyolojik cinsiyet sosyal hayattan yalıtılmış bir alan ve zamanda meydana gelmemekte, sosyokültürel yaşamın temel değer ve dünya görüşünün kodlarına bağlı olarak şekillenmektedir. Dolayısıyla sosyokültürel yaşam toplumsal cinsiyet ve biyolojik cinsiyetin temel karakteri üzerinde belirleyici bir etkide bulunmakta, ancak bireyler yine sosyal yaşam içindeki konumları ile sosyokültürel hayatın sunduğu bu özellikleri kendi bağlamlarına göre, kendi değer ve dünya görüşleri ekseninde süzerek öznelleştirmektedirler. Bu yönüyle sosyokültürel yaşam kadın ve erkek olmaya dair cinsiyet algısını inşa etse de bireyler de özgün bireysel ve toplumsal varoluşları ile sürece müdahil olabilmektedirler.

Kadın ve erkeğin sosyal dünya ve kendi özgün varoluşları temelinde sergiledikleri söz konusu farklılaşmanın tipik bir biçimde yansıdığı bağlamlardan birisi de dindarlıktır. Tıpkı sosyokültürel yaşamın genel bağlamı gibi dindarlık da bir yönüyle cinsiyet algısının oluşmasında etkili olurken diğer yönüyle de cinsiyet algısından etkilenen bir boyuta sahiptir. Dindarlığın cinsiyet algısını etkileyen aynı zamanda da mevcut cinsiyet algısından etkilenen boyutu ise cinsiyet dindarlığında somutlaşmaktadır.

Bu makale cinsiyet merkezli dindarlık farklılaşmasının temel bir boyutu olarak kadın dindarlığını sosyolojik bir bakış açısıyla değerlendirmeyi amaçlamaktadır. Problemin özelde kadın dindarlığıyla sınırlandırılması nedeniyle dindarlıkla ilgili genel tartışmaların detaylarına inilmemiştir. Bunun yerine dindarlık tipolojisi içinde güçlü bir biçimde kendisini hissettiren cinsiyet kategorisine dayalı kadın dindarlığına odaklanılmış, kültürel bağlam ve yansımalar ekseninde kadın dindarlığını açıklamaya dönük kuramsal yaklaşımlar irdelenmiştir. Türk akademi dünyası için yeni bir adım olsa da Batı'da genelde cinsiyet dindarlığı, özelde ise kadın dindarlığına dair pek çok kuramsal yaklaşım geliştirilmiştir. Söz konusu yaklaşımlar biyolojik vurgusu yüksek eğilimlerden sosyolojik vurgusu baskın eğilimlere kadar geniş bir yelpazeyi oluşturmaktadır. Sosyolojik yöntem içinde analize konu edilen ilgili kuramsal yaklaşımlara özellikle Türk kadın dindarlığını tanımlama ve açıklamada sundukları karşılaştırma potansiyelleri çerçevesinde işaret edilecektir. Ancak bundan önce kadınlık konumunun şekillendiği özel koşulların ortaya konmasının dindarlığın da dahil olduğu kadın araştırmalarının 
metodolojik zorluklarından birisi olduğu göz önünde bulundurularak cinsiyet olgusuna dair kuramsal eğilimlere yer verilmiştir (Sirman, 1993: 248).

Böylece bir yandan kadın dindarlığının sosyokültürel kurum ve süreçlerdeki zihni ve pratik alt yapısı, kadınla ilgili özgül biçimlerin belli faktörlere indirgenmeksizin ele alınması sağlanırken diğer yandan da Batı merkezli kuramsal yaklaşımların kültürel çeşitliliği sınırlı düzeyde yansıtan eğilimi eleştirel bir bakışla okuyucunun değerlendirmesine sunulmuştur. Bu yönüyle sadece kadın dindarlığına dair kuramsal eğilimlere temas edilmemiş aynı zamanda toplumsal gerçekliğin özgüllüklerini göz ardı eden tipolojik kurgular eleştirel bir yaklaşımla değerlendirilmiştir. Çalışmanın kapsamına teorik yaklaşımların yanı sıra kadın dindarlığına dair Batı'da ve Türk toplumunda yapılan bazı alan çalışmalarının verilerine dayalı olgusal bir boyut da dahil edilmiştir. Kuramsal yaklaşımlarla toplumsal gerçekliği buluşturan yöntemimiz, nispeten bu çerçevede özgül bir kavramsallaştırmayı hedeflemektedir. Elbette bu kavramlaştırma girişimi sosyokültürel gerçekliğin dünyasına da dokunan problemler çerçevesinde zihinsel bir inşa sürecini gerektirmektedir.

Her şeyden önce bu çalışma cinsiyet temelinde dindarlıkta bir farklılaşmanın olduğunu, kadınların kendi özgün varoluşları ile sosyokültürel bağlamları temelinde farklılaşan bir dindarlık tipini temsil ettiklerini varsaymakta, bu çerçeveden olmak üzere bir kadın dindarlığının imkânını sorgulamaktadır. Burada gerek "kadın dindarlı̆ı"” nın kuramsal ve olgusal bir zeminde kavramlaştııımasına gerekse de söz konusu kavramın bu çalışmada yer verilmeyen çeşitli boyutlarına dair okuyucunun zihninde yeni açılımlar yaratılmasına yardımcı olacağı düşünülen bazı sorulardan hareket edilmiştir: "Kadın dindarlığı" kadınların kendi özgün duruşları ile sosyokültürel bağlamlarına referansla içi doldurulmuş bir kavram mıdır yoksa ataerkil yapı ve kurumsal dindarlıkla ilişkileri çerçevesinde merkeze konmuş erkek kategorisine nispetle şekillenmiş bir kavram mıdır? Bu yönüyle kadın dindarlı̆̆ı ile kadın kategorisinin kendi özgün karakterinden beslenen bir dindarlık mı yoksa erkek dindarlığına nispetle ya da başka bir ifadeyle erkek dindarlığına göre teşekkül etmiş bir dindarlık mı kastedilmektedir? Kadın dindarlığını erkek dindarlığına göre konumlandırmak kadın dindarlığının erkek dindarlığının ötekisi olarak algılanışını beraberinde getirir mi? Kadın dindarlığını erkek dindarlığına göre anlamak ya da kavramlaştırmak, kadın kategorisini ve bu kategorinin temsil ettiği dindarlığı erkeğin gölgesinde görmek suretiyle kadın ve kadın dindarlığına dair epistemik bir probleme işaret eder mi? Kadın kategorisi ve dindarlığının erkek kategorisi ve dindarlığına nispetle algılanışına karşı çıkmak ve erkeğe rağmen bir kadın dindarlığından bahsetmek feminist bir eğilimi mi temsil eder? Kadın ve erkek kategorilerini diyalektik bir biçimde ilişkili görmek suretiyle kadın dindarlığını kadın kategorisinin özgün varoluşu ve sosyokültürel bağlamı ile erkek kategorisi ve dindarlığı arasında kurulacak analojiler çerçevesinde ele almanın imkânı var mıdır? 
Epistemik bağlama ilişkin bu türden sorular, olguyu daha spesifik ve mikro düzeyde ele alan soruları da problem alanına çıkarmaktadır. Buna göre, her şeyden önce olgusal düzeyde bir kadın dindarlığından söz etmek mümkün müdür? Kadın dindarlığının oluşumundaki temel değişkenler veya unsurlar nelerdir? Kadın dindarlığını nicel ve nitel düzeyde erkek dindarlığından ayrıştıran etkenler nelerdir? Cinsiyet temelli dindarlık farklılaşması, nitelik ve nicelik olarak erkek ve kadın arasında dindarlığın farklı yoğunluklara sahip olması anlamına gelir mi? Oldukça yaygın bir genellemeyle ifade edildiği gibi, kadınlar erkeklerden daha dindar mıdır? Eğer öyleyse bu dindarlık kendini hangi boyutlarda göstermektedir? Eğer kadınlar, erkeklerden daha dindarlarsa bunun toplumsal ve kültürel güdüleyicileri nelerdir? Kadın dindarlığı için öngörülen bu varsayımlar, sosyolojik geçerliliği yüksek sayıltılar mıdır, ya da bir başka deyişle tüm toplumlar için genel-geçer midir, değilse toplumlara özel kadın dindarlıkları mı üretilmektedir? Cinsiyet dindarlığı değişmez ve statik bir olgu mu dur? Genel dindarlık anlayışının kadın dindarlığı ile etkileşim düzey ve biçimi ne şekilde olmaktadır?

Kadın dindarlı̆̆ını genelden özele derinleştirecek bir biçimde sınıflandıran bu sorulara ilave olarak bu çalışma kültürel bağlamla ilişkili şu soruları da ilgi alanının dışında tutamayacaktır. Türk toplumunda kadın dindarlığının güdüleyicileri nelerdir? Bu güdüleyiciler eğitim ve gelir düzeyi, sosyokültürel statü, yaş, medeni durum, kent ya da kır kökenli oluş, ikamet süresi ve sosyalizasyon araçlarıyla ilişki gibi değişkenlere bağlı olarak özel kadın dindarlıklarını üretmekte midir? Bu bağlamda Türk toplumunda bir kadın dindarlığının imkânı nedir?

Tüm bu ve çalışmanın sınırlarını aşan ancak zihinlere yansıyan benzeri sorularla işaret edilmek istenen önemli bir husus da kadın dindarlığının çok yönlü, kapsamlı, derinlemesine sosyolojik analiz ve değerlendirmelere muhtaç bir konu olduğu gerçeğidir. Zira her ne kadar kadın merkezli sosyolojik çalışmaların sayıları giderek artsa da halen bir sosyal kategori olarak kadın dindarlığını ele alan sosyolojik çalışmaların yeterli düzeye ulaştığını söylemek oldukça güç görünmektedir. Kadın kategorisi, Türkiye'deki mevcut dindarlık çalışmaları içinde sadece cinsiyet değişkeni olarak kendisine yer bulurken, kadın dindarlığı da kuramsal ve kavramsal eğilimlerin gelişmesini de beraberinde getirecek biçimde derinlemesine analizlere konu olamamaktadır. Bu makale kadın kategorisi ve kadın dindarlığına dair sosyolojik bakışın niteliksel ve niceliksel olarak derinleşmesi için büyük adımlar uğruna küçük de olsa bir adım atmayı hedeflemektedir.

\section{Cinsiyet ve Toplumsal Cinsiyet: Kadın Doğmak ve Kadın Olmak}

'Cinsiyet' ve 'toplumsal cinsiyet' kadın ve erkek olmanın biyolojik ve fizyolojik boyutu ile sosyokültürel bağlam ekseninde şekillenen ikili karakterini ortaya koyan kavramlardır. Marshall, bu ayrımı yansıtacak biçimde 'cinsiyet'in (sex) 
biyolojik özellikler temelinde erkek ve kadını, 'toplumsal cinsiyet'in (gender) ise toplumsal olana referansla erkek ve kadın olmayı temsil eden kavramlar olduğuna dikkat çekmektedir. Bu yönüyle toplumsal cinsiyet bireysel kimlik ve kişiliğin dışında, sembolik düzeyde erkeklik ve kadınlığın kültürel idealleri ile kalıp yargılarını, yapısal düzeyde de kurumlar ve organizasyonlardaki cinsiyet merkezli işbölümünü kapsayacak kadar geniş bir içeriğe sahiptir (Marshall, 1999: 98-9). Ancak şunu da belirtmek gerekir ki her ne kadar toplumsal cinsiyet kavramı her iki cinse ilişkin referansları bünyesinde barındırsa da sosyolojik dilin erkek olmaktan daha ziyade kadın olmayı ifade etmek üzere toplumsal cinsiyet kavramına başvurduğu anlaşılmaktadır. Ayrıca, cinsiyet ve toplumsal cinsiyet, Batı orijinli kavramlar olup, dilden sosyal yapı ve kültürel anlam dünyasına kadar toplumsal bir gerçeklik ve tasavvur dünyasının kuramlarda kavramlaşmış biçimleri olarak sosyokültürel bir bağlamı temsil etmektedir. Bununla birlikte kadın ve erkek olmanın biyolojik ve toplumsal boyutlarının çeşitli toplum ve kültür tiplerinde kendine özgü formlarıyla mevcut olduğu, tutum ve davranışları etkilediğine dair yaygın sosyolojik kanaat toplumsal cinsiyet kavramını işevuruk hale getirmektedir. Böylece toplumsal cinsiyet ve biyolojik cinsiyet kavramları sosyokültürel bir bağlam çerçevesinde cinsiyetlerin değer ve dünya görüşleri ile tutum ve davranışlarının değerlendirilmesi için bir analiz aracı niteliğine bürünmektedir.

Giddens, kadınlarla erkeklerin davranışları arasındaki farklılıkların 'toplumsal cinsiyet'ten mi, yoksa 'biyolojik yapı'dan mı kaynaklandığı konusunda çeşitli yaklaşım farklııklarına işaret etmektedir. Örneğin sosyobiyolojinin bulguları, kadınlar ile erkekler arasındaki davranış farklılıklarını, bütün kültürlerde varolan, doğuştan gelen biyolojik farklııklara dayandırmakta, biyolojik belirleyicilerin etkisini vurgulamaktadır (Giddens, 2000: 97). Cinsiyet tartışmalarında biyolojik belirleyicilerin etkinliğini vurgulayan bu türden yaklaşımlardan daha yaygın olarak sosyal yapı ve kültürün cinsiyetle olan ilişki ve etkileşimi öne çıkartılmaktadır. Zira kadın biyolojik açıdan bir kategori olduğu kadar, sosyal açıdan da bir kategoridir. Dolayısıyla bu şekilde incelenmesi ve kategorik tasnifler içinde ele alınıp sorgulanması metodolojik bir gerekliliktir (Çelebi, 1990: 1).

Benzer bir biçimde cinsiyet ile sosyal statü ve rolleri biyolojik anlamda belli bir etkileşim içinde görülse de, bu etkileşimde yönlendirici olanın büyük ölçüde bireyin sosyal konumu olduğu ifade edilmektedir (Fişek, 1990: 82). Bu yönüyle cinsiyet olgusunu sadece biyolojik özelliklerdeki benzerliklere dayalı iki cins kategorisinde değerlendirmek, salt fiziksel özellikleri vurgulamaktan öte bir anlam taşımamaktadır. $\mathrm{O}$ halde erkeklere ve kadınlara atfedilen ve cinslere ait görülen pek çok davranış biçimi, sonradan edinilmiş toplumsal roller olarak görülmelidir (Doltaş, 1991: 83). Psikolojik algı biçimlerinin sosyokültürel belirleyicilerin etkisiyle son şeklini aldığına dair görüşüyle Malinowski de sosyokültürel etkenlerin yönlendiriciliğini vurgulamaktadır (Malinowski, 1989: 162). Çünkü içgüdüler ve biyolojik faktörler insan davranışlarını yönlendirse de, birey, her 
gün karşılaştığı töreler, gelenekler, adetler ve daha pek çok toplumsal uygulamaların neticesinde bir kişi olabilmekte ve kişiliğini şekillendirmektedir (Kağıtçıbaşı, 1992: 246). Biyolojik farklılıklar ise toplumsal rollerin cinsiyetler bağlamında ayrışmasının bir nedeni olmaktan çok habercisi niteliğini taşımaktadır (Giddens, 2000: 99). Öte yandan sosyal yapı ve organizasyon biçiminin genelde cinsiyet, özelde ise kadın kategorisi üzerindeki bu şekillendirici etkisinin yanında kültür de temsil ettiği değer ve dünya görüşü bağlamında cinsiyet ve kadınlık algısının oluşumunda etkin bir rol oynamaktadır.

Sosyal bir kategori olarak kadına ilişkin algı, kültürün kendine özgü değer ve dünya görüşüne uygun tasavvurlar çerçevesinde farklılaşmakta, her kültür kendi karakteristiği ile örtüşen bir kadınlık algısını yaratmakta ve barındırmaktadır. Kültürün tasavvur dünyası kadınlara ilişkin algının temel karakteri için önemli bir belirleyicidir (Berktay, 1996: 17). Kültürün tasavvur dünyasının önemli bileşenleri ise gelenek, örf, âdet ve dindir. Toplumsal cinsiyetin, yani kadınlık ve erkeklik tanımlarının kültürlere göre farklılaşan karakteri noktasında pek fazla tartışma bulunmamakta, söz konusu tanım veya sınırların toplum içinde hangi güç odakları ya da kesimler tarafından şekillendirildiği sorunu odakta yer almaktadır. Söz konusu tartışmalar bağlamında sıklıkla işaret edilen temel güç odağı ise erkeği merkeze alan karakteri ve bu çerçevede şekillenen kendine özgü değer sistemi ile ataerkil yapıdır. Buna göre cinsiyet kültürünün oluşumunda güçlü bir etkisi bulunan ve daha çok geleneksel toplumla özdeşleştirilen ataerkillik, kadın ve erkek rollerini belirgin ve değişmez ve hatta yer yer kutsal bir içerik de kazandırarak şekillendirmektedir. Ataerkil yapı bu durumu erkeğin toplumsal konumunu güçlendirecek ve böylece erkeğin öznelliğini güvence altına alacak şekilde yapmaktadır (Berktay, 2002:276-284).

Tüm bu tartışmaların ötesinde her toplumun hangi güç ya da otorite tarafından belirlenirse belirlensin kendine özgü "kadınlık" ve "erkeklik" tanımları olduğu hususunda uzlaşılmaktadır. Ancak bahsi geçen tüm bu sosyokültürel belirleyicilerin yönlendiriciliğini de gösterecek biçimde sözü edilen tanımlar tek biçimli olmayıp toplumdan topluma değişmekte, aynı toplum içinde bölgeden bölgeye, zaman içinde farklıık arz etmekte, değişmez ve homojen bir kadın ya da erkek kavramından ya da kimliğinden bahsetmek mümkün olmamaktadır (Türköne, 1995: 2). Sorun sadece kadınlığın tanımlanması noktasında düğümlenmemekte, aynı zamanda kadınlık ve erkeklik tanımları ile bunlara ilişkin özellikler, imajlar, kalıp yargılar, cinsiyet rol ve statüleri, davranış kalıpları, cinsiyete dayalı işbölümü, cinsiyet kimlikleri ve bunların oluşum süreçleri üzerinde de kendi içinde farklılaşma eğilimleri taşıyan bir cinsiyet kültürünü ilgilendirmektedir. Sosyolojik bağlamda bireyler kendilerini verili bir cinsiyet kültürü içinde bulmakta ve bu yolla sosyalleşmektedirler. Dolayısıyla cinsiyet algısı, bireylerin kendi müdahale ya da belirlenimlerinin fazlaca etkili olmadığı bir süreçte gerçekleşmektedir (Delaney, 2001: 57). Böylesi bir yaklaşımla sosyolojik vurguyu bireye rağmen öne çıkartan Delaney, esasında geleneksel bir toplumun 
sosyal organizasyonunda doğuştan gelen biyolojik özelliklerin belirleyiciliği ve değişime müsaade etmeyen sosyal ilişkiler ağını esas almaktadır.

Oysa cinse dayalı kimliklerin oluşum ve dönüşümü tekil değil, bireyin de etkin olduğu çok boyutlu toplumsal etkileşimler vasıtasıyla şekillenmektedir (Kandiyoti, 1997: 188). Toplumsal cinsiyetin öğrenilmesi ise Giddens'in de belirttiği gibi, gündelik hayat içerisinde sayısız eylemlerde yeniden üretilmekte, tekrar tekrar oluşturulmaktadır. Toplumsal cinsiyet, başkalarıyla olan etkileşimler vasıtasıyla tekrar tekrar yaratılmakta (Giddens, 2000: 104), böylece cinsiyetler farklılıklardan başlayarak, birbirleriyle ilişkileri bağlamında değer ve anlam kazanmaktadır (Agacinski, 1998: 75). O halde toplumların sosyal yapı ve organizasyon biçimleri ile kültürel değerler sistemi cinsiyet algııını şekillendirmekte, söz konusu algıya uygun rol ve statülerle bireyleri donatmakta, tüm bu etki bir süreç olarak gündelik hayat içinde devam etmektedir.

Çok boyutlu toplumsal etkileşimler vasıtasıyla şekillenen cinse dayalı kimliklerin ve toplumsal cinsiyet algılarının oluşumunda ve dönüşümünde sosyal yapı ve değerler sisteminin önemli bileşeni olan din ve dindarlık da etkin bir rol oynamaktadır. Dinler, sosyokültürel yapılanma tarafından meydana getirilen cinsiyet algılarının meşruiyet kazanmasına hatta yer yer statikleşerek muhafazakâr bir karaktere bürünmesine neden olabilmektedir. Namus kavramı etrafında şekillenen ve dinsel değerlerle meşruiyet kazanan cinsiyet algısı bunun en iyi örneğini oluşturmaktadır. Türk toplumu örneğinde olduğu üzere aile şerefinin ve toplumun biyolojik devamlılı̆ının kadına bağlı görülüşü, kadının anne olma vasfına kutsal bir anlam ve değer yüklemekte, neticede kadın, korunması gereken kutsal bir emanet olarak algılanmaktadır. Bu anlamda bir toplumun cinsiyet algıları geleneksel dinî anlayışla meşrulaştırılmaktadır (Şahin, 2001: 17).

Sosyal yapı ve gelenek, görenek, adet ve dinin önemli bileşenleri olduğu kültürel değerler sistemi ile bir bütün olarak söz konusu bu toplumsal süreç sadece cinsiyet algısını şekillendirmekle sınırı bir etki yaratmamaktadır. Aynı zamanda mevcut cinsiyet algısı ve bu algının sosyal yapıdaki yansımaları ile toplumun diğer sosyal yapı ve değerler sistemi ile ilişki ve etkileşimini de kurmaktadır. Cinsiyet algısı ve bu algıyla örtüşen yapısal özelliklerin ilişkilendirildiği sosyal yapının ve değerler sisteminin önemli bir bileşeni ise dindarlıktır. Bu yönüyle cinsiyet algısı ve cinsiyetlerin sosyal yapıdaki konumları kendine özgü bir cinsiyet dindarlığı oluşturmakta, söz konusu dindarlık kadın kategorisi söz konusu olduğunda kadın dindarlığı ile somutlaşmaktadır.

\section{Kenarda Dururken Daha Dindar Olmak: Kadının Dini}

Kadın ve din ya da kadın ve tanrı ilişkisinin tarihi ve kültürel seyrine genel bir bakış, söz konusu ilişkinin toplumların sosyokültürel organizasyon biçimleri ile dinlerin karakteristik özelliklerine göre farklılaştığını gözler önüne serecektir. Ancak şunu da belirtmek gerekir ki kadın-din ilişkisi incelenmeye başlandığında aslında çok yönlü ve karmaşık bir sorunsalın içine dalınmaktadır. Kadın katego- 
risi ve din olgusunun bizatihi kendileri tek bütün bir karakter taşımayan, çeşitlilik ve farklılaşmaları bünyesinde barındıran karmaşık sosyokültürel gerçekliklerdir. Her şeyden önce din, teoride ve pratikte çeşitlenen boyutları içermekte, değişik tarihsel ve toplumsal bağlamlarda insanlar tarafından algılanışında, yorumlanışında ve yaşanışında farklılaşmalar ortaya çıkmaktadır. Öte yandan kadınlar da bütünsel ve tek örnek bir kategori oluşturmamakta, sosyal yaşamın gereği olarak bir takım demografik, etnik, sınıfsal ve dinsel ayrımlar içinde bölünmekte ve farklılaşmaktadır (Berktay, 1996: 8).

Inanç ve pratik sistemleri ile değer ve dünya görüşleri birbirinden farklı olmakla birlikte hangisi olursa olsun; geleneksel ya da tek tanrılı tüm dinler bir şekilde biyolojik ve toplumsal cinsiyet özellikleri itibariyle kadın algısına ve kadın dindarlığına tipik bir biçimde yansıyan ögeleri bünyesinde barındırmaktadır. O halde dinler inanç ve pratikleri itibariyle cinsiyet merkezli bir kategorizasyon biçimini gözler önüne sermektedir. Söz konusu cinsiyet merkezli kategorizasyonu dünyevi bir bağlamdan aşkın bir boyuta kadar uzanan bir yaşam tasarımının önemli bir parçasını oluşturmaktadır. Genel olarak dinler özellikle de tek tanrılı dinler dünyevi hayat tasarımlarında olduğu gibi öbür dünya tasavvurlarında da cinsiyet farklılığını dikkate alan kategorik ayrımları bir model olarak sunmaktadır. Öyle ki sosyal hayatın ataerkil değerler sistemi ve ataerkil yapı merkezli organizasyonunun bir yansıması olacak biçimde kadın ve erkeklerin öbür dünyadaki konum ve statüleri de birbirinden farklılaşmaktadır. Dinlerin cennet ve cehennem tasavvurları dikkate alındığında erkekler salt kendi iradeleriyle yaptıklarının sonucunda edinilmiş bir statüye erişirken kadınlar eş ve ailelerine bağlılık ve sorumlulukları neticesinde atfedilmiş bir statü kazanmaktadırlar. Bu yönüyle dinler dünyevi hayat ile ölümden sonraki hayatı süreçsel devamlılı̆ı olan bir sosyal yapı üzerine inşa etmekte, dünyevi yaşamın ataerkil sosyal yapılanmasının benzeri bir modelini öbür dünya için de öngörmektedir. Kadın ve erkek cinsiyetlerine dayalı kategorik ayrımın izlerine kadının erkekten sonra ve onun bir parçası olarak yaratıldığını vurgulayan yaratılış hikâyesinde somut bir biçimde rastlanmaktadır. Dahası yine dünyevi yaşamın erkek merkezli sosyal yapılanmasını ve değerler sistemini işaret edecek biçimde tek tanrılı dinlerde Tanrı ve dinde aktif rol üstlenen şahsiyetler eril bir karakter taşımakta, kutsal kitaplar eril bir dille muhataplarına hitap etmektedir (Giddens, 2000: 477, 478).

Tüm bu hususları dikkate alarak Delaney, Yahudilik, Hıristiyanlık ve islam'da Tanrı'nın açık veya kapalı biçimde erkek olarak simgelenmesinin erkekler ve kadınlara, otoritenin doğası ve iktidar yapılarına dair düşüncemize nasıl etkilemektedir? sorusunu dile getirmektedir (Delaney, 2001: 19-20). Sorunun cevabını ararken Delaney, kadın ve erkek arasında yapılan ayrıma, özellikle de cennetten kovulma figürüne dayalı olarak genellikle kadın kimliğinin olumsuzlanışına, kadının kötü, zayıf, kaypak, cezalandırılmış ve sürekli denetim altında tutulması gereken birisi olarak tanımlanışına dikkat çekmektedir (Delaney, 
2001: 118, 119-120). Yaratılış ve cennetten kovulma mitine dayalı tüm bu algı biçimlerinden hareketle değerler sisteminden başlayarak sosyal yapıya kadar uzanan cinsiyetlerin konum ve statüleri ile cinsiyetler arası ilişkinin değiştirilmesine yönelik her türlü teşebbüsün ise yaratılış, evrenin doğası ve düzenine karşı bir tehdit olarak yorumlanacağını belirtmektedir (Delaney, 2001: 320). Dinlerin değer sistemi ve sosyal yapı anlayışı içinde cinsiyetlerin konumunun statik bir karakter taşıyışına dikkat çeken Delaney'in bu görüşüne Berktay biyolojik bir boyut katmaktadır. Berktay'a göre hemen hemen tüm kültürlerde erkek zihnî ve tinsel olanla özdeşleştirilirken, kadının varlık nedeni anneliktir, zira doğa kadını tek bir amaçla, doğurmak için yaratmıştır (Berktay, 2002: 281).

Erkeğe atfedilen öncü ve üstün karakter ile kadına yüklenen biyolojik özelliklerin kategorik ayrımlarda kendini gösterdiğine dair tüm bu değerlendirmeler esasında dinlerin tarihsel süreçte ortaya çıktıkları toplumların kültürüyle etkileşimini yani tarihselliklerini gözler önüne sermektedir. Günümüzde bu ayrımların ve cinsiyet farklılı̆ının yaşamın ve dindarlığın hemen her alanında varlığını sürdürüyor olması ise değişimin artan gücüne karşın kutsallaşmış geleneğin özellikle kadın konusunda direnç gösteren yüzü olarak okunabilir. Bu yönüyle kadın dindarlığı, meşruiyetini dinin cinsiyet ayrımı temelinde farklılaşan buyruklarından aldığı gibi, tarihsel ve toplumsal bir olgu olarak ataerkil kültürün kalıcı tortularından da beslenmektedir. Ataerkil yönelimler büyük ölçüde, geleneksel dünya görüşüyle süreklilik kazansa da modern kurumsal yapılanma da söz konusu yönelimlerden bütünüyle sıyrılmış değildir. Dolayısıyla ister geleneksel isterse de modern olsun toplumlar bir şekilde ataerkil değerleri bünyesinde barındırmakta, kadın kategorisi söz konusu ataerkil yapı ve dinlerin kutsal bir gelenek haline gelmiş algıları çerçevesinde konumlandırılmakta, bu algıyla örtüşen bir kadın dindarlığı kendini hissettirmektedir. Bu yönüyle bulundukları toplumların sosyal ve kültürel özelliklerinden de beslenen dinlerin kadın kategorisine yönelik algı biçimi kadın dindarlığının oluşumu ve temel özelliklerinin şekillenmesinde öncelikli olarak etkili görünmektedir.

Toplumların ataerkil değer ve yapılarının da etkisiyle dinlerin dirençli ve güçlü kutsal bir gelenek halinde süreklilik kazanan cinsiyet merkezli kategorizasyonu sadece kutsal metinlerle sınırlı kalmamış, dinlerin teorik boyutunun yanında pratik boyutuna, dahası dinin sosyolojik görüntülerine ve halk dindarlığına da aksetmiştir. Fas'da yaptığı alan araştırmalarına dayalı olarak Buitelaar'ın da işaret ettiği üzere kurumsal İslam'ın zekât, kurban, cemaatle namaz gibi ibadetlerinin genelinde erkekler merkezde yer alırken kadınlar daha çok halk dindarlığının türbe ziyareti, aşure, mevlit gibi uygulamaları ekseninde kenarda yer almaktadır. Buitelaar'a göre kadınlar bu dışarıda bırakılmışlıklarını telafi etmek üzere kimi zaman erkekler tarafından hurafe ve batıl olarak da tanımlanan anılan alternatif etkinlikleri geliştirmişlerdir (Buitelaar, 1991: 146). Benzer bir görüşü Holy yine Müslüman topluluklar örneğinde zikretmekte, ìslam'ın özüne dahil olmayan geleneksel inançların toplumsal yaşamda devamlıık 
kazanmasını kadınların ibadetlere tam katııımdan dışlanmış olmalarına bağlamaktadır. Kadınlar katıldıkları geleneksel pratikler vasıtasıyla dışlanmışlıklarını telafi etmektedirler. Dahası ibadetler bir yana Holy'e göre erkekler kutsal kitap merkezli inançları daha çok vurgulasalar da kadınlar bu inançlardan ya daha düşük düzeyde etkilenmekte ya da bu inançları geleneksel inançları içine karıştırmakta ve eritmektedir. Dinî pratiklere katılımda görülen cinsiyet merkezli bu farklılaşma kadınların genellikle büyü, hurafe ve batılla, erkeklerin ise dinle yetkili ve ilişkili görülmesi sonucunu beraberinde getirmektedir (Holy, 1988: 469-470).

Holy'nin bu değerlendirmesine kadınların inanç ve uygulamaları anonimleştirerek toplumsallaştırma ve kolektif bir paylaşımın konusu haline getirme kabiliyetlerini de ilave etmek gerekmektedir. Zira geleneksel inanç ve uygulamaların kadın kategorisiyle ilişkilendirilmesi kadınların bir yönüyle kurumsal dindarlı̆ın kenarında yer alan konumlarını gösterse de bir yönüyle de gelenek ve din arasında bir tampon olma, iki güçlü ve dirençli değerler sistemini bir araya getirerek, kendi yaşamlarında eriterek anonimleştirme yeteneklerini gözler önüne sermektedir. Ayrıca her ne kadar kadınlar hakim dinî gelenek ve erkeklerin etkinliğiyle özdeşleşen inanç, söylem ve pratik alanından soyutlanmış bir dindarlık biçimiyle ilişkilendirilse de Tapper'in söylediği gibi bu duruma bir dinî sistemin değişik yönlerinin kadın ve erkeğin yaşam alanına farklı boyutları ile girişi olarak da bakılabilir (Tapper-Tapper, 1996: 42).

Her ne şekilde olursa olsun cinsiyet merkezli bu kategorizasyona bağlı olarak geleneksel inanç ve uygulamalar baskın bir biçimde bir kadın meselesi olarak görülürken, din erkek alanı olarak tanımlanmaktadır. Nitekim dinî bir otorite olmak sadece erkeklere özgü bir durumdur. Toplumsal yaşamın huzur ve refahıyla ilgili ritlerden, dua törenlerine, kurban kesmekten cemaatle namaz kılmaya kadar uzanan tüm pratiklerde erkekler birer dinî otoritedir (Holy, 1988: 482).

Buna karşın kurumsal dindarlığın inanç ve pratiklerinin dışında kalan ya da gelenekle dini katıştıran halk dindarlığının inanç ve uygulamalarını sürdürmek bir yandan kadınların ikincil pozisyonlarını güçlendirirken diğer yandan da kadınların dinî değerlerinin, konumlarının erkeklere göre ikincil olduğu kanaatini güçlendirmektedir (Buitelaar, 1991: 123). Bu yönüyle cinsiyet farklılaşması dindarlı̆ın çeşitli biçimleri bağlamında, değişen yoğunluk düzeylerinde hissedilmektedir. Ancak ilginç olan nokta dinlerin kadına yönelik algısına ve kadınları yerleştirdiği konuma rağmen kadınların dindarlığın çeşitli boyutlarına daha yoğun bir biçimde yönelmeleridir. Öyleyse cevabı aranması gereken soru; İslamiyet örneğinde zikredildiği üzere kadınlar kurumsal dindarlığın kenarında yer alıyorlarsa neden gelenek ve dini uzlaştırarak ya da dinî inanç ve pratiklere yoğun bir biçimde yönelerek dindarlığın aktif bir aktörü haline gelmektedirler? 
Kadınların dindarlığa böylesi bir katılımı Ozorak'a göre aslında bir paradoksu gözler önüne sermektedir. Çünkü genel olarak kadınlar erkeklerden daha dindar olsalar da pek çok dinî sistem, kutsal sembolleri, dil ve pratikleri itibariyle ataerkil bir yapı özelliğini taşımakta, bu durum ise şu soruyu akla getirmektedir: "neden kadınlar değerlerini düşüren yerleşik bir geleneğin içinde orantısız bir biçimde bu kadar zaman geçirmekte ve emek harcamaktadır?" (Ozorak, 1996: 17). Aslında Ozarak'ın sözünü ettiği bu paradoksun köklerini biyolojik özellikleri esas alan cinsiyet ve sosyokültürel belirleyicileri temel alan toplumsal cinsiyet farklılaşmasında aramak gerekmektedir.

\section{Kadın Doğmak, Daha Dindar Olmak}

Cinsiyet ve kadın dindarlığı araştırmaları bağlamında genellikle bir paradoks olarak görülen söz konusu sorunun cevabı aranırken dindarlık çoğu zaman kadının belirgin ve ayırıcı niteliği olarak değerlendirilmektedir. Bu yönüyle dindarlık "kadınsı" doğası nedeniyle daha çok kadının karakteristik bir özelliğidir (Fromm, 1998: 24). Kadının biyolojik karakterini öne çıkartarak dindarlığı bu doğrultuda kadınla ilişkilendiren böylesi eğilimlere ilave olarak yine doğuştan getirdiği özelliklerin doğal süreçlerle uzlaşan karakterine dikkat çekilerek kadın dinle ilişkilendirilmektedir. Nitekim bu durumu işaret edecek biçimde Mensching şöyle bir değerlendirmede bulunmaktadır: "kadın, hayatın orijinal kuvvetlerine duygularıyla erkekten daha yakın olup, tabiatıyla erkekten çok, halk inançlarına meyyaldir" (Mensching, 1994: 140).

Tüm bu hayatın orijinal güçleri ve doğa ile kadının üretmeye ve yaratmaya dayalı biyolojik özellikleri temelindeki analojiler için "toprak ana", "ana tanrıça" gibi simgeler somut tarihi örnekler olarak sunulmaktadır (Türköne, 1995: 26). Eliade geleneksel toplumlarda din ve büyünün erkekten çok kadına ait bir alan ve orijinal Şamanlıkta Şamanların kadın oluşunu, ataerkil dönemlerde de erkek Şamanların kadın kıyafetleri giyerek kadın rolü yapışını, kadının "büyük hayat verici" ile doğrudan teması ve doğurma gücüyle alakalı görmektedir. Eliade, beslenmeye yönelik bitkileri ilk kez kadının yetiştirdiğini, böylece kadının toprağın ve hasadın sahibi haline geldiğini belirterek, kadının büyüsel-dinsel prestiji ile buna bağlı toplumsal üstünlüğünün, kozmik bir modele sahip olduğunu vurgulamaktadır. Nitekim kadının şahsında sembolize edilen ve hayatın yaratıcı ve orijinal gücünü temsil eden "toprak ana" yaşamı tek başına yaratma gücüne sahiptir ve kozmos üzerinde de egemendir (Eliade, 1991: 120-123).

Cinsiyetlerin biyolojik varoluşlarını dikkate almak ise tek tanrılı dinlerde somutlaştığı üzere beden ve buna bağlı olarak da pratik ve eylem vurgusunu beraberinde getirmektedir. Hiç şüphesiz ki beden toplumsal ve tarihsel bir öğedir. İnsan bedeni her kültürde farklı yönleriyle vurgulanmış ve şekillenmiş olarak karşımıza çıkmaktadır. Bu anlamda beden, bir kültürün merkezî kurallarının, hiyerarşilerinin ve hatta metafizik bağlılıklarının yazılı olduğu bir yüzeyi ifade eden güçlü sembolik bir form mahiyetindedir. Bu nedenle dinler ve kültürler 
temel ilke ve öğretilerini insan bedeninde somutlaşacak ve eyleme dönüşecek bir genişlikte sunmaktadır (Berktay; 1996: 130-131).

Delaney, İslamiyet'in gündelik hayat içerisinde bedenin anlamları ve davranışları aracılı̆̆ıyla açığa çıktığını ifade ederken Müslümanlığın bu sembole verdiği öneme işaret etmektedir. Zira İslam dinî, bedenin etkinliklerinin nasıl sunulması ya da icra edilmesi gerektiğini en ince ayrıntılarına varıncaya kadar teferruatlı bir biçimde tarif etmekte ve kişinin bedenine sürekli dikkat etmesini gerektirecek bir sistemi dile getirmektedir (Delaney, 2001: 43-44). Beden vurgusu, eylemi önceleyen bir karakteri de beraberinde getirmektedir. Söz konusu beden nosyonu ve bedensel pratikleri belirleyen, yönlendiren boyutuna binaen İslamiyet sosyokültürel yaşamın değer ve dünya görüşünü doğrudan etkileyen ortopraktik bir din olarak tanımlanmaktadır. İslamiyet örneğinde olduğu üzere bazı dinler ortopraktik ifadesiyle kavramlaştırılan uygulama merkezli karakterleri ile dikkat çekerken Hristiyanlık örneğindeki diğer bazı dinler ise inanç merkezli karakterleri ile dikkat çekmektedir. Dinlerin bu türden temel karakterleri ise dinî pratiklerdeki cinsiyet kategorizasyonunu etkilemektedir.

Kadın dindarlığını biyolojik ve doğal etkenlerle ilişkilendiren sözü geçen eğilimlere karşın dindarlıkta yaşanan cinsiyet farklılaşmalarının aslında büyük ölçüde kültürel değerlerin ve sosyal etkenlerin bir yansıması olduğu unutulmamalıdır (Loewenthal-MacLeod-Cinnirella: 2002: 138). Nitekim yaş, meslek, medeni durum, sosyoekonomik statü, kentleşme düzeyi, kitle iletişim araçları, eğitim, modern teknolojik dönüşümler ve bütün bu faktörlerin yarattığı sosyal değişimin biçim ve şiddetinde yaşanan çeşitlilik, toplumların dinî hayatlarının tipolojik özelliklerinin, bu çerçevede de kadın dindarlığının temel karakterinin belirmesinde etkin rol oynamaktadır. Bu nedenle bireyler sosyal yaşam içinde kendi cinsiyet özelliklerine bağlı olarak farklı dinî yaşayış modellerini sergilemektedir. Ayrıca sadece sosyal gerçeklik kadın dindarlığını şekillendirmekle kalmamakta, aynı zamanda kişiler arası etkileşim ile özelde cinsiyetler arası etkileşim bu gerçekliğin yaratılmasına katkı sağlamaktadır.

Bireysel ve sosyokültürel bileşenlerin çoklu etkileşimi ortasında hayat bulan bu niteliği ise tek kültürlü, tek etkenli ya da değişkenli metodolojik yaklaşımlarla kadın dindarlığının değerlendirilmesinin imkânsızlığını, sosyokültürel gerçekliğin kendine özgü doğasının sosyolojik gerçeklik alanına yansımasının gerekliliğini bir kere daha hatırlatmaktadır. Zira kadın dindarlığının sosyokültürel bağlamın farklı bileşenlerinin etkisine açık karakteri göz önünde bulundurulduğunda söz konusu çoklu etkileşim temelinde ele alınmasının gerekliliği daha iyi anlaşılacaktır. Tek bir kültürel bağlam temelinde geliştirilmiş ölçekler ile buna dayalı araştırmaların tüm din ve kültürlere uyarlanabilir bulunması, hatta uyarlanması sığ genellemeleri beraberinde getireceğinden kültürel bağlamla örtüşen araştırma modellerinin geliştirilmesi büyük önem taşımaktadır.

Bu demek değildir ki farklı kültürel bağlamları temsil eden çalışma bulguları ile teorik yaklaşımlara kadın dindarlığına dair değerlendirmeler çerçevesinde 
yer verilmesin. Tam aksine kültürler arası karşılaştırmalı araştırma ve analizler, ya da diğer kültürel bağlamlarda gerçekleştirilmiş çalışmalara yapılacak referanslar kadın dindarlığının özgün niteliklerinin kavramlaştırılmasında önemli bir açılım sağlayacaktır. Gerek kültürel bağlamla örtüşen kuramsal modeller, araştırma stratejileri, ölçekler ya da araştırmalar gerekse de farklı kültürel bağlamlardan edinilmiş verilerle beslenen bilimsel bir eğilim ile genelde dindarlı̆̆ın özelde de kadın dindarlığının kendi kültürel bağlamı içinde derinlemesine analizi mümkün olacaktır. Aksi bir yaklaşım bir kültüre başka bir kültürden bakmaktan öte bir anlam taşımayacaktır.

Kadın dindarlığının metodolojik boyutuna dair temas edilen bu değerlendirmelerle esasında bilimsel bir öz eleştiri yapılmak istenmektedir. Zira Türkiye örneğinde olduğu üzere pek çok toplum kendi özgün duruşuna dair kuramsal ve kavramsal açılımları yeterince üretemediğinden Batı merkezli sosyolojik bir atıf çerçevesine müracaat etmektedir. Sosyal bilimlerin felsefi ve düşünsel zemin itibariyle kültürler ötesi süreçsel bir boyutu bulunmakla birlikte toplumların söz konusu kuramsal ve kavramsal birikime kendi özgün varoluşlarıyla katkı sağlamaları kendi gerçekliklerini ifade etmeleri açısından büyük önem taşımaktadır. Söz konusu bu değerlendirmeler ışığında kadın dindarlığına tekrar dönüldüğünde bu çalışmanın temel tartışmalarından birisi olan ve yaygın bir biçimde vurgulanan kadınların erkeklerden daha dindar oldukları yorumunun büyük oranda Hıristiyan kültürler ve Hıristiyan örneklemlerle ilişkili çalışmalara dayandığı görülecektir. Diğer kültürlerin cinsiyet dindarlığına duyarlı yeterli araştırmayı üretemeyişi, hatta kadın kategorisi ve dindarlığına dair araştırmaların bilimsel ortodoksi tarafından istihza ile karşılanışı zikredilen Batı merkezli kuramsal eğilimlerin güç ve hakimiyetini de beraberinde getirmiştir. Ayrıca kültürler arası karşılaştırmaya imkân tanıyacak sosyokültürel gerçeklikle örtüşen kadın araştırmalarının yapılmayışı Hıristiyan toplumlar temelinde geliştiriliş ölçeklere dayalı bu sonuçların Hıristiyan olmayan kültürlere uygulanabilirliğini de müphem hale getirmektedir.

Kadın dindarlığına ilişkin olarak öne çıkan metodolojik sorunlardan birisi de, nasıl ölçüleceği sorusu etrafında şekillenmektedir. Yukarda da bahsi geçtiği üzere kadınlarla ilgili dindarlık araştırmalarında kullanılabilecek ölçekler, hâlihazırda mevcut Hıristiyan toplumlarda geliştirilmiş ölçeklerdir. Müslüman katılımcılar için kullanılabilecek ölçekler geliştirilmeye çalışılmışsa da bu tür ölçekler çoğunlukla kültürel-dinî gelenekte belirleyici ibadet ve inançlar hakkındaki sorulardan ibaret kalmıştır (Loewenthal -Mac Leod-Cinnirella, 2002: 134).

Dahası derinlemesine görüşmeler ve katılımlı gözlemlerle nitel bir yaklaşımla kadın dindarlığının araştırıldığı çalışmalar ise Türkiye gibi toplumlar bir yana Batı'da da çok sınırlı düzeyde gerçekleştirilmektedir. Kadın dindarlığının aynı ya da farklı din bağlamında kültürler arası karşılaştırmalı bir perspektifle ele alınışına ise çalışmalar içindeki sınırlı referanslar bir yana neredeyse hiç rastlanmamaktadır. Sosyokültürel gerçeklikle örtüşen araştırmalar, geliştirilmesi 
muhtemel kuram ve kavramlar için bir açılım sağlayabileceği düşüncesiyle bu çalışma alana dayalı bir çalışmadan önce çeşitli kültürel bağlamlarda gerçekleştirilmiş kadın dindarlığına ilişkin bulgular ile bu çerçevede oluşturulmuş kuramların kısa bir değerlendirmesini tercih etmiştir. Kadın dindarlığı, özellikle de kadınların daha dindar olduğuna dair bulgu ve kuramlara genel bir bakış bir öz eleştiri ile söz konusu araştırmalara ne kadar katkı sağladığımızı da göstererek kadın dindarlığının sosyokültürel bağlam çerçevesinde derinlemesine analizlerine kapı aralayacaktır.

\section{Kadın Olmak, Daha Dindar Olmak: Kenarda Ama Daha Dindar}

Araştırmalar göstermiştir ki kadın dindarlı̆ının en tipik ve ayırt edici özelliğini, kadınların nicelik ve nitelik olarak dindarlığın özellikle pratik boyutuna yoğun yönelimleri oluşturmaktadır. Söz konusu yönelim erkek kategorisiyle yapılan karşılaştırmalar ve kadın kategorisinin kendi sosyal ve biyolojik özgün belirleyicilerinin gözler önüne serilmesiyle aşikâr hale gelmektedir. Kadınların nicelik ve nitelik olarak dindarlığın içinde yoğun bir biçimde yer alışının belirleyicilerine geçmeden önce kadınların erkeklere nazaran daha dindar olduğunu işaret eden bulgulara temas etmekte, "kadınlar daha dindardır" varsayımına kültürel bağlamlı veriler çerçevesinde dikkat çekmekte yarar bulunmaktadır.

Stark genel bir yaklaşımla dindarlıktaki cinsiyet farklılaşmasının hemen her kültürde rastlanan bir olgu olduğunu çeşitli kültürler örneğinde yaptığı çalışmasıyla ortaya koymuştur. Stark'ın World Values Surveys'in 1991-92 ve 1995-97 yılları arasındaki verilerine dayalı cinsiyet dindarlığına ilişkin bulguları kendini dindar olarak tanımlama, dinden güç alma ve huzur bulma, dinin yaşamında önemli olduğunu söyleme, tanrıya inanma gibi hususlarda Avrupa ve Amerika'nın çeşitli ülkelerindeki cinsiyet kanaatlerini yansıtmaktadır. Avrupa ve Amerika'dan toplam 49 ülkeye ilişkin verinin sunulduğu bu ölçeğe göre tüm bu ülkelerde kadınlar erkeklerden daha dindardır (Stark, 2002:497-498). Davie'ye göre "Batıda kadınlar erkeklerden daha dindardırlar. Batı bağlamında, kadınların inanç ve pratiklerinin ve (genel olarak) inandıkları şeylere erkeklerden daha bağlı olduklarını gösteren ikna edici kanıtlar vardır. Bunun niçin böyle olduğu ve durumun olası değiş̧iklikler gösterip göstermeyeceği sosyolojik tartışma için epey gündem teşkil edecektir" (Davie, 2005: 113).

Batı'da kadın ve erkeklerin dindarlıkları üzerine yapılan araştırmalar, bu kültürel bağlamın şaşırtıcı şekilde birbiriyle tutarlı sonuçları için bir zemin oluşturduğunu göstermektedir. Örneğin Almanya'da yapılan ampirik araştırmalar kadınların açık bir şekilde erkeklere göre daha dindar olduklarını ortaya koymaktadır (Volz, 2000: 115). Bulgular, diğer sosyokültürel alanların aksine dindarlık bakımından söz konusu ayrımların yıllardır sabit kaldığını ve cinsiyetler arasında dindarlık düzeyi açısından herhangi bir yakınlaşmanın söz konusu olmadığını göstermektedir. Nitekim birçok alanda cinsiyetler arasında bir yakınlaşma olmasına rağmen, dindarlıkta farkın sürmesi dikkat çekicidir. Cinsiyet din- 
darlığındaki farklılı̆ın sürmesine koşut giden bir diğer durum ise kadınların halen eğitim düzeyi, meslek sahibi olma oranları bakımından erkeklere göre düşük ortalamaları sergilemeleridir (Kecskes, 2000: 85). Öyle anlaşılıyor ki söz konusu sosyoekonomik ve kültürel etkenlerin dindarlık üzerindeki etkisi cinsiyet dindarlığını dışta bırakmayacak kadar güçlüdür.

Erkeklere göre nicelik ve nitelik olarak yoğun bir dindarlık biçimini temsil eden kadın kategorisi kendi bünyesinde barındırdığı sosyokültürel belirleyiciler bağlamında da dindarlığın biçim ve düzeyi bakımından farklılıklar sergilemektedir. Bu yönüyle kadınların daha dindar olduklarına ilişkin yaygın kabul, genel gözlemlerle bağlantılı bir varsayım olup kadın kategorisi düzeyindeki farklılaşmalar kadın dindarlığının da tek biçimli olmadığını göstermektedir. Ayrıca, kadınların dindarlığa yönelimlerini, biçim ve düzey olarak etkileyen belirli sosyokültürel etkenlerin olduğu da bir gerçektir. Dolayısıyla kadınların sosyal konum ve statüleri dindarlığa yönelimlerini, dindarlık biçim ve düzeylerini doğrudan doğruya etkilemektedir. Özellikle mesleki ve sosyoekonomik farklılaşmaya bağı olarak kadın dindarlığı değişiklikler göstermektedir (Luckmann, 1991: 64). Ancak sosyal konumun belirleyiciliğine işaret etmeden önce şunu belirtmek gerekir ki dinsel gelenek ve kültürlerin kendi karakteristikleri kadınların dindarlığa katıım biçim ve yoğunluğunda önemli bir belirleyicidir.

Pek çok dinî gelenek kadın ve erkeklerin dinî yükümlülüklerini müdahaleye ve kişisel tercihe imkân bırakmayacak biçimde ayırmakta, ibadet ve kutsal metin okumaları gibi dinî sorumlulukları yerine getirmeyi daha çok erkeklerle ilişkilendirmektedir. Geleneksel Yahudilik ve İslamiyet merkezî dinî yükümlülüklerin çoğunu kadınlarla ilişkilendirmemekte, kadınların öncelikli görevinin biyolojik farklııklarını öne çıkaran bir anlayışla ev işleri ve çocuk bakımı olduğunu vurgulamaktadır. Örneğin Yahudi ve Müslüman kadınların ibadet yerlerindeki ritüellere katıım oranları oldukça düşüktür. Kadınların ev işleri ve çocuk bakımıyla sorumlu görülüşleri ibadet ve diğer dinî etkinliklerle ilgili sorumluluklarının sınırlandırılmasına sebep olmuş görünmektedir. Bu durumda Yahudi ve Müslüman kadınların dindarlıkları üzerine yapılacak bir ölçümde kadınlar erkeklerden daha az dindar çıkacaklardır. Tam aksine olmak üzere Hıristiyanlık temel alındığında dinî ibadet ve pratiklere katılımın erkeklerden daha yüksek olduğu ölçülecektir. Bu durum, aynı zamanda kültürel farklılıkların dindarlık ölçeklerine farkIılaşan sonuçlarıyla yansımasına bir örnektir. Öte yandan gelenek ve dinin belirleyici gücüne ilave olarak kadınların söz konusu sosyal konumları da dindarlığa yönelimi pozitif yönde etkileyebilmektedir. Kadınların bireysel ya da kolektif olarak icra edilen dinî pratiklerin pek çok türüne erkeklerden daha fazla katıldıklarına dair araştırma ve gözlemler kadınların bu türden dinî etkinliklere katılmak için daha fazla imkân ve yeterli zamana sahip olduklarını işaret etmektedir. Kişilik ve sosyalizasyon farklılıkları bu türden etkinliklere yönelimleri artırmaktadır (Loewenthal-MacLeod-Cinnirella, 2002: 133-134). 
Sosyal konumları itibariyle genellikle aile bağlamı ile sınırlı bir yaşam sürüşleri, ekonomik gelirlerinin kısıtıılığ ve bir mesleğe sahip olmayışlarının kadınlarda erkeklere göre nispi bir yoksunluk duygusunu ürettiği ve bu yoksunluk duygusunu telafi etmek üzere kadınların dine daha fazla yöneldiği de belirtilmektedir (Şahin, 2008: 338). Sosyoekonomik statüye bağlı bu görece yoksunluk duygusunun telafisi genellikle ya kurumsal i̇slam'ın dışında kalan halk inanç ve uygulamalarına dinî bir karakter atfederek niceliksel olarak sıklıkla yönelmek, ya da dinî veya geleneksel halk inanç ve uygulamalarına güçlü aşkın bir boyutta niteliksel olarak yoğun bir biçimde yönelmek suretiyle sağlanmaktadır. Buitelaar, kurumsal dindarlığın parçası ve prestij kaynağı olan çeşitli ibadetlere katılımdan dışlanan kadınların dinî haz ve memnuniyet kazanabilecekleri, doyuma ulaşabilecekleri diğer etkinliklere yöneldiklerini görmüştür. Ona göre sosyal statü ve konuma dair bir telafiyi sağlamanın ötesinde dindarlık, resmi ve prestijli ibadetlere katılamayışları nedeniyle kazanamadıkları sevabı telafi etme ve kazanmanın yollarını kadınlara sunmaktadır (Buitelaar, 1991: 125).

Gerek sosyoekonomik pozisyonları gerekse de din kurumu içindeki konumları için bir telafi sağlamak üzere Tapper'in Türkiye örneğinde geleneksel halk dindarlığının bir uygulaması olan mevlit ritüeli bağlamında işaret ettiği üzere kadınlar ibadetlere erkeklere nazaran aşkın bir boyut katmaktadır. Bu durum bir yandan geleneksel cinsiyet rollerini kabul etmiş kadınlara ev dışında kendilerini ispatlama ve liderlik duygularını tatmin etmek için bir fırsat (Tapper-Tapper, 1996: 43, 49) diğer yandan da cinsiyet hiyerarşisine dair eleştirel bir yorum sağlamakta, kadınlar aleni bir biçimde sorunlarını ifade edebilmektedir (Buitelaar, 1991: 116-117). Dolayısıyla kadınların dindarlığa özellikle de kurumsal dindarlığa alternatif uygulamalara nicelik ve nitelik olarak yoğun yönelimleri bir yönüyle sosyal ve dinî konumları için bir telafi diğer yandan da söz konusu konumlarının ince bir biçimde eleştirisine imkân tanımaktadır. Ayrıca, Tapper sosyalizasyon şeklinin dine yönelimi etkileyişini gözler önüne serecek biçimde kadınların daha günahkâr olduklarına dair dinî söylemlerle sosyalleştiklerini, bu durumun ise dine eğilimlerini artırdığını ifade etmektedir (Tapper-Tapper, 1996: 45).

Sosyoekonomik statü ve mesleki farklılaşmanın yanı sıra yaşam alanı, eğitim düzeyi, yaş gibi etkenler de kadın dindarlığının belirleyicilerindendir. Avrupa genelinde Polonya hariç, yaşlı erkeklerin genç erkeklerden daha dindar, büyük kentlerde yaşayanların küçük kentlerde yaşayanlara göre daha az dindar oldukları olgusuyla karşılaşmaktayız. Eğitim faktörü Tanrı inancı üzerinde sorgulayıcı bir eğilimle olumsuz bir etkiyi yaratırken, kiliseye gitme sıklığı üzerinde pozitif bir etkiyi meydana getirmekte, eğitimin düzeyindeki artışla Tanrı inancı zayıflamakta, buna karşın kiliseye gidiş sıklığı artmaktadır (Kecskes, 2000: 92). Duruma Türkiye örneğinde bakıldığında ise eğitim ve dindarlık ilişkisini inceleyen bazı araştırmaların ortaya koyduğu bulgular üniversiteye giden erkek öğrencilerin dindarlık düzeyinin kız öğrencilerden daha yüksek olduğunu göstermiştir. Başka 
araştırmaların bulguları da erkeklerin kızlardan dindarlı̆ın inanç ve ibadet boyutları bağlamında daha dindar olduğuna işaret etmiştir (Onay, 2004: 103). Biri hariç genellikle üniversite öğrencileri düzeyinde yapılan bu araştırmalar, bir değişken olarak eğitim düzeyinin sonuçlarda farklı bir görüntünün ortaya çıkmasında ne kadar etkili olacağını göstermektedir. Zira bu sonuçlar gerek Batı'da ve gerekse Türkiye'de din sosyolojisi alanında yapılan diğer ampirik araştırmaların sonuçlarından farklı bir tabloyu ortaya koymaktadır. Ancak kadın dindarlı̆ıında eğitim düzeyine bağlı olarak bir düşme beklendiği gibi, entelektüel düzeyin artışına bağlı olarak aynı düşmenin erkek dindarlığında da yansımalarını görmek mümkündür.

Bu araştırma bulgularına karşın dindarlıkta cinsiyet farklılaşmalarını analiz etmek üzere Stark'ın çalışmasında yer verdiği ve World Values Surveys tarafından yürütülen araştırma sonuçlarına göre Türkiye'de de kadınların erkeklerden daha dindar olduğu görülmektedir. Kendini dindar olarak tanımlama, dinden güç alma ve huzur bulma, dinin yaşamında önemli olduğunu söyleme, Tanrıya inanma gibi hususlarda kadınların daha dindar bir tutum sergiledikleri saptanmıştır. Sadece Türkiye'de değil Hıristiyan olmayan topluluklara örnek olmak üzere seçilen Azerbaycan ve Arnavutluk'ta da kadınların erkeklerden daha dindar olduğu görülmektedir. Asya'dan örnek olarak seçilen Japonya, Tayvan, Çin, Kuzey Kore ve Hindistan'da da aynı sorular bağlamında kadınların daha dinar olduğu tespit edilmiştir (Stark, 2002:499-500).

Dindarlıktaki cinsiyet farklılaşmasına kültürel bağlamlı bulgulardan hareketle bakmaya devam ettiğimizde görmekteyiz ki büyük şehirlerde kadın ve erkeklerin kiliseye gidiş oranlarında ciddi bir farklılaşma görülmezken, asıl farklılaşma eğitim düzeyine bağlı olarak yaşanmakta, eğitim düzeyindeki artışla birlikte kiliseye devamlık eğilimi azalmaktadır. Daha genel bir bakışla şunu söylemek mümkündür ki dinî inanç ve uygulamalar yerleşim yeri büyüklüğünün artışılla birlikte hem kadınlar hem de erkeklerde azalmakta, ancak bu azalma eğilimi erkeklerde daha yüksek bir düzeyde seyretmektedir. Buna karşın küçük yerleşim birimlerinde yaşayan kadınlar erkeklerden daha dindar bir profili sergilemektedir. Yerleşim yeri büyüklüğünün dindarlığa olan etkisinin altında şehirlerin sunduğu eğitim ve iletişim olanaklarındaki çeşitliliğin yanı sıra heterojenlik, çok farklı alt-kültürler ve anlam çevreleri ile yüz yüze gelinmesinin izlerini de aramak gerekmektedir. Kentliler, cinsiyet, eğitim ve meslekten bağımsız olarak, kırsal yerleşim birimlerinde yaşayanlara göre çoğullaşmış dünya görüşleriyle daha yoğun bir biçimde yüz yüze gelmektedir. Kentsel heterojenlik, kentlerin kırsala göre daha az dindar bir görüntüyü sunuşunun nedeni hakkında da bir fikir vermektedir (Kecskes, 2000: 85-86, 87).

Kentlerin genel olarak dindarlığa özelde ise cinsiyet dindarlığına yansıyan bu türden etkilerini sekülerleşme açısından okuyan Berger, kentleşme ve sanayileşme süreçleriyle koşut giden sekülerleşmenin kırsal kesimden çok şehirlerde, kadınlardan ziyade erkekler üzerinde güçlü etkiler ve izler bıraktığını belirt- 
mektedir (Berger, 1993: 163). Kecskes benzer bir biçimde modernleşmenin farklı yüzleri ile değişen yoğunluklarda karşılaşan kadın ve erkeklerin sosyal konumlarının ve buna bağlı olarak da dindarlıklarının farkılışan karakterine dikkat çekmiştir. Buna göre tarihsel gelişim bakımından, erkek ve kadınların farklılaşan dindarlıkları, kadınlara göre erkekleri daha fazla etkileyen seküler toplumsal gelişmeyle yakından ilgilidir. Modernleşme sürecinde artan rasyonalite ve bilimsel bilgi, Hıristiyan dünya görüşü ile bir rekabet sürecine girmiştir. Ancak bu bilginin edinme yolu ve eğitim imkânları uzunca bir müddet kadınlara kapalı kaldığından kadınlar erkeklere göre daha dindar kalmışlardır. Ayrıca meslekî ve meslek dışı alanda ortaya çıkan işbölümü ve bununla bağlantılı fonksiyonel farklılaşma da kadın ve erkeklerin dindarlık düzeylerini etkilemiş, iki kategori arasındaki farkı artırmıştır. Böylece modernleşme süreciyle etkileşimlerinin sınırlıı̆ı̆ına bağıı olarak meslek sahibi olma oranlarının düşüklüğü, kadın dindarIı̆̆ı için açıklayıcı etkenlerden birisi olarak ortaya çıkmıştır (Kecskes, 2000: 8687).

Dahası tarihi süreç içinde kadınların sosyal konum ve statülerinde yoğun bir dönüşümün olmayışına da bağlı olarak kadınların tabir yerindeyse daha dindar kalışları ya da dindar olmaya devam edişleri "dinin kadınsılaşması" ya da "dindarlığın kadınsılaşması" olarak değerlendirilmiştir. Böylesi bir ifade kadınların erkeklerden daha dindar oluşlarını tarihsel ve kültürel bir olgu ve süreç olarak açıklamaya ve kavramlaştırma yöneliktir (Carroll, 2004: 275).

Tarihi süreç içinde çok da hızlı değişmeyen yapısal konumları kadınların daha dindar oluşlarını sağlayan bir diğer önemli etken olarak karşımıza çıkmaktadır. İ̧bölümünün cinsiyetler düzeyinde farklılaşan karakteri kadınların dindarlığa yönelimlerini artıran önemli yapısal belirleyicilerdendir. Kadınların yüksek oranda seyreden dinî katılımları ile yapısal konumları arasında bir ilişki kuran lannaccone, dini bir hane ürünü, dinî katııımı da iş bölümünün zımni bir göstergesi olarak ele almıştır. lannaccone, ekonomik merkezli bir çözümleme yapmak suretiyle özellikle de insan sermayesi kuramı ve hane üretimi yaklaşımına bağlı olarak hane içi üretim ve beşeri sermaye ile dinî üretim ve dinî sermaye arasında bir ilişki kurmuş, dindarlığı, özellikle de cinsiyet dindarlı̆̆ını bu yolla bir hane içi üretim ve hane ürünü olarak değerlendirmiştir. Buna göre kadınlar dinî tüketici rolü içinde sosyalleşmekte, bu suretle de dinî etkinliklere erkeklerden daha fazla zaman ayırmaktadır. Böylece işbölümünü dinî etkinliklere uyarlayan lannaccone, işbölümündeki geleneksel farklılaşmayı kadınların dinî etkinliklere erkeklere oranla daha fazla yönelmelerinin ve erkeklerden daha dindar olmalarının nedeni olarak görmektedir. Genellikle çalışmayan ve boş zamanı çok olan kadınlar bir hane içi üretim olan dinî etkinliklere erkeklerden daha fazla katılmaktadır (lannaccone, 1990: 299, 312).

Bu yönüyle sosyal konumlarının bir gereği olmak üzere işgücüne daha düşük katııım kadınlara dinî pratiklere yönelim için geniş bir zaman bırakırken aile bağlamlı statüleriyle ilişkili annelik rolleri aile huzuruna dair endişeleri eksenin- 
de dindarlığa yönelimlerini artıran bir etkiyi yaratmaktadır. Bununla birlikte Avustralya örneğinde gerçekleştirilen bir diğer ampirik araştırma farklı bir bulguyu işaret etmekte, kadınların annelik ve çocuk bakımı rolünün daha büyük bir dindarlığa yol açmadığını, işgücüne katııımın çeşitli dinî davranış ölçekleriyle olumsuz bir ilişkiyi ortaya koyduğunu göstermektedir (Miller-Hoffmann, 1995: 63-64).

Avrupa örneğinde görüldüğü üzere belli bir kültürel çevrede hemen hemen ortak özellikleri sergilemesine rağmen bu türden farklılaşan bulgular cinsiyet dindarlığının açıklanması için tek başına kültür gibi makro düzeydeki değişkenler ya da bireysel özellikleri ifade etmede kullanılan yaş, eğitim ve gelir düzeyi gibi değişkenlerin yeterli olmadı̆̆ını gözler önüne sermektedir. Zira aynı yaş, eğitim ve gelir düzeyinde kadın ve erkeklerin dindarlıkları arasındaki karşılaştırmalar kadınların erkeklerden daha dindar olduğu sonucunu vermektedir. Bu nedenle derinlemesine analizler için karşılaştırmalara imkân tanıyacak ve farklı sosyokültürel bağlamları çeşitli özellikleri ile yansıtacak etkenlerin karşııılı etkileşimleri temelinde dikkate alınması gerekmektedir (Kecskes, 2000: 99).

Kadın dindarlığına tesir eden çoklu etkenlerin kesişim noktasını ise sosyalizasyon süreci oluşturmaktadır. Zira tüm bu etkenler sosyal ve kültürel değerlerin edinildiği bir süreç bağlamında şekillenmekte ve dindarlığı etkileyen nihai karakterine bürünmektedir. Nitekim Kecskes Amerika ile birlikte on Avrupa ülkesini kapsayan verilerden hareketle cinsiyet dindarlığını analiz ederken cinsiyet dindarlı̆ı̆ın salt yaş, eğitim meslek ve yerleşim yeri gibi değişkenlerle açıklanamayacağını, bunun yerine daha derinlemesine değerlendirmeler için sosyalizasyon sürecinin dikkate alınmasının gerekliliğini vurgulamıştır. Sosyalizasyon süreci toplumsal yaşamın yapısal ve kültürel unsurlarının etkilerini topyekûn bireye yükleyen karakteri ile kadınların erkeklerden daha dindar olmasını sağlamaktadır (Kecskes, 2000: 92).

Her şeyden önce kadınlar erkeklere nazaran daha uysal, edilgen ve itaatkâr olarak eğitilmekte, bu özellikleri ise tipik bir biçimde dindarlıklarına yansımaktadır (Miller-Hoffmann, 1995: 63). Buitelaar, sosyalleşmenin dindarlığa yansıyan boyutunu Fas örneğinde izah ederken kadınların daha çok sabırla, erkeklerin ise akılla özdeşleştirildiğini, bu durumun kadınların dindarlığın çeşitli boyutlarına yoğun bir biçimde yönelmelerini beraberinde getirdiğini ifade etmektedir (Buitelaar, 1991: 102-104).

Toplumsallaşma biçimine bağlı olarak kazanılan geleneksel cinsiyet rolleri daha dindar olmaya yol açarken din eğitimi de geleneksel cinsiyet rollerine ideolojik bir destek sağlamaktadır. Dolayısıyla edilgin, pasif, yetiştirici ve merhametli bir biçimde toplumsallaşan kadınlar daha dindar olmaya yatkın hale gelmektedir (Miller, Stark, 2002: 1402). Rol ve konumlarını belirleyen söz konusu sosyalizasyonun izlerini kadınların Tanrı inancı ve Tanrıya müracaat biçimlerinde somut bir biçimde görmek mümkündür. Kadın ve erkeklerin Tanrı imajının sosyal rollerine, dolayısıyla da sosyalleşme şekillerine bağlı olduğunu göstere- 
cek biçimde kadınlar için Tanrı sevgisi belirleyiciyken, erkekler için Tanrının gücü ve adaleti öne çıkmaktadır. Öyle görünüyor ki kadın ve erkekler sahip oldukları Tanrı imajı ile sosyalleşme sürecine bağlı olarak edindikleri sosyal rol ve konumları, toplumsal bağlamları arasında bir özdeşleştirme yapmaktadırlar (Ozorak, 1996: 17).

Kadınların sahip olduğu tanrı imajı aynı zamanda kültürlenme biçimleri ve kültürün cinsiyetle ilgili beklentileriyle de tutarlıık arz etmektedir. Dinlerin Tanrı imajının genelde maskulen bir karakter taşımasına karşın dindarlığın çeşitli boyutlarına yoğun bir biçimde katılan ve Tanrıya ilişkin bu ataerkil imajları kabul eden kadınlar Tanrıyı genelde destekleyici olarak tasvir etmektedirler. Zira kadınların destekleyici, büyütüp besleyen rolleri sahiplenmeleri ve oynamaları beklenmektedir (Nelsen, Cheek, Au, 1985: 397).

O halde kadınların daha dindar oluşları sosyalleşme biçimleri ve toplum tarafından kendileri için uygun görülen kadın rolünü özümsemeleri ile ilişkilidir. Buna karşın erkekler çeşitli dinî uygulamaları da içeren kadınsı etkinliklerden kaçınmaları yönündeki kültürel beklentilerle karşı karşıya kalarak maskulen kültürel fikirleri özümsediklerinden kadınlardan daha az dindardırlar. Dolayısıyla sosyalleşme biçimlerinin bir sonucu olarak kadınlar daha dindar erkekler daha az dindar bir nitelikle donanmış olarak sosyal hayattaki yerlerini almaktadır (Thompson, 1991: 382).

Sosyalleşmenin kadın dindarlığına olan etkisini alana dayalı bulgularla somutlaştırmak gerekirse Hollanda ve İrlanda hariç tüm Batı ülkelerinde kadınlar erkeklere nazaran daha dindar olmalarını sağlayacak sosyalleşme süreçlerinden geçmektedir. Söz konusu sosyalleşme süreçleri bir yandan kadınları daha dindar olacak biçimde eğitirken diğer yandan da dinsel davranışların tatbik edilmesini erkeklerden daha ziyade kadınlardan beklemektedir. Bu bakımdan kadınlar çocukluklarından itibaren erkeklere göre daha dinî bir yaklaşımla sosyalleştirilmekte, çocuk bakımının da dahil olduğu aile bağlamlı bir konum ve rol de söz konusu dinî yaklaşımın bir parçası olmak üzere sıkı sıkıya kadınla ilişkilendirilmektedir (Kecskes, 2000: 99).

Kız çocuklarının sosyalleşme süreçlerinde manevi değerlerin ve dinselliğin çok etkin ve baskın bir şekilde kullanılması namus ve şeref kavramları ya da aile güvenliğinin kadın bağlamında düşünüldüğü geleneksel algı biçimini çağrıştırmaktadır. Ayrıca dinin makro düzeyde sosyokültürel hayat içindeki geleneksel konumunun devamlılığının mikro düzeyde aile bağlamındaki kararlılık ve sürekliliğine bağı olduğu göz önünde bulundurulduğunda söz konusu devamlılığı sağlama rolünün kadına biçildiği toplumsal bir ön kabulle karşılaşılacaktır.

Miller ve Stark sosyalleşme biçimi, toplumsal konum ve rol, işbölümü ve buna dayalı boş zaman imkânlarının kadınların daha dindar oluşunu tek başına açıklamakta başarısız olduğunu farklı bir etkenin daha işe dahil edilmesinin gerekliliğini Japonya örneğinde dile getirmişlerdir. Buna göre şayet farklı top- 
lumsallaşma biçimi farklılaşan dindarlığa yol açıyorsa cinsiyet rolleri bakımından oldukça geleneksel bir ülke olan Japonya'da kadın ve erkeklerinin dindarlıklarında yaşanan farklılaşmanın çok büyük bir düzeyde seyretmesi gerekirdi. Ayrıca, erkeklerin sürekli çalışmasına karşın kadınların evle ilişkili bağlamları daha belirgin olduğundan daha fazla boş zamanları bulunmaktadır. Bu durumda da dindarlık ile boş zaman arasında bir ilişki varsa kadın ve erkeklerin dindarlıkları arasında büyük bir farkın oluşması beklendirdi. Buradan hareketle Miller ve Stark dindarlık düzeyi bakımından Japon kadınları ile erkekleri arasında büyük farkın olmadığını, bu yönüyle kadınların daha dindar oluşunun açıklanması için sosyalleşme ve işbölümünden daha ziyade risk faktörünün de işe karıştırılmasının gerektiğini belirtmektedirler (Miller, Stark, 2002: 1417).

Sosyalleşme biçimi ile biyo-psişik kişisel belirleyicilerin gölgesinde şekillenen kadın ve erkeklerin 'risk' almaktaki tutum farklılıkları cinsiyetler arası dindarlık farklılaşmasına müdahil bir diğer etkendir. Kadın ve erkeklerin toplumsal yaşamda aldığı risk düzeyi dindarlık biçimlerini etkilemekte, erkekler risk almaya, kadınlar ise riskten kaçmaya meyilli olup, böylesi bir eğilim diğer tutum ve davranışlara olduğu gibi, dinî yaşayışa da yansımaktadır. Sözü edilen risk analizi modeli, çeşitli davranışsal farklılıkları risk faktörü temelinde incelemek üzere kullanılmış bir yaklaşımdır. Risk analizi yaklaşımının kullanıldığı sınırlı düzeydeki dindarlık araştırmasında dindarlık riskten kaçınma eğilimi çerçevesinde açıklanmaktadır. Buna göre dindarlık bir toplumda denetlenemeyen şeyleri kontrol etme isteği ve ölüm korkusuyla başa çıkma eğilimiyle doğrudan ilişkilidir. Riskten kaçan kişiler korku ve şüphelerinin üstesinden gelmek üzere kültürel yaşamın onayladığı meşru bir yolu aramakta, bu arayış ise dinî inanç ve pratiklere daha yoğun bir biçimde yönelmekle sonuçlanmaktadır. Zira yapılan araştırmalar risk alan insanların yenilikçi cevaplar aramalarının muhtemel olmasına karşın riskten kaçan insanların sıkıntılı ve belirsiz durumların üstesinden gelen geleneksel yolları tercih ettiğini göstermiştir (Miller-Hoffman, 1995: 64-65).

Risk faktörü diğer değişkenlerle dindarlık arasındaki ilişkinin açıklanmasında da önemli bir analiz aracı haline gelebilmektedir. Cinsiyet ve yaş risk faktörü ile ilişkilendirilerek dindarlığı açıklamak üzere özellikle başvurulan değişkenlerdendir. İnsanların yaşlandıkça fâniliklerini ve ölümlülüklerini fark ederek daha dindar hale geldikleri dindarlık araştırmalarında çeşitli biçimlerde vurgulanmakla birlikte risk analizi yaş ve dindarlık ilişkisini fark edilmiş risk temelinde açıklamaktadır. Buna göre yaş artışına bağıı olarak dinî bağlıı̆̆ın eksikliği hissi kendini gösterecek, böylece fark edilmiş riskin artmasıyla birlikte dine yönelim baskın bir biçimde kendini hissettirecektir. Dolayısıyla dinî bağılı̆̆ın eksikliğiyle ilişkili fark edilmiş risk yaş artışıyla koşut bir biçimde artmakta, bu nedenle kişiler yaşlandıkça dine daha yoğun bir biçimde yönelmektedir. Risk faktörü ve cinsiyet ilişkisine bakıldığında ise genel olarak kadınların hayatın hemen tüm alanlarında riski daha fazla fark ettikleri ve risk alan tutum ve davranışları daha düşük düzeyde sergiledikleri görülecektir. Buna karşın erkeklerin risk alan tutum ve dav- 
ranışlarına hayatın hemen her alanında rastlanmaktadır. Riskten kaçan tutumları kadınları dinin de dahil olduğu risksiz, bilindik geleneksel mekanizmalara daha yoğun bir biçimde yönlendirirken erkekleri risk alan tutumları dinin de dahil olduğu geleneksel olandan farklı yeni yöntem ve mekanizmalara yönlendirmektedir (Miller-Hoffman, 1995: 64-65).

Şunu da söylemek gerekir ki riskten kaçınma eğilimi ve buna bağlı dindarlık artışı sosyalleşme özellikleri ekseninde kadınlarla ilişkilendirilse de benzer sosyalleşme durumlarında erkeklerin de riskten kaçan bir tutumu ve daha dindar bir profili sergilediği görülmektedir. Dolayısıyla riskten kaçma eğilimleri daha yüksek olduğundan kadınlar erkeklerden daha dindar gözükmektedir. Ayrıca, risk tercihleri cinsiyetler arasında olduğu kadar, aynı cinsiyet kategorisi içinde de dindarlığı etkilemektedir (Miller-Hoffman, 1995: 63-75). Burada risk analizinin, ya da bir başka deyişle kadınların riskten kaçınma eğilimlerinin yüksekliği ile dindarlık arasında kurulan ilişkinin daha çok cinsiyet farklılaşması temelinde psikolojik güdülerden hareketle yapılan bir genelleme iddiasını içerdiği söylenebilir. Esasen bu tür bir yaklaşım biraz da yapısal ve sosyal etkenlerin erkekler için de bağlayıcı olan yönünü göz ardı etmektedir.

Kadınların erkeklerden daha dindar olduğunu gösteren bu bulgular ve daha dindar oluşlarını gerekçelendirmek üzere geliştirilen tüm bu kuramlara karşın yapılan çalışmaların tümünde kadınların erkeklerden daha dindar çıkmadığını belirtmekte yarar vardır (Thompson, 1991: 381). Buradan hareketle yapılan araştırmalarda kadınların daha dindar çıkışının aslında cinsiyet ve dindarlığı iki değişkenli bir ilişki olarak ele alan metodolojik bir yaklaşımdan kaynaklandığı vurgulanmaktadır. íki değişkenli bir yaklaşımdan çok değişkenli bir yaklaşıma kayan bazı araştırmalar cinsiyetin etkisinin belirtildiği kadar büyük olmadığını ve cinsiyet gibi demografik değişkenlerle dindarlık arasında doğrudan bir ilişki bulunmadığını ifade etmektedirler (Roberts, Davidson, 1984: 346-347).

Thompson, dindarlık üzerine özellikle de cinsiyet dindarlığı üzerine yapılan pek çok çalışma da kadınların erkeklerden daha dindar olduğu sonucuna ulaşılmış olmasını cinsiyet farklılı̆ının abartılmış olması şeklinde yorumlamaktadır. Ona göre cinsiyet sadece demografik bir özellik olarak ele alındığından kadınların erkelerden daha dindar olduğu sonucuna ulaşılmaktadır. Oysa dindarlığı etkileyen temel unsur demografik bir özellik olarak cinsiyet değil, çoklu sosyokültürel ve kişisel etkileşimlerin bir ürünü olan cinsiyet bakış açısıdır. Kadınsı ya da erkeksi bakış açısı sadece bir cinsle ilişkili olmayıp her iki cins de kadınsı ya da erkeksi bir bakış açısını geliştirebilmektedir. Kadınsı bir bakış açısına sahip olmak dindarlığı artıran bir etkiyi beraberinde getirmektedir. Zira kadınsı bakış açısını geliştiren erkeklerin dindarlık düzeylerinde belirgin bir artış meydan gelmektedir. Dolayısıyla kadın olmak ile kadınsı bakış açısına sahip olmak dindarlık üzerinde farklı biçimlerde etkili olan faktörlerdir (Thompson, 1991: 390391). 
Dindarlığı kadın olmaktan ziyade kadınsı bakış açısına sahip olmakla ilgili bir durum olarak gören Thompson ve Remmes yaptıkları araştırmaların sonucunda yaşlandıkça feminen eğilimleri artan erkeklerin dindarlığa yönelimlerinde sadece biçimsel olarak değil yoğunluk olarak da bir artışın olduğunu görmüştür (Thompson, Remmes, 2002: 523). Bu doğrultuda yürütülen ve biyolojik etkenlerin feminen bir eğilimi yaratmaktaki gücüne de işaret eden araştırma sonuçlarına göre feminenlik düzeyi yüksek kadın ve erkekler maskulenlik düzeyi yüksek kadın ve erkeklere oranla daha dindardır (Francis, Wilcox, 1998: 467). Ayrıca, dindarlığı çok boyutlu bir yapı olarak ele alan araştırmacılar dinî katııımda beklendiği ve söylendiği gibi bir farklılaşmanın olduğunu bulmuşlarsa da bu farklılaşmanın dinî inançlarda söz konusu olmadığını da görmüşlerdir (Thompson, 1991: 381).

Anlaşılacağı üzere çeşitli kültürel bağlamlarda gerçekleştirilmiş araştırma verileri kadınların kültür, toplumsal normlar ve din, sekülerizasyon gibi makro etkenlerin yanı sıra yerleşim yeri, yaş, eğitim düzeyi gibi mikro etkenlerin tesiriyle daha dindar bir profili sergilediklerini gözler önüne sermektedir. Ayrıca dinlerin kadın-erkek kategorizasyonunu dinî pratikler merkezinde organize edişi, din eğitimi, cinsiyetlerin sosyalizasyonu, risk alma tutumlarındaki farklılık, sosyoekonomik statü, cinsiyet merkezli işbölümü de kadınların daha dindar bir tutum sergilemelerinde etkili bulunmaktadır. Ancak görüldüğü üzere daha dindar olma durumu inanç boyutundan daha ziyade dindarlığın pratik ve sosyal boyutu temelinde erkeklerle kurulan karşılaştırmalar ekseninde izah edilmektedir.

\section{Sonuç}

Kadınların doğuştan getirdikleri cinsiyet özellikleri ile sosyokültürel yaşam bağlamında edindikleri toplumsal cinsiyet özelliklerinin çeşitli biçimlerde dindarlıklarına yansıdığı ve kadına özgü bir dindarlık biçimini yarattığı anlaşılmaktadır. Kadın dindarlığı bu bakımdan kadınlık/erkeklik algılamaları, anlayışları ve rolleri üzerine kültürden gelen değer ve normların içselleştirilme sürecinde somutlaşmakta ve biçimlenmektedir. Kadına özgü bu dindarlık biçimi dindarlığın özellikle halk inanç ve uygulamaları boyutuna yoğun bir yönelimi temsil ettiği gibi, nitelik olarak da yüksek bir katııımı sunmaktadır. Kadın dindarlığının nicelik ve nitelik olarak yüksek katılımlı bu özelliğine çeşitli kültürler örneğinde somut bir biçimde rastlanmakta, olgusal veriler kadınların daha dindar olduğu varsayımını desteklemektedir.

Dindarlığın sosyokültürel temelleri göz önünde tutulduğunda, kadınların özellikle büyüsel, sihirsel ve duygusal boyutu öne çıkmış eğilimlerle daha çok özdeşleşmesinin, sosyokültürel statü düşüklüğü, sosyal ve fiziki hareketsizlik, ekonomik bağımlılı̆ın yüksekliği gibi özellikler arasında bir bağıntı kurmak mümkündür. Bu ayrışmayı elbette kadın ve erkek dinî sosyalleşme süreç ve mekânlarının farklılı̆ı daha da derinleştirmektedir. Kadınlarda dinî bilginin akta- 
rımı, pratiklerin ve ritüellerin icrasının daha geleneksel, içsel ve mahrem boyutta sürmesi önemli bir ayrışma faktörüdür. Kadın dindarlığını açıklamak üzere zikredilen bu etkenler aslında kadınların cinsiyet özellikleriyle ilişkilidir. Başka bir deyişle doğuştan getirdikleri biyolojik cinsiyetleri ile sosyokültürel yaşam bağlamında edindikleri toplumsal cinsiyetleri dindarlık biçimlerini şekillendirmektedir. Ancak toplumsal cinsiyet özellikleri ile dindarlıkları arasında daha güçlü bir ilişki kurulmaktadır. Tüm bu zikredilen hususlar kadınların dinî kurum ve sosyal hayattaki konumlarına rağmen neden daha dindar olduklarını açıklamak üzere geliştirilen kuramsal yaklaşımlar bağlamında sıklıkla sunulmuştur. Böylece konumları ile örtüşmeyen bir dindarlık biçimi ya da yaygın söylemle bir paradoksun söyledikleri analiz edilmeye çalışıımıştır. Söz konusu paradoksun aslında sosyokültürel yaşamın geneli gibi çoklu etkileşimlerin müdahalesini temsil ettiği kuramsal yaklaşımların özetle üzerinde uzlaştığı husustur.

\section{Notlar}

(*) Doç. Dr., Erciyes Üniversitesi Illahiyat Fakültesi, e-posta: celikc@erciyes.edu.tr

$\left.{ }^{* *}\right)$ Dr., Erciyes Üniversitesi Illahiyat Fakültesi, e-posta: isahin@erciyes.edu.tr

\section{Kaynaklar}

Agacinski, Sylviane (1998). Cinsiyetler Siyaseti, Çev. İsmail Yerguz, Dost, Ankara. Berger, Peter L. (1993). Dinin Sosyal Gerçekliği, Çev. Ali Coşkun, İnsan Yayınları. Berktay, Fatmagül (1996). Tektanrılı Dinler Karşısında Kadın, Metis, İstanbul.

Berktay, Fatmagül (2002). “Doğu ile Batı'nın Birleştiği Yer: Kadın İmgesinin Kurgulanışı”, Modern Türkiye'de Siyasi Düşünce: Modernleşme ve Batıcılık. Tanıl Bora, Murat Gültekingil (eds.), iletişim Yayınları, İstanbul, ss.275-285.

Buitelaar, Marjo (1991). Fasting and Feasting in Morocco An Ethnographic Study of the Month of Ramadan, Academisch Proefschrift, Nijmegen.

Carroll, Michael P. (2004). "Give Me that Ol' Time Hormonal Religion", Journal for the Scientific Study of Religion, 43:2, ss. 275-278.

Çelebi, Nilgün (1990). Kadınlarımızın Cinsiyet Rolü Tutumları, Sebat Kitabevi, Konya.

Davie, Grace (2005). "Din Sosyolojisi”, Din, Toplum ve Kültür, Der. ve Çev. A. Coşkun, İz yay., ist. 2005, 101-120.

Delaney, Carol (2001). Tohum ve Toprak, İletişim Yayınları, İstanbul.

Doltaş, Dilek (1991). "Feminizm Açısından Sekizinci Günah ve Bir Cinayet Romanı”, Toplum ve Bilim, Sayı: 53, ss.83-95.

Eliade, Mircea (1991). Kutsal ve Dindışı, Çev. Mehmet Ali Kılıçbay, Gece, Ankara.

Fişek, Güler O. (1990). "Cinsiyet Konumu ve Psikoloji: Eleştirel Bir İnceleme”, Toplum ve Bilim, Sayı: 50, ss.73-84.

Francis, Leslie J., Carolyn Wilcox (1998). "Religiosity and Femininity: Do Women Really Hold a More Positive Attitude Toward Christianity?", Journal for the Scientific Study of Religion, 37 (3), ss. 462-469.

Fromm, Erich (1998). Anaerkil Toplum ve Kadın Hakları, Çev.Acar Doğangün, Arıtan, İstanbul. Giddens, Anthony (2000). Sosyoloji, Çev. Hüseyin Özel-Cemal Güzel, Ayraç Yayınları, Ankara. Holy, Ladislav (1988). "Gender and Ritual in an Islamic Society: The Berti of Darfur", Man, New Series, Vol.23, No.3, ss. 469-487. 
Iannaccone, Laurence R. (1990). “Religious Practice: A Human Capital Approach”, Journal for the Scientific Study of Religion, , 29 (3), ss. 297-314.

Kağıtçıbaşı, Çiğdem (1992). Insan ve insanlar, Evrim, İstanbul.

Kandiyoti, Deniz (1997). Cariyeler Bacılar ve Yurttaşlar, Çev. Aksu Bora vd., Metis, İstanbul.

Kecskes, Robert (2000). "Religiosität von Frauen und Männern im internationalen Vergleich", Religion und Geschlechterverhältnis, (Hrsg.) Ingrid Lukatis, Regina Sommer, Christof Wolf, Leske+Budrich, Opladen, 85-100.

Loewenthal Kate M., Andrew K. MacLeod, Marco Cinnirella, (2002). “Are Women More Religious Than Men? Gender Differences in Religious Activity Among Different Religious Groups in the UK", Personality and Individual Differences, 32, ss.133-139.

Luckmann, Thomas (1996). Die unsichtbare Religion, Suhrkamp Verlag, Frankfurt am Main.

Malinowski, Bronislaw (1989). IIlkel Toplumlarda Cinsellik ve Baskı, Çev. Hüseyin Portakal, Kabalcı, ìstanbul.

Marshall, Gordon (1999). Sosyoloji Sözlüğü, Çev. Osman Akınhay-Derya Kömürcü, Bilim ve Sanat, Ankara.

Mensching, Gustav (1994). Dinî Sosyoloji, Çev. Mehmet Aydın, Tekin Kitabevi, Konya.

Miller Alan S., John P. Hoffmann (1995). "Risk and Religion: An Explanation of Gender Differences in Religiosity", Journal for the Scientific Study of Religion, 34(1), ss. 6375.

Miller, Alan S., Rodney Stark (2002). "Gender and Religiousness: Can Socialization Explanations Be Saved?", American Journal of Sociology, 107/6, 1399-1423.

Nelsen, Hart M., Neil H. Cheek, Paul Au (1985). "Gender Differences in Images of God", Journal for the Scientific Study of Religion, 24(4), ss.396-402.

Onay, Ahmet (2004). Dindarlık Etkileşim ve Değişim, Dem Yayınları, İstanbul.

Ozorak, Elizabeth Weiss (1996). "The Power, but not the Glory: How Women Empower Themselves Through Religion", Journal for the Scientific Study of Religion, 35 (1), ss. 17-29.

Roberts, Michael K., James D. Davidson, (1984). "The Nature and Sources of Religious Involvement", Review of Religious Research, 25 (4), ss.334-350.

Sirman, Nükhet (1993). "Köy Kadınının Aile ve Evlilikte Güçlenme Mücadelesi", 1980'ler Türkiyesinde Kadın Bakış Açısından Kadınlar, Şirin Tekeli (Der.), İletişim, İstanbul, ss.247-277.

Stark, Rodney (2002). "Physiology and Faith: Addressing the "Universal" Gender Difference in Religious Commitment", Journal for the Scientific Study of Religion, 41:3, ss. 495507.

Şahin, İlkay (2001). Gelenek ve Değişim Açısından Kadınların Dinî Yaşantıları, Tutum ve Davranışları: Boğazlıyan Örneği, (Yüksek Lisans Tezi) Erciyes Üniversitesi Sosyal Bilimler Enstitüsü, Kayseri.

Şahin, İlkay (2008). Göçmen Kadınların Dinî Ritüellere Katılımı: Amersfoort (Hollanda) ve Boğazlıyan Örneğinde Karşılaştırmalı Bir İnceleme (Doktora Tezi), Erciyes Üniversitesi Sosyal Bilimler Enstitüsü, Kayseri.

Tapper, Nancy-Richard Tapper (1996). "Peygamberin Doğumu: Türk İslamında Ritüel ve Cinsiyet”, Çev: Hülya Küçük, Türkiye Günlüğü, Mayıs-Haziran, sayı: 40, ss.40-56.

Thompson Edward H., Kathryn R. Remmes (2002). "Does Masculinity Thwart Being Religious? An Examination of Older Men's Religiousness", Journal for the Scientific Study of Religion, 41:3, ss. 521-532.

Thompson, E. H. (1991). "Beneath the Status Characteristic: Gender Variations in Religiousness", Journal for the Scientific Study of Religion, 30(4), ss.381-394.

Türköne, Mualla (1995). Eski Türk Toplumunun Cinsiyet Kültürü, Ark Yayınları, Birinci Basım, Ankara. 
Volz, Rainer (2000). “Über die Hartnäckigkeit des 'kleinen' Unterscheids-Religiosität und Kirclichkeit im Vergleich der Geschlechter und ihrer Rollenbilder", Religion und Geschlechterverhältnis, (Hrsg.) Ingrid Lukatis, Regina Sommer, Christof Wolf, Leske+Budrich, Opladen, 115-129. 


\title{
POPÜLER KÜLTÜRÜN İLAHIYYT FAKÜLTESI ÖĞRENCILERININ YAŞAM STILLERI ÜZERINDEKI ETKISİ
}

\begin{abstract}
The influence of popular culture on the life styles of faculty of divinity students. In this study, the effects of popular culture elements on the life styles of undergraduate students of theology are examined. The analysed variables are as follows: how their everyday experiences are shaped; TV watching routines of them; their use of Internet; their interest in music, movies and plays; reading behavior; comsumptions preferrences: attitudes towards dressing and fashion; sparetime activities, topic shared by peers and friends; the features of their favourite figures in the fields of music, sports or popular domains; and sociocultural and socio-economic factors that determine their perspectives on social problems experienced in Turkey and on the world, life and events in general. These variables are analysed following an approach based on popular culture criticism. Based on the findings it is safe to argue that destructive effects of various social change processes leading to negative psychological and sociological consequences such as hedonist approaches and extremely individualistic life styles are not influential on the subjects' life styles and preferrences.
\end{abstract}

key words

Life styles, everyday life, faculty of divinity students, popular culture. 


\section{Giriş}

Iktisadi ve politik açılardan Türk toplumu için tarihi bir dönüm noktası olarak nitelenen ve küresel ölçekte kendisini hissettiren 1970'li yılların birtakım iktisadi ve yönetsel krizlerine karşı bir tepki olarak ortaya çıkmış ve Türkiye'de birçok özgün tarihsel, toplumsal ve kültürel deneyimin yaşanmasına vesile olmuş olan 1980'li yıllar, ülkemizin küresel iktisadi ilişkiler dünyasına ve postFordist (1) üretim sürecine ve pazar ilişkilerine dahil olduğu, yeni liberal ideolojinin yükseldiği bir dönemin başlangıcı olmuştur. Türkiye'nin yakın tarihinde gerçekleşen bu değişimlerden önce, CHP'nin merkez solu temsil eden ve ulusal ekonomiyi ve sosyal refahı devlet kontrolü altında tutarak geliştirmek şeklinde özetlenebilecek olan politik söylem ve uygulamalarının yürütüldüğü 1970'li yılları takiben, temel ideolojik dayanağı "serbest pazar ekonomisi" olan bir dizi yeni politik ve iktisadi programın Turgut Özal hükümetiyle birlikte hayata geçirildiği bir döneme tanık olunmuştur (Yarar, 2005; Bali, 2004; Kozanoğlu, 1992).

Dönemin başbakanı Özal'ın uyguladığı "dışa açılma” politikaları neticesinde geleneksel iktisadi üretim ilişkileri ve yapıları çözülmeye uğramış ve küreselleşme sürecinin etkileri, özellikle başta İstanbul olmak üzere büyük şehirlerimizde yoğun bir şekilde hissedilmeye başlanmıştır. Serbest piyasa ekonomisinin ilkelerine göre yapılanan bu yeni iktisadi pazar ilişkilerinin gündelik yaşam kültürü içinde hakim unsur haline gelmesiyle birlikte "tüketim" insanların "kimlik" ve "sosyal statülerini" belirleyen en önemli unsur haline gelmeye başlamıştır (Arık, 2006:108).

1980 sonrası dönemde Türkiye'de uygulanan ekonomi politikalarına (2) ve teknolojik gelişmelere bağlı olarak yaşanan hızlı toplumsal değişme süreci, birer olgu olduğu kadar sorun olarak da ele alınması gereken bazı kavramları, genelde kamuoyunun özelde de sosyal bilimlerin ilgisine ve tartışma gündemine taşımıştır. Bu sıkça kullanılan kavramların başında "küreselleşme", "geç kapitalizm" ve "tüketim kültürü" gelmektedir. Günümüz toplum sorunları üzerine düşünen ve çözümlemelerde bulunan sosyal bilimciler sık sık bu kavramlara işaret etmektedirler. Dolayısıyla "Elektronik teknolojisi", "tüketim ekonomisi" ve "magazinelleşme" gibi birbirleriyle hem neden sonuç ilişkisi hem de etkileşim içindeki dinamikler üzerinde yükselen" (Atay, 2004b: 11) "popüler kültür" olgusunun ülkemizdeki çeşitli görünümlerini de bu bağlama yerleştirerek incelememiz gerekmektedir.

1980 sonrası dönemde Türkiye'nin küresel ekonomiye eklemlenme sürecindeki hızlanmaya paralel olarak iç pazara giren ithal tüketim mallarındaki çeşitliliğin artması, toplumun daha geniş kesimlerinin "yeni tüketim kalıpları"yla tanışmasına vesile olmuştur. Bu yeni tüketim kalıplarının oluşmasında kuşkusuz kitle iletişim araçlarının ortaya koyduğu söylemin de rolü önemlidir (Demir, 1994:357). Başta iletişim ve bilişim sektörleri olmak üzere teknolojinin bütün 
alanlarındaki küresel gelişmeler, değişimler ve dönüşümlerin sonuçlarından ülkemiz de payına düşeni almıştır (Oktay, 2002; Oskay, 2000, 2001).

1980'ler Türkiye'de gündelik yaşam kültürünün medya yoluyla denetim altına alınarak biçimlenmeye ve özellikle "televizyon"un gündem oluşturma etkisinin yoğun biçimde hissedilmeye başlandığı yıllar olmuştur. Bu dönemle birlikte televizyon izlemek, toplumda en popüler (yaygın) zevk ve alışkanlık haline gelmiştir (3). Televizyon, ekran başında geçirilen zamanın ötesinde dilden, müziğe, tüketimden, politikaya birçok kültürel pratiğin içeriğine yeni anlamlar katarak gündelik yaşama adeta damgasını vurmuştur (Kozanoğlu, 1996). Bu dönemde kültürel yaşamın en belirgin karakteristiği, televizyonun etkisiyle "görselliğin" ön plana çıkması ve bütün temaların seyirlik "eğlence" (4) (temaşa) biçiminde işlenerek sunulmaya başlamış olmasıdır (Oktay, 1996; Postman, 2004).

Türkiye'nin 1980 sonrasında dahil olduğu küresel iktisadi piyasa düzeninin koşulları doğrultusunda iç piyasalarda değişen üretim biçimleri ve ilişkileri, aynı zamanda sosyo-kültürel yapıda da birtakım değişim ve dönüşüm süreçlerinin yaşanmasına ve toplumda yeni davranış kalıplarının ve yaşam stillerinin oluşmasına zemin hazırlamıştır. Örneğin büyük kent merkezlerimizde yeni yaşam biçimleri ve farklı sosyal ilişkilerin şekillendiği yeni tüketim mekânları ve alışveriş merkezleri açılmaya başlamıştır. Küreselleşen dünyanın merkez ülkelerinin gündelik yaşam kültürlerine hakim olan, bazı yeni tüketim kalıpları ve boş zaman aktivitileri, büyük kentlerimizin yeni açılan rekreasyon alanlarında da etkisini göstermiş ve tüketim potansiyeli artan orta sınıfın ilgisini çekmeye başlamıştır. Bu yeni sürecin kentlerimizdeki sosyo-ekonomik görünümlerine; orta sınıfa özgü yeni tüketim kalıplarının ve mekanlarının ortaya çıkışı ve yeni mekanlarıyla rekreasyon olanaklarının çeşitlenmesi örnek olarak gösterilebilir. Yaşanan bu hızlı sosyal hareketliliğin doğurduğu önemli sosyo-kültürel oluşumlardan biri de, boş zaman aktiviteleri (5) ile tüketim eylemi arasındaki ayrımın ortadan kalktığının ve bu iki etkinliğin iç içe geçtiğinin görülmeye başlanması olmuştur. Adeta kentte yaşayanlar için boş zamanı değerlendirmek, tüketme eylemi içinde olmak ile eş anlamlı hale gelmiştir (Demir, 2002: 133; Bali, 2004).

Ancak postmodern toplum, veya tüketim toplumu olarak da adlandırılan ve post-Fordist üretim ilişkileri temelinde biçimlenen küresel toplumların yapısında teknolojik gelişmelere bağlı olarak yaşanan maddi değişimlerin; gündelik yaşama getirmiş olduğu bazı kolaylıkların yanı sıra, Türkiye gibi küreselleşme sürecinin aktörü olmayan ve bağımlı ekonomik ilişkiler içinde bulunan çevre ülkelerin sosyo-kültürel ve sosyo-ekonomik yapılarında oluşan; işsizlik, çarpık kentleşme, aşırı ithalata dayalı lüks tüketim, gelir dağılımındaki adaletsizliklere bağlı olarak toplumdaki sosyal tabakalar arasındaki uçurum, terör, suç ve boşanma oranlarındaki artış, uyuşturucu ve madde bağımlıı̆ıının artması, şiddet, eğitimin kalitesindeki düşüş ve devletin üstlendiği sosyal politikalardaki gerile- 
meler gibi pek çok sosyal problemin her geçen gün artarak yaşandığı da görülmektedir.

Bu dönemde Türkiye bir "kitle toplumu" (6) görünümü almaya başlamış ve gündelik yaşam kültürüne de kitle iletişim araçlarının yaydığı kültür olan "popüler tüketim kültürü" egemen olmaya başlamıştır. Bu anlamda popüler kültürü genel olarak "görüntü"yü merkeze alan ve görselliği vurgulayan kitle iletişim araçlarının ve kültür endüstrilerinin imal ettiği kültür olarak tanımlayabiliriz. Teknoloijk gelişmelerin üretim süreçleri aracılığıyla sosyal yaşamın bütün kurumsal ve kültürel ilişkilerini biçimlendirdiği bir ortamda, kitleyi yönlendiren en etkili araç olarak işlev gören medya ve reklam sektörü, kültürel yaşamdaki yüksek kültür ve aşağı kültür (popüler kültür) şeklindeki klasik ayrımı ortadan kaldırarak bu sınırı bulanıklaştırmıştır. Medya ve reklam kuruluşları kültür endüstrileri aracılığıyla istediği kültürel içeriği seçerek popülerleştirip ticari mal (meta) haline dönüştürebilme, istemediğini ise kenara iterek kötüleyip marjinalleştirebilme yeteneğine ve imkanına sahip hale gelmiştir. Türkiye'de medya (7) özellikle 1990'ı yıllarla birlikte; çoğunlukla sanayi devrimi öncesinde, köylülüğün hakim olduğu dönemlerde özgün insan emeği ile üretilmiş ve benzerlerinin yeniden üretilebileceği sosyo-kültürel ve sosyo-ekonomik koşulların günümüzde artık ortadan kalktığı kültür ürünlerini, gerçek sanat yapıtlarını veya otantik, orijinal halk (folk) kültür ürünlerini, kendi ideolojisi doğrultusunda yeniden kodlayarak işleyip, piyasaya sürerek, kültürel bir erozyonun yaşanmasında etkili olmuştur. Bu durum hem geçmiş kültürün muhafazasını güçleştirmekte hem de yeni zengin içeriğe sahip, kalıcı ve rafine bir kültürel üretim ve etkinliğin yaratılabileceği elverişli zeminini ortadan kaldırmaktadır.

Kitle iletişim araçları insanları eğitmek ve bilgilendirmek işlevinin yanı sıra, küresel sermayenin, kapitalist pazar ilişkilerine dönük yapısını destekleyen enformasyon ve mesajlar içeren programlar hazırlayarak, kitleleri yönlendirmek işlevine de sahiptirler. Erdoğan'ın da (2004:9) belirttiği gibi günümüzde artık kitle kültürü, kitle iletişim araçları ve bu araçların desteklediği küresel pazarın mal, hizmet ve ideolojisiyle birlikte düşünülür olmaya başlamıştır. Popüler kültür de bu bağlamda ele alındığında, bu kültür kategorisinin, kitle üretimi yapan küresel piyasaların iktisadi ve politik zihniyetinin somut ifadesi olan kitle kültürünün türevi olarak değerlendirilmektedir.

Günümüzde sosyal hayata hakim olan "tüketim kültürü” Baudrillard'ın (1998) "simülasyon kuramı"na göre bir anlamda, toplumda üretimi aşırı boyutlarda gerçekleşen, bol miktardaki her türlü "nesne"nin farklı bir biçimde anlamlandırılması sürecidir. Gündelik yaşamda kullanılan gösterge (işaret, im) ve imajların çoğalması bu nesnelerin gerçekliği ile hayali arasındaki ayrımı silikleştirerek bir "simülasyon" dünyası yaratmıştır. Birey sahip olduğu nesnelerin kullanımından çok bu "simülasyon" dünyasının yarattığı konum içinde kendini tanımlayarak savunulan "gerçekdışıı̆ı̆” (ki Baudrillard buna "hiper gerçeklik" der) yaşamaya başlar. Modern dünyada "ihtiyaç" var olan somut gereksinimlerin 
karşılığı olmaktan çok; aksine yönlendirici ve manipüle edici bir şekilde bütüncül piyasalar tarafından oluşturulmuş bir duygudur.

Popüler kültür ürünlerinin, tüketimi körüklemek adına piyasaya sunulması, (ki Ritzer (2000) bu durumu "büyüleme" süreci olarak nitelemiştir) yarattığı sahte gereksinim duygusu ile Batı'daki alışveriş merkezleri için yaşamsal öneme sahip ticari bir strateji olarak kabul edilmektedir. Ritzer (2000)'in "tüketim katedralleri" (8) olarak tanımladığı bu merkezler yeterli sayıda tüketiciyi çekebilmek için kendilerine mitsel bir hava verirler ve tüketimi büyülü bir etkinliğe dönüştürme yönünde büyük çaba sarf ederler. Çünkü "büyüleme" tüketimi körüklemekte ve "sahte ihtiyaçlar" yaratarak "yabancılaşmanın" üzerini örtmektedir.

Kapitalizm kendi varlığını daim kılmak için yukarıdaki tanımlamalara benzer din dışı (profan) kutsallar yaratarak sistemin işleyişini desteklemekte ve böylelikle arzuları yönlendirebilir kılmaktadır.

Batıda sanayileşme sürecine bağıı olarak kentsel üretim tarzının, nüfus artışına paralel biçimde, iş bölümüne dayalı olarak gerçekleşmesi, tüketim mallarının çeşitliliğindeki artışa sebep olmuş ve teknolojik gelişmeye koşut olarak üretilen bu ürünlerin hızlı dağıtımı, yayılımı ve kitleselleşmesi sonucunda bir de insanların üretilen bu ürünlere ihtiyaç duyar hale getirilmesi sağlanmış. Bu durum ise insanlara yeni toplumsal koşullara uyum sağlamaları halinde daha yüksek standarda sahip bir yaşama kavuşacakları umudunun aşılanması ile birlikte olanaklı hale gelmiştir. Illk dönem sanayi toplumunda iş̧̧ileri ve alt tabakadaki sınıfı, orta sınıf değerlerine ve yaşamına özendirmek, talebi arttırmak için bu aşamada gerekli görülmüş, bunun için kentlerde "vitrinler", "bulvarlar", "cafe"ler gibi yeni rekreasyon alanları ve alışveriş mekânları oluşturulmuştur. Yavaş yavaş oluşturulan bu tüketim ideolojisinde metaların ömrünü kısaltarak tüketimin daim bir süreç olmasını sağlamak artık moda (9) yoluyla gerçekleşir hale gelmiştir. Kitlelere tüketimin zevk ve mutluluk olduğu inancının benimsetilmesi, tüketim eyleminin bireyi toplumsal gerçeklerden soyutlayan ve onları hayaller (fantazyalar) alemine sürükleyen sahte karakteristiğininin giderek ticaret çevreleri tarafından keşfedilmesine ve bu yönde artan ticari bir ilginin de örgütlenmesine zemin hazırlamıştır (Oskay, 2000, 2001). Bireyin toplumsal konumunu ve çıkarlarını algılamasını engelleyen bu "yanlış ihtiyaçlar" (10) ve "yanlış bilinçlilik" hali, daha sonraki yıllarda Frankfurt Okulu'nun kitle kültürü eleştirilerine ilişkin "güdüp yönetme" kuramının temel varsayımlarının kaynağını teşkil eden kavramlar olarak karşımıza çıkmış ve sosyal bilim çevrelerinde uzun yıllar tartışma gündemini meşgul etmiştir (Özbek, 2002: 66).

Gündelik yaşam pratiklerinde tüketime yönelik yeni davranış kalıplarının oluşması ve toplumda yeni tüketim alışkanlıklarının yerleşmesi artık "tüketim kültürü" olarak tanımlanan ve tüketimin kültür haline geldiği bir toplumsal yapıyı ortaya çıkarmıştır. Toplumsal ve ekonomik anlamdaki her hareketliliğin yansımasının gündelik kültürel pratiklerde gerçekleştiği bu süreç, gündelik ya- 
şam kültürüne dair hemen her şeyin popüler hale getirildiği, popüler olanın gündelik hayata daha çok girmeye başladığı ve bu gündelik kültürel pratiklerin bir moda, bir furya halinde tüketilmeye başlandığı bir toplumsal durumu anlatmaktadır (Güngör, 2005: 174-175).

Yukarıdaki tanımlamalar doğrultusunda popüler kültüre yönelik bir yaklaşım; tüketim, kitleselleşme, moda, reklâm, kitle iletişim araçları, medya, küresel kapitalizm ve boş zaman aktiviteleri gibi sosyolojik olgu ve süreçlerle birlikte düşünülmesi gereken karmaşık ilişkiler ağına sahip bir yapıyı ifade etmektedir.

Günümüz Türkiye'sinde tüketim mallarının çeşitliliği ve bolluğu, tüketicilere sağlanan taksitlendirme ve kredilendirme imkânları (11), radyo ve televizyon yayınlarının yaygınlaşması, reklâm şirketlerinin sayısının ve sağladıkları hizmetlerin artması ve iletişim teknolojilerinin geliş̧mesi ile birlikte tüketim kültürü gittikçe yaygınlaşmaktadır (Aydoğan, 2004: 134).

Dolayısıyla, Amerika ve Batı Avrupa toplumları için geçerli olan ve yukarıda ana hatlarıyla izah edilen kitle toplumu eleştirileri, artık ülkemiz için de geçerli olmaya başlamıştır (12). Ancak burada Atay'ın (2004b: 12) da vurguladığı gibi ülkemiz açısından kaydedilmesi gereken, Batı'ya göre farklı ve sorunlu bir nokta bulunmaktadır: "Türkiye bu sürece onun arka planını oluşturan endüstriyel hayatın içerisinden değil, bir toplumsal ve ekonomik yaşam biçimi olan "köylülük"ten geçiş yapmıştır. Tarımcı sözlü kültür geleneğinin hala büyük ölçüde geçerli olduğu bir noktadan, yazılı kültürle gerektiğince haşır-neşir olunamadan görsel kültüre sıçranmıştır. Bu durum da beraberinde küresel kültürün bu coğrafyaya intibakının bize özgü birtakım sorunlarını gündeme getirmiştir (13)".

\section{Araştırmanın Problemi}

Araştırmanın giriş kısmında ifade edilmeye çalışılan ve Türkiye'nin yaklaşık son 25 yıldır tecrübe ettiği sosyal, iktisadi, politik ve kültürel dönüşümlerin etkileri, kuşkusuz toplumun bütün kesimleri açısından önemli sosyolojik sonuçlar içermektedir. Ancak bu sürecin, sosyo-kültürel ve sosyo-psikolojik yansımaları, toplumun bilhassa genç kuşakları üzerinde daha yoğun olarak hissedilmekte ve gözlenmektedir. Çünkü ergenlik döneminde bireyler bir yandan fiziksel, zihinsel, duygusal ve psiko-sosyal gelişim alanlarında çocukluktan kurtulup genç olma ve yetişkinliğe hazırlanma çabası içindelerken öte yandan da bu dönemin en önemli gelişimsel görevlerinden birisi olan "özerklik" ve "kimlik kazanma" çabası içindedirler (Kulaksızoğlu, 1998).

“Genç" kavramı Neyzi (2004:108)'nin de ifade ettiği gibi, ABD’nin íkinci Dünya Savaşı'ndan süper güç olarak çıkmasıyla birlikte değişen sosyo-ekonomik dengelerin yapılandırdığı toplumsal şartlarda ilk olarak Amerika'da ve daha sonra da Avrupa ve çevre ülkelerde artık belirli bir tüketici kitlesini tanımlar hale gelmiştir. Ancak bu aşamaya gelinceye kadar Batı'da gençliğin anlamını ve tanımını değiştiren bazı sosyal süreçler vuku bulmuştur. Sanayileşme süreci; 
toplumda "küçük yetişkinlik" tanımıyla, çocukların bir an önce yetişkin yaşama katılmasının beklendiği geleneksel yapıyı ve geleneksel rol tutumlarını ortadan kaldıran bir sosyal süreci hayata geçirmiştir. Bu dönüşüm aynı zamanda eğitimli olmayı, sanayi sektörü için bir zorunluluk olarak ortaya çıkarmıştır. Sanayinin yetişmiş insan gücüne duyduğu ihtiyaç, ergenlik döneminin özel bir eğitim, beceri ve performans geliştirme dönemi olarak kabul görmesini sağlamıştır (Doğan, 2004: 332). Dolayısıyla gençlik üretim sürecinden zorunlu olarak kopmuş çağ nüfusunun oluşturduğu bir kesim olarak, kendisinden önceki nesle bağımlı ve daha çok tüketim merkezli bir yaşam biçimiyle sınırlı hale gelmiştir. Günümüzde gençlik aynı zamanda kitle iletişim araçları tarafından sunulan popüler kültür ürünlerinin, mesajların ve değerlerin tüketicisi konumuna getirilmiştir. Storey (2000: 119)'in de ifade ettiği gibi “ticari eğlence (14) pazarının sunduğu kültür, gençlerin duygu ve davranışlarına ayna tutması ve aynı zamanda bu tavrın yansıyabileceği bir ifade edici alan ve semboller bütünü sunması bakımından önemli bir işleve sahiptir. Popüler kültürün doldurduğu bu alan, gençler açısından kendini ifade etme, ticari kuruluşlar açısından ise verimli bir kar alanı oluşturmuştur".

Popüler kültürün, gençliğin zihniyet dünyasına ve davranış kalıplarına olan yansımaları üzerine yapılan araştırma, değerlendirme, yorum ve tartışmaların merkezinde; gençlik alt kültürünün "kitlesel bir pazar için değişime uğratılarak aynı zamanda da depolitize edilmekte ve popüler tüketim için kabul edilebilir hale getirilmekte" (McRobbie, 1999: 235) olduğu savı yer almaktadır. Örneğin gençler Spenle'ye (1980: 9) göre "bugün kendilerini bir grup olarak onlar için yapılan ticari sömürünün içinde bulmaktadırlar, onlar için yayınlanan dergiler, beklentilerini somutlaştıran idoller, pop müziği vb". Willis (1993: 37-38) da konuyla ilgili olarak birkaç kuşak önce çocukların 10-11 yaşlarındayken fabrikalara iş̧i olarak sokulduklarından, bugün ise kapitalizmin, çocukları toplumun yeniden üreticileri olarak yönlendirmek istediğinden bahsetmektedir. Çocukların giderek daha erken yaşta tüketici olmayı öğrendiklerinden ve günümüzde 2-3 yaşındaki çocukların dahi düzenli olarak oyuncak istediklerinden söz etmektedir. Hatta Willis'a (1993) göre bu çocuklar ne istediklerini ve markalarını da tam olarak bilmektedirler. Dolayısıyla kapitalist toplum, yetişmekte olan neslin zihinsel ve bedensel değişim deneyimini "tüketim" alanı dışında başka yaratıcı alanlarda gerçekleştirme açısından çok az olanak tanımaktadır (Willis, 1993: 39). Bu bağlamda bir tüketim toplumunda gencin sosyo-psikolojik ihtiyaç ve beklentilerinin artık aile ve okul gibi toplumsal kurumlardan önce ve daha kolayca kendileri için üretilmiş ve hedonist yaşam stillerini dayatan ticari popüler kültür ürünleri tarafından karşılandığını ifade etmek mümkündür.

Öte yandan gençliğin içinde bulunduğu sosyal konum, gelişmiş ülkelerin kalkınma modellerini örnek alan ve uygulayan çevre ülkelerin toplumları açısından sorun teşkil eden bir başka olgusal gerçeklikle birlikte düşünüldüğünde ise, bu gençlerin düşünsel ve duygusal gelişim evrelerini atlatmalarının, Batılı genç- 
lere oranla daha sancılı olduğu dikkati çekmektedir. Çünkü çevre ülkelerin gençleri, gençlik döneminin psiko-sosyal bunalımlarına ek olarak Batılılaşmamodernleşme-geleneksellik kutuplaşmasının ve gelgitinin yaşandığı Türkiye gibi toplumsal değişim ve dönüşümlerin hızlı gerçekleştiği geçiş toplumlarında, toplumsal, bireysel ve kültürel kimlik krizlerinin sebep olduğu birtakım duygusal ve zihinsel savrulmalar da yaşamaktadırlar. Böylece Atay'ın, (2004a: 87) kültürel şizofreni olarak tanımladığı bu toplumsal ruh halini "gelenekten moderne, oradan da postmoderne (15) hızla savrulan üç parçaya ayrıımış hayatımızın" yol açtığı ve tecrübe ettiğimiz bir gerçeklik olarak değerlendirebiliriz. Tüketim toplumunun kültürü olan popüler kültür de adeta "uyuşturucu" etkisiyle bu şizofren hali yeniden üreterek, kişiliğini ve kimliğini aradıkları bir dönemde gençlerin kimlik ve rol kargaşasıyla sonuçlanabilecek bir çıkmaza girmelerine neden olmaktadır.

Geleneksel toplumların din ile yoğrulmuş kültürünün aksine modern toplumların akılcı ve seküler kültürü, dini ihtiyaç ve arzuların tatminini sağlayan değerler sisteminin çökmesinde en büyük sorumlu kabul edilmektedir. Modern insan değerler sisteminde yaşanan bu çöküş nedeniyle davranışlarının anlamlı, değerli veya ölçülü olup olmadığını hatırlatacak kutsal temellerden gittikçe uzaklaşmakta ve psikolojik dayanaklarını büyük ölçüde kaybetmekle karşı karşıya kalmıştır. Ancak bu kayıp, dini temellerin ortadan kalktığı anlamına gelmemektedir. Zira fıtri niteliği sebebiyle insan, din dışı bir çerçevede bile bağlandığı ve anlam aradığı fikir ve ideolojilerle aslında dine ayrılan boşluğu doldurmaya çalışmaktadır. Böylece gerçekte "dini olmayan dini bir bağlııı" geliştirmektedir (Bahadır, 2002: 143-144). Özellikle gençlik söz konusu olduğunda bu tür bağlanmaların gözlemlendiği durumlar arasında popüler kültür unsurlarının etkisini de göz ardı edemeyiz.

Erikson, bireyin gençlik dönemine girişiyle birlikte ya kimlik kazanımıyla ya da rol karışıklığıyla sonuçlanacak bir dizi kararın alınması gerektiği varsayımını geliştirmiştir. Erikson'a göre rasyonel kararları alabilen gençler, yaşam deneyimlerini açıkça tanımlanmış bir kimlikle bütünleştirmeye yetenekli olacaklardır. Rasyonel kararları alamayanlar ise gençlik dönemi sona erdiğinde ve yetişkinlik başladığında, geliştirilecek çeşitli kimliklerle ve oynanacak rollerle ilgili cevabını bulmakta zorlandıkları birtakım sorularla bunalacaklardır (Gander ve Gardiner, 2001: 491).

Gençliğin insan yaşamının farklı bir evresi olarak ortaya çıktığı tarihsel devirlerde, yani sanayi toplumunun öncelikli intiyacı olan mesleki bilgi ve beceriye sahip eğitimli bireyler haline gelinceye kadar belli bir zaman dilimini okulda ve eğitim merkezlerinde geçirmek zorunda kalan gençlik, önceleri zorunlu olarak üretim sürecinden, daha sonra ise yönetimde karar alma süreçlerinden kopmuşlardır. Günümüzde ise gençlik daha çok tüketim süreçleri tarafından belirlenen, bağımlı bir toplumsal konum ve kimliğe sahiptirler (McRobbie, 1999; Neyzi, 2004; Şişman, 2003; Bayhan, 1997, 2002). 
Gençliğe yönelik olarak yapılan birçok değerlendirme, yorum ve analizin merkezinde yer alan popüler kültür olgusunun, yüksek din eğitimi alan ve din adamı olarak yetiştirilen Türkiye'deki ilahiyat fakültelerinde öğrenim görmekte olan yüksek öğrenim gençliğinin yaklaşımlarına nasıl yansıdığı sorusu bu araştırmanın temel sorununu oluşturmaktadır. Ülkemizde gençliğin, popüler kültürün beslediği tüketim toplumunun kuşatması altıdaki sahipsiz konumuna bağıı olarak yaşadığı bilinç ve zihniyet sorununun, yüksek din eğitimi alan ilahiyat fakültesi öğrencileri özelindeki durumu bu araştırmanın cevabını aradığı temel sorunu teşkil etmektedir.

\section{Araştırmanın Amacl}

Bu araştırma, günümüzde özellikle medya tarafından biçimlenen popüler kültürün ilahiyat fakültesi öğrencilerinin gündelik yaşamlarında olup bitenlere etkisinin hangi boyutlarda gerçekleştiğine, Türkiye'de popüler kültürün bu gençlerin dünyaya, toplumsal yaşama, insanlığa ve kendi öz varlıklarına ilişkin bakışlarını, tutum ve davranışlarını, değer, duygu ve düşüncelerini nasıl biçimlediğine, değiştirdiğine veya dönüştürdüğüne ilişkin saptamalarda bulunmayı amaçlamaktadır.

Bu araştırmanın kapsamına okuyan gençlik kategorisi içinde bulunan ve üniversite gençliğinin belirli bir kesimini oluşturan illahiyat Fakültesi öğrencileri dahil edilmiştir. Bu araştırmada a) eğitim süreci içinde olmaları, b) tüketime dönük olmaları, c) çalışan gençlik kesimine oranla yeni teknolojik, kültürel ve toplumsal değişmelerin daha fazla farkında olmaları ve etkisine daha açık gençlik kesimi oldukları da dikkate alınarak, ticari eğlence pazarının sunduğu popüler kültürün bu gençlik kesimi üzerinde bıraktığı izler ve etkiler gençlerin tüketim tercihleri, kültürel zevkleri ve entelektüel ilgileri üzerinden anlaşılmaya çalışılacaktır. Ayrıca araştırma kapsamına dahil olan öğrencilerin yüksek din eğitimi alıyor olmalarının bu tercihler üzerindeki etkisi de tespit edilmeye çalışılacaktır. Bu araştırmanın temel amacı ilahiyat fakültesi öğrencilerinin popüler kültür unsurlarına ilişkin yaklaşımlarını belirlemektir. Bu amaçla popüler kültürün; televizyon, müzik, sinema, hayran kitlesi kültürü ve alışveriş (tüketim) (Storey, 2000) gibi farklı alt boyutlarının, ilahiyat fakültesi öğrencilerinin; kitap, dergi ve gazete okuma alışkanlıkları üzerinde, bilimsel içerikli faaliyetlere olan ilgileri ve katılım durumları, çeşitli sanat türlerine (görsel, edebi ve plastik) olan ilgi düzeyleri ve çeşitli dernek faaliyetlerini yürütmek, desteklemek veya katılmak ve toplumsal içerikli problemlere duyarlı tutum ve davranışlarda bulunmak gibi genel olarak gençliğin entelektüel ve estetik ilgilerini ifade eden yaşam felsefeleri ve sahip oldukları tüketim kalıpları üzerindeki etkisi tespit edilmeye çalışılacaktır. Bu amaçla cevaplandırılmaya çalışılacak sorular şunlardır:

\section{Alt Amaçlar}

Araştırmanın alt amaçları şunlardır: 
1) İlahiyat Fakültesi öğrencilerinin popüler kültür unsurlarına ilişkin yaklaşımları, cinsiyet durumlarına göre nasıl bir dağılım göstermektedir?

2) İlahiyat fakültesi öğrencilerinin popüler kültür unsurlarına ilişkin yaklaşımları, ailelerinin sosyo-ekonomik düzeylerine göre nasıl bir dağılım göstermektedir?

3) İlahiyat fakültesi öğrencilerinin popüler kültür unsurlarına ilişkin yaklaşımları, barınma yeri türüne göre nasıl bir dağılım göstermektedir?

4) İlahiyat fakültesi öğrencilerinin popüler kültür unsurlarına ilişkin yaklaşımları, öğrenim gördükleri fakültelere göre nasıl bir dağılım göstermektedir?

\section{Araştırma Evreni ve Örneklem}

Araştırmanın örneklem tespitinde, 2006-2007 öğretim yılında en çok öğrencisi bulunan 5 ilahiyat fakültesinde (Ankara Üniversitesi, Marmara Üniversitesi, Atatürk Üniversitesi, Selçuk Üniversitesi ve Uludağ Üniversitesi İlahiyat Fakülteleri) öğrenim görmekte olan üniversite öğrencileri evreninden 1 . ve 4 . sınıfta öğrenim görmekte olan öğrenciler değerlendirmeye alınmıştır. Örneklem büyüklüğünün belirlenmesinde araştırmanın amacı, evrenin büyüklüğü, örneklemin evreni temsil yeteneği, maliyet, zaman ve toplanacak olan verinin, analize elverişliliği gibi şartlar dikkate alınmıştır. Araştırmada 400 öğrencinin cevapladığı anketler değerlendirmeye alınmıştır.

Tablo 1: Araştırmaya Katılan Öğrencilerin Fakülte, Sınıf ve Cinsiyete Göre Dağılımları

\begin{tabular}{|l|c|c|c|c|c|}
\hline & \multicolumn{2}{|c|}{ Sınıf } & \multicolumn{2}{c|}{ Cinsiyet } & Toplam \\
\hline Üniversite-Fakülte & 1. Sınıf & 4. Sınıf & Kız & Erkek & \\
\hline $\begin{array}{l}\text { Ankara Üniversitesi } \\
\text { Illahiyat Fakültesi }\end{array}$ & 85 & 36 & 86 & 35 & 121 \\
\hline $\begin{array}{l}\text { MarmaraÜniversitesi } \\
\text { illahiyat Fakültesi }\end{array}$ & 63 & 44 & 68 & 39 & 107 \\
\hline $\begin{array}{l}\text { Selçuk Üniversitesi } \\
\text { illahiyat Fakültesi }\end{array}$ & 34 & 37 & 56 & 15 & 71 \\
\hline $\begin{array}{l}\text { Atatürk Üniversitesi } \\
\text { ilahiyat Fakültesi }\end{array}$ & 51 & - & 33 & 18 & 51 \\
\hline $\begin{array}{l}\text { Uludağ Üniversitesi } \\
\text { ilahiyat Fakültesi }\end{array}$ & 29 & 21 & 35 & 15 & 50 \\
\hline Toplam & 262 & 138 & 278 & 122 & 400 \\
\hline
\end{tabular}

\section{Veri Toplama Teknikleri}

Araştırmada örneklemden veri toplama tekniği olarak anket kullanılmıştır. $\mathrm{Bu}$ araştırmada araştırmaya katılanların durumuna ilişkin saptamalarda buluna- 
bilmek amacıyla hazırlanan ölçme aracında açık uçlu sorular ve likert türde hazırlanmış maddeler de yer almaktadır. Araştırmanın amaçları doğrultusunda geliştirilmiş olan ölçme aracına (popüler kültür anketi) son şekli, iletişim bilimleri, sosyoloji, psikoloji, eğitim bilimleri, antropoloji ve ilahiyat alanından çeşitli uzmanların görüşleri ve önerileri alındıktan ve ayrıca öğrencilerle yapılan mülakatlardan ve pilot uygulamadan sonra verilmiştir. Anket, 2006-2007 öğretim yılı bahar dönemi Mart-Nisan-Mayıs aylarında belirtilen fakültelerde öğrencilere uygulanmıştır.

\section{Araştırma Bulguları ve Yorumlar}

Tablo 2: Araştırmaya Katılan Öğrencilerin Ülke ve Dünya Gündemini Takip Ederken Kullandıkları Kitle İletişim Aracına Göre Dağııımı

\begin{tabular}{|l|c|c|c|c|}
\hline & & Sık sık & Ara sıra & Hiç \\
\hline \multirow{2}{*}{ TV } & $\mathrm{N}$ & 35 & 205 & 144 \\
\cline { 2 - 5 } & $\%$ & 8,8 & 51,3 & 36 \\
\hline \multirow{2}{*}{ Radyo } & $\mathrm{N}$ & 76 & 187 & 51 \\
\cline { 2 - 5 } & $\%$ & 19 & 46,8 & 12,8 \\
\hline \multirow{2}{*}{ Gazete } & $\mathrm{N}$ & 12 & 170 & 201 \\
\cline { 2 - 5 } & $\%$ & 3 & 42,5 & 50,3 \\
\hline \multirow{2}{*}{ Dergi } & $\mathrm{N}$ & 52 & 215 & 48 \\
\cline { 2 - 5 } & $\%$ & 13 & 53,8 & 12 \\
\hline \multirow{2}{*}{ Internet } & $\mathrm{N}$ & 45 & 200 & 121 \\
\cline { 2 - 5 } & $\%$ & 11,3 & 50 & 30,3 \\
\hline
\end{tabular}

Illahiyat fakültesi öğrencilerinin gündelik yaşam deneyimlerinin incelendiği bu araştırmada televizyon boyutuna ilişkin bulgular tablo $6^{\prime}$ da gösterilmiştir. Buna göre öğrencilerin \% 60.1'i ülke ve dünya gündemine ait gelişmeleri takip ederken TV'yi sık sık ve ara sıra tercih ettiklerini belirtmişlerdir. \% 50.3'ü ise gazeteyi hiç tercih etmediklerini belirtmişlerdir. İnterneti ise \% $61.3^{\prime}$ lük bir kesimin kullandığı görülmektedir. Bunun yanında bir bilgilenme aracı olarak dergiyi tercih edenlerin oranı ise \% 66.8 olarak belirlenmiştir.

$\mathrm{Bu}$ bulgulara göre öğrencilerin sıkça kullandıkları enformasyon kaynaklarının, TV gibi görsel sunumlar tarafından biçimlendirilen kitle iletişim araçları olduğu anlaşımaktadır. Gazete gibi okuyarak bilgi edinilebilecek yazıı iletişim araçlarının kullanımının, görselliğin hakim olduğu TV ve internet gibi kitle iletişim araçlarının etkisiyle azalmaya başladığı görülmektedir. Öte yandan ilahiyat fakültesi öğrencilerinin dergileri tercih etme oranlarının oldukça yüksek seviyelerde çıkmıs. Dergi aboneliği sisteminin bu öğrenci grubu arasında yaygın olduğu anlaşılmaktadır. 
Tablo 3: Araştırmaya Katılan Öğrencilerin Günlük Ortalama TV İzleme Sürelerine Göre Dağılımları

\begin{tabular}{|l|c|c|}
\hline & $\mathrm{N}$ & $\%$ \\
\hline 1 saatten az & 210 & 52,5 \\
\hline $1-3$ saat arası & 98 & 24,5 \\
\hline $3-5$ saat arası & 32 & 8,0 \\
\hline 5 saatten fazla & 8 & 2,0 \\
\hline Diğer & 52 & 13,0 \\
\hline Toplam & 400 & 100,0 \\
\hline
\end{tabular}

Tablo $10^{\prime}$ da ilahiyat fakültesi öğrencilerinin günlük ortalama TV izleme süreleri gösterilmiştir. Buna göre öğrencilerin \% 52.5'inin günde ortalama 1 saatten az televizyon izlemektedirler. \% 24.5'i günde ortalama 1-3 saat arası, \% $8^{\prime} i$, 3-5 saat arası ve \% $2^{\prime}$ si ise 5 saatten fazla televizyon izlediklerini belirtmişlerdir. Elde edilen bu bulgular Tablo 2'deki bulgularla karşılaştırılarak yorumlandığında; öğrencilerin, televizyonu haber saatlerinin dışında çok fazla izlemedikleri ve televizyon başında çok fazla zaman harcamadıkları sonucuna ulaşılmıştır.

Tablo 4: Araştırmaya Katılan Öğrencilerin İzledikleri TV Programının Türüne Göre Dağılımları

\begin{tabular}{|l|c|c||}
\hline & $\mathrm{N}$ & $\%$ \\
\hline Yerli TV dizileri & 80 & 20,0 \\
\hline Müzik Programları & 6 & 1,5 \\
\hline $\begin{array}{l}\text { Yarışma Programları (Pop Star Alaturka, Buzda Dans, Yemek- } \\
\text { teyiz...) }\end{array}$ & 8 & 2,0 \\
\hline Dini içerikli TV dizileri ve programlar & 66 & 16,5 \\
\hline Magazin Programları (televole, paparazzi...) & 38 & 9,5 \\
\hline Haberler (Saat başı haberler, Ana haber bültenleri) & 113 & 28,3 \\
\hline Futbol maçlarını yorumlayan programlar & 6 & 1,5 \\
\hline $\begin{array}{l}\text { Tartışma Programları (Ceviz Kabuğu, Tarafsı Bölge, Ne- } \\
\text { den...) }\end{array}$ & 15 & 3,8 \\
\hline Bilim ve Teknoloji ile ilgili belgeseller, programlar & 12 & 3,0 \\
\hline Tarihi Belgeseller & 14 & 3,5 \\
\hline Talk Show Programları (ibo show, Beyaz show...) & 2 &, 5 \\
\hline Doğa Belgeselleri & 13 & 3,3 \\
\hline Kültürel, eğitsel programlar & 14 & 3,5 \\
\hline Diğer & 13 & 3,3 \\
\hline Toplam & 400 & 100,0 \\
\hline
\end{tabular}

Tablo 4'de ise öğrecilerin izledikleri TV programlarının türüne göre izlenme oranlarının yüzdelik dağııımları gösterilmektedir. Buna göre öğrencilerin \% 
28.3'ü TV'de en fazla haber programlarını, \% 20'si yerli TV dizilerini, \% 16,5'i dini içerikli TV dizileri ve programlarını izlediklerini belirtmişlerdir. Araştırma bulguları, ilahiyat fakültesi öğrencilerinin; yarışma programları, dedikodu, magazin programları, müzik programları, futbol programları ve talk show programları gibi popüler kültür endüstrisinin eğlence ürünlerini izlemeyi çok az tercih etikleri sonucunu ortaya çıkarmıştır. Öte yandan magazin programlarını izlediğini belirten \% 9.5'lik bir kesimin bulunması ise ilahiyat fakültelerinde öğrenim gören öğrencilerin büyük bir bölümünün kız öğrencilerden oluşması ile açıklanabilir.

Tablo 5: Araştırmaya Katılan Öğrencilerin İzlemeyi Tercih Etmedikleri TV Programlarının Türüne Göre Dağılımları

\begin{tabular}{|l|c|c|}
\hline & N & $\%$ \\
\hline Yarışma Programları (Pop star Alaturka, Buzda Dans...) & 199 & 49,8 \\
\hline Eğlence programları (M.Ali Erbil in programları) & 122 & 30,5 \\
\hline Magazin Programları (Televole, Paparazzi...) & 22 & 5,5 \\
\hline Haberler (Saat başı haberler, Ana haber bültenleri) & 1 &, 3 \\
\hline Futbol maçlarının yorumları & 32 & 8,0 \\
\hline Tartışma Programları (Ceviz Kabuğu, Tarafsız Bölge...) & 4 & 1,0 \\
\hline Bilim ve Teknoloji ile ilgili belgeseller, programlar & 1 &, 3 \\
\hline Talk Show Programları (ibo Show, Beyaz Show...) & 3 &, 8 \\
\hline Müzik Programları & 1 &, 3 \\
\hline Yerli TV dizileri & 1 &, 3 \\
\hline Doğa Belgeselleri & 3 &, 8 \\
\hline Kültürel, eğitsel programlar & 1 &, 3 \\
\hline Gündüz kuşağında yayınlanan kadın programları & 10 & 2,5 \\
\hline Toplam & 400 & 100,0 \\
\hline
\end{tabular}

Tablo 5, ilahiyat fakültesi öğrencilerinin izlemedikleri TV programlarının dağıımını göstermektedir. Buna göre Popstar Alaturka, Biri Bizi Gözetliyor, Buzda Dans gibi yarışma ve magazin programlarını izlemediklerini belirten öğrencilerin oranı \% 49.8 ve Mehmet Ali Erbil'in programlarına benzer eğlence programlarını izlemediklerini belirtenlerin oranı ise \% 30.5 olarak belirlenmiştir. Bu bulgular öğrencilerin büyük bir bölümünün, birer popüler kültür ürünü olan bu eğlence programlarını izlemekten zevk almadıkları sonucunu ortaya çıkarmışır.

Ana haber bültenlerini, saat başı haberleri, ceviz kabuğu, tarafsız bölge gibi tartışma programlarını, bilim ve teknoloji ile ilgili belgesel programları, doğa belgesellerini ve kültürel, eğitsel TV programlarını izlemediklerini belirtenlerin oranının çok düşük çıkması ise bu öğrenci gençliğin, TV'de, prime time zaman dışında gösterimde bulunan ve eğitici, bilgilendirici türden yapımları izledikleri sonucunu ortaya koymuştur. Bu açıdan ilahiyat fakültesi öğrencilerini bilinçli TV izleyicileri olarak nitelendirebiliriz. 
Tablo 6: Araştırmaya Katılan Öğrencilerin Günlük Ortalama Bilgisayar/İnternet Kullanma Sürelerine ve Amaçlarına Göre Dağılımları

\begin{tabular}{|l|c|c|}
\hline Bilgisayar ve İnternet Kullanma Amacı & $\mathbf{N}$ & $\mathbf{\%}$ \\
\hline Oyun/Eğlence/Sohbet & 37 & 9,3 \\
\hline Bilgilenmek amacıyla & 151 & 37,8 \\
\hline Film izlemek için & 13 & 3,3 \\
\hline Ödev araştırma raporu hazırlarken & 124 & 31,0 \\
\hline Müzik dinlemek için & 10 & 2,5 \\
\hline Haberleşme & 54 & 13,5 \\
\hline Diğer & 11 & 2,8 \\
\hline Toplam & 400 & 100,0 \\
\hline Günlük Ortalama Bilgisayar Kullanım Süresi & $\mathbf{N}$ & $\mathbf{\%}$ \\
\hline 1 saatten az & 154 & 38,5 \\
\hline $1-2$ saat arası & 121 & 30,3 \\
\hline 2-3 saat arası & 34 & 8,5 \\
\hline 3 saatten fazla & 22 & 5,5 \\
\hline Diğer & 69 & 17,3 \\
\hline Toplam & 400 & 100,0 \\
\hline
\end{tabular}

Tablo 6 öğrencilerin bilgisayarı ve interneti kullanma amaçlarına ve günlük ortalama bilgisayar kullanım sürelerine göre dağılımlarını göstermektedir. Buna göre öğrencilerin \% 37.8'i bilgisayarı bilgilenmek amacıyla kullandıklarını ifade etmişlerdir. \% 31'i ödev ve araştırma raporu hazırlarken özellikle internetten faydalandıklarını ifade etmişlerdir. Interneti bir haberleşme aracı olarak kullandığını belirtenlerin oranı ise \% 13.5 olarak tespit edilmiştir. Interneti ve bilgisayarı oyun, eğlence ve sohbet amacıyla kullandığını ifade edenlerin oranı ise \% 9.3 olarak belirlenmiştir. Bu bulgulardan hareketle ilahiyat fakültesi öğrencilerinin bilgisayarı ve interneti daha çok bilgilenmek ve araştırma yapmak amacıyla kullandıkları sonucu ortaya çıkmaktadır. Ancak interneti, ödev ve araştırma raporu hazırlarken kullananların oranının biraz yüksek çıkması, kütüphane çalışmasının ve kaynak eser kullanımının bu elektronik yenilikler karşısında gerilediği sonucunu da akla getirmektedir.

Öğrencilerin günlük ortalama bilgisayar kullanma sürelerine göre dağılımları incelendiğinde ise \% 38.5'inin bilgisayarı 1 saatten az kullandığı anlaşılmaktadır. Günlük ortalama 1-2 saatini bilgisayar başında geçirdiğini ifade edenlerin oranı ise \% 30.3 olarak belirlenmiştir. Bu bulgulara göre öğrencilerin büyük çoğunluğunun günlük ortalama bilgisayar ve internet kullanımına harcadıkları zamanın çok fazla olmadığı sonucuna ulaşılmıştır. Dolayısıyla ilahiyat fakültelerinde öğrenim görmekte olan gençlerin bilgisayar kullanımı açısından aşırıya kaçmadıkları, bilgisayar bağımlısı olmadıkları, bilgisayarı hayatlarının tek eğlencesi olarak görmedikleri ve bilgisayar kullanımı açısından bilinçli bir konumda yer aldıklarını söyleyebiliriz. 
Tablo 7: Araştırmaya Katılan Öğrencilerin Serbest Zaman Aktivitelerine Göre Dağılımları

\begin{tabular}{|l|c|c|}
\hline & $\mathrm{N}$ & $\%$ \\
\hline Ders çalışıım & 137 & 34,3 \\
\hline Müzik dinlerim & 16 & 4,0 \\
\hline Okuyarak geçiririm & 80 & 20,0 \\
\hline Bilimsel toplantılara katılırım & 1 &, 3 \\
\hline Dernek, vakıf faaliyetlerine katılırım & 13 & 3,3 \\
\hline Şiir, öykü, hikaye, roman, deneme vb. yazarım & 1 &, 3 \\
\hline TV izlerim & 16 & 4,0 \\
\hline Kahveye veya cafeye giderim & 1 &, 3 \\
\hline Arkadaşlarımla sohbet ederim & 70 & 17,5 \\
\hline Kitapçıları, sahafları gezerim & 3 &, 8 \\
\hline Bilgisayar/internet başında geçiririm & 17 & 4,3 \\
\hline Spor yaparım & 4 & 1,0 \\
\hline Kütüphanede geçiririm & 3 &, 8 \\
\hline ibadet ederek geçiririm & 20 & 5,0 \\
\hline Alışveriş merkezlerine giderim & 1 &, 3 \\
\hline Diğer & 17 & 4,3 \\
\hline Toplam & 400 & 100,0 \\
\hline
\end{tabular}

Tablo 7, öğrencilerin okul dışındaki zamanlarını hangi aktiviteleri yerine getirerek geçirdiklerini göstermektedir. Buna göre bu zamanı ders çalışarak geçirdiklerini ifade edenlerin oranı \% 34.3 olarak belirlenmiştir. Okuyarak geçirdiğini belirtenlerin oranı \% 20, arkadaşlarıyla sohbet ederek geçirdiğini ifade edenlerin oranı \% 17.5, ibadet ederek geçirdiğini belirtenlerin oranı \% 5, bilgisayar/internet kullanarak geçirdiğini ifade edenlerin oranı \% 4.3 ve TV izleyerek geçirdiğini belirtenlerin oranı ise \% 4 olarak belirlenmiştir. Bu bulgulara göre ilahiyat fakültesi öğrencilerinin büyük bir kısmının okul dışındaki zamanlarının çoğunluğunu ders çalışarak ve okuyarak geçirdiklerini söyleyebiliriz. Kafelere, eğlence yerlerine ve alışveriş merkezlerine gitmek, ilahiyat fakültesi öğrencilerinin boş zamanlarında yerine getirmeyi tercih etmedikleri aktiviteler olarak karşımıza çıkmaktadır. Bunun yanında bilimsel toplantılara katılmak, kitapçıları dolaşmak ve kütüphaneye gitmek gibi aktivitelerin oldukça düşük düzeylerde yerine getirildiği sonucu da ortaya çıkmıştır. Ayrıca İlahiyat fakültelerinde öğrenim görmekte olan kız öğrenci nüfusunun erkeklere oranla daha fazla olması, serbest zaman aktivitelerinin cinsiyet esasına göre biçimlenmesinde etkili faktör olarak karşımıza çıkmaktadır. Dolayısıyla ev, yurt veya okulun dışındaki mekanlarda gerçekleşen serbest zaman aktivelerine bu kız öğrencilerin çok fazla rağbet etmedikleri anlaşılmaktadır. 
Tablo 8: Araştırmaya Katılan Öğrencilerin Arkadaş Seçiminde Önem Verdikleri Ölçütlere Göre Dağılımları

\begin{tabular}{|l|c|c|}
\hline & $\mathrm{N}$ & $\%$ \\
\hline Ekonomik durumunun iyi olması & 4 & 1,0 \\
\hline Yakın bölge ve kültür geçmişine sahip olması & 17 & 4,3 \\
\hline Bilgi ve kültür düzeyinin yüksek olması & 93 & 23,3 \\
\hline Zevk ve beğenilerde ortaklık bulunması & 84 & 21,0 \\
\hline Düşünce ve inanç yakınlığı bulunması & 117 & 29,3 \\
\hline Aynı politik ve ideolojik görüşe sahip olmamız & 3 &, 8 \\
\hline Duygusal yakınlığın oluşması & 77 & 19,3 \\
\hline Diğer & 5 & 1,3 \\
\hline Toplam & 400 & 100,0 \\
\hline
\end{tabular}

Tablo 8, öğrencilerin arkadaş seçiminde göz önünde bulundurdukları sosyo-kültürel ve sosyo-ekonomik ölçütleri göstermektedir. Buna göre öğrencilerin \% 29.3'ü arkadaşlarıyla aralarında düşünce ve inanç yakınlığı bulunmasını temel kriter olarak ifade etmişlerdir. \% 23.3'ü arkadaş seçiminde bilgi ve kültür düzeyinin yüksek olmasını, \% 21'i zevk ve beğenilerde ortaklık bulunmasını, \% 19.3'ü ise aralarında duygusal yakınlığın oluşmasını önemli gördükleri temel kriter olarak ifade etmişlerdir. Ekonomik durumunun iyi olması gibi maddi koşulları ön planda tutan bir yaklaşımın, bu öğrencilerin çoğunluğu tarafından benimsenmediği anlaşılmaktadır. Dolayısıyla liberal kapitalist tüketim toplumlarının kültürü olan popüler kültürün; materyalist, hazcı ve faydacı dünya görüşünü empoze eden yapısının, ilahiyat fakültesi öğrencilerinin arkadaş seçimlerine ve buradan hareketle dünyayı, insanları ve yaşamı algılamadaki düşünsel süreçlere olan etkisinin çok fazla olmadığını söyleyebiliriz.

Arkadaşlık yapacağı kişinin kendisi ile yakın bölge ve kültür geçmişine sahip olmasını ve kendisi ile aynı politik ve ideolojik görüşü paylaşması gerektiğini vurgulayanların oranının düşük olması ise bu öğrenci grubunun aşırı politize olmadığını ve farklı düşünce, kanaat ve tutumlara karşı hoşgörülü bir yaklaşımı benimsediklerini ortaya koymaktadır.

Tablo 9: Araştırmaya Katılan Öğrencilerin Arkadaş Sohbetlerinde Konuştukları Konulara Göre Dağılımları

\begin{tabular}{|l|c|c|}
\hline & $\mathrm{N}$ & $\%$ \\
\hline Ülke ve dünya gündemine ait konuları konuşuruz & 111 & 27,8 \\
\hline $\begin{array}{l}\text { Popüler sanatçı veya sporcuların yaşamlarına dair konu- } \\
\text { lar }\end{array}$ & 2 &, 5 \\
\hline $\begin{array}{l}\text { Mesleki açıdan gelecekteki konumumuza dair } \\
\text { konuşuruz }\end{array}$ & 92 & 23,0 \\
\hline
\end{tabular}




\begin{tabular}{|l|c|c|}
\hline & N & $\%$ \\
\hline TV programları, diziler, sinema, yarışma programları vs & 3 &, 8 \\
\hline Karşı cinsle ilgili konular hakkında konuşuruz & 9 & 2,3 \\
\hline Toplum, bilim, felsefe ve sanat hakkında konuşuruz & 13 & 3,3 \\
\hline Dini konular hakkında konuşuruz & 128 & 32,0 \\
\hline Evlilik hakkında konuşuruz & 6 & 1,5 \\
\hline Spor karşılaşmaları hakkında konuşuruz & 4 & 1,0 \\
\hline Siyasi konular hakkında konuşuruz & 10 & 2,5 \\
\hline Giyim moda, bakım, güzellik ile ilgili konuşuruz & 4 & 1,0 \\
\hline Diğer & 18 & 4,5 \\
\hline Toplam & 400 & 100,0 \\
\hline
\end{tabular}

Tablo 9, öğrencilerin arkadaşları ile daha çok hangi konular hakkında sohbet etmekten zevk aldıklarını göstermektedir. Buna göre öğrencilerin \% 32'si dini konular hakkında konuştuklarını belirtmişlerdir. \% 27.8'i ise ülke ve dünya gündemine ait konular hakkında konuştuklarını ifade etmişlerdir. \% 23'ü ise mesleki açıdan gelecekteki konumlarına dair sohbetler yaptıklarını belirtmişlerdir. Araştırma bulguları öğrencilerin kendi aralarında en çok kariyer gelişimleri üzerine sohbet ettiklerini ortaya koymaktadır. Bunun dışında ilahiyat fakültelerinde öğrenim görmekte olan gençlerin aralarında yaptığı sohbetlerde; popüler sanatçı veya sporcuların yaşamlarına dair konular, TV programları, diziler, sinema filmleri, yarışma programları, spor karşılaşmaları, ve giyim, moda, bakım ve güzellik ile ilgili popüler kültürün malzemesini teşkil eden konuların çok az yer aldığı anlaşılmaktadır.

Tablo 10: Araştırmaya Katılan Öğrencilerin Öğrenim Gördükleri Alanın Dışındaki Kitapları Okuma Sıklıklarına Göre Dağılımları

\begin{tabular}{|l|c|c|}
\hline & $\mathrm{N}$ & $\%$ \\
\hline Zamanım olmuyor & 48 & 12,0 \\
\hline Ayda 1 kitap & 143 & 35,8 \\
\hline 15 günde 1 kitap & 96 & 24,0 \\
\hline Haftada 1 kitap & 56 & 14,0 \\
\hline Diğer & 57 & 14,3 \\
\hline Toplam & 400 & 100,0 \\
\hline
\end{tabular}

Tablo 10, öğrencilerin öğrenim gördükleri alanla ilgili kitapların dışındaki kitapları okuma sıklıklarını göstermektedir. Buna göre öğrencilerin \% $35.8^{\prime} \mathrm{i}$ ayda bir kitap okuduklarını belirtmişlerdir. \% 24'ü 15 günde bir kitap ve \% 14'ü haftada bir kitap okuduklarını belirtmişlerdir. \% 12'si ise ders kitapları dışında farkı konularda okumaya zaman bulamadıklarını belirtmişlerdir. Bu bulgular öğrencilerin yoğun ders ve sınav programlarına rağmen okuma faaliyetlerinin ortalama sıklıkta gerçekleştiğini göstermektedir. Bu bulgulardan hareketle ilahiyat fakültesi öğrencilerinin, TV ve internetin hakim olduğu, gösteri ve görüntü 
merkezli bir sosyal yaşamın içinde, okuma etkinliğini elden geldiğince inmal etmemeye çalışan bir öğrenci gençlik kesimini oluşturdukları söylenebilir.

Tablo 11: Araştırmaya Katılan Öğrencilerin Öğrenim Gördükleri Alan Dışında Okudukları Kitap Türlerine Göre Dağııımları

\begin{tabular}{|l|c|c|}
\hline & $\mathrm{N}$ & $\%$ \\
\hline Ekonomi & 13 & 3,3 \\
\hline Mizah & 36 & 9,0 \\
\hline Teknoloji & 21 & 5,3 \\
\hline Macera, polisiye romanlar & 14 & 3,5 \\
\hline Siyaset & 36 & 9,0 \\
\hline Aşk & 6 & 1,5 \\
\hline Sosyoloji & 4 & 1,0 \\
\hline Spor & 17 & 4,3 \\
\hline Psikoloji & 38 & 9,5 \\
\hline Edebiyat & 58 & 14,5 \\
\hline Fantastik kurgu & 3 &, 8 \\
\hline Tarih & 71 & 17,8 \\
\hline Sanat & 4 & 1,0 \\
\hline Moda, giyim & 1 &, 3 \\
\hline Felsefe & 12 & 3,0 \\
\hline Çevre & 2 &, 5 \\
\hline Kişisel Gelişim & 50 & 12,5 \\
\hline Diğer & 14 & 3,5 \\
\hline Toplam & 400 & 100,0 \\
\hline
\end{tabular}

Tablo 11, öğrencilerin öğrenim gördükleri alanın dışındaki kitap türlerini okuma durumlarına göre dağıımlarını göstermektedir. Buna göre öğrencilerin \% 17.8'i tarih kitaplarını okumayı tercih ettiklerini belirtmişlerdir. \% 14.5'i edebi (roman, hikaye, şiir) kitapları okumayı tercih ettiklerini belirtmişlerdir. \% 12.5'i kişisel gelişim kitaplarını tercih ettiklerini belirtmişlerdir. \% 9.5'i psikoloji biliminin konusunu teşkil eden kitapları okuduklarını belirtmişlerdir. Daha çok siyaset ve mizah ile ilgili kitapları tercih ettiklerini belirten öğrencilerin oranı ise \% 9 olarak belirlenmiştir. Öte yandan araştırma bulguları, öğrencilerin moda, giyim, çevre, sanat, fantastik kurgu, sosyoloji ve aşk hakkında yazılmış kitaplara fazla ilgi göstermediklerini ortaya koymaktadır.

Illahiyat fakültesi öğrencilerinin öğrenim gördükleri alanın dışındaki kitaplar ve konu başlıklarına olan ilgi düzeyleri bir bütün olarak değerlendirildiğinde; tarih ve edebiyat konu başıklarının bu öğrenci gençlik kesimi arasında daha fazla tercih edildiği anlaşılmaktadır. Öte yandan çoğunlukla en çok satanlar listesinin en başında yer alan kişisel gelişim, moda ve güzellik gibi popüler kitapların ve konuların ise bu öğrenci grubu arasında oldukça düşük düzeylerde tercih edildiği ortaya çıkmıştır. Araştırma bulguları, ilahiyat fakültesi 
öğrencilerinin en çok Mehmed Niyazi (özellikle "Çanakkale Mahşeri" adlı eseri), Necip Fazıl Kısakürek, İsmet Özel, Fethullah Gülen, İskender Pala, Peyami Safa, Tarık Buğra, Said-i Nursi, Senai Demirci, Ahmet Turan Alkan ve Ahmet Hamdi Tanpınar gibi yazarların eserlerini okumayı tercih ettiklerini ortaya koymuştur.

Tablo 12: Araştırmaya Katılan Öğrencilerin Tüketim Alışkanlıkların Göre Dağılımları

\begin{tabular}{|l|c|c|}
\hline & $\mathrm{N}$ & $\%$ \\
\hline Gıda & 79 & 19,8 \\
\hline Teknolojik araç & 29 & 7,3 \\
\hline Ĕ̆lence & 3 &, 8 \\
\hline Sinema, konser & 3 &, 8 \\
\hline Kitap, dergi, gazete & 127 & 31,8 \\
\hline Giyim & 58 & 14,5 \\
\hline Spor, hobiler & 3 &, 8 \\
\hline Eğitim & 83 & 20,8 \\
\hline Kaset, CD & 1 &, 3 \\
\hline Kişisel bakım & 3 &, 8 \\
\hline Diğer & 11 & 2,8 \\
\hline Toplam & 400 & 100,0 \\
\hline
\end{tabular}

Tablo 12, ilahiyat fakültesi öğrencilerinin tüketim alışkanlıklarının ve en çok harcamayı yaptıkları tüketim alanlarııın dağııımını göstermektedir. Buna göre öğrencilerin \% 31.8'i en çok kitap, dergi ve gazete için harcama yaptıklarını belirtmişlerdir. \% 20.8'i en fazla harcamayı eğitimleri için yaptıklarını belirtmişlerdir. \% 19.8'i ise en fazla harcamayı gıda için yaptıklarını belirtmişlerdir. \% $14.5^{\prime} \mathrm{i}$ ise giyim için en fazla harcamayı yaptıklarını belirtmişlerdir.

Araştırma bulgularına göre öğrencilerin; popüler kültür endüstrilerinin yoğun olarak faaliyet gösterdikleri eğlence, sinema-konser, kaset-CD, kişisel hobiler ve kişisel bakım gibi tüketim alanlarına ilişkin çok az harcama yaptıkları ve öncelikli hedeflerinin bilgilenmek ve eğitim almak olduğu anlaşılmaktadır.

Tablo 13: Araştırmaya Katılan Öğrencilerin Dinlemekten Zevk Aldıkları Müzik Türlerine Göre Dağılımları

\begin{tabular}{|l|c|c|}
\hline & $\mathrm{N}$ & $\%$ \\
\hline Türk Sanat Müziği & 179 & 44,8 \\
\hline Türkçe Sözlü Pop & 93 & 23,3 \\
\hline Arabesk & 15 & 3,8 \\
\hline Türk Halk Müziği & 39 & 9,8 \\
\hline Caz & 3 &, 8 \\
\hline Protest, Özgün & 10 & 2,5 \\
\hline Yabancı Pop & 5 & 1,3 \\
\hline New Age & 1 &, 3 \\
\hline
\end{tabular}




\begin{tabular}{|l|c|c|}
\hline & $\mathrm{N}$ & $\%$ \\
\hline Rock & 7 & 1,8 \\
\hline Hip Hop & 1 &, 3 \\
\hline Enstrumantal & 14 & 3,5 \\
\hline illahi, Tasavvuf & 33 & 8,3 \\
\hline Toplam & 400 & 100,0 \\
\hline
\end{tabular}

Tablo 13, ilahiyat fakültesi öğrencilerinin en çok dinledikleri müzik türlerine göre dağılımlarını göstermektedir. Buna göre öğrencilerin \% 44.8'i en çok Türk Sanat Müziği dinlediklerini belirtmişlerdir. \% 23.3'ü Türkçe sözlü pop müzik, \% 9.8'i Türk Halk Müziği, \% 8.3'ü tasavvuf, ilahi, \% 3.8'i Arabesk, \% 3.5’i enstrumantal müzik dinlediklerini belirtmişlerdir.

Bu bulgulara göre ilahiyat fakültesi öğrencileri arasında popüler kültürün müzik boyutuna ilişkin olarak yabancı pop, Rock ve Hip Hop gibi küresel kültürün kitleselleştirdiği ve dünyanın farklı kültürlerindeki birçok gencin ortak beğenisi haline gelmiş ve onları peşinden sürükleyen popüler müzik türlerine olan ilginin düşük olduğu görülmektedir.

Tablo 14: Araştırmaya Katılan Öğrencilerin Ünlü (Popüler) Kişilerde Hayranlık Duydukları Özelliklere Göre Dağılımları

\begin{tabular}{|c|c|c|c|c|c|}
\hline $\begin{array}{l}\text { Hayranlık Duyulan } \\
\text { Ünlü Kişi }\end{array}$ & $\mathrm{N}$ & $\%$ & $\begin{array}{l}\text { Ünlü Kişilerin Hayranlık } \\
\text { Duyulan Özellikleri }\end{array}$ & $\mathrm{N}$ & $\%$ \\
\hline \multirow{6}{*}{ Evet } & \multirow{6}{*}{211} & \multirow{6}{*}{52,8} & Fiziki Görünümü & 1 & 0,3 \\
\hline & & & Sosyal Statüsü & 11 & 2,8 \\
\hline & & & Mesleki Başarısı & 52 & 13 \\
\hline & & & Diğer & 13 & 3,3 \\
\hline & & & Kişilik özelliği & 130 & 32,5 \\
\hline & & & Yaşam Standardı & 4 & 1 \\
\hline Hayır & 189 & 47,2 & & & \\
\hline Toplam & 400 & 100 & & & \\
\hline
\end{tabular}

Tablo 14, öğrencilerin hayranı oldukları ünlü kişilerin hangi özelliklerini benimsediklerini göstermektedir. Öğrencilerin \% 52.8'i hayranı olduğu ünlü bir kişinin bulunduğunu belirtmişlerdir, \% 47.3'ü ise hayranı olduğu ünlü bir kişinin bulunmadığını ifade etmişlerdir. Hayranı olduğu ünlü bir kişinin bulunduğunu ifade eden öğrencilerin \% 32.5'i hayranı oldukları sanatçı, bilim adamı, politikacı veya sporcu gibi tanınmış simaların, kişilik özelliklerinin kendileri için anlamlı olduğunu belirtmişlerdir. \% 13'ü mesleki başarılarını, \% 2.8'i sosyal statülerini, \% 1'i yaşam standartlarını ve \% 0.3'ü ise fiziki görünümlerini, kendileri açısından anlamlı bulduklarını ifade etmişlerdir. Bu bulgulara göre öğrencilerin önemli bir kısmının, hayranı oldukları ünlü kişilerin mesleklerinde başarılı olmak için verdikleri çabaya, mesleki yeteneklerine ve yaptıkları işteki ustalıklarına hayranlık 
duydukları anlaşılmaktadır. Sosyal statü, yaşam standardı ve fiziki görünüm gibi materyalist unsurlara önem vermedikleri görülmektedir.

Tablo 15: Araştırmaya Katılan Öğrencilerin Kişisel Görünüm ve Bakım Tercihlerini Etkileyen Faktörlere Göre Dağııımları

\begin{tabular}{|l|c|c|}
\hline & $\mathrm{N}$ & $\%$ \\
\hline Moda & 11 & 2,8 \\
\hline Geleneklerim & 19 & 4,8 \\
\hline Tanınmış bir marka olması & 14 & 3,5 \\
\hline Dini İnançlarım & 200 & 50,0 \\
\hline Ucuz olması & 15 & 3,8 \\
\hline İhtiyacımın olması & 130 & 32,5 \\
\hline Diğer & 11 & 2,8 \\
\hline Toplam & 400 & 100,0 \\
\hline
\end{tabular}

Tablo 15, öğrencilerin kişisel görünüm ve bakım tercihlerini etkileyen faktörlerin dağııımını göstermektedir. Buna göre öğrencilerin \% 50'si dini inançlarının, kişisel görünüm ve bakım tercihlerini belirlediğini ifade etmişlerdir. $\% 32.5^{\prime} \mathrm{i}$ kişisel görünüm ve bakım tercihlerini en çok ihtiyaçlarının biçimlendirdiğini belirtmişlerdir. Kişisel bakım ürünlerinin, giysilerin vs'nin ihtiyacı karşıladığı oranda kullanışı ve tercih edilebilir olduğunu belirtmişlerdir. Bu sonuçlara göre öğrencilerin kişisel görünüm ve bakıma ilişkin kullandıkları ürünlerin (giysi, aksesuar, kozmetik, vs.) moda olması, çoğunluğun tercih etmesi ve tanınmış bir markaya sahip olması gibi popüler unsurlara önem vermedikleri anlaşılmaktadır.

Tablo 16: Araştırmaya Katılan Öğrencilerin Kişisel Değer Algılarını Belirleyen Temel Faktörlere Göre Dağılımları

\begin{tabular}{|l|c|c|}
\hline & $\mathrm{N}$ & $\%$ \\
\hline Din & 330 & 82,5 \\
\hline Arkadaş çevresi & 13 & 3,3 \\
\hline Gelenek & 5 & 1,3 \\
\hline Yazılı basın (gazete, dergi) & 2 &, 5 \\
\hline Görsel medya(TV) & 3 &, 8 \\
\hline Diğer & 3 &, 8 \\
\hline Aile & 40 & 10,0 \\
\hline Kitap & 4 & 1,0 \\
\hline Toplam & 400 & 100,0 \\
\hline
\end{tabular}

Tablo 16, ilahiyat fakültesi öğrencilerinin kişisel değerlerini belirleyen temel faktörlerin dağılımını göstermektedir. Buna göre öğrencilerin \% 82.5'i dinin; kişisel değerlerini ve dünyaya, topluma ve insanlığa bakış açılarını belirleyen en kapsayıcı temel unsur olduğunu belirtmişlerdir. Öğrencilerin \% $10^{\prime} u$ ise ailelerinin, kişisel değer algılarını şekillendiren en temel faktör olduğunu ifade 
etmişlerdir. Bu bulgulara göre yazılı basın (gazete, dergi) ve görsel medya (TV) gibi araçların yaydığı enformasyonun, medya kültürünün ve dolayısıyla popüler kültürün, bu gençlerin zihniyetlerinin biçimlenmesinde ve yaşam tercihlerinin oluşmasında çok fazla etkili olmadığı sonucu ortaya çıkmıştır.

Tablo 17: Araştırmaya Katılan Öğrencilerin Mutlu ve Güvenli Bir Yaşam İçin Uyum Sağlanması Gerektiğini Düşündükleri Sosyal Çevrelere Göre Dağılımları

\begin{tabular}{|l|c|c|}
\hline $\begin{array}{l}\text { Mutlu ve Güvenli Bir Yaşam İçin Uyum Sağlanması Ge- } \\
\text { rektiği Düşünülen Toplumsal Çevreler }\end{array}$ & $\mathrm{N}$ & $\%$ \\
\hline Meslek ya da iş çevresi & 22 & 5,5 \\
\hline Arkadaş çevresi & 27 & 6,8 \\
\hline Yetiştiği aile ortamı & 158 & 39,5 \\
\hline Dünya görüşünü, yaşam biçimini paylaştığı sosyal çevre & 68 & 17,0 \\
\hline Mahalle & 1 &, 3 \\
\hline Kendi kurduğu aile & 83 & 20,8 \\
\hline Dini cemaat & 36 & 9,0 \\
\hline Diğer & 5 & 1,3 \\
\hline Toplam & 400 & 100,0 \\
\hline
\end{tabular}

Tablo 17, öğrencilerin mutlu ve güvenli bir yaşam için hangi toplumsal çevrelere uyum sağlamaları gerektiği sorusuna ilişkin verdikleri cevapların dağılımını göstermektedir. Buna göre öğrencilerin \% 39.5'i mutlu ve güvenli bir yaşam için yetiştikleri aile ortamının önemine işaret etmişlerdir. \% $20.8^{\prime} i$ ise kendi kuracakları ailelerin mutlu ve güvenli bir yaşam sürmelerinde en önemli unsur olduğunu belirtmişlerdir. Dolayısıyla öğrencilerin yarısından çoğu aile kurumuna ve aile içi ilişkilerin önemine vurguda bulunmuşlardır. Bu bulgulara göre bencilliğin, maddeciliğin, egoist ve hazcı bir yaşam anlayışının ve bireysel yaşam stillerinin; reklamlar, moda ve medya yoluyla sürekli bir biçimde yeniden üretilerek empoze edildiği tüketim toplumunda, bu toplumun kültürel biçimi olan kitle kültürünün ve popüler kültürün bireyi yalnızlaştıran ve yabancılaştıran bozucu ve yıkıcı etkilerinin ilahiyat fakültesi öğrencilerinin büyük çoğunluğu açısından sorun teşkil etmediği söylenebilir. Öğrencilerin \% 17'si dünya görüşünü, yaşam biçimini paylaştığı sosyal çevrenin ve \% 9'u ise dini cemaatlerin mutlu ve güvenli bir yaşam sürmelerinde önemli işlev gördüğünü belirtmişlerdir. Meslek ya da iş ve arkadaş çevresinin mutlu ve güvenli bir yaşam sürmede önemli işlevlerinin olduğunu belirtenlerin oranı ise (\% 5.5) oldukça düşük çıkmıştır. 
Tablo 18: Araştırmaya Katılan Öğrencilerin Yaşamı Anlamlı Kıldığını Düşündükleri Sosyal, Kültürel ve Ekonomik Unsurlara Göre Dağılımı

\begin{tabular}{|l|c|c|}
\hline $\begin{array}{l}\text { Yaşamı Anlamlı Kılan Sosyal, Kültürel ve Ekonomik } \\
\text { Unsurlar }\end{array}$ & $\mathrm{N}$ & $\%$ \\
\hline Aile & 46 & 11,5 \\
\hline Eğitimde veya işte başarı & 7 & 1,8 \\
\hline Eş/sevgili & 10 & 2,5 \\
\hline Bir eser bırakmak & 4 & 1,0 \\
\hline Din/inanç & 291 & 72,8 \\
\hline Eğitim & 2 &, 5 \\
\hline İdealleri uğruna mücadele vermek & 29 & 7,3 \\
\hline Para/zenginlik & 1 &, 3 \\
\hline Bilgi & 7 & 1,8 \\
\hline Diğer & 3 &, 8 \\
\hline Toplam & 400 & 100,0 \\
\hline
\end{tabular}

Tablo 18, öğrenciler için yaşamı anlamlı kılan sosyal, kültürel ve ekonomik unsurların dağııımını göstermektedir. Buna göre öğrencilerin \% $72.8^{\prime} i$ yaşamı anlamlı kılan en önemli unsurun din ve inanç olduğunu belirtmişlerdir. \% $11.5^{\prime} \mathrm{i}$ ise ailenin yaşamı anlamlı kılan en önemli kurum olduğunu belirtmişlerdir. İdealleri uğruna mücadele vermenin yaşamın en anlamlı unsuru olduğunu belirtenlerin oranı \% 7.3, eş ve(ya) sevgilinin yaşamı anlamlı kılan en önemli unsur olduğunu belirtenlerin oranı \% 2.5 , eğitimde veya işte başarının yaşamı anlamlı kılan en önemli unsur olduğunu belirtenlerin oranı \% 1.8 bilginin yaşamı anlamlı kılan en önemli unsur olduğunu belirtenlerin oranı \% 1.8, para ve zenginliğin yaşamı anlamlı kılan en önemli unsur olduğunu belirtenlerin oranı $\% 0.3$ ve bir kalıcı eser bırakmış olmanın yaşamı anlamlı kılan en önemli unsur olduğunu belirtenlerin oranı \% 1 olarak tespit edilmiştir. Bu bulgular değerlendirildiğinde, para, zenginlik, mesleki kariyer ve iş başarısı gibi ekonomik göstergeleri ön planda tutan tüketim toplumunun; medya, reklam ve moda endüstrileri aracılığıyla yoğun bir şekilde empoze ettiği yaşam biçimlerinden ziyade din ve aile gibi geleneksel ve koruyucu, kalıcı, muhafazakar değerleri ihtiva eden sosyolojik kurumların ilahiyat fakültesi öğrencileri tarafından daha fazla benimsenip içselleştirildiği anlaşılmaktadır. 
Tablo 19: Araştırmaya Katılan Öğrencilerin Ülke Sorunlarının Çözümüne En Çok Katkı Sağladığını Düşündükleri Kişi ve(ya) Kurumlara Göre Dağııımları

\begin{tabular}{|l|c|c|}
\hline Ülke Sorunlarının Çözümüne En Çok Katkı & & \\
Sağladığı Düşünülen Kişi ve/veya Kurumlar & $\mathrm{N}$ & 17,8 \\
\hline Meclis & 71 & 5,0 \\
\hline Gençlik & 20 & 4,5 \\
\hline Öğretmenler & 18 & 6,5 \\
\hline Siyasi partiler & 26 &, 5 \\
\hline iş adamları & 2 & 2,3 \\
\hline Sivil toplum örgütleri & 9 & 6,0 \\
\hline Cumhurbaşkanı & 24 & 7,8 \\
\hline Basın/Medya & 31 &, 8 \\
\hline Mahkemeler & 3 & 4,8 \\
\hline Dini cemaatler & 19 & 37,0 \\
\hline Hükümet & 148 & 2,0 \\
\hline Bilim adamları & 8 & 5,3 \\
\hline Diğer & 21 & 100,0 \\
\hline Toplam & 400 & \\
\hline
\end{tabular}

Tablo 19, öğrencilerin ülke sorunlarının çözümüne en çok katkı sağladığını düşündükleri kişi veya kurumların dağııımını göstermektedir. Buna göre hükümet, ilahiyat fakültesi öğrencilerinin \% 37'sine göre ülke sorunlarının çözümüne en çok katkıyı sağlayan kurum olma özelliğini taşımaktadır. Öğrencilerin \% 17.8'ine göre ise ülke sorunlarının çözümüne en çok katkıyı sağlayan kurumun meclis olduğu anlaşılmaktadır. Öğrencilerin $\% 7.8^{\prime} \mathrm{i}$, basın/medya kuruluşlarının, \% 6.5'i siyasi partilerin, \% 6'sı cumhurbaşkanının, \% $5^{\prime}$ i gençliğin, \% 4.8'i dini cemaatlerin, \% 4.5'i öğretmenlerin, \% 2.3'ü sivil toplum kuruluşlarının, \% 2'si bilim adamlarının, \% $0.8^{\prime} i$ mahkemelerin ve \% $0.5^{\prime}$ inin iş adamlarııı, ülke sorunlarının çözümüne en çok katkıyı sağlayan kişi ve kurumlar olduklarını belirtmişlerdir. Bu bulgulardan, öğrencilerin büyük bir kısmının, ülke sorunlarının çözümünde en çok katkıyı sağladığını düşündükleri kurum olarak, siyaseti gösterdikleri anlaşılmaktadır.

Tablo 20: Araştırmaya Katılan Öğrencilerin Başka Bir Ülkede Yaşama İsteklerine Göre Dağılımları

\begin{tabular}{|l|c|c|}
\hline Başka Bir Ülkede Yaşama İsteği & N & $\%$ \\
\hline Evet & 98 & 24,5 \\
\hline Hayır & 302 & 75,5 \\
\hline Toplam & 400 & 100,0 \\
\hline
\end{tabular}

Tablo 20, öğrencilerin başka bir ülkede yaşama isteklerine göre dağılımlarını göstermektedirler. Buna göre öğrencilerin \% 75.5'i başka bir ülkede yaşamak istermisiniz sorusuna hayır yanıtını vermişlerdir. $\% 24.5^{\prime} \mathrm{i}$ ise 
evet yanıtını vermişlerdir. Bu bulgulara göre, öğrencilerin büyük bir bölümünün kendi ülkesinde yaşamaktan memnun oldukları ve bir Avrupa ülkesinde veya Amerika'da iş bulma, yerleşme ve yaşam sürme ile ilgili popüler hayalleri ve beklentilerinin bulunmadığı sonucu ortaya çıkmıştır.

\section{Sonuç}

Yüksek din eğitimi alan ve din adamı olarak yetişen ilahiyat fakültesi öğrencilerinin popüler kültür unsurlarına ilişkin yaklaşımları hakkında, alandan toplanan verilere dayalı bilgiler ve yorumlar sunmayı amaçlamış olan bu araştırmanın sonuçları bir bütün olarak değerlendirildiğinde, araştırmaya katılan öğrencilerin popüler kültürün farklı boyutlarına (ki bu boyutlar araştırmada TV, müzik, sinema, tüketim kültürü ve hayran kitlesi kültürü olarak ele alınmıştır) ilişkin davranış ve eğilimlerinin aldıkları eğitimin türü dikkate alındığında manidar sonuçlar ortaya koyduğu görülmüştür.

Araştırma için hazırlanan soru kâğıdında yer alan ve ilahiyat fakültelerinde öğrenim gören geçlerin TV izleme davranışları, internet kullanma biçimleri, müzik, sinema ve tiyatro gibi sanat türlerine yönelik ilgi ve zevkleri, okuma davranışları, tüketim eğilimleri, giyim, kuşam ve modaya ilişkin tutumları, yerine getirdikleri boş zaman aktiviteleri, arkadaş seçiminde önem verdikleri ölçütler, arkadaş sohbetlerinde konuştukları konular, hayranı oldukları sanatçı, sporcu veya popüler kişilerin özellikleri, Türkiye'deki sosyal problemlere ve dünyaya, yaşama ve olaylara bakış açılarını belirleyen sosyo-kültürel ve sosyo-ekonomik etkenlerle ilgili sorulara verilen cevaplar, merkezinde popüler kültür eleştirisi olan bir çözümleme yaklaşımıyla değerlendirilmiştir.

Bu araştırmanın sonucunda öğrencilerin popüler kültür unsurlarına yaklaşımları açısından bazı dikkat çekici bulgulara ulaşıımıştır bunlar:

Öğrencilerin TV ve internet gibi görselliğin hakim olduğu kitle iletişim araçlarını, gazete gibi okunarak bilgi edinilebilecek yazılı iletişim araçlarına tercih ettikleri sonucuna ulaşılmıştır.

Dünya ve ülke gündemine ait gelişmeleri takip ederken TV'yi en çok tercih ettiğini belirtenlerin oranının ailesi veya akrabaları yanında kalan öğrenciler arasında düşük düzeyde olduğu görülmektedir.

Araştırmaya katılan öğrencilerin \% 43.9'luk bir diliminin medya yapımlarına yansıyan lüks yaşam biçimleri ve rol modellerinden etkilendikleri sonucuna ulaşılmıştır.

Medya yapımlarına yansıyan lüks yaşam biçimleri ve rol modellerinden erkek öğrencilerin kız öğrencilere oranla daha yüksek düzeyde etkilendikleri sonucuna ulaşılmıştır.

Medya yapımlarına yansıyan lüks yaşam biçimleri ve rol modellerinden aileleri veya akrabalarının yanında kalan öğrencilerin yurtlarda kalan öğrencilere oranla daha az düzeyde etkilendikleri sonucuna ulaşılmıştır. 
Erkek öğrencilerin kız öğrencilere oranla bilgisayar/interneti daha yüksek düzeylerde oyun, eğlence ve sohbet amaçlı olarak kullandıkları sonucuna ulaşılmıştır.

Bilgisayar/interneti oyun eğlence ve sohbet amacıyla kullandığını belirten öğrencilerin daha çok yurtlarda kaldığı sonucuna ulaşılımıştır.

Öğrencilerin serbest zaman aktiviteleri olarak bilimsel toplantılara, sempozyumlara, konferanslara katılmak, kütüphaneye gitmek, kitapçıları dolaşmak gibi etkinlikleri oldukça düşük düzeylerde yerine getirdikleri sonucu ortaya çıkmıştır.

Öğrencilerin en fazla harcamayı kitap, dergi, eğitim masrafları ve gıda için yaptıkları sonucuna ulaşılmıştır. Araştırma sonuçlarına göre barınma yerine ilişkin harcamaların fazla yer tutmadığı anlaşılmaktadır.

Öğrencilerin en çok Mehmed Niyazi, Necip Fazıl Kısakürek, İsmet Özel, Fethullah Gülen, İskender Pala, Peyami Safa, Tarık Buğra, Said-i Nursi, Senai Demirci, Ahmet Turan Alkan, Ahmet Hamdi Tanpınar gibi muhafazakar, gelenekçi ve İslamcı kimlikleriyle tanınan yazar, sanatçı ve düşünürlerin eserlerini okudukları sonucuna ulaşılmıştır.

Öğrencilerin büyük çoğunluğunun Türkçe sözlük müzik dinlediği ve en çok da Türk Sanat Müziği (\% 44.8) dinlediği sonucuna ulaşıımıştır.

Araştırmaya katılan öğrencilerin kişisel değer algılarını belirleyen temel faktörün din (\% 82.5) olduğu sonucu ortaya çıkmıştır.

Öğrencilerin mutlu ve güvenli bir yaşam için uyum sağlanması gerektiğini düşündükleri sosyal çevre olarak en çok aileyi ve daha sonra ise yaşam biçimini paylaştığı sosyal çevre ve dini cemaati önemli buldukları sonucuna ulaşıımıştır.

Öğrencilerin \% 72.8'i yaşamı anlamlı kılan en önemli unsurun din ve inanç olduğunu belirtmişlerdir.

Bu sonuçlar dikkate alındığında özellikle 1980 sonrasındaki sosyoekonomik dönüşümler neticesinde, yetinen bir toplumdan tüketen bir topluma doğru evrilen, yani liberal kapitalist bir tüketim toplumu haline dönüşen Türkiye'de, ilahiyat fakültesi öğrencilerinin, yaşam stillerine ilişkin birtakım tercih, tutum, davranış ve eğilimler açısından dönemin hakim değerleri haline gelmiş bireyci, materyalist ve hazcı popüler kültürel değerlerden ziyade dayanışmacı, cemaatçi dini ve geleneksel kültürel değerlerin etkisi altında oldukları söylenebilir.

Seküler bağlılıkları karakterize eden popüler kültürün, bu gençlerin dünyaya, toplumsal yaşama, insanlığa ve kendi öz varlıklarına ilişkin bakışlarını, tutum ve davranışlarını, değer, duygu ve düşüncelerini hiç etkilemediğini söylemek mümkün değildir. Ancak insanlık açısından varoluşsal kaygılara yönelik anlamlı ve tutarlı yanıtlar bütününü teşkil eden din kurumunun, bu gençlerin yaşam dünyalarını ve zihniyetlerini şekillendiren en temel unsur olduğunu ortaya ko- 
yan araştırma bulguları göz önünde bulundurulduğunda, dini hayatın modern zamanlarda uğradığı alan kaybına bağlı olarak sosyal hayata egemen olmaya başlayan hedonist (hazcı yaşam) ve aşırı bireyci yaşam stilleri ve insan ilişkileri gibi psikolojik ve sosyolojik çözülmelere sebep olan çeşitli toplumsal değişme süreçlerinin zararlı sonuçlarının, bu gençlerin yaşam dünyaları ve tercihleri üzerinde çok fazla etkili olmadığı söylenebilir. Burada dinin önemli bir koruyucu kalkan işlevi üstlendiği, insan yaşamının ve düşüncesinin bütününü kapsayan ve biçimleyen bir referans çerçevesi ve anlam kaynağını teşkil ettiği görülmektedir. Zira geleneksel toplumların dini, manevi, dayanışmacı değerlere dayalı gündelik yaşam kültürünün aksine, modern toplumların akılcı, bireyci, pozitivist, seküler (profan, dünyevi) ve dolayısıyla rekabetçi ve sömürüye dayalı toplumsal ilişki biçimlerini üreten doğası, insanın sosyo-psikolojik ihtiyaç ve arzularının tatminini sağlayan dini, ahlaki ve insani değerler sisteminin aşınmasında en büyük sorumlu kabul edilmektedir.

Aydınlanma çağında modernite projesini yaşama geçiren batılı toplumlar, bilim ve teknolojideki gelişmelere paralel olarak endüstride kullanılan hammaddelerin çeşitliliğinin artmaya başladığı ve günden güne genişleyen üretim potansiyeline sahip ileri sanayi toplumlarını kurmuşlar ve maddi yaşamdaki zenginliği, bolluğu, refahı sömürgeci oryantalist bir anlayışıyla da olsa sağlamışlardır. Ancak zamanla, huzurlu ve mutlu, dengeli bireylerden oluşan sağlıklı toplumsal yapıların kurulmasında maddi zenginliklerin sağlanmasının yeterli tek ölçüt olmadığı görülmüştür. Çünkü, insanlar bu evren ve dünya üzerinde anlamIı bir yer işgal ettiklerine inandıkları oranda tatmin olmaktadırlar. Buna rağmen yaşamı ve varlığı anlamlandıran, insanın ruh dünyasını aydınlatan dini ve ahlaki değerler alanının modern toplumların değerler sisteminde yaşadığı bu çöküş nedeniyle çözülmeye başlamış olması, toplumlarda dini temellerin ortadan kalktığı anlamına gelmemektedir. Zira yaratılış özellikleri itibariyle insanoğlunun, seküler çerçevede de bağlandığı ve anlam aradığı fikir ve ideolojilerle aslında dine ayrılan boşluğu doldurmaya çalıştığı söylenebilir. Böylece insan, gerçekte dini olmayan ancak bir bakıma modern zamanların dini bağılığı olarak tanımlanabilecek bir tür bağlılık geliştirerek anlam arayışı içerisine girmektedir. İşte bu araştırmanın konusunu teşkil eden popüler kültür de bu türden seküler bağlılıkların yaşanabildiği en bariz sosyolojik olgulardan biri olarak kabul edilmektedir. Bu anlamda modern sanayi toplumlarında yüksek teknolojiye bağlı olarak gerçekleşen aşırı üretimin ortaya koyduğu arz fazlasının tüketimine endeksli iktisadi ve beşeri ilişkiler temeline dayanan kapitalizm ve neo-liberalizm gibi insanın aktif kabiliyetlerini sınılandıran kalkınma ve gelişme projeleri, insanın bu anlam arayışını maddi unsurlara ağırlık vererek ve egosunu şişirerek tatmin etme yoluna gitmişler ve sürekli artan bir tüketim ortamı yaratarak mutluluğun, huzurun ve rahatlamanın daha fazla tüketerek, daha çok eşyaya sahip olmakla sağlanabileceğini vurgulayan yaşam stilleri üretmişlerdir. 
Bu bağlamda günümüzde popüler kültürün "bilgiden çok seyri, görgüden çok görüntüyü, düşünceden çok popülariteyi sanattan çok magazini ve gerçekten çok imajı (hayal)" (Atay, 2004) üreten doğası karşısında düşünce ve yorum merkezli bir yaşamın sosyal ilişkilere egemen hale gelmesinde bilim, sanat, felsefe ve din gibi uğraş alanlarının sağladığı bilgiye intiyaç duyulmaktadır.

\section{9. Öneriler}

Araştırma bulguları doğrultusunda gençleri popüler kültürün düşünce ve yorumu yok eden popülarite, magazin, görüntü ve imaj ağılıklı kültürel mantığının zararlı etkilerinden alıkoyabilecek ve düşünmeyi derinleştiren, ciddilik, tutarlılık, süreklilik ve bütünlük gibi kavramlara ve değerlere yaşama imkanı sağlayacak bazı öneriler aşağıda sunulmuştur. Bu öneriler devlet kuruluşlarını, kitle iletişim araçları sahiplerini, üniversiteleri, öğretmenleri ve aileleri ilgilendiriyor olması açısından önem arz etmektedir. Bu bağlamda popüler kültürün, aynılaştırıcı, tektipleştirici ve kimliksizleştirici etkisine karşı panzehir oluşturabilecek kültürel enstrümanların hayata geçirilmesi gerekmektedir. Burada temel olarak eğitimcilerin ve öğretmen yetiştiren fakültelerin ve Milli Eğitim Bakanlığının; eğitimden televizyonu, bilgisayarı, vd. medyayı denetlemekte nasıl yararlanabiliriz sorusu üzerinde yoğunlaşarak bu yöndeki bir toplumsal bilincin oluşturulmasına öncülük etmeleri önerilmektedir.

Öğrencilerimizin erken yaşlardan itibaren okullarda özgün düşünsel birikime sahip bireyler olarak eğitilmelerini sağlayacak sorgulayıcı ve müzakereci eğitim ortamlarının hazırlanması gereklidir. Öğrencilerin sanat, felsefe, kültür, sosyoloji, edebiyat, tarih gibi konu alanlarına ilişkin temel klasik eserlerle tanışmalarını ve bu eserler üzerinde yoğunlaşmalarını sağlayacak müfredat programlarının hazırlanması önerilmektedir. Yani öğrencilerimize gerçek bilim, sanat ve felsefe ürününün ne olduğuna ilişkin entelektüel bir bakış açısının kazandırılmasına erken yaşlardan başlanılarak öncülük edilmelidir. Burada program geliştirme boyutuyla ilgili olarak Milli Eğitim Bakanlığı ve üniversitelerin işbirliği içinde çalışmaları önerilmektedir.

Ayrıca alınacak bu önlemlerin sadece eğitim kurumuyla sınırlı kalması halinde istenilen verimin alınamayacağı, bu çalışmaların aileler, anne babalar ve kitle iletişim araçlarının özverili ve bilinçli yaklaşımları ile desteklenmesi gerekmektedir.

Araştırmanın sonuçları doğrultusunda, gençlerin popüler kültür unsurlarına yaklaşımlarını hangi değerlerin, ne ölçüde etkilediğini araştıracak benzer çalışmalar yapılmalıdır. İlahiyat fakültesi öğrencileri ile diğer fakültelerde öğrenim gören öğrencilerin popüler kültür unsurlarına ilişkin algılarının karşılaştırmalı olarak incelenmesi ve daha uzun sürelere yayılan boylamsal araştırmaların katılımlı gözlem, görüşme ya da mülakat gibi nitel yöntemlerle desteklenerek gerçekleştirilmesi önerilmektedir. 


\section{Notlar}

(*) Dr., Gazi Üniversitesi Gazi Eğitim Fakültesi, e-posta: mcemsahin@gmail.com

(1) Post-Fordist üretim sisteminin örgütlediği yeni iktisadi ilişkilere dayalı olarak sosyokültürel yapıda meydana gelen değişim süreçlerini ifade eden ve sosyal bilimcilerce postmodern olarak da nitelendirilen bu yeni dönemin temel özellikleri ana hatlarıyla şu şekilde özetlenebilir: a) Standart üretim yerine çok farklı tüketici kategorilerine göre çeşitlenmiş bir üretim sistemine geçilmesi, b) İşgücü süreci ve iş yönetiminde merkezin gücünün zayıflatılması ve esnek bir uzmanlaşmaya gidilmesi, c) Üretimin sektörler arası geçişkenliğe izin verilecek şekilde düzenlenmesi ve hizmet sektörünün genişlemesi, d) Tüketimin giderek artan bir biçimde özel hale gelmesi ve bireyselleştirilmesi, e) İşgücünün kalifiye, nitelikli ve erkek işçi ağılıklı özelliğinin, hizmet sektörü ve beyaz yakalı işçilerin artmasına bağlı olarak değişmesi, f) Özellikle esnek zamanlı ve yarım gün çalışma esasına dayalı sektörlerde işgücünün büyük ölçüde kadınlara yönelik olmaya başlaması, g) Yeni finans piyasalarının küre-selleşmesi, h) Enformasyon yayılımı ve iletişimde sayısal iletişime ve bilgisayar tek-nolojisine dayalı yeni bir aşamaya geçilmesi, i) Kültürel alanda çeşitliliğin artması (Hall, 1995:109; Lury, 1996:94; Morley ve Robins, 1995: 5056).

Post-Fordizmin, sosyal, ekonomik, politik, psikolojik ve kültürel anlamları bünyesinde barındıran oldukça geniş toplumsal ilişkiler ağına ve etkileşim alanına işaret eden bir kavram ve olgu olduğu söylenebilir. Örneğin, küresel ölçekte Fordist üretim biçiminin yükseliş̧ ile sosyal devlet anlayışının düşüşü aynı dönemde gerçekleşmiştir. Devletin düzenleyici güç olarak tüm ilişkilerin merkezinde bulunması fikri doğ-rultusundaki yönetsel uygulamalar, yerini piyasanın kendi kendini sınır tanımadan ve denetlenmeden düzenlemesi görüşüne bırakmıştır. Ulus devletin küçülmesi, tüm dünyada bütünleşmiş tek pazar anlayışı ve bu pazarın kontrolünün artık çokuluslu dev şirketlerin eline geçmesi, neo-liberalizm olarak tanımlanan bu dönemin en önemli iktisadi ve politik gelişmeleri olarak değerlendirilmektedir (Dağtaş ve Dağtaş, 2006: 12).

(2) 1980'ler ve 90 'larda yaşanan ekonomik ve toplumsal değişimler, bugün, ar-tık Türk toplumunun da bir "tüketim toplumu" olarak kabul edilmesini doğrular niteliktedir. 24 Ocak 1980 kararları olarak bilinen ekonomi politikaları üretim eko-nomisinden tüketim ekonomisine geçişin altyapısını hazırlamıştır. Özelleştirme, serbest ticaret ve yeniden yapılanmayı hedefleyen 24 Ocak Kararları, Türkiye'de bugün küreselleşme olarak adlandırılan dünya ekonomisiyle bütünleşme sürecinin başlangıç aşamasını teşkil etmektedir. Uygulanan serbest döviz kuru ve faiz politika-ları, bir yandan ekonomik faaliyetleri rant ekonomisine kaydırırken diğer yandan serbest ticaret politikaları ile de ithalat ve ihracat artmış; bunun sonucu olarak lüks tüketim de dahil olmak üzere her tür tüketim malı rahatça ülkeye girebilmiştir. Ekonomideki bu değişim toplumsal değerleri de etkilemiş; 1980 'li yılların ortaların-dan itibaren ve $1990^{\prime}$ lı yıllarla birlikte tüketim artık kitleler için önemli bir değer göstergesi ve statü belirleyen bir edim haline gelmiştir (Kozanoğlu, 1992: 7).

(3) Türkiye'de hane içi faaliyetler, aile ilişkileri, komşuluk ilişkileri ve sosyal iliş-kiler $80^{\prime}$ li yıllarda televizyonun evlere girişi ile birlikte biçim değiştirmiştir. Televiz-yon ev içi dinlenme, birlikte olma ve oturma gündemini belirleyen ve yöneten bir araç haline gelmiştir. Salonun, misafir odasının en güzide köşesine oturan televizyon, söyleyen ve dinlenen olmuştur. Odada gözler sürekli onun üzerinde toplanır olmuştur. "Evde popülerin ne olduğunu sürekli öğreten televizyon ev dışı popüler faaliyetleri de belirler olmuştur" (Erdoğan ve Alemdar, 2005: 100). 
(4) Günümüz medyalarında televizyonun eğlendirme işlevinin öne çıkarak, eğ-lence amaçlı TV programlarının yayın akışı içindeki dağııımının arttığı ve televizyon anlatısının sonunda bütünüyle bir eğlence metnine dönüşmüş olduğunu gözlemle-mekteyiz. “Mediascape 1998" araştırma bulguları, Türkiye'de TV yayın akışı içinde en çok yer alan yapımların, \% 22'lik bir oranla, eğlence ve güldürü programları olduğu sonucunu ortaya koymuştur (Alankuş ve İnal, 2000: 67).

(5) Çoğunlukla Amerikan orta sınıf değerlerini temsil eden bu küresel popüler boş zaman değerlendirme kalıpları, kendi kültürel kodlarını beraberinde getirmiştir. Kitle iletişim araçları ve gündelik etkileşim kalıpları içinde bu imgeler, simgeler ve söylemler birlikte dolaşıma girerek, yeni anlamlar yüklenmişler, bu yeni anlamlar toplumda yayılarak, paylaşıımış ve hatta kitleye çoğu zaman da empoze edilmiştir. Böylece toplumda boş zaman tüketimine ilişkin yeni bir normatif dil gelişmiştir (Castoriadis, 1997).

(6) Kitle toplumuna ilişkin ilk sosyolojik çıkarımlar, 1830'larda demokratik ide-allerin ve süreçlerin oluşum koşullarının Amerika Birleşik Devletleri'nde nasıl elve-rişli bir zemine yayıldı̆ıını incelemek üzere Amerika'ya giden Alexis de Tocqueville ile başlamaktadır. Tocqueville, (1994: 275-278) Amerika'daki insanların sahip olduk-ları fikirlerin ve değerlerin benzerliğinden çok ekilenmiş ve böylesi bir toplumun zamanla kitle ya da sürü zihniyetinin kurbanı olabileceği doğrultusunda bir tahminde bulunmuştu. Tocqueville'nin "Amerika'da Demokrasi" adlı eserindeki klasik kitle toplumu açıklamaları daha sonraki tüm toplum kuramı tarihi boyunca kapsayıcılığını ve geçerliliğini korumuştur: "birbirine benzeyen ve eşit olan insan kalabalığı ucuz ve bayağı zevklerini tatmin etmek için hiç durmadan çalışmaktadırlar. Birbirinden ayrı yaşayan bu kişiler diğerlerinin kaderlerine yabancılaşmışlardır, çocukları ve arkadaş-ları onlar için tüm insanlığı simgelemektedir, bu insanlar diğer yurttaşlarıyla birlikte yaşarlar ancak onları görmez, onlara dokunur ama onları hissetmezler, kendi içinde ve yalnız kendisi için varlığını sürdürürler, belki hala bir yerlerde bir akrabaları vardır ama o ülkesini yitirmiştir (Tocqueville, 1994: 265266).

On dokuzuncu yüzyılın Avrupalı öncü sosyologları Tocqueville'nin sanayi toplumu-nun ortaya çıkmakta olan kültürü hakkındaki kaygılarının çoğunu paylaşmışlardır. Örneğin Durkheim, yeni toplumsal örgütlenme biçiminin "anomi"yi ortaya çıkaran özelliğini teşhis etmiş, Weber, toplumların yönetsel süreçlerinde ortaya çıkan bü-rokratik ilişkilerin rutinleşmiş yapaylığına vurguda bulunmuştur. Tönnies, "Gemeinschaft und Gesellschaft" adlı eserinde Avrupa'da ortaya çıkmakta olan kentsel kitle toplumları üzerine eğilmiştir. William Kornhauser (1959) ise toplulukla-rın akıntıya kapılarak istikrarlı küçük grup yaşantısından uzaklaştıklarını ve tek tip katı ideolojileri yüzünden totaliteryan olarak nitelendirilen kitlesel hareketlerin (1930'lu ve 40'lı yıllarda Avrupa'da, Sovyetler'de, Uzak Doğu'da güçlenen politik iktidarların uygulamalarında görüldüğü gibi) çağrılarına son derece açık bir ruh haliyle hareket etmeye yöneldiklerini öne sürmüştür (Marshall, 1999: 411-412).

(7) Eserinde "Amerikan toplumunun yaşamına giren televizyonun yaklaşık 300 yıl bu toplumun gidişatını belirlemiş olan "kitap"ın yerini aldığı, bunun da düşünce ve yorum merkezli bir hayatı, hızla seyir ve eğlence merkezli bir hayata dönüştürdü-ğünü" anlatan Postman, her şey hakkında artık fikrin değil görüntünün üretildiği sorunlu bir dünyaya geçişin ortaya çıkardığı kültürel çelişkilere işaret ederek, "siya-setin, dinin, eğitimin, sanatın, acının, dehşetin, aşkın, şiddetin, eğlencelik olarak sunulduğu bir dünya"da gençliğin yaşadığı topluma ve dünyaya yabancılaşmasının önüne geçilmesinde başta eğitimciler olmak üzere konunun bütün muhataplarından ciddi atılımlar gerçekleştirmelerini beklemektedir (Atay, 2004b: 60). Postman, "kitap"a ve dolayısıyla yazılı iletişime, nitelikli bir kamusal söylemin oluşturulmasında etkin rol oynadığı, düşünmeyi derinleştirdi- 
ği, ciddilik, tutarlılık, süreklilik ve bütünlük gibi kavramlara ve değerlere yaşama imkanı sağladığı için ayrı bir önem atfetmiş ve matbuat kültürünün hakim olduğu tarihsel devirleri "yorum" çağı olarak nitelemiştir. Günümüz toplumları ise bilhassa televizyonun ve daha sonraları da internetin icat edilmesinden sonra görsel kültürün, gösteri kültürünün etkisi altında bu özelliğinden yoksunlaştırılmıştır. Bu kültür daha çok hızlı tüketimin ve süreksizliğin, kalıcı olmayan ürünlerin ve buna dayalı insan ilişkilerinin ortaya çıkardığı bir toplumsal ve ekonomik dönüşümün ürünü olarak insanı nesneleştirmekte (şeyleştirmekte) ve düşünceyi, anlamayı, eleştiriyi, yorumu ve buna dayalı entelektüel üretimi engellemektedir.

(8) Ritzer'e (2000: 23-24) göre yeni tüketim araçları "tüketim katedralleri" ola-rak görülebilir. Yani onlar, birçok insan için büyülü, hatta bazen kutsal, dinsel bir karaktere sahiptirler. Onun için de, sürekli daha da fazla tüketiciyi kendilerine çek-mek için bu tüketim katedrallerinin tüketim için daha da büyülü, fantastik, sihirli ortamlar sunmaları ya da en azından sunuyor görünmeleri gerekir. Tüketim kated-ralleri yalnızca alışverişin gerçekleştiği mağaza (hipermarketler) ve diğer alışveriş merkezlerini değil, konulu parkları (Disneyland), kumarhaneleri ve yolcu gemileri ile daha somut yeni tüketim araçlarına şaşırtıcı derecede benzemeye başlayan stad-yumları, hatta üniversiteler, hastaneler ve müzeler gibi öteki ortamları da içine alır. Tüketim araçları, üretim, dağıtım, reklam, pazarlama, satış, bireysel beğeni, stil, moda gibi mal ve hizmetlerle ilgili daha geniş bir olgular kümesinin parçasıdır.

Ritzer'in (2000) "tüketim katedralleri” olarak tanımladığı bu merkezler yeterli sayıda tüketiciyi çekebilmek için kendilerine mitsel bir hava verirler ve tüketimi büyülü bir etkinliğe dönüştürme yönünde büyük çaba sarfederler. Alışveriş merkezlerinin ticari ve mali girişimlerden daha fazla bir şey olduğunu ve geleneksel toplumların din merkezleriyle ortak çok yanları olduğunu iddia eder. Alışveriş merkezlerinin gele-neksel olarak tapınakların sağladığı türde bir merkezilik sağlayacak biçimde ve ben-zer bir dengeye ve simetrik düzene sahip olacak şekilde inşa edilmeleri dolayısıyla bu mekanlarda insanlar kendilerine özel cemaat hizmetlerinin yanı sıra bir topluluğa dahil olma duygusu da edinirler. Çoğu insan için bu merkezlerde gezinmek büyülü, kutsal, dinsel bir etkinlik gibidir. Bazen bu büyü bilinçli bir organizasyonun sonucu olarak meydana gelir. Bazen de hiç hesapta olmayan etkenler bu merkezlere mitsel bir anlam yüklenmesine neden olur.

Tüketici ile alışveriş merkezi arasında kurulan bu mitsel ve dinsel bağın etkisini ve işlerliğini devam ettirebilmesi, işletme sahiplerinin sürekli olarak yeni büyüleme stratejileri geliştirmelerine bağlıdır. Bu bağlamda merkez yöneticileri yeterli sayıda tüketiciyi kendilerine çekebilme ve sistemin rasyonalitesini devam ettirebilme adına ciddi yatırım ve araştırma yapmaktadır. Örneğin özel olarak yetiştirilmiş gözlemciler tarafından müşteri davranışları takip edilip değerlendirilmekte ve yeni popüler oluşumlar, eğilimler doğrultusunda işletme stratejileri yeniden yapılandırılarak müşteriyi büyüleyerek daima ihtiyacından fazlasını satın almaya motive edecek yollar keşfedilmeye çalışılmaktadır. Eğer mağazalara sırf ihtiyaç duyduğumuz şeyleri satın almak için girersek ve yalnızca ihtiyaç duyduğumuz şeyleri satın almakla yetinirsek ekonomik dengeler alt üst olur. Bu yüzden kapitalist sistem gerçek bir talebe yönelik arzdan çok hayali bir talebin arzına, tüketimin ve tüketicinin üretimine yö-nelmektedir (Arık, 2006: 103).

(9) Bir kurum olarak modanın başarısının kaynağı, her iki işlevi de aynı anda yerine getirmedeki benzersiz yetisinde yatmaktadır. İnsanlar, bir yandan, başkalarını taklit edebilir ve böylece bir topluluğun üyesi olmanın psikolojik güvencesine sahip olabilirler. Diğer yandan, modayı, verili bir tarzda belki de sadece ince ayarlamalar yaparak kendi bireyselliklerini açıklamak amacıyla kullanabilirler (Smith, 2005: 37). 
(10) Marx'ın meta fetişizmi ve yabancılaşma üstüne geliştirdiği düşüncelerinden Horkheimer ve Adorno'nun “Aydınlanmanın Diyalektiğine” uzanan toplum felsefesi geleneği içerisinde yer alan Marcuse, insanların metalar ve konfor ile baştan çıka-rılmış olduğunu ileri sürmüştür. Insanlar maddi bollukla mutlu ve boş zamanları dolduran popüler kültür unsurları ile oluşturulan sahte özgürlükler içinde yüzmek-ten memnundurlar. Marcuse'un ileri sürdüğüne göre, öznellikler kapitalist sistemin ihtiyaçlarıyla şekillenmektedir. Tek boyutlu insan, eleştirel akılla oluşturulan gerçek bakışı elde etmekten çok, yanılgı içinde yaşayan ve gönüllü olarak sahte ihtiyaçlarını tatmin etme çabası içinde olan sığ bir insandır. Marcuse'a (1990:4) göre rahatlama, eğlenme, reklâmlara uygun olarak davranma ve tüketme, başkalarının hoşlandığı ve nefret ettiği şeylerden hoşlanma veya nefret etme gibi yaygın gereksinimlerin çoğu bu yanlış ihtiyaçlar kategorisine aittir.

(11) Türkiye'de iletişim teknolojilerinin son yıllarda hızla yaygınlaşması, küresel piyasaların bu yaygınlaşmayı kendi çıkarları için gerekli görmesi, ticari iletişim şirket-lerinin özellikle reklâm şirketlerinin artması ve basının ve radyonun artık ülkenin her köşesine ulaşması, çeşitli açılardan popülerlik kavramının ve popüler tüketici kitle-sinin kompozisyonunu genişletmiştir. Tüketim toplumu kişinin şu an sahip oldukla-rının yanında gelecekte sahip olacaklarını da taksitlerle ve kredi kartlarıyla tanımla-dığı için satın alma ve tüketmenin boyutları da genişletilmiş olmaktadır (Erdoğan ve Alemdar, 2005: 98-99).

(12) Türkiye, 1980 sonrası küreselleşme süreci dünya marketleriyle hızlı bütün-leşme ve neo-liberal ekonomik politikalar açısından dünyanın geri kalanı ile benzer-lik gösteriyordu. Turgut Özal hükümeti "ulusal kalkınmacılık" politikalarından ödün vererek, Türkiye pazarlarını serbest ticarete açarak, neo-liberal ekonomi politikala-rını hayata geçirmiştir. IMF paketleri ile Türkiye ekonomisi yavaş yavaş uluslararası piyasalar ve sermaye ile bütünleşmiştir. Neo-liberal ekonomi politikaları bir yandan belirli bir azınlığı avantajlı konuma getirirken, öte yandan ücretlerdeki düşüş ve yüksek enflasyon nedeniyle geniş kitlelerin dezavantajlı bir toplumsal konuma sü-rüklenmesine neden olmuştur. 80'lerdeki bu politikalar bir yandan sermaye biriki-mini desteklerken, diğer yandan toplumun tabakalaşma yapısında ortaya çıkan bozulmalar, toplumsal kesimler arasındaki sosyal ve ekonomik uçurumların oluşma-sına ve kutuplaşmalara yol açarak toplumsal bütünleşmeyi engeller bir niteliğe bürünmüştür (Zaim, 2006: 90).

(13) Illeri teknolojiyi kullanan endüstriyel toplumların yarattığı "enformasyon çağı" batı merkezli bir kültürün ürünüdür. Bu teknolojik bilgi ve donanıma sahip olmadan, bu teknolojileri üretebilecek duruma gelmeden, bu enformasyonları, hazır kullanıp tüketen çevre ülkeler, endüstrileşme-sömürgeleşme süreciyle başlayan "batılılaşma" problemini daha ileri boyutlarda yaşama intimal ve tehlikesini beraberinde taşımaktadırlar (Bilgin, 1990: 5-7).

(14) Postman'a (2004) göre bu sorunu ortadan kaldırmanın tek yolu, insanın iki önemli becerisi olan ancak, tüm yaşamı bir eğlence gibi gösteren televizyon nedeni ile yok olmaya başlayan; öğrenme ve anlama yeteneğini yeniden keşfedebilmektir. Bu da ancak eğitimle mümkün olabilir. Teknolojik gelişmeye karşı olmayan ancak, bunu tüketmek yerine anlamak gerektiğini savunan Postman'a göre, sadece eğitim-cilerin değil, aynı zamanda anne ve babaların da başlıca görevi, yeni iletişim medya-larından gelen enformasyon bombardımanı karşısında savunmasız kalan gençlere, haberler arasından bir seçim yapabilme becerisini kazandırmak, bu medyaların gerçeği nasıl aktardığını açıklamak ve olası olumsuz etkilerinden korunma yollarını öğretmektir.

(15) Postmodernliği modernlikten kesin bir kopuş olarak değil de modernliğin içinde örtük ya da zayıf bir biçimde varlığını sürdüren sosyal ve kültürel eğilimlerin egemen hale 
gelmesi biçiminde yorumlamak kavramın daha net anlaşılmasına yar-dımcı olacaktır. Modernlikten postmodernliğe geçiş, genel olarak büyük, merkezi ve tek doğrulu siyaset, üretim ve ideolojiden "küçük ölçekli", "merkezsiz", "çok doğru-lu" ve "belirsiz" bir oluşuma geçiş anlamına gelmektedir. Modernlik kesinliğin, zo-runluluğun alanıysa, postmodernlik de sonsuzlaştırılmış tüketici tercihi anlamında özgürlüğün ve bulanıklığın alanıdır (Çabuklu, 2004: 8-9).

\section{Kaynaklar}

Alankuş, S. ve A. İnal (2000). Güldürü Programlarında Kadının Temsili ve Kadına Yönelik Şiddet. Televizyon, Kadın ve Şiddet. Der: Nur Betül Çelik. s. 65-109. Dünya Kitle İletişim Vakfı Yayınları. Ankara.

Arık, M. Bilal. (2006). Iletişim Yazıları. Tablet Kitabevi. Konya.

Atay, Tayfun. (2004a). Din Hayattan Çıkar. İletişim Yayınları. İstanbul.

Atay, Tayfun. (2004). Yaşasın Meşhuriyet Çağı. Popüler Kültürden Kitle Kültürüne Türkiye İzlenimleri. Epsilon Yayınları. İstanbul.

Aydoğan, Filiz. (2004). Medya ve Popüler Kültür. MediaCat Akademi Yay. İstanbul.

Bahadır, Abdülkerim. (2002). Insanın Anlam Arayışı ve Din. İnsan Yayınları. İstanbul.

Bali, Rıfat. (2004). Tarzı Hayattan Life Style’a: Yeni Seçkinler, Yeni Mekânlar, Yeni Yaşamlar. İletişim Yayınları. İstanbul

Baudrillard, Jean. (1998). Simülakrlar ve Simülasyon. (Çev: Oğuz Adanır). Dokuz Eylül Yayınları. İzmir.

Bayhan, Vehbi. (1997). Üniversite Gençliğinde Anomi ve Yabancılaşma. Kültür Bakanlığı Yayınları. Ankara.

Bayhan, Vehbi. (2002). Genç Kimliği. Üniversite Gençliğinin Sosyolojik Profili. İnönü Üniversitesi Uygulaması. İnönü Üniversitesi Yayınları. Malatya

Bilgin, Vedat. (1990). Enformasyon, Toplum ve Kültür. Türkiye Günlügü. Sayı:12. s. 5-7.

Castoriadis, Cornelius. (1997). Toplum Imgeleminde Kendini Nasıl Kurar?. (Çev: Hülya Tufan). I. Cilt. İletişim Yayınları. İstanbul.

Çabuklu, Yaşar. (2004). Postmodern Toplumda Kriz ve Siyaset. Kanat Kitap. İstanbul.

Dağtaş, Erdal ve Dağtaş, Banu (2006). Tüketim Kültürü, Yaşam Tarzları, Boş Zamanlar ve Medya Üzerine Bir Literatür Taraması. Eğitim Toplum Bilim. Cilt:4. Sayı:14. s. 4-31.

Demir, Erol. (1994). 1980 Sonrası Türkiye'de Uygulanan Ekonomi Politikalarının Kent Emekçi Ailelerinin Geçim Stratejileri Üzerine Etkisi. Dünya'da ve Türkiye'de Güncel Sosyolojik Gelişmeler. Cilt: I. s. 357-366.

Demir, Erol. (2002). Kamusal Mekân ve İmge: Gençlik Parkının Değişen Anlamı. Toplum ve Bilim. Sayı:94. s. 109-142.

Doğan, İsmail. (2004a). Toplum ve Eğitim Sorunları Üzerinde Felsefi ve Sosyolojik Tahliller. PegemA Yay. Ankara.

Erdoğan, İrfan. (2004). Popüler Kültürün Ne Olduğu Üzerine. Eğitim. Popüler Kültür ve Gençlik Özel Sayısı. Yıl:5 Sayı:57 s. 7-19.

Erdoğan, İrfan ve Alemdar Korkmaz. (2005). Popüler Kültür ve iletişim. Erk Yayınları. Ankara.

Gander, J. V; Gardiner, Harry W. (2001). Çocuk ve Ergen Gelişimi. (Haz: Bekir Onur). İmge Kitabevi. Ankara.

Hall, Stuart ve Jacques Martin (1995). Yeni Zamanların Anlamı. Yeni Zamanlar. 1990'larda Politikanın Değişen Çehresi. (Çev: Abdullah Yılmaz). s. 105-124. Ayrıntı Yayınları. İstanbul.

Kozanoğlu, Can. (1992). Cilalı İmaj Devri. 1980'lerden 90'lara Türkiye ve Starları. İletişim Yayınları. İstanbul. 
Kozanoğlu, Can. (1996). 80’lerde Gündelik Hayat. Cumhuriyet Dönemi Türkiye Ansiklopedisi. Yüzyıl Biterken. Cilt: 13. İletişim Yayınları. İstanbul.

Kulaksızoğlu, Adnan. (1998). Ergenlik Psikolojisi. Remzi Kitabevi. İstanbul.

Lury, Celia. (1996). Consumer Culture. Cambridge. Polity Press.

Marcuse, Herbert. (1990). Tek Boyutlu Insan. (Çev: Aziz Yardımlı). İdea Yayınları. İstanbul.

Marshall, Gordon. (1999). Sosyoloji Sözlügü. (Çev: Osman Akınhay, Derya Kömürcü). Bilim ve Sanat Yay. Ankara.

McRobbie, Angela. (1999). Postmodernizm ve Popüler Kültür. (Çev: Almıla Özbek). Sarmal Yayınevi, İstanbul.

Murray, Robin (1995). Fordizm ve Postfordizm. Yeni Zamanlar. 1990'larda Politikanın Değişen Çehresi. (Çev: Abdullah Yılmaz). Ayrıntı Yayınları. İstanbul.

Neyzi, Leyla. (2004). “Ben Kimim?” Türkiye'de Sözlü Tarih, Kimlik ve Öznellik. İletişim Yayınları. İstanbul.

Oktay, Ahmet. (1996). 80'lerde Türkiye'de Kültürel Değişim. Cumhuriyet Dönemi Türkiye Ansiklopedisi. Yüzyıl Biterken. Cilt: 13. İletişim Yayınları. İstanbul.

Oktay, Ahmet. (2002). Türkiye'de Popüler Kültür. Everest Yayınları. İstanbul.

Oskay, Ünsal. (2000). XIX. Yüzyıldan Günümüze Kitle İletişiminin Kültürel İşlevleri: Kuramsal Bir Yaklaşım. Der Yayınları. İstanbul.

Oskay, Ünsal. (2001). Kitapsız Toplumun Televizyonu. Yıkanmak Istemeyen Çocuklar Olalım. s. 11-19. YKY. İstanbul.

Özbek, Meral. (2002). Popüler Kültür ve Orhan Gencebay Arabeski. Iletişim Yayınları. İstanbul.

Postman, Neil. (2004). Televizyon: Öldüren Eğlence (Çev: Osman Akınhay). Ayrıntı Yay. İstanbul.

Ritzer, George. (2000). Büyüsü Bozulmuş Dünyayı Yeniden Büyülemek. (Çev: Şen Süer Kaya). Ayrıntı Yayınları. İstanbul.

Storey, John. (2000). Popüler Kültür Çalışmaları. Kuramlar ve Metodlar. (Çev: Koray Karaşahin). Babil Yay. İstanbul.

Spenle, Anne-Marie. (1980). Ergenlik Psikolojisi: Ergen ve Dünyası. Çev: Bekir Onur. Maya Matbaacılık. Ankara.

Smith, Philip. (2005). Kültürel Kuram. Babil Yayınları. İstanbul.

Şişman, Nazife. (2003, 25, 05). Gençliğin İcadı Ya Da Hayatın Ertelenmesi. Zaman Gazetesi. 22.

Tocqueville, Alexis De. (1994). Amerika'da Demokrasi. (Çev: İhsan Sezal ve Fatoş Dilber). Yetkin Yayınları. Ankara.

Willis, Susan. (1993). Gündelik Hayat Kılavuzu. İstanbul; Ayrıntı Yayınları.

Yarar, Betül. (2005). Hegemonic Struggle, The State And Popular Culture: The Case of Football in Turkey. European Journal Of Cultural Studies. Vol. 8 (2) s. 197-216.

Zaim, Ayça. (2006). 80 Sonrası Orta Sınıf Gençliğinin Kendini Farklılaştırma Stratejileri. Birikim. Sayı: 208. s. 89-96. 


\title{
INTIHAR EYLEMCISINININ SOSYAL KIMLİĞì: FÍLISTINLİ İLK KADIN EYLEMCI VEFA İDRIS
}

\begin{abstract}
Social idendity of the suicide bomber: first woman suicide bomber of the Palestine-Wafa Idris. This article, which deals with the social profile of a woman suicide bomber and the process of becoming a human bomb based on the first Palestinian woman human bomb Wafa Idris, particularly aims to assess the Wafa Idris example by utilizing the main theories of suicide bombing. It can be said that the social conditions in which Wafa Idris lived were not so harsh as to push Ms. Idris into committing such a brutal attack when especially attention is paid to the general economic structure and living standard of the Palestinian society. Since there are many Palestinians more desperate than Idris who don't carry out suicide missions as Idris did, the social deprivation theory doesn't fully give us an accurate explanation of the phenomenon. Psychologically Wafa Idris has a damaged personality with feelings of anger, hopelessness and desperation. At this point she makes the important choice of becoming a suicide bomber and rationalizing the idea of being a human bomb. Here it is important to note that Israel has expansion policies towards the Palestinian territory, violating the borders of 1967 and many Palestinians still perceive the Israel state in the historical Palestinian territory as an illegitimate and occupying entity. Besides it doesn't seem possible to explain Wafa Idris's attack relying merely on the meaning realm consisting of fundamentalism, radicalism or political Islam. Rather than being the fundamental cause of the suicide bombing, religion is used to legalize and justify the attack within the theological context of jihad, 201shahaded, and sacrificing yourself for the dawah.
\end{abstract}

\section{key words}

Suicide bombing, social identity of suicide bomber, Wafa Idris. 


\section{Giriș}

Bu makale Filistinli ilk kadın intihar eylemcisi Vefa İdris örneğinden hareketle kadın intihar eylemcisinin sosyal kimliğini ve canlı bomba haline gelme sürecini ele almaktadır. Makalede özellikle intihar eylemleriyle ilgili temel yaklaşım ve teorilerden hareketle Vefa İdris örneğinin değerlendirilmesi amaçlanmaktadır. Siyasi içerikli terör ve şiddet eylemleri politik, dini ya da cinsel kanaatler gibi sosyal araştırmalarda deneysel bilgi toplamanın kolay olmadığı "mahrem" konuların başında gelmektedir. Bilgi kaynağının eylemcinin kendisi olması, intihar eylemcilerinin sosyal profilinin tasvir edilmesini neredeyse imkânsız hale getirmektedir. Operasyonunda başarılı eylemciyle deneysel teknik ve metotlar kullanılarak bilgi toplamak mümkün olmazken, eylem ya da hazırlık süreci içinde yakalanan eylemciler de, kendi adlî ve güvenlik durumlarını gözeterek anket ya da mülakat yapmayı kabul etmemektedirler. Görüşmenin kabul edildiği durumlarda ise yönetimin/otoritenin politik nedenlerden ötürü bilgi alışverişine müsaade etmemesi, müsaade ettiği durumlarda da araştırma sürecine müdahale etmesi bir diğer sorun olarak ortaya çıkmaktadır. Bu makalede, Vefa İdris ile ilgili bilgiler, konuyla ilgili kitaplar yanında büyük oranda, İdris'in başta ailesi olmak üzere yakın çevresiyle yapılan görüşmelere ve eylemle ilgili bilgiler sunan mahalli ve uluslararası medyaya dayanmaktadır.

Orta Doğu'da bu günkü anlamda intihar eylemlerinin Hizbullah'ın 1982'de Lübnan'daki Batılı güçlere karşı düzenlediği saldırılarla başladığı görülmektedir. Eylemlerin Filistin'e geçişi 1948 ve özellikle 1967 'de Güney Lübnan'a sürülen Filistinliler vasıtasıyla olmuştur. Nitekim bu dönemde Güney Lübnan bölgede zaten faaliyet gösteren Şii Amal hareketinin, Filistinli mültecilerin ve İsrail'e karşı vur kaç taktikleriyle mücadele veren Yaser Arafat'a bağlı El-Fetih fedailerinin toplandığı bir coğrafyaya dönüşmüştür (Acar, 1999: 49 vd).

Vefa İdris'e kadar eylemlerde erkekler aktif roller üstlenmiş, kadınlar Filistin direnişinde erkeklerin gerisinde yer almıştır. Tarihsel olarak kadınlar çatışmanın başlangıcından beri kendilerini çeşitli şekillerde göstermeyi başarmışlarsa da(1), kadınların temel işlevi nüfusun devamını sağlama, doğan çocukları yetiştirme, onların eğitim ve sağlığıyla meşgul olma olarak tayin edilmiştir. Daha çok mücadele edecek neferleri dünyaya getiren bir varlık olarak algılanan kadın, dini ve kültürel normların da öngördüğü gibi, mümkün mertebe çatışmanın dışında tutulmaya çalışılmıştır (Tzoreff, 2006: 14).

Bu genel yönelimin I. İntifada (1987-1992) döneminde değişmeye başladığı görülmektedir. Henüz "şehide" olarak değilse bile, "şehit anası" olarak kadınların bu dönemde ilave bir statü kazanımına uğradıkları dikkat çekmektedir. Filistin kadının millileştiği, politikleştiği ve direnişin içinde daha aktif rol oynadığı bu süreç sosyal cinsiyet ilişkileri açısından bir değişimin ilk göstergeleri olarak okunabilir (Tzoreff, 2006: 14-15) Sosyalist eğilimli Filistin Halk Cephesi üyesi Leyla Halid'in devrimci arkadaşlarıyla birlikte 1969 ve 1970'de gerçekleştirdiği uçak kaçırma operasyonları bireysel nitelikli eylemler olarak görülürse (2), İntifada 
süreçleri kadınların kendilerine biçilen ev hanımı ya da çocuk bakma rollerini belirli oranlarda aşıp erkeklerle birlikte daha eşit şartlarda direnişe katılabileceklerini göstermiştir. Ekim 2000'de başlayan II. İntifada birincisiyle mukayese edildiğinde kadınların çok daha geniş bir yelpaze içinde kendi varlıklarını ortaya koyduklarını göstermektedir. Bu dönemin kadınlarını erkek egemen ulusal liderliklere alternatif, sosyal cinsiyet ilişkilerinin farkında olan feminist kadınlar; geleneksel milli annelik anlayışının dışına çıkmış alternatif annelik telakkilerine sahip kadınlar ve intihar eylemcisi kadınlar şeklinde üçlü bir kategori haline getirebiliriz (Tzoreff, 2006: 16-17). Bu kategoriler dikkate alındığında, sonuçta ortaya koyduğu eylemle üçüncü tipe giren Vefa İdris, kocasının ikinci bir kadınla evlenmesine şiddetle karşı çıkarak ne kadar feminen olduğunu göstermek suretiyle, aynı zamanda, ikinci tipe de girmektedir. Birinci Intifada döneminde 12 yaşlarında bir çocuk olan Vefa İdris'in 2000'lere gelindiğinde halkının kendisi için biçtiği "milli anne" misyonuna, adeta bir kadının neler yapabileceğini göstermek istercesine, karşı çıktığı görülmektedir.

\section{1. İntihar Eylemleriyle İlgili Temel Yaklașımlar}

\subsection{Sosyolojik Yaklaşım}

İntihar eylemleri dikkate alındığında, sosyolojik yaklaşım eylemlerin geliştiği sosyal ve ekonomik faktörlerle şekillenen sosyal kriz ortamına işaret etmektedir. Arızalı ekonomik büyüme, ürettiğinden fazla tüketme, adaletsiz gelir dağılımı, refahın tabana yayılmaması, eğitim ve sağlık imkânlarından gereği gibi faydalanamama, büyük şehirlere göç, çarpık kentleşme, istihdam sorunları, işsizlik, yaygın nepotizm kültürü, kimlik krizi, kötü yönetim, askeri mağlubiyetler eylemlerin beslendiği sosyal kriz ortamının temel göstergeleri olarak sıralanabilir. Bununla birlikte, Müslüman köktenciliğinin, sosyal kriz ortamının meydana getirdiği laiklik-irtica, çağdaşlık-muhafazakârlık, seküler elitler-geleneksel halk, liberal elitler-sosyalist aydınlar, milliyetçi İslamcılar-ümmetçi İslamcılar, sûfi gelenek-dini militanlık gibi karşıtlık ve gerginliklerden beslendiği ileri sürülmektedir (Wikan, 2001: 17 vd; Dökmeciyan, 1997: 37-40).

Özellikle temel sosyal dinamikler olarak şehirleşme ve göç geleneksel ilişkilerin dokusunu sarsmaktadır. Çocuk ve gençlerin eğitim ve iş hayatına aktif katılımları, kendilerini hem dünya görüşü, hem de ekonomik açıdan özgürleştirmekte, geleneksel değerlerle modern gerçekler arasında gelgitler yaşayan gençlik, baba otoritesinden ziyade toplumsal aktörlerin tesiriyle kendi kimliğini oluşturmaya çalışmaktadır. Kültür yaratma süreci içinde şaşırtıcı ve zıtlıklar taşıyan tercihlerle yüzleşen gençler, dini/kültürel değerlerle materyalist/kapitalist dünya arasında sıkışmakta, muhafazakâr geçmiş ile seküler gelecek arasında ikilemler yaşamakta, kendi kimliklerini yeniden kurabilme çabası içinde yalnızlaşmakta, yabancılaşmakta, melankolikleşmekte, yanlış yönlendirme ve telkinlerle istikametlerini kaybetmektedirler. Bu sosyal bağlam, gençlerin 
cazibesini kazanmasını çok iyi bilen radikal hareketlerin toplumsal aktör olarak sivrilmesini kolaylaştırmaktadır (Hoffman, 1994: 200-212; Blair, 2002: 19).

Sosyal kriz ortamının dışında intihar eylemcisinin sosyal kimliğiyle ilgili bilgiler sosyolojik yaklaşımın bir diğer parçasını oluşturmaktadır. 1993-2005 arasında Filistin'de gerçekleşen intihar eylemlerini inceleyen Hafez, eylemcilerin sosyal kimliğinin genelleme yapılamayacak kadar farklı özellikler taşıdığını ifade etmektedir. Eylemcilerin en yaygın özelliği 18-28 yaşları arasında bekâr gençlerden oluşmalarıdır. Bazıları fakir, bazıları orta tabakadan, bazıları çok zengin olan eylemciler arasında, orta öğretimini tamamlayamayanlar bulunurken üniversitelerin mühendislikten gazeteciliğe prestijli bölümlerinde okuyanlar da vardır (Hafez, 2006: s.172). Berko ve Erez'in (Filistin örneği) bulgularına göre, eylemciler bölge olarak hem şehir, hem kasaba, hem de mülteci kamplarından gelmekte; yaşları 16-28 arasında değişmekte; ortalama aile üyesi 10 kişi olan geniş ailelere mensuplar; eğitim durumları ilkokul 3. sınıftan üniversite 2. sınıfa doğru değişmekte; bayan eylemcilerin eğitim seviyeleri erkeklere nazaran daha yüksek; büyük çoğunluğu bekâr; ekonomik durumları Filistin toplumunun genelini yansıtmakla birlikte bazı eylemciler genel standardın üstünde bir ekonomik güce sahiptir (Berko-Erez, 2005: 608) (3). Topraklarına el konulmuş bir toplum psikolojisi içinde "Filistin sosyal kimliğinin baskı altında tutulması ve aşağılanması" mülakatlarda sürekli tekrar edilen temalardan biri olmaktadır. Çatışma içine doğan eylemciler savaş ve çatışma şartlarının yön verdiği bir ilişkiler ağı içinde 1948 sonrası İsrail-Filistin çatışmalarını dinleyerek sosyalleşmişlerdir. İsrail işgalinin farklı yüzlerini birinci ağızdan dinlemeleri -ya da bizzat tecrübe etmeleri, eylemcilerin sosyo-kültürel şahsiyetlerinin oluşumunu doğrudan etkilemiştir denilebilir (Berko-Erez, 2005: 609-610). Eylemcilerin sosyal profili içinde örgütsel kimlikleri ve eylem tarihlerine bakıldığında, uzun dönem süren bir örgüt hayatları ve eylem geçmişlerinin olmadıkları dikkat çekmektedir. Umumiyetle travmatik bir olay ya da olay silsilelerinden sonra şehit olma düşüncesi nüks ederek örgüt temsilcileriyle temasa geçilmektedir (Berko-Erez, 2005: 616617).

Özel olarak kadın eylemcilerinin sosyal kimliğine bakıldı̆ı̆nda yaş, eğitim düzeyi, eylem tarihi ve örgüt mensubiyetine göre kadın ve erkek eylemciler arasında farklılaşma olduğu görülmektedir. Kadın eylemcilerin yaş ortalamalarının erkeklere oranla daha yüksek olduğunu tespit eden Shayovitz'in bulguları, kadınların eğitim düzeylerinin de, erkek eylemcilere göre daha yüksek olduğunu göstermektedir. Eylem tarihi açısından kadınlara oranla erkeklerin eylem geçmişlerinin daha kabarık olduğu görülmektedir. Medeni hale göre sosyal cinsiyet özellikleri arasında önemli bir değişme görülmezken, organizasyon ilişkileri açısından, kadın eylemcilerin erkeklere nazaran, daha seküler ve ulusal yönelimli olan El-Fetih'i tercih ettikleri dikkat çekmektedir (Shayovitz, 2007: 165). 


\subsection{Psikolojik Yaklaşım}

İntihar genel olarak açıklanması zor bir olgu olarak karşımıza çıkarken, intihar eylemcisinin psikolojik motivasyonlarını ortaya koymak daha da karmaşık bir hal almaktadır. 1980'lerden bu yana Filistin ve Lübnan örnekleri üzerinde çalışan Merari, intihar eylemcisinin psikolojik profilini çıkarmanın mümkün olmadığını ileri sürerken, konuyla ilgili bir diğer referans kaynağı İsraili daha da ileri giderek, eylemcilerde intihar davranışına yol açacak risk faktörlerinin görülmediğini iddia etmektedir (Lester, Yang, Lindsay, 2004: 285-286).

Intiharda depresyon, madde bağımlılı̆ı ve önceden intihar teşebbüsü şeklinde üç temel risk faktörü sayan Merari, kendi örneklemi içinde bu özelliklerin hiç birini tespit edemediğini ifade etmektedir (Merari, 2004: 439). Açık psikopatolojik belirtilere rastlanmadığını söyleyen Merari, kişisel sarsıntı sebebi olarak eylemcilerin aile ve yakın çevrelerinde görülen ölüm ve tutuklamalar dikkate alındığında, intihar eylemi ile intikam duygusu arasında kurulan bağa dikkat çekmektedir. Bu çerçevede, ölüm ve işkenceler kişisel sarsıntılara, incinme ve sarsıntılar intikam duygusunun gelişimine, intikam duygusu da intihar eylemine yol açmaktadır (Merari, 438).

İntihar eylemleriyle ilgili diğer psiko-dinamik spekülasyonlar şu şekilde özetlenebilir. Kushner, ümitsizlik ve öfke duygularının tecrübe edilebileceğini önerirken, Volkan potansiyel intihar eylemcisinin incinmiş kişilik yapısına sahip olduğunu, iç dünyasını durağanlaştırmak için bazı dış temsil araçlarını bilinçli ya da bilinç dışı özümsediğini ve kendi doğasının bir parçası haline getirmeye çalıştığını ifade etmektedir. Eylemciyi idealist ve olgunlaşmamış olarak gören Rosenberg, intikam güdüsünü öne çıkararak gurur ve haysiyetin onarımını ileri sürmektedir. Lackhar ise duygusal düzensizlik, siyah ve beyaz görme, kaotik ilişkiler biçimi, utanç ve başkalarını suçlama gibi özelliklerle nitelendirilen sınır kişilik bozukluğuna vurgu yapmaktadır (Lester, Yang, Lindsay, 2004: 286). Onur incinmesi ve alenî aşağılanma faktörlerine dikkat çeken Post, işgal altında yaşayan Filistinlilerin süreğen aşağılanma ve küçük düşürülme karşısında intihar eylemleri vasıtasıyla yaşadıkları onur kııılmasını ve aşağılanmayı tamir etmeye çalışıklarına dikkat çekmektedir (Post-Denny, 2003: 171-176) (4).

Özel olarak kadın intihar eylemcileri dikkate alındığında, dini ya da milli heyecanın daha belirgin gözlemlenebildiği erkeklere nazaran kadın eylemcilerde kişisel bunalım ve sarsıntıların daha önemli bir motivasyon kaynağı olduğu iddia edilmektedir (Bloom, 2005: 145). Beyler, kadın intihar eylemcisi görülen toplumlarda ataerkil bir yapı olduğunu ve kadınların kamu hayatından soyutlanarak özel alana hapsedildiğini ileri sürerken (Beyler, 2003: 10-11), McDonald, kadın eylemcilerin kendilerini sadece politik baskının kurbanı değil, aynı zamanda, erkek yoldaşlarının da baskısı altında gördüklerini, dolayısıyla iki yönlü bir baskı altında kaldıklarını ifade etmektedir (McDonald, 1991: 232). 
Intihar eylemlerinde sosyal cinsiyetin önemini gösteren Barbara Victor, kadın intihar eylemcilerinin Filistin'i özgürleştirmenin ötesinde gerekçeleri bulunduğunu ifade ederek kadın eylemcilerle ilgili temel iki sonuca dikkat çekmektedir. Öncelikle istisnasız bütün kadın eylemciler aile, akraba, arkadaş, öğretmen ya da dini lider mutlaka bir erkek tarafından eğitilmiştir. İkinci olarak incelediği kadınların tümü kendi kültür ve toplumsal yapıları içinde hayatı katlanılmaz hale getiren -bazen ekonomik, bazen psikolojik, bazen kültürel, bazen de bunların tümü geçerli olmak üzere- kişisel problemlere sahiptir (Victor, 2003: 193 vd). Eylemlerin işgalin yakıcı etkisi altında dini köktencilik ve coşkulu vatanseverlik karışımı içinde gerçekleştiğini söyleyen Victor, kadın eylemcilerde gözlemlediği kişisel bunalımları hayatın yeterince acı ve zorluğu karşısında eşin kaybedilmesi, kültürel yapı içinde onaylanmayan kadın erkek ilişkilerinin getirdiği sosyal utanç ve aşağılanma, çocuk sahibi olamama ve aile hayatına yansıyan tahribatlar, yalnız bir ana olarak çocuk yetiştirmenin tüm sorumluluklarını üzerine almak zorunda kalma, kendisi için mümkün olmayan bir eğitimi şiddetle arzulama, aileler arasında yapılan anlaşmalı evliliklere zorlanma, aşağılanmış ya da öldürülmüş sevgilinin intikam sorumluluğunu üzerinde hissetme şeklinde sıralamaktadır. Bunların yanında, öz saygı ve bağımsızlığı gerçekleştirecek kurumsal destekten yoksun olma, mâli meseleleri ve duygusal çalkantıları düzenleyecek mekanizmaların geliştirilmemesi, hayatta bir ikinci, üçüncü şans ve alternatiften mahrum olma intihar eylemlerinin gizemini yok ederek önemli bir seçenek ya da çıkış yolu haline getirmektedir (Victor, 2003: 233-234).

Sosyal cinsiyet ilişkilerindeki ataerkil kültür yapısına ve onurun muhafazası çerçevesinde şekillen ilişkiler biçimine işaret eden Cunningham ise, "kara dullar" şeklinde de isimlendirilen Çeçen kadın eylemcilerde aile fertlerinden bir ya da bir kaçının öldürülmesi üzerine parçalanan kimlik ve kişilik bunalımıyla doğrudan ilgili intikam duygusuna işaret ederken, Tamil Kaplanları'na mensup kadın intihar eylemcilerinde cinsel şiddet ve istismarların göründügüne dikkat çekmektedir (Cunningham, 2001: 171-175).

\subsection{Politik Yaklaşım}

İ̧̧al intihar eylemleriyle ilgili politik tartışmaların merkezinde yer almaktadır. Milli bağımsızlık ve özgürlük mücadelesi intihar eylemlerinin arkasında yatan en önemli faktörlerden biri olarak sunulmaktadır. Tilhami, Filistin Otoritesi'nin Filistin'in özgürlüğünü gerçekleştirememesini ve Filistin halkını aşağılanmaktan kurtaramamasını intihar eylemlerinin temel sebebi olarak yorumlamaktadır. Pearlman ise bu konuda çok net bir ifadeyle intihar eylemi şeklinde ifade edilen fenomenin İsrail'in işgal politikaları tarafından yaratıldığını ileri sürmektedir (Kimhi-Even, 2004: 816; Telhami, 2002: 36; Pearlman, 2002: 14).

Dünya çapında, 1980-2003 arasında gerçekleştirilen 315 intihar eylemini derleyerek oluşturduğu bilgi bankasından hareketle, intihar eylemlerinin "stratejik mantığını" inceleyen Robert Pape, intihar eylemlerine 
seküler/politik/stratejik hedeflerin yön verdiğini ifade etmektedir. Pape'in teorisine göre, eylemci gruplar kendi vatanları olarak gördükleri topraklarda işgalci kabul ettikleri modern demokratik ülkelerin askeri varlığına karşı direniş göstermektedirler (Pape, 2005: 4). Pape göre, en mühim çıkarlar tehlikede olduğunda stratejik olarak mantıklı hale gelen intihar terörizmi, vatanın yabancı etki ve kontrolden kurtarıımasında ya da topyekûn bağımsızlığa kavuşma yolunda son çare olarak başvurulan bir eylem tipidir (Pape, 2005: 42) (5).

Filistinli gruplar başta olmak üzere PKK ve Tamil Kaplanları örneklerini kullanarak intihar eylemlerini tahlil eden Bloom, halk desteği kazanmak ve finans olarak pazardan pay almak için rakip politik güçler arasındaki etkileşim ve çatışma sürecini öne çıkarmakta, bir bölgedeki intihar eylemlerinin başarısını kanıtladıktan sonra diğer bölge ve gruplara "bulaştığı" tezini işlemektedir (Bloom, 2005: 3-4). Amerika'nın Orta Doğu'daki varlığına ve müdahaleci politikalarına dikkat çeken Esposito, Müslüman radikalizmini, Müslüman dünyanın Amerika'ya yönelik beslediği politik hoşnutsuzluklarla açıklamaktadır. Bu hoşnutsuzluklar Esposito tarafından şu şekilde açıklanmaktadır: (1) Demokrasi, insan hakları ve kendi kendini yönetme gibi değerlere gerçekten sahip çıkılmamakta, reel uygulamaların gölgesinde bütün bunlar boş birer söylemden ibaret kalmaktadır. (2) Bütün barış çabalarına rağmen İsrail'e yapılan yardımlar hiçbir şekilde anlaşıIır değildir (Esposito, 2003: 154). (3) Çeçenistan, Kosova ve Keşmir gibi bölgelerde, Müslümanlara uygulanan etnik temizlik karşısında, Amerika'nın yavaş davranarak işi ağırdan alması. (4) Pakistan'a (ve İran'a) nükleer silahlanma konusunda uygulanmaya çalışılan yaptırımların İsrail'e uygulanmaması. (5) Doğrudan Saddam Hüseyin'le alakası olmayan yaptırımlarla, Irak'ta, 1.5 milyondan fazla çocuğun hayatını kaybetmesi. (6) İslam dünyasındaki muhafazakâr hareketlerin tümünün köktencilikle itham edilip demokratik sürecin sekteye uğratılması ve otoriter rejimlerin desteklenmesi (Esposito, 2003: 156).

\subsection{Dini Yaklaşım}

Dini yaklaşıma göre, intihar eylemleri dini anlam evreni içinde rasyonalize edilerek cihad, şehitlik, kendini yaratıcıya kurban etme bağlamları içinde değerlendirilmektedir. Erkek intihar eylemcileri, hayatlarının en yüksek noktasında aktif ve aşırı zinde (euphoric) olarak tanımlayan Victor, son videolarından hareketle, eylemcilerin eylemlerini şehitlik ve kendilerini yaratıcıya kurban etme anlayışı içinde meşrulaştırdıklarını anlatmaktadır (Victor, 2003: 232).

Dini şiddet eylemlerine madde ötesi gayelerin yön verdiği görülmektedir. Gayelerin ulvî olması, zafer ümitlerini de ulvîleştiren bir evren, tarih ve son inşa ederek savaşı barış ümitlerine nazaran daha mantıklı hale getirmektedir (Juergensmeyer, 2002: 32). Juergensmeyer dinin "dünya görüşü, motivasyon, organizasyon ve meşrulaştırma" sağlayarak dini şiddetin motoru olabildiğini ifade ederken (Juergensmeyer, 2003: 7), Berko ve Erez cihad ve şehitlikle ilgili dini metin ve sembollerin hem seküler, hem de köktenci gruplar tarafından 
kullanıldığına dikkat çekerek, canlı bomba haline gelme süreci içinde, eylemcinin bulunmasında, hazırlanmasında ve motive edilmesinde dini anlam evreninin devreye girdiğini anlatmaktadır (Berko-Erez, 2005: 605). Dinin kişisel motivasyonun önemli bir parçası olduğunu söyleyen Moghadam ise, şehidin günahlarının bağışlanmasını, kabir azabından kurtulmasını, cehennem korkusundan kendini emin hissetmesini, şehitliğin dünya ve içinde bulunan her şeyden daha hayırlı olmasını, eylemcinin 72 huriyle evlenecek olmasını ve yakın 70 kişiyi de kapsayacak şekilde bu ayrıcalıkların genişletilmesini dini meşrulaştırmanın unsurları olarak sıralamaktadır (Moghadam, 2003: 73).

Bununla birlikte, ilahi ödüllendirmelerin yanlış yorumlandığını, nihai gayenin Allah'ın rızasını kazanmak olduğunu ifade eden Şeyh Ahmed Yasin, canlı bombanın arkasındaki gücü şöyle ortaya koymaktadır. "Şehitlik, kalbin derinliklerinde [yatan] bir aşktır. Fakat bu ödüller, bizatihi şehitliğin hedefi değildir. Tek gaye, Allah'ın hoşnutluğunu kazanmaktır. Allah'ın davası içinde ölmekle, bu [gayeye] en yalın ve en hızlı şekilde ulaşılabilir. Ve şehidi seçen Allah'tır." "Bütün şehitlik operasyonları, eğer Allah adına yapılıyorsa, bir sinek ısırmasından daha az acı verir" diyen eski [eyleminde başarısız] bir intihar eylemcisi de eylemlerde niyetin önemine işaret etmektedir (Hassan, 2001: 38-40).

\section{Filistinli İlk Kadın İntihar Eylemcisi Vefa İdris}

\subsection{Sosyal Kimliği}

Vefa İdris El-Amarî göçmen kampında 1975'de doğdu. Tipik bir eylemcinin 18-22 yaşları arasında tasvir edildiği düşünülürse, olay esnasında 27 yaşında olan Vefa İdris'in yaş faktörü açısından genel intihar eylemcisi tipolojisine uymadığı görülmektedir. 27 yaş ilk gençlik heyecanlarının/heveslerinin atlatıldığı ve hayatın iş, eş, aş açısından daha düzenli hale girdiği bir dönemi ifade etmektedir. Dolayısıyla İdris örneği, intihar eyleminin ilk gençlin dönemine ait bir fenomen olmadığını göstermektedir. Diğer taraftan İdris doğduğu günden eylem anına kadar hayatını bir göçmen kampında geçirmiştir. Kendine özgü bir varoluş biçimi ve kültür meydana getiren kamp hayatı, sosyolojik olarak bireylerin ve grupların gelişim sürecinde önemli bir değişkendir. İdris'in ailesinin 1948 Arapİsrail savaşından sonra İsrail sınırları içinde kalan Ramla bölgesinden El-Amari göçmen kampına sürülmüş olması, kamp hayatının kısıtlı imkânlarının negatif etkileriyle birleşerek toprağından çıkarılma ve işgal altında olma duygusunu daima canlı tutmuştur (Bennet, 2002). Kampın İsrail müdahalelerine açık olması ve kampta sokak çatışmalarının sıklıkla yaşanması İdris'in ateş hattı üzerinde bir sosyal hayat yaşadığını göstermektedir. Nitekim yengesinin (ağabeyinin eşi) "erkek intihar eylemcilerini izleyen Vefa'nın kendisinin de intihar eylemi yaparak şehit olmak istediğini" ifade etmesi, İdris'in bu çatışma sürecinden etkilendiğini ve mücadele sürecinin bir parçası olmak istediğini göstermektedir (Victor, 2003: 37). 
İdris, toplam üç odası bulunan küçük bir evde annesi, ağabeyi, yengesi ve ağabeyinin beş çocuğuyla birlikte yaşamıştır. Ağabeyi kendilerine ait ticari takside çalışarak ailenin nafakasını temin etmektedir. Göçmen kampında ev kirası vermedikleri düşünülürse, kendilerine ait bir taksilerinin olması, İdris'in ailesinin en azından düzenli bir gelire sahip olduğunu ve ekonomik olarak Filistin standartları içinde ortalama bir yerde bulunduklarını göstermektedir. 8000 kişinin yaşadığı kampın geneliyle karşılaştırıldığında "İdris'in ailesinin ne zengin, ne fakir, ortalama bir aile olduğunu" ifade eden Ameri kampındaki gençlik derneği yöneticisi de bu gözlemi desteklemektedir (Biedermann, 2009). İntihar eylemlerinin yoksunluk teorisi ya da iktisadi faktörlerle açıklanması ve eylemcilerin alt gelir grubuna mensup ailelerden geldiği varsayımının İdris örneği tarafından tamamıyla desteklenmediği görülmektedir (Matza, 2002; Bennet, 2002).

Vefa İdris 15 yaşında evlenmiş, ancak kendisinin hayatında önemli etkileri olacak bir dönüm noktası olarak evliliği 25 yaşında ayrılıkla sonuçlanmıştır. Düşük yapan İdris'in çocuk sahibi olamaması, Filistin'e ait kültürel normlar da dikkate alındığında, boşanmalarında çok önemli bir etken olarak karşımıza çıkmaktadır. Üniversite mezunu olup olmadığı tespit edilememekle birlikte, İdris'in ilk ve orta öğrenimi bitirdiği ve Birleşmiş Milletler'e ait hemşirelik kurslarını bitirerek iki ayrı sertifika aldığı görülmektedir. Tam zamanlı olmasa da, İdris Filistin Kızılay'ına ait bir saha hastanesinde gönüllü sağlık çalışanı olarak görev yapmaktadır. Özelikle Cuma Namazı'ndan sonra Ramallah'ta gerçekleştirilen gösteriler esnasında çıkan çatışmalara giden ekibin içinde yer almaktadır. İdris'in bu işi "Filistin davasına katkımdır" diyerek ağabeyinin ikazlarına rağmen her hangi bir ücret almaksızın gönüllü olarak yaptığı dikkat çekmektedir (Victor, 2003: 51; Matza, 2002; Bennet, 2002).

İ̧ arkadaşları İdris'i daima hareketli, yüzünden gülümsemenin eksik olmadığı hiper bir insan olarak tasvir etmektedirler. İş arkadaşlarının tanıkıklarından hareketle içine kapanık bir insan olmadığı söylenebilecek İdris'in, aynı zamanda, cesaretli bir insan olduğu da ifade edilmektedir. Kendisi hayatî tehlikenin olduğu sokak çatışmalarına girerek yaralılara müdahale etmekten çekinmemektedir (Victor, 2003: 53). Idris'in çocukluk arkadaşı Manal Shaheen kendisinin "çok güçlü olduğunu, asla [bir şeyden] korkmadığını, onun karakterinde bir kişinin böylesi bir eylemi yapabileceğini" söylerken (Matza, 2002), El-Fetih yanlısı faaliyetlerde bulunduğu için sekiz yıl bir İsrail hapishanesinde yatan kardeşi Halil İdris, bütün engelleme, yasak ve tehlikelere rağmen kardeşinin her fırsatta ziyaretine geldiğini anlatmaktadır (Biedermann, 2009).

Vefa İdris çevresiyle sosyal münasebet kurmada zorlanmayan ve hayatın içinde var olmayı seven bir insan olarak karşımıza çıkmaktadır. Giyinmeyi seven İris, şakalaşmaktan hoşlanmakta, mahallesindeki küçük çocuklara oyunlar yapmaktadır (Franklin, 2002). Yine İdris çevresindeki sosyal aktivitelerin bir parçası olmaya özen göstermektedir. Kardeşi Halil, İdris'in birinci intifada (19871993) döneminde kampın Kadın Komitesi'nde yer aldığını ifade etmektedir. 
Akrabaları İdris'in Sokağı çıkma yasağı olduğu günlerde yiyecek dağıtımına yardım ettiği, tutukluların ailelerine ziyaretlerde bulunduğu ve sosyal destek sağladığını anlatmaktadırlar (Biedermann, 2009) “Özgür düşünceli” bir kadın olduğunu ifade eden kardeşi, İdris'in kendisiyle ilgili başkalarıyla paylaşmadığı kararlar alabildiğini ifade etmektedir. Ailesinin bazı durumlarda sosyal hizmetlerde bulunmasına karşı çıkmasına rağmen İdris, kararından dönmeyerek bu konudaki çalışmalara katılmaya devam etmiştir (Bennet, 2002). Eylem anında Fetih'in güvenlik müdürlerinden olan Cibril Recep, İdris'in politik kimliğiyle ilgili bilgiler vermektedir. İdris'in baş örtüsü takmadığını söyleyen Recep, kendisinin aşırı dindar olmadığını, depresif bir kişiliğin de İdris'i tanımlayamayacağını öne sürmekte ve idris'in eylemini "başka bir şey değil, sadece milli duygular içinde gerçekleştirdiğini" ifade etmektedir (Biedermann, 2009).

\subsection{Psikolojik Kimliği}

Küçük yaşta babasını kaybeden Vefa İdris'in bir göçmen kampında geçen hayatının kolay olmadığı ortadadır. Topraklarından çıkarıımış, işgal altında yaşayan bir insanın/toplumun kişilik yapısıyla ilgili özellikler İdris için de fazlasıyla geçerli olmakla birlikte, arkadaşı Ahlam Nâsır İdris'in depresif bir insan olmadığını, yaşanılan acı ve sıkıntılara rağmen iyimser ve umutlu olduğunu ifade etmektedir. Hatta bir arkadaşı kendisinin fırsat bulduğunda yabancı dergilere baktığını, oradan elbise ve takılar beğendiğini anlatmaktadır (Victor, 2003: 41).

Babasının ölümünün üzerindeki menfi etkilerini tam olarak bilememekle birlikte, babası öldüğünde henüz çok küçük olan (tam olarak kaç yaşında olduğuyla ilgili bir bilgi tespit edilememiştir) İdris'in kardeşleri ve annesiyle birlikte düzenli bir aile çatışı altında yetiştiğini görmekteyiz. Özellikle ailede yetişkin erkek kardeşlerin olması babaya duyulan intiyaç ya da eksikliğin belirli oranda telafi edildiğini göstermektedir. Babasız yetişmesi dışında İdris'in psikolojik kimliğini doğrudan etkileyebilecek en önemli faktörlerden birisi erken yaşta yaptığı evliliğidir. 16 yaşında aynı göçmen kampında yaşayan kendisinden 10 yaş büyük kuzeni Ahmet ile evlenen İdris'in bu evliliği ilk çocuğunun düşmesiyle ciddi bir krize girmiştir (Matza, 2002). Filistin şartlarında yapılan tıbbi tetkiklerden sonra -ki kendisini bir jinekolog yerine normal bir hekim herhangi bir MRI ya da sonogram çektirmeden muayene etmiştir- kendilerine, Ahmet'in ailesinin de hazır bulunduğu bir ortamda artık çocuk sahibi olamayacakları söylenmiştir. Aile Ahmet'i ve Idris'i bu konuda suçlarken İdris, giderek depresif bir kişilik haline gelmektedir. Ahmet eşinin bu dönemdeki durumunu şu sözlerle anlatmaktadir (Victor, 2003: 43):

Bebeğini kaybettikten sonra İdris yemeyi, içmeyi ve konuşmayı kesti. Bütün gece ve gündüzlerini yatakta geçirmeye başlayarak ev temizliği yapmayı ya da yemek pişirmeyi reddediyordu. Kaygıdan delirmek üzereydim ve bu durumla nasıl başa çıkacağımı bilemiyordum. Yardım etmek için İdris'in kardeşi Halil'i arayarak durumu izah ettimse de hiçbir şey değişmedi, İdris sessiz kalmaya devam ediyordu. 
Vefa'nın içinde bulunduu psikolojiyi tam bir durgunluk ve atalet (inertia) şeklinde ifade eden yakın arkadaşlarından İtimad Ebu Lidbah şunları söylemektedir (Victor, 2003: 45):

Bebeğini kaybettiğinde Vefa yaşam arzusunu kaybetmişti. Niçin böyle davrandığını tam anlamıyla çözemedim, fakat böyle davranmaya devam ediyordu. Hiçbir şey söylemese de Wefa'nın çok büyük bir acı hissettiğini görebiliyordum. Hayatını devam ettirmek için hiçbir arzusu kalmadığını hissedebiliyordum.

Böylesi bir bunalım halindeyken Ahmet'in ikinci bir evlilik yapmak istemesi Vefa'yı histerik bir hale getirmiştir. Kendisini çok sevdiğini ve asla bir başka kadınla paylaşamayacağını söylemesine rağmen Ahmet ikinci evliliğini yapmış ve 1998 'de İdris'i boşayarak baba evine geri göndermiştir. İdris'in büyük bir acı içinde eski eşinin evlilik merasimini kendi evlerinin penceresinden izlemek zorunda kalması oldukça hazindir. Annesi Vasfiye Mebruk İdris, kızının kocası tarafından geri gönderilmekle aşağılandığını söyleyerek İdris'in durumu şu şekilde açıklamaktadır (Victor, 2003: 41):

Kızım çocuk sahibi olamadığı için kocası tarafından boşanmıştır. Vefa bu şekilde boşanmış bir kadının tekrar evlenemeyeceğini çok iyi biliyordu... Gençti, akıllıydı, güzeldi; ancak kendisini hayata bağlayan herhangi bir şey yoktu."

Vefa zaten zor geçinen ailesi için mâli bir yük olacağının farkındalığı içinde evine dönmüştü. Bu dönemde, yenge Vissim İdris, televizyonda erkek eylemcileri izleyen Vefa'nın "böylesi bir eylemi keşke ben yapmış olsaydım" dediğini ve aşağılanarak yaşamaktansa kutlu bir son olan şehitliği tercih edeceğini söylediğini ifade etmektedir (Victor, 2003: 27). Bu durum plansız ve belirsiz bile olsa İris'in zihin dünyasında intihar eyleminin bir seçenek olarak var olduğunu göstermektedir. Zira normal intihar davranışında ya önceden intihar teşebbüsü ya da intihar öyküsü sıklıkla rastlanan iki özellik olarak karşımıza çıkmaktadır (Lester, 1998: 657-665).

Vefa İdris'in psikolojik kimliğiyle ilgili bir diğer nokta kendisinin çatışmanın içine doğmuş olmasıdır. Evinize bombalar yağarken ya da siz içecek su bulamazken İsrailli çocukların havuzlarında yüzerek eğlendiklerini gördüğünüzde, barış ve sevgi yerini nefret ve kıskançlı̆g bırakmaktadır diyen Sarraj, intihar eylemleriyle işgal altında yaşamak arasında doğrusal bir ilişki olduğunu ileri sürmektedir (Victor, 2003: 118). Bu anlamda 1987'deki birinci intifada döneminde henüz 12 yaşında bir çocuk olan İdris ayaklanma, isyan ve çatışma sürecinin acılarını gözlemleyerek/yaşayarak kendi kişiliğini bulmuştur. Anne Vasfiye İdris, Vefa'nın daha çocuk yaşta diğer Filistinli çocuklar gibi işgali reel olarak yaşadığını ve bu durumdan derinden etkilendiğini anlatmakta, özellikle çatışma sürecinde gözünü kaybeden bir arkadaşın Vefa'yı derinden sarstığını ifade etmektedir (Victor, 2003: 40). Yine bu süreçte ailesi Vefa'nın sadece çatışmaları izlemekle kalmadığını, üç sefer plastik mermiyle vurulduğunu ve İsrail güvenlik güçleri tarafından dövüldüğünü anlatmaktadır. Çatışmalarda aile fertlerinden birisini kaybetme- 
mekle birlikte, Fetih (FKÖ’ye bağlı silahlı grup) üyesi ağabeyi Halil'in İsrail tarafından tutuklanması ve 8 yıl hapis yatması Vefa'nın hayatında, babasını da erken yaşta kaybettiğini düşünürsek, önemli bir dönüm noktası olarak görülebilir (Biedermann, 2009).

Kızının Filistin'in özgürlüğü için kendini feda etmesini onurlu bir davranış olarak görmekle birlikte, önceden haberim olsaydı kızımı engellerdim diyen Vasfiye İdris, gerçekte kızının niçin böyle bir karar verdiğini tam olarak anlayamadığını, fakat çalışırken gördüğü manzaralardan etkilendiğini, neticede "Vefa'nın Filistin'in kızı" olduğunu ifade etmektedir. Yengesi Vissim İdris, Vefa'nın "Ramallah'daki çatışmalar esnasında vurulan ve öldürülen çocukları gördüğünde" çileden çıktığını anlatmaktadır. Gönüllü sağlık çalışanı olarak sürekli yaralanan insanlarla uğraşması, onların acılarına şahit olması, aile ve çocuklarının ıstırabını doğrudan müşahede etmesi Vefa İdris'in ruh sağı̆̆ını derinden etkileyen bir unsur olarak görülebilir (BBC.Co.Uk, 29.01.2009).

Bütün bu psikolojik faktörlere rağmen, ailesi ve yakınları İdris'in eylemini depresyonda olduğu ya da travma yaşadığı için gerçekleştirmediği konusunda ısrar etmektedirler. "Kızım bunalımda olduğu için bunu yapmadı" diyen Vasfiye İdris, Vefa'nın düşük ve boşanman sonrası yaşadığı bunalımları atlattığını ileri sürmektedir (Bennet, 2002). Vefa'nın acılarını dindirmek ya da depresyon geçirdiği için böyle bir karar vermediğini her fırsatta dile getiren aile üyeleri, kızlarının gerçek ölümünü işgal ve baskı kavramlarıyla açıklamaya çalışmaktadırlar (Biedermann, 2009). Benzer yorumlar yapan çocukluk arkadaşı Rafah Abu Hamid de Vefa'nın Filistin'in bağımsızlığı konusunda çok kararı bir insan olduğunu ve çocuk sahibi olabilse bile böyle bir kararı verdiğinde kendini feda edebilecek bir karakter taşıdığını ifade etmektedir (Victor, 2003: 27)

\subsection{Organizasyonla Bağlantı: Vefa İdris Eylem Yolunda}

Vefa İdris'in üç erkek kardeşi de El-Fetih üyesi olmasına rağmen, kendisinin Filistinli herhangi bir militan grubun üyesi olmadığı ifade edilmektedir. Genel terör teorilerinin aksine İris'in önemli bir örgütsel tarihinin olmadığı dikkat çekicidir (BBC.Co.Uk, 29.01.2009) (6). Ancak intihar eylemleri yalnız ifâ edilmemektedir. Eylemci, kendisine rehberlik eden bir grup tarafından seçilmekte, eğitilmekte ve motive edilmektedir (Richardson, 2006: 17). Canlı bomba haline gelme sürecinde, organizasyonun öldürme isteği ile eylemcinin ölme arzusunun kesiştiği noktada, örgütsel-kurumsal yapının etki eden faktör olarak devreye girdiği görülmektedir (Moghadam, 2003: 68).

Şehide olmak istediğini çeşitli vesilelerle dile getiren İdris'in bu düşüncesi zaman içinde ciddi bir karar haline gelmiş ve bu konuda kardeşi Halil ìdris'ten ısrarla yardım istemiştir. Halil kardeşinin ısrarları üzerine kendisinin Aksa Şehitleri Tugayları (Fetih'in askeri kanadı) ile bağlantıya geçmesini sağlamıştır. Dolayısıyla eylemde örgütsel bağlantı ve desteğin Vefa'nın bizzat kardeşi tarafından temin edildiği görülmektedir. Halil İdris, Vefa'yı eylemden sadece iki hafta önce 
Fetih kurmaylarıyla tanıştırdığını ifade ederek, bu görüşme esnasında, Vefa'ya bütün kadın adaylar içinden kendisinin ilk kadın şehide olarak seçildiğinin deklare edildiğini anlatmaktadır. Çocukluğunda beri sokak çatışmalarının içinde büyüyen Vefa'nın tercih edilmesinde üç önemli faktörün rol oynadığı görülmektedir. Bunlardan ilki kardeşlerinin El-Fetih tarafından zaten tanınması, dolayısıyla gönüllü eylemciyle ilgili bir güven, itimat ya da ilave bir güvenlik ve istihbarat probleminin olmamasıdır. İkincisi Vefa'nın sıcak çatışmaların içine korkusuzca girerek adeta İsrail askerilerinin elinden Filistinli yaralıları çekip alacak kadar cesur biri olmasıdır. Üçüncü faktör sosyal cinsiyetle ilgilidir. Vefa'nın kadın olması -makyaj yapması, başının açık olması, Batılı bir turist gibi giyinebilmesi gibi- kamuflaj avantajı sağlamakta ve daha az dikkat çekerek İsrail içlerine kadar girebilmektedir (Victor, 2003: 23-24).

27 Ocak 2002 Pazar sabahı erkenden kalkan Vefa, hoşça kal demek için annesini uyarır ve işe geç kaldığını söyleyerek kuzenlerine ait bir meyve suyunu da yanına alarak evden çıkar. Ancak iş yerinde hiç görünmez, zira o gün Vefa'nın çalışma günü değildir. Operasyonu düzenleyen tutuklu, Fetih üyesi Muhammed Hababa, Vefa'nın Ramallah'tan Kudüs'e doğru çıktığı son yolculuğunda kontrol noktalarından bir ambülâns yardımıyla geçtiğini ifade etmektedir. Avrupai parkesi ve fuları, yapılmış uzun kıvırcık saçları, kusursuz makyaj ve manikürü yeni yapılmış elleriyle Yaffa Caddesindeki lüks sayılabilecek ayakkabı dükkânına girdiğinde Vefa, insanları cezp etmekten öte başka bir şekilde dikkat çekmemektedir. 27 Ocak Pazar öğlenden sonra sırt çantasında taşıdığı 10 kg bombayı dükkândan çıkarken patlatan Vefa, kendisiyle birlikte Pinhas Tokatı ıdında yaşlı bir İsrail vatandaşını öldürürken yüzden fazla kişinin yaralanmasına sebep olmuştur (Victor, 2003: 21-22) (7).

El-Fetih'le bağlantılı Nâsır Şavih, operasyonu hazırlayanların Vefa'nın kurbanlarıyla birlikte kendisini havaya uçurmasını planlamadıklarını, ancak sonucun intihar eylemi şeklinde gerçekleştiğini ifade etmektedir. Muhtemelen Vefa bombayı ya bir yere yerleştirecekti ya da yerleştirecek kişi için teslimatçılık yapıyordu. Yine de bombanın olası bir aksilik karşısında hemen patlatılacak şekilde düzenlenmesi ve Vefa'nın gerektiğinde bombayı patlatacağını bilerek yola çıkması eylemin mahiyetiyle ilgili tartışmaları önemsizleştirmektedir. İdris arkasında tipik intihar eylemcisinin yaptığı gibi -özellikle Hamas ve İslami Cihad'ın eylemlerinde görüldüğü gibi- son sözlerini, eylemi niçin ve kimin adına yaptığını ifade ettiği bir kayıt bırakmamış; ancak eylem 48 saat içinde El-Fetih'e bağlı Aksa Şehitleri Tugayları tarafından üstlenilmiştir (Schwweitzer, 2006: 25; Victor, 2003: 20-25).

\subsection{Eylemin Sembolizmi: Toplumsal Kahraman Vefa İdris}

Intihar eyleminin bombanın patlamasıyla sona ermediği, ürettiği sembolizmle etkisini kalıcı hale getirdiği görülmektedir. İntihar eylemi, eylem sonrası düzenlenen seremoni ve kutlamalarla hissiyatı kabartan, mensubiyet duygusu- 
nu derinleştiren, kolektif şuuru güçlendiren, kimlik ve hedef tayin ederek kişileri kutsal bir tarihe bağlayan ve sosyal kabul telkin eden bir ritüel haline dönüştürülmektedir. Eylem sahibine atfedilen onur, bu onuru izleyenleri de onurlandıran bir mekanizmaya dönüşmekte ve eylem kendi gerçek bağlamının ötesinde toplumsal onay almaktadır (Hafez, 2006: 41).

Yarattığı etki bakımında olağanüstü olan eylemlerin, eylemciler açısından da bir kahramanlaş(tır)ma süreci olduğuna dikkat çeken Victor, güçsüzün "akıllı bombası" olan intihar eylemcilerinin Batı Şeria ve Gazzede, süper starlar haline geldiğini gözlemlemiştir (Victor, 2003: 16). Vefa İdris'in öldüğü gece, eylem henüz resmi olarak üstlenilmeden el bildirileri dağıtılmaya başlanmış, sabah olduğunda, tüm Ramallah İdris posterleriyle bezenmiştir. Başında bandajı, arka fonda Mescid-i Aksa ve İbrahim Camii, üzerinde şehitlerle ilgili ayetlerle bu posterler Filistin direniş ikonolojisi içinde anlam dünyaları haykıran sembolik unsurlar olarak karşımıza çıkmaktadır. Sadece Filistin'de değil, başta Mısır ve Ürdün olmak üzere pek çok komşu Arap ülkesinde çeşitli gazete ve dergiler, eylemi, çok büyük bir kahramanlık örneği olarak takdim etmiş, Vefa İdris kendisi gibi Filistin'de yaşamış olan Hz Meryem'e benzetilmiştir (Victor, 2003: 26). Feminist, dindar, seküler, milliyetçi ya da devrimci fark etmeksizin "şehitlik" ve "şehitlik operasyonları" çevresinde oluşturulan bir sosyo-kültürel yapı ve bu kültürel zemin üzerinde inşa edilen sembolizm aracılığıyla Filistin toplumu kendisini şehitlerle bütünleştirmektedir. Şehitlere öykünme ya da şehitlerle aynîleşme yeri geldiğinde benzer eylemler gerçekleştirebilecek bir hissiyat ve duygudaşığın motoru olmaktadır (Victor, 2003: 192).

Vefa Idris'in mahalli televizyonlarda kliplerinin yapılması, kendisiyle ilgili şarkı ve ezgilerin kulaktan kulağa dolaşması bir şiddet fiili olmasının ötesinde intihar eyleminin nasıl sembolik anlamlar taşıdığını ve eylemcilerin nasıl sosyal kahramanlar haline getirildiğini göstermektedir. Vefa'nın bir idol haline geldiğini anlatan Victor, Batı için Britney Spears neyse Filistin için Vefa Idris odur diyerek toplumun eylemciler çerçevesinde nasıl bir kahramanlık kültü oluşturduğuna dikkat çekmektedir. Cebelye Kampı'nda çeşitli okulları ziyaret eden Victor, ilköğretim çocuklarının bile en büyük özleminin şehit olmak olduğunu; şehitlerin sosyalleşme sürecinde referans çerçevesi ve rol modelleri haline geldiğini anlatmaktadır (Victor, 2003: 188-189 ve 191-192).

Eylemi Batının Filistin karşıındaki yanı duruşunun bir sonucu olarak yorumlayan dönemin Irak başbakanı Saddam Hüseyin'in, Bağdat'ın ana caddelerinden birinde dikilmek üzere Vefa İdris'in heykelini yaptırdığını ilan etmesi eylemlerde sembolizm ve toplumsal kahramanlaştırmanın belki de en somut göstergelerinden biridir (Matza, 2002; BBC.Co.Uk., 30.01.2002). İdris'in hayatını konu edinen yeni bir film teklifinin Arap dünyasının en meşhur aktörlerinden Hanan Türk tarafından kabul edilmesi, eylemin mahalli ve ulusal sınırlar ötesinde nasıl bir popüler kültür unsuru haline geldiğini göstermektedir (Bertz, 2006). Popüler kültür unsuru olmasının dışında, Vefa İdris eylemi stratejik ve sosyal 
cinsiyet ilişkileri açısında da çeşitli sonuçları olan bir operasyon olarak karşımıza çıkmaktadır. Nitekim Aksa Şehitleri Tugayları, Vefa İdris isminde kadın intihar eylemcilerini eğitecek özel bir birimin kurulduğunu açıklarken, Aksa Tugayları'na mensup bir bölge lideri "vatanı için kendisini feda edecek sadece Bethlehem bölgesinden 200 kadın gönüllünün kendileriyle temasa geçtiğini" ifade etmektedir (Bloom, 2005: 148).

Arap medyasında büyük yankı uyandıran Vefa İdris eyleminin Orta Doğuda kadın özgürlüğünün sembolü olarak takdim edildiği görülmektedir. El-Eyyam gazetesi El-Fetih liderlerinden birine izafetle "uzun özgürlük mücadelesi içinde en büyüleyici kahramanlık tablosu" olan Vefa Idris'in Filistin kadının onur ve şerefinin timsali olduğunu ifade ederken (El-Eyyam, 01.02.2002), Mısırlı film yapımcısı Emire Ebu Fetih El-Vafd'da çıkan "Oskar Kazanan Film" adlı yazısında Vefa eylemini bir kahramanlık filmi olarak yorumlamaktadır (El-Vafd, 07.02.2002). Şavt'ül Ümme' editörü Adil Hammuda “cennet gelinine" benzettiği Vefa'nın "kadın erkek eşitliğiyle ilgili tartışmalara son vererek... Arap kadının değerini yükselttiğini" (Şavt'ül Ümme', 03.02.2002) ifade ederken, El-Ahram yazarı Salih Muntasır Vefa'yı "Mona Liza'ya" benzetmekte (El-Ahram, 10.02.2002), El-Düstûr yazarı Yaser Za'atrah Vefa'nın “bir kadının kazanabileceği en büyük ödülü" elde ettiğine işaret ederken (El-Düstûr, 24.02.2002), Nakva Tantavî ise Vefa'nın “Arabizmin ve İslam'ın kızı" olduğu yorumunu yapmaktadır (El-Kuds El-Arabî, 04.02.2002). Burada Arap basının kahramanlaştırmanın politiği denilebilecek bir tutum sergilediğini de dikkatlerden kaçmamaktadır. Nitekim Suudi basını Vefa İdris'i görmezlikten gelirken yine Suriye ve Lübnan medyasının da olay karşısında sessiz kaldığı dikkat çekmektedir (Bennet 2002).

\section{Sonuç}

Kadın intihar eylemcilerinin sosyal mahrumiyet ve depresyon altına kişiler olduğu ileri sürülmektedir. Sosyal mahrumiyet teorisinin açıklama gücü Vefa İdris örneği dikkate alındığında tartışmalıdır. İdris'in kamp hayatı yaşaması, ekonomik bağımsızlığını tam olarak elde edememesi, boşanmayla sonuçlanan bir evlilik geçirmesi ve çocuğu olmadığı için en azından istediği biriyle evlenmesinin zor olması gibi sosyal faktörler "göreceli mahrumiyet teorisini" hatırlatmaktadır. Özellikle boşandıktan sonra ailesi için ilave bir ekonomik yük olduğunun farkında olan İdris'in arzuladığı hayatı yaşamadığı açıktır. Bununla birlikte kişinin standartlarını içinde bulunduğu grubun standartları tayin etmektedir. 8000 civarında Filistinlinin yaşadığı Ameri Kampı'nda kendisine benzeyen, hatta kendi şartlarından çok daha kötü şartlar altında hayat mücadelesi veren insanları gözlemleme imkânı bulan İdris'i içinde bulunduğu toplumunun sosyal şartlarıyla değerlendirmek gerekmektedir. İdris'in sosyal kimliğiyle ilgili bulguların, Filistin toplumunun geneli dikkate alındığında, kendisini intihar eylemine sürükleyecek kadar kötü olmadığı ileri sürülebilir. Bir çatışma toplumu olan Filistin'de 
İris'ten çok daha mahrum, fakat intihar eylemcisi olmayan Filistinlilerin varlığı göreceli mahrumiyet teorisini kırılgan hale getiren bir diğer noktadır.

9 sene süren bir evlilikten sonra, özellikle çocuk sahibi olamadığı için boşanması, İdris'te ümitsizlik ve öfke duyguları içinde incinmiş bir kişilik yapısına işaret etmektedir. Bununla birlikte, İdris, Rosenberg'in iddia ettiği gibi olgunlaşmamış ve idealist değilken, Lackhar'ın ileri sürdüğü gibi utanç sahibi ve kendi eksiklikleri için başkalarını suçlayan bir kişi de değildir. Yakınlarının İdris'in boşanma sonucu yaşadığı depresyonu atlattığını ifade etmelerine rağmen, boşanmanın etkisiyle incinmiş bir kişilik geliştiren İdris'in kendi iç dünyasını durağanlaştırmak için bazı dış temsil araçlarını özümsediği ve bu bağlamda zihninin bir köşesinde daima var olan intihar eylemi fikrini rasyonalize ederek önemli bir seçenek haline getirdiği söylenebilir. Yine onur incinmesi ve alenî aşağılanma faktörlerine dikkat çeken Post'un, işgal altında yaşayan Filistinlilerin süreğen aşağılanma ve küçük düşürülme karşısında, intihar eylemleri vasıtasıyla, yaşadıkları incinmeyi ve aşağılanmayı tamir etmeye çalıştıkları yaklaşımı, İdris örneği dikkate alındığında geçerli bir açılım olarak görülebilir.

Bu psikolojik açıklamalar geçerliliğini korumakla birlikte, Vefa İdris intihar etmemiş, içkin politik anlamlar taşıyan intihar eylemi ya da mahalli ifadesiyle istişhâd ameliyesi (şehitlik eylemi) gerçekleştirmiştir. Politik faktörlerin göz ardı edilip Vefa İdris eyleminin sadece psiko-sosyal faktörlere indirgenmesi doğru bir yaklaşım olarak görünmemektedir. Toprağından çıkarılma, bağımsızlığını kaybetme ve İsrail'in asimetrik bir biçimde Filistin içlerine doğru ilerlemesi, intihar eylemini, sıradan intihar fenomeninin ötesinde bir var oluş biçimi ve özgürlük mücadelesi haline getirmektedir. Sonuçları itibariyle Vefa Idris eyleminin bir terör fiili olması bu gerçeği değiştirmemektedir. Bu anlamda, Vefa İdris örneği, mevcut Filistin Otoritesi'nin beklenen bağımsızlığı gerçekleştirememesini ve Filistinlileri aşağılanmaktan kurtaramamasını intihar eyleminin temel sebebi olarak gören Tilhami'nin ya da intihar eylemi şeklinde ifade edilen fenomenin İsrail'in işgal politikaları tarafından yaratıldığını ileri süren Pearıman'ın yaklaşımlarıyla örtüşmektedir. Eylemcilerin kendi vatanları olarak gördükleri topraklarda işgalci kabul ettikleri modern demokratik ülkelerin askeri varlığına karşı direniş gösterdiklerini iddia eden Pape'in teorisi de, intihar eylemlerine, seküler/politik/stratejik hedeflerin yön verdiğini ortaya koymaktadır.

Vefa İdris eylemini göreceli sosyal mahrumiyet teorisiyle açıklayan Pedahzur, intihar eylemlerinin örgütsel/kurumsal faktörlere vurguyla açıklanabileceğini öne sürmektedir. Sadece İdris'i değil, diğer bütün Filistinli kadın intihar eylemcilerini sosyal açıdan yoksun ve depresyon altında olan kişiler olarak tanımlayan Pedahzur'un yaklaşımı, bizim bulgularımızla örtüşmemektedir. Bir taraftan küçük bulgulardan hareketle basitleştirme hatasına düştüğü görülen Pedahzur'un, diğer taraftan, bütün örnekleri tek bir kalıba sokarak genelleme hatası yaptığı dikkat çekmektedir (Pedahzur, 2002: 138-139). Öncelikle çok gerilere giden bir örgütsel tarihi olmadığı görülen Vefa İdris'in, örgütle bağlantı- 
ya geçtiği son iki hafta içinde de yoğun ve özel bir doktrin aşılama sürecine tâbi olmadığı görülmektedir. Yukarıda da ifade edilmeye çalışıldığı gibi, Vefa İdris örneğini, sosyal mahrumiyet teorisinden ziyade, politik mahrumiyet teorisi açıklamaktadır. Yabancılaşmanın sosyal yoksunluktan değil, politik yoksunluktan kaynaklandığı, sosyal yoksunlukların politik yoksunlukları hatırlattığı ve keskinleştirdiği, bu süreçte dönemsel olarak devreye giren depresyon, incinme ve krizlerin birer ara form şeklinde işlev görerek eylemi mantıklı hale getirdiği ileri sürülebilir.

Diğer taraftan Vefa Idris'in Hamas ya da Filistin İslami Cihat gibi siyasal islamcı hareketlerin oluşturduğu kültürel iklimden çok fazla etkilenmediği görülmektedir. Vefa İdris, eylem yolunda, sadece kardeşleri vasıtasıyla yarı sosyalist milliyetçi bir hareket olarak tanımlanabilecek El-Fetih'le ilişki halindedir. Kendisinin iyi bir inanan, ancak zorunlu olarak dindar bir kadın olmadığı sıklıkla ifade edilmektedir. Dolayısıyla Vefa İdris eylemini, siyasal İslamclık, köktencilik ya da fanatizm gibi kavramların öne çıkarıldığı bir anlam evreniyle açıklamak mümkün gözükmemektedir. Din faktörünün, eylemin temel sebebi olmaktan ziyade, eylemin cihad, şehitlik ve kendini kurban etme gibi teolojik bağlamlar içinde rasyonalize edilmesinde ve meşrulaştırılmasında kullanıldığı görülmektedir. Eylemden sonra meydana gelen toplumsal kahramanlaştırma süreci, özellikle eylemci çevresinde oluşturulan şehitlik kültü bu durumun bir göstergesi olmaktadır. Bununla birlikte, eylemci, bir taraftan eylemiyle kendi ulusuna hizmet ettiğini düşünürken, diğer taraftan, şehit olacağı düşüncesinden de güç almaktadır.

\section{Notlar}

$\left(^{*}\right) \quad$ Dr., Marmara Üniversitesi Illahiyat Fakültesi, e-posta: halil.aydinalp@marmara.edu.tr

(1) Örneğin 1936 ve 1939 Arap isyanlarında vatanseverliklerinin doğurganlığın ötesinde olduğunu göstermişler ve bu dönemin gazetelerinde oldukça geniş yer edinmişlerdir. Bkz. Tzoreff, 2006: 14.

(2) Leyla Halid'in hayatı ve eylemleriyle ilgili daha geniş bilgi için bkz. Khaled ve Hajjar, 1975.

(3) Araştırma Haziran 2003-Şubat 2005 arasında, intihar eylemine teşebbüs eden 2'si erkek, 5'i kadın İsrail hapsanelerinde tutuklu toplam 7 sanıkla yapılan derinlemesine mülakatlara dayanmaktadır. Görüşmeler asgari 2 bölümde ve her bir bölüm 4-5 saat sürmüştür. Örneklemin beşi eylem yolunda yakalanırken $1^{\prime} i$ eylem esnasında başarısız olmuş, 1'i de son anda fikrini değiştirerek vazgeçmiştir.

(4) Ayrıca bkz. Atek, 2001. Bunların dışında, din ya da beyin yıkamanın ötesinde, intihar eylemini beyinde meydana gelen tahribatlar ve sinirsel bozukluklarıyla açıklayan yaklaşımlar da mevcuttur. Nevrotik faktörler psikolojik yaklaşımlar içinde en zayıf ve tartışmalı olanlarıdır. Böyle bir yaklaşım için bkz. Tudge Colin, "Natural Born Killers", New Scientist, S. 174/2342: 36-37.

(5) Dale, Pape'in temel perspektifini yansıtır bir şekilde Müslüman Asya'da intihar eylemlerinin sömürgeci güçlere karşı kullanıldı̆̆ını tartışmaktadır. Bkz. Dale, 1988: 37vd.

(6) İsrailli gazeteci ve terör uzmanı Ehud Ya'ri, Vefa İdris'in El-Fetih'e bağlı Fetih Anaları adlı bir kadın organizasyonun üyesi olduğunu ifade etmektedir. Bkz. Victor, 2003: 25. 
(7) Dükkândaki satış elemanı Vefa'nın tedirgin bir şekilde ayakkabılara göz attığını söylerken, olayı gözlemleyen bir müşteri de Vefa'nın panikle dükkândan dışarı çıkmak istediğini, tam çıkarken çantasının kapıya takıldığını ve çantasının içinden makyaj malzemelerini çıkardığı bir sırada aniden patlamanın gerçekleştiğini anlatmaktadır. Bkz. Victor, 2003: 22. Aynı gün öğlenden önce Yaser Arafat kadınların Filistin mücadelesinde daha fazla rol almaları gerektiğini ifade eden bir konuşma yaparak Filistinli kadınlara hitaben "sizler benim İsrail tanklarını mahvedecek güller ordumsunuz" demektedir. Bkz. Victor, 2003: 19.

\section{Kaynaklar}

Acar, ì. C., Lübnan Bunalımı ve Filistin Sorunu, Türk Tarih Kurumu Basımevi, Ankara 1989. Atek, N., "Suicide Bomber: A Palestinian Chiristian Perspective" Cornerstone, July 1, 2001. BBC, "Female bomber's mother speaks out", 30 January, 2002, http://news.bbc.co.uk/2/hi/middle_east/1791800.stm, 29. 01.2009.

Bennet, J., "Arab Woman's Path to Unlikely 'Martyrdom'", The New York Times: World Section, January 31, 2002.

Berko, A. ve E. Edna, “Ordinary People and 'Death Work': Palestinian Suicide Bombers as Victimizers and Victims", Violence and Victims, V.20, N.6, December 2005.

Bertz, A., Wafa Idris, Movie Star, Arutz Sheva, Opinion Section, 10.08.2006.

Beyler, C., "Messengers of Death: Female Suicide Bombers." International Policy Institute for Counter Terrorism, February 12, 2003.

Biedermann, F.,, "The Palestinians' first female bomber", http://dir.salon.com/story/mwt/feature/2002/01/31/female_bomber/index.html, Friday, Jan 30, 2009.

Blair, T., "The Blair Files-Poverty Cause Terrorism?", Review, 2002.

Bloom, M., Dying to Kill: The Allure of Suicide Terror, Columbia University Press, New York 2005.

Cunningham, K. J., "Cross-Regional Trends in Female Terrorism," Studies in Conflict and Terrorism, V. 26, N.3, May-June 2003.

Dökmeciyan, R. H., Arap Dünyasında Köktencilik, Çev. Muhammed Karahanoğlu, illke Yayınları, İstanbul 1992.

Erdin, M., Hizbullah ve Hamas, Sarmal Yayınları, i̇stanbul 1999.

Esposito, J. L., Unholy War : Terror in the Name of Islam, Oxford University Press, 2003.

Franklin, S., Chicago Tribune (IL); 01/30/2002.

Hafez, M. M., "Rationality, Culture, and Structure in the Making of Suicide Bombers: A Preliminary Theoretical Synthesis and Illustrative Case Study", Studies in Conflict \& Terrorism, No.29, 2006.

Hafez, M. M., Manufacturing Human Bombs: The Making of Palestinian Suicide Bombers, United States Institute of Press, Washington D. C. 2006.

Hassan, N., "Letter from Gaza: An Arsenal of Believers-Talking to the "human bombs'", The New Yorker, November 19, 2001.

Hoffman, V. J., "Muslim Fundamentalists: Psychosocial Profiles”, Fundamentalism Comprehended, Ed. Martin E. Marty-R.Scott Appleby, C.5, Chicago 1994.

Juergensmeyer, M., "Religious, Terror and Global War", Understanding September 11, (Ed.) Craig Calhoun, Paul Price ve Ashley Timmer, The New Pres, New York 2002.

Juergensmeyer, M., Terror in the Mind of God: The Global Rise of Religious Violence, University of California Press, 2003.

Khaled, L. ve G. Hajjar, My People Shall Live: Autobiography of a Revolutionary, NC Press, Toronto 1975. 
Kimhi, S. ve S. Even, "Who are the Palestinian Suicide Bombers?", Terrorism and Political Violence, Vol.16, No.4, 2004.

Lester, D., "Theories of Suicidal Behavior Applied to Sylvia Plath", Death Studies, 22, 7, Oct/Nov 1998.

Lester, D., B. Yang, Mark Lindsay, "Suicide Bombers: Are Psychological Profiles Possible?", Studies in Conflict \& Terrorism, N. 27, 2004.

Matza, M., "A woman's double life: Volunteer-Suicide Bomber", Philadelphia Inquirer, 01/30/2002.

McDonald, E., Shoot the Women First, Fourth Estate, London 1991.

Merari, A., "Suicide Terrorism", Assessment, Treatment, and Prevention of Suicidal Behavior, (Ed.) Robert I. Yufit, John Wiley \& Sons Press, 2004.

Moghadam, A., "Palestinian Suicide Terrorism in the Second Intifada: Motivations and Organizational Aspects", Studies in Conflict \& Terrorism, N.26, 2003.

Pape, R. A., Dying to Win: The Strategic Logic of Suicide Terrorism, Random House, New York 2005.

Pearlman, W., "Suicide Bombers Not the Only Martyrs-Israel Creates Many More", Washington Report on Middle East Affairs, May 2002.

Pedahzur, A., Suicide Terrorism, Polity Press, Madison/Cambridge 2005

Post, J. ve L. M. Denny, "The Terrorists in Their Own Words: Interviews with 35 Incarcerated Middle East Terrorist", Terrorism and Political Violence, S.15, 2003.

Richardson, L., What Terrorists Want: Understanding the Enemy, Containing the Threat, Random House, 2006.

Schwweitzer, Y., "Palestinian Female Suicide Bombers: Reality vs. Myth", Female Suicide Bombers: Dying for Equality?, Edt. Yoram Schwweitzer, Jaffee Center for Strategic Studies, Kedem Printing, Tel Aviv 2006.

Sela-Shayovitz, R., "Suicide Bombers in Israel: Their Motivations, Characteristics, and Prior Activityin Terrorist Organizations", International Journal of Conflict and Violence, V.1(2), 2007.

Telhami, S., "Why Suicide Terrorism Takes Root", The New York Times, April 4, 2002.

Tzoreff, M., "The Palestinian Shahida: National Patriotism, Islamic Feminizm, or Social Crisis", Female Suicide Bombers: Dying for Equality?, Edt. Yoram Schwweitzer, Jaffee Center for Strategic Studies, Kedem Printing, Tel Aviv 2006.

Victor, B., Army of Roses: Inside the World of Palestinian Women Suicide Bombers, Rodale, 2003.

Wikan, U., "My Son-A Terrorist? He was Such a Gentle Boy", Anthropological Quarterly, V.75/1, 2001

\section{Gazete ve Dergiler}

Al-Ahram, 10 Şubat 2002.

Arutz Sheva, 10.Ağustos 2006.

Chicago Tribune (IL); 30 Ocak 2002.

El-Düstûr, 24 Şubat 2002.

El-Eyyam, 1 Şubat 2002.

El-Kuds'ül Arabî, 4 Şubat 2002.

El-Vafd, 7 Şubat 2002.

Philadelphia Inquirer, 30 Ocak 2002.

Şavt'ül Ümme', 3 Şubat 2002.

The New York Times, 31 Ocak 2002.

The New York Times, 4 Nisan 2002. 



\title{
DİNI YÖNELİM ÖLÇEĞİ VE GÜVENIRLİK ÇALIŞMASI: SANAYI IŞÇILLERİ ÜZERINNE BİR ARAŞTIRMA
}

\begin{abstract}
Religious attitudes scale and validity-reliability analysis: a study on the industrial workers. Tendencies are in general studied three dimensions; belief dimension and behaviour dimension and feeling dimension. This research examined the "religious attittudes scale" that consist of belief dimenson, behaviour dimension and feeling dimension to. Attitudes related of the belief dimension consist of the responses about the belief dimension in the questionnaire and the attitudes related of the behaviour dimension consist of the responses about the behaviour dimension in the questionnaire and the attitudes related of the feeling dimension consist of related responses in the questionnaire. In the study examined reliability and validity analysis of each three dimensions.
\end{abstract}

\section{key words}

Religious belief, religious behaviour, religous feeling, religious attitudes, religious attitudes scale. 


\section{Giriş}

Yönelim kelimesinin karşılığı olarak İngilizcede, tendency (meyil, istidat, eğilim); orientation (yönelme, yöneltme), trend (meyletmek) gibi kelimeler kullanılmaktadır. Psikoloji, Sosyal Psikoloji ve Din Sosyolojisi ile ilgili çalışmalara baktığımızda yönelim ve dini yönelim terimleri için daha çok orientation kelimesinin tercih edildiğini görüyoruz (1).

Türkçede 'kendi durumunu veya bulunduğu yerin durumunu başka yerlere göre belirleme', bireyin, karşılaştığı karışık ve sorunlu durumlar karşısında belirlediği tutum... (2) gibi anlamlara gelen yönelim kelimesinin çeşitli eserlerde cinsel yönelim, mesleki yönelim, içe yönelim ve dini yönelim gibi kullanımları mevcuttur.

Daha çok sosyal psikolojide kullanılan tutum kavramı ile anlam ve içerik bakımından örtüşen yönelimin çeşitli çalışmalarda duygu, düşünce ve davranış olmak üzere üç boyutta ele alındığını görmekteyiz. Bir kimsenin veya grubun bir konu hakkındaki yönelimin ortaya konması sürecinde bu üç boyut incelenmektedir. Burada konu yönelim objesi olarak ifade edilmektedir.

Bireyin yönelimine ulaşmak, onun yönelim objesi hakkındaki değerlendirmelerinin ortaya çıkarılmasıyla mümkündür. Bu da çeşitli yollarla yapılabilir. En çok başvurulan yöntem bireye ilgili ifadeler yönelterek bu ifadelere verdiği tepkileri/cevapları tespit etmek/kaydetmek ve onları analiz etmektedir. Bu tepkiler duygu, düşünce ve davranış formunda olabilir.

Sonuç olarak yönelimler bireyin bir konu bir konu hakkındaki değerlendirmelerini ifade etmekte ve açığa çıkan/çıkarılan sözlü, yazılı, davranışsal, heyecansal tepkiler vasıtasıyla tespit edilebilmektedir.

\section{Dinî Yönelim}

Dini yönelimde yönelim objesi dindir. Dini yönelimin "düşünce boyutu, kişinin Tanrı'ya inancı ve bu inançtan kaynaklanan kabulleri; "davranış boyutu", inancı gereği yaptığı her türlü davranış, mesela namaz kılması, kiliseye gitmesi, oruç tutması, hacca gitmesi... gibi ameli hususlar ve "duygusal boyutu" da kişinin inanç ve amelleriyle ilgili psikolojik hali, Tanrı'dan başarı, korunma, cennet beklentisi veya bela, cezalandırılma ve cehennem endişesidir.

Dinî yönelim, bu üç boyutta ifadesini bulan tepkilerin tamamından oluşarak bireyde söz konusu dini benimseme veya benimsememe şeklinde bir değerlendirmeye sebep olur (Onay, 2002: 186).

\section{Problem}

Bu çalışmada sanayi işçileri örnekleminde inanç boyutu, uygulama boyutu ve duygu boyutundan oluşan "dini yönelim ölçeği” üzerinde durulacaktır. 
Dinî yönelimi ölçme çalışmaları dindarlık ölçme çalışmaları içinde değerlendirilmektedir. Dindarlık ölçme çalışmalarının dünyada ilk ortaya çıkmaya başladığı yıllar 1940'lardır. Illk örneklerine Amerika'da rastlanan dindarlık ölçme çalışmalarının Avrupa'da görülmesi 1970'li yıllara; Türkiye'de Müslüman dindarIığını konu alan benzer çalışmaların ortaya çıkması ise $1980^{\prime}$ li yıllara rastlar (3).

Dini yönelim ölçeklerinde bireylerin dini yönelim düzeyleri duygu, düşünce ve davranış boyutlarında ele alınır. Amaç yönelim objesi olarak kabul edilen dine karşı bireyin sahip olduğu değerlendirmeyi tespit etmeye yönelik tepki cevapların duygu, düşünce ve davranış seviyelerinde ölçülmesidir (Onay, 2001: 439).

\section{Yöntem}

Dini yönelim ölçeğimiz, beş madde inanç boyutu; altı madde uygulama boyutu ve altı madde duygu boyutu olmak üzere toplam on yedi maddeyi içermektedir. İnanç boyutu ölçek maddeleri "peygamberlere inanııı", "Kur'anın haber verdiği her şey doğrudur", "Allah vardır", "meleklere inanırım", "Cennet ve Cehennem vardır" maddelerinden; uygulama boyutu ölçek maddeleri "hata işlediğim zaman Allah'tan af dilerim", "haramlardan sakınırım", "ibadetlerimi yaparım", "dinin yasak ettiği şeyleri yapmam", "dua ederim", "dinî inanç gereklidir" maddelerinden ve duygu boyutu ölçek maddeleri ise "ibadetlerimi yapınca daha huzurlu hissederim, "Kur'an dinlerken heyecanlanırım", "Kandil gecelerinde manevi duygularım artar", "Ramazan'da manevi duygularım artar", "dinî kuralları yerine getirme zorunluluğu hissederim", "Mevlit okunurken içime huzur dolar" maddelerinden oluşmaktadır.

Araştırmada dini yönelimle ilgili değişkenler; negatif tavır (katılmıyorum ve kesinlikle katılmıyorum), pozitif tavır (katılıyorum ve tamamen katılıyorum) ve ilgisizlik (kararsızım) olarak üç kategoride ele alınmıştır.

Hazırlanan anket formu 404 denekten oluşan bir örnekleme uygulanmış, ölçeğin geçerlik ve güvenirlik testleri SPSS paket programı vasıtasıyla yapılmıştır.

Ölçeğin yapı geçerliği faktör analizi ile incelenmiştir. Faktör analizi veri toplama aracının alt ölçeklerden oluşup oluşmadığı (Onay, 2001: 445), oluşuyorsa ilgili alt ölçeklerin her birinin aynı yapıyı ölçüp ölçmediğini (Akyüz, 2007: 48) test etmek için yapılan bir analizdir. Faktör analizi birbiriyle ilişkisi yüksek olan, aynı yapıyı ölçen maddeleri tek bir gurupta toplamanın yanı sıra bir ölçekte farklı yapıları ölçen maddeleri ve bu yapıların neler olduğunu (Karaşahin, 2006: 18); başka bir ifadeyle, ölçeğin, katılımcıların verdikleri tepkiler arasındaki farkı ayırt edip edemediğini, yani teorik varsayım ile kişilerin tepkilerinin örtüşüp örtüşsmediğini (Onay, 2001: 445) ortaya çıkaran matematiksel bir analiz tekniğidir. 
Yapı geçerliliğinden sonra dini yönelim ölçeğinin güvenirlik çalışmalarına geçilmiştir. Güvenirlik bir testin veya bir ölçeğin ölçmek istediği şeyi tutarlı ve istikrarlı bir biçimde ölçme derecesidir, başarılı bir test veya ölçek benzer şartlarda tekrar uygulandığında benzer sonuçlar vermelidir (Altunışık ve diğerleri, 2004: 113).

Geçerlilik ve güvenirlilik arasında yakın bir bağ vardır. Eğer ölçek mükemmel bir geçerliliğe sahipse, mükemmel bir güvenirliğe de sahiptir. Eğer ölçek güvenilir değilse mükemmel bir geçerliğe de sahip olamaz, çünkü ölçülen değerler tesadüfî hata terimini de içermektedir. Kısacası güvenilir olmama geçerliliği de riske sokmaktadır. Ancak bir ölçeğin güvenilir olması geçerliğin sağlandığı anlamına gelmeyebilir. Geçerlilik için güvenirlik bir gerek şarttır, ancak yeterli değildir (Altunışık ve diğerleri, 2004: 117).

Dini yönelim ölçeğinin iç tutarlılı̆ının bir göstergesi olarak güvenirlik katsayısı (Cronbach Alpha) hesaplanmıştır.

\section{Evren}

Araştırmanın evreni Çorum'daki çeşitli fabrika ve sanayi kuruluşlarında çalışan bütün iş̧̧ilerdir.

Çorum SSK il Müdürlüğü’nden aldığımız bilgilere göre anketin uygulandığı zaman olan Ağustos 2007 tarihi itibariyle Çorum ili sınırları içerisinde Müdürlüğe kayıtlı sigortalı iş̧̧i sayısı 37.928 (otuz yedi bin dokuz yüz yirmi sekiz)dir. Yine Organize Sanayi Bölgesi Müdürlüğünden aldığımız bilgilere göre sadece Organize Sanayi Bölgesinde yer alan çeşitli fabrikalarda çalışan kayıtlı iş̧i sayısı 50005500 kişidir. Bu sayının büyükten küçüğe göre sektörel dağılımı şu şekildedir; tekstil (iplik fabrikası, gömlek fabrikası, halı vb.) 1800-2000 kişi, Toprak Sanayi (vitriye seramik, banyo gereçleri) 600 kişi, makine 500 kişi, ve diğerleri (gıda, yem, galveniz, boru, kereste, ziraat aletleri, egzoz, medikal ürünler, çivi ve tel, kaset, suntalem, boya, PVC doğrama, kalıp...) yaklaşık 2000 kişidir.

\section{Örneklem}

Bir araştırmada örneklem belirlenirken iki yöntem kullanılır. Bunlardan biri "tesadüfi” yöntem diğeri ise "kota" yöntemidir (Duverger, 1990: 169). Tesadüfî örnekleme (random sampling) tekniği herhangi bir kitleden o kitleyi oluşturan birimlerden her birine örneğe girmek bakımından eşit şans tanımak anlamına gelir. Kütlenin birimlerine eşit seçilme şansı vermenin yolu seçme işleminin belli kurallar uygulanarak matematik tesadüfliliğe bağlanmasıdır (Sencer, 1974: 46). Tesadüfî yönteme göre belirlenen örneklem oldukça sağlam fakat uygulaması aynı oranda zor ve masraflıdır. Diğer taraftan kota yöntemine göre belirlenen örneklem daha az sağlam fakat daha ucuz ve uygulaması daha kolay bir örnekleme yöntemidir. Bu araştırmada kota yöntemi tercih edilmiştir. Kota yönteminde kota içerisine girecek olan deneklerin seçimi iki aşamada gerçekleştirilir. 
Birinci aşamada incelenecek olan grubun minyatür bir modeli oluşturulur. İkinci aşamada ise her kategorideki katılımcıların sayısı (kotası) kararlaştırılır. Model, kişilere, ailelere, mesleklere, ikamet yerine, bölgeye... göre oluşturulabilir. Burada önemli olan her kategorideki oranın evrenin tamamındaki orantısal dağılıma mümkün olduğu kadar yakın olmasıdır (Duverger, 1990: 169-170).

Örneklemimizin modeli sektörel dağılıma göre oluşturulmuştur. Bunun için Çorum ili sınırları içinde faaliyet gösteren en büyük sektörler olan tekstil, makine ve toprak sanayi içerisinde değerlendireceğimiz vitriye seramik/banyo gereçleri sanayi ele alınmıştır. Ayrıca Ankara-Samsun karayolu çevresinde yerleşik tuğla-kiremit, makine ve un fabrikalarında çalışan işçileri de örnekleme dâhil edilmiştir. Anket uyguladığımız işçi sayısı 404'dür. Sektörlere göre işçi dağııımı ve anket formu dağılımı aşağıdaki gibi olmuştur.

Vitriye seramik ve banyo gereçleri ile tuğla kiremit sanayinin içinde bulunduğu Toprak Sanayi işçi sayısı yaklaşık 4148 kişi $(\% 44,2)$; anket uyguladığımız kişi sayısı $177(\% 44,25)$.

İplik sanayi ve hazır giyim sanayinin de içinde bulunduğu Tekstil Sanayi iş̧̧i sayısı 2829 kişi $(\% 30,3)$; anket uyguladığımız kişi sayısı 121(\%30,25).

Oto yedek parça (özellikle oto radyatör) ve döküm sanayinin içinde bulunduğu makine sanayi işçi sayısı 1394 (\%15); anket uyguladığımız iş̧̧i sayısı $61(\% 15,09)$.

Kağıt ve Kağıt ürünleri Sanayi iş̧̧i sayısı 572 (\% 6,1); anket uyguladığımız işçi sayısı 24(\%6).

Un fabrikalarından oluşan Un Sanayi iş̧̧i sayısı 411 (\%4,4); anket uyguladığımız iş̧̧i sayısı $17(\% 4,2)$ dir.

\section{Dini Yönelim Ölçeğinin Hazırlık Aşaması}

Anket formunun hazırlanmasında, önce bilimsel araştırma teknikleri ile ilgili eserlerden, daha sonra sanayileşme, iş̧̧i kültürü, değerler, din ve dini yönelim, tutumlar, sosyal psikoloji ve din sosyolojisiyle ilgili çeşitli çalışmalardan, saha araştırmalarından yararlanılmış, bu alandaki uzmanların görüşlerine başvurulmuştur. Konunun, dinî yönelimlerle ilgili olması, ayrıca örneklemin farklı eğitim seviyesinden bireyler içermesi anket sorularının hazırlanmasında çok dikkatli davranmamızı gerektirmiştir. Anket maddeleri, mümkün olduğu kadar sade, açık ve kısa ifadelere indirgenmiş, zaman zaman konuyu ifade eden yerleşmiş ifadeler, vecize ve deyişlerden yararlanılmıştır. Maddeler seçilirken araştırmanın hedeflediği konu dışına taşmadan, araştırmada yer alan varsayımlarla ilişkili, araştırılmak istenen konunun/sorunun tam ve eksiksiz yansıtılmasını sağlayan, yalın ve anlaşılır ifadeler kullanılmış, tepki yaratabileceği, ürkütücü veya kaçamak yanıtlara yol açabileceği tahmin edilen ifadelerden kaçınılmıştır. Bu durumda olan fakat anket formunda yer alması gereken ifadeler ise tekrar düzenlenerek forma yerleştirilmiştir. Aynı tutumu ölçmek için seçilmiş, aynı 
yöndeki ifadeler herhangi bir yönlendirmeye sebep olmaması için rastgele dağıtılmıştır. Soru sayısının fazlalığından kaynaklanabilecek bir takım sakıncaları ortadan kaldırmak amacıyla madde sayısı mümkün olduğunda az tutulmaya çalışılmıştır.

Anket formu, ilk olarak araştırma evreninden 61 kişiye uygulanmıştır. Ön araştırma niteliğindeki bu işlem 18 soruyla yapılmış Bu ön uygulamadan sonra formdan 1 soru çıkartılmış ve bazı sorular da yeniden düzenlenerek forma yerleştirilmiştir. Bu işlem sounda, dini yönelim tutumuna yönelik olmak üzere 17 adet madde tespit edilerek anket formuna son hali kazandırımıştır.

\section{Dini Yönelimin İnanç Boyutu İle İlgili Tutum Ölçeğinin}

Geçerliği ve Güvenirliği

Tablo 1'de Dini Yönelimin İnanç Boyutuna Yönelik Tutum ölçeğinin faktör ve madde analizi sonuçları verilmiştir. Buna göre tabloda yer alan 5 adet maddenin birbiriyle ilişkisini ve aynı yapıyı ölçüp ölçmediğini gösteren birinci faktör yük değerleri .78 ile .59 arasında; diğer taraftan maddelerin ayırt etme gücünü gösteren madde toplam korelasyon değerleri ise .60 ile .37 arasında değişmektedir. Faktörün açıkladığı varyans \%50; Cronbach Alpha güvenirlik katsayısı ise .71 'dir. Bu değerlere bakarak ölçeğin yeterli derecede geçerlik ve güvenirlik taşıdığı rahatlıkla söylenebilir.

Tablo 1: Dini Yönelimin İnanç Boyutu ile illgili Tutum Ölçeğinin Faktör ve Madde Analizi Sonuçları

\begin{tabular}{|l|c|c|}
\hline $\begin{array}{l}\text { Dini Yönelimin İnanç Boyutuna Yönelik Tutumun } \\
\text { Ölçek Maddeleri }\end{array}$ & $\begin{array}{l}\text { Birinci Faktör } \\
\text { Yük Değeri }\end{array}$ & $\begin{array}{l}\text { Madde } \\
\text { Toplam } \\
\text { Korelasyonu }\end{array}$ \\
\hline Peygamberlere inanırım & .78 & .60 \\
\hline Kur'an'ın haber verdiği her şey doğrudur & .73 & .51 \\
\hline Allah vardır & .73 & .54 \\
\hline Meleklere inanırım & .67 & .45 \\
\hline Cennet ve Cehennem vardır & .59 & .37 \\
\hline $\begin{array}{l}\text { Açıklanan Varyans: \%50 } \\
\text { Cronbach Alpha: .71 }\end{array}$ & & \\
\hline
\end{tabular}

\section{Dini Yönelimin Uygulama Boyutu İle İlgili Tutum Ölçeğinin} Geçerliği ve Güvenirliği

Tablo 2'de de görüldüğü gibi Dini Yönelimin Uygulama Boyutuna Yönelik Tutum Ölçeği 6 maddeden oluşmaktadır. Bu maddelerin birinci faktör yük değerleri .68 ile .57 arasında; madde toplam korelasyon değerleri ise .49 ile .36 arasında değişmektedir. Faktörün tek başına açıkladığı varyans \%42; Cronbach Alpha güvenirlik katsayısı ise .71'dir. Bu değerlere göre Dini Yönelimin Uygulama Boyutuna Yönelik Tutum Ölçeği geçerli ve güvenilir bir ölçme aracıdır. 
Tablo 2: Dini Yönelimin Uygulama Boyutu ile ilgili Tutum Ölçeğinin Faktör ve Madde Analizi Sonuçları

\begin{tabular}{|l|c|c|}
\hline $\begin{array}{l}\text { Dini Yönelimin Uygulama Boyutuna Yönelik } \\
\text { Tutumun Ölçek Maddeleri }\end{array}$ & $\begin{array}{l}\text { Birinci Faktör } \\
\text { Yük Değeri }\end{array}$ & $\begin{array}{l}\text { Madde } \\
\text { Toplam } \\
\text { Korelasyonu }\end{array}$ \\
\hline Hata işlediğim zaman Allah'tan af dilerim & .68 & .49 \\
\hline Haramlardan sakınırım & .66 & .48 \\
\hline Ibadetlerimi yaparım & .66 & .47 \\
\hline Dinin yasak ettiği şeyleri yapmam & .65 & .48 \\
\hline Dua ederim & .65 & .45 \\
\hline Dini inanç gereklidir & .57 & .36 \\
\hline $\begin{array}{l}\text { Açıklanan Varyans: \%42 } \\
\text { Cronbach Alpha: .71 }\end{array}$ & & \\
\hline
\end{tabular}

Dini Yönelimin Duygu Boyutu İle İlgili Tutum Ölçeğinin Geçerliği ve Güvenirliği

Dini Yönelim Ölçeğinin Duygu Boyutuna Yönelik Tutum Ölçeğinin Faktör ve Madde Analizi Sonuçları Tablo 3'de verilmiştir. Buna göre ölçek 6 maddeden oluşmaktadır. Ölçek maddelerinin birinci faktör yük değerleri .77 ile .62 arasında; madde toplam korelasyon değerleri ise .63 ilse .48 arasında değişmektedir. Yine faktörün açıkladığı varyans $\% 53$ ve Coronbach Alpha güvenirlik katsayısı ise .81 olarak tespit edilmiştir. Dolayısıyla Dini Yönelimin Duygu Boyutuna Yönelik Tutum Ölçeğinin güvenirlik ve geçerlik kriterlerini yerine getirdiği görülmektedir.

Tablo 3: Dini Yönelimin Duygu Boyutu ile ilgili Tutum Ölçeğinin Faktör ve Madde Analizi Sonuçları

\begin{tabular}{|l|c|c|}
\hline $\begin{array}{l}\text { Dini Yönelimin Duygu Boyutuna Yönelik } \\
\text { Tutumun Ölçek Maddeleri }\end{array}$ & $\begin{array}{l}\text { Birinci Faktör } \\
\text { Yük Değeri }\end{array}$ & $\begin{array}{l}\text { Madde Toplam } \\
\text { Korelasyonu }\end{array}$ \\
\hline $\begin{array}{l}\text { Ibadetlerimi yapınca daha huzurlu hisse- } \\
\text { derim }\end{array}$ & .77 & .63 \\
\hline Kur'an dinlerken heyecanlanırım & .75 & .62 \\
\hline $\begin{array}{l}\text { Kandil gecelerinde manevi duygularım } \\
\text { artar }\end{array}$ & .74 & .61 \\
\hline Ramazan'da manevi duygularım artar & .74 & .59 \\
\hline $\begin{array}{l}\text { Dini kuralları yerine getirme zorunluluğu } \\
\text { hissederim }\end{array}$ & .70 & .48 \\
\hline Mevlit okunurken içime huzur dolar & .62 & \\
\hline $\begin{array}{l}\text { Açıklanan Varyans: \%53 } \\
\text { Cronbach Alpha: .81 }\end{array}$ & & \\
\hline
\end{tabular}




\section{Sonuç}

Dindarlık ölçme çalışmalarına sosyal-psikolojik bir yaklaşım olarak değerlendirilebilecek olan dini yönelim ölçeğinde, din, bir yönelim objesi olarak ele alınmış ve katılımcıların bu yönelim objesine karşı sahip oldukları değerlendirmenin bir sonucu olarak düşünce, duygu ve davranışları konu edilmiştir. Örneklem olarak sanayi işçilerinden oluşan bir denek grubunun seçildiği araştırmada, katılımcıların hayatlarında dinin nasıl bir rolünün olduğu, başka bir ifadeyle dinin hayatlarında ne derece yer bulduğunu tespit etme amacına yönelik geliştirilen dini yönelim ölçeğinin geçerli ve güvenilir bir ölçme aracı olduğu sonucuna varılmıştır.

\section{Notlar}

(*) Dr., Hitit Üniversitesi İlahiyat Fakültesi, e-posta: seferyavuz@hotmail.com

(1) Örnek çalışmalardan bazıları için bkz. Allport, 1998; Watson, 1990, 1999; Jurkovic ve Gordon, 2006.

(2) Ayrıntılı bilgi için bkz. http://tdkterim.gov.tr/bts/?kategori=veritbn\&kelimesec=346615

(3) Ayrıntılı bilgi için bkz. Onay, 2001: 439.

\section{Kaynaklar}

Akyüz, N., illahiyat Fakültesi Öğrencilerinin Din Anlayışı, Gündüz Yayınları, Ankara, 2007.

Allport, G. W. ve M. Hovemyr, "The Attribution of Success and Failure as Related to Different Patterns of Religious Orientation", International Journal for the Psychology of Religion, Vol. 8, 1998.

Altunışık, R. ve diğerleri, Sosyal Bilimlerde Araştırma Yöntemleri, 3.bs., Sakarya Kitapevi, Sakarya, 2004.

Bilgiseven, A. K., Genel Sosyoloji, 5.bs., Filiz Kitabevi, İstanbul 1995.

Duverger, M., Sosyal Bilimlere Giriş, çev. Ünsal Oskay, 4.Baskı, Bilgi Yayınları, Ank., 1990.

Freyer, H., Din Sosyolojisi, çev. Turgut Kalpsüz, AnkaraÜniversitesi Illahiyat Fakültesi Yay., Ankara 1964.

Jurkovic, D. ve G. A. Walker, "Examining Masculine Gender-Role Conflict and Stress in Relation to Religious Orientation and Spiritual Well-Being in Australian Men", The Journal of Men's Studies, Vol. 14, 2006.

Karaşahin, H., Gördes ve Çevresinde Dini Hayat, Yayınlanmamış Doktora Tezi, Ankara Üniversitesi Sosyal Bilimler Enstitüsü, 2006.

Onay, A., "Dindarlık Ölçme Çalışmaları", İslami Araştırmalar, Ankara, 2001, c. 14, sayı: 3-4.

Onay, A., "Dini Yönelim Ölçeği", İslamiyat, Ankara, 2002, c. 5, sayı: 4.

Sencer, M., Türkiye'de Sınıfsal Yapı ve Siyasal Davranışlar, May Yayınları, İstanbul, 1974.

Watson, P. J. Ve diğerleri, "Experiential System: Relationships of Constructive Thinking with Religious Orientation", International Journal for the Psychology of Religion, Vol. 9, 1999.

Watson, P. J., R. J. Morris ve R. W. Hood Jr, “Attributional Complexity, Religious Orientation and Indiscriminate Proreligiousness", Review of Religious Research, Vol. 32, 1990.

Weber, M., Sosyoloji Yazıları, çev. Taha Parla, İstanbul 1987. 


\section{SOSYOLOJİ VE DİN( ${ }^{* * *}$}

Kısa süre önce bir öğrencim şöyle bir soru sordu: "Din üzerine mükemmel bir araştırma konum var" diye söze başladı, "fakat bunu nasıl sosyolojik hale getireceğimi bilmiyorum." Araştırma konusu hakkında kısaca konuştuk (neden kardeşler (siblings) genellikle farklı dini görüşlere sahip olurlar) ve birkaç okuma parçası önerdikten sonra öğrencim yanımdan ayrıldı. Fakat sorusu kafamda kalmıştı. Din konusunda çalışmaya meraklıydı, ancak bunu nasıl sosyolojik bir şekilde yapacağı konusunda kafası karışıktı.

Bu öğrencinin içinden çıkamadığı durum, dinden ve yirmi birinci yüzyılın başında dinin karşısındaki entelektüel meydan okumalardan sosyolojik bir araştırma sahası olarak bahsetmesiydi. Sorusu kafamda kalmıştı, çünkü o daha önceden de çok defa sorulmuştu. Deneyimlerime göre, bu soru genellikle öğrenciler son sınıf tezleri için konu ararken ortaya çıkmaktadır. Öğrenciler, ilgilerini o zamana kadar üzerinde çalıştıkları diğer projelerden daha fazla canlı tutacak bir konu bulmak için haftalarca uğraştıktan sonra doğal olarak bir konu seçmektedirler. Onlar, konunun, belki kendi inanç ve değerlerini sınıflandırmalarına yardımcı olacak ya da daha geniş topluma hitap edecek düzeyde anlamlı olmasını istemektedirler. Bu nedenlerden biri ya da her ikisi için, dinle alakalı olan bir şeye karar vermektedirler (bazılarını saymak gerekirse; dinler arası evlilik, toplumsal cinsiyet ve din, belirli bir etnik grup veya göçebe topluluğun dini deneyimleri, dinin diğergamlık ruhunu nasıl harekete geçirdiği, neden bazı insanların Tanrı'ya inanırken diğerlerinin inanmadığı, dinin oy verme davranışını etkileyip etkilemediği, insanların neden mezheplere katıldığı ya da din ve aile). Bu öğrenciler, sosyolojiden ders almamış da değillerdir. Bu zamana kadar, ortalama bir ya da iki teori dersi, bir ya da iki metot dersi ve dört ya da beş diğer sosyoloji derslerinden almışlardır. Buna rağmen konularına sosyolojik olarak nasıl yaklaşacaklarını bilememektedirler. Aslında, sosyoloji ve din, garip ama yakın iki şey olarak öğrencileri etkilemektedir. Eğer son sınıflar bu algıdan rahatsız oluyorlarsa, ilk kez bir din sosyolojisi dersinde bu disiplinle karşılaşan öğrencilerin de bu tür kaygılar taşımaları yadırganmamalıdır. Din konusundaki sosyolojik perspektifin, örneğin bir ilahiyat bölümündeki ya da Amerikan çalışmaları programında- 
ki Amerikan din dersi incelemesinde ne gibi değişiklikler gösterdiği muhtemelen hemen anlaşılamayacaktır.

Bu tür soruları olanlar sadece lisans öğrencileri değildir. Editörler kurulunda hizmet veren biri sıklıkla şöyle yorumlar duymaktadır: "ilginç bir kitap, ancak pek sosyolojik değil," veya "Bu, bir din dergisi için iyi bir makale olurdu, fakat sosyoloji dergisi için değil." Ve eleştiri komitelerine katılanlar da, din sosyolojisi çalışmalarının bir bütün olarak disipline ne gibi bir katkısı olacağına ilişkin sorular sorulduğuna şahit olmaktadır.

Bu gibi yorumlar, geleceklerini birer din sosyologu olarak hayal eden ve büyük bir hata yapıp yapmadıklarını merak eden mezun öğrencilerin geceleri uykularını kaçıracak kadar yoğundur. Kendilerini, pekâlâ, belki bir gün bir makama sahip olursam gerçekten yapmak istediğimi yapabilirim, diyerek avutmaktadırlar. Şimdilik, kendilerinden kıdemli çok sayıda akıl hocasının mücadeleyi bu alanı tamamen terk edecek kadar zor buldukları, bu yüzden muhtemelen daha rahat alanlar olan din çalışmaları bölümlerine, din okullarına veya Amerikan çalışmaları, Musevilik ya da Orta Doğu ile ilgili bölümlere kaçtıkları gerçeğini görmezden gelmektedirler (bakınız Wentz, 1999).

Bununla birlikte lisans öğrencilerinin kaygıları benzersiz değilse de; umut verici derecede samimidir. Mezun öğrenciler, teori ve yöntem gerekliliklerini yerine getirdikten ve birkaç fakülte forumuna katıldıktan sonra, genellikle farklı sorular sormaktadırlar: "Profesör X ne tür tavsiye mektupları yazmaktadır?" ya da "Bu veri grubunu şu ana kadar başka biri analiz etti mi?" Karşılaştırmak gerekirse, üniversite öğrencilerinin (akademideki bütün çalışmaları için) hala bir ayakları sağlamca gerçek hayatta bulunmaktadır. Bazen, gerçekten önemli oldukları için ve bu konuların kendilerinin ve diğerlerinin çalışmaları, aileleri ve toplulukları arasında nasıl bağlantı kurulacağına dair fark yaratacağını düşündükleri için bir konuyu seçmektedirler. Bu öğrencilerin dinin nasıl çalışılması ve nası sosyolojik hale getirilmesi gerektiğine ilişkin soruları ciddiye alınmalıdır.

Bu bölümde, din araştırmalarının neden sık sık sosyoloji disipliniyle gerilim içerisinde olduğunu incelemek istiyorum. Savunduğum şey, bu gerilimin genelde sanıldığından daha az ciddi olduğu ve aslında, büyük ölçüde kuram, yöntem ve normatif perspektiflere ilişkin yanlış anlamalardan kaynaklandığıdır. Sosyolojik din araştırmalarının sık sık yanlış anlaşılmaya maruz kaldığı bu yolların her birini dikkate alarak, bu bölümün en son kısmında din sosyolojisindeki disiplinsel bütünlük için bir temel ve verimli disiplinler arası değiş tokuş olasılıklarına ilişkin tartışmaya geri döneceğim. Fakat öncelikle, din ve sosyoloji çalışmalarının kolaylıkla uzlaştırılabileceği düşüncesine karşı ifade edilen iki genel itirazı açıklığa kavuşturmak gerekir. 


\section{İtiraz 1: Sosyologlar Dinin Saçma Bir Şey Olduğunu}

Düşünmektedir

Bu itirazın daha ayrıntılı şekli şöyledir: Sosyoloji, diğer tüm sosyal bilim disiplinleri gibi, Aydınlanma Çağı'nın ürünüdür. Auguste Comte gibi kurucularından bazıları felsefenin yavaş yavaş dinin yerini alacağına, bilimin (sosyoloji dahil) de zamanla onun yerini alacağına inanmıştır. Diğer kurucular, örneğin Karl Marx, dinin kendisi gibi parlak düşünürlerin yanlışlarını bir bir ortaya dökmesi gereken baskıcı bir sistem olduğuna inanmışlardır; bazıları ise Emile Durkheim'in ateizminde ya da Max Weber'in dinsel açıdan uyumsuz olduğuyla ilgili çok alıntı yapılan ağıtında kendilerini bulmuşlardır. Sosyoloji geliştikçe, dünyanın giderek daha az dindar olacağı iddiasını büyük ölçüde kabul etmiştir. Bu sebeple din, aydınlanmamışlar arasında bir çeşit serpinti olarak kalacak, ancak kendine saygı duyan hiçbir akademisyenin fazla vakit harcamak istemeyeceği bir konu olacaktı.

Sosyolojinin tarihine ilişkin bu tanımlama, bazen daha geniş disiplin içinde din sosyolojisinin durumuna ilişkin şikâyetlerle desteklenmektedir. Üniversite öğrencileri, diğer derslerindeki profesörlerin dinden nadiren söz ettiklerini ya da konu açıldığında utanmış göründüklerini fark edebilir ve örgütler, tabakalaşma, aile ve kriminoloji hakkında düzenli dersler verilirken, din sosyolojisinin neredeyse hiç okutulmadığını ya da başka bir bölümde okutulduğunu gözlemleyebilirler. Mezun öğrenciler, din konusunda bir tez yazsalar iş bulma olasılıklarının azalmasına yönelik kaygılarını ifade edebilir ve din sosyolojisi üzerine uzmanlaşmış bir fakülte bazen yaptıkları işin bölümlerinde ya da disiplin liderleri arasında hiç saygı görmediğini iddia edebilir.

Bununla birlikte bazı kanıtlar, din üzerinde sosyolojik olarak çalışmanın (ve bununla başa çıkabilmenin) zor olmasının sebebinin, sosyologların dinin saçma olduğunu düşünmeleri olmadığını göstermektedir. Bazılarına göre, bu tarihsel argüman kolaylıkla başa döndürülebilir. Weber kendisinin dini olarak uyumsuz olduğunu düşünmekle birlikte, hayatının büyük bölümünü (Protestan etiği, eski Musevilik, Çin ve Hindistan dinleri üzerine pek çok araştırma yaparak ve önemli karşılaştırmalı denemeler yazarak) din araştırmalarına adamıştır. Durkheim'ın hayatının on beş yılını verdiği son büyük çalışması, Elementary Forms of the Religious Life (1912/1976)'dır. Marx bile din hakkında dikkatli bir okuyucunun doğal olarak kabul edebileceğinden daha kapsamlı (ve daha sempatik) yazılar yazmıştır. Aslında, (klasik metinlerinde dine ilişkin düşüncelerin azlığından yakınabilecek) politik bilim adamları, her zamanki gibi din araştırmalarının ciddiye alınacağı doğal alan olarak sosyolojiyi göstermektedirler. Çünkü disiplinin tüm kurucularının yazılarında bu durum çarpıcı şekilde görülmekteydi.

Bu alana ilişkin şu anki bir inceleme de, sosyologların dine ilgi duymadığı iddialarını yalanlamaktadır. Beş yüzden fazla sosyolog, Amerikan Sosyoloji 
Derneği'nin Din Sosyolojisi Bölümü'ne üye olmuştur; bu da bu bölümü, derneğin kapsadığı yaklaşık kırk bölüm arasında büyüklük açısından tam da merkeze yerleştirmektedir. Bu üyelerin çoğunluğu aynı zamanda Din Sosyolojisi Derneği ve Bilimsel Din Araştırmaları Topluluğu gibi örgütlere de üyedirler. En az iki dergi (Sociology of Religion ve Journal for the Scientific Study of Religion) neredeyse tamamen toplum bilimsel din araştırmaları üzerinedir; ve American Sociological Review, American Journal of Sociology, Social Forces ve Sociological Forum gibi bu konuda uzmanlaşmamış dergilerde yılda ortalama bir defa din üzerine makaleler yayınlanmaktadır. Ayrıca bu makaleler, çalışmaları sadece din üzerine yoğunlaşan uzmanlar tarafından değil, aynı zamanda tabakalaşma, aile, demografi, göç ve ırk ilişkileri gibi alanlarda çalışan sosyologlar tarafından da yazılmaktadır.

Bazıları, muhtemelen, din sosyologlarının muhafazakâr bir topluluk olduklarını iddia ederek, pek çok meslektaşları dinin aydınlanmış bir dünyaya uygun olmadığına inandıkları halde, onların böyle yapmalarına tepki göstereceklerdir. Bu kanaatin, bir kuşak önce daha yaygın olduğu görülmektedir. 1960'ların başında, Marx, Weber ve Durkheim'ın mirasları, genellikle modernleşme teorisi olarak bilinecek şekilde yeniden biçimlendirilmişti. Modernleşme teorisinin muhtelif versiyonları; sanayileşme, bilim ve teknoloji, eğitim ve genişleyen ekonomi pazarlarının yavaş yavaş dinin artık pek bir rolünün kalmadığı bir kültür oluşturduğunu iddia etmiştir. 1970'lerin sonunda, bu gibi tartışmaları ciddiye almak çok daha zor hale gelmişti. Şii Müslüman Ayetullah Ruhullah Humeyni'nin taraftarlarının (ki çoğu üniversite tahsili yapmış profesyoneller ve iş sahipleriydi) Muhammed Rıza Şah Pehlevi hükümetini (ki çağdaşlaşma çabalarıyla gurur duymaktaydı) devirdiği 1979 İran devrimi, tüm Batılı sosyal bilimcilere bir uyanma çağrısı yapmıştır: Din hala dünya ilişkilerinde dikkate alınması gereken bir güçtü. Mezhep lideri Jim Jones'un Jonestown, Guayana'daki (çoğu Amerikalı olmak üzere) dokuz yüz taraftarının toplu katliamı olan 1978 toplu intiharı, merkezdeki ilişkilerde dinin hala var olan gücü hakkında sorulara neden olmuştur. Sosyologlar arasında 1960 sonlarındaki ve 1970 başlarındaki sivil haklar hareketi ve Vietnam Savaşı'na karşı protestoları çevreleyen kargaşa, toplumsal ayaklanma ve çelişkiye yönelik daha fazla farkındalıktan, "postmodernist" edebi perspektiflere ve feminist teorisiyle kadın çalışmalarından kaynaklanan yeni düşünüşe duyulan ilgiye, karşı kültürel akımlarda ve etik davranışta dinin oynadığı rollerin farkındalığına kadar pek çok konuda modernleşme modelinin yeniden ele alınmasını teşvik etmiştir. Ayrıca ABD'nin başında kendi kendini başkan ilan eden "yeniden doğuş̧̧u" Güneyli Baptist Jimmy Carter bulunmaktaydı. Bu dönemde, insanlar, kısa zaman içinde Reverend Jerry Falwell ve televizyon vaizi Pat Robertson gibi muhafazakar liderlerin partizan politikalarda platform kazandığını görecektir. Sosyologlar dini canlılı̆ıın bu gibi pekçok tezahürü yüzünden hala biraz şaşkın olabilirdi 
(ya da vazgeçmiş bile olabilirlerdi), fakat dini görmezden gelmek artık kesinlikle zor hale gelmişti.

Dini canlanmanın bu yeniden dirilişi, asla dinin saçma bir şey olduğu (ya da en azından yozlaştığı) varsayımına karşı gelmemiştir. Aslında, öğretim üyeleri ve mezun öğrencilerin 1970 'lerin sonundaki incelemeleri, halka ve hatta doğal ve uygulamalı bilimlerdeki öğretim üyelerine ve mezun öğrencilere kıyasla, sosyal bilimciler arasında dini inançsızlığın nispeten yüksek oranlarda bulunduğunu göstermiştir (Wuthnow, 1989: 142-57). Ancak kişinin konusuna duyduğu sempati, araştırma ve öğretim için nadiren bir önkoşul olmaktadır: Sosyologlar cinayetlere sempati duymadan rutin bir şekilde cinayetleri, ırkçılara sempati duymadan ırk ayrımını, devrimci olmadan devrimleri ve bunun gibi pek çok şeyi incelemektedir. Yirminci yüzyılın sonunda sosyologlar, tam da Weber'in yapmış olduğu gibi, yalnız kişisel inanç yüzünden bağlananlardan daha az olmamak üzere ateist ve agnostisizm perspektifi üzerinden din çalışan çarpıcı figürleri de din araştırmalarına dahil etmişlerdir.

Bu durumda, din ve sosyoloji arasındaki gerilimlerin, dine soğuk bakan sosyologlar açısından düşünüldüğünde anlaşılabileceğini iddia etmek bize bir şey kazandırmaz. Elbette, resmi örgütler ya da kriminolojide uzmanlaşan bir sosyolog, din sosyolojisi alanındaki son gelişmelere coşkuyla yaklaşmayabilir. Ancak bu durum, din araştırmaları alanında belli bir fayda sağlamaktan ziyade, disiplini oluşturan alt-dallarda uzmanlaşmanın fazlalığını gösterir.

\section{İtiraz 2: Sosyolojinin Dünyaya Tuhaf Bir Bakışı Vardır}

Din ve sosyoloji arasındaki gerilimler, sosyologların din hakkında karamsar bir görüşe sahip olmaları ile açıklanamayacağı gibi, aynı şekilde onların dünyaya ilişkin tuhaf bir bakışa sahip oldukları şeklinde yaftalanmaları ile de açıklanamaz. Bir an için, dinle ilgili çalışmasını nasıl "sosyolojik" hale getireceğini merak eden öğrencime dönelim. Zorluk çekmesi kısmen sosyologların dünyaya diğerlerinden daha farklı gözlerle baktıklarını düşünmesinden kaynaklanabilir. Böyle düşünmesinin muhtemel sebebi nedir? Bu durumun muhtemel sebebi, sosyolojinin entelektüel gelişiminde diğer konulardan daha sonra edindiği bir dile sahip olmasıdır: Pek çok üniversite öğrencisi gibi, lise eğitimi onu tarih, biyoloji, edebiyat, kimya ve fizikle tanıştırmıştır, fakat sosyolojiyle ancak üniversitede tanışmıştır. Ya da belki sosyoloji profesörleri, sosyolojinin temelde sağduyu olduğu şüphesinden onu kurtarmak için, arkalarına yaslanıp ona, sosyolojinin özel düşünmeyi gerektirdiğini, zor olduğunu ve yeni bir kelime dağarcığı edinmesi gerektiğini söylemişlerdir. Şimdi önünde "sosyolojik" olması gereken büyük bir proje bulunmaktadır, o artık ilgilerini kabul edilebilir olmaları için tercüme etmesi gereken yabancı bir kültüre dayandırması gerektiğini fark etmiştir.

Bu durum, özellikle dine ilişkin bir konuyu ele alan öğrenciler için kaygı verici olabilmektedir. İnanç sistemleri (doğal olarak) dış müdahalelere karşı di- 
renmektedir. Çünkü onlar bu şekilde hayatiyetlerini devam ettirebilmektedir (ve bu yüzden bazı eleştirmenler onlara kapalı sistemler adını vermektedir). Öğrencimizin gözlemlediği gibi, bir kardeş diğerinden daha dindar olursa, bir inanç sistemi bu durumu, Tanrı'nın bazılarına aydınlık diğer bazılarına ise karanlık getiren gizemli lütfu olarak açıklayabilir. Bu açıklamaya tamamen inanmayan bir öğrenci için bile, doğum-sırasının şekli veya aile dinamiklerinde açıklama aramak zararlı gibi görünebilir. Bunu yapmak lütfa inananlara karşı bir saygısızlık gibi görünmektedir. Onu sosyolojik yapmak, eğer öğrenci aile dinamikleri hakkında tuhaf sosyolojik görüşlerin var olduğunu düşünüyorsa, kendisinin bile kabullenmekte zorlandığı daha az ilgi çekici bir konu gibi gelebilmektedir.

Yine de şaşırtıcı olan, öğrencinin konusunu zaten büyük ölçüde sosyolojik açıdan ele alıyor olmasıdır. Sorusu, kendi dini görüşlerini kardeşlerden biriyle kıyaslaması sonucu ortaya çıkmış olabilir, fakat o bir otobiyografi yazmak niyetinde değildir. Ya da şu gibi sorular sormamaktadır: Tanrı gerçekten var mıdır? Kardeşler cennette birbirlerini tanıyabilecekler mi? Ya da Kur'an kardeşler hakkında neler söylemektedir? Sosyolojik perspektif zaten onun düşünüşünü yönlendirmektedir. Bunun sebebi, büyük oranda, sosyoloji için bir ödev hazırladığını bilmesi ve belki derslerinde fark ettiğinden daha fazla sosyolojik perspektifi kafasına kazımış olmasıdır. Bununla birlikte sosyolojik perspektif de çağdaş kültürde sıradan hale gelmiştir. Gazeteler ve televizyon programları sık sık sosyolojik çalışmaların sonuçlarını yayınlamaktadır. Ve dini yönden karma kültür içerisinde bulunan bizler, dini inançlarımızdan ve uygulamalarımızdan en azından küçük bir ölçüde ayrılmayı öğrenmiş bulunuyoruz; bu da dini inanç ve uygulamalara biraz tarafsız bakabilmemizi mümkün kılmaktadır. Neden bazılarının diğerlerinden daha dindar olduklarını ya da neden insanların farkı dinlere bağlandıklarını sorabiliriz. Böylece, sosyolojinin dünyaya tuhaf bir bakışı olduğu düşüncesi ilk etapta düşünüldüğünden daha küçük bir problem haline gelir.

Yine de öğrenci muhtemelen konuyu sosyolojik açıdan formüle etmekten çok, ona sosyolojinin uzmanlık alanından bilgiler uyarlamaya intiyaç duyacaktır. Gazete bilgisi, profesyonel sosyologların insan davranışının gizemini incelemek için harcadığı binlerce insan-yılının yerini ancak tutabilmektedir. Aynı öğrenci "Aminoasitler hakkında ilginç bir konum var, fakat bunu nasıl moleküler biyolojiyle ilişkilendireceğimi bilemiyorum" şeklinde bir soruyu herhalde sormazdı. Öğrenciler, belli becerilerin, kavramların ve eski çalışmaların, araştırma sürecinde iyice öğrenilmesi gerektiğini fark edecektir.

Bu nedenle, asıl kafa karıştırıcı olan, bu öğrencinin, neden sosyolojinin uzmanlık dilinin projesini canlandırmak yerine zayıflatacağını düşündüğüdür. Sosyologlar bazen, sosyolojik hayal gücü olarak adlandırdıkları şeyi geliştirmiş olmakla övünürler. Belli becerilerin, kavramların ve çalışmaların insanların diğerlerinin kaçırabileceği şeyleri görmelerine yardım ettiğini anlatırlar. Bu ticari araçlar, sosyolojide uzmanlaşmış bir öğrencinin onun hakkında soru sormasını gerektirmeyecek kadar çok ve çeşitli olmalıdır. Elbette bunlar içinden atla- 
nacak anlamsız çemberler serisi olarak değil (pek çok öğrenci için olduğu gibi) yararlı şeyler olarak algılanmalıdır. Yeni fikirler öğrenmek zorunda olmakla ilgili bazı endişeler bulunsa da, öğrenci geleceğini geçmişte olduğundan daha keskin şekilde görmesini sağlayacak böyle bir fırsata sahip olmaktan memnuniyet duymalıdır.

Fakat farz edelim ki öğrenci sadece bilinmeyenin korkusuyla değil, sosyoloji hakkında sezgisel bir rahatsızlıkla hareket etmektedir. Sosyolojinin öğrenmek istediği şeye tamamen uygun olmadığı endişesinin bir temeli olduğu ihtimalini düşünürsek, o zaman daha derinden inceleme yapmamı gerekmektedir. Sosyolojinin, bazı öğrencilerin (ve profesörlerin) din çalışmalarına kattığı değeri anlamalarını böylesine zorlaştıran -ya da genelde böyle görülmesine neden olan- nedir? Bu soruyu cevaplamak için öncelikle sosyolojik teorinin genellikle yanlış anlaşılan yönleri üzerinde düşünmemiz gerekir.

\section{Teoriye İlişkin Yanlış Anlamalar}

Çalışmalarını neyin belirgin derecede sosyolojik kıldığı sorulduğunda, sosyologlar er ya da geç disiplinlerinin teori tarafından yönlendirildiği iddiasını savunmakta ve yeterince teorik olmayan çalışmalardan kaçınmaktadırlar. Bir çalışma yerinde olması için teorik olmalıdır (ya da en azından belli teorik anlamları olmalıdır). Din çalışmalarında bunun anlamı nedir?

Sosyolojide teorinin bir anlamı, disiplinin teori-kurucu bir girişim olmasıdır. Bu yorumlamada sosyoloji araştırmalarının amacı, biraz da evrenin birleşik bir teorisini yaratmak gibi, doğru kabul edilen kanunlar ve bilimsel genellemelere dayanarak, insan davranışının ikna edici bir teorisini yaratmaktır. Bir nesil önce (ve periyodik olarak ondan sonra), teori-kurma hakkındaki sosyolojik düşünce indirgemecilik sorusuyla; yani, sosyal bilimlerin içinde iyi bir insan davranışı teorisi oluşturulması gerekip gerekmediğiyle ya da her şeyin kolayca biyolojik ya da kimyasal açıklamalara indirgenip indirgenemeyeceğiyle meşgul olmuştur. Bu konu insan davranışının indirgenebileceği, ancak sosyolojik açıklamaların yine de ilginç olmaya devam ettiği görüşüyle geniş ölçüde çözümlenmiştir. Ancak bu, bir teorinin (din teorisi şöyle dursun) tam olarak nasıl görünmesi gerektiği sorusunu cevapsız bırakmıştır.

Din konusunda kapsamlı bir teori olmaya en yakın aday, karşılık olarak modernleşme ile ilgili varsayımlara dayandırılan, sekülerleşme düşüncesiydi. Sekülerleşme teorisi, dinin toplumsal etkisinin kabaca on beşinci yüzyıl ve yirminci yüzyıl arasında kaybolduğunu öne sürmek için diğerleri arasında Marx, Weber ve Durkheim'ı kullanmıştı. Sekülerleşme kurumsal farklılaşmanın, yani daha geniş, karmaşık ve ekonomik olarak gelişmiş toplumlarda kurumların birbirinden daha özerk olduğu sürecin, bir örneği olarak alınmıştı. Bu nedenle sekülerleşme düşüncesi, gözlenmesi gereken bazı önemli süreçleri öne sürerek ve bu süreçleri yorumlayarak, din araştırmalarını daha geniş bir tarihsel çerçeve içine yerleştirmiştir (Swatos ve Christiano, 1999; Gorski, 2000). 
1970 ve 1980'lerde modernleşme daha fazla sorgulanmaya başladıkça, sekülerleşme teorisi de sorgulanmıştır. Bu teoriden test edilebilir hipotezler çıkarma çabaları, uzun vadeli süreçlerde genellikle önemini göz önünde tutmayı başaramamıştır, fakat bu çabalar kısa vadede kısıtlamalarını da göstermiştir. Örneğin Birleşik Devletler'deki, sanayileşme, bilim, teknoloji ve yüksek eğitim oranlarında sürekli bir artış olmasına rağmen dini bağlılık oranlarında herhangi bir düşüş olmamıştır. Bu çerçevede yeni dini akımların sayılarındaki artışı ya da Protestan ve muhafazakar akımların dirilişini açıklamak da zordur. Teori-kurmak, modernleşme ve sekülerleşme düşüncelerini destekleme amaçlı din çalışmaları yapmak anlamına gelseydi, o zaman gittikçe azalan sayıda din sosyologu bu çabaya ilgi duyardı.

Günümüzde çok az sayıda din sosyoloğu, dini yorumlayabilecek birleşik bir insan davranışı teorisi aramaya devam etmektedir. Örneğin 1980'li yıllarda, davranışı kendi kişisel memnuniyetini artırmaya çalışan rasyonel bireyler tarafından yapılan tercihler açısından açıklamayı amaçlayan ekonomi biliminden alınmış bir kavram olan rasyonel tercih teorisine kısa süreli geçici bir ilgi görülmekteydi (Young, 1997). Bu bakış açısı, ekonomi sosyolojisi olarak bilinen yeni bir alt alanın gelişimini hızlandırmak dışında, daha geniş sosyoloji disiplini üzerinde önemli bir etkiye sahip olamamıştır, çünkü insan davranışının sosyolojik anlayışlarına temel olan bireylerin sosyal iç içeliğini inkar etmiştir ve bazı eleştirmenlerin gözlemlediği gibi, bunu deneysel kanıtla ispatlamayı ya da çürütmeyi zorlaştıran varsayımlara dayanmıştır (Smelser, 1994, 1995). Din araştırmalarına ilgi duyanlar için, ortaya çıkardığı anlayışlar son derece kısıtlı olmuştur. Örneğin, dini davranışta kardeşler arası farklılıklarla ilgilenen bir öğrenci, bir kardeşin dini zevklere yönelik güçlü bir "tercih"i olduğunu öğrenebilir, fakat bu tercihin arkasındaki nedenlere, yetiştirilmenin ne kadar rol oynadığına ve farklı dini görüşlere sahip kardeşlerin birbirleriyle ilişkilerini nasıl sürdürdüklerine yönelik merakı devam edecektir.

Bununla birlikte sosyologların çoğu, pratikte, inanç davranışının birleşik bir teorisini arıyormuş gibi görünmemektedir (Martin, 1999). Şu an disiplinde genel olarak, teori-kurma, kendisi bir amaç olmaktan ziyade, amaca giden bir yol olarak görülmektedir. Yani, toplumsal hayatın çok sayıdaki kurallarını düzenleyen tümdengelimli önerilerin cimri bir grubu olarak ders kitabı betimlemelerinin deneysel sosyolojinin gerçekleştirildiği yollara hemen hemen hiç karşılığı yoktur. Bunun yerine, teori insanın deneysel bulguları anlamasına yardımcı olan bir hassas kavramlar grubu olarak daha iyi tanımlanmaktadır. Bu kavramlar bir çalışmadan diğerine dağınık şekilde çevrilebilir, ancak temel olarak rolleri, insan davranışının tüm taraflarını açıklayan bir teoriyle birleştirilmek yerine, deneysel anlayışlar yaratmaktır. Sosyal sınıf, cinsiyet, ırk, etnisite, kimlik, kendilik, hareket, alt kültür, iktidar, sosyal sermaye, topluluk ve bireysellikle ilgili fikirlerin tamamı hassas kavramlar olarak büyük ölçüde bu şekilde bir fonksiyon icra etmektedir. 
Teori böyle anlaşıldığında, dikkati dini davranışı doğru anlamaya çalışmaktan uzaklaştıran bir çaba yerine, din araştırmaları için bir araç olarak görülmektedir. Kardeşlerle ilgilenen bir öğrencinin, projesini sekülerleşme teorisine ya da rasyonel tercih teorisine bir katkı gibi yönlendirmesine gerek yoktur; ancak doğum sırası etkileri, kardeş rekabeti, cinsiyet farklıııkları ve ebeveyn tarzları gibi hassaslaştırıcı kavramlar kullandığında, çalışmasının zenginleşmiş olduğunu görebilir.

Örnekleyici kavramlar neredeyse tamamen dünyanın küçük bir yönüne dair anlayışımıza kattıkları değer bazında seçilirse, o zaman sorulması gereken soru, din araştırmalarının toplumsal hayatın diğer alanlarına ilişkin algılarımıza ne düzeyde katkıda bulunduğudur. Başka bir deyişle, din araştırmaları geniş sosyoloji disiplini içindeki çalışmalardan kısmen soyutlanmakta mıdır ya da aralarında verimli bir değiş tokuş mu vardır ve eğer varsa, din araştırmaları çoğunlukla diğer alt dallardaki anlayışlara dayanan bir alıcı mı, yoksa daha geniş ilgiye yönelik teorik anlayışlar üreten bir bağış̧ı mıdır?

Din sosyologları tarafından yüzyılın geçtiğimiz çeyreğinde ya da sonrasında gerçekleştirilen çalışmaların çoğu, kesinlikle kabul edilmelidir ki, geniş sosyoloji disiplini içinde kısmen az etkiye sahip olmuştur. Ve durum böyle olduğu sürece, din araştırmaları (ne kadar sosyolojik olursa olsun) ile toplumsal hayatın diğer yönlerine ilişkin araştırmalar arasında biraz gerilim olacak gibi görünmektedir. Fakat bu anlaşılabilirdir, çünkü dinin kendisi toplumsal sorgulamanın zengin olduğu bir alandır. Göç eden bir kilisenin kendi içindeki çalışmalarını tarif etmek ya da gençlerin neden olağandışı dini akımlara katıldıklarını açıklamak, kriminoloji veya iktisat sosyolojisi öğrencilerinin ilgisini çekse de çekmese de- din sosyolojisindeki önemli araştırma konularının örnekleridir. Aslında, teorinin bir hassas kavramlar grubu olarak anlaşılması, birinin çalışmasının "teorik olmadığı" suçlamasının anlamını yeniden yorumlamaya yardım etmektedir. Eleştirmenin muhtemelen söylediği şey, ilgi çekecek kavramları olduğu (örgütler, güç, suç) ve dinin bir yönüne ilişkin araştırmaların bu kavramlarla ilgilenmediği yönünde olacaktır.

Tüm alt alanları birbirinden ayıran nispeten yüksek derecedeki uzmanlaşmaya rağmen, çeşitli alt alanlarda hâkim olan kavramlar arasında yine de karşılıklı bir etkileşim söz konusudur. Din sosyolojisi daha çok bir alıcı mı, yoksa bağışçı mıdır? Din araştırmalarının son yıllarda diğer sosyoloji alanlarından çok şey aldığını gösteren pek çok kanıt bulunmaktadır. Örneğin Protestanlık araştırmaları, protestanlığın nasıl varlığını sürdürdüğünü -aslında, çoğulcu kültürel bir ortamda nasıl geliştiğini- açıklamak için alt kültür literatüründen faydalanmıştır (Smith ve diğerleri, 1998). Pazar ve tüketici davranışı araştırmaları dindarlık araştırmalarına uygulanmıştır (Roof, 1999a). Örgütlerdeki yeni kurumsal perspektifler cemaatlerdeki çelişkileri açıklamak için kullanılmıştır (Becker, 1999). Ne var ki, din sosyolojisi de disiplinin diğer bölümlerine çok sayıda katkıda bulunmuştur. Örneğin, karizma fikri, örgüt ve toplumsal akımlardaki liderlik türlerini anla- 
mak için kullanılmıştır (Zablocki, 1980). Ayin ve dini sembolizm anlayışları seküler örgüt çalışmalarına uyarlanmıştır (Bell, 1997). Teolojik çelişkilerle ilgili fikirler ise daha genel anlamda kültürel çelişkiler üzerine yapılan çalışmalarda kullanılmıştır (Hunter, 1991).

Sadece bu gibi örnekler ele alındığında, din çalışmalarının geniş toplumsal söylemlerden septiklerin bazen öne sürdüğü kadar izole olmadığı dışında az şey sağlamaktadır. Ama din araştırmalarını sosyolojik yapan şeyin önemli kısmı sadece kavramsal alıcılığın kanıtı değildir. Bundan ziyade, din araştırmalarının, sosyolojideki en kritik konuların aydınlatılmasına katkıda bulunma derecesidir. Bu nedenle, -belki de şu an sosyolojide diğerlerinden çok daha fazla dikkat çeken- ırk, cinsiyet ve sosyal sınıfla ilgili konular, özellikle üzerinde düşünülmeye değerdir.

Din araştırmaları birkaç önemli yolla ırk anlayışlarına, özellikle de çoğu Amerikan cemaatlerini ve mezheplerini karakterize eden ırk ayrımını anlama hususunda katkı sağlamıştır. Irk ayrımını ya da toplumsal ağlardaki çaprazırksal bağların varlığını ya da yokluğunu anlamaya yönelik herhangi bir çaba, er ya da geç dinin önemli bir etmen olduğunu kabul etmektedir. Dahası, düşükgelirli topluluklarda dini örgütlerin bir kaynak olarak ırksal kimlikler tarafından belirlenen rolü de daha fazla fark edilmektedir (Anderson, 1992, 1999). Örneğin Afrika kökenli Amerikalı kiliseler, pek çok kentsel bölgedeki sosyal ve politik etkinliği harekete geçirmede önemli rol oynamaktadır (Pattillo-McCoy, 1998; Harris, 1999). Ayrıca, bazı araştırmalar toplumsal akımları yaratmada ve onlara temel oluşturmada çapraz-ırksal dini ittifakların rolünü kanıtlamaktadır (Marsh, 1997).

Son yıllarda cinsiyet ve din arasındaki ilişkiler, ırk unsurunu içeren ilişkilerden daha fazla incelenmiştir. Din çalışmaları için cinsiyet önemli bir faktördür. Zira kadınlar erkeklere göre dini tecrübenin hemen hemen bütün şekillerine daha aktif ilgi göstermekte ve son yıllarda din alanında yaşanan ilginç gelişmelerin çoğu kadınlar tarafından teşvik edilmektedir (Davidman, 1991; Eller, 1993). Dini liderliğin ve papazların otoritesi hakkındaki dini iddiaların cinsi karakteri de ilgi çekmeye devam etmektedir (Chaves, 1997). Diğer ortamlardaki cinsi davranış çalışmaları da dinin rolüne artan bir ilgi göstermektedir. Örneğin kürtaj araştırmaları, kürtaja yönelik tutumların dini ortamlarda benzer düşünceye sahip insanlar arasındaki etkileşimle güçlendiğini göstermektedir; babaların rolü ve boşanma sonuçları konusunda yeni soruların sorulduğu aile araştırmaları ise, ebeveyn davranışının dini katılım kalıplarına bağlı olarak değiştiğini göstermektedir (Luker, 1984; Ginsburg, 1998; Wall ve diğerleri, 1999; Wilcox, 1998).

Bir gerçeklik ve sosyolojik sorgulama konusu olarak toplumsal sınıfın devam eden önemi düşünüldüğünde, belki de tuhaf şekilde, onun, din araştırmalarında tahmin edilenden daha az ilgi çektiği görülmektedir. Toplumsal sınıf ve din arasındaki ilişkiler klasik sosyolojik çalışmalarda vurgulanmış (özellikle de Marx ve Weber) ve son yıllarda nispeten az sayıda deneysel çalışma, bu ilişkileri 
incelemiştir. Fakat insanların kendi sınıf pozisyonlarını algılama biçimleri üzerine yapılan bazı çalışmalar, dini inançların ve ahlaka ilişkin dini temelli tahminlerin bu anlayışlarda büyük rol oynadığını iddia etmektedir (Lamont, 1992). Dinin toplumsal sınıf farklııklarının devamı ya da sınıf savaşlarıyla olan ilgisi; din ve gönüllülük, hayırseverlik, topluluk örgütlenmesi, yurttaşlık ve toplumsal adalet anlayışları arasındaki ilişkilerle ilgilenen pek çok çalışmada görülmektedir (Ronsvalle ve Ronsvalle, 1996; Verba ve diğerleri, 1995; Wuthnow, 1991, 1994, 1998).

Bunlar, sosyoloji ve din çalışmalarının teorik olarak kesiştiği alanlardan bazılarıdır. Teori insan davranışının tüm yönlerini kendi etrafında örgütlemek için sıkıca kurulmuş tümdengelimli ilkelerin aranması olarak yanlış şekilde anlaşılırsa, bu durumda öğrenciler din çalışmayı ve onu sosyolojik hale getirmeyi denediğinde muhtemelen bir huzursuzluk hissi yaşamaktadır. Ancak eğer teori bir hassas kavramlar grubu olarak algılanırsa, o zaman bu kavramlar sadece din araştırmalarını zenginleştiren araçlar olmaktadır. Aslında, cemaat hayatı, dini tecrübe, dinin politikadaki rolü, kişisel gelişimin dini temelleri ve topluluklarda dini örgütlerin yeri gibi önemli konular hakkındaki mevcut bilgilerimizin çoğu, kaynağını, sosyolojik kavramların kullanıldığı araştırmalardan almaktadır.

\section{Yönteme İlişkin Yanlış Anlamalar}

Dine ilgi duyan pek çok öğrenci ve daha geniş??? kamu alanındakiler için, "sosyolojik" bir çalışmayla en çok bağdaştırılabilecek özellik, onun belli yöntemler için kullanılmasıdır. Bu yöntemler bazılarına çekici, bazılarına ise çirkin (ya da gizemli) gelebilmektedir. Fakat burada da oldukça önemli bir yanlış anlama vardır.

Özellikle de bu disipline kısmen aşina olmayan öğrenciler ve bilginler arasındaki yaygın bir yanlış anlama, sosyolojinin sayısal verileri çözümleme işlemi gerektirmesidir. Bu izlenim, kalıp yargıların çoğu gibi, kısmen olgu içinde kökleşmiştir: Özellikle de disiplinin uzmanlaşmamış dergilerindekiler olmak üzere, dinle ilgili pek çok araştırma makalesi, dini hizmetlere ya da Tanrı hakkındaki inançlara katılmak gibi bir davranıştaki kalıplar ve eğilimler için bunu etkili bir şekilde analiz ederek nicel veri kullanmaktadır. Fakat din sosyolojisi, belki de diğer pek çok alt alandan daha başarılı bir şekilde, nicel ve nitel yaklaşımlar arasında arzu edilen dengeyi sağlamıştır. Genellikle geniş-ölçekli anketleri içeren nicel araştırmalar, ABD nüfusu ve diğer ülkelerin nüfuslarının dini inançları ve uygulamaları hakkında değerli ve açıklayıcı kanıtlar sağlamaktadır; aslında, son yıllarda, dini hizmetlere kaç kişinin katıldığı ve dini katııım oranlarının sabit mi düşüşte mi olduğu gibi temel olgulara ilişkin detaylı hesaplamalara şaşırtııı oranda ilgi gösterildiği görülmektedir (Gallup ve Lindsay, 1999; Hadaway ve diğerleri, 1993, 1998; Hout ve Greeley, 1998; Woodberry, 1998; Putnam, 2000). Aynı zamanda, kapsamlı katıım ve doğrudan gözlemi içeren etnografik yakla- 
şımlar cemaatlerin ve dini akımların içsel dinamiklerini anlama konusunda yararlı olurken; derinlemesine görüşmeler, basılı metinler ve arşiv materyalleri de dini söylemin doğasına yönelik anlayışlar sunmaktadır (Becker ve Eiesland, 1997).

Bu farklı yöntemler literatüre değerli bilgiler kattığı halde, diğer bir yaygın yanlış anlamayı da belirtmek gerekir: Nicel veri her nedense kendi içinde din araştırmalarına (belki de karmaşık bir konuyu basitleştirdiği için) düşmandır. Gerçekte durum bunun tamamen zıttıdır. Din hakkındaki ölçüm ve anketler son yıllarda öyle yaygınlaşmıştır ki, bunlar dini anlamda kim olduğumuz anlayışını kendiliğinden edinmemize neden olmuştur: Bir anketin kilise katılımında hafif bir yükseliş eğilimi gösterdiğini ve gazetecilerin "dini uyanış" ilan ettiklerini; bir diğer anketin ise hafif bir düşüşü gösterdiğini ve dini "çöküş"ten bahsedildiğini varsayalım. Disiplinleri ne olursa olsun, tüm eğitimli insanların yapması gereken, anketlere, örneklemelere ve istatistiksel analizlere yönelik temel bir anlayış geliştirmektir. Şaşırtıcı görünse de, özellikle ulusal seçimlerde kullanılan anket miktarlarıyla, küçük bir örnek topluluk kullanılarak bütün bir nüfusa nasıl genelleme yapıldığını, "örnek" teriminin ne zaman kullanılıp ne zaman kullanılamayacağını ve kişinin sahip olduğu ırk, cinsiyet ya da eğitim düzeyinin "kontrol grubu" olarak nasıl kullanılacağını bilmeyen üniversite öğrencilerine ve mezunlarına (genelde beşeri bilimlerde) rastlamak mümkündür. Henüz bunu yapmamış öğrenciler, sosyolojik yöntemlere ilişkin okunabilir pek çok tanıtımdan birine başvurmalıdır (örneğin, Babbie, 1997).

Nicel verinin toplama ve yorumlama becerisi gerektirmesi gibi, nitel çaIışmalar da uzmanlaşmış eğitime dayanmaktadır. Burada zorluk, genellikle, bilginlerin, din sosyologlarının aldığı eğitimi yeterince ciddiye almamasından kaynaklanmaktadır. İlginç bir konuyla ve iyi bir konuşmacı olmanın verdiği güvenle dolu edebiyat eleştirmenleri, din bilimcileri ve tarihçiler (belki de küçük bir araştırma sonucunun verdiği cesaretle), sorular oluşturma, onları doğru şekilde sorma ve doğru takipleri koyma sanatının, kendilerine bir sosyologun arşivdeki olağanüstü müsveddeleri incelemesi kadar yabancı gelmesi gerektiğini fark etmeyerek, nitel görüşmeler yapmaya kalkmaktadırlar. Nitel yöntemleri kullanmaya meraklı bilginlerin, en azından gerekli becerilere yönelik temel bir anlayış geliştirmeleri gerekir (Burawoy, 1991; Strauss ve Corbin, 1998; Atkinson, 1998).

Nitel ya da nicel veriden biri kullanılsa da, bir başka yanlış anlama da, çaIışmanın kesin hipotezler kullanıldığında, kullanılmamasına kıyasla daha sosyolojik olduğudur. Hipotez oluşturma sosyolojide önemli bir iştir, fakat bunun sorgulayan öğrenciye neden yabancı göründüğünün de bir nedeni vardır: Genellikle, her olayın doğal olarak çok sayıda nedeni ve açıklaması olduğunu fark etmek yerine, eşdeğer bir başka saf görüşe karşı dünyaya yönelik saf bir görüşü yerme şekline bürünmektedir. Hipotezlerin en yararlı olduğu yer, birinin bir iddiası olup olmadığına karar vermektir. Bu bakımdan açık, güçlü ve zorla- 
yıcı bir iddiaya sahip olmak, tıpkı başka bir disiplinde yapılmış çalışma gibi, sosyolojik din çalışmalarına da yardım etmektedir.

Din sosyolojisi olgunlaştıkça, genellikle iyi işi vasat işten ayıran tek metodolojik özellik, karşılaştırmaların stratejik kullanımı olmaya devam etmektedir. Elbette, nicel araştırma karşılaştırmalar içerdiği gibi; nitel araştırma da içermelidir. Din öğrencileri de, ya bir durumu yoğun şekilde incelemek istediklerinden ya da uygun bir karşılaştırmanın nasıl olması gerektiğini düşünmeyi reddettikleri için, bu temel anlayışı genellikle inmal etmektedirler. Entelektüel mücadele, geçici ve uzamsal karşılaştırmalarla cinsiyet, din ve etnisiteye dayananlar da dahil, karşılaştırmalar için her zaman var olan zengin olasılıkların farkında olmak zorundadır.

\section{Normatif Kaygılara İlişkin Yanlış Anlamalar}

Din ve sosyoloji arasındaki ilişkilerde, teorik ve metodolojik sorunların yanı sıra, normatif konulara yönelik kaygılar da ısrarla varlığını sürdürmektedir. Kardeş farklılıklarıyla ilgilenen öğrencim, sosyolojinin ilgisini kardeşler arasındaki çelişkileri gidermeye yönlendirmesini ya da dini inançlarda kökleşen otoriter ebeveyn tipleriyle mücadele yollarını bulmaya çalışmasının ilginç olduğunu düşünebilir. Ona konusuna "bilimsel" yaklaşması gerektiğinin söylenmesi, konusunu kendi kişisel deneyiminden gelen derin endişe yüzünden seçtiği için bu öğrenciye tuhaf görünecektir. Sosyolojide okuduğu pek çok şeyin normatif endişelerden uzak olmadığını fark ettiğinde ise, "nötr-değer" perspektifini benimsemek oldukça zor gelecektir.

Illahiyat fakültesinin bir diğer üyesi tarafından çalışmasının normatif bir vurgu içerip içermeyeceği sorulduğunda, normatif bir amacı olduğunu şiddetle inkar eden mezun bir öğrenci bu kaygıların örneği olabilir. Çalışması -Yahudi kitsch'in ilginç bir analizi (Nike sinagog şapkaları, Mickey Mouse Musevi oyunları, plastik Tevratlar)- sadece araştırılan fenomene ve neden bazı insanların buna diğerlerinden daha çok ilgi gösterdiğine odaklanacaktır. Fakat öğrencinin neden öncelikle bu konuyla ilgilendiğini merak ettim? Ayrıca bu konuda parlak bir çalışma yapması nasıl bir fark yaratacaktı?

Bu örnek, normatif ve deneysel kaygılar arasında kesin bir çizgi çizmenin (ve sosyolojiyi deneysel kaygılarla ilişkilendirmenin) zorluğunu göstermektedir. Öğrenci, son zamanlarda özellikle de dini açıdan çeşitli bir ortamda teolojik tartışmalardan daha derin anlamı ve daha kalııı gücü olan dini tecrübenin ilgi çekici bir boyutu olarak maddi kültüre duyduğu ilgiden dolayı bu konuyu seçmiştir (McDannell, 1995; Joselit, 1994; Wuthnow, 1999). Fakat öğrenci aynı zamanda seri tüketim için üretilen malların kutsal olanı önemsizleştirdiğini ve gerçeklikten uzaklaştırdığını da fark etmiştir. Dahası, bir insanın kitsch için yaptığı tarif, (genellikle toplumsal sınıf farklılıkları yüzünden) başka bir insanın güzel sanatlar tarifi olabilir. Kısacası, proje tam anlamıyla normatif konularla örülmüştür ve bunları görmezden gelmek, bunu yapmanın önemini küçümsemektir. Öğren- 
cinin kastettiği, kitsch kavramının iyi ya da kötü olduğuna dair kanaatin başlangıçta yer almayacağıdır. O, çalışmasının sonunda bazı değerlendirici iddialarda bulunabilmeyi ummaktadır.

Elbette disiplindeki bilginlerin çoğunda var olan ve bazen din sosyolojisindeki çalışmalarının algılarını etkileyen korkularından biri, belli bir dini oryantasyona (yönelime), çalışmaları (bütün kariyer yörüngeleri değilse bile) bu vaatle yönlendirilecek kadar bağıı olmalarıdır. Bununla birlikte, bu korku (hangi alanda olursa olsun) bilim adamlığının belki de bir kimsenin kariyerini desteklemek veya kendilerine başka birinin incelemediği bir gariplik olduğu için bir çeşit oyun gibi takip edildiği yönündeki daha büyük bir endişe ile karşılaştırıldığında azalmaktadır. Entelektüel mücadelenin amacı, aynı düşüncede olan birkaç akranın ötesinde dışarıdan bir izleyicide etki yaratmak için yeterince ciddi problemleri tanımlamaktır. Bu mücadele gerçekleştirilmezse, o zaman dine ilişkin "sosyolojik" bir duruşa sahip olmak tuhaf görünecektir.

Normatif konulara ilişkin kaygılar, teori konusuna kısaca dönmemizi gerektirmektedir. Marx, Weber, Durkheim ve diğer klasik figürlerin çalışmaları, eski kuşak sosyologlar tarafından inmal edilmiş belli hipotezler için olmasa da, bir çeşit ortak retorik olarak, çağdaş din sosyologlarına ilginç gelmeye devam etmektedir. Bu bölümde retorik, tıpkı kurucu şahısların hikâyelerinin bir ulusa uyum sağlaması gibi, alanı bir arada tutan bir zamk gibidir: Hiçbir şey olmasa bile, aksi takdirde az şey paylaşan insanlar, aynı yazarları okudukları ve aynı kitapları bildikleri için birbirlerine karşı sempati duyabilirler. Daha geniş açıdan, klasik çalışmalar, genellikle, bu gibi durumları hoş karşılamayan bilimsel ortama normatif endişeler taşımanın yasal bir yolu olmaktadır. Örneğin kişinin yoksulları çalışması, onun gerçekten yoksulları düşündüğünü göstermek yerine, Weberyen bir toplumsal sınıf analizi açısından doğrulanabilir.

Klasik çalışmalar geçmişe daha çok gömüldükçe, din sosyologlarının karşısına çıkan bir sorun da normatif kaygılarını ifade edebilecek bir dil geliştirmektir. Pek çokları için, ırksal baskı, cinsiyet eşitsizliği, cinsel tercihe dayalı ayrım konuları böyle bir dil sağlamaktadır. Ancak bu gibi diller her zaman yakın inceleme, uzatma ve yeniden buluş gerektirmektedir. Gelecekte, normatif kaygıların yarattığı en büyük entelektüel mücadele, dini çoğulculuk alanında gerçekleşecek gibi görünmektedir. Dini topluluklar arasında daha fazla çeşitlilik ve etkileşim, belli dini öğretilerin doğruluğu ve belli dini toplulukların varlığı konusunda zor sorularla karşılaşmayı gerektirecektir.

\section{Disiplinsel Bütünlük İçin Bir Temel}

Şu ana kadar, din çalışmalarının bir disiplin olarak sosyolojinin teorik kaygılarıyla bazen sanıldığından daha kolay harmanlandığını, metodolojik çeşitlilik için oldukça fazla alanın var olduğunu ve din öğrencilerinin saygın sosyoloji çalışmaları yapmak için normatif kaygılarını rafa kaldırmaları gerekmediğini savundum. Durum gerçekten böyleyse, o zaman akla şöyle bir soru gelmek- 
tedir: Din çalışmaları kolayca disiplinler arası bir ilişkiye çevrilemez mi? Bence bu sorunun cevabı büyük ölçüde evettir ve bunun hakkında biraz sonra daha fazla şey söyleyeceğim. Fakat öncelikle, sosyoloji gibi disiplinlerin önemi ve neden önemli oldukları konusundaki tutumumuz açık olmalıdır.

Sosyoloji gibi disiplinler önemlidir derken, bunu hem entelektüel hem de pragmatik anlamda söylüyorum. Bu disiplinler, başka yerde bulunmayan anlayış ve kavrayışları içerdikleri için entelektüel olarak önemlidir (ya da önemli olmalıdır). Aynı şekilde onlar, kendilerini tanımlayan uzmanların çalışmalarına ilişkin değerlendirmelerin güçlü standartlarını gösterdikleri için pragmatik olarak önemlidir (ya da önemli olmalıdır). Fakat bu entelektüel ve pragmatik "önem"in temeli ne olabilir? Bana göre bu, sosyolojinin hitap ettiği kanıtlayıcı konulardan daha fazla önemi olan farklı teorik bir yapının inşasına yönelik çabalarını bağladığı ve sadece alan uzmanlarının kullanabildiği metodolojik aygıtın yayılması olamaz. Farklı normatif kaygıları dile getirmek de -ya da bu kaygılardan kaçınmak- disiplinsel bütünlüğe temel oluşturamaz.

Din araştırmalarına farklı bir yaklaşım için sosyolojik diyebileceğimiz savunulur tek temel keyfi olmalıdır: Gelişiminin bu aşamasında akademik girişim, öyle büyük ve öyle karışık olmalı ki, uzmanlaşma bir gereklilik olsun. Bu, hem iyi bilimsel çalışmanın üretilmesi hem de böyle bir çalışmanın değerlendirilmesi için bir gerekliliktir. Bilimin sadece araştırmadaki değil öğretimdeki amacı da kesinlikle " $A$ " kalite işi " $B$ " kalite işten üstün tutmak ve " $B$ " kalite işi " $C$ " kalite işten daha fazla teşvik etmektir ve bu böyle devam etmektedir. Ancak böyle yapmak kişinin zamanını ve enerjisini bir literatür bütününü öğrenmeye harcamasını ve uygun bir araştırma becerileri grubunu iyice öğrenmesini gerektirmektedir. Ayrıca böyle bir çalışmayı değerlendirmek benzer şekilde zaman ve enerji odaklanmasını gerektirir.

Bu nedenle disiplinsel sınırlar keyfi fakat aynı zamanda gereklidir. Keyfidirler çünkü pek çok değişik uzmanlık alanı ve bilgi anlaşılırdır. Farklı koşullarda da gelişebilme ihtimaline sahip olan pek çok durum, tarihsel ve kurumsal (entelektüel) nedenlerin etkisiyle ortaya çıkmıştır. Onlar yine de önemlidirler, çünkü bilim sadece yalıtılmış bireylerin çalışmalarından oluşmaz, ayrıca o her zaman toplumsal bir yatırımdır. Bilginler, entelektüel, profesyonel ve sosyal olarak etkileşimde bulundukları insanlardan fikir almakta ve bu ağlar birbirlerinin çalışmalarını değerlendirmek için bir temel oluşturmaktadır.

Bütün bu açıklamalarla birlikte, din sosyolojisi, (iyi-kurumsallaşmış) sosyoloji disiplini içinde yine iyi-kurumsallaşmış bir alt alandır. Dini inanç ve katıımın sosyal korelasyonları, dini akımlar, cemaatlerin sosyal özellikleri ve farklı dini alt kültürlerin ortaya çıkışı ve işleyişi gibi konulardaki en iyi çalışmaların çoğunu, din sosyologları gerçekleştirmektedir. Onların ilgileri genellikle dini araştırmalar, antrolopoloji, siyaset bilimi, psikoloji, tarih ve teoloji alanındaki bilginlerin ilgileriyle çakışmaktadır. Bununla birlikte din sosyologlarının çalışmaları farklı bir 
şekilde kendi entelektüel geleneklerini, yol gösterici ilişkileri ve toplumsal ağları kullanmaktadır.

Din sosyologları ve diğer alanlara ilgi duyan sosyologlar arasındaki disiplinler arası etkileşim, bölümler, disiplinsel öncüler, disiplinsel lisansüstü programlar gibi kurumsal konfigürasyonlar tarafından da teşvik edilmektedir -ve edilmelidir. Araştırmaların genellikle metinler ve belli dini geleneklerin uygulamalarına yoğunlaştığı dini çalışma programlarından farklı olarak, din sosyolojisi, temelde dini etmenlerin ve toplumsal hayatın diğer yönlerinin (aile, politik davranış, gruplar, iş, cinsellik, sanat ve boş zaman gibi) kavşağında faaliyet göstermektedir. En iyi araştırma, çoğunlukla, söz konusu diğer uzmanlık alanlarındaki yeni gelişmelerle dine ilişkin yorumları birleştirmektedir. Aslında, din sosyolojisinin bir alt alan olarak etkinliğinin açık bir işareti, diğer sosyal fenomenlere ilişkin çalışmaların gittikçe artan bir şekilde düşünülmesi gereken bir etken olarak, tıpkı toplumsal sınıf, cinsiyet ve ırk gibi, din ölçümlerini de içermesidir.

Bu disiplinsel bütünlük tartışması, disiplinsel uygunluğu birilerinin yapmak istediğinden daha fazla vurguladığında, diğerleri disiplinsel sınırları çok yükseklere çıkarmaksızın onları savunmaya başlamaktadır. Sosyoloji çalışan meslektaşlar, yol göstericiler ve öğrenciler arasındaki ağlar, disiplinler arası çalışmanın hevesini kırma noktasına gelmeden, şu an olduğu gibi geliştirilmelidir. Bununla birlikte, din sosyologlarını birbirine bağlayan ağlar din sosyologları ve diğer uzmanlık alanlarındaki sosyologlar arasında gelişen ağlardan daha güçlü olacağa benzemektedir -e-posta, internet ve diğer elektronik iletişim şekillerinin yaygınlaşmasıyla büyüyen bir olasılık. Böylece, din çalışmalarını daha sosyolojik hale getirmek için yardım bulmak amacıyla profesörlere gelen öğrenciler, büyük olasılıkla kendilerini diğer üniversitelerde ve kendi üniversitelerinde başka bölümlerde çalışan uzmanlarla doğrudan bağlantı kurmak için kitaplardan, makalelerden ve fırsatlardan söz edilirken bulacaklardır.

\section{Disiplinler Arası Değiş-Tokuş (Çalışma) Olanakları}

Disiplin sınırlarının korunması gerektiği halde, din sosyologlarının diğer alanlardaki bilginlerle etkileşimine yönelik olanaklar son birkaç on yılda artmıştır ve yakın gelecekte daha da gelişeceğe benzemektedir. Bu olanaklar çok disiplinli örgütlere katılma (Bilimsel Din Çalışmaları ve Amerika Din Akademisi Topluluğu gibi), lisans öğrencileri için uzmanlık programları ve yeni anadallar (Amerikan Çalışmaları, Afrika-Amerikan Çalışmaları ya da Kadın Çalışmaları gibi) ve çeşitli araştırma merkezleri ve enstitüleri yoluyla ortaya çıkmaktadır (Roof, 1999b).

Disiplinler arası etkileşimin bir şekli de, diğer disiplinlerden bilim adamlarını da içeren araştırma ve öğretimi veya disiplinleri kapsayan ve bir bilim adamı tarafından yapılan çalışmayı içermektedir. Buna yönelik örnekler tarihi ve etnografyayı birleştiren çalışmalar, cinsiyet çalışmaları ya da örgütsel analizden 
yeni anlayışlarla tarihi veri veya teolojik yorumları içeren sosyolojik cemaat araştırmalarıdır (Orsi, 1985; Griffith, 1997; Hall, 1999). Ana yazarın eğitimi başka bir disiplinde bile olsa, bu gibi çalışmalarda genellikle sosyolojik kavram ve yöntemler kullanılmaktadır. Etkileşimin ikinci bir şekli de örgütsel araştırma projeleri ya da merkezlerinden oluşmaktadır. Bu çeşit etkileşim, araştırma için gerekli fonların daha kolay bulunabilir olmasıyla birlikte son yıllarda oldukça artmıştır. Fakat diğer bir çeşit disiplinler arası etkileşim çeşitli disiplinler arasında değiştokuşu özendirmek için özel dizayn edilmiş programlar ve merkezler yoluyla gerçekleşmektedir.

Disiplinler arası etkileşimin asıl avantajı, bilimin varsayımları ve varlığının nedenleri hakkında daha açık olmayı teşvik etmesidir. Disiplinler arası etkileşimin başka bir avantajı da (belki de bir yan ürünü olarak) genellikle belirli bir disipline özgü yaklaşımın güçlü yanlarına yönelik daha geniş bir beğeni yaratmasıdır. Ayrıca, disiplinler arası araştırma ve öğretim, dinin yalnız inananlar ya da yoldaş seyyahlar tarafından nüfuzlandırılan özerk bir alan değil; insan hayatının, politika, ahlak ve edebiyat gibi farklı alanlarının anlaşılması için de geniş çıkarımları olan bir özelliği olduğunu göstererek, din araştırmalarını çeşitli disiplinlerle ve bölümlerle bütünleştirmektedir.

\section{Sonuç}

Dinle ilgili herhangi bir konuyu çalışmanın ve onu sosyolojik hale getirmek istemenin belki de en caydırıcı tarafı, bu gibi konulara ilgi duyan çalışmaların, fakülte ve öğrencilerin sayısının son elli yıl boyunca -ve özellikle geçtiğimiz yirmi yılda- mantar gibi çoğalmış olmasıdır. Bu büyüme bir bakıma bu dönem boyunca yüksek öğrenimin artmış olmasından kaynaklanmaktadır. Ayrıca bu büyümeyi, sponsorlu araştırma için kurumların kaynakları ve üniversitelere çok sayıda din ile ilgili dersin dahil edilmesi de tetiklemiştir. Bir önceki çağda verilen mücadele belirli bir takım konular hakkında bilgi bulabilmek içinken, bugünkü mücadele en iyi çalışmaları sınıflandırmak ve gerçekten zaman ayırmaya değecek konular üzerine yoğunlaşmak içindir.

Bu bilgi patlamasını baş edilebilir kılan, elektronik indekslemenin ve referans hizmetlerinin ilgili çalışmaları artık daha kolay araştırma imkânı sunmasıdır. Metinler, antolojiler ve el kitapları başlangıç noktalarını sunmakla birlikte, online ders özetleri, tartışma forumları ve tam-metinli dergiler yoluyla kolaylıkla takviye edilebilmektedir. Dindeki farklılıkları bulmak isteyen bir öğrencinin, düzinelerce ilgili metin ve kitap saptaması için sadece birkaç anahtar kelime belirlemesi yeterlidir.

Elektronik bilgi yine de, dini sosyolojik bir perspektifle çalışmaya yönelik tuhaf bir şey olabileceğine dair uzun süredir var olan endişeye tamamen hitap edemez. Bana göre, bu tuhaflık çoğunlukla sosyolojik teori, yöntem ve normatif kaygılar hakkındaki yanlış anlamalardan kaynaklanmaktadır. Din gibi sosyoloji de kendisi için bir kimlik yaratıp varlığını doğrulayan tartışmalar ortaya 
çıkararak çevresine uyum sağlamaktadır. Eski kuşak sosyologlar tarafından üretilen literatüre bakan bir kişi, genellikle, onların -dünyada bir sosyolojik perspektifi benimsemenin yararlı olduğunu göstermeyi amaçlayan çalışmalar ve anlaşmalar ortaya koyarak- çok fazla protesto ettiğini hissetmektedir. Disiplin olgunlaştıkça, bu çeşit duruşa daha az intiyaç duyulmaya başlanmıştır. Ve sosyoloji kendi kimliğine ilişkin daha sağlam bir hissiyat kazandıkça, din araştırmaları da gelişmek için kesinlikle daha fazla fırsat bulacaktır.

\section{Notlar}

$\left(^{*}\right) \quad$ Prof. Dr., Princeton University Department of Sociology.

$\left({ }^{* *}\right) \quad$ Dr., Ankara Üniversitesi İlahiyat Fakültesi, e-posta: ihsancapcioglu@yahoo.com

$(* * *)$ Robert Wuthnow, "Studying Religion, Making it Sociological", Michele Dillon (ed.), Handbook of the Sociology of Religion içinde, Cambridge: Cambridge Univesity Press, s. 16-31.

\section{Kaynaklar}

Anderson, Elijah. 1992. Streetwise: Race, Class, and Change in an Urban Community. Chicago: University of Chicago Press.

Anderson, Elijah. 1999. Code of the Street: Decency, Violence, and the Moral Life of the Inner City. New York: Norton.

Atkinson, Robert. 1998. The Life Story Interview. Newbury Park, CA: Sage.

Babbie, Earl. 1997. The Practice of Social Research. San Francisco: Wadsworth.

Becker, Penny E. ve Nancy L. Eiesland, eds. 1997. Contemporary American Religion: An Ethnographic Reader (ss. 121-46). Walnut Creek, CA: AltaMira/Sage.

Becker, Penny E. 1999. Congregations in Conflict: Cultural Models of Local Religious Life, New York: Cambridge University Press.

Bell, Catharina. 1997. Rituel: Perspectives and Dimensions. New York: Oxford.

Burawoy, Michael. 1991. Ethnography Unbound: Power and Resistance in the Modern Metropolis. Berkeley: University of California Press.

Chaves, Mark. 1997. Ordaining Women: Culture and Conflict in Religious Organizations. Cambridge, MA: Harvard University Press.

Davidman, Lynn. 1991. Tradition in a Rootless World: Women Turn to Orthodox Judaism. Berkeley: University of California Press.

Durkheim, Emile. 1912/1976. The Elementary Forms of the Religious Life. London: Allen \& Unwin.

Eller, Cynthia. 1993. Living in the Lap of the Goddess: The Feminist Spirituality Movement in America. New York: Crossroad.

Gallup, George, Jr., ve D. Michael Lindsay. 1999. Surveying the Religious Landscape: Trends in U.S. Beliefs. Harrisburg, PA: Morehouse.

Ginsburg, Faye. 1998. Contested Lives: The Abortion Debate in an American Community. Berkeley: University of California Press.

Gorski, Philip. 2000. "Historicizing the Secularization Debate: Church, State and Society in Late Medieval and Early Modern Europe, ca. 1300 to 1700." American Sociological Review 65: 138-167. 
Griffith, R. Marie. 1997. God's Doughters: Evangelical Women and Power of Submission. Berkeley: University of California Press.

Hadaway, C. Kirk ve diğerleri. 1993. "What the Polls Don't Show: A Closer Look at U.S. Church Attendance." American Sociological Review 58: 741-52.

Hadaway, C. Kirk ve diğerleri. 1998. "Overreporting Church Attendance in America: Evidence that Demands the Same Verdict." American Sociological Review 63: 122-30.

Hall, John R. 1999. Cultures of Inquiry: From Epistemology to Discourse in Sociohistorical Inquiry. Cambridge: Cambridge University Press.

Harris, Frederich. 1999. Something Within: Religion in African-American Political Activism. New York: Oxford University Press.

Hout, Michael ve Andrew Greeley. 1998. "What Church Officials' Reports Don't Show: Another Look at Church Attendance Data." American Sociological Review 52: 325-45.

Hunter, James D. 1991. Culture Wars: The Struggle to Define America. New York: Basic Books.

Joselit, Jenna Weissman. 1994. The Wonders of America: Reinventing Jewish Culture 18801950. New York: Hill and Wang.

Lamont, Michele. 1992. Money, Morals and Manners: The Culture of the French and the American Upper-Middle Class. Chicago: University of Chicago Press.

Luker, Kristin. 1984. Abortion and the Politics of Motherhood. Berkeley: University of California Press.

Marsh, Charles. 1997. God's Long Summer: Stories of Faith and Civil Rights. Princeton: Princeton University Press.

Martin, David. 1999. "Christian Foundations, Sociological Fundamentals." In Leslie J. Francis, ed., Sociology, Theology, and the Curriculum (ss. 1-49). New York: Cassell.

McDannell, Colleen. 1995. Material Christianity. New Haven, CT: Yale University Press.

Orsi, Robert. 1985. The Madonna of 115th Street: Faith and Community in Italian Harlem, 1880-1950. New Haven, CT: Yale University Press.

Pattillo-McCoy, Mary. 1998. "Church Culture as a Strategy of Action in the Black Community." American Sociological Review 63: 767-84.

Putnam, Robert. 2000. Bowling Alone. New York: Simon and Schuster.

Ronsvalle, John ve Sylvia Ronsvalle. 1996. Behind the Stained Glass Windows: Money Dynamics in the Church. Grand Rapids, MI: Baker Books.

Roof, Wade Clarke. 1999a. Spiritual Marketplace: Baby Boomers and the Remaking of American Religion. Princeton, NJ: Princeton University Press.

Roof, Wade Clarke. 1999b. "Religous Studies and Sociology." Contemporary Sociology 28: 522-24.

Smelser, Neil J. 1994. "The Sociological Perspective on the Economy." In Neil J.Smelser ve Richard Swedberg, eds., The Handbook of Economic Sociology (ss. 3-26). Princeton, NJ: Princeton University Press.

Smelser, Neil J. 1995. "Economic Rationality as a Religious System." In R. Wuthnour, ed., Rethinking Materialism: Perspectives on the Spiritual Dimension of Economic Behavior (ss. 73-92). Grand Rapids, MI: Eerdmands.

Smith, Christian ve diğerleri. 1998. American Evangelicalism: Embattled and Thriving. Chicago: University of Chicago Press.

Strauss, Anselm L. ve Juliet M. Corbin. 1998. Basics of Qualitative Research: Techniques and Procedures for Developing Grounded Theory. Newbury Park, CA: Sage. 
Swatos, William H. ve Kevin Christiano. 1999. "Secularization Theory: The Course of a Concept." Sociology of Religion 60: 209-28.

Verba, Sidney ve diğerleri. 1995. Voice and Equality: Civic Voluntarism in American Politics. Cambridge, MA: Harvard University Press.

Wall, Sally ve diğerleri. 1999. "Gender Role and Religion as a Predictors of Attitudes toward Abortion in Croatia, Slovenia, the Czech Republic, and the United States." Journal of Cross-Cultural Psychology 30: 443-65.

Wentz, Richard E. 1999. "The Hidden Discipline of Religious Studies." Chronicle of Higher Education 46 (October 1): A72.

Wilcox, W. Bradford. 1998. "Conservative Protestant Childrearing: Authoritarian or Authoritative?" American Sociological Review 63: 796-809.

Woodberry, Robert D. 1998. "When Surveys Lie and People Tell the Truth: How Surveys Oversample Church Attenders." American Sociological Review 63: 119-22.

Wuthnow, Robert. 1989. The Struggle fo America's Soul: Evangelicals, Liberals, and Secularism. Grand Rapids, MI: Eerdmans.

Wuthnow, Robert. 1991. Acts of Compassion: Caring for Others and Helping Ourselves. Princeton, NJ: Princeton University Press.

Wuthnow, Robert. 1994. Sharing the Journey. New York: Free Press.

Wuthnow, Robert. 1998. After Haven: Spirituality in America Since the 1950s. Princeton, NJ: Princeton University Press.

Wuthnow, Robert. 1999. Growing Up Religious: Christians and Jews and Their Journeys of Faith. Boston: Beacon Press.

Young, Lawrence, ed. 1997. Rational Choice Theory and Religion: Summary and Assessment. New York: Routledge.

Zablocki, Benjamin. 1980. Alienation and Charisma: A Study of Contemporary American Communes. New York: Free Press. 


\title{
ANA BAŞLIKLARIYLA DİN SOSYOLOJISI
}

\author{
Hakkı KARAȘAHINN $\left.{ }^{*}\right)$
}

Editörler: Niyazi Akyüz-ìhsan Çapcıoğlu

Ankara: Gündüz Eğitim ve Yayıncılık, 2008, 447s.

ISBN 978-975-6859-80-3

Niyazi Akyüz ve İhsan Çapçıŏlu'nun hem editörlüğünü hem de birçok kısmın yazarlığını yaptıkları bu çalışma, Ana Başlıklarıyla Din Sosyolojisi ismiyle Gündüz Eğitim ve Yayıncılık tarafından yayımlanmıştır. Kitap, önsöz, sunuş, giriş, dört bölüm, yazar ve editörler, genel kaynaklar ve dizin ile birlikte toplam 447 sayfadır. Eser, editörlerin önsözü, Prof. Dr. Zeki Aslantürk'ün, "sosyoloji ve din sosyolojisi" konulu sunuşuyla başlamaktadır. "Din ve toplum" probleminin analiz edildiği giriş kısmı, Aslantürk'ün, "sosyolojinin konusu", Akyüz ve Çapcıoğlu'nun, "din sosyolojisinin konusu", "sosyolojik din tanımları", "din toplum ilişkileri", "dini tecrübenin ifade şekilleri", "din bilimi ve din sosyolojisi" ana başlıkları adı altında oluşturulmuştur. Kitabın "din sosyolojisinin tarihçesi ve çağdaş perspektifler" konulu birinci bölümü, Akyüz, Çapcıoğlu, Gürsoy, Çoşkun ve Uçar'ın katkılarıyla inşa edilmiştir. Din sosyolojisinin yöntem ve tekniklerinin incelendiği ikinci bölüm neredeyse bütünüyle Aslantürk tarafından yazılmıştır. Ancak bu kısma Akyüz, Gürsoy ve Çapcıoğlu tarafından din sosyolojisinin yöntem ve teknikleri üzerine bir değerlendirme ilave edilmiştir. Kitabın, "toplumsal gruplaşma ve din" konusunun çözümlendiği üçüncü bölümü, Kirman’ın, "dini grupların marjinal formu olarak yeni dini hareketler" başlıklı çalışması dışında Akyüz tarafından kaleme alınmıştır. Kitabın dördüncü bölümünde, Günay, Usta, Doğan, Akyüz, Kurt, Arabacı, Gürsoy, Çapcıoğlu ve Yavuz, "toplumsal yapı, değişme ve din" konusunu, aile, eğitim, sosyalleşme, siyaset, ekonomi, kültür, küreselleşme, değişme, modernleşme, sekülerleşme gibi yapı ve süreçlerin din ile olan ilişkileri çerçevesinde incelemişlerdir. Kitap, yazarlar ve editörler, genel kaynaklar ve dizin kısımlarıyla son bulmaktadır. Ana Başlıklarıyla Din Sosyolojisi isimli çalışmanın şekil yönünden betimsel analizi göstermektedir ki, bu çalışmanın dizini, konuları, başlıkları ve bölümleri oldukça güçlü bir şekilde dizayn ve sistematize edilmiştir.

(*) Dr., İnönü Üniversitesi İlahiyat Fakültesi, e-posta: hakkikarasahin@hotmail.com

(C) Toplum Bilimleri • Ocak-Haziran 2006-2009 • 1-3: 249-251 
Din sosyolojisinin bilimsel bir disiplin olarak doğuşunu, gelişimini, konularını ve problemlerini geçmişten günümüze çözümlemek gerçekten zor bir iştir. Çünkü, XIX. yüzyılın ortalarından itibaren sosyal yapıdaki din fenomenine başlayan ilgi gittikçe artmış, birçok farklı kavram ve teorik perspektif geliştirilmiştir. Özellikle son yıllarda din sosyolojisi, ulusal ve küresel boyutta şaşırtıcı ve hayranlık uyandırıc şekilde revaç bulmaktadır. Bir taraftan din ve sosyal yapı ilişkileri problemine odaklanan empirik din sosyolojisi eğilimi, diğer taraftan Weber ve Durkheim gibi büyük sosyolog ve kurucuları yeniden keşfetme ve okumaya yönelik kuramsal perspektifler hızla artmaktadır. Birinci eğilim, din sosyolojisine kavramsal ve kuramsal açıdan yeterli ve beklenen katkıyı yapacak bir araca dönüştürülememesine rağmen bazı açılımlar ve yenilikler getirmiştir. İkinci eğilimde ise öncüler, kurucular ve büyük teoriler veya Luckmann, Berger, Bellah, Stark, Swanson, Beckford, Wilson, Robertson vb. gibi din sosyolojisine çağdaş kuramsal katkılar dikkat çekmektedir. Aynı şekilde din sosyolojisinin metodolojisi, nitel ve nicel araştırma teknikleri başlangıçtan bugüne oldukça gelişmiş ve zenginleşmiştir. Bütün bunlardan dolayı, din sosyolojisinin tarihçesini, kavramsal, kuramsal yaklaşımlarını, metot ve tekniklerini, disiplinin çeşitliliğini, karmaşıkığını, problemlerini ve konularını ele alıp incelemek ve okuyucuya sunmak daha da güçleşmektedir. Bu yüzden olmalı ki, bu kitapta, din sosyolojisinin tarihçesini geçmişinden günümüze bütün yönleriyle okuyucuya iletmekten ziyade din sosyolojisinin tarihi gelişim sürecindeki Farabi, Gazali, İbn Haldun, Durkheim, Marx, Weber, Wach, Mensching, Le Bras gibi sosyologları, büyük teorik yaklaşımları ve metodolojik ana çizgileri takip ederek medolojik, kavramsal ve kuramsal çerçeve inşa edilmiştir.

Belki de Türkiye'de yapılan benzer çalışmalarda olduğu gibi bu çalışmanın da en büyük eksikliği rasyonel seçim ve alışveriş kuramı gibi çağdaş teorik yaklaşımlara, nitel ve nicel metot ve tekniklere yeterince eğilmemesi olarak görülebilir. Ancak bu eser, büyük geleneksel teorik ve metodolojik yaklaşımları, dinî grupların özelliklerini, sosyal yapı ve din ilişkilerini oldukça sürükleyici bir üslupla okuyucunun ilgisine sunmaktadır. Eserin bu özelliği, din sosyolojisine ilgi duyanların bu disiplinin metot, teknik, kavram ve kuramsal derinliğini anlamalarına ve toplumsal çevredeki olgulara ve problemlere din sosyologu bakış açısıyla gözlemleme, betimleme ve yorumlama becerisi kazanmalarına büyük katkı sağlayacaktır. Aynı zamanda eser, din sosyolojisinin ana kuramsal ve metodolojik yaklaşımlardan, İslam dünyası ve Türkiye'de bu alandaki gelişmelere, dinî gruplardan sosyal yapı din ilişkilerine kadar pek çok konuyu araştırmaktadır. Doğu ve Batıdaki belli başlı din sosyolojisi yönelimlerini birlikte değerlendirmesiyle eserin Batı'da yapılan benzer çalışmalardan farkı daha ilk bakışta ortaya çıkmaktadır.

Eser, din sosyolojisinin temel kavramlarını, kuramlarını, metotlarını, tekniklerini, konularını ve problemlerini tanıtması açılarından Türk din sosyolojisi geleneğine önemli katkılar yapacaktır. Onun için, Türkiye'de din sosyolojisi öğ- 
rencilerine ve adaylarına din sosyolojisi disiplininin ana temaları ve tarihsel gelişimi hakkında yol gösterecek ve rehberlik edecektir. Eserde, Türkiye'de din sosyolojisi alanında teorik ve uygulama sorunlarına yönelik çözümleri bulmak mümkündür. 



\section{İSIM KÜLTÜRÜ VE DİN}

\section{İsmail GÜLLÜ $\left.{ }^{*}\right)$}

Yazarı: Celaleddin Çelik

Konya: Çizgi Yayınları, 2007, 311s.

ISBN- 975-8867-36-9

\section{Giriş}

Türk toplumun yaşadığı çok farklı tecrübeler, kitle iletişim araçlarındaki değişim ve dönüşümler, sanayileşme, kentleşme, küreselleşme vb. olgular birçok alanda olduğu gibi isim kültürü konusunda da oldukça etkili olmuş görünmektedir. Ancak bu değişim, farklı sosyal çevre ve kesimlerde farklı düzey ve yoğunluklarda etkili olmuştur. Modernleşme sürecinde yaşanan değişimler, geleneksel algı kalıplarının değişmesine yol açmış, farklı düzeylerde kııılmalara neden olmuştur. Hızlı ve çarpık şehirleşme sürecinde ortaya çıkan melez kültürel yapı beraberinde kendine özgü bir yaşam biçimi ve bakış açısı getirmiştir. Erciyes Üniversitesi İlahiyat Fakültesi Din Sosyolojisi bölümü öğretim üyesi olan Doç. Dr. Celaleddin Çelik'in 310 sayfalık teorik ve ampirik iki temel bölümden oluşan, ampirik boyutu Konya örneğinde yapılan saha araştırmasına ve anket, görüşme gibi uygulamalara dayanan bu çalışması, sosyo-kültürel değişim sürecinde Türk isim kültürü ve din ilişkisini sosyolojik bir yaklaşım ve yöntem içinde incelemeyi amaçlamaktadır. Teorik bağlamda isim kültürünün tarihsel ve toplumsal dinamikleri, isim tipolojisi, isim verme geleneği, dindarlık ve isim ilişkisi gibi konular ele alınmış; uygulamada ise halen Türk toplumunda isimle ilgili anlayış, eğilim ve tutumların saptanması ve bunların dindarlıkla ilişkisinin analiz edilmesi için ampirik bir boyut eklenmiştir. Bu çerçevede isimler, isimbilim, isim sosyolojisi ve din sosyolojisinin ilgi konu ve yöntemlerinin kesiştiği bir araştırma konusu olarak değerlendirilmiştir. Kitabın tanıımı sırasında kitaptan aynen alınan ifadeler tırnak içerisinde öbek metin olarak aktarılmış ve kitabın hangi sayfalarında yer aldığı (s.) olarak belirtilmiştir.

${ }^{(*)}$ Arş. Gör., Erciyes Üniversitesi Illahiyat Fakültesi, e-posta: igullu@erciyes.edu.tr

(C) Toplum Bilimleri • Ocak-Haziran 2006-2009 • 1-3: 253-258 


\section{Kitabın Analizi}

Bir kültürel olgu olarak isim ve isim verme olgusunu inceleyen bu çalışma, Giriş (s. 1-12); Kavramsal ve Teorik Çerçeve (s. 12- 145); Uygulama ve Yöntem (s. 146-162); Bulguların Yorumu (s. 162-250); Genel Değerlendirme, Sonuç ve Öneriler (s. 252-267) bölümlerinden oluşmaktadır. Kavramsal ve Teorik Çerçeve adını taşıyan bu ilk bölüm: İsim Teorisi ve Şahıs İsimleri Bilimi, (s. 12-14), Dil Sosyolojisi Konusu Olarak İsimler (s. 14-21), Gündelik Hayat Dünyasında İsim (s. 21-23), Sosyo-Kültürel Bir Olgu Olarak İsimler (s. 23-28) adlı bölümlerden oluşmaktadır.

Temelde beş bölümden ( $A, B, C, D$ ve $E$ ) oluşan çoğu anket çalışmasına dayanan 86 tablo, 21 isim hikayesi, 40 bireysel görüşme ifadesi (A.n.) içeren bu çalışma nicel ve nitel yöntemleri bir arada kullanmayı denemektedir.

Sosyo-kültürel değişim sürecinde Türk isim kültürü ve din ilişkisini sosyolojik bir yaklaşım ve yöntem içinde incelemeyi amaçlayan bu çalışmada teorik bağlamda isim kültürünün tarihsel ve toplumsal dinamikleri, isim tipolojisi, isim verme geleneği, dindarlık ve isim ilişkisi gibi konular ele alınmış; uygulamada ise halen Türk toplumunda isimle ilgili anlayış, eğilim ve tutumların saptanması ve bunların dindarlıkla ilişkisinin analiz edilmesi için ampirik bir boyut eklenmiştir. Bu çerçevede isimler, isimbilim, isim sosyolojisi ve din sosyolojisinin ilgi konu ve yöntemlerinin kesiştiği bir araştırma konusu olarak değerlendirilmiştir (s. II).

Hayatın önemli aşamalarından ve geçiş ritlerinden biri olan isim verme pratikleri, Türk toplumunda da değişik anlayış ve uygulamaları içeren zengin bir kültürel örüntüdür (s. 2). Bu bağlamda şahıs isimlerinde ortaya çıkan değişmeler, tarihsel ve kültürel dönüşümü anlamanın araçlarından biri olarak özel işlevler taşımaktadır. Çünkü belli dönemlere özgü kültürel sistemlerle ilişkili unsurlar olan isimler sözkonusu değişimleri gösterme ve sembolize etme imkanını içermektedir (s. 3).

Çelik, çalışmanın amacını şu şekilde belirtmektedir: Bu çalışma isimler bağlamında sözel yapı ile sosyal yapı arasındaki bağlantıyı dikkate alarak, sosyal gerçekliği yapısal bir perspektiften anlamayı amaçlamaktadır. Konunun sosyolojik cazibesi, toplumsal gerçekliğin en somut ifadesi olan dilden ve isimlendirme olgusundan hareketle, yine toplumsal ilişki ve süreçlerin analizine imkân vermesinden kaynaklanmaktadır (s. 5).

Modernleşme sürecinde kültürün birçok alanında yaşanan değişmelerle birlikte, isim verme uygulamalarında da bazı farklılaşmalar ortaya çıkmıştır. Kentleşme ve sanayileşme nedeniyle geleneksel algı kalıplarının değişmesi ya da çözülmesi, artan kitle iletişim araçları ve beraberinde gelen küreselleşme olgusu, Türk toplumunda şahıs isimlerinin de gelenek ve modernlik ekseninde tartışılmasına neden olmuştur. (s. 10) Çalışma temelde Yapısal-işlevselci yaklaşıma göre ve gündelik hayat gerçekliğinin öznel ve nesnel yanlarını birlikte değerlen- 
diren çok boyutlu bir yaklaşım ya da yaklaşımların sentezi şeklinde oluşturulmuştur (s. 8).

Çalışmanın teorik çerçevesi, "İsim Sosyolojisi", "İsimbilim ve "Din Sosyolojisi", "Sosyo-Kültürel Antropolojide İsim", "Türk Toplumunda İsim Verme Ile IIIgili İnanç, Anlayış ve Uygulamalar", "İsim Vermede Etkili Olan Faktörler: Türk İsim Tipolojisi", "Aile İsmi (Soyadı)", "ísim Hukuku", "Sosyo-Kültürel Değişme Sürecinde İsim ve İsim Verme" başlıklarından oluşmaktadır.

Kişiler kendi sosyal konumlarıyla ilişkili dilsel söylemlerle topluma katılırlar, ancak o söylemi geliştirme hatta dışına çıkma imkânına da sahiptirler. Bu dinamik ilişkinin benzerini isim verme tutumlarında da görürüz. İsimlendirme, sosyolojik boyutta kültürel aidiyetin veya sosyal pozisyonun tescillenmesi, bir başka deyişle gruba katıımanın sağlanması anlamına gelir. Bu durum büyük ölçüde grubun öngördüğü normlara uymak suretiyle gerçekleşir (s. 16).

Farklı bilimsel disiplinlerin ilgi konusu haline gelen "isim", özellikle edebiyat, folklor ve antropoloji araştırmalarında dilsel, tarihsel yapısı ile birlikte örf, adet ve geleneklerle ilişkisi içinde de değerlendirilmektedir (s. 13). Modern gündelik hayat kültürü içinde isim verme ve isim gelenekleri, toplumsal yapının dinamiklerine göre değişmektedir. İnsanlar kendi sosyal yaşam tecrübelerine ve dünya görüşlerine uygun isimleri tercih etmekte, bu seçimler daha çok aidiyet hissettikleri çevreleriyle ilişkili olmaktadır (s. 22).

Sosyoloji isimlerle, gündelik hayatın bir fenomeni olarak, onun sosyokültürel yapıda, sosyal ilişkilerde ve süreçlerdeki taşıdığı sembolik değeri bakımından ilgilenir. Inssanlar doğdukları toplumsal sistem içinde sosyalleşirler. Bu sosyalleşmenin temel araçlarından biri ise, toplulukları belli bir kültür etrafında toplayan ve sürdüren dil olgusudur. Dil bir toplumsallaşma aracı olarak, kültürel birikimin kuşaklar arasında aktarıımasını sağlar (s. 23).

Türkiye'de isimleri sosyolojik anlamda önemli kılan faktörlerden birisi de, hızlı sosyo-kültürel ve siyasal değişmeler ile isim koyma ve belirleme eğilimleri arasındaki çok kırılgan ilişkidir. Tarihsel ve folklorik bakımdan isim koymanın belli ritüel haline gelmiş biçimleri bulunmakla birlikte, bunun istikrarlı bir şekilde süren bir gelenek olduğu kolaylıkla söylenemez (s. 25).

İsim verme olgusu da diğer gelenekler gibi sosyo-kültürel değişmeden etkilenmekte, yeni form ve eğilimlerle değişen yeni konum ve durumlara uygun bir şekilde sürdürülmektedir. Kentleşme ve sanayileşme gibi fizikî ve demografik yapısal değişimlerin hız kazandığı süreçlerde, kültürün ve insan ilişkilerinin de değişeceği ve hayatın geleneksel toplumda olduğundan farklı olarak modernseküler bir temelde şekilleneceği beklenir (s. 28).

Dinî inanç ve pratikler boyutunda ortaya çıkan farklılıklar, isimlerle ilgili anlayış ve kabullere de yansıyabilmektedir. Dindarlığın ve dinin, isim kültüründeki temel faktörlerden biri olması, bu etkileşimi kaçınılmaz kılmaktadır. Zira isim seçilirken, ismin anlamına, konulma zamanına veya kimler tarafından konulaca- 
ğına ilişkin ritüel, hep belli bir inançlar ve pratikler örüntüsü içinde yürütülmektedir. Bu anlamda isim kültürünü dinden bağımsız düşünmek adeta imkansız gibidir (s. 30).

Farklı din ve kültürlerde isim kültürü üzerinde duran Çelik, Hıristiyanlıkta isimlerin aynı zamanda kişilerin kimliğini ifade ettiğini vurgulamaktadır. İbrani erkek çocuklarına doğduktan hemen sonra değil, sekizinci günde sünnet olduktan sonra isim koyulduğunu ve ismi genellikle baba veya anne verdiği belirtilmektedir. Çelik'e göre, isim ve isim koyma konusu, İslam dininde özellikle hadislerde çok yoğun bir şekilde işlenen ve bu anlamda fıkhî boyuta da sahip bir olgu olarak önem taşımaktadır. İslam kültüründe kişilerin önceden tanındıkları ismi taşımaları esas olmakla birlikte, onur kırıcı, anlam ve kavram olarak islam'ın inanç ve ahlakına aykırı düşenler değiştirildiğine vurgu yapılmaktadır. Müslüman toplumlarda isimle ilgili anlayış ve uygulamalar konusunda bazı ortak unsurlar bulunmakla birlikte İslam tarihinin erken dönemlerinden bu yana Peygamberin ismi çocuklara verilmektedir.

Geçmişten bugüne Türk isim kültürünü karakterize eden unsurların önemli bir kısmı varlığını sürdürmekle birlikte, hızlı ve köklü değişimin etkileriyle isim kültüründe bazı farklılaşmaların da ortaya çıktığı anlaşılmaktadır. Geleneksel ve dinî nitelikli isimler, yerini dindarlı̆ı̆ algılanma biçimine göre ya daha fazla dinselliği ya da modernliği temsil eden isimlere bırakmaktadır. Estetik veya ideolojik kaygılar, bir anlamda Türk isim kültürü içinde yabancılaşma ve yozlaşma riski taşıyan eğilimler olarak varlığını sürdürmektedir. Kentleşme sürecindeki ailenin yapısı ve fonksiyonlarının değişmesi, sekülerleşme ile dindarlı̆ı̆n yeni görüntülerinin ortaya çıkması, gündelik hayatın bütün ayrıntılarında ve doğal olarak isim kültüründe de bu sürecin yapısına uygun bir yenilenme ve değişimi getirmektedir. Bunun en önemli göstergelerinden birisi, isim tercihlerinde kolektif anlamlar ve kimliğe bağlı referansların yerine, bireysel tercih ve yorumların giderek ön plana çıkmaya başlamasıdır ( s. 265).

Araştırmanın dikkat çekici sonuçlarından biri kişilerin öğrenim düzeyi arttıkça çocuklara verilen isimler daha bilinçli ve anlamı soruşturularak seçilmekte, isim tercih edilirken kolektif bağlılıklardan çok, ismi bir ömür boyu taşıyacak olan çocuğun kişiliğine ve ilişkilerine olan etkileri dikkate alınmaktadır. Sonradan beğenilmeyen veya rahatsızlık veren isimleri değiştirme de, yine daha çok eğitim düzeyi yükselen kişiler arasında yaygındır (s. 262).

Kırsal kesimde isimler verilirken genellikle bunun dinî ve geleneksel nitelik taşımasına önem ve öncelik verilmektedir. Uygulama ise büyük çoğunlukla aile büyüklerinin isimlerinin çocuklara aktarılmasıdır. Bu uygulama 'ocak kültü'nün güçlü olduğu Türk toplum ve kültür hayatının bir uzantısıdır. Bu bağlamda hem ebeveynin ismini verme geleneği sürmekte, hem de bu isimler zaten dinî ve geleneksel bir mahiyet kazanmaktadır (s. 258). 
İsimle ilgili olarak değişik yaş gruplarına göre farklı eğilim ve tutumlar ortaya çıkmaktadır. Nitekim genç yaş kategorilerine giren örneklemin, isimlerde "çarpıcı, cazip, gizemli, estetik, kulağa hoş gelen, moda ve fantezi özellikler" aradığını; orta ve ileri yaş kategorisindeki kişilerin ise daha çok "gelenekselkültürel motifleri" vurguladığı ve isimlerde "dinî, millî nitelikleri öne çıkaran muhafazakar tutumlara" sahip olduğu görülmüştür (s. 263).

Çoklu bir yöntem anlayışının benimsendiği, "farklı sosyolojik yaklaşımların iş birliği" şeklindeki bu çalışma, temelde işlevsel bir bakış açısına dayanmaktadır. Araştırmanın uygulama boyutunu ise anket ve görüşme oluşturmakla birlikte, farklı veri kaynakları kullanılmıştır. "içeriden Biri", "Profesyonel Uzmanlar", "Geniş Anlamda Bilgi Verenler" gibi orijinal veri toplama teknikleri dikkat çekicidir.

71 sorulu anket formu, 386 kişilik örneklem grubuna uygulanmış, verilerin analizinde ise, faktör analizi, tek yönlü varyans analizi (ANOVA) ve Scheffe Post hoc karşılaştırma test tekniklerinden yararlanılmıştır.

\section{Genel Değerlendirme}

Gerçekten yoğun ve ciddi bir akademik bir birikimin ürünü olduğu anlaşılan bu çalışmanın orijinal yönlerinden birisi, Türk toplumunda isimler ile ilgili tutum ve eğilimleri ortaya koymak amacıyla geliştirilen "İsim Ölçeği" ve bu ölçeğin geçerliliğinin muhteva ve yapı bakımından değerlendirilmesidir. 8 boyutta toplanan isim ölçeği ${ }^{1}$ faktör analizi sonucunda ortaya çıkmıştır.

İsim verme ile ilgili tarihsel kodlar, toplumda yaşanan değişimden etkilenmiş ancak yeni formlar altında yeni konum ve durumlara uygun bir şekilde varlığını sürdürmektedir. , Türk toplumunda isimle ilgili çok farklı anlayışların bulunduğu, istikrarlı, kalıplaşmış ve oturmuş bir isim örüntüsü yerine, sınırları belirsiz, keyfi, savruk, dil bakımından hatalı ve özenti mahiyetinde verilen isimlerle bir zihin karışıklığı yaşandığı tespit edilmiştir.

Konya örneğinden hareketle Türk toplumun isim ile ilgili anlayış, tutum ve davranışları sosyolojik bir bakış açısıyla analiz edilmektedir. Bu çerçevede isimlerde geleneksel çizginin muhafaza edilmesi yönündeki güçlü eğilime karşılık, isim verilirken yine de "bunun anlamına ve kulağa hoş gelmesi" ne önem verme tutumu yüksek bir temsil düzeyine sahiptir. İsim verme tutum ve eğilimlerinde estetik boyutun giderek öne çıktığı görülmektedir. Geleneksel-dinî isimlerle yeni isimleri bir araya getirmeye çalışan eklektik eğilimde, 'yeni' olan tarafı ya 'öztürkçe' ya da modern çağrışımlı isimler temsil etmektedir. Eski isimlere duyulan tepkilerde, telaffuz ve yazım zorlukları, kötü çağrışım, zaman içinde hatalı kullanımdan dolayı değersizleşme gibi unsurlar etkili olurken; yeni isimlere yö-

1 İsim Ölçeği’nin sekiz boyutu şunlardır: Bunlar dindarlık, tarihî-millî boyut, sosyal etki boyutu, gelenek ve değişme, hoşgörü, bireysellik, soyisim ve mekân ismi alt ölçekleridir.

(C) Toplum Bilimleri • Ocak-Haziran 2006-2009 • 1-3: 253-258 
nelik tepkiler ise onları daha çok popüler, medyatik, moda, içeriksiz, anlamsız, kısaltılmıs vb. özellikleri vurgulamaktadır.

Çelik, Türk toplumunda, isim ile kişilik yapısı arasındaki etkileşime yönelik güçlü kabullerin bulunduğunu, isim verme geleneklerinde de göz önünde tutulan bu ilişki, isim ile kişilik yapısı arasındaki söz konusu değerlendirmelerin kaynaklarından olduğunu belirtmektedir. Yazara göre Türk isim kültüründe, isme atfedilen özelliklerin çocuğa geçmesi ve isimle bir özdeşleşme için ad verilmektedir.

Geleneksel ve dinî nitelikli isimler, yerini dindarlığın algılanma biçimine göre ya daha fazla dinselliği ya da modernliği temsil eden isimlere bırakmaktadır. Estetik veya ideolojik kaygılar, bir anlamda Türk isim kültürü içinde yabancılaşma ve yozlaşma riski taşıyan eğilimler olarak varlığını sürdürmektedir. Kentleşme sürecindeki ailenin yapısı ve fonksiyonlarının değişmesi, sekülerleşme ile dindarlığın yeni görüntülerinin ortaya çıkması, gündelik hayatın bütün ayrıntılarında ve doğal olarak isim kültüründe de bu sürecin yapısına uygun bir yenilenme ve değişimi getirmektedir. Bunun en önemli göstergelerinden birisi, isim tercihlerinde kolektif anlamlar ve kimliğe bağlı referansların yerine, bireysel tercih ve yorumların giderek ön plana çıkmaya başlamasıdır.

Çalışmanın sonuna ek olarak konulan "isim Hikâyeleri", "Sevilen ve Sevilmeyen İsimler" bölümleri de çalışmanın orijinal parçaları olarak belirtilmelidir. Belirtilen bu yönleri ile çalışma alanında orijinal, akademik bir niteliğe sahip ve bu alanda ciddi bir boşluğu doldurmaktadır. 